

\section{THE UNIVERSITY}

OF ILLINOIS

$$
\begin{aligned}
& \text { LIBRARY } \\
& 581.97 \\
& \text { Ea } 8 \mathrm{~m} \\
& 1818
\end{aligned}
$$

MATURAL

HISTORY 
Ome

JUN 31938

JUL 251939

APR 11958

Aug.4 1961 
$5 x+30$. 3.

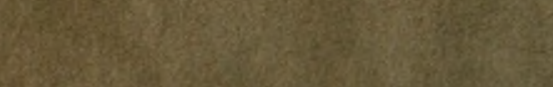

\section{$+3$}

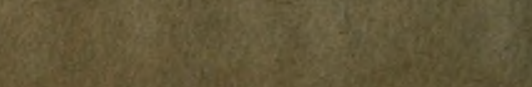

What 

FOR THE

NORTHERN AND MIDDLE

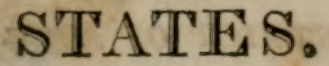

\section{PART I.}

CONTAINING

GENERIC DESCRIPTIONS OF THE PLANTS TO THE NORTH OF VIRGINIA, WITH REFERENCES TO THE NATURAL ORDERS OF LINNAUS

\section{AND JUSSIEU.}

\section{PART II.}

\section{CONTAINING}

SPECIFIC DESCRIPTIONS OF THE INDIGENOUS PLANTS, WHICH ARE WELL DEFINED

AND ESTABLISHED; AND OF THE CULTIVATED EXOTICS.

\section{BY AMOS EATON, A. M.}

Lecturer on Botany, Mineralogy and Chemistry. Corresponding Member of the Lyceum of Natural History of New-York.

Second Edition, correcled and enlarged

\section{ALBANY :}

FRINTED AND PUBLISHED BY WEBSTENS AND SHXNNEBS, 


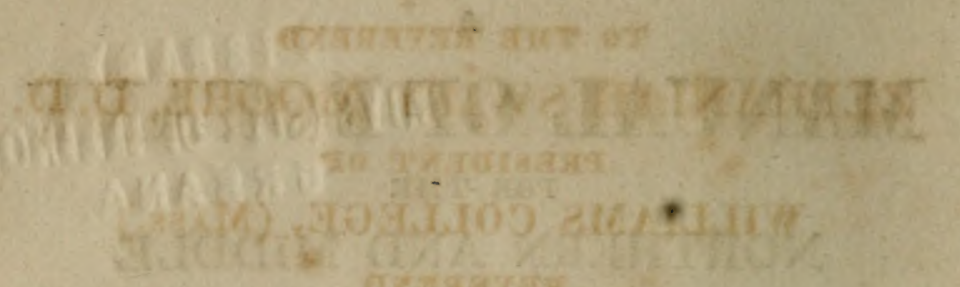

AORTHERN DISTRICT OF NEW.YORK, SS.

BE IT REMEMBERED, That on the twelfth day of May, in the forty-first year of the Independence of the United States of America, Websters and Skixxers, of the said district, have deposited in this office, the title of a book, the right whereof they claim as proprietors, in the vords following, to wit:

"A Manual of Botany for the Northern and Middle "States. Part I Containing Generic Descriptions of the "Plants to the North of Virginia, with references to the "Natural Orders of Linnæus and -Jussieu. Part II. Con"taining Specific Descriptions of the Indigenous Plants, " which are well defined and established; and of the culti"vated Exotics. By Amos Eaton, A. M. Lecturer on Bota" ny, Mineralogy and Chemistry; Corresponding Member. "of the Lyceum of Natural History of New-York. Second "edition, corrected and enlarged."

In conformity to the act of the Congress of the United States, entitled " an act for the encouragement of learning, by securing the copies of maps, charts, and books, to the authors and proprietors of such copies, during the times therein mentioned," and also to an act entitled "an act supplementary to an act entitled an act for the encourage. ment of learning, by securing the copies of maps, charts, and books, to the authors and proprietors of such copies, during the times therein mentioned, and extending the benefits thereof to the arts of designing, engraving, and etching historical and other prints."

RICHARD R. LANSING, Cherk of the M. District of Newo.Yopk. 
ZEPHANIAH SWIFT MOORE, D. D.

PRESIDEN'T OF

WILLIAMS COLLEGE, (Mass.)

REVEREND

\section{CHESTER DEWEY, A. M.}

PROFESSOR OF MATHEMATICS,

NATURAL PHILOSOPHY AND CHEMISTRY :

AND THE REVEREND

EBENEZER KELLOGG, A. M.

PROFESSOR OF LANGUAGES.

The Science of Botany is indebted to you for its first introduction into the interior of the Northern States. And I am indebted to you for a passport into the scientific world ; after that protracted series of misfortunes, which sunk me to the lowest ebb of human misery.

Permit me, therefore,

TO INSCRIBE TO YOU

\section{THIS MANUAL,}

AS A TESTIMONY OF THAT GRATITUDE

AND ESTEEM, WHICH IS DUE

TO THE PATRONS OF SCIENCE,

AND OF SUFFERING HUMANITY.

YOUR GRATEFUL

HUMBLE SERVANT,

AMOS EATON. 


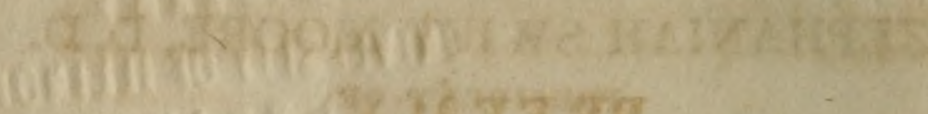

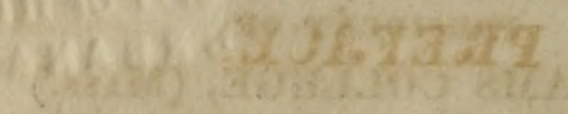

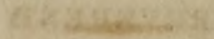

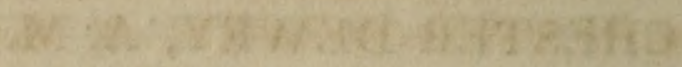

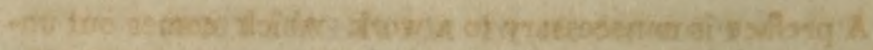

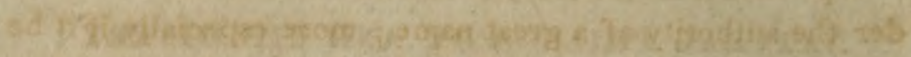

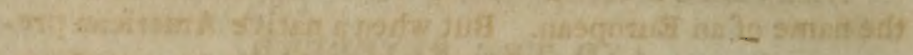

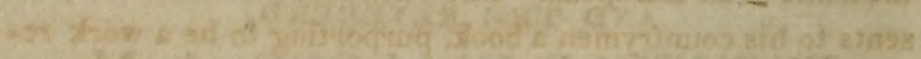

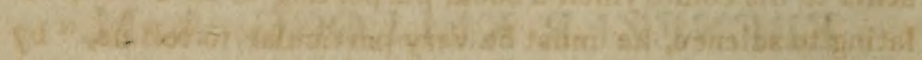

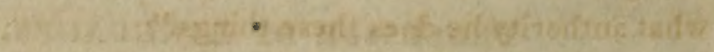

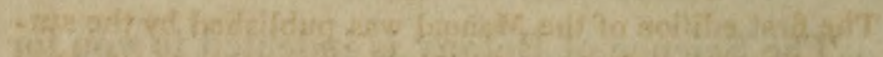

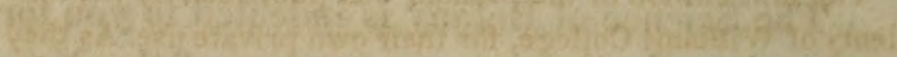

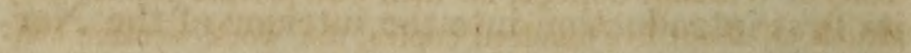

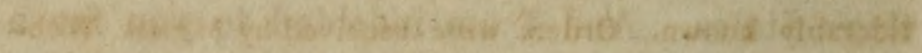

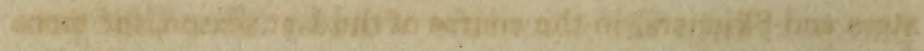

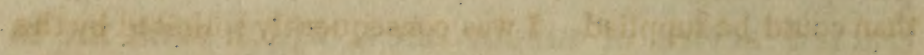

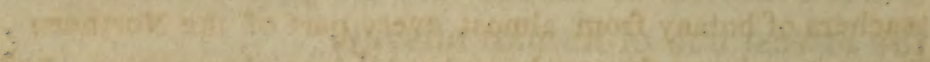

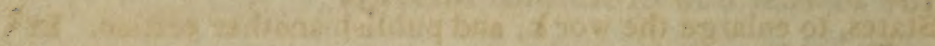

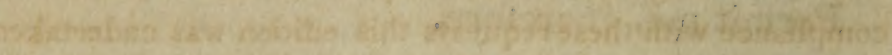

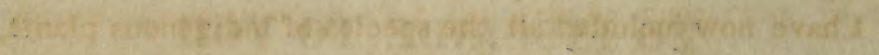

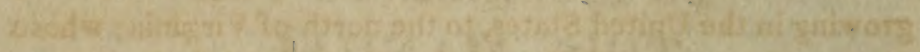

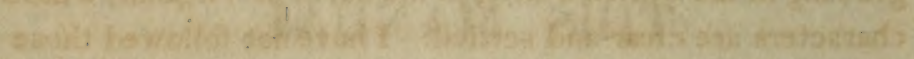

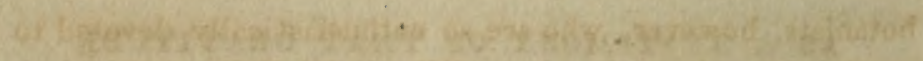

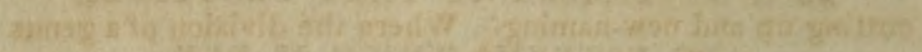

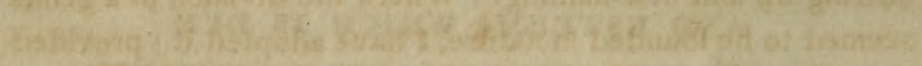

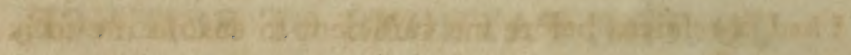

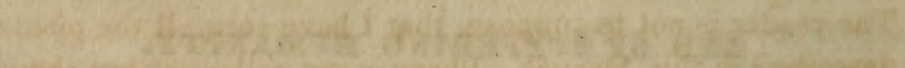

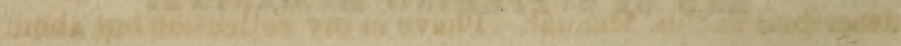

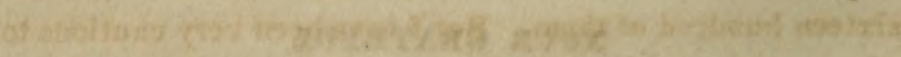

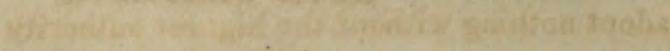

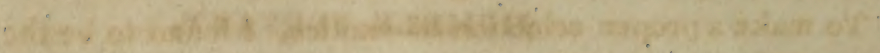

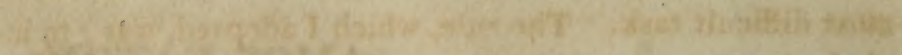

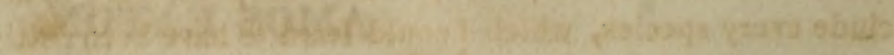
2. 4. 


\section{PREFACE.}

A preface is unnecessary to a work which comes out under the authority of a great name; more especially if it be the name of an European. But when a native American presents to his countrymen a book, purporting to be a work relating to science, he must be very particular to tell us, "by what authority he does these things."

The first edition of the Manual was published by the students of Williams College, for their own private usc. As they struck off about five hundred copies, the work became collsiderably known. Order's were receired by Messrs. Websters and Skinners, in the course of the last season, for more than could be supplied. I was consequently solicited by the teachers of botany from almost every part of the Northern States, to enlarge the wor $\mathbf{k}$, and publish another edition. In compliance with these requests this edition was undertaken.

I have now included all the species of indigenous plants, growing in the United States, to the north of Virginia; whose characters are clear and settled. I have not followed those botanists, however, who are so enthusiastically devoted to cutting up and new-naming. Where the division of a g'enus seemed to be founded in nature, $I$ hare adopted it ; provided $\mathrm{I}$ had specimens before me sufficient to enable me to judge. The reader is not to suppose, that $I$ have seen all the plants described in this Manual. I have in my collection but about sixteen hundred of them. But $I$ have been very cautions to adopt nothing without the highest authority.

To make a proper selection of exotics, I found to be the most difficult task. The rule, which I adopted, was; to include every species, which I could learn to have been culti- 


\section{$\left[\begin{array}{lll}6 & 6 & ]\end{array}\right]$}

vated in the interior of New-England and New-York. But I presume there are many, which have not fallen under my observation.

The genera are arranged according to the Linnean artificial system, improved by Smith and Persoon. Nothing can be more interesting, than the study of the natural affinities of plants. But there has been no natural arrangement yet devised by which we can find out the names of plants to which we are strangers. We must therefore follow the Linnean system, as the only safe guide to direct our steps among strangers in the regetable kingdom.*

The species of cryptogamous plants, excepting the ferns, are not complete. No botanist has hitherto settled their localties in our district of country, to any consillerable extent. I have included all which have been examined by Dr. Bigelow, Professor Dewey, and myself. But our researches in this department have been very limited. Some species I have taken from Dr. Muhlenberg ; others have been adopted on very slight unsatisfactory examination. The generic characters are chiefly from Sprenger, in the first, second and third orders-from linneus in the fourth and sixth-from Smith's translation of Acharius in the fifth. On the whole, 7 have reason to hope, that the generic characters of the cryptogamous plants will be pretty satisfactory.

The gencric descriptions of the phenogamous plants, are chiefly a me:e translation of so much of Persoon, as come within the compass of my design. The specific descriptions,

* Mr. Rafinesque, and scveral other learned botanists, con. sider a natural classification, alone, adequate to the purpose of investigating plants. In a letter, which I received from that geritleman, he says: "I hope to be able, at some future period, to convince you, and many more, that you have not yet a correct idea of the natural classification." I am sure, no botanist will hesitate to receive Mr. R's natural classification, when he shall have so far perfected it, that our pupils can dispense with the artificial arrangement. But I fear: this great degideratum is rery distant. 


\section{$\left[\begin{array}{ll}7 & 1\end{array}\right.$}

where there are but few species in a genus, are also mostl from Persoon. But where the specic: are numerous, and of course longer descriptions than Persoon gives are required, I have generally given a translation of Willdenow's descrip. tions, taken from Pursh.

In giving English names and popular characters, I hare been governed by the best authorities, which $X$ could procure.* But these names are so variable anil so different in different neighborhoods, they are never to be relied on, without test. ing the plants by their essential characters. As we always remember a plant better by an English, than by a Latin name, it is adrisable for students to name all plants in English. A mere translation of the specific name, after the manner of Muhlenberg, does not appear to be of much use. Students may better assume the most common English name of the genus, and prefix to it an adjective, descriptive of its most striking character. Take for example the Aster novae-angliae. I would not call it the New. England star-flower; because more than twenty species would be entitled to the same appellation. But I would fix upon some of its most a triking characters, drawn from an inspection of the plant; as car-leaf star-flower, gay star-flower, \&:c.

I have giren neither synonyms nor authorities, crcept. ing in cases where they appeared indispensable. To have given them partially would have been of very little use; and to have given them complete would have greatly encroased the size of the book. To know the various synonyms and the author of every discovery, is never interesting to students in botany at the first outset. But after making such progress, as to begin to extend their researches to larger works, synonyms and authoritics become interesting, and even necessary. It may be proper to inform such persons, that Mr. Edwin James, of Alhany, is preparing a list of synonyms and au. thorities for publication; which will serye as a bey to all

* See note to page 96. 


\section{[ 8 ]}

works oil dinerican botany, as well as to Dispensatories and trorks on Materia Medica.

In technical descriptions, where errors caunot be detected by the sense, perfect accuracy cannot be expected.

In Persoon's Synopsis, which is so celebratel for its accusacy, he has himself discovered and noted ninety-nine errors. And I have found about sixty errors in it, while engaged in this work, which be overlooked. In this Manual all the cssential errors will either be found corrected in the errata, or they may be corrected by comparing different parts. For example, some of the references to the natural orders are set down wrong. These may be corrected by looking over the enumeration of the genera, under Jussieu's orders, \&\&c.

I have ventured upon my own opinion in but rery few cas. es. A great proportion of this work was translated two years ago, under the immediate inspection of professor Ives, of Yale College. The plan of the work, and a great proportion of the materials were examined by Dr. James McBride, of South-Carolina ; while he was at New-Haven, in the sum. mer of 1816. Several questions and doubts having arisen in my mind since that time, I made a long list of queries, which I presented to Dr. Jacob Bigelow, of Boston, last win. ter. Most of these he answered in a very satisfactory manner ; and added many interesting remarks, which have been highly useful to me. During the last two years, I have been in the habit of corresponding with Dr. John Torrey, of NewYork, upon all questions of doubt and difficulty. This gentleman's situation, joined to his habit of accurate observation, enabled him to answer all enquiries of this nature in a very satisfactury manner. He has free access to the best col. lections in this country, and to the best American and European authorities. But what renders his opinions of still higher authority, he enjoys the advantage of a regular correspondence with Mr. Elliot, of South Carolina (who is a second Mullenberg) and is in the labit of conferring with a Ilosack, 


\section{[ $9 \begin{array}{ll}9 & ]\end{array}$}

a Mitchill, a L.e Conte, an E.ldy, Mr. Rafinesque, and othey experienced naturalists.

Notwithstanding these and other checks, I may still have misjudged, and shall need much public indulgence. Tho new species, which I have given as my own discoveries, have been particularly examined by others, and their advice deliberately taken. The new species of Messrs. Le Conte, Rddy and Torrey, were obligingly sent to me by Mr. Torrey.

In a work of this kind, which is expressly designed for those, who are not adepts in botany, some remarks upon the adventages of the study of this science might be expected. The annesed letter, which I received from Dr. IIosack, while I was giving a course of lectures at Catskill academy, gives such an excellent and concise riew of this branch of learning; that I renture to publish it, though widlout the author's consent or knowledge.

\section{Newv-York, Augrost 30ih, 1810.}

\section{Dear Sir,}

I receired yours of the 8 th instant, anc am happy to be informed of the progress of the Botanical Institution at Cats. kill under your direction. You have set an example that, I do not doubt, will be fullowed by many, if not most, of the academies throughout the state. I am satisfied, thire is no study so well calculated to occupy the young mind, as the study of natural history. It affords an agrecable exercise to lise memory, at the same time that it teaclies us the habit of attentively observing those objects which otherwise we pass by with careless indifference. We acquire by this study a habit of analysis, or inrestigation, that cannot be attained by those pursuits, that are usually made the subjects of education at this early age.

Since my acquaintance with the principles upon which the subject of natural history are arranged, I ccrtainly look with very different cyes upon crery object that falls under my view, whether it be the production of nature or of ait. 


\section{[ 10 ]}

In early life, before our external senses are completely envolved; when we are, in truth, endeavoring to bring them into exercise and use; it has always appeared to me a very absurd practice in our schools, to occupy children with studies of an abstract nature, and which require faculties to comprehend them, that are not yet unfolded.

You have adopted. in my opinion, the true system of ed. ucation; and very properly address yourself to the senses and to the memory, instead of the faculties of judgment and of reason, which are comparatively of slow growth. By this system of instruction their minds will be stored with truths, that cannot fail to prove useful : not only as they exercise their faculties in acquiring them ; but from the information which they also thereby receive upon a very interesting subject of human learning.

But this is not all. In proportion as the mind attaches itself to subjecte of this sort, it is diverted from those vicious propensities and pursuits, which otherwise attract attention at their early period of life. Studies of this nature too are no less calculated to improve the morals of youth, inasmuch as the mind is naturally led from the contempla. tion of the beauties of creation to that intelligence and pow. er which gave them birth. Thereby improving their virtue, as well as their wisdom; which should always be kept in view, inasmuch as.happiness is the great end of all our pur. suits.

Lord Kaimes, in his Elements of Criticism, has very pro. perly observed, that "among the many branches of educa. " tion, that, which tends to make deep impressions of virtue, " ought to be a fundamental orject in a well regulated gov" ernment. For depravity of manners will reuder ineffectu"al the most salutary laws; and in the midst of opulence, "what other means to prevent such depravity, but early and "virtuous discipline."

Such is the system you are pursuing, independent of the sride field to which you will hereafter lead your pupils, 


\section{[ 111$]$}

wherein they will learn the uses of planits as articles of medicine, of agriculture, and of the arts. At the same time they will acquire a knowledge of the native productions of our own soil and country, which are ye unexplored.

The state of New-York having passed an act for the pur. chase of the Botunic garden in the neighborhood of this city, I hope to see among its fruits the establishment of many similar institutions throughout the state; as so many scions from this parent stock. By the diffusion of botanical knowledge, I anticipate the discovery of many valuable plants; which are this moment trodden under foct as unworthy of regard.

To your pupils and their teacher, as first on the field, much praise is due. I doubt not they will reap both pleasure and profit, as the reward of their enterprise. If I can contribute to either, I shall be huppy to do it, in any manner that you may suggest.

You have stated to me, that it is the intention of the trus. tees of your academy to set apart two or three acres for the cultivation of plants, to be made the subjects of instruction; and to erect a green-house for the more valuable exotics. If these be effected, I shall have it in my power to supply you with the necessary plants from the Botanic garden liere. Its produce will be sufficient in a short time to furnish plants for a small garden, connected with every actdemy throughout the state.

I sincerely wish your example may be followed. Nothing could so effectually tend to the investigation of the native psoducts of our country.

I am yours, respectfully,

\section{HOSACK.}

\section{A roo Estox, Esq.}

In confirmation of the opinion of Dr. Hosack, that subjects of natural history, when taught familiarly and practicilly, are well adapted to the capacities of those who have not 


\section{[ 12]}

been liberally educated; it may not be improper to subjoin the following. It is only the last paragraph, which can be interesting to the public.

Northampton, (ifass.) Nov. 24th, 1817.

To all, whom it may concern :

On the recommendation of the president and faculty of Williams College, together with that of professors Silliman and Ives, of Yale College, and professor Mitchill, of New.York; Mr. Amos Eaton was employed in this town to deliver a course of lectures on botany, and a course of erening lectures on the elements of chemistry, mineralogy and genlogy. He has now closed his course, to the entire satisfaction of his employers, and, we think, much to the advantage of his pupils.

As his class consisted chiefly of ladies, and as these branches of learning bave not hitherto generally engaged the attention of that sex; we take the liberty to state, that, from this experiment, we feel authorised to recommend these branches as a very useful part of female education.

CALEB STRONG, [late Governor of the state of Massachusetts ]

SOLOMON IVILLIAMS,

[D. D. Pastor of the Presbyterian church in Nurthampton]

EBENEZER HUN', [Physician.] JOSIAH DWIGHT, [County clerk.] ELIJAH H. MILLS, [Representative in Congress.]

DAYID HUNT, [Physician.] 


\section{LINNEAN SYSTE.M OF VEGETABLES.}

All Vegetables are divided into twenty-two* cxassr.9. These crasses are divided into ornens. Onnfus are livided into gescra. Gexrina are divided into sprenes. Spectes are frequently changed into vurieties. Tarielies, however, are more properly within the province of the Gardner, than of the Butanist; at least the method of procuring varieties.

When a Botanist sces a plant, which he never saw before, and wishes to know its name and uses; he proceeds as follows :

1. He takes the unknown flower in his hand (no unknown plant can ie ascertained without the flower) and compares its parts with the description of each class, until he finds the class to which it belongs.

2. IIe then goes to the orders of that class and finds its order in the same way.

3. Next he goes to the genera of that order, and reads thcir descriptions, until he finds the genus to which it belongs.

4. At last lonks orer the species of that genus, until he finds the exact description of his plant.

5. Tiuus he finds the Apple to be Crass 12, Order, 5, Gewus Pyrus, Sexcies Malus.

* Linneus divided them into 24 classes. But firther dis. coveries, since his death, have pruved the classes rulyadel. phia and Polygamia to be tno uncertin and rariable to be any longer retained. Persoon, therefore, and other emuent Botanists, have rejected them. 


\section{ILNNEAY CLASSES.}

1. Movisnert, 1 stamen, or one sessile anther in the flover.

2. Drisnru, 2 stamens, or 2 sessile anthers.

3. Tnxixnrs, 3 stamens, or 3 sessile anthers.

4. Tetraxnits, 4tamens, or 4 sessile anthers.

5. Prisaxprir, 5 stamens, or 5 sessile anthers.

6. Hexavmri, 6 stamens, or 6 sessile anthe:s.

7. Heptaxnira, 7 stamens, or $\tau$ sessile anthers.

8. Octaspirid, 8 stamens, or 8 sessile anthers.

9. Exreasdna, 9 stamens, or 9 sessile anthers.

10. Decaxpria, 10 stamens, or 10 sessile anthers.

21. Dodechyoria, 12 to 19 stamens, or sessile anther's.

12. Icostaxnnts, about 20 or more, standing on the calyx.

13. Polxasonit, always 20 or mare, on the receptacle.

14. Dinxysirs, 4 stamens, 2 of them uniformly the longest.

15. Tetrangsamis, 6 stamens, 4 of them uniformly the longest.

16. Mosdnelpits, stamens united by their filaments in one set, anthers remaining separate.

17. Diadrupin, stamens united by their filaments in two sets (sometimes in one set) flowers papilionaceous.

18. Syngeresta, stamens 5 , united by their anthers in one set, flowers compound.

19. Grisunid, stamens stand on the germ, style, or stigma, separate from the base of the calyx and corol.

20. Mnxoecra, stamens and pisiils in separate flowers, on the same plant.

21. Droecra, stamens and pistils on separate plants.

C2. Criptogama, stamens and pistils so obscure that the plants can only be classed by natural families. 


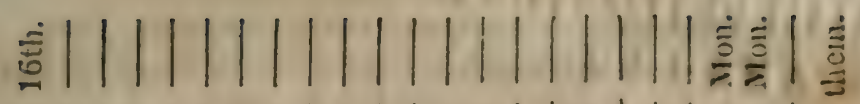

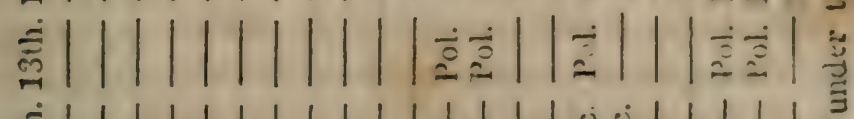

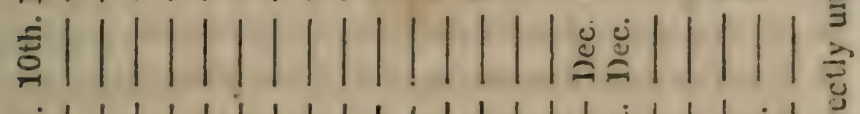

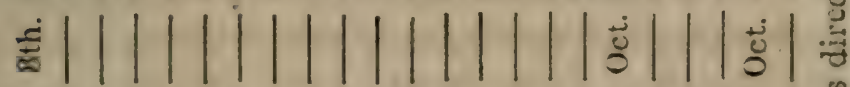

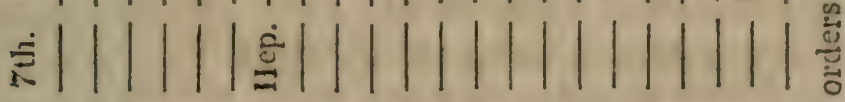

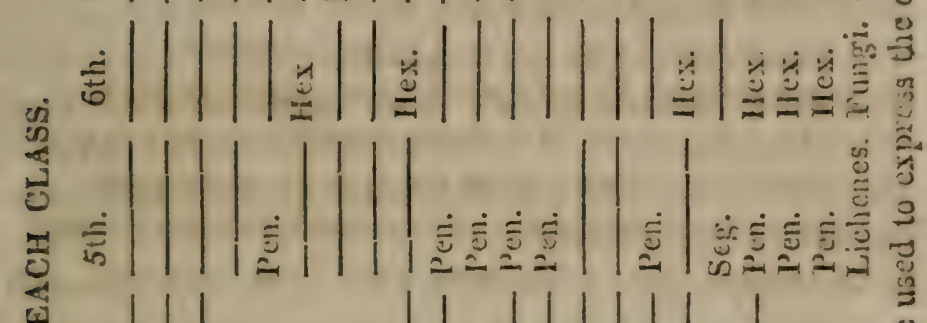

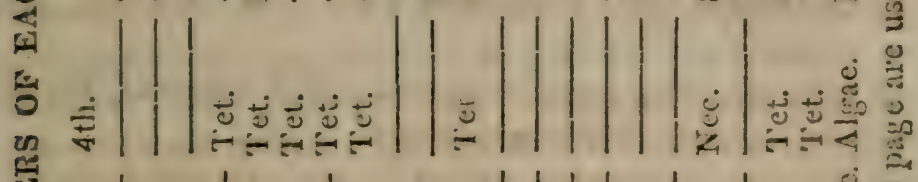

篅

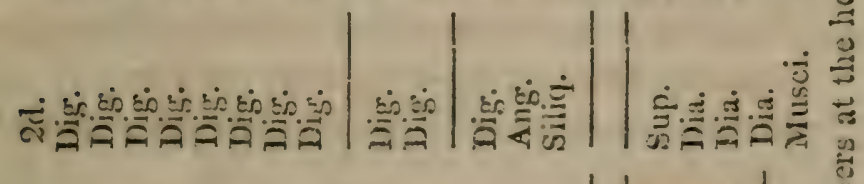

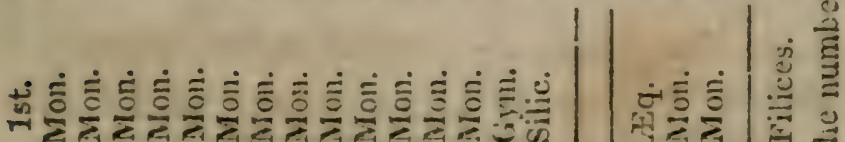

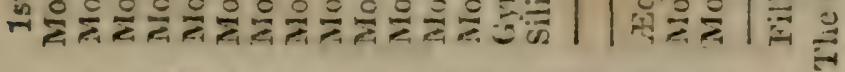
पुल2 峞 


\section{EXPLAXATIONS FON THE PRECEDING PAGE.}

Mon. Monogynia, 1 style, or 1 sessile stigma.

Dig. Digynia, 2 styles, \&c.

Tri. Trigynia, 3 styles, \&c.

Tet. Tetragynia, 4 styles, \&c.

Pen. Pentagynia, 5 styles, \&c.

Hex. Hexagynia, 6 styles, \&c.

Hep. Heptagynia, 7 styles, \&c.

Dec. Decagynia, 10 styles, \&c.

Pol. Polygynia, more than 10 styles, \&c.

Gym. Gymnospermia, seeds naked.

Ang. Angiospermia, seeds in capsules.

Silic. Siliculosa, having pods whose length and breadth are nearly equal.

Siliq. Siliquosa, having pods whose lengths are more than double their breadths.

In the 16th, 17th, 19th, 20th, 21st classes, the names and characters of preceding classes, are taken for orders. In which, Mon. Monandria. Dia. Diandria. Tri. Triandria. Tet. Tetrandria. Pen. Pentandria. Hex. Hesandria. Oct. Octand!ra. Dec. Decandria. Pol. Polyandria. Mon. Monadelphia.

In the 18th class. 1. Eq. Polygamia Equalis. 2. Sup. Polygamia Superfua. 3. Frus. Polygamia Frustranea. 4, Ncc Polygania Necessaria. 5. Seg. Polygamia Segregata.

The 1st order in the $18 \mathrm{th}$ class is distinguished by having ail the florets perfect. The $2 \mathrm{l}$, by having those of the disk perfect, while these of the ray are pistillate. The $3 \mathrm{~d}$, by having those of the disk perfect, while those of the ray are neutral. The 4th, by haring those of the disk staminate, while those of the ray are pistillate. The 5 th, by having the florets all perfect, while each floret has a perianth of its own.

In the $22 \mathrm{~d}$ class, the orders are distinguished by natural family characters. 1. Filices, (ferns) which bear fruit on the back of the leares, or in which some part of the leares seem as it were mctamorphosed into a kind of fruit-bearing. 
spike. The appendix to this order inclules the Pteriodes, which bear fruit on a peculiar appenlage. 2. Mhusci, (mos. ses) which bear, on leafy stems and banclies, onc-celled capsules, opening at the top, where they are corered by a peculiar lid. 3. Ilefaticae, (liverworts) which bear, on herbaceous frouds, four-celled capsules opening with four valves. 4. A'scae, (seaweeds, \&c.) which bar in an acquatic or gelatinous frond, vesiculous or filamentous fruit. 5. lichenes, (lichens) which bear firuit, on fibrous, compact or gelatinous fronds; contained in clefts, spangles, puffis, buttons, tubercles, hollows, cellules, globules, shields, targets, orbs, or knobs. 6. Fungi, (mushroom, \&c.) which are destitute of herbage, consisting of a spungy, pulpy, leathery or woody substance, and bear fiuit in a naked dilated membrane, or within the substance of the plant.

Explaxations of the chanacters. aysexed to tue gexERIC DESCRTPTIOXS.

The first number following the generic description is the number of the natural order of Linneus, to which the genus belongs; the second number is that of Jussieu. By referring to the subjoined natural orders of Linneus, the qualities of plants may be so far ascertained, as they depend on these natural affinities.

(*) Placed before one or more gencric names, at the end of an order, indicates that these genera sometimes vary from the classes and orders to which they belong, and are found 20 possess the characters of the class and order under which their names are thus set down. 


\section{NATURAL ORDERS OF LINNEUS.}

1. Parme. Pulms and their relatives; as Cocoanut, Frogs bit. Farinaceous diet.*

2. Prpenrtx. Pepper and its relatives. In crowded spikes; as Indian-turnip, Sweet flag. Tonics and Stome chics.

3. Caramaniz. Reed-like grasses, with culms without joints; as Cat-tail, Sedge. Coarse cattle foclier.

4. Graxixa. The proper grasses with jointed culms; as Wheat, Rye, Oats, Timothy-grass, Indian-corn. Farinaceous cliet and cattle fodder.

5. Tripctalotaex. Corol 3-pettalled or calyz 3-leaved; as Water-plantain, Rush-grass, Arrow-head. Tonics and rough cattle focder.

6. Exsate. Liliaceous plants with sword-form leaves ; as Iris, Blue-eyed grass, Virginian spiderwort. Antiscorbutice and Tonics.

7. Orchroes. With fleshy roots, stamens on the pistils, pollen giutinous, fower's of singular structure with the germ inferior ; as Ladies slipper, Arethusa. Furinaceons diet and Stomaclics.

S. Scitamizex. Liliaceous corols, stems herbaceous, leaves broad, germ blunt-angular; as Cinger, Turmeric. Warming Stomachics.

9. Spathacrz. Liliaceous plants with spathes; as Daffo. dil, Onion, Snow-drop. Secernant Stimu!ants.†

10. Conosaniz. Liliaceous plants without spathes; as Lily, Tulip, Star-grass. The nauccous scented and bitter are Antiscorbutic and Cathartic, the others Emollient.

11. SAR stems; as Smilax, Aspr:agus, Bell-wort. Tonics and Secernant Stimulants.

* The qualities of the natural orclers are selected from Milne, Woodville, 'Thornton and Darwin.

Which promote the secretions of perspirable matter, sic. Ec. 
12. Otrmaces, or llocenaes: Having flowers destitute of beauty, at least of gay colouring ; as Beet, Blight, Pigweed, Dock, Pepperage. If nacusus, Cathartic; others, mild Stimulants and Nutrientics.

13. Seccelesta. Plants with veig: thick succulent leaves; as Prickly-perr, Ilouse-leek, Purslain. Antiscorbutic and En: ollient.

14. Gruisales. Corals with 5 petals, capsules beak. ed; as Flax, Wood-sorrel, Cranebill. Tonics and Refrig. erants.

15. Isusuata. Growing under water and having flowers destitute of beauty; as Hippuris, Pond-weed. Astrin. gents.

16. Caliciflonx. Plants without corols, with the stamens on the calyx ; as Poet's cassia, Seed buckthorn. Astringents and Refirigerants.

17. Calycasthemx. Calyx on the germ or growing to it, flowers beautiful; as Willow-lerb, Ludwigia, CEnothera. Astringents.

18. Brcorses. Anthers with two strait horns; as Whortleberry, Spicy and Bitter Wintergreen, Laurel. .2s. tringents.

19. Hesperinfs. Swcet-scented, leaves evergreen; 28 Myrt!e, Cloves, Mock-orange. Astringent and Stomachic.

20. Rotacex. Corals wheel-form; as St. John's wort. Tonics.

21. Precre. Plants witls early spring flowers of an elegant specious appearance; as Primrose. Astringents.

22. Carmophyleze. Ilants with caryophyllous corols; as P'ink, Cockle. Astringent and Secemant Stimulants.

23. Triulate. Flowers with 3 stigmas, capsules infla. ted and winged, and generally 3 sceded with distinct hilums; as Nasturtion, IIorse-chesnut. Tonics and Nutrientics.

$\dagger$ Nutrientics of Darwin, which serve as nutriment merely, without producing any extraordinary effects. 
24. Convoares. Corols spurred or anomalnus; as Fum; atory, Touch-me-11ot. Narcotic and Antiscorbatic.

25. Potamere. Plants which bear shell-fruit; as Caperbush. Detergent and Antiscorbutic.

26. Mectrsilique. Having several pod-furm capsules to. each flower ; as Columbine, Larkspur, Rue, American cowslip. Cathartic and Caustic.

27. Ruefadeæ. Plants with caducous calyxes, and cap. sules or siliques; as Poppy, Bloodroot, Celandyne. Anodyne and Antiscorbutic.

28. Lunios. Corols lurid, mostly monopetalous; flowers Pentandrous, or Didynamous with capsules; as Tobacco, Thorn-apple, Nightshade, Foxglove. Narcotic and Antiscorbutic.

29. Campaxacea. Having bell-form corols, or those whose general aspect is somewhat bell-form; as Morning glory, Bell-flower, Violet, Cardinal flower. Cathartics and Seceruant Stimulants.

30. Contonte. Corols twisted or contorted; as Milkweed, Periwinkle, Choak-dog. Cathartics and Antiscorbutics.

31. Vernecol.E. Having monophyllous calyxes, coloured like corols; as Leatherwood, Thesium. Antiscorbutic and Emetic.

32. Paprionaceæ. Having papilionaceous flowers; as Peas, Beans, Locust tree, Clover. Emollient, Dinetic, $\mathcal{N} u$ * trientic.

33. Lomextace.e. Having legumes or loments, but not perfect papilionaceous flowers with united filaments; as Cassia, Sensitive plant. Emollient, Astringent, Cathartic.

34. Cucentitacere. Fruit pumpkin-like, anthers mostly united; as Melons, Cucumbers, Passion-flower. Cathartic and $\boldsymbol{R}$ efrigerant.

35. Sexricosæ. Prickly or hairy, with polypetalous $\mathrm{co}$ rols and a number of seeds either naked or slightly covered; as Rose, Raspberiy, Strawberry. Istringent and Refrigesant. 
36. Pomace.e. Haring many stamens on the calyx, and drupaccous or pomaceous fruit; as Pear, Currant, Clierry, Peach. Refrigerants.

37. Colcmsrane. Stamens united in the form of a co. lumn; as Hollyhoc, Mallows, Cotton. Emollient.

38. Tricocicx. IIaving 3-celled capsules; as Castor oil plant, Spurge, Box. - Cathartic.

39. Srurecosx. Having silique pods; as Cabbage, Mustard, Shepherd-purse. Diurctic, Antiscorbutic, Nitrientic.

40. Pensorate. Having personate corols; as Snapdragon, Monkey-flower. Deubstruents and Cathartics.

41. Aspenfolix. Corols monopetalous, with 5 stamens, secds 4, naked, leares rough ; as Comfrey, Stone-seed (lithospermum.) .1stringents and Deobstruents.

42. Virticilats. Having Labiate flowers; as Sage, Tlyme, Catmint, Motherwort. Stomaclics and Astringents.

43. Duros.玉. Busly pithy plants with small flowers, petals in 4 or 5 divisions; as Sumeh, Elder, Holly. T'onic and Cathartic.

41. Serranis. Having mostly tubular divided corols with few stamens; being omamental shrubs; as Lilac, Jas. mine. Astringent.

45. Uмвецат. Flowers in umbels with 5-petalled co. rols, stamens 5, styles 2 , and 2 naked seerls; as Fernel, Dill, Carrot, Poison-hemlock. Stomachic and tarcotic.

46. Heveracex. Corols 5-cleft, stamens 5 to 10 , fruit berry-like on a compound raceme; as Grape, Ginseng, Spikenard. Tonics and Refrigerants.

47. Stritar玉. Corols 4-cleft, stamens 4, seeds 2, naked, leaves mostly whorled; as Bedstraw, Dogwood, Venus? pride. Tonics and Deobstments.

48. Aggreglta. Having aggregate flowers; as Button. bush, Marsh-rosemary. Tonics and Secernant Stimulunts.

49. Composite. All the compound flowers; as Sunflower, Boneset, Tansey, Tlistle. Tonics and Secernunt Stimulants. 
50. Axeytacex. Bearing pendant aments; as Hazle Oak, Chesnut, Willow. Astringents.

51. Coxrfers. Bearing strobiles; 25 Pine, Juniper, Cedar. Tonics and Stomachics.

52. Coapendtx. Several berry-like pericarps, which are adnate; as Tulip-tree, Magnolia, T'onics.

53. Scaвnidz. Leaves rough, flowers destitute of beauty ; as Nettle, Hemp, Hop, Elm. Astringents.

54. Miscercaxie. Plants not arranged by any particklar character; as Pond-lily, Poke-weed, Amaranth. Their qualities are various.

55. Fincrs. All ferns; as Brakes, Maidenhair. Secernant Stimulanss.

56. Moscr. All mosses; as Polytrichum. Cathartics and Secernant Stimularits.

57. Alg 3. All Liverworts, Lichens and Sea-weeds; as Jungermannia, Fucus, Usnea. Tonics.

53. Fovgr. All fungusses; as Mushroom, Toadstool, Puff-ball, Touchwood, Mould. Tonics and Calhantice. 


\section{RULES FOR DISTINGLISIING POISONOES PLANTS}

\section{FROM THOSE WHRCH ARE NOT POISONOUS.}

\section{Plants not poisonous.}

1. Plants with a glume calyx, never poisonous. As Wheat, Indian-corn, Foxtail-grass, Sedge-gr:ass, Oats. Linneus.

2. Plants whose staments stand on the calyx, never poisonous. As Currant, Apple, Peach, Struwbery, Thorn. Smith, page 304, Big. ed.

3. Plants with cruciform flowers, rarely if erer poisonous. As Mustard, Cabbase, Watcreress, 'Turnip. Smith, pase 337, Big. ed.

4. Plants with papilionaceous flowers rarely, if ever, poisonous. As Pen, Pean, Locust-tree, Wild-indigo, Clover. Smith, page 344, Big. ed.

5. Plants with labiale corols bearing seeds without pericarps, never poisonous. As Catmint, Hyssop, Mint, Motherworth, Marjoram. Smith, p:ge 335, Big.ed.

6. Plants with componal flowers rarely poisonous. As Sunflower, Dandelion, Lettuce, Burdock. Milne.

\section{Poisonnus Plants.}

1. Plants with 5 stamcns and one pistil, with a dull-ccl. oured hurid corol, ard of a nauseous sickly smell, always poisonous. As Tobacco, Thorn-apple, Henbane, Nightshade. The degree of poison is diminished where the flower is briginter coloured and the smell is less nauseous. As potatoes are less poisonous, though of the same genus with nightshade. Smith, page 320, Big: ed.

2. Umbelliferous plants of the aquatic kind and a nause. ous scent are always poisonous. As Water-hemlock, Cowparsley. But if the smell is pleasant and they grow in dry land, they are not poisonous. As Fenuel, Dill, Coriander, Sweet-cicily. Smith, page 322, Big. ed.

3. Plants with labiate corols, and seeds in capsules, fre. quently poisonous. As Snap-dragon, Fos-glore. 
4. Plants, from which issues a milky juice on being broken, are poisonous, unless they bear conipound flowers. As Milk. weed, Dogbane. Milne's Contortr and Lactescentia.

5. Plants having any appendnge to the calyx or corol, and eight or more stamens, generally poisonous. As Columbine, Nasturtion. Linneus.

The most greneral rule is,

Plants with few stamens, not frequently poisonous, except the number be five; but if the number be 12 or more, and the smell nuser:us, heary and sickly, the plants are generally poisonous. Milne's Multisiliqua and Sapor.

Note. Many plants possess some ciegree of the rarcotic principle, which are still by no means hurtful. But the use of such plunts is to be deferred, till fully investigated. 


\section{NATURAL ORDERS OF JUSSIEU.}

The Linnean artificial arrangement is the only system Jitherto brought into use by which we are enabled to find out a plant with which we are unacquainted. But after we have determined a plant by the aid of that system, we should proceed to examine its affinities or relations to other plants.

In the annexed arrangement, Jussieu has distributed all plants into 100 orders, according to their natural affinities. If we are acquainted with any plant in an order, we may infer something from that respecting the qualities of the whole order. Therefore, when we arc analyzing a plant, and suppose we have hit upon the right genus, we should turn to its natural order, as referred to by the second number at the end of the generic description, and see whether it is there associated with any plants with which we are acquainted. Then, by comparing it with its associates, we may not only be considerably aided in settling our opinion respecting the right naming of the plant, but may derire much satisfaction from considering its affinities to the rest of that family of plants.

1st Dirrsios. Seedo without iobes or cotyledons.

1. Fusar. All fungusses.

Agricus, 117. Merulius, 11\%. Moletus, 117. Thaelac. phora, 117. Hỵdnum, 117. Morellus, 118. Clavaria, 118. Clathrus, 118. Peziza, 118. Cyathus, 118. Lycoperdon, 118. Fuligo, 118. Stemonitis, 118. Acidium, 118. Sphaeria, 118. Sclerotium, 118. Uredo, 118. Tubercularia, 119. Mucor, 119. Monila, 119. Xylostroma, 119.

2. AxG.E. Lichens and Seaweeds.

Fucus, 110. Ulva, 110. Conferva, 111. Lepraira, 111. Spiloma, 111. Variolaria, 112. Opegraphia, 112. Lecidea. 112. Calicium, 112. Gyrophor:, 113. Bathelium, 113. Verrucaria, 113. Endocarpon, 113. Thelotrema, 113 splaejuphhoron, 114. Urceolaria, 114. Isidium 114. Parmelia, 115. 


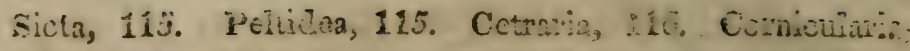
116. Usnea, 116. Sterccialon, 11\%. Bnemyces, 11\%

\section{IERATICAE. LiverTworts}

Jungermanili, 109, Marchntin, 10s, Anthoceros, 110. Riccia, 110,

\section{Mitsca. Mrosses.}

Phascum, 106. Sphagnum, 106. Gymnostumum, 10\%. Tetraphis, 106, Splachnuiz, 106. Grimmia, 107. Mas. chalocarpus, 10\%. Dicranum, 10\%. Trichostomum, $10 \%$. Polytrichum, 107. Didymodon, 10\%. Barbula, 107. Di。 phascum, 107. Othotricum, 10\%. Neckera, 108. Timmia, 108. Climacium, 108. Meesia, 108. Leskea, 108. Bar. Cramia, 108. Mnium, 108. Bryum, 108. Hypnum, 108. Fontinalis, 109. Burbaumia, 109. Funaria, 109.

5. Frirces. Ferns.

Acrostichum, 101. Polypodium, 102. Onoclea, 102. Blechnum, 102. Pteris, 102. Vitraia, 102. Asplenium, 102. Scolopendrium, 103. Woodwardia, 103. Adiantum, 103. Aspidium, 103. Dicksonia, 104. Woodsia, 104. Cheilanthus, 104. Schizaea, 104. Osmunda, 104. Ligo. dium, 105. Botrichium, 105. Ophioglossum, 105. Psilo tum, 105. Lycopodium, 105. Equisetum, 106.

6. NAIAdES. Water plants.

Hippuris, 25. Callitriche, 25. Tillaea, 36. Potamoge. Ion, 36. Ruppia, 36. Saururus, 53. Fuvialis, 90. Chara, 90. Najas, 90. Lemna, 90. Podostemum, 90. Ceratophyllum, 93. Myriophillum, 94.

2d. Divisiox. Seeds with a single lobe, or one cotyledon.

7. Aroidez. Indianturnip-like.

Pothos, 35. Orontium, 51. Acorus, 51. Calla,' 94. A. sum, 94 .

8. TYPH及. Cattail-like.

Typha, 91, Sparganium, 91.

9. Cxpenornse. Cyperus-like.

Kyllingia, 28. Schoenus, 28، Rhynchospora, 29. Cyper. 
us, 29. Afutisuln, 59. Dulichium, 29. Sulipus, 29. Eric phorum, 20. Trichophorum, 20. Fuinen, 29. Limnctis. 29. Carze, 91. Scleria, 91.

\section{Grimive The proper grasses.}

Cinn, 55. Aithorantlum, 27. Cenchrus, 29. Orgzop . sis, 30. Panicum, 30. Digitaria, 30, Paspalum, 30. Aris. tida, 30. Stipa, :0. Alopecurus, S0. P':alaris, 30. IIordeum, 30. Rrilium, 30. Agrostic, 30. Sascharım, 81. Muhlenbergia, 31. Leersia, 31. Trichoinan, 31. Phteum, 31. Aira, 31. Elymus, S1. Melicn, 21. Mletsine, 31 Secale, 31. Triticum, S1. Loliun, 32. Atheropogon, 32. Uniola, 32. Briza, 52. Sorghum, 32. Wactj 1is, 32. Poa. 32. Festuca, 32. Eromus, 32. Avena, 32. Arundo, 33. Andropogon, 33. Holcus, 33. Oryza, 51. Zea, 91. Trig. sacum, 91. Coix, 91. Zizania, 93.

11. PALM $刃$. Palm-like.

We have no plants in this order. The cocoanut, \&xc. aro placed here.

12. Asparagi. Asparagus-like.

Dracæena, 50. Asparagus, 50. Convallaria, 51. Meder ola, 52. Trillium, 52. Smilax, 100.

\section{Joxcr. Rush-like,}

Commelina, 28. Leptanthus, 28. Heteranthera, 28. Xyri28. Tradescantia, 48. Juncus, 51. Melanthium, 53. Veratrum, 52. Helonias, 52. Xerophyllum, 52. Scheuchzeria, 52. Triglochin, 53. Alisma, 53. Eriocaulon, 92. Sagittaria, 94.

\section{Lirtacr . Lily.like.}

Erythronium, 50. Lilium, 50. Tulipa, 50. Fritillaria, 51. Uvularia, 51. Asphodelus, 51.

15. Bromelta. Pineapple-like.

Bromelia, 48.

16. Asreonert. Asphodel-like.

Allium, 49. Aletris, 50. Polyanthes, 50. Hyacyintlus, 50. Narthecium, 51. Ornithogalum, 51. Tofielda, 52. 


\section{NARcissi. Daffodil-like.}

Amaryllis, 49. Hypoxis, 49. Galanthus, 49. Nareissus, 49. Pontederia, 49. Hemerocallis, 50.

18. IntDes. Iris-like:

Crocus, 27. Iris, 28. Dilatris, 28. Sisyrinchium, 75.

19. Mus层. Banana-like.

We have no plants of this order. The banana is placed here.

20. CAxxa: Indianreed-liké.

We have no plants of this order. The ginger is placed. here.

\section{ORCarden. Orchis.like.}

Orchis, 88. Limmodorum, 89. Satyrium, 89. Neottia. 39. Epipactis, 89. Cimbidium, 89. Malaxis, 89. Arethu'sa, 89. Cypridium, 89.

22. Hтdzoerariprs. Frogbit-like.

Proserpinca, 33. Floerkea, 49. Sarracenia, 64. Nym. phaea, 64. Nuphar, 65. Vallisneria, 97.

3d Drrisios. Seeda suith truo lobes, or iwo cotyledons.

23. Anistozocuiz. Birthwort-like.

Asarum, 60. Aristolochia, 90.

24. FLLEAgXt.

Thesium, 43. Hippophae, 98. Nyssa, 99.

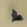

\section{TнXMELEx.}

Dirca, 54. Daphne, 54.

26. Рлотед. Silvertree-like.

We have no plants of this order. The silvertree is plac: ed here.

27. Ladri. Camphor-like.

Laurus, 55.

28. Poltgonez. Buckwheat.like;

Rumex, 53. Polygonum, 55. Rheum, 55. Lapaihum, 100. 
129. Atriplices. Orache-like.

Salicornia, 25. Blitum, 25. Rivina, 36. Salsola, 44. Chenopodium, 44. Beta, 44. Atriplex, 44. Spinacia, 99. Acnida, 99. Phytolacca, 60.

30. Amaratтит. Cockscomb-like.

Gomphrenia, 42. Celosia, 42. Illecebrum, 42. Ama. ranthus, 93.

31. Praxtagixes. Plantain-like.

Plantago, 34.

32. Nrctagixis.

Mirabilis, 41. Ambrosia, 93.

33. Pluaragives. Leadwort-like.

Statice, 48.

34. Lrsmacme: Loosestrife-like.

Utricularia, 26. Anagallis, 38. Lysimachia, 38. Do. ecatheon, 38. Menyanthes, 38. Villarsia, 38. Primula, 38. IIottonia, 38. Samolus, 40. Trientalis, 53. Buchnera, 72.

35. Pedxcurares. Lousewort-like.

Teronica, 26. Callistaclia, 26. Obolaria, 70. Orobanclie, 71. Bartsia, 71. Rhinanthus, 71. Euphrasia, 71. Melampyrum, 71. Erinus, 72. Pedicularis, 72. Pentstemon, 73.

36. Aсыгтнr. Bearbreach-like.

Justicia, 26. Ruellia, 72.

37. Jisarxez. Jasmine-like.

Jasminum, 25. Ligustrum, 26. Chionanthus, 26. Syringa, 26. Fraxinus, 98.

38. Vrrices. Chastetwee-like.

Callicarpa, 34.

39. Liвгіт.. Rigent-flowered plants.

Lycopus, 26. Monarda, 27. Ilosmarinus, 27. Salvia, 2\%.

$\mathrm{Bb} \cong$ 
Collinsonia, 27. Teucrium, 67. Isanthus, 68. Verbina, 68. Lavandula, 68. Lameum, 68. Brachystemum, 68. Pycnantheum, 68. Nepeta, 68. Hyssopus, 68. Mentha, 68: Stachys, 68. Galeopsis, 69. Satureja, 69. Betonica, 69. ILeonuris, 69. Marrubium, 69. Ballota, 69. Cunila, 69. Hedeoma, 69. Gleshoma, 69. Melissa, 69. Trichostema, 69. Ocymum, 70. Scutellaria, 70. Origanum, 79. Thy. snus, 70. Clinopodium, 70. Prunella, 70. Phryma, 70.

40. Scrophularis. Figwort-like.

Gratiola, 26. Chironia, 39. Lindernia, 26. Dracocephalum, 70. Scwalbea, 71. Limosella, 71. Zapania, 71. Browallia, 71. Scrophularia, 71. Antirrhinum, 72. Gerardia, 72. Degitalis, 72. Mimulus, 72: Chelone, 72.

41. Solane玉. Nightshade-like:

Lycium, 34. Datura, 38. Nicotiana, 38. Verbascum; 39. Atropa, 39. Phacelia, 39. Hyoscyamus, 39. Solanum, 40. Physalis, 40. Capsicum, 40. Diospyros, 100.

42. Boraginez. Borage-like.

Pulmonaria, 36. Cerinthe, 36. Lithospermum, 36. Cynoglossum, 37. Batschia, 37. Anchusa, 37. Myosotis, 37. Heliotropium, 37. Onosmodium, 37. Barage, 37. Symphitum, 37. Echium, 37. Hydrophillum, 37. Nolana, 38.

43. Coxvolvurr. Bindweed-like.

Convolvulus, 38. Diapensia, 39. Ipomaea, 39. Pyxidan. ihera, 39. Cuscuta, 43.

44. Polemonta. Greekralerian-like.

Phlox, 39. Polemonium, 39.

45. Bignoniz. Trumpetflower-like.

Eatlapa, 26. Bignonia, 72. Martynia, 73.

46. Gexinisi. Gentian-like.

Epigelia, 38. Swertia, 43. Gentiana, 43. Frascra, 34.

47. Apoctives.: Dogbane-like.

Vinca, 40. Periploca, 43. Apocynum, 43. Nerium, 43. Asclepias, 89. Cynanchum, 90. 
48. Sayota:

We have no plants of this order.

49. Guaracaxæ. Lignumvitx-like.

We have no plants of this order. The lignum-ritx is placed here.

50. Ruovodexdra. Rosebay-like.

Azalia, 40. Itea, 42. Menziesia, 54. Rhodora, 56. Rluododendron, 57. Kalmia, 57. Ledum, 57. Leiophyllum, 57.

\section{Erice. Heath-like.}

Orycocceus, 53. Erica, 54. Clethra, 56. Pyrola, 56: Chimaphila, 56. Andromeda, 57. Vaccinium, 57. Epi. gaea, 57. Gualtheria, 57. Arbutus, 57. Iundsonia, 6n. Empetrum, 98.

52. Campayulace. Bellfower-like.

Campanula, 41. Lobelia, 41.

53. Cichonaczre. (Compound.) Endive-like.

Tragopogon, 81. Apargia, 82. Leontodon, 82. Prenan. tiles, 82. Lactuca, 82. Hieracium, 82. Sonchus, 82. Hyoseris, 82. Krigia, 83. Cichorium, 83.

51. Crxarocepuaz. (Compound.) Bearing headform flowers,

Cynara, 82. Liatris, 83. Cnicus, 83. Carthamus, 83. Onopordun, 83. Carduus, 83. Arctium, 83.

55. Conтмангne. (Compound.) Corymb-bearing.

Scorzonera, 82. Picris, 83. Tolpis, 83. Scholymus, 83. Ternonia, 83. Sparganophorus, 84. Bidens, 84. Kuhnia, 84. Eupatorium, 84. Ethulia, 84. Mikania, 84. Cacalia, 84. Balsamita, 84. Baccharis, 84. Cunyza, 85. Gnaphalium, 85. Artemisia, 85 Tanacetum, 85 Chrysanthemum, 85. Zinnia, 85. Tagetes, 85. Bellis, 85. Pyrethrum, 85. Arnica, 86. Doronicum, 86. Inula, 86 Erigeron, 86. Solidigo, 86 Senecio, 86. Tussillago, 86. Cineraria, 86. Aster, 86. IL liopsis, 86. Buplithamum, 8т. 
IJeelenium, 87. Boltonia, 87. Matricaria, 87. Anthemis, 87. Achillea, 87. Verbesina, 87. Rudbeckia, 87. Helianthus, 87. Coreopsis, 88. Centaurea, 88. Silphium, 88. Polymnia, 88. Calendula, 88. Iva, 88. Elephantopos, 88. Echinops, 88.

56. Drpsacez. Teazel-like.

Valeriana, 27. Fedia, 27. Dipsacus, 35.

57. Rubracex. Madder-like.

Houstonia, 34. Mitchella, 34. Cephalanthus, 34. Rubia; 35. Scabiosa, 35. Galium, 35.

58. Capnifolta. Honeysuckle-like.

Linnaea, 34. Cornus, 35. Lonicera, 40. Xylosteum, 40. Die!'villa, 41. Hedera, 42. Viburnum, 47. Sambucus, 47. Triosteum, 41

59. Ararr 4s. Spikenard-like.

Panax, 44. Aralia, 48.

60. UMafiferz. Bearing umbels.

Eryngum, 44. Coriandrum, 45. Hyclrocotile, 45. Sanicula, 45. Heracleum, 45. Caucalis, 45. Daucus, 45. Angelica, 45. Sison, 45. Ferula, 45. Ligusticum, 45. Ammi, 45. Sium, 46. Selinum, 46. Conium, 46. Chae. rophyllum, 46. Myrrhis, 46. Cicuta, 46. Imperatoria, 46. Smyrnium, 46. Pastinaca, 46. Anethum, 46. $\Lambda$ pium, 47. Carum, 47.

61. Raxuxcurace. Crowfoot-liké.

Zanthorhiza, 48. Actaea, 46. Podophyllum, 64. Paconia, 65. Delphinium, 65. Aconitum, 65. Aquilegia, 65. Nigella, 66. Hydrastris, 66 . Clematis, 66. 'Thalictrum, 66. Helleborus, 66. Coptis, 66. Caltha, 66. Anemone, 66. Hydropeltis, 66. IIepatica, 66. Nelumbium, 67. Ranuncuius, 67. Trollius, 67. Atragene, 67. Adonis, 67. Caulophyllum, 48.

62. Papatemaceir. Poppy-like.

Chclidonium, 63. Papayer, 64. Sanguinaria, E4. Ar. 
gemone, 65. Cimicifuga, 65. Fumaria, 77. Corydalis, 78. Polygala, 78.

63. CrectFerz. Bearing cruciform flowers.

Myagrum, 73. Draba, 73. Lunaria, 73. Bunias, 73. Isatis, 73. Alyssum, 73. Cochlearia, 74. Iberis, 74. Lepidium, 74. Thlaspi, 74. Arabis, 74. Turritis, 74. Dentaria, 74. Hesperis, 74. Erysimum, 74. Brassica, 75. Raphanus, 75. Cheiranthus, 75. Cardamine, 75. Sisym. brium, 75 . Sinapis, 75 .

64. Cippanidrs. Caperbush-like.

Parnassia, 47. Drosera, 48. Cleome, 49. Reseda, 61. Capparis, 64 .

65. SAPINDI. Soapberry-like.

Cardiospermum, 55 .

66. Acend M, Maple-like.

Esculus; 53. Acer, 54.

\section{MALPIGHIR.}

We hare no plants of this order.

68. HYPERICA. John's wort-like.

Ascyrum, 64. Hypericum, 65.

69. GutTIFen及. Bearing secreted drops.

We have no plants of this order. 70. Aurasta. Orange-like.

Citrus, 64 .

71. Meita. Beadtree-like.

Melia, 56. Thea, 64 .

72. Vites. Grape-like.

Vitis, 41. Ampelopsis, 42.

73. Geraxis. Cranebill-like.

Impatiens, 42. Linum, 48. Tropoeolum, 55. Dionaes, 57. Oxalis, 59. Erodium, 76. Pelagonium, 76. Geranium, 76 .

74. Martacez. Mallows-like.

Gordonia, 76. Nàpaea, 77. Sida, 77. Hibiscus, 77. Malra, 77. Althaea, 77. Lavatera, 77. Gossipium, 77. 
75. Magnourz. Magnolia-like,

Liriodendron, 67. Magnolia, 67.

76. Axvoxes. Papaw-like.

Annona, 66. Porcelia, 67.

77. Mevisperma. Moonseed-like.

- Menispermum, 100.

78. Bernerrdes. Barberry-like.

Mamamelis, 36. Berberris, 48.

79. Trumacede. Basswood-like.

Tilia, 64.

80. Cistr. Rockrose-like.

Viola, 42. Cistus 64 .

Ruta, 56.

81. Rutaces. Rue-like.

82. Carynphyllez. Pink-like.

Holosteum, 33. Lechea, 33. Mollugo, 33. Queria, 33. Sagina, 36. Sarothra, 47. Alsine, 47. Dianthus, 58. S2. ponaria, 58. Arenaria, 58. Stellaria, 59. Silene, 59. Cucubalus, 59. Spergula, 59. Agrostemma, 59. Cerastium, 60. Lychnis, 60 .

83. Sexpertiv 1. Liveforevor-like.

Sedum, 59. Penthorum, 59. Sempervivum, 61.

84. Saxifraga. Saxifrage-like.

IIeuchera, 44. Oldenlandia, 35. Saxifraga, 58. Tiarella, 58. Mitella, 58 .

85. Cactr. Pricklypear-like.

Ribes, 42. Hydrangea, 58. Hortensia, 59. Cactus, 62.

86. Pontulacceiz. Purslane-like.

Claytonia, 42. Tamaris, 47. Chrysosplenium, 55. Sclesanthus, 58. Portulacca, 60.

$$
\text { 87. Frcoidea. Fig-like. }
$$

Mesembryanthemum, 63. Ficus, 98.

88. ONAGRE.

Circaea, 27. Ludwigia, 35. Gaura, 53. Epilobium, 54. Enothera, 54. 
89. Mrrir. Myrtle-like.

Decumaria, 60. Philadelphus, 61. Mystus, 62.

90. Melastoma.

Rhexia, 54. Melastoma, 56 .

91. Salicaniæ.

Ammannia, 35. Isnardia, 35. Glaux, 43. Lythrum, 60. Cuphea, 60.

\section{Rogacez. Rose-like.}

Sanguisorba, 34. Agrimonia, 61. Prunus, 61. Armeniaca, 61. Punica, 62. Amygdalus, 62. Crataegus, 62. Sorbus, 62. Aronia, 62. Mespilus, 62. Pyrus, 62. Spiraea, 62.- Rosa, 63. Rubus, 63. Dalibarda, 63. Fragaria, 63. Potentilla, 63. Geum, 63. Comarum, 63. Calycanthus, 63. Poterium, 94.

93. Legcmross. Bearing legumes.

Podalyria, 56. Cercis, 56. Cassia, 56. Mimosa, 76. Petalostemon, 77. Amorpha, 78. Lupinus, 78. Crotolaria, 78. Genista, 78. Spartium, 78. Arachis, 78. Ulex, 78. Pisum, 79. Lathyrus, 79. Vicia, $79 . \quad$ Robinia, 79. Phascolus, 79. Dolichos, 79. Colutea, 79. Glycyrrhiza, 79. Indigofera. 79. Vexillario, 80. Galactia, 80. Gly. rine, 80. Galega, 80. Medicago, 80. Trigonella, 80. Astragalus, 80. Trifolium, 80. Melilotus, 80. Lespede. za, 81. Hedysarum, 81. Stylosanthes, 81. Eschynomene, 81. Geditschia, 100.

\section{TEREBISTET.}

Rhus, 47. Juglans, 94. Zanthoxylum, 99.

95. Rнампт. Buckthorn-like.

nex, 36. Rhamnus, 41. Ceanothus, 41. Celastrus, 6!. Euonymus, 41. Staphylea, 47. Prinos, 49.

96. Euphoraie. Spurge-like.

Euphorbia, 61. Esula, 61. Buxus, 93. Acalypha, 95 , Ricinus, 26. Phyllanthus, 96. 


\section{Cucunaracez. Pumpkin-like.}

Passifora, 76. Momordica, 97. Sycios, 97. Cucurbita, 97. Cucumis, 97. Melothria, 97.

98. UnTic屈. Nettle.like.

Boehmeria, 92. Urtica, 92. Parietaria, 92. Morus, 92. Serpicula, 93. Humulus, 99. Canabis, 99.

99. Amextaceø. Bearing pendant aments.

Ulmus, 44. Celtis, 44. Fothergilla, 65. Comptonia, 92. Alnus, 92. Quercus, 94. Fagus, 95. Castanea, 95. Betula, 95. Carpinus, 95. Ostrya, 95. Corylus, 95. Platanus, 95. Liquidambar, 95. Salix, 97. Myrica, 98. Broussonetia, 93. Populus, 100.

100. Conifere. Bearing strobiles, or cones.

Pinus, 96. Cupressus, 96. Thuja, 96. Juniperus, 101. Taxus, 101. 


\section{SYSTEM OF GENERA,}

FOR TIE

\section{NORTHERN AND MIDDLE}

\section{STATES.}

\section{$\rightarrow+$ \\ CLASS I. MONANDRIA. \\ Order I. Monogyni.}

Sarrcorvia. Calyx inflated, entire : corol o: seed 1, inclosed in the calyx. 12. 25-(samphire.)

Hrperras. Calyx superior, obsolete, with a O-lubed margin : corol o : seed 1 : stigma sinple. 15. 6-(marestail.)

* Scirpus, Cyperus.

\section{Order II. Drgynia.}

Culutrache. Calyx inferior, 2-leaved : capsule membranareons and margined: (flowers sometimes monoccious, and by some the calyx is called the corol.) 12. 6-(water-starwort.)

Burtc . Calyx 3-cleft, berry-like : corol o : seed 1. 12. 29-(blite.)

Cirsx. Calyx, 1-flowered glume, 2-valved: corol a 2 -ralveri glume : seed 1. 4. 10.

* Uniola.

\section{CLASS II. DIANDRIA.}

Order I. Moyogrnia.

1. Corol inferior, 1-retalled regular : borler, except in Jasminum, 4-parted.

Jasmaxu, Copol salver-foim, is to s-cleft : berry 2-seede!, earh secel solitary, ariled. 44. 37-(jasmine.) Exotic. 
Ligestrem. Calyx 4-toothed : corol with orate divisions : berry 4-seeled. 44.5\%-(prim.)

Cinonaxturs. Corol 4 -cleft, with very long divisions: nucleus of the drupe striate-fibrous. 44. $3 \%$-(fringe tree.)

Syrixga. Corol salver-form : capsule 2-celled. 44. 5\%-(lilac.) Exotic.

B. Corol inferior, 1-petalled, irregular : fruit cupsular.

Lirricturid. Calyx 2-leared, equal : corol ringent, spurred : capsule 1-celled, globular. 24. 34-(bladder-wort.)

Catalua. Corol 5-cleft : calyx 2 -leaved : capsule 2-celled. 40.45-(catalpa tree.)

Justicr.. Calyx simple or double, 5-parted: corol ringent or nically erqual : capstile 2 -celled, bursting with an elastic claw : partitions transverse. 40.56-(malabar nut.) Exutic.

Gratrola. Calyx s-leaved, sometimes with a 2-leaved calycle : corol 4-cleft, 2-lipped, reversed: stamens 4 : ( 2 of them barren) stigma 2 lipped : capsule 2-celled. 40.40. (hiedge-hysops.)

Lrvoervi. Calyx 5-parted, equal : corol ringent, the upper lip rery short, the lower one $3-$ clett, 2-keeled at the base : anthers cohering by pairs : stigma bilamellate : capsule 2-celled, 2ralved, the partition parallel to the ralres. 40.

Veronica. Calyx 4-parted : corol 4-cleft, lower division smaller : capstile 2 -celled. 40. 35 -(speerlwell.)

Callistacmi. Caly x 4-parted : corol tuljular, 4-cleft, with one divisin smaller: capsule orate, 2-celled. (Culver's physic.) This genus was taken from the Veronica by M. Ratinesque. Not having his generic description, I am compelled to take it from my specinens ; perhaps inaccurately. 40.35 .

C. Corol inferior, 1-petallen, irregular": seeds na-
liel.

Lrcopus. Calyx tibular, half 5-cleft: corol 


\section{CLASS III. ORDER I.}

tubular, 4-cleft, nearly erual, 1 division cmarghinate: stamens distant: seeds 4, retuse. 42. 39(water-horehound.)

Movarna. Calyx cylindric, striated, 5-tonthed : corol ringent, upper lip linear, involving the filaments. 42.39-(10swrge t(ai, momtain-mint.)

Rosuanixes. Corol ringent, mper lip a-parted : filaments long, curved, simple, with a tooth. 42. 39-(roscmary.)

Sonvra. Calyx tubular. 2-lipped, underlip otoothed : corol ringent: filamevits transwersely aflixed to a pedicel. 42. 39-(siace.)

Coularsosu. Calyx tubulat, o-lipped: corol mequal, underlip masy-cleft, (appilia'y : one perfect seed. $\frac{10}{20} 39$-(hriese-balm.)

\section{Corol superior.}

Circara. Calyx \&-leaved: corol e-petallerl: capsule hispiel, 2 -celled. not gaping ; cells 1 -sceded. 48. 88-(cnchanter"s nightsiande.)

* C'unila, Schoemus, Scirpus, Verbena.

\section{Order II. Digreit.}

Axtroxuxwry. Calyx, glume 2-ralved,'1flowered : corol gilume 2-ralred, anuminate, awnod : seerl 1. 4. 10-(sweet remal grass.)

* Holcus, Festuca, Saccham.

\section{CLASS III. TRIANDRIA.}

\section{Order I. Monogyni.}

\section{A. Flower's simerior.}

Varmona. Calyx 0, or with an extremely small matgin: colol 1-potalled, 5-rleft, base gitibous : seed 1 : stamens, $1,2,3$ ani 4, crsert. 48 . 56-(valerian.) Exotic.

Fevra. Calyx 3 to 6 -toothes : coirol s-parted: ntit 2 or 3 -ccl!ed: sood naked, or crowned with a tooth. 48.56-(lami-lettice.)

Croces, Spathe ralicail corol fumel-form, 
with a long slender tube : stigma deep-gashed, crested. 6.18-(saffron.) Exotic.

IRrs. Calyx, spathe 2-valved : corol 6-parted, dirisions alternately reflected : stigmas petallike. 6. 18-(flower-de-luce, iris or flag:)

Dilatris. Corol 6-petalled, superior, hirsute: the third filament less t'ian the rest : stigma simple: capsule globose, s-celled, crowned.

\section{B. Flower's inferior.}

Covmexrra. Calyx, spathe cordate: corol 6petalled : nectaries 3 , cross-form, inserted on peculiar filaments : capsule sub-globose, 3-celled. 6. 13-(day-flower.)

Leptintuds. Calyx, spathe 1-flowered: corol long-tubular; border 6-parted with the stamens on the divisions, anthers uniform, filaments equal : capsule S-celled, many-seeded, gaping at the angles. 6. 13.

Heteranthera. Calyx, spathe 1-flowered : corol with a long slender tube, border 6 -parted with the stamens on the divisions; anthers of two different forms, filaments of unerual lengths : capsules 3-celled, many seeded, dehiscent at the angles. 6.15-(odd shives.)

XYRIs. Calyx, glume 2-ralved, in a head : corol 3-petalled, equal, crenate : capsule 3-valved, many secled. 6. 13-(yellow-eyed-grass.)

C. Flowers grassy : valies of the calyx glumelike: corol none.

Fruturgi.. Spilie (or ament) roundish-oblong, sessile, or umbel-iike : calyx of 2 mequal leaves or valves, 1-flowered : corol 2-ralved, or 2 leaved, greater than the calyx : seed 3-sided. (stemens and stigmas vary from 1 to 3.) 3. 9(false bog-rush.)

Scrosves. Spikelets sub-convolute, acute; scales heaped in fascicles, outer ones dry, shining: comol 0 : seed 1 , roundish, naked or surrounded with bristles. 3. 9-(bog-rush.) 
Rurnchospona. Scales of the calyx fascicled into a spike, lower ones empty : corol 0 : stsles permanent at the base : bristles at the base of the seeds. 3. 9.

Cypents. Glumes chaffy, scales imbricated 2-ways : seed single, beardless : spikelets compressed. 3. 9.

Maniscus. Flowers distinct, subimbricate in a spike : calyx 2 -ralved, about 3 -flowered : corols 2 -ralred, the lower one embracing the upper: style 3-cleft. 3. 9.

Dumcrum. Spikes sub-raccmed, proceeding from the axils of the leaves; spikclets lincarlanceolate, sub-compressed : scales somewhat $\Omega-$ ranked, closely cmbracing: styles very long, aclelt : germ with small bristles rough backwards. 5. 9-(galing:ale.)

Scripes. Glumes chaffy, scales imbricated every way : sced single, naked, surrounded witi hairs of bristles. S. 9 -(club-rush.)

Erropronum. Glume chaffy, imbricated erery ray : seed beset round with rery long dense wotily hairs. 3. 9-(cotton-greass.).

Thichopronum. Calyx, scales imbricated evcry way : seed beset with capillary bristles, which at length project out, always 6 in number : spikelets ovatish. 3. $9-$ (light-hair.)

Furexi. Scales of the calyx mucronate, erery where imbricate in a spike : seed broad-inrolucred, chaff-like, often awned. 3. 9.

D. Flowers grassy: valves of the calyx glumelitie: corol 2-valved.

Lrunferss. Calyx ¿-valued compressed, one of them kecled and longer than the other: corol 2-ralved. 3. 9-(silt girass.)

Cexcmes. Invilucre divided, echinate, 3 or 4-flowered: glumes i-ralrel, 2-fiowered : corol 2-valied, awiless : style 2 -cleft, 4, 10-(hedge. hog-grass.)

*uncus, Galium. 


\section{Order II. Digymia.}

\section{The proper Grasses.}

\section{A. Flowers perfect.}

1st. Glume 1-flowered.

ORYzopsis. Calyx 2-valved, lax, oborate : corol teretish-orate, leathcry : valves 2 , outer one awned at the apex: appendages 2, linear, chaffy. 4. 10-(mountain-rice.)

Puivicur. Calyx s-ralved, the third ralre dor'sal and rery minute : corol 2-ralred : inflorescence various. 4. 10-(coclifoot grass, panicgrass.)

Digitina. Calyx 2 or s-ralred, concave; the outer one very shall or none, the imnost one of the length of the corol : corrol 2-Talved, oblongorate, awnless: style very long: spikes cligitate, limear: flowers in pairs. 4. 10-(finger-grass.)

Paspatem. Calyx d-ralred, valves roundish, of the form of the corol: llowers unilateral. 4.10 -(paspalon.)

Arrstina. Calyx 2-Talued : corol 1-ralved, with 3 awns at the tip. 4. 10-(beard-grass.)

STIP.A. Calyx 2-valred: corel 2-valved : valses involute truicate; awn terminal, very long, twisted at the base. 4. 10-(feather-grass.)

Alopecrrus. Calyx 2 -ralved : corol 1-ralred, simple at the tip; sometimes awned at the base. 4. 10-(foxtail-grass.)

Phaldris. Calyx 2-ralred, valves keeled, nerved, equal in length, including the a-ralied pilose corol. 4. 10-(ribbon-grass, canary-giass.)

Hordecr. Calyx laterail, 2-ralred, 1 or 2 flowered ; florets in threes, the middle one scssile, lateral ones often barren : corol 2-ralved, acute, outer valve awned. 4. 10-(barley.)

Minicm. Calyx 2-valved, 1-fiowered, rentricose : corol 2-ralived, very short: stigmas penciliorm. 4. 10-(millet.)

Agiostis. Calyx 2-ralved; 1-flowercel, valves 


\section{CIASS IIT. ORDFR II. 3I}

acute : corol 2-ralved : stigmas longitudinally lispirl or plumose, florets spreading. 4. 10-(redtop.)

Saccuarear. Calyx insoluceded with long wool, Q-ralved: corol 1 or 2 -ralved: stigmas 1 to 3. 4.10-(sugar-cane.) Exotic.

Mumenibria. Calyx 1 or 2 -valved, very minute : corol 2-ralyed, base hairy, outer valve awned at the tip : seed 1, oblong acuminate : flower's panicled. 4. 10-(dropseced grass.)

LeErsia. Calyx 0 : corol 2-valued, closed; valves compresseil, boatlorm, awnless. 4. 10. - (cut-grass.)

'ínchonex. Calyx ¿-ralred, valves nearly equal, acute; keel with small spines: corol 1 valved, awnless, shorter than calyx : stigmas nearly sessile, sub-hispid. I'anicled. 4. 10(thin-grass.)

Prinevar. Calyx indurated, 2-ralred, sessile, linear, truncate, bicuspidate : corol inclosed. 4. 10-(timothy-grass.)

¿d. Glumes 2 or s-flowered ; panicled.

Arra. Calyx glossy, ¿-ralyed, 2-flowered : corol ¿-ralved, awnless, or awned at the base. 4. 10-(hair-grass.)

sd. Glumes 2-flowered or more; close-spiked.

Elrmes. General calyx inrolucre-like, gencrally 4-leared, 2-spiked or with spikelets in pairs; partial calyx lateral, 2-valved, many-Howered. 4. 10-(lime-grass, wild rye.)

Melica. Calyx ¿-ralred, coloured, obtuse: corol a-valved, ventricose, with the rudiment of a third among the flowers. 4. 10-(nclic-grass.)

Eleusine. Calyx awnless, many-flowered: inflorescence an unilateral digitate sjilie : corol 9-ralred, awnless. 4. 10-(dog-tail-grass.)

Secale. Calyx o-valved, 己 or many-flowered, opposite, solitary : olumes linear-lanceolate, smooth or channelled both sides. 4. 10-(rye.) Exotic.

Triticer. Calyx z-ralyed, about 3 -flowered, 
altermate ; florets obtusish and pointed : glumes beardless or interruptecily bearded : spikelets shortish. 4. 10-(wheat.)

Lourum. Calyx 1-leafer, permanent, manyflowered : florets in a 2-rowed simple spike. 4. 10-(darnel-grass.)

Athenopogon. Calyx 1-valved, 2-flowered: corol 2-ralved, awned. ¿. 10-(hairy-beard.)

4th. Glumes many-flowered; in panicles.

UNIOLA. Spikelets flat, 2-erlged, ovate: calyx many-glumed : corol 2-ralved, awnless, imner one smallest: stamens 1 to 3 : appendages 2 , somewhat 2-horned. 4. 10-(sea-rush-grass.)

Buz.. Calyx 2-valved, many-flowered : spikelets of the panicle $2-1 \times n k c i$ : valvelets inflated, heart-form, obtuse ; inner one minute. 4. 10(quake-grass.)

Sorghum. Polygamous. Florets in pairs; one perfect and sessile, the otlier staminate or neutral and pedicilled. 4. 10-(broom-corn.) Exotic.

DACryzrs. Calyx 2-ralred, one valre smaller : corol 2-valved, awnless, compressed, carinate : style long : panicles strait; spikclets imbricate with lateral florets. 4. 10-(orchardgrass.)

1'os. Calyx 2-valved, many-ffowered : corol orate; ralves 2-coloured, acutish, scarious at their nargins: spikelcts of the panicle orate, atuless. 4.10-(meadow-grass, blue-grass.)

Festeca. Calyx 2-ralved, many-flowered ; spikelets oblong, teretish, or diverging ; awnless or furnished widh a terminal awn. 4. 10-(fescuegrass.)

Frunes. Calyx 2-valied; spikelets oblong, ferete-2-ranked; ralres awned below the tip. 4. 10-(chess, broom-grass.)

Arexs. Calyx 2-ralved, many-fowered; ralres with a twisted awn on the back: glumes membranaccous and somewhat follicle-like. 4. 10 -(oats.) 


\section{CLASS III. ORDER III.}

Aruxno. Calyx \&-ralved, one or many-flowered, glalorous : florets heaped together: corol surrounded with wool. 4.10-(reed-grass.)

\section{B. Florver's polygamous.}

1st. Glume 1-flowered.

Axpropogox. Calyx, glume 2-ralied: corol s-valved : flowers in pairs; 1 sessile preflect ; the other peduncled, staminate, awnless-rarely neutral. 4.10-(beardgrass.)

\section{2d. Glume ¿-flowered, or more. Panicled.}

Hoxcus. Calyx, glume ¿-valved, opake, nervous : corol smaller than calyx, 2-vaired, the outcr one awned under the tip: nectary linear $\approx$ parted : stigma subsessile. 4.10-(soit-grass.)

* Alsine.

\section{Order III. Trigyui.}

\section{A. Corol 5-petalled.}

HoLosters. Calyx 5-leaved : capsule 1-celled, nearly cylindric, bursting at the top. 22. 82 -(succulent chickweed.)

\section{B. Corol s-petalled.}

Lechea. Calyx s-leaved: capsule s-celled, 3-ralved, with 3 inner valrelets : seed 1. 22. S2 -(pinweed.)

\section{Corol none.}

Moltego. Calyx 5-leaved, inferior: capsule S-celled, S-valved, many-sceded. 2:. 82-(calpet-weed.)

Qrerra. Calyx 5-leaved, inferior: capsule 1-crlled : seed 1. 22. 82-(fork chickweed.)

Proserpixaca. Calyx 3-parted superior: nut s-sided, S-celled, crowned by the calyx. 15. 20(mermaid-weed.)

* Zauthoxylon, Alsine. 


\section{CLASS IV. TETRANDRIA.}

\section{Orner I. Moyogynia.}

A. Flowers 1-petalled, inferior, calyx 4-cleft.

Catilicarpa. Corol 4-cleft, tubular: berry 4seeded. 43. 38-(Bermula mulberry.)

Puantago. Corol 4-cleft reflexed: capsule 2. colled, opening transrerseîy : stamens very long. 54. 31 -(plantain, ribwort.)

Lxcurs. Corol tubular, having the throat closed by the beards of the filaments : berry 2celled, niany-seeded. 38.41 -(box thorn.)

Frasera. Corol 4-cleft, spireaciing; segments with bearded giands in the midrlle : capsule compressed, sub-inargined, 2-ralved : sceds few, imbricated-(pypanid flower.)

Bartoxia. Cornl 4-cleft, bell-form, permanent: capsule 1-celled, 2-ralved, many-seeded(screw-stem.)

Houstoxra. Corol salver-form: capsule 2celied, 2-ralred, 2-sceded. 4\%. 5\%-(Venus?. pride.)

\section{B. Flowers 1-pcilliled, superior.}

Mitcheris. Calyx 4-toothed: copols 2 on each germ, tubuha : berry donble, 4-seeded: stigmas 4. 48. 5\%-(paxtrilge-berry, checlierberry.)

Singursonea. Calyx inferior, 2-leaved : corol superior, 4 parted : capsule between the calyx and corol. 5\%.92-(binnet saxifrage.)

Cepmanandus. Inforescence in a heal : general calyx nene: proper calyx superior: corol funncl-foim : receptacle globular, hairy : capsules 2 to $4-p a r t i b l e:$ sced solitary, oblong. 48 . 57-(button-bush.)

Linnar. Calyx louble: that of the fruit 2 . leared, inferior ; that of the fiower 5-parted : corol bell-furm: stanens somewhat didyamous; berry s-ceiled, dry. 48. 58-(twin-ilover.) 
Ruвra. Calyx t-toothed: corol 4 or 5-cleft, bell-form: berries 2 , one-seeded, (stamens 4-5; leaves stellate.) 47.5\%-madder.) Exotic.

Scabiosa. Common calyx many-leaved; proper one double, superior: receptacle chaffy or naked. (Flowers aggregate.) $47.5 \%$-(scabiosis.) Exotic:

Gisırm. Caiyx 4-tucthed : corol flat: firuit dry : secds 2,10 undish: (leares stellate.) 47.57 -(bedstraw.)

Drpsicus. Commoncalyx many-leaved : proper calyx 1-leaferl superior: receptacle chatfy : seed 1 , crowned : llowers agsiregate. 48.56 - (teasel.)

C. Flocers 4-petalled, inferior.

Ammxna. Calyx tubular. plaited, 8-toothed: petals t, or nome. on the calyx : capssile 4 -celled -(sometimes $\approx$-celled and \&-stamenead.) 17.91(tooth-cup.)

D. Florecrs t-petalled, superior.

Comxrs. Calyx 4-toothed: diupe with a 2 celled nut. Some species have a 4 -leared involucre. 45. 58-(dogwood, false box.)

Lrowrin. Calyx i-parted, the divisions long, permanent : capsule -cornered, 4 -rehled, periorated at the top, many-secder! - (petals sumctimes wanting.) 1\%.88-(sced-box.)

Ounexumun. Corol 4-petalled : calyx 4parted, stukrior: (apsule 己-celled, many-seceicd: columella liree. (Styles $100^{\circ}$.)-(round head.)

\section{E. Flowers not compiete.}

Potuos. Grueral calyx a spathe: perianth o: spadix simple, corered with flowers : petals 4 , wedge-form : berries globose, 2-seeded, indrsed in a sjomgy receptacle. .7 - 7 (skmu-calnbage.)

Isxarain. Calyx bell-form, $\frac{1}{4}$-parted superi-

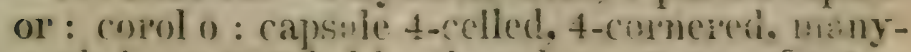
seeded, suroumted by the calyx. 1\%.91-(waterpurslane.) 
Rivrva. Corol 4-petalled, inferinr, permanent : calyx 0 : berry 1 -seeded : seed lenticular, rough, (stamens 4, 8 or 12.) 12.29-(rough seed.) * Convallaria, Cardamines Prinos.

\section{Order II. Digymia.}

Hamamelis. Involucre S-leaved: perianth 4-leaved : petals 4, very ling, linear : nut 2-cellel, 2-horned. 54. 78-(witch hazel.) Flowers in autumn, and perfects its seed the following spring. * Cuscuta, Swertia, Oldenlandia, Gentiana.

\section{Order IV. Tetragynia.}

Itex. Calyx 5-toothed; corol 4-parted, wheel-form ; style o ; berry 4-celled, cells 1-seedel. 43. 95-(holly.) ed.

Rupra. Calyx o : corol o : seculs 4, pedicell.

Sigrna. Calyx 4-leared ; petals 4 ; capsule 4-celled, 4-ralrod, many seeded. 22. 80-(pearlwort.)

Trusias. Calyx 3 or 4 -parted : petals 3 or 4 , erinal : capsules 3 or 4 , two or many-secded. 15. $6 \frac{-}{1}$ (pigmy-weed.)

Pothmogeros. Calyx o: petals 4 : style 0 : sceds 4. 15.6-(pond-iveed.)

\section{CLASS V. PENTANDRIA.}

\section{Order I. Monoginia.}

A. Flowers 1-petalled, inferior; having 4 uated seeds. Rotigh-leaved plants.

Prumoxaria. Calyx prismatic 5-angled : corol fumel-form, with an open throat: seeds roundish, obtuse. 41.42-(ling-wort.)

Cenryme. Limb of the copol tubular, ventricose, throat pervious : nuts two, 2-celled. 41. 42-(honey-wort.) Exotic.

Litrospersuc. Calyx 5-jarted : corol funnel-form, with an open throat: sceils ovate, pointed, stoney : stamens and pistils incloserl. $41.4 \%$ -(stone-seed or gromivell.) 


\section{CLASS V. ORDER I.}

Crocotosstm. Calyx 5-parted : corol fimnol-form. vaulted, throat closed : serds depresscol, allixed latcrally to the style within. 41.42(hound-tongue.)

Bsтscui. Calyx about 5-rleft: comol sal-

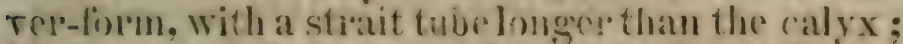
having a bearded ring within at the base ; thinat naked. with romented vlisisions: secels haved and shining. 41. 40-(filse bugloss.)

Axcutsa. Calyx 5-parted : corol funnel-form, raulted, throat clised : seeds marlied at the base, and their surface gencrally reined. $41.40 .-$ (biggloss.) Exotic.

Mrosoris. Calyx half-5-cleft: corol salverform, curved, 5-clefi, railted, throat closerl, the lobes slightly emarginate : seerls smooth or cehinate. 41.40 -(worpinn-g'ass.)

Hrantroprim. Calyx tibtilar, 5-toothed: corol silver-fortir, 5-dedt, with fecth or folds between the divisinns; throat riphn. (Spikes recurved, involute.) 41.4.-(turnsole.)

Orosmonom. Calyx deply 5-parted : corol oblong, somewhat bell-iorm, with the acute divisions converging. the myper part of the corol being rentricose and half-5-cleit, throat open : anthers sessile enclosed : styles exsert. (Slukes revolinte.) 41. 42-(false gromwell.)

Borigo. Comol when-fom, the throat closed with rays. 41.49-(borige.) Exulic.

Srmprerem. Limb, on a? jer pat of the corol, fubular'-swelling, the throat closed with subulate rays. $41.42-($ comfiey.)

Hсинм. Cumbl most ipregular, fluroat naked, large : stigma deft. $41.42-\left(V i r^{\prime} r^{\prime}\right.$ biagloss.)

B. Foreers 1-petalled, inferion : see?'s corered reith a 1-ce!led capsule : calyx 5-panteid or 5-tootheil.

HYDropuYuem. Cosol bell-írm, 5-cleft, with 5 longitudinal honey-bearing groses insiste: calpsale gionose. $2-1$ al ied : stigina 2 -cleit. 41.42 -(water-leat; bur'-flower.) 
Norana. Calyx 5-cleft, divisions broad : corol bell-form : stigma capitate, somewhat 5-angled : secrls 5 : receptacle fleshy, thickening. 41.42. Exotic.

Anagalis. Corol wheel-form, deeply 5-partcd: capsule opening transversely : stamens hairy. 20. 54-(scarlet pimpernel.)

Lxsinachia. Corol wheel-form : capsule globular, 10-valved, mucronate : stigma obtuse.(In some species the filaments are united at the base.) 20. 34-iloose-strife.)

Dodecatuzon. Corol wheel-form, reflexed capsule oblong: stamens on the inside of the tube : stigma obtuse. 20. 34-( (ialse-cowslip.)

Menyantues. Corol hairy : cajsule orate : stigma 2-cleft. 21. 34-(buck bean.)

Fillarsia. Capsule 1-celled, valveless : corol whecl-form ; divisions bearded at the base, margin inflexed. 21. 34-(spir-stem, heart watershield.)

Prinela. Umbellets intulucred : tube of corol cylindric, throat open, divisions of corol emarginate: capsule 1 -celled with a 10-clelt mouth: stigma globular. 21. 34-(jrimrose, cowslip.)

Hottonia. Corol salver-form : stamens un the tube of the corol : stigma globular. 21.34(feather-leaf.)

Differ from the abore in having 2-celled capsules.

Spigelia. Corol funnel-form : twin capsules 4-valred, 2-celled : stigma simple : seeds many. 47. 46-(pink-poot.)

Convolvulus. Corol funnel-form, plaited: stigma 2 -cleft or double : cells of the capsule 2 or 3 ; each 2 seeded. 29.45 -(bind-weed.)

Datura. Calyx tubular, angled, carlucous : corol furnel-form, plaited ; capsule 4-ralved, 4celler, smooth or thomy. 28.41-(thorn-apple.)

Nicotran. Corul fumnel-form, limb plaited : stigima notcherl: stamens inclined: rapsules 2 celled, 2-valved. 28.41-(tobacco.) Exotic. 
Verascers. Corol whecl-form, somewhat irregular : stamens declinerl, hairy : capsules 2celled, 2-ralred; ralves inflexed : many seeded. 28. 41 -(mullein.)

Cinnosia. Calyx somewhat bell-form : corol salver-form or whecl-form : anthers becoming spiral ; filaments on the tube of the corol : pistil declined : pericarp) 4-celled. 20. 40-(centany.)

Atropa. Corol bell-form: stamens distant: berry globular, 2-celled, sitting on the caly $x .28$. $41-$ (deally nightshade. ) Exstic.

Pracelia. Coroi somewhat bell-form, 5 -cleft: stamens exsert : capsule 2-celled, 2-ralred, 4seederl. 41. 42.

Hroscramus. Corol fumnel-form, obtuse, ire regular : stamens inclined : capsule s-relled, covcred with a liil. 28. 41 -(henbane.) Exotic.

Differ from the abore in hawing s-ceiled capsules.

Diapensia. Calyx 5-leaved, imbricated with leafets : corol salver-form; limb liat, 5-cleft: stamens crowning the tulje of the corol : capsule 3-valved, many sected, 21. 43.

Proox. Calyx prismatic : corol salver-form; with a tube somewhat curved : filaments unerial in length : stigmas 3-clefit: capsule 3-celled, 1 seeded. 20. 44-(lichnedia.)

Polemonium. Calyx-half 5-cleft: copol wheclform, 5-parted : stanens on 5 valves ciosing the bottom of the tube : stigma 3-cleft. 29. 44(Greek-valerian.)

IPOAOEA. Corol funnel or bell-form, with 5 plaits : stimma globe-headed, papillose : capstile 2 or 3-celled, many-seeded. 29. 43-(cypress vine, morning glory.)

Pyzidanthera. Wirisions of calyx lying over each other, chafly-membranaceeus : corol bellform, 5-parted : filaments lanellar : celis of anthers opening transwersisly : stigmas 3 ; style thick. 21. 43--(box-flower.) 
Differ from the above in having 5-celled capsules.

Azates. Corol tubulars half-5-cleft, somewhat oblique : stamens on the receptacle; stigma oltuse, usually ending with 5 short papillae. 18. 50-(wild honey-suckle.)

Vract. C'orol salrer-form, twisted, border 5cleft, with oblique divisions; 1h'oat 5-angled : seed naked, oblong : follicles 2, erect, terete, narrow. 30. 47-(periwinkle.)

- Differ from the abore in having 2-celled berries.

Soxarcm. Calyx peimanent : corol bell or wheel-form, 5-lobed, plaited: anthers thickened, with two pores at the top : berry containing many secds. 23. 41-(potatoe, nightshade, bittersweet.)

Pursalis. Corol bell or wheel-form: anthers converging : beries contained in an inflatted calyx : secás muinerous. 28. 41-(winter cherry.)

Carsicrm. Corol whecl-form : berry juiceless : anthers converging: calyx angular. 28. 41-red pepper.) Exotic.

C. Flowers 1-petalled, half inferior : calyx 5-cleft.

Sanours. Corol salver-form, 5-lobed, with intrrmediate scales fencing the stamens between thein ; capssile 1-celled, 5-toothicd ; many seeded. 21. 34--(brookweed.)

D. Fiowers 1-petalled superior : culyx 5-cleft.(stems woody.)

Loxrezra. Corol tubular, 5-cleft, unequal : beary o or 4-colled : seeds many. 48.58-(trumpet honcy-suckle.)

Xrnosteck. Corol tubular, border 5-parted, neaty efiul : berries in pairs, whose bases are conntitc, or single coatumate; 2 -cellod. 48. 58(ily home-suckile, twin-borry.) 
Drervilua. Calyx whomg: corol twice as long as calyx, fumnel-form. border 5 -cleft, spreading: capsite oblong. 4 -relled, many seeded. 48. 58-(bush honey-suckle.)

\section{(Stems not ruoody.)}

Campanula. Corol bell-form, closed at the bottom by valves bearing the stamens: stigma 3 to 5-cicit: capsule 5 to 5-celled, opening by lateral pores. 29. 52--(bell-ilower.)

Lobelia. Corol irregular, often irregularly slitted : anthers cohering and somewhat curred : stigma simple: capsule 2 or 3 -celled : 29. 5:--(cardinal flower, wild tobacco.)

Miradilis. Comol fimmel-forni, coaretate below: calyx inferior: germ between the calyx and corol : stigma globular. 54. 32-(lour o'clock.) Exotic.

Triostevar. Calyx of the length of the corol: corol tubular, 5-lobed : berry 3-celled, 3-seeded. 48. 53-(feverwort, horse ginseng.)

E. Florcers 5-petalled, inferior. (Stems woody.)

Rrimses. Calyx cup-form, 4 or 5-cleft; corol consists of scales fencing in the stamens and inserted on the calyx (sometimes wanting'); stigma cither simple, 2 or 4 -cleft ; berry 3 or 4 sceded: (sometimes polygamous or dioecious.) 45. 95-(buck-thorn, dwarf alder.)

Crancothus. Petals bay-lilie, vaulted, standing in the cup-form calyx ; berry, or capsule dry, 3-grained. 43.95-(New-Jersey tea.)

Cenastru- Calyx flat : corol spreading: capsule S-anglerl, 3-celled, berry-like : stignat 3clclt: soeds calyptred. 43. 95--(staff tree, false bittersweet.)

Euon zaus. Calyx 5-parted, flat: corol flat : capsule 5-angled, 5-celled, 5-ralved, coloured: seeils calyptred. 43. 95--(spindle tree)

VIIIS. Calyx 5-tonthed: petals cohering at D 2 
the lip hoorl-like, withering : berry 5 -sceded, globilas. (Oftendinecinus.) 46.72-igrape vine.) Ampelopsis. (alyx 5-tontlied : petals peflexer. spresding : berry 5-secled, globular. 46. 72 ---(false grane.)

Irea. Calyx 5-cleft, bearing the 4 long linear reflexed petals: stigma capitate, 2-lobed: capsule 2-valied; the ralves bearing the seeds and having inflexed margins. 18. 50 .

\section{(Stems not woody.)}

Gompurras. Calyx 5-leaved coloured ; exterior on: 3-leaved ; two leafets converging, keelcl : petals 5 , villose (or rather no (orol) nectary cylindric, 5-torthed : capsule ojening transrelseli, 1-sceded : style semibifo-bachelor"s buttons.) Exotic.

Impatrexs. Calyx ¿-leared : corcl irregular, spimped : anthess cohering : camsile elastic, 5valmel. 24. 73-(jewel weed, touch-me-not, or balsam weed.)

Cerosia, Calys 3-lcared : corol 5-petalled: stamms joined at the base by a plaited nectary : rojsule lingizntally dichiscent : syle 2 or 3-cleft. Leares uiways opposite)- cockscomb.) Exotic.

Vrora. Calyx z-leaved : corol iregular, with a horn behind (sometimes the horn is wanting :) anthers attarlecl by a membranous tip: caipsile 1-celled, 3-ralved 29. 80- violet.)

Contonia. Calyx 2 -ralyed : st igma S-cleft: rapistle 1-celled, 3-ralred, s-secuicd. 13. 80(siring beanty.)

\section{F. Florers 5-petulled, supierior.}

RrBes. Corol and stamn ins inserted on the calyx : style o-rleft : berry many-secded. 36.85 (currant, gocsiberry.)

IItDERA. I etals oblong: berry 5-sederl, surpounded by the calyx : style simple. 46. 53(Europlean iry.) Exotic.

G. Corois reanting.

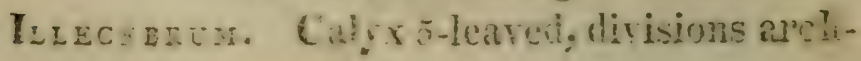


col at the tips : corol o : stigma simple or a-cleft : capsule 5-valved, 1 -seeded.

Giraux Calyx inferior, 5-lobed, coloured: capisule 1-celled, 5-valiod, 5-seded, surrounded ty the calyx. 17.91-- sea-milk wort.)

"Thesrum. Calyx stuperior, hall 5-cleft. bearing the stamens: mit 1 -sreded, covered with the permanent calyx. 31. 24-(false toad-flax.)

\section{Order It. Digunia.}

A. Follicles $\curvearrowright$ : corol 1 -petalled, with a fire-parted
border.

A msoxis. Corol fumel-form, throat closed : follicles erect : secds terete, naked, obliquely truncate. (Stigma with a marginal ring. Leaves always alternate.)

Nerium. Calyx 5-parted, small, permanent : corol fumnel-form ; throat with a lacerated crovin: follicles converging, long acuminate-(oleander. Exotic.

l'errploca. Nectary pitcher-form, putting om 5 threads, suromeling the stamens : conol wheriform : stigma calpitate, 5 -corniered. 30.4\%-(foli(le vine.)

Arocyxum. Corol bell-form : stamens aiternating with 5 filamentous pointed nectaries : stigma broad almost sessile : follicles long-linear. 30 . 4 7 ---(log-bane, Indian hremp.)

B. Capsules 1 or 2-called, 2-ralved: corol 1-prial$e d:$ calyx 5-cleft.

Swertia. Copol wheel-form with nectariferous pores at the base of the div isions : capsule 1 celled. 20.4 (j---(talse gentian.)

Gentrana. Corol with a tubular base, without pores : capsule 1 -celled, oblong: columellas 2, longitudinal. 20).46-.-(gentian.)

Cuscra. Copol 5-cldil: capsule 2-celled, di$\checkmark$ ding ratisterkely at tho base: sceds binate. 29. 43 -(dodder.) 


\section{Corol 5-petalled.}

Hevcrera. Calyx inferior : corol on the ca. lyx : capsule 2-beaked, 2-ceiled. 13. 84-(allum root.)

Panax. Polygamous. Umbelleal. Involucre many leaved: calyx 5-tootled, superior : berry heart-form, 2-seeded : calyx, in the staminate flowers, entire. 46.59-(ginseng.)

\section{Corol o.}

(Stem herbaceous, except Atriplex halimus.)

Salsola. Calyx 5-leared with a capsular base : capsule 1-celled, with a spiral seed. 12.29-(saltwort.)

Chropodium. Calyx 5-learer, 5-angled, inferior: seed 1 , lens-like, invested by the calyx. 12. ๑9. (pigweed, oak of Jerusalem.)

Beta. Calyx 5-leared: seed kidney-form within the fleshy substance of the base of the caIyx. 12, 99-(beet.) Exotic.

Atriplex. Calyx 5-leaved, inferior ; style 2. parted : seed 1, depressed. Pistillate floweis are intermixed, in which the calyx is 2-leaved. 12.29 -(orach.)

Ulmus. Calyx bell-form withering, border 5-clefi: : seed 1, enclosed in a flat membranaceous samara. (Stamens rary from 4 to 8.) 53. 99(elm.)

Celtrs. Polygamons. Calyx 5-parted : styles thickish, spreading : drupe 1-seeded : staminate flowers beneath the perfect ones, with 6-parted calyxes : stamens 6. 53. 99-(nettle-tree.) E. Plants umBelliferous. Flower's 5-petallel, 2-seeded.

With general and partial inrolucres.

Eryagium Involucres many leaved: flowers in heads, all fertile : receptacle chaffy : firuit crowned, a-jartib+e. 45. 60-(sea-holly.) 
Confaxdrum. Corols radiate, with petals inflected, emarginate : general involucre 1-leafed; partial one halred : fruit globular. 45. 60-(coriander.) Exotic.

HYDROCOTYLE. Umbels simple and very small ; flowers all lertile: involucre 4-leared: petals entire : fruit half-orbicular, compressed. 45.60 -(water-navelwort.)

Saxicula. Flowers of the disk abortive : umbels crowded into head-like heaps : secels prickly. 45. 60-(sanicle, blackroot.)

Heracleum. General involucre caducous: flowers unequal : petals inflexed, emarginate : fruit oval, compressed, striate, margined, emadginate. $45.60-$ (cow-parsely.)

Caucalis. Corols mostly radiate with the disk flores staminate: petals inflexed, cmarginate : fruit hispid with bristles : involucre maryleaved, entire or none. 45. 60-(hase-parsicy.) Southern states.

Baucus. Involucres pimnatifd : finwers somewhat radiate, those of the disk abontive: frit hispid with hairs. (Umbels funnd-form.; 45. 60 -(carrot.) Exotic.

AxGelica. P'etals incurred : corols equal: calyx 5-toothed : style refiexed : fruit romdish, solid, 5-winged both sides. 45. 60- angelica.)

Sisox. Petals lanceolate, inllected : umbels with few peduncles : fruit orate, striate : involucres about 4-leaved. 45. 60-(honewort.)

Fen letals heart-form : fruit oval, flat compressed, with 3 lines on both sides: flowers uniorm, all fertile : gencral involucre carlucous, partial ones many leaved. (Grenerally tall.) 45. 60-(giant-tenuel.)

Ligusticem. Involiere membranaceous : calyx 5-toothed: petals equal. involute, entire : fruit 3 or 5 -ribbed each side, oblong. 45. 60-Jorage, smellage.) Exotic.

Asmi. Involucres many leared: corols radiate, 
all perfect: fiuit smooth or striate : umbels lar, 45. 60 -(bishop-weed.)

Srum. Inrolucres many-leared : petals heartfor'm : fruit somewhat orate, striate, compressed. 45. 60-(water parsnip.)

Seline M. Involicre reflexed: perianth entire: petals heart-form, equal : fruit flat-compressed, striated in the midule, oval-oblong. 45. 60(milk-parsley.)

Conium. Partial involucres halved, somewhat 5-leaved: fruit somewhat globular, marked with 5 lines, crenate at both ends. 45. 60-(poison hemlock.)

- With a partial, and without a general, invo. lucre.

Cinaeropinglum. Involucre concave, reflexen, 5 to 8-leaved: petals inflexed, heart-form : fruit oblong, smooth oi striated, very glabrous. 45. 60-(poison cicily.)

My rurs. Unbel compound : involucres erect: fruit oblong, deeply furrowed, angles sub-membranaceotis. 45.60-(sweet cicily.)

Cicura. Involucre 3 to 5-leared: fruit sub. orate, gromed. 45.60 - cowbane.

Imperatoria. Fruit roundish, compressed, gibbons in the mictde, bound at the margin with a wing: pctals inflex-emarginate. 45.60 - (master-wort.)

_- Without a partial involucre, and rarely haring a general one.

Smyriuar. Fruit somewhat compressed, gibbous, striate: petals acuminate, keeled.-( Fruil becoming black.) 45. 60 -(alexander's.)

Pastrnaca. Fruit oval, flat-compressed : petals involate, entire. 45. 60-(parsnip.)

AnEThum. Fruit ovatish, compressed, striate: petals involute, entire. 45. 60-(lenncl, dill.) Exotic. 


\section{CLASS V. ORDERS III. IV.}

Aprum. Fruit orate, striate: involucre 1-leafcd : petals equal. 4560 -(celery, parsley). Exotic.

Carvar. Fruit ovate-oblong, striate: involucres about 1-leafed: petals keel-form, inflexcmarginate 45. 60-('allaway.) Exotic.

* Polygonum, Scleranthus.

Asclepais and Cynanchum, are usually placed here; but they are carried to the 19 th class on the authority of B1. Smith.

\section{Order HI. Trigynia.}

\section{A. Corols superior, 5-cleft.}

Viburxus. Calyx 5-parted : berry or drupe 1-seeded. 45. 58-(snowball, sheep-berry, high cranberry.)

Samnecus. Calys 5-parted : berry s-secticd. 43. 68 -(elder )

Tasinix. Calys 5-parted : petals 5: capsule 1-celled. S-valved: seed furnished with liairs. (tamarisk ). Exotic.

B. Corols inferior, 5-petalled.

St:pryzeA Caly 5-parted: capsiles inflated, commate; nuts globular, having a cicatrice. 23. 95-(bladder nut.)

Ruvs. Calyx 5-jarted; berry 1-sceded. 43. 94-(sumach, poison ivy.)

Sarothra. Calyx 5-parted : capsule 1-celled, S-ralred, colomedi. $\approx 0.82-$ (pine-weed.)

Alsrex. Calyx 5-leaved : petals erual : capsule 1-celled, S-ralved, many-sected ; having a free central columella. $22.82-$ (chick-weed.)

* Euphorbia, Panax.

\section{Order IV. Tetragyia.}

Parnassia. Calyx 5-parted: corol 5-petalled: nectaries 5, with stamen-like dirisions, ghlobstar tips : capsule 4-valred, 2-celled : seed membranaceous-margined. 14.64-(parnassus-gratss, fialse plantain.) 


\section{Order V. Pentagynia.}

Aralia. Umbellets involucred: perianth $5_{\mathrm{K}}$ tonthed, superior: petals 5: berry crowned, 5 celled; cells 1 -seeded. 46. 59-(spikenard, wild sar'saparella.)

Lixum Calyx 5-leared: corol 5-petalled: cajsile 5-valved, 10 -relled : seeds solitary : filaments thickening at the base. 14. 75-(flax.)

Drosera Calyx 5-cleft: colol 5-petalled: cansule 1-celler!, 3 to 5 -ralved at the top. seerls many. Sometimes 6-sityled. (The leaves are always beset with glandular hairs resenbling dew.) 14. 64 - (sindew.)

Sritice. Calyx 1-leaved, entire, plaited, scarincis, inferior: rorol 5-petalled : seed 1.48.33(marsh-rosemary

* Spergula, Ceratium.

\section{Order X!li. Polyginia.}

Z. хтнวлнIz 1 . Calyx 0 : petals 5: nectaries 5 , pedi elled: cansules 1-sceded, about 5 in number. 26. 61 -(yellow-root)

\section{CLASS VI. HEXANDRIA.}

Order i. Monogynta.

A. Flower reith a perianth and corol, rithout a spathe.

Bromelia. Calyx 3-rleft, superior : petals 3 , arith nectaricurots srales at the base : berry $3-$ celled. 10-(pine-apple.) Exotic.

'T'r : descantra. Calyx inferiol, s-leaved: corol s-pletalled: filaments with jointed heads : capsules 3-rclled. 6. 13-(spiderwort.)

Berberris. Calyx inferior, 6-leaved : petals 6 , with $\approx$ giands at the claw of each: style 0 : berry 1 -rellel. -seeted. (Stigma narelled: stamens spring ip on being irritated.)-(harberry.)

Cinlopracum. Calyx inferior, 6-leaved: petals 6 , opposite to the leaves of the caly $\mathrm{x}$ : drupe 
x-sected : antlier D-colled, gaping at the margin. 24. 7 S- (proppoose-root.)

Presos. Calyx inferior, (i-cleft : corol wheelform. G-cleft ; berry 6-secded. 4.3. 95-(winter* berry )

Ch, ome. Calyx 4-leaved : petals 4, ascending: glands 3 , che at each simmate division of the calyx except the lowest : stamens from 6 to 20, or mire: cajpsule silięur-like, 1-celled, 2-ralred. Tetradynamous. 25. 64-(false-mustard)

Floreran. Calyx s-leatred, comol s-petalled: sty le O-cleft : caipsule blatiler-like, $2-$ grained. 15. 22-(tialse-mermaid.)

13. Flowers with a spathe or gluine without a perianth.

Amaryeris. Corol superion, 6-petalled, unequal : tilaments une pual in moportion or direction, decined, inserted in the throat of the tube. 9. 1:-(ataunask lily.)

Hrposis. Glume-like spathe g-valved: corol sinperin, 6-patited, permanent: capsule clongated, narrow at the base : seed roundish. 10.17(star-gr'ass.)

Al.tuc s. Sjathe many flowered: petals inferior, or ate, spreadling, sessile. (Flowers in close unlfls of lieats.) 9. 16-(leck, garilic onion, cives.)

(ianistues. Petals 3, concave, superior: nectaries 3, small, emarginate: stigma simple. 6. 15-(4ilgw-drop.) Esotic.

Yarcissus. Petals 6, erpual, superior: nectary bell-form, 1-leafed, including the stancus. 9. if -(jomequil, dationlil., Rxotic.

fONTEDERI. Corol inferior, 6-deft, a-lipwed: canpuse ileshy, 3-celled, many seeded : 3-stan is commenly inserted on the tip, and three on the tube of the coral. 6. 1i-(pickeril wecil.)

C. Flowers without spathe, perianth or slume. Agave. Corul erect, superior, tubular, or funE 
nelform ; filaments erect, longer than the corol: capsule triangular, many-seetied. 10.15-(agare.)

Aletris. Corol superior, fumnel-form, wrinkled, somewhat 6-rleft; with the stamens inserted on the base of its divisions : capsule 3-celled, many-seeded, half inferior when mature. 10. 16 (ílse aloe.)

Hemerocallis. Corol 6-parted, tubular-funnelform : stamens declined : stigma small, simfile. 10.17-(lay-lily.) Exotic.

Dracaena. Corol inierior, 6-parted; or 6petalled cohering at the base: filaments somewhat thickened in the mildle: berry with 3 onesceded cells. 11. 12-(Dragoness-plant.)

Coxostrets. Corol more than hall inferior, 6-cleft, permanent, with branching hairs : anthers erect: style conic, 3 -jarted : stigma simple: capsule opening at top, s-celled, many-seeded.

Errthronium. Corol liliaceous, inferior, 6petalled ; petals reflexed, having a tubercle-form nectaries at the base of the three imer alternate petals. 11. 14-(dog-tooth violet, or adciertongue.)

Asparages. Corol superior, 6-parted, erect ; the three imner petals reflexed at the apex : ber-s ry s-celled ; many-seeded. 11. 12-(asparagyus.) Lxotic.

Polyanthes. Corol funnel-form, incurved: flaments inserted in the throat: germ within the bottom of the corol. 10.16-(tuberose.) Exotic.

Hyacistres. Corol roundish or bell-form, erpual, 6-cleft: 3 nectariferous pores at the top of the germ : stamens inserted in the midale of the Grol : cells somewhat 2-secued. 10. 16-(hya(inth.) Exotic.

liniua. Corol inferior liliaceous 6-petalled ; fetals with a longitudinal line from the middle to the base: capsule with the valres comnected by hair's crossing as in a sieve. 10. 14-(lily.)

'I'ulipa. Corol 6-petalled, liliaceous: style none. 10. 14-(tulip.) Exotic. 
Fintilaara. Comel 6-petalled, bell-formom. with a meriarilerous cavity above the rlaw of each: stancens of the length of the comel : seeds flat. 10. 14-(crown imperial.) Exiti".

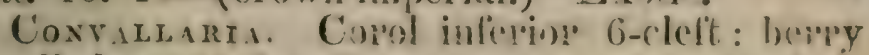
s-celled, spotted before ripening. 11.12-solomon-seal.)

Evclarua. Copl inferior, 6-petalled, with a nectarilerous hollow at the base of each petal : filazints very short. 11. 1t-(bellwort.)

Grovtum. Recepte le spalix-like, cylindric,

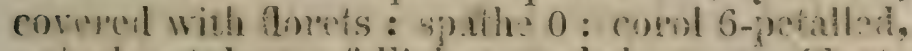

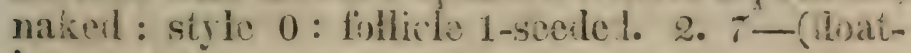
ing avom.)

Tartincium. Comol 6-petalled, inferior,

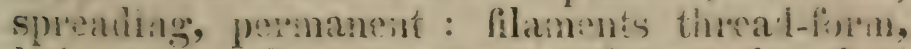

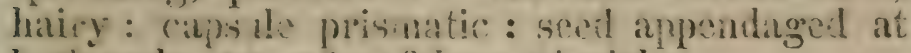

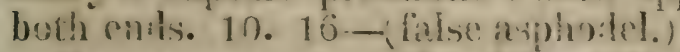

(brituogaidu. Carol (j-pmalied, emert. permanent. spreating above the midile : flaments dilated or subulate at the base : cansule roundsh, angleh, i-relled : seed iounlish, naked.10.16(star of Bethlehem, Exotic.

Asprodecus. Comol 6-parted, spreaning : nectary coveriig the germ with 6-ralves. 10. 1t -(kings spear, or asiladel Exotic.

Acorus. Rerepiat le sparlix-like, cylindric, covered with florets: calyx 6-pated : coiol o:

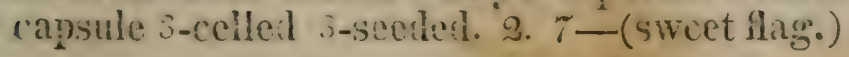

\section{Flowers without corol.}

Juncus. Glume 2-valied : calyx 6-leared, permanent : stigmas 3 : capsules 1 or 3 -eclied, $3-$ valverl, many-seeded. 5. 13-rish-giass, ballr'ush.)

Trientalis, Polygonum, Laturus, Corydalis. Order Il. Digynia.

Oryz!. Calys, glume afnalvel, 1-flowered: corol 2-ralred, alliering to the seed. 4. 10(rice.) Exotic.

* Ulmus. 


\section{Order Hit. Trieynta.}

Meproza. Calyx o : corol deeply 6-parted, revolute: berry 3-seeded. 11. 12--(Indian cucumber.)

Melanthum. Polygamous. Calyx n : corol wheel-form, 6-parted or 6-petalled, each part with 2 glands at the base : stamens from the lengthened claws of the petals : capsule ovatish, somewhat 3-cleft at the apex, S-celled ; seeds membrane-winged, numerous. 10. 13-(blackflower.)

Veratrum. Polygamous. Calyx o : corol 6 . petalled, without glands : capsules 3, manyseeded. (The staminate flowers have the rudiment of a pistil. 10.13-(itchweed, or swamp helleboie.)

Hrioni s. Calyx o: corol 6-petalled : styles distinct : capsules 3-celled, 3-horned, few-seeded. 10. 13 - helonias.)

Xerophylum. Corol wheel-form : filaments contignthus to the base : stigmas 3 , revolute, sub-comate at the base : capsule subglobose, opening at the top into three fissures, scelled, each 2-seeded. 10. 13.

Tofielda. Calyx 3-rleft inferior : petals 6 : rapsules 3 , joined at the base, many seeded. 10 . 10.

Scheuchzerit. Calyx 6-parted inferior: corel :) : anthars linear : stignas sessile, lateral : rajistles s, intiated, 1 or os-seeder. (fonnetimes the culyx is taken for the corol.) 5. 13-(less flowering-1rish.)

Zigaderes. Calyx 6-leaved, spreading, with

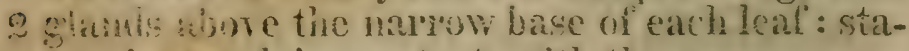
mens insted in contact with the germ : cap-

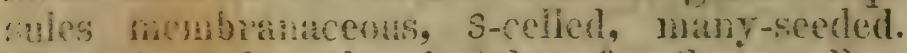
(bonctines the calyx is taken for the corel) (zigadene.)

"Trilliex, Calyx 3-leaved, inferior, sprearling : corol s-petaillod : beiry s-celled, manysected. 11. 12-(wake-robin.) 
Triglochen. Calyx s-leared, inferior ; corol 3-petalled, resenibling the calyx : stigmas sometimes 6 : capsules dehiscent at the batse. 5 . 13-(arrow-grass.)

Rumex. Calyx s-leared : petals 3, conrerging; stigma many-cleft : seed 1, naked, threesided. 12. ¿8--(dock.) Vide Lapathum.

\section{Order XiII. Polygynia.}

A.rsma. Calyx s-leared : petals 3: capsules numerous, 1-seeded. 5. 13--(water-plantain.)

\section{CLASS VII. HEPTANDRIA.}

Order I. Monogymia.

Trientalis, Calyx 7 -leaved : corol 7 -parted, equal, flat : berry juiceless : number of stamens variable. 20. 54 - (chick-wintergreen.)

Esculus. Calyx inflated, 4. or 5-toothed: corol 4 or 5-petalled, inserted on the calyx, unequal, pubescent : capsule 3-celled : seeds large, chestnut-form. 93.66 -(horse-chestnut.) Southern states.

\section{Order IV. Tetragyia.}

Sacrurus. Calyx an ament with 1 -flowered scales : corol 0 : germs 4 : berries 4,1 -seeded. 2 . 6-(lizard-tail.)

* Polygonum orientale.

\section{CLASS VIII. OCTANDRIA.}

\section{Order i. Morogyina.}

\section{A. Flowers superior.}

Oxrcoccus. Calyx superior 4-cleft : corol 4parted, the divisions nearly linear, revolute : filaments converging, anthers tubular, 2-parted: berry many-seeded. 18.51-(cranberry.)

Gaura. Calyx 4-cleft, tubular : corol 4-petalled, ascending towards the upper side ; nut 1 . cceded. 17. 88-(Virginian loosestrife.) 
Erilobiusr. Calyx 4-cleft : tubular : corol 4petalled : capsule oblong and of great length: seeds feathered. 17. 88-(willow herb.)

Oenothera. Calyx 4-cleft, tubular: caducous, divisions deflected : petals 4 , inserted on the calyx : stigma 4-cleft; capsule 4-celled, 4-valred: seeds not feathered.17.88-(scabish, or treeprimrose.)

\section{B. Flowers inferior.}

Rhexra-Calyx pitcher-form, 4 or 5-cleft : petals 4, oblique, inserted on the calyx : anthers declined : capsule 4-celled, within the ralyx, setose : seeds numerous, cochleate. 17.90-deergrass.)

Acer. Polygamous. Calyx 5-cleft: corol 4 or 5-petalled : samaras 2 , united at the base, 1sceded. 23. 66-(maple.)

JeffersoniA. Calyx 5-leared, coloured, carlucous : corol 8-petalled : capsule oborate, sub-pefluncled, 1-cchied, dichiscent below : seeds many, oblong, arilled at the base-('twin-leaf.)

Mexzissa. Calyx inferior monophyllus : coyol monopetalous, ovate: filaments inserted on the recentacle: capsule 4-celled, the partitions from the inflexed masgins of the valres: seeds many, oblong:

Enica. Calyx 4-leared, permanent : corol 4eleft, permanent: filaments inserted on the receptacle : anthers bifid : capsniles membranaceous, 4 to 8-celled, the partitions from the margins of the valves: sceds many in each cell. 18.51(heath.) Exotic.

Diн с . Calyx o : corol tubular, limb obsolete, unequal; stamens longer than the tube of the corol : berry or drupe, 1 -secied. (The corol may be taken for a coloured calyx.) 31.25-(leatherswood.)

D phne. CalyX o : corol 4-cleft, withering, including the stamens: drupe 1-seeded. (mezereon.) Exotic. 


\section{CLASS IX. ORDERS I. III.}

'Troponony. Calyx 4 or 5-cleft, colomed, sporied : petals 4 or 5, unequal : nuts leathery, sulcate. 23.73-(nasturtion.) Exotic.

\section{Order II. Dygrinia.}

Cinrsospiexirm. Calyx 4 or 5-cleft, coloured : corol o: capsule g-beaked, 1-celled, many seched. ('The terminal Howers in the European specimens are decandrous.) 13. 86-(golden saxifrage, water-carpet.)

\section{Order Hil. Trigumia.}

Cinntospernum. Calyx 4-leaved; petals 4 ; nectary 4-leared, unequal: capsules 3 , commate, inflated. 23. 65-(heart-sced.)

Porygorum. Calyx inferior, 5-parted, coloured, corol o: seed 1, angular, covered with the calyx.-(Stamens and pistils vary in number'The calyx in some species might be taken for' at corol.) 12. 28-(knot-grass, water-pepper, buckwheat, hearts-ease.)

\section{CLASS IX. ENNEANBRIA.}

\section{Order I. Monogynia.}

Latres. Calyx 4 to 6-parted : corol o: nee. taries 3, two-bristled glands, surrounding the germ : drupe 1 -seeded. (Stamens vary from 3 to 14 -often diocious-The calyx may be taken for a corol.) 12. 27-(sassafras, spice-bush.)

\section{Order ill. Trigynia.}

Ruecr. Calys none : colol 6-cleft, permatnent: seed 1, S-sided. 1:. $28-($ rhubab.) H.xntic. 


\section{CLASS X. DECANDRIA.}

\section{Order I. Monogynia.}

\section{A. Flowers many-petalled, irregular.}

Podalyria. Calyx 5-cleft, somewhat 2-lipped : corol papilionaceous, wings of the length of the banner : legume inflated, smooth, manyseeded. 32. 93-(wild indigo.)

Cercis. Calyx 5-toothed, gibbous below: corol papilionaceous, banner under the wing short : legume oblong. 33. 93-(judas-tree.)

CAssia. Calyx 5-leaved : corol 5-petalled: anthers, 3 lower ones beaked : legume membranaceous. 53. 93-(cassia.)

Rhodora. Calyx 5-toothed, corol s-petalled: stamens declined : capsule 5-celled. 18.50-(rho(lora.)

\section{B. Flowers 5-petalled, regular.}

Cletrira. Calyx 5-parted, permanent: style permanent : stigma 3-cleft : capsule S-celled, 3valved, surrounded by the calyx. (Spiked.) 18. 51-(sweet pepper-bush.)

Prrola. Calyx 5-parted : anther's with 2 pores : capsule 5-celled, dehiscent at the angles. 18. 51 -(shin-leaf.)

Cimmaphil. Calyx 5-parted : petals 5: stigma sessile, thick, orbiculate; germ immersed : anthers beaked, opening with a kind of 2valved aperture : capsules 5-celled, dehiscent at the angles. 18. 51-(prince's pine, pipsissiwa.)

RuTs. Calyx 5-parted: petals concave : receptacle surrounded by 10 nectariferous dots: capsule lobed. (Petals sometimes 4, and stamens 8.) 26.81-(rue.) Exotic.

MienI. Calyx 5-toothed; petals 5 : nectary cylindric, toothed, bearing the anthers in the thrnat : drupe with a 4-celled nut.-(bead-tree.) Southern states.

Melastoma. Calyx 5-cleft, bell-form : petals 


\section{CLASS X. ORDER I.}

5. inserted on the calyx : anthers long, lowed : berry s-celled. obrolute with the calyx. (Stamens vary from 8 to 13 . Leaves elegantly veined.)

Drovara. Calyx 5-leared : stigma fringed: capsule 1 -celled, gibbous: secds numerous. (Petals sometimes 6.) 14. 73 -(Venus fly-trap.)

\section{Florvers 1-petalled.}

Aromomen. Calyx 5-parted, inferior : corol ovate or romdish. with a 5 -clefit reflexed mouth : capsule 5-colled, with partitions contrary. (Stamens sometimes 8.) 18. 51-(11hitebush, leather-leaf.)

Ruododexnnox. Calyx 5-parted : coml somewhat finnol-form and oblique: stamens declin-. ing: capsule 5-celled, 8. 50-(1rosebay.)

hamais. Calyx 5-parted: corol whed-salreriorm, with 10 horns beneath and 10 carilies within : capsule 5-cellet. 18. 50-(laimel.)

Vaccricm. Calyx 5-torthed or 5-paited: corol bell or pitcher-lorm. 5-clelt, the divisens lefiected: filanents insertcd on the germ 11 ith the corcl : berry 4 or 5-colled, maing secded. (The fur eign species aie sometimes ectandrous.) 18. 51 -(whortieberry.)

Errcara. Calyx couble, nuter S-leared, inner 5-parted : corol salver-form; caipsile 5-celled, many-szeded. 13. 51 -(trailing arbutas.)

Guatieria. Calyx interion. double nuter D-leavei, inner 5-cleit : comol ovate : aysule 5celled, invested with the imer, berried, cal!x: nertary 10-pointed. 18.51--(spicy winter-gines.)

Anbutrs. Colyx inferio, 5-parted : comal orate, frllucis at the base : berry j-celied. 18. 51 -(bear-berry.)

Lепxм. Calyx 5-cleft : corol flat, 5-parted : rapisule 5-celled, deliscrent at the base. (Bitamelis semctimes 5, leares downy.) 13. 50-(laibrador'tea.)

Leropurutu. Calyx 5-deft : corol fat, 5- 
parted : capsule 5-celled, dehiscent at the top (leaves always glabrous.) 10. 50-(sleek leaf.)

\section{Calyx none,}

Moxotropa. Comol 10-petalled; 5-outer with nectariferous hollows at the base : capsules 5valred. (A fifth part of the carpogenation sometimes wanting) - (beech-drops, birl's nest.) * Geranum, Rhexia, Portulacca, Lythrum.

\section{Order II. Drgynia.}

HrDpaxgea. Calyx 5-tonthed, superior : corol 5-petalled : capside 2-celled, 2-beakerl, dehiscent beiween the beaks. 13.85-(hydrangea.) Vid. Hortensia.

Saxifraga. Calyx 5-parted : corol 5-petalled : capsile 1 -celled, ¿-beaked ; many-sceded. 13. $84-$ (saxifrage.)

Trarelia. Calyx 5-parted : corol inserted on the calyx : 5-petalled, petals entire: capsule 1 celler, D-valved, 1 valve larger. 13.84-(miterwort.)

Mícelul. Calyx 5-cleft : petals 5 on the calyx, pimatifid: capsule 1-celled, 2 -valved, valves ergual. 13. 84-(ialse sanicle, currant leaf.)

Dinstres. Calyx inferior, cylindrical, 1Inafed, with 4 to 8 scales at the base: petals 5 with claws : capsule cylindrical, 1-celled, dehiscent at the top. 22. 82-(pink, sweet-william.) Exotic.

Saporaria. Calyx inferior; 1-leafed, tubular, without scales: petals 5, with claws : capsule oblong, 1-celled.22. 82-(soap-wort.)

Schenaxtucs. Calyx inferior, 1 -leafed : corol 0 : seeds 1 oi 2 , inclosed in the calyx : stamens inserted on the calyx. 22.86-(knawell.)

* Cluysosplenium.

\section{Order III. Trigyni.}

Arexaria. Calyx inferior, spreading, 5 leaved : letals 5 , entire : capsule 1 -celled, many sceded. 22. 82-(sandwort.) 
S'tem zarra. Calyx 5-leaved, inferior. spreading: petals 5, decply cleft, mostly to the claw, spreading: capssule ovate, 1 -celied, many-sceded, 6-tonthed at the top. 22. 80-(starwort.)

Sruexf. Calyx 1-teafcel, interior, conic : petals 5, with (laws appendaged at the mouth : (aj)sule imperfoctly s-celled. 20. 80-(catrh-fly.)

Cecebarss. Calyx inferior, 1-leafed, bellform, inflated: petals 5 with claws, not ajpendaged at the moutin: cansule S-celled. 20.82(bladder-campion.)

Hortexsia. Howers deformed : forets solitary : calyx 5-toothed, minute: corol 5-petalled. The gay fiowers composing the cyme, have a laige coloured, permanent petal-like 5-icared calyx, and a minute caducous, 4 or 5 -petalled conol : stamens 8, 10 or 11. 13. 8z̃-(changeable hydrangea.) Exotic.

\section{Order V. Pentagyia.}

Senru. Calyx in!erior 5-cleft: petals $5: 5$ nectariferous scales at the base of the germ : capsules 5. 13.83-(lire-forever, or orpine, stmecrop.) Exotic.

l'exthoruy. Calyx 5-10-rleft : petals 5 or 0 : capsule 5-cuspidate, 5-ceiled. 13.83-(Virginian or'pine.)

Oxins. Calyx 5-leared inierior: petals 5, cohering by the claws: capsule 5-celled, 5-cornered, dehiscent at the comers : stamens, with 5 shorter : outer ones adhering at their bases. 14.73 -(wood sorrel.)

SPERGLLA. Calyx 5-leared inferior : pretals 5, entire: capsule ovate, 1 -celled, 5 -ralred. (Stamens often 5.) 20. 82-(spury.) [l'rotessor Ives considers all the Ameriran speries of spergula and sagina, as a natural assemblage of plants, which ouglit to be united in one gentis.]

Acinostemma. Calyx 1-leared coriaceons: petals 5 with claws, borkler oltuse, cntire : capsule 1-celled, mauy-secded. 22, 82-(cockle.) 
Cernstium. Calyx 5-leaved: petals 5, 2cleft : capsule 1 -celled, deliscent at top, toothlike. $20.82-$-(mouse-ear chickweed.)

Lrchys. Calyx 1-leaved, wblong, smooth: petals 5, with claws : the limb somewhat 2-cleft: capsule 1 or 5-celled. 22.82-(campion.) Exotic.

* Phytolacca.

\section{Order X Decagyni.}

Prirtoracc.. Calyx o : corol -petallal, calyx-like, inferior : berry 10-celled, 10-sceded. 54. 89-(pokeweed.)

\section{CLASS KI. DODECANDRIA.}

Order l. Monogynia.

As.rer. Calyx 5 or 4-cleft, superior : corol 1): stigma 6-cleit : capsule coriaccous, crowned with the caljx. 11.23-(wild ginger, or white snake-1oot.)

Hicososr. Calyx tubular, s-Ieaved, inferiol: colol 5-petalked : stameus 1 s: capsule 1-celled, 3-ralved, s-seeded. 18.51-(bise-heath.)

Pontcracca. Calyx a-cleft, inferior: corol 5-petulled : capsule 1 -celled, opening transrerse1y : columella 5, filiform. 13.86-(puislane.)

Lytrnex. Calyx 6, 8, 10 ol 12-tonthed, inferior : petals or on the calyx : capsule o-colled, many-seeded, covered. 1\%. 91-(milk-willowherb.)

becruara. Calyx 10-leaved, sumerior: corol 10-petalled : capsile abont \& $0 \mathrm{i}^{\circ} 10$-celled, seedis numerous. 19.89-(decumary.)

Tarexcm. Calyx inferior, 2 or 5 -leaved : corol 5-petalled : capside 1-celled, s-vaived, many sceded, seeds arilate : colmudla giobuse-(taliny.)

Crpirea. Calyx tibular-rentricose, 6 to 12tosthed, inequal : perols 6 , mostly ane paal, inserted un the caiyx: capsale 1-celied, cheniscent 


\section{CLASS XII. ORUER T.}

Intigitudinally with the calyx ; follicle S-sided: secels lenticular.

\section{Order II. Digynia.}

Agrmoxra. Calyx 5-toothed, invested with an witer one : petals 5 : speris ${ }^{2}$, in the bottom of the callyx. 35. 92-agrimon!y.)

* Delphinium.

\section{Order III. Trigynta.}

Erpuonus. Calyx 1-leared, infated: prials 4 or 5 . standing on the calls $\mathrm{x}$ : capsule 3 -gramed. Whowers mot ninbelled. 38 96-(sputge.,

Estu. Calgx t-leared, inhated : petals $4 \mathrm{or}^{\mathrm{P}}$ Sh standing oi the cals $\mathrm{x}$ : cupsules 3 -sceder? : fibrers more or less untelled. 38. 96-(caper, or spunge caper.) Exotic.

Resnus. Calyx 1-leafed, 4 to 6-parted : jetals in many divisions : capsule 1-celled, dehiscent at the top) : seed reniforin (stamens 11 to 15 : styles 3,5, or none) 54. 64-(nignonette, dyer's weed.)

\section{Order Xill. Polygynia.}

Snmparivem. Calyx 9 to $12-$ parted : petals

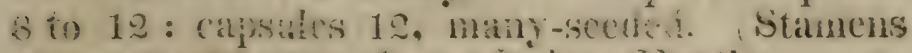
$160 \%$ 20., 13. 83- houm-hiok.) Exotic.

\section{CLASS XII. ICOSANDIRIA.}

\section{Order I. Mlovogymi.}

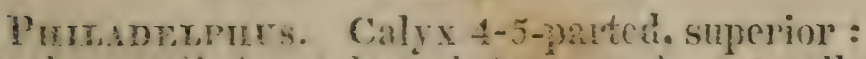

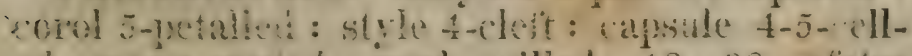
ef. many-seded ; seed ailled. 19. 89-- laise syringa, or mock-orange.)

Prives. Calyx 5-cleft, inferior: corol 5-petalled : nut of the drope smooth with pominent Scams at the sutures. 36. 92-(dherry, phis.in.)

Anveriaca. Hlowers sessile : calls s rerieft,

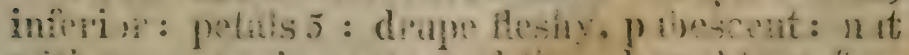

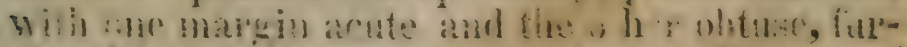
mowed both situs. 30. 9:3-apricose) Lixutic. 
Cacters. Calyx superior, 1-leafed, imbricate: petals numerous, in many series, the inner ones larger; stigma many-cleft : berry 1-celled, manysceded, navelled. 13. 85-(prickly-pear.)

Mrrtes. Calyx superior, 5-cleft : petals 5: berry 2 or s-celled, many-seeded. 19. 89--(myrtle.) Exotic.

Puxica. Calyx 5-cleft, superior: petals 5: pome or berry many-celled, many-seeded : receptacle parietal : seed berried. 36. $92-$ - pomegranite.) Exotic.

Amygnates. Calyx 5-cleft, inferior : petals 5 : drupe with a nut perforated with poies: flowers sessite. 36.92--(peach.) Exotic.

* Lythrum.

From Order II. Dygixia, to Order V. PentaGYNIA.

Crataegrs. Calyx superior, 5-cleft: petals 5 : styles generally $\dot{S}$ or 5 : berry mealy : seeds 2 to 5 , bony. $56.92-($ thorn-bush.)

Sorbes. Calyx 5-cleft, superior : petals 5 : styles 2 to 3 : berry pomaceous : seeds 2 or 3 cartilaginous. 36. 92-(mountain ash.)

Aroxia. Calyx 5-toothed : petals 5 : fruit pomacerous : berry 5 or 10 -celled; cells 1 or 2 seeded; seeds cartilaginous. 36. 92-(shad-flower, choake-berry.)

Mesprucs. Calyx 5-cleft, superior, divisions generally foliaceous : corol 5 -petalled : styles 2 5 : drupe or berry with from 2 to 5 bony sceds. 36. 92-(medlar, or erergieen thorm.)

\section{Order V. Pentagyna.}

Praus. Calyx 5-cleft, superior: corol 5-petalled: pome 5-celled, many-seeded. 36. 93(pear, apple, quince.)

Sprraes. Calyx 5-cleft, inferior, spreading : corol 5-petalled : capsule 2 -ralved within, manysceded. 36. 92-(steeple bush, or hard-liack.) 


\section{CLASS XIIT. ORDER I. 63}

Mesembraxtuemem. Calyx superior, 5cleft : petals numerous, linear collering at the base : capsule fleshy, many-seeded, turbinate. 13. 87-(ice-plant.) Exotic.

Order Xill. Polygyita.

Rosı. Calyx urn-form, 5-cleft, fieshy, contracterl towards the top : petals 5 : seeds numerous, bristly, fixed to the sides of the calyx within. 35. 92-(rose.

Renes. Calyx 5-cleft, corol 5-petalled : pistils muinerous : berry composed of many juicy, 1-seded, acines. 3.5.92-(raspberry, blackberry.)

Dalubarda. Calyx 5-clelt: comol 5-petalled: styles long, calucouis, 5 to 8 ; berry composed of dry granulations. 35. 9:-(diry strawberry.)

Frigaria. Calyx 10-cleit, 5 alternate divisions smaller: corol -petalled : receptacle ovate, berry-like caducous. 3 . 92-(strawberry.)

Pórextrula. Caly $\mathrm{x}$ 10-rleft, 5 alternate divisions smaller: corrol 5-petalled : seeds awnless, roundish, rugose, fixed to a diy small receptacle. 35. 92-(fire-finger. cinquefoil.)

Germ. Calyx 10-rleit, 5 alternate divisions smaller: corol š-petalled : sceds with a bent awn: rereptarle columnar, vilious. 35. 92-(arcus, or her'b bennct.)

Comarry. Calyx 10-cleft, 5-alternate divisions smaller : petals 5 , smaller than the calyx : receptacle ovate, spongy, permanent, villous. 35. 92-(marsh five-finger:)

Cancastues. Calyx 1-leafed, pitcher-shaped, scurfy, with coloured divisions : corol none: styles many, with glandular stigmas : seeds many, tailed, in the succulent calyx. 35. 92-(Carolina allspice.) Southern states.

\section{CLASS XIII. POLYANDRIA.}

Order I. Moxogyuia.

Cuelidonicm. Calyx s-leared: corol 4-pet: 
alled : silique-like capsule 1-celled, linear : seeds crested, many. 2\%. 62-(celandine.)

A TaEa. Calys 4-leaved, cadicous: corol 4-petalled : brrey 1-celled : seeds half orbicular: 26. 61-(neck'are weed, or bane-ber'y.)

Ascrrom. Calyx 4-leasei : 2 interior leafets cordate, large : corol 4 -pretalled : filaments disposed in 4 parcels : capsule oblong, 1-celled, 2 valved, included in the ralyx leaves. 20.68(St, Anirew's cross, or St. 1 Pter's wort.)

Cistes. Calys -leaved, 2 of them smaller, corol -petalled : capstile s-ralred, opening at the top. 20.80 -(rock-rose, frost-plant.)

SAfracexu. Calyr double, 3 and 5-leaved: corol 5-petalled; stigma peltate, corering the stamens : capsule 5-celled. 13.22-(side-saddle flower.)

Tines. Calyx 5 or G-leared : corol 6 or 9 petalled: capsuli 3 -seeder-(tea.) Exotic.

Criaes. Calyx j-cleft: petals 5, oblong: flaments dilated at the liase, in several parcels: bery 9 to $18-$ clle -0 adelphous. 18. 70 - $(0 \mathrm{~m}$ ange, lemon. (Exotic.)

P.Aparre. Calyx o-leared, cadicous : corol 4-jetalled: capsule 1-celled, dehiscent by poies under the permanentstigna. 2\%. 62-(poppy.)

Trux. Calyx 5-parted: corol 5-petalled: capsule 5-celled, globular, coniaceous, deluscent at the base, 1-seeded. 3\%. 79-(bass-wond.)

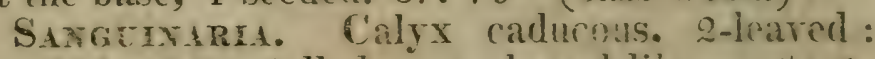
corrd about 8-petallad : capsule pod-like, ovate, 1 celled. $2 \pi .62$ - (bland-root.)

lodorirumen. Calsx s-leared : colol about 9 petalled : berry 1 -cellet, crownd with the stigma. 27.61 -(wild mandrake.)

Cappari. Caly $x$ thared, coriareous, caducous : petals 4 : strimens $10 n g$ : berry coriaceous, pediunled, 1-celled, globulai or porthike-(ca. per-bush.) Exotic,

Nrspuled. Calyx 4 to $r$-leated, larger than 


\section{OLASS XIII. ORDER V.}

the petals : comol many-petallet : stigma matked with ratiated liness : berry many-celled, man!sceded. 13. $22-$ (pond-lily.)

Nermon. Calyx 5 of o-leaved, potals many inserted on the receptacle with the stamens, nectariferous on their batcks : sagma with raliats: furrows, sessile : berry many-celled, many-seeded. 13. 22-(water-lily, or yellow pond-lily.)

ARgEmone. Calyx s-leaved: corol 6-petalled ; capsule semi-ralred. $2 \%$. 62-(horned poppy.)

Fron Order II. Digymi, to Order F. Pei. TAGYNIA.

Fotimergili.. Calyx truncate, cutire : corol o: filaments vely long, clavate : germ bifid : capsule 2-celled, 2-horned : seed bony, solitary. 50. 99-(Fothergill's bush.)

Paeoric. Calyx 5-leared : petals 5 : styles 0 ; stigmas 2 or 3 : capsules pod-like, many-seeded. 26. 61--(peony.) Exotic.

Hypericum. Calyx 5-parted, divisions sub. ovate: corol 5-petalled : filament.s often united at the base in 3 or 5 sets: strles $\approx$ to 5 : capsules roundish with a number of cells ergal to the number of styles. 20. 68--(St. John's wort.)

Delphinicur. Calyx 0 : corol 5-petalled, miequal : nectary 2-cleft, homed behind : capsules 1 or 3, pod-like. 26.61-(larkspur.) Exotic.

Acoxitum. Calyx 0 : petals 5, upper one vaulted : nectaries 2 , hooded, piefuncled, recuryed : calpsules 3 or 5 , pod-like. 26. 61-(monk's hood.) Exotic.

Aquilegia. Calyx $0:$ petals 5 : nectaries 5 , alternating with the petals and ending in horns beneath: capsule's 5, distinct. 26.61-(columbỉne.)

Crumcifera. Calyx 4-leared : petals (ornectaries) to pitcher-form, cartilagimens : cajpsules 4: seeds scaly. (Petals, pistils and ralyx-leares, variable.) $\approx 6.62$-(bug-bane, colosh.) 
Nigera. Calyx none; petals 5 : nectaries 5 , three-cleft, within the corol : capsules 5 , conrex. 26. 61-(fernel-flower.) Exotic.

* Reseda, Ascyrum, Caltha, Helleborus, Anemone, Hepatica.

\section{Oreer XIII. Polygyma.}

Hrorastis. Calyx 0: corol 3-petalled : berry composed of 1 -seeded acines. 26. 01 - orangeroot.)

Clemitis. Calyx 0: petals, 3, 4, 5, or 6 ; sceds compressed: styles permanent, becoming long tails. (Some species are diwcious.) 26.61(virgin's bower.)

Tinfictre u. Calyx 0 : petals 4 or 5 : filaments very long: sceds without tails, striate, teirte. (Some species are dieciotis.) 26.61(meadow rue.)

Heluezores. Calyx 0: petals 5 or more: nectary 2 -lipped, tubular : capsules 5 or 6 , manyseeded, erectish, compressed. 26. 61-(hellebore.). Exotic.

Cuptrs. Calyx 0 : petals 5 or 6 , caducous : nectaries 5 or 6 , cowled : capsules 5 to 8 , stiped, stellate, beaked, many-sceded. 26. 61-(goldthread.)

Cultua. Calyx 0 : petals 5 to 9 : capsules numelous, many-secled : nectarics 0 : (styles raviable in number.) $\approx 6.61-$ (American cowslip.) Arenoxe. Calyx 0 : petals 5 to 9 : seeds numerous, naked. 206 . 61-(wind-flower, rue ancmone.)

Hyoropeltis. Calyx 6-leaved somewhat conrerging: colol o : caibsules oblong. somewhat lleshy, numerous, 2-celled, 1 or 2-sceded. 26. 61 -(water-shield.)

Hepatrc. Calyx 3-leared: petals 6 to 9: sceds naked. 26.61 -(liverleaf.)

Axxoxa. Calyx 3-leared : corol 6-petalled: stigma obtuse: beries 1-cellesl, many-secder?, 


\section{CLASS XIV. ORDER I.}

romdish with a scaly bark. 50.76-(custard apple.)

Ponceita. Calyx s-leared : petals 6, immo ones largest: co rms many : stigmass sessile, chlotuse : berry ( 1 or many) cylindric of ovate, many-seeded : seed connected to an internal suture, arilled. 52.76-custand apple / Sonthern states.

Luronendron. Calyx s-leaved : corol $6 \mathrm{ol}^{\circ}$ 9-petalled, liliaccous : seeds in a samara, imbricate on a stroblic-like spike. 52. 75 -tulip tree, or white wood.)

Magnoura. ('alyx s-leaved : corol 6 to 9-petalled : capsules numerous, imbricate on a strobile-like spike, 2 valved: sceds berried, pendulous. 52. 75 -(magnolia, or bearer tree.)

Nequmbicm. Caly 4 ol 5 -leaved : petals 5 or more : muts half immersed in a truncate receptacle, and crowned with the permanent style. 26. 61-(nelumbo.)

Rixurceus. Calyx 5-leaved : petals 5, with claws and a nectariferous pore or' scale on the inside of each: sceds numerous. 26.61-(crow(oot.)

Troumus. Calyx 0 : petals from 5 to 14 : capsules many, orate, many-seeded. 26. 61globe-flower.)

A'tragene. Calyx 2 or 4-leaved, sometimes inrolucred : petals ntimerous, onter ones laugest: seeds tailed. 26. 61-(atiagene.)

Anoxis. Calyx 4-5-leared: petals 5 monore, without nectariferous pores: seeds atwnless. 20. 61 -(plieasant's eye.) Exotic.

\section{CLASS XIV. DIDY SAMIA.}

\section{Order I. Gymaspermit.}

4. Calyxes 5-parted reith the divisions or teeth nearly equal.

Tecorrur. Conol deep-cleft on the upper sirk and without an ripjer lip; lower lip s-clelt, the 
middle division rounded : stamens and pistils irs curved, stamens exsert. 42.30-(wood-sage, or' wild germander.)

Isanthus. Calyx bell-form: corol 5-parted, tube strait, narrow; divisions orate equal : stamens nearly equal : stigma linear, pecurred. 40. 39 -(blue gentian.)

VERBEA. Corol fumnel form with a curred tube, border 5-cleft nearly equal : calyx 5-cleft : seeds 2 or 4 : sometimes but 2 stamens or 2 barren ones. 42. 39-(vervain.)

Lavandula. Calyx orate subdentate, bracts under-studded : corol resupinate : stamens in the tube. 40. 39-(lavander.) Exotic.

Lasiux. Corol with the upper lip entire, vauted ; under lip 2 -lobed ; throat with a tooth at each margin. 42.39-(dead nettle.)

BRACHYTEMU. Corol with the upper lip sub-emarginate, lower lip obtusely S-lobed : filaments rery short nearly equal : seed oblong-cylindiric. 4D. 39-(Virginian thyme.)

Prcanantenuar. Inwolucre bract-like, many-leaved, under small heads of flowers: calyx thibular, striate : corol with the upper lip sub-entire, lower lip 3-cleft : stamens nearly equal. 42. 39-(wild basil, or mountain mint.)

NeperA. Calyx diry : striated: corol with a longish tube, under lip with the middle division crenate, throat with a reflected margin : stamens aploximate. 42.59 - catmint.)

Hrssopes. Corol with the under lip s-parted, its intermediate division sub-crenate: stamens strait, distant. 42. 39-(hyssop.)

Mextha. Corol nealy equal, 4-cleft : broadest division emarg̣inate : stamens erect, distant. 42. 39-(spear mint, pepper mint.)

Stacurs. Corol with the upper lip raulted, the lower lip reflexed at the sides, the middle division largest, emarginate : stamens reflered towards the sides after discharging the pollen. 4a, 39-(false horehound.) 


\section{CLASS MIV. ORDER I.}

Gismopsis. Calyx with the upper lip sulicrenate, athed: loweip lip 2 -toothed above. 42. 59 (llowering nettle.)

Saturesa. Calyx tubular, striate: corol with. divisions neatly equal : stamens distant. $4:$. $3 ! ?$ (sivory.)

Broxica. Calyx awned : corol with the upper lip ascending, Hattish, tube somewhat cylindric. 42. 39-(betony, shell-flower.) Exotic.

Leovures. Calyx 5-angled, 5-tonthed, colont with the "pper lip villose, flat chtire : lower lip 3-parted, middle division undivided. 42. 30(notherwort.)

Marrubum. Calyx salver-fome rigil, manked with 10 lines: copol with the upper lip $\gtrsim$-clets linear, strait. 4.2. 59-horelsuni.)

Balouta. Calyx salver-form, 5-tonthed, 10. striate: corol with the upper lip comeare, crenate : seed orate, 3-sided. 42. 39- litse motherwolt.)

Cexila. Calyx cyindric, 5-tonthed, thent villose, col ol ringent; mile lip chet. flat, ('uarginate: 2 of the stanens tisually barion. 42.39 - (dittany.)

Fieneoma. Calyx 2-lipper, gibhose at the base : corol ringent : 2 of the stancus bainen 120 39 - (penny-r.oyal.)

Gleос ном. Calyx 5-clefi: rach pair of antthei's alpurnaching so as to exhibit the form of a

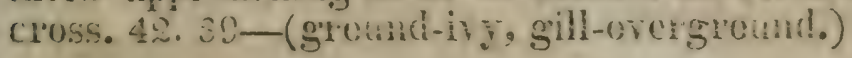

B. Calyxes 2-lipped.

Melissa. Calys dry, fatish abore, with the upper lip sub-lastigiate: corril with the mpycre lip smonchat raulferl, ¿-cleft; Inwer lip with the middle Lobe cordate. 42. 39-(balm.)

'richostema. Coñol with the upper lip fal-

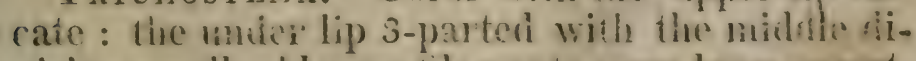
vicion small, oblong : hilanchts rery long-exsert. 42.39-(blue-curls.) 
Dracocephaxcm. Corol with the throat infiated the upper lip concave, the middle division of the lower lip roundisin, notched. 42.40-(dragon-head.)

Ocrmum. Calyx with the upper lip orbiculate, the lower one 4-cleft : corol resupinate ; one lip 4-cleft, the other undivided : outer filaments sending out a process from the base. 42. 39(sweet-basil.) Exotic.

Scetediarm. Calyx with an cntire mouth, which is closed with a lial after the corrol falls out: tuhe of corol bent. 42.30-(skill-cap.)

ORicarey. Calyxes collerted into a 4-sided strobile-like cone, with broad intervening bracts: corol with the riper lip erect, flat : moler lip sparted, divisions manly equal. 42. 35-(marjoram.)

Tirmes. Calyx with the throat closed with hail's : colol with the upuer lip flat, emarginate; lower lip longer. 42.39-(thyme.) Exotic.

Crevropica. Involucre nany-bristled, bractlike, under the whorl : perianth o-lipped: corol with the upper lip hat, obcordate, strait. 42. 39 - (field-thyme.)

Pruveria. Calyx with the upper lip dilated: flaments 2 -forked with an anther on one of the points : stigma 2-cleft. 42. 39-(self-heal, or heal all.)

Prrrmara. Calyx 5-tonthed; seed single. ('The under lip of calyx shorter, 2-toothed.) 40. 39-(lopseed.)

Order II. Angiospermia.

A. Calyxes 2-cleft, or 2-leaved.

Obolaria. Corol 4-cleft, bell-form : capsule 1-celled, 2-valved, many seeded: stamens firom the divisions of the corol. [Persoon says the calyx is 5-cleft-Muhlenburgh says it is 2-leaved.] 40 . 35-(penny-wort.) 


\section{B. Calyxes 4-cleft.}

Orobaxche. Calyx of Q-lobed lateral leafets: corol ringent : capsule 1 -celled, 2-valved, manyseceded : glands under the hase of the germ. 35-(rancer-1'ont. false beech-dropls.)

Bartsia. Calyx lobed, emarginate, coloured : conrol less than calyx; upper lip longest : cajpsule 2-celled; seed ingled. 40. 35-(painitell cup.)

Ruxaxtures. Calyx inflated : corol ringent: the upper lip mostly compressed, the under lip spuread 5-parted : cinpsule 2-celled, obtuse, conipressed. 40. 35-(rollow-cockscomb.)

Euphasra. Cailyx cylindric : corol o-lipped; upper lip 2 -cleft. lovier lip 3-lobed, with the divisions 2-cleft : lower anthers lobed spinose. 40. 35 -(eye-bright.)

Melampyear. Corol with the upper lip compressed, the margin fiblded back : apsule a-ceiled, obliqu : dchiscent on one side : seeds 2, gibbous. 40. 35 -(cow-wheat.)

Scawalizea. Calyx tubular-inllated; upper division small, lower division large emarginate : corol ringent : causule ovate, compresseti, 2-celled, 2-ralied with a double partition : seeds man ny, chatfiy. 40. 40-(chaff-seed.)

$$
\text { C. Calyxes 5-cleft or 5-leared. }
$$

Lrmoselia. Calyx 5-cleft : corol 5-cleft, equal : stamens approaching each other by pairs: capisule 1-celled, 2-ralved, many seeded. 40. 40 -(mudwort.)

Zapaxza. Flowers capitate : calyx 5 -toothed: rorol 5-cleft: stigma heaul-peltate, oblique : pericarp blackler-like, vanishing, connecting the two secds. 40. 40-(fog-firuit.)

Browalua. Calyx 5-tonthed : corol with a closed navel: anther's 2, large : capsule 1-celled. 40. 40. Exotic.

Scrophutaria. Calyx 5-cleft : corol subglobose resupmate, middle division of lower lip 
leflexerl : capsule o-celled. 40.40--(figwort.) Enrves. Calyx j-leaved : colol with the limb equally 5-cleft, lobas c!atuginate; upper lip rery sinit, reflered : catpsule 2-celled. 40. 35--(erinus.)

Brgsoxia. Calyx 5-rleft cur)-form: corol with the linot bell-form. 5-rleft vrutricose bemeath : capuile silique-like, a-celled : sced menbiane-wingod. 40. 45--(trumpet-lowr.)

Lemeri. Calyx 5-patel, ofter a-blarted: combl sumewhat bell-fo:m, limb j-hbed : stamens conjugate : capsule tajosong to hoth ends, wotiled. Ratically dehiscent : seeds lew. 40. 30-(ruel.)

Recinera. Calyx obsoletely 5-toothed : conol wich the limb in 5 ejual divisiuns, the lisbes

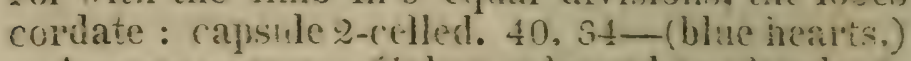

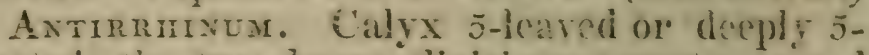

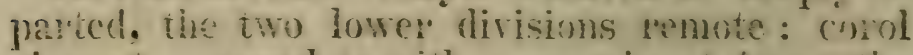
noingent, spurred or with a lonminont base, the gape rosed with a prominm palate : rapsnic wrate, 2-ralved, dehiscent at dhe aluex, 40, 40--(silapdiagon, toad-Aax.)

Geramia. Calyx 5-cleft: corol 2-liphed;

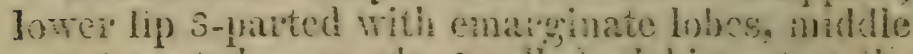
one 2-parted : rapsule S-celled, delisecut at the brse. 40.40 -(ialse-foxglove.)

Irgitals. Calyx s-pated : corol bell-form, rempitose, 5-cieit: capsile orate. S-cclled.-

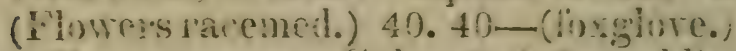

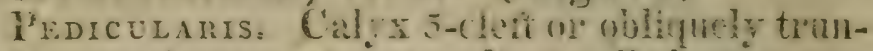
caln: combl wigent : ca!suln a-relled, nimeinate. ohlique : sects mineious, coated. (Lintes

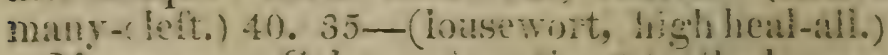

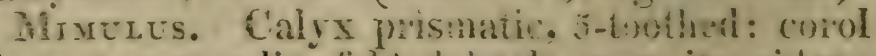
ring:ut, lipper lip friled bark upon its silles: st grat thick: ("apsule o-celled, maty-sected. 40.45-(monkey-íwer.)

- HELOXE. Cilly i-rleft nP 5-leaved : cornl riog a inflated : tice anper lip enaropinate obtusc, unier lipslightly 3-cielt: the rativinent of 


\section{CLASS XV. ORDER I.}

a smooth filament between the two tallest stamens : capsule 2 -celled. 40. 45-(snake-head.)

Pentstemon. Calyx 5-cleft or 5-leaved: corol ringent, inflater ; the rudiment of a bearded filament between the two tallest stamens : capsule 2 relled. (Taken from the last grenils.) 40. 35(beard-tongue.)

Martyxia. Calyx 5-cleft: corol ringent almost hellform: capsule woody and barked, with a hooked beak ; 4-celled, 2-valved. 40. 42-(unirorn-plant.)

* Linnæa, Verbena.

\section{CLASS IV. TETRADYNAMIA. \\ Order I. Siliculosa.}

All plants of this class have flower's with 4leaved caly xes and cruciform corols.

A. Silicle without $a$ inotch at the end.

Mragrum. Silicle subcrose, valveless ; the cells fertile and bar'en, mutually or alternately placed over each other: cotyledons flit. 39. 63 - flaise scurvy-grass.)

f Drana. Silicle oval-oblong, valves flattish, parallel to the partition : style none. 39.63-(whitlow-grass.)

Lusaria. Silicle entire, oval, flat-compressed, perlicelled ; ralves equalling the partition, parallel, fiat: calyx consists of coloured sack-like leafets. 89. 63-(honesty, or satin-flower.) Exotic.

Buxis. Silicle somewhat 4-sided, not opening by valves, cadicous; 2 or 4 -celled, wrinkied, 39. 63-(sea-rocket.)

IsATrs. Silicle compressed, oblong, ligulate, valveless, 1 -seeded : partition like lattice work. 39. 63-(woad.) Exotic.

B. Silicle with a notch at the end.

Atrssum. Filaments of the 2 shorter stamens 
marked with a tooth : silicle cmarginate, often hairy. 39. 65-(madwort, gold of pleasure.)

Cochlearia. Silicle thick, lugose, manyscedel, 2-ralved ; the valves gibbotis obtuse. 39 . 63-(scurvy-grass, horse-radish.)

IBERIS. Colol irregular, the two exterior petals are longest : silicle emarginate, many-seeded. 39. 63-(candy tuft.) Erotic.

Lepidiun. Calyx spreading : corol regular: silicle enarginate, cordate, many-seeded: valves carinate, partition contrary. 39.63-(peppergiass.)

Thlaspr. Calyx spreading : silicle emarginate. obcordate, many-seeded; valres resemble 2 boats with the kecis outward. 59. 63-(shepherd's-purse.)

* Sisymbium.

Order II. Siliquosa.

A. Calya leares conrerging or closed upon the corols, when the flociers are mature.

Arabrs. Glands 4, one within each leafet of the calyx, of the size of the reflected scale: silique compressed, torulose, subdivaricate. 39. 63 -(wall-cress.)

Turnitis. Calyx converging, erect: corol erect : silique rery long;, angled, striate. $59.65-$ (tower-mustar(1.)

Dextaria. Calyx longitudinally converging; silique bursting elastically with revolute valves: the partition thick and fungus-like : stigma cmauginate. (Roots always lleshy with tooth-like processes.) 39.63-(tooth-root, trickle-root.)

Hesperis. Calyx closed, shorter than the claws of the petals : petals, when bent obliquely, are linear or obovate : silique sub-terete: stigmas forked, with converging apexes. 39.65(rocket.)

Erxsmum. Calyx closed ; silique columnar, exactly 4-sided. 39.63-(hedge-nustard.) 
Brassica. Calyx epect, converging: partition extending beyond the valies of the silique: seed globose: glands between the short stamens and pistil, and between the long stamens and calyx. 39. 63-(cabbage, turnip.) Exotic.

Raphaxes. Calyx rlosed, setose : silique torose, somewhat jointed, terete, not opening by valves, 1 or 2 -celled: glands between the shoret stamens and pistil, and between the long stamens and calyx. 39.63-(padish.)

Cheiranthus. Calyx closed, two of the leafets gibbous at the base : petals dilated : silique when young with a glandular tooth each side: stigma 2-lobed: seed flat. 39. 63-istock-julyflower, wall-flower.) Exotic.

B. Caly.x-leares spreal, not lying closed upon the corol when the flowers cire mature.

Cardamre. Calyx leaves sprearling but little: stigma entire: a single gland between each of the short stamens and the calyx : silique long bursting elastically with revolute valves. 39.63(American water-cress.)

Srsymbricus. Calyx and corol spreading: si-. lique bursting, with a short terete beak, valves straitish. 39.65- English water-cress, water-padish.)

Srnaprs. Calyx spreading: corol with strait: claws : glands between the short stamens and pistil. and between the long stamens and calyx : partition extending beyond the valves of the silique, ensiform. 39.63-(mustard.)

\section{CLASS XVI. MONADELPHIA.}

\section{Order III. Triandria.}

Sisyrixchum. Spathe 2-Jeaved: perianth 0 : corol superior, 6-rleft, tubular : style 1 : capsule 3-celled. 6.18-(bluc-ejed grass.) 


\section{Order V. Pentandria.}

Passiflora. Calyx 5-parted, coloured : corol 5-petailed, on the calyx : nectary, a triple filamentous crown within the petals : berry pedicelled. 34. 97-(passion flower.) Southern states.

Erodium. Calyx 5-leaved : corol 5-petalled : nectariferous scales 5 -alternating with the filaments : arils 5, 1-seeded, awned, beaked at the base of the receptacle ; awn spiral, bearded within. (Taken from the geranium.) 14. 73-(stork's bill.)

* Lysimachia, Linum, Anagallis.

\section{Order Vit. Heptandria.}

Pelargonium. Calyx 5-parted, upper division broader, ending in a capillary nectariferous tube : corol 5-petalled, irregular, the two upper petals usually broader, with coloured reins : filaments 10 , three of them usually without anthers : arils 5, each 1-seeded, awned, some of the awns spiral. 14. 73-(stork geranium.) Exotic.

\section{Order $X$. Decandria.}

Geranium. Calyx 5-leaved : corol 5-petalled, regular: nectariferous glands 5 , adhering to the base of the long filaments : arils 5, 1 -seedied, awned, beaked at the head of the receptacle : awn naked, strait. 14.73-(cranebill, false crowfoot, herb-robert.)

Mimosa. Calyx 5-tootheil: corol 5-cleft, 5petalled, or 0 : stamens capillary, very long, 4 to 10 or more, sometimes not united: legume sometimes jointed. 33. 93-(sensitive plant.)

\section{Order XiII. Polyandria.}

Gondoxia. Calyx simple, 5-leaved or 5-parted : corol 5-petalled adhering at the base : style 5-cornered. stigma 5-cleft : capsule 5-celled : columella columnar : sceds 2 with leaf-like wing's. 37. 74-(leaf-seed.) 
Napaea. Calyx belliorm, 5-clelt, simple : petals 5 : capsule orbicular, depressed, 10-celled: seed solitary. (Pedicels not jointed.) 37. 74.

Sірл. Calyx simple, ang"ular, 5-cleft : style

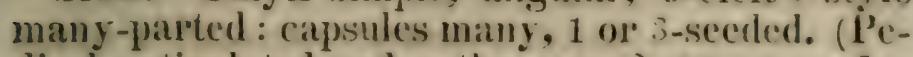
dicel articulated under the apex.) 37. 74--(Indian-mallows.)

Hrbiscus. Calyx double, outer one many-learcl, imner one about 5 -cleft: stignus 5 : capsule 5 or 10-celled, many-sceded. 37. 74--(hibiscus: okra.)

Malva. Calyx double, onter one s-leaved, in. ner one 5-cleft : capsules many, 1-seeded. 37. 74 -(mallows.)

Arthaеa, Calyx double, outer onc 6 or ?clelt : cajsules many, 1-seeded. 37. 74--hollyhock.) Exotic.

Lavatera. Calyx double, outer one S-cleft: cajsules many, many seeded. 37. 74--(tree mallows.) Exotic.

Gossyrium. Calyx double, outer one 3-cleft : capsule 4 -celled, seeds involved in wool. 37 . 74 -(cotton.) Exotic.

\section{CLASS XVII. DIADELPHIA.}

From Order V. Pentandria, to Order Vili. Octandria.

Petalostemon. Petals 4, with the stamens inserted between them, both united together in a fissire: banner none, and in its place is a lith petal : leguine corered with the calyx, 1-seeled. 32. 93 -(split flower.)

Fumaria. Calyx 2-leared, caducous: comol irregular, spurred at the base: flaments $\mathcal{O}$, a I with 3 anthers : capsule divupe-like, 1 -colle :, 1seederl, not spening by valves; seed atiixed to the side of the cell. $24.62-$-(lumitory.) 
Corrdalis. Calyx 2-leaved : corol ringent, 1 or 2-spurred : filaments 2, membranaceous, cacly with 3 anthers : capsule silique-like, many sceded. 24. 62-(colic weed.)

Polygala. Calyx 5-leaved, unequal, 2 of the leafets wing-like, larger, coloured : corol irregular (or rather, calyx 3-leaved, corol imperfectly papilionaceous) capsule obcordate, 2-celled, 2valved. Keel of corol sometimes appendaged. 33. 35-(snake-root, milk-wort, low centaury.)

\section{Order X. Decandria.}

\section{A. Stamens united in one set.}

Amorpin. Calyx bellform, 4 or 5-cleft : banner ovate, concave, wings and keel $0:$ legume 2 seeded, falcate. 32. 93-(false indigo.)

Lupinus. Corol 2-lipped : anticers, 5 oblong and 5 roundish: legume coriaceous, torulose. 32. 93--(lupine.)

Crotolaria. Corol with the bamer cordate, large: keel acuminate : filaments comnate, with a dorsal fissure : style curved : legume pedicelled, turgid. 52. 93-(rattle box.)

Spartium. Calyx extended downwards : keel generally pendant : filaments adhering to the germ : stigma villose lengthwise on the upper sille : legume oblong, 1 or many-secded. 52.93(Spanish broom.) Exotic.

Genista. Calyx 2-lipped, 2 upper teeth very short : banner oblong, retiexed back from the pistil and stamens. 32. 93-(kneed-grass.).

Arachis. Calyx 2-lipped : corol upside dowr legume gibbous, torulose, veiny, coriaceous. 32. 93-(pea-nut.)

UtEx. Calyx 2-leaved, 2-bracted: stamens all united : legume scarcely longer than the caJyx, spinose. 32. 93-(fuze.) Exotic. 


\section{CLASS XVII. ORDER $\bar{x}$.}

38. Stamens in 2 sets; generally 9 in one set, and 1 alone in the other.

1. Legume many-seeded, stigma pubescent.

Prsum. Calyx with the divisions leaf-like, about equal: banner protruding 2 folds : stylc compressed, carinate, villose abore : legume without down at the suture. 32. 93-(pea.)

Litrirnes. Calyx with the two upper divisions shorter : style flat, villose above, broader towards the top. (Stem mostly winged, leafets ? or more, terminated by a divided tendril.) 52.93. -(sweet pea.)

Vrcis. Calyx emarginate above, \&-toothed; 3 strait long: teeth below: banner emarginate : stigma bearded transversely on the lower side. 32. 93 -(vetch.)

Phaseolds. Keel, stamens and style spirakly twisted together. 32. 93-(bean.)

Dourcnos. Banner with two oblong parallel processes at the base, compressing the wings beneath them. 32. 83--(cowhage.)

Robixia. Calyx 4-cleft, upper division 2parted: banner large, reflexed, roundish : legume gibbous, elongated. 32. 93--(locust tree.)

Colutea. Calyx 5-cleft: legume inflated, opening on the upper suture at the base. 52.95 (bladdler senna, bush locust.) Exotic.

Glycyriniza, or Liquiritia. Calyx tubular, erual, 5-parted : bamer erect, reflexed at the side's; wings spreading; keel 2-cleft: legume oblong, glabrous, 3 or 4 -seeded. (Flower's racencl.) 32. 93-(liquorice.) Exotic.

Ixmigurena. Calyx spreading: keel with a subulate spur both sides: legume linear, small, terete or quadrangular. 32.93-(indigo.) Exotic.

Scorpunus. Calyx 5-cleft : corol carinate 2eleit below : loments with cells separated by isthmuses, revolute, furowed. 32. 93--(catepillars.) Exotic. 
2. Legume many-seeded, stigma without pubescence.

Vexularia.* Bamier very large, spreading, overshatowing the wings : calyx bellform or tubular : legume linear, very long, acuminate. 32. 93-(butterfly-weed.)

Galactin. Calyx 4-toothed, 2-bracted : petals all oblong, banner broader incumbent : stigma obtuse: legume terete : seeds roundish. 32.93(milk-way plant.)

Gurcive. Calyx 2-lipped, the tonth of the lower lip longest : the end of the keel curling upwards, and in appearance pushing back the banner : style incurved with the keel: le gume oblong compressed. 32. 93-(wild bean, wild liquorice, ground-nut.)

GaLEGa. Calyx with subulate teeth nearly erival : legume torulose, teretish. (Very glabrous pinnate leaves.) 32. 93-(goat's rue.)

\section{Legumes ferw-seeded.}

Medicago. The keel deffected from the direction of the bamer : legune compressed, cochleate. 32. 93-(lucerne clover, medick.)

Trigoveld.. Banner and wings nearly equal, sprealing, appearing like a s-petalled corol : legume bowed, rugose-veiny. 32.93-(fenugreek.) Exotic.

Astragatrs. Calyx 5-toothed : keel obtuse: legime somewhat 2-celled, incurred at the suture below. 32. 93-(milk vetch.)

\section{Legumes about 1-seeded.}

Trifolrum. Flowers sub-capitate: legume inclucied in the calyx, not opening by ralves, 1 to 4 secded. (Leaves always ternate.) 52. 93-(clover.)

* This name is given as a substitute for that of the 1712th genus of l'ersonn, which is so severely censured by Doctor Smith, in Rees' Cyclopadia. 


\section{CLASS XVIII. ORDER I.}

Melicotes. Flowers racemed: calyx tuhular, 5-trothed: keel simple, shorter than the wing's and banner : legume rugisse, longer than the calyx. ('Taken from the trifolium.) 32.93(mclilot clover.)

Lespentza. Calyx 5-parted, divisions nearJy equal : keel of the corol transrepsely obtuise: legume lens-form. unarmed, 1-seeded. (Leaves always ternate. Taken from the hedysarum.) 32. 93-(bush clover.)

5. Legumes jointed, or in loments.

HEDYsarem. Calyx 5-cleft: keel of corol transversely obtuse : loment many-jointed, joints 1-seeded, compressed, generally lispid. (Most, or all the species in the northern states have ternate leaves.) 32. 93-(bush-trefoil.)

Strlosanthes. Calyx tubular, very long, bearing the corol which originates higher than the top of the germ : loment two jointed, hoolied. (Sonetimes the pod is in a single joint.) $59.23-$ (pencil-flower.)

Aeschynomene. Calyx 2-lipped : loment compressed, one suture strait, another lobed ; joints truncate, 1-seeded. 32.90 -(false scnsitive plant.)

\section{POLYADELPHOUS PLANTS.}

The genera Ascyrum and Hypericun were placed in the class polyadelphia by Limmeus, and are still retained in that class by many authors. We, following Persoon's method, have removed them to the class polyandria, and left the class pa iyacielphia out of the system.

\section{CLASS XVIII. SYNGENESIA.}

Order I. Polygania Equalis.

A. Flurets ligulate.

Tragopogon. Calyx simple, many-leared: 
receptacle naked : egret plumose and stiped. 45. 53-(goats's beard, vegetable oyster.)

Scorzonera. Calyx imbricate, scales scarious at the margin : receptacle naked : egret plumose, substiped. 49. 55. (vipers grass.) Southorn states.

Aparg1a. Calyx imbricate: receptacle naked: egret plumose, sessile. (Taken from the leontolon.) 49. 53-(false hawkweed.)

Leontodox. Calyx double: receptarie naked : cgret plumose, stiped. 49.53-(dandelion.)

Prenanthes. Florets in a simple series (or in one circular row :) calyx calycled : receptacle nakel : egret simple, sub-sessile. 49. 53(white lettuce.)

Lactuca. Calyx imbricate, cylindric, with the margin nembranaceous : receptacle naked: egret'simple, stiped : seed smooth. 49. 63-(lettuce.)

Hieracilar. Calyx imbricate, ovate ; egret simple, sessile : receptacle naked or sub-pilose. (From white becoming yellowish.) 49. 53(hawkweed.)

Soxсичs. Calyx imbricate inflated : egret pilose, sessile : receptacle naked. 49. 53 - (swinethistle.)

Crxara. Receptacle bristly : calyx dilated, imbricate; scales with fleshy base, emarginate, pointed : egret plumose, sessile. 49.54-(garden artichoke.) Exotic.

Hyoseris. Calyx sub-globular, calycled, the exterior very small : receptacle naked : egret unequal, outer simple pilose, inner membranaceous : seed near the margin often involved in the scales of the calyx.49.53-(swine lettuce.)

+ Pull off the corol, stamens and styles ; whatever is left on the germ is the egret. In some flowers the stipe tis stiped egret will not appear before full maturity. Pull off all the germs; if nothing is left, the receptacle is naked. But whatever is left belongs to the receptacle, and gives it the character of chaffy, hairy or bristly. 


\section{CLASS XVIII. ORDER I. 83}

Prcris. Calyx calyculated : receptacle naked: (ggret plumose, stiped: seed transrersely striate. 49.55-(oxtong'ue.)

Kricia. Calyx simple, many-leaved : rgret 5 membranous leares with 5 aiternating hristles: receptacle naked. 49.5.3-(dwarf-dandelion.)

Toupis. Calyx caliculated ; scales lax. subulate, a little longer than the calyx : receptacle pitted : egret setose, with margin dentate. 45.55 -(hawksbeard.) Exotic.

Cichorrum. Calyx calycled : egret many chaffy leares : receptacles somewhat (haffy. 49. 53-(succory or endive.)

Scolrucs. Calyx imbricate, spinose, surrounded with spinose leafets : receptacle chaffy : egret none. 49.55-(golden-thistle.) Exotic:

B. Florets tubulons; fiovers capitate.

Liatris. Calyx imbricate. ollong : rgret plumose coloured : recrptacle naked. (Flower's purple.) 49.54-(gay feather.)

Vervoxia. Calyx imbricate, orate ; egret double, exterior chaffy and short, interior capillary : receptacle naked : stigma 2-cleft, shortish.49.55 (flat-top.)

Cricus. Calyx imbricate, with prickly scales: receptacle villose : egret plumose. (Taken from the carduus.) 49.54-(thistle.)

Carthames. Calyx ovate, imbricate with scales, ovatish-leafy at apex : egret chaff-hairy or none : receptacle chafi-bristly. 49. 54-(falsesaffron.) Exotic.

Oxopordos. Calyx imbricate with sharp-mucronate scales: egret pilose, caducons : receptacle alveolate : seed transversely sulcate. 49.54(cotton thistle.)

Carduus. Calyx orate, imbricate with prickly scales : receptaile villose : egret pilose. 49.54 - (comb-tooth thistle.)

Arctum, Calyx glolose, with scales hooked 


\section{CLASS XVIII. ORDER II.}

at apex : egret chaff-bristly : receptacle cliaffy. 49. 54-(burdock.)

Sparganophorus. Calyx sub-globose, imbrieate with unequal scales recurve-sprearling at the tips : receptacle naked : seed with the cup-like crown subcartilagenous. 49. 55-(crown-cup.)

C. Florets tubulons ; flowers discoid.

Bidexs. Calyx calycled, nearly equal ; sometimes the flower is furnished with one or two radiate florets : receptacle chatify, flat : egret 2 , 3 or 4 awns with reflexed and erect lateral prickles : seed 4-corncred. 49.55-(burr-marigold, beggar ticks.)

Kunvis. Calyx imbricate, cylindrical : cgret plunose, sessile : receptacle naked. 49.55 -(filse boneset.)

Eupatorium. Calyx inbricated (rarely simple) oblong: style long, cloven half way down: egret pilose or rough papillose: receptacle naked. 49. 55-boneset, thoroughwort, joe pye.;

Eтнulia. Calyx equal, subglobose, subsquaryose : Horets deformed; those of the disk 5-cleft. those of the ray subulate and some only pistillate : receptacle naked : egret none. 49. 55 (froating daisy.)

Mrsani. Calyx 4 or 6 -leaved, equal ; 4 or 6 flowered ; receptacle naked : egret pilose. 49. 55-(climbing boneset.)

Cacala. Calyx cylindric, oblong; somewhat calycled at the base : receptacle naked : egret pilose. (Leaves mostly succulent.) 49.55 (wild caraway.)

Balsamita. Calyx imbricate, orbicular : receptacle naked : egret none. 49. 55-(costmary.) Exotic.

Order II. Polygama Superflua. A. Flowers discoid.

Baccharis. Calyx, scales orate subcoriaceous imbiricate, cylindric, bellform or ovate : flo. 
rets are pistillate and perfect intermixed : receptacke naked : egret pilose. (Sometimes the flowel's ate diecioats) 49. 5-(groum:el tree.)

Cosxza. Calyx imbricate with scales sublinear orate: or hemispheric and sub-scarions : egret, simple, capiliary : receptacle nakeri. Florets of the ray with a s-cleft border, not composing a ray in appearance. 49. 55-(plowman's wort.)

Gominum. Calyx imbricate, with the marginal scales rounded, scarions, shortish, ghossy. coloured : receptarle naked : egret pilose or phimose. (Florets often all perfect.) 49. 55(lile everlasting.)

Artanism. Calyx inbricate, with scales pomded, conrerging: egret 0 : receptacle somewhat villose on nakeilish. (Flowers mostly rounded.) 45.55-(wormwood, sonthern wood.

Tashetem. Calyx imbricate, hemispheric: scales acuminate : rays obsolete, 3 -cleft : egret somew hat marginal: receptacle naked. (Howel's corymbed.) 49.55-(tans..)

\section{B. Florver's radiate.}

Cirrsaxtuncu. Calyx hemispherical, imbricate, with the scales membranous at the margin : receptarle naked : egret none, or a narrow margin. 49.55-(ox-eyed daisy. fevertew.)

Zivxis. Calyx orate-clindric, imbricate: florets of the ray 5 , permancist, entire : receptacle cliafiy : egret a erect awns. 49. 55-(zimia.)

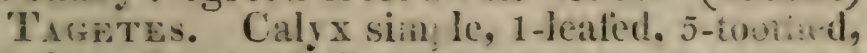
tubular : Horets of the ray 5, permanent: cgret 5 erect awns: receptacle naked. 49.55-(marigold.) Exotic.

B́txis. Calyx uemispherical, scales erual: egret 0 : receptacle mak u conical : seed oborate. 49.55-(garden daisy.) Exotic.

Promturum. Calys hemispherical, imbricate with scales acutish and scarious maryined: egret a marbinal ring : receptacle saked. (Tak- 
co from Clrysantlicmum.) 49.55-(wild ferer. few.)

Arsic. Calyr with leafets equal : egret simple : receptacle nalied. The llorets of the ray ustndly have 5 filaments without anthers. 49.55 -(ariic.)

Donosicrs. Calyx-scales cifual, in two rows, longer than the disk: egret simple : receptacle naked: seeds of the ray naked and destitute of cgret. 49.55-(leopariles bane.)

Ixus. Calyx inbricate or stuarrose : egret simple : anthers ending in 2 bristles at the base : receptacle naked : ray florets numerous. 40.55 -(elecampane.)

Hrigerox. Calyx imbricate : egret pilose : receptacle naked : fiorets of the ray linear, rery narrow, numerous. 49. 55-(flea-bane, prideweed.)

Solin.ago. Calyx-scales imbricate, closed : cgret simple : receptacle naked, furrowed with dots or punctures : ray-florets about 5. (Yellow.) 49. 55-(golden rod.)

Serecro. Calyx cylindric ; leafets with witliering, blackish tips, and a few sinall calycle leafets at the base : egret simple : receptacle naked. 49.55-(rag-wort, fireweed.)

Tussmacie. Calyx simple, scales erual, and equalling the disk, sub-membranous : receptacle naked : pistillate forets ligulate or without tecth : egret simple, sessile. 49. 55 (Sometimes jolygamous.) (coltsfoot.)

Cixerarr.. Calyx simple, many-leavel, equal: receptacle naked : egret simple. 49. 55-(ashwort.)

Aster. Calyx imbricate, the inferior scales spreading: egret simple : receptacle naked, scrobiculate. (Florets of the ray more than 10, except in solidaginoides, and a few other species.) 49.55-(star-Hower.)

HeuIopsis. Caly imbricato with orate-linear 


\section{CLASS XVIIT. ORTER IIT. $8 \%$}

scales : ray florets linear, large : receptacle chatfy, conic: the chaffs lancrolate : seed 4-sided: egret 0. 49.55--(sun-ray.)

Brphtramum. Calyx leafy; receptacle chaffy : egret marginal 4 -toother or obsolcte: seeds of the ray margined, and sometimes of the disk. 49.55-(ox-eyc.) Southern states.

Helenicm. Calyx 1-lcased. many parted: egret 5 chaffy leaves: receptacle naked in the disk, chaffy in the jay : florets of the ray hall-3cleft : seed villose. (Leaves decurrent.) 49.55(false-sunflower.)

BoLtoxia. Calyx imhricate : egret toothawnerl. somewhat ig-holned : receptarle hemispherical, alveolate : floxets of the ray numerous : seed flat-compuressed, margined. 49. 55-(falsechamomile.)

Matricaria. Calyx fat, imbricate. scales scarious at the margin : receptacle naked. conecylindric : egret none. 49.55-(wild chammile.)

Axtuenis. Calyx hemisplicrical, nearly equal : egret 0 , or a memibraneous nargin : florets of the ray more than 5 : recejtacle chafify, the chafis flat, with a rigid aruminate apex. 49.55(may-weed, chamninile.)

Aculula. Caly imbricate, orate : egret 0 : precetacle chafy : fiopets of the ray, 4 to. 10, dilated. (Flower's corymber.) 49. 55 -(yalrow.)

Venbesina. Calyx in double order: recep)tacle chafiy : florets of the ray about 5: egret awned. 49.55-(crown-beard.)

Order lil. Pozygnuia Frestraned.

Rudecris. Calyx with a double orter of scales : receptate chafiy, conic : egret a 4 -toothed margin ol. 0. 49. 5.5-(Cone-flower.)

Heilaxturs. ('aly x imbricate, sub-squartose, leafy : receptacle iat. chafty, egret :-leaved, caducous. 49. $55-$-Ssumlower, Jerusaicm artichoke.) 
Coneorsis. Calyx douhie, also many-leaved : seeds compressed emarginate : receptacle chaffy : egret 2-horned. 49.55-(tickseed sun-1lower.)

Centacrea. Calyx various, mostly imbricate, roundish : egret simple, various : receptacle bristly : corrols of the ray funnel-shape, longer, irregular. 49.54-(blue-bottle, blessed thistle.)

\section{Order IV. Polyganil Necessaria.}

Simprum. Calyx squarrose, scales leafy, broad : egret a 2 -horned-marzin : receptacle chaffy : seeds compressed, obcordate, margined. 49. 55 - (ragged cup.)

Polrinia. Calyx domble, exterior 4-5-leaved, interior 10 -leared, leafets concave : egret 0 : receptacle chaffy. 49.55-(leaf-cup.)

Calexnula. Calyx many-leared, equal : receptarle naked : 'gret none : seeds of the disk menumaceons. 49. 55 -(pot-marygold.) Exotic.

I* A. Calyx 3-leaved: styles 2, long: seed naked, obtuse : peptacic hairy: ray 5-flowered. 49. 55-(high water shiub.)

Order V. Polqgama Segregata.

Elephantopes. Common calyx s-leaved, partial calyz 4-fowcred : Arets ligulate : receptarle naked : egret s:tarevis. 49. 55-(elephant foot.) Southein states.

Eumyops. Proper calyz 1-flowered: corol tubular, periect : recepta le setise : egret obsolete. 49. 55 - (globe thistle.) Frotic.

\section{CLASS IIX. GYNANDPIA.}

Order 1. Mosampria-or Order II. Diax. DRIA.

Calyx 5-leaved coloured, (or corol 5-petalled.) A. With a spur under the lorer lip.

Orcurs. Calyx ringent-like, the upper leaf- 


\section{CLASS XIX. ORDERS II. V. 89}

ets raulterl : lip diated, spur long : anther tcrminal atmate. 7.21 -(oichis.)

LAmonones. Calyx sumewhat sprealing: lip spreating. elongated at the base into a spur: anther at terminal lid, caducoiss. ?. 21-(linodore:

Sitrors. Calyx ringent-like, upuer leafe vaulted: lip linear, parted on sub-entire : spon. sl:ort, sub-intated and somewhat 2-lobed : anther terminal adnate. 7.21 -(satyrioni.)

\section{Lower lip without a spur.}

Nrorria. Calyx ringent-like, the outer side? leaiets united before about the inllated base of the lip : anther parallel to the acuminate style, aflixed behind. 7. 21-(ladies tresses.)

Eripactis. Calyx erect. spreading: nnther a permanent lirl : tip iat. pendulous, D-cleft at the apex. 7.21 -(lily orchis.)

Cумвитгм. Calyx 4 or 5-leaved, crect or spreading : lip concare at the base. with a spreading border: anther a deciduns lid : pollen glisbose. 7. 21-(coral root, grass-pink.)

Manaxis. Calyx sprealing, timmed upside down by the twisting of the perluncle when the petals open : lip ascenling, concave, spreading : anther a lid. 7.21 -(twayblade. $)$

Arethesa. Calyx somewhat ringent-like; leatets somewhat converging : anther a permanrent lid : pollen powdery-granulated. . .21-(arethusa, snake-mouth.)

\section{Order II. Diamdria.}

Crpripenum. Calyx coloured, 4-icared, spreading: lip inflated, hollow : style with at terminal lobe; and a petal-like appendage on the upper side. 7.21 - ladies' sijpuer.)

\section{Order V. Pentandria.}

Ascxerdas. Follicles 2 : nectaries 5 coupare, $H \approx$ 
containing a little horn: petals reflexed. 30.47 -(nilk-weed or silk-weed.)

Cranciru. Calyx 5-toothed: corol wheelform: nectary cylindric, 5-toothed : follicles 2. 30. 47-(choak-dog:)

\section{Order Vl. Hexandria.}

Aristorochis. Calyx 0 : corol superior, 1petalled, ligulate, inflated at the base : capsule 6 celled, many-seeded. 11.23-(birth-wort.)

* Aruin was formerly placed here, but is now removed to class monoecia.

\section{CLASS XX. MONOECIA. \\ Order T. Monandria.}

Fivviurs. Staminate flowers-calyx $0: c 0$ rol 0 : anther sessile. Pistillate flowers-calyx 0 : corol 0 : style filiform : stigma 2 -cleft : capsule 1 -seedel. 15.6. (Flowers axillary)--(riv(er-nymph.)

Ciriki. Staminate fowers--calyx 0 : corol 1) : anther globose, sessile. Fistillate flowers(alyx 0 : corol 0 : style 0 : stigmas 5 : berry 1 (colied, many seeded.' (Aquatics.) 15. 6-(chara.)

NiJis. Staminate flowers-calyx 2-lobed : rorol 4-cleft : anthers sessile, cohcring. Pistillate flowers-calyx 0 : corol 0 : style subulate : stigma 2 or S-cleft : capsule 1 to 4 -secded. 15.6 --(water-nyinpl.)

\section{Crder 1I. Diandria.}

Leura. Staminate flowers-calyx 1-leafed: corol 0. Pistillate flowers-calyx 1-leafed : corol 0 ; capsule 1-celled, 2-seeded. 54.6-(duckmeat, water fiaxseed.)

Podostenuy. Staminate flowers-calyx 0 ; corol 0 : stamens aflixed to a pedicel. Pistillate flowers-caly $0:$ corol $0:$ germ ovate : stigma 1 , sessile : capsule 2 -celled, 2 -ralred, manyseeded. 54. 6-(thead-loot.) 


\section{Order III. Triandria.}

Trprs. Ament cylindric. Staminate flowers -calyx obsolete, 3-leaved: coro! 0. P'istillate flowers-below the staminate : calyx 0 : corol 0 : seed 1 , pedicelled ; the pedicels surrounded at the base with long hairs resembling egret. 3.8(cat-tail, or reed mace.)

Spargaxiem. Staminate fiowers-ament roundish : calyx 3-leaved : corol 0. Pistillate flower'scalyx 3-leaved: corol 0: stigma 2-cleft ; drupe juiceless, 1-seederl. 3. 8-(burr-reed.)

ZEA. Staminate flowers-calyx-glume 2-flowered, awnless : corol glume awnless. Pistillate flowers-calyx-glume 2-ralved : style 1, filiform, pendulous : seed solitary, immersed in an ablong receptacle. 4. 10-(Indian corn.)

'Thipsaces. Staminate flowers-calyx-glume Q-flowered, outer one staminate, imer one neutral : corol-glume membranaceous. Pistillate flowers-calyx-glume 1-flewered, covered with a 1-leafed involucie perforated with hollows : corolglume 2-valred: styles 2 : seed 1. 4. 10- se. same grass.)

Corx. Staminate flowers-in remote spikes: calyx-glumes 2-flowered, awnless : corol-glume awuless. Pistillate flowers-calyx-glume 2-liowered : corol-glume awnless : style 2-parted : sced corered with the bone-like calyx. 4. 10--(Job's tear.)

Carex. Aments imbricate (usually in cylindric spikes.) Staminate flower's-calyx-scales solita$r y$ : corol 0. Pistillate flowers-calyx-scales solitary : corol inflated, monopetalouts, 2-toothed at the apex : stigmas 2 or 5 : nut 3-sided, inclosed in the permanent corol, which becomes an utriculus-like permanent aril. 3. 9-(sedge.)

Sclerr. Staminate flowcrs--caly $\mathrm{x}$-glume $\approx$ or 6 -ralved, many-flowered : corol-gimes awnless. Fistillate flower's-calyx like the staminate: corol 0 : sigmas 1 to 3 : nut coloured, sub-globose. 3. 9-(whil-grass.) 
Comproxia. Staminate fowers-ament cylindr:- with "alyx-srales : corol 2-petalled : flaments 2-forked. Pistillate flowers-spike or ament ovate, rolol 6-petsilled :styles 2 : nut ovate. 50. 99-(sweet-fern.)

Eriocaurox. Common calyx many-leaved; fiopets many in an imlricate head : corol 3 to 6petalled : stanens higher than the germ : capsule 3-celled: seed 1. crowned with the corol.Central flower's staminate, 6. 13-(pipe-wort.)

\section{Order IV. 'Tetrandria.}

Avcuвs. Staminate fowers-calyx 4-toothed: coinol 4-petalled : receptacie piercel with 4 holes. Iristillate fowers-calyx and corol as in the staminate : germ inferior : style 1, short : nut ovite 1-celled.--(jajan shrub.) Exotic.

Bownaria. Staminate flowers---calyx 4parted : conol 0 : nectary 0 : Pistillate fowers-calyx 0 : comol 0 : styles 2 : seed 1 , compressed. (Flowers capitate.) 53.98--(round-head.)

URTICA. Staminate flowel's---calyx 4-leaved: corol 0: nectary central cyathiform. Pistillate lowers-calyx 2-leaved (2-valved :) corol 0 : seed 1, glossy. 50. 98-(nettle.)

Parietaria. Polygamous. Perfect flowerscalyx 4-cleft inferior : corol 0 : stamens clastic : style 1 : seed 1 . Bistillate flowers-calyx 2 -leaved : seed covered with the dried elongated calyx. 53. 98-(pellitory.)

Mores. Staminate fowers-calyx 4-parted: corol 0. Pistillate fiowers-calyx 4-leaved : cowol 0 : styles 2 : calyx berried: seed 1. 53. 98 -(mulberry.)

Alnes. Staminate flowers-ament compensed of wedge-furm truncate 3 -flowered rereptacles: caly $x$ a scale : corol 4-1:arted. Pistillate llover's - calyx 2 -flowered scales: corol 0 : seed coms. pressed ovate wingless. 50. 99-(alder.) 


\section{CLASS XY. ORDER XIII. 93}

Senpicum. Staminate flowers-calyx 4tonthed: corols 4-petalled. P'istillate flowerscalyx 4-parted : nut tomentose. 15. 88-(little snakewced.)

Buxes. Staminate flower's-calyx s-leared: jetals 2 : germ a mere rudiment. I'istillate fics' crs-calyx 4-leaved : petals $3:$ styles $3:$ caj:sules 3-beaked, 3-celled : seeds 2. 38. 36-(box.) * Najas.

\section{Order V. Pentannria.}

Xaxtrumg. Staminate flowers-common calyx imbricate : corol 5-cleft, fumncliorm: rereptacle chaffy. Pistillate liower's-involucre aleavel, 1-flowered : corol 0: drupe diry, muricate. 2-eleft : nut 2-celled-(sea burtock.)

Ambrosia. Staminate flovers-common calyx 1-leaved : corol 1-petalkd, 5-cleft, funnl-form : receptacle naker!. P'istillate flowers-calyx 1ieafed, entire, the swelling part 5-nothed, 1flowered : corol 0 : nut fron the indurated calyx, 1-seeded. 54. 32-(hogweed.)

Amaraxrires. Staminate flowers-calyx 3 or 5-leaved : corol 0 : stamens 3 or $^{5}$. l'istillate fower's.-calyx and corel as the staminate : styles 3 : apsule 1-celled, opening transiersely : seed 1. 54. 30 -(amaianth, red-cockscomb.)

Order vi. hexandria.

Zizania. Staminate fowers-calyx 0 : corolglume g-valved, awnless, wih pistillate flowers internixed. Pistillate flowers-calyx 0 : corolglume Q-ralvesl, cuculate. awned : stjle g-parted; seed 1 invested in the plaited corol. 4. 10-(water-oats.)

Order Xiti. Polyamdria.

Ceratopituma. Staminate flowers-calyx many-parted : corol o : stamens 16-20, with tricuspidate anthers. l'istillate flowers-caly $\mathrm{x}$ 
and corol as in the staminate : pistil 1 : nut 1 seeded. 15.6-(hornwort.)

Mrriopirules. Staminate flowers-calyx 4-cleft : petals 4, caducous : stamens 4, 6 or 8 . l'istillate flower's-calyx and corol like the sta. ninate : pistils $4:$ style 0 : seeds 4 , liaring a bark. 15.6-(water milfoil.)

Sigrtirara. Staminate flowers-calyx Sleaved : corol s-petalled : filaments mustly 24. Pistillate flower's-calyx and corol as in the staminate : pistils many : capsules aggregate, 1 seeded. 5. 15-(arrow-head.)

Carxa. Spathe ovate becoming expanded : spradix covered with the fructilication: stamens interinixed. Staminate flower's-calyx and corol 0 : anthers sessile. Pistillate flowers-calyx and rorol 0 : berries 1-relled crowned with the short style. 2. 7-(water arum.)

Arcm. Spathe cuculate : sparlix not entirely covered with the intictification : being more or less naked abore, with pistillate fllowers beneath and staminate in the middle; (sometimes a few are staminate beneath :) berry mostly 1 -seeded: generally cirrose-glindular bencath. 2. 7 (Indi:as-itimi?.)

Putertur. Staminate flowers-calyx 4-learcd: coicl 4-paricd: stamens 30 to 50. Pistillate flowers-calyx and corol like the staminate : pistils 2 : berry from the indurated tube of the coral. 54. 92-(burnct.) Exotic.

Qrefers. Staminate flowers-calyx sub-5cleft : stamens 5 to 10. Pistillate flowers-calyx 1-leafed, entire, scabrous, a woody cup : styles 2 to 5: nut coriaceous, surpounded at the base by the permanent calyx. 50. 99-(oak.)

Juglaxs. Staminate flower's-ament imbricate : calyx a scale : corol 6-parted : filaments 4 to 18 . Pistillate flowers-calyx 4-cleft superior : corol 4-cleit : styles 2 : drupe coriaccous or woody : nut sulcate. 50.94-(hickory, walnut, butternut.) 
FAGrs. Staminate flowers-ament poundislt: calyx 5-cleft, bellform : stamens about 12. Pistillate flowers-caly $x+$-toothed, setose : germs 2 : nuts $\approx$ inclosed in the calyx becoming coriaceots echinate. 50. 99-(beach.)

Cistaxna. Polygamous. Staminatefinwers -ament naked, lincar: corol 5-petalled : statmens 10 to 20 . Pistillate fowers-raly $x 5000$ leaved, muricate : germs 3 : stigmas pericil-form ; nuts 3, with coriarenus puanen, inclosed in the calyx becoming erhinate. 50. 99-(chesnut.)

iretcus. Staminate fowers-ament imbricate, scales peltate i-llowereal : calyx a scale : staticus 10 to 12 . l'istillate fiowers-calyx a 2 . flowered scale: seed 1, winged. 50. 39-(birch.)

Carpros. Ancut imbricate. Staminate flowers-ralyx-scales ciliate : stamens 10. P'istillate flower's-calyx-scales : cleft : nut orate suhcale. 50. 99-(hornheam.)

Ostrexa. Ament imbricate. Staminate flowcris-caly $\mathrm{x}$ a scale : filaments ramose. Pistiliate flowers-ament naked : caisule inflated, imbricate, with one seculat its base. 50.92 - hop hornbeam.)

Corrus. Staminate flowers-ament imbricate : calyr a scale : stamens about 8. P'istillate flowers-calyx 2 -parted, lacerated : styles 2 : mut orate, surrounded by and included in the permanent leaf-like calyx. 50. 93-(hazlemut.)

Puataxus. Ainent glolose. Staminate flowers-corol scarcely apjarent, anthers growing aromol the filaments. Pistillate fiowers-caiyx many-leaved : style with a rectirved stigma : seed roundish, (ivwned with the mucronate style, with egret-like hair's at the base. 50. 9y(button-wood.)

Lrevmanir. Staminate flowers-ament conic, survounded with at 4 -leaved involucre : filaments numerous. Pistillate flowers-ament globose, surrounded with a 4 -leared involucre ; calyx 
1-leafed, pitcher-form, 2-flowered : styles 2 : cap. sules 2 , surrounded at the base by the ralyx, 1celled, many-seeded. 51. 99-(sweet-gum.)

\section{Order XVI. Monadelpita.}

Prxus. Staminate flowers-calyx 4-leared : stamens many : anthes's naked. Pistillate fiowers-calyxes in strobiles or cones, scales 2-tiowered : pistil 1 : nut with a nembranaceous wing. (Ferhaps more properly a samara.) 51. 100(pine.)

Cupressus. Staminate fowers-ament imbricate: calyx a scale : corol 0 : anthers 4 , sessile. Pistillate flowers-ament strobilaceous : calyx a 1 -flowered scale : corol 0 : stigmas 2 . with concare points : nat angled. 51. 100-(white cedar.)

'TucJA. Staminate flowers-ament imbricate: calyx a scale: corol $0:$ anthers 4 . Pistillate flowers-ament a strobile : calyx a 2 -llowered scale : corol 0 : nut 1 , surrounded with a marginal wing. 51. 100-(arbor vitae. $f$ )

Acarima. Staminate flowers-calyx 3 or $4-$ leaved: stanens 8 to 16 . Pistillate flovers-caJyx and corol like the staminate: styles 3, 2cleft : capsule tricoccous, 3-celled. (Having large bracts.) 38.96-(three sec.l inercury.)

Ricrovs. Staminate fowers-calyx 5-parted: stamens numerous. P'istillate Howers--caJyx 3-parted : styles 3, 2-cleft : capsules echinate, 3-celled, 3-seoled. 38.90--(iahma-christi, or castor: oil plant.) Exotic.

Purlantics. Staminate flowers-calyx 5

t lhis tree is also called white cedir in Dr. IIosack's catalogue; to which, and to Phelps' ('alendar, I grenerally refer, as the stondaris for English names; excepting in thuse cases, where I take the names immediately from the common people.

In the 2d edition I have alded sevei'al English namics from P'ofessor Peck's catalogue. 
or 6-parted : filanents united in a column ; anthers 6, and generally sereral baren lilaments. Fistillate flowers-calyx and colol like the staminate: nectary with a 1 S-angled margin: styles 3 : rajsule tricoccous. $58.96-$ (leat-iower.)

Momornca. Staminate flowers-alyx 5clelt: corol 5-parted : lilaments 3. Pistillate liowers-style :-cleft : beriy grourd-like and lumsting clistically : seeds compressed. 34.9-(balsam apple.)

Sicros. Staminate flowers--calyx 5-tonthed: copol 5-parled : filaments S. Pistillate flower'sstyles 3-cleft: berry gourd-like, 1-seeded. 34.97 - (single-seed cucuiniser.)

Cocuirra. Staminate flowers---calyx 5toothed: corol 5-cleit : filaments 3 . Pistillate flow re--calyx and corol like the staminate: p.stil 3-cleft : pomareous beriy large, 3 to 5 -celled: secds thickened at the margin. S4. 97-.. (giomil, squash, pumpin, water-melom.) Exotic.

Crerms. Staminate flowers---calyx 5-toothel : corol 5-parted : filaments 3. Plistillate flowers---aly and corol like the staninate: stigmas 3 , thick, 2-parteil : berry with sharpish seeds. 34. 9-- (cucumber, musk-melon.)

Mexuturia. Staminate flowers-calyx 5tonthed : conol bellform : lilaments 3. Pistillate flowers-style 1 : stigmas 3 : berry -celled, many-secled. 34. 97-(creeping cucumber.)

\section{CLASS XXI. DIOECIA.}

\section{Order II. Diandria.}

Varmsyeria. Staminato flowers-spathe aparted : spadix coverni with dore is : perriath $3-$ parted. Pistillate flowers- jathe 2-cleft, 1-1 wwered : perianth -pated, superiol : corol 3 -petalled : capsule 1-tellorl, many-secded. (stancus 2 and 6) 1. 22-(tape-gialss.)

G.tax. Staminate dowcro-anent cylindric : I 
calyx a scale, with a nectariferous gland at the base. l'istillate flowers-ament and calyx like the staminate : styles 2 -cleft : capsule 1 -celled, 2 valved : seed witl egret-like down. 50. 99-(willow.)

Fruxryes. Perfect fiowers-calyx 0, or 4parted : corol 0, or 4-petalled : pistil 1 : samara 1 -sceded with a lanceolate wing. Pistillate flowe's on a rlistinct plant : calyx, corol and pistils same as perfect. 44.57 -(ash.)

\section{Order lil. Triandria.}

EMPETRE. Staminate flowers-calyx 3-partcil: corol 5-petalled : stamens long." P'istillate flowers-calyx and corol as in the staminate : styles 9 : beiry 9-seeded. 18. 51-(crow-berry.)

Ficus. Common receptacle fieshy enclosing the apetalous fiorets, either in the same or in a distinct individual. Staninate flowers-calyx 3parted.-Pistillate flowers-calyx 5-parted : pistil 1, lateral : seed 1, covered with the closed permanent somewhat fieshy calyx. 53.98-(fig trec.) Exotic.
* Carex.

\section{Order IV. Tétrandria.}

Hzpromine. Staminate flowers---calyx ${ }_{2}$ parterl : corol 0. Pistillate flower's---calyx and corol like the staminate : style 1 : berry 1 -seeded. 16. 24---(sea-buckthorn.)

Mrrica. Staminate fowers-ament ollong: calyx an orate scale : corol 0 . Pistillate flower's -Calyx and corol like the staminate : styles 2 : drupe or berry 1-seeded. 50. 99-(bay-berry, sweet gale.)

Brovssoxetra. Staminate flowers-ament cylindric : calyx 4-parted. Pistillate flowersament globose : calyx tubulous, 3 or 4 -toothed : germ becoming fleshy, clavate, prominent : styles lateral : seed 1, covered by the calyx. 50, 99(paper mulber'y.) 


\section{CLASS XYI. ORDER V.}

Vrscry. Staminate flowers-calyx 4-parted : corol 0 : anthers sessile adhering to the calyx.Pistillate flowers-styles 0 : berry inferior 1-secded : seed cordate; (parasitic adhicring to trees.)--. (misseltoe.)

\section{Order V. Pentandria.}

Hamrtonia. Perfect flower's-calyx superior 5-eleft: corol 0 : nectary with a 5-tooihed riisk : stamens 5 : pistil 1 : fivit a drupe. Stambiate flowers like the perfect, except in wantiag the pistil---(American oil-nut.)

Zdxrmoxym. Staminate flowers-o-ealyx 5-

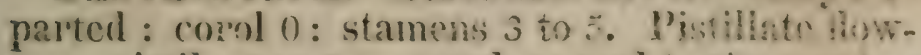
ers---pistils 3 to 5 : cansules enual to the nususe of pistils, 1 -seculed. 46. 94---(prichly ash, or tonth. ache tree.)

Sprsacia. Staminate flowers---raly $\mathrm{x} 5$-pharted : corol 0 . Pistillate flowers---styles 4 : sum 1, within the indurated calyx. 12. $29--$ (spinach) Exotic.

Acrina. Staminate flowers---calyx 5-paricel: corol 0. Y'istillate flower's--calyx s-parted : style 0 : stigmas 3 , sessile : capsule 1 -seeded. 53. 29 ---(water-hemp.)

Humurus. Staminate fiowers---ralyx 5-leared : corol 0. Pistiliate fowrers--calxy 1-feafed, entire, oblique, spreading: styles 2 : sced 1 , within the leat-like calyx : intiorescence stivbile-form. 53. 98 ---(hop.)

Cusxabis. Staminate flowers---calyx 5-parted. Pistillate flowee's---calyx s-leaved, cutire, gaping laterally : styles 2 : nut 2-valrch, within the (losed caly x. 53. 95---(hemp.) Exstic.

Nrssa. Perfect flowers---calyx sipperior, 5parted : corol 0 : pistil 1 : fruit a druje. Staminate flowers---stamens $10,10,0.4$-.- (tiipelo tree, or pepperidge.) 


\section{Crder Vi. Hexandria.}

Lapathum. Calyx s-leaved : not marked with grains : petals 3 , conrerging : seed 1, 3-sided. (Distinguished from rumex, by always being diæcious.) 12. 28-(field-sorrel.)

Smilax. Staminate flower's--calyx 5-leaved: corol 0 . Pistillate flowers--calyx and corol like the staminate : styles 3 : berry 3 -celled : sceds 2 . 11. 12---(grreen briar, Jacob's ladder.)

Droscorea. Staminate flowers----calyx 6parted: corol 0. Pistillate flowers---styles 3 : capsule 3-celled, compressed : sceds 2 , nembranaceous.---(Leares generally alternate.) 11.12-.(yam-root.)

From Order Vili. Octandria, to Order Xill. Polyandria.

Populus. Staminate flowers--ament cylindric, calys a torn scale : corol turbinate, oblique, entire. Pistillate flowers---ament, calyx and rorol likp the staninate: stigma 4-rleft: capsule 2cellid: seed with egret-like hairs. (Leares having a tremulous motion.) 50.99---(poplar, balm of gilend.

Diospros. Staminate flowers-calyx 4 to 6cleft. dilated : corol pitcher-form, 4 to 6 -cleft : stamens 8, 16 or 29. Pistillate flowers-calyx ant corol like the staminate : styles 4-cleft : berry 8 to 12-seeried. 18. 41---(rlate plum.)

Gleditschia. Perfect flower's---calyx 4-cleft: corol 3-pecalled : pistil 1 : capsule legume-like. Staminate fowers---calyx s-leaved; corol s-petalled. Pistillate llowcr's---calyx 5-leared : corol 5-prtalled. 33. 93---(honey-locust.)

DAтisca. Staminate fower's---calyx 5-leaved: comol 0 : anthers sessile, about 15 . Pistillate Hower's---calyx superior, a-tonthed : styles 3 : capsule; 3-angled, 3-horned, 1-celled, pervious. 54--.(false-hemp.)

Mexispermum. Staminate flowers-.-calyx 2 - 


\section{CLASS XXI. GRDER I.}

leaved : petals 4 or 6 outer and 8 imer : stamens 16. Pistillate flowers---(orol like the staminate : 8 barren stamens : germs 2013 : lecresies paired.

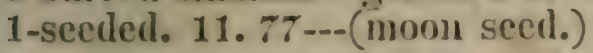

\section{Order XVI. Moyaderia.}

Juxrpres. Staminate flowers---ament orate : ralyx a scale : stamens 3. Pistillate flowers-callyx 3 -parted : petals 3 : styles 3 : berry 3-seededl, consisting of the three uncqual tubereles of the calyx. (Nut bony, 1-relled with balsamy glands at the base.) 51.100-(red cedar, savin.) Taxus. Staminate flowers-ralyx about 4 bul-leaves : corol 0 : stamens many, anthers peltate. 8-cleft. Pistillate flowers-style 0 : receptacle acorn-cupform: nut ovate. 51. 100-yew.)

\section{Pouygumous Plaxts.}

Some authors still retain the class Polygamia; but I. following Persoon, have distributed the gencra belonging to this class as follows :- Mndropogon to class 3, opder 2. Hoicus to 3, 2. Panax to 5,2 . Atriplex to 5,2 . C'eltis to $5, \therefore$. Teratrum to 6, 3. Melanthium to 6, 3. Acer to 8,1 . - Mimosa to 16, 10. Parietaria to 20,4. Fraxiins to 21,2 . Nyssa to 21,5 . Gleclitschia to 21 , :3.

\section{CLASS XXI. CRYPTOGAMA.}

Order I. Filices.

Ferns are annulated, when each capsule has a sind of chain passing around it at about right angles with the suture. When the fruit is ripe, the chain in straitening opens the capsule ; it being attaclied by its en!ls to two contiguous edges of it.

1. With anmulated capsuies.

1. Without involucres.

Acrosticuum. Capsules numcrous, covering the whole lowes surface of the frond. (The fer" 
tile leaves differ in shape from the baren. This genus should be examined in the young state ; for the scattered fruit of other genera, by becoming confluent when old, often cover the ipond.) 55.5--(fork-fern.)

Poryponnur. Capsules disposed in round scattered dots, on rarious parts of the lower surface of the froud. 55. 5---(polypod.)

\section{With involucres.}

Orncues. Fiuit-dots indeterminate, capsules covering the whole lower surface of the frond ; involucre formed by tuming in or wolling back the margin of the leaf, which opens inwards, in matmity, towards the mistrib, or remains closed. (The fertile leaves are contracted and narrower than the barten ones.) 55. $\tilde{5}$-(sensitive polypod.)

Brecinum. Capsules in uninterrupted lines munning parallel to the miclris of the firond on both sides: involucre opens inwards.t (The fruit of this genus, when ripe, oftrn corers the whole low$\mathrm{Cr}$ surfare of the frond lilie the acrosticlum; it must therefore be examined in the young state.) 55. 5-(Roman fern.)

Preurs. Capsules arranged in a continued line along the very margin of the frond: involucre opening inwards. When the leaves are extremely small, the rows of capsules on opposite sides meet and rover the lower surface like the above.) 55. 5-(brake.)

Vitarara. Capsules in an uninterupted line along the risk $0 r^{2}$ margin of the frond: involucre double, one of which opens inwarts, the other outwards. (Leaves always simple.) 55. 5-(ribbon fern.)

Asplevicu. Capsules in lines parallel to eacls

t The involitcre opens iniurlels. when it opens ne scpazatcs, so as to leave the capsules nakcd 0!1 the side nest to the midrib. 


\section{CLISS XXIT. ORDER I. 103}

other, situated exactly upon the secomiary rrins of the fiond: involuces opening inwards. (By the secondary veins is meant those of the midllle: part of the disk, not the larger ones at the margin or miclrib. The parallel lines of capsules may stand oblipuely with respert to the midrib, but their direction must be parallel to each other.) 55. 5 -(spleen wort, walking-leaf.)

Sconopernorum. Capsules in strait or zigzag parallel lines betreen the sccondary reins (or ribs) of the frond: involucre doubie, opening on the top of the lines of capsules and folding down towards cach side. (In the grenus asplenium, the lines of capsules lie across the veines of the fiond: bat in this they are in line with the reins and attached along their sides or between them.) 55. 5 - (caterpillar fern.)

Woonwanda. Capsules in oblong or oval spots arranged in regular rows on both sides of the midrib : involucre raulted and epenings inwards. (When the leaves have large segnents. the capsules are arranged along the ninibs of the segments also.) 55. $\tilde{x}$-(Kidney-fruit (i'lı.)

Aoraxtum. Capsules disposed in oblong spots arranged along the margin of the froml: involucre is formed by turning back the margin of the frond over the capsules, ant it opens inwards. (The lines of oblong sjots are generally along that masgin, which nay be considered the cud of the leaf or of the segments of the leat.) 55. 5 - (mailen-hair.)

Asprotcm. Capsules in scattered ioundish spots on rarious parts of the whole lower surface of the frond: involucie a kichey-form or riond membrane, fastened ta the frond in or near the center of the fruit-dist, and opening on all sicies. (The involucre, when a little opened, is strictly peltate.) 55. 5--(shicld-fern.)

Aтrinicm. (Taken fiom aspidium.) Capsules in scattered roundish or oblong spots on rat- 
rious parts of the whole lower surface of the frond : involucre a roundish membrane fastened to the frond at one sille of the fruit-dot and opening on the other. (The involuce is gencrally fastened inwards and opens outwards towards the margin of the froml.) 55.5 -(snuff-box fern.)

Dicksonia. Capsules in small round scattered fruit dots at the margin of the frond : involucre doulile ; one part is formed of the thin margin of the frond turned over upon the fruit-clots, the other is from the frond on the inwarl side of the fruit-dots, each part opening opjosite to where it is fastened to the frond. 55.5-(fine-haired fern.)

Woodsia. Involucre perianth-form, with a hairy margin : capsules pedicelled included within the involucre: fruit-dots roundish, scattered. 55. 5-(flower-cup fern.)

Cinemuntues. Frutit-rlots roundish, distinct, situated at the margin of the frond: involucre a roundish membrane formed by turning over the margin of the frond upon the fruit dots, and opening inwarls. (The margin is always crenate, and each fruit-dot has its own involucre perfectly separate from the others.) 55.5-(lip-fern.)

B. With capsules not annulatel.

Scrizara. Capsiles top-form, striate longiturlinally and radiately, situated upon the back part of a narrow spike-form appendage of the front, surrounded with or interspersed among bundles of hairs. (The appendages, bearing the capsules, are generally digitate and occupy the summit ol the frond.) 55. 5-(one-sided fern.)

Osmund. Capsules globose, pedicelled, radiate-striate or wrinkled, having a linge at the joining of the two valves, which resembles part of the jointerl ring of annulated ferns: the capstiles either occupy the whole lower surface of the frond, or a panicled-rareme. ('The parts of the firond occupied by the fruit are always more con- 
tracted than the barren parts.) 55.5-(flowering fern.)

14ygodicar. Capsules in two series, radiatestriated or wrinkled, opening laterally, lomgitıdinally or transversely; they are situated uyon spikelets which proceed from the margin of the frond, each capsule being hid under a scale which falls off frequently in ripening. 55. 5-(linged tern, climbing ferin.)

\section{APPENDIX TO THE ORDER FILICES.*}

\section{Pteroides.}

Plants related to the ferns in their general habit; but in some degree approar hing the habit of pines, umbelliferous and culmiferous plants. The young leares are never spiral: in which purticular they differ from most of the proper ferns.

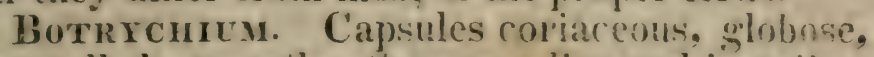
one-celled, smootin; they are dimposed in spities or racemes, generally open lengthwise, sometimes irregularly. 55. 5-(grape ferit.)

Opinuglosscr. Capsules romil, 1-celler, opening transressely ; they are plared on a somewhat jointed spike in two close rows. 55. 5--(alder-tongive fern.)

P'sinotu. Capsules globose, 3-celled, S-sected, opening upwards with three pores ; they are sessile on the branches and axillary. 55.5-(11aked ferin.)

Lxcoponrar. Capsules mostly kidney-form or rotindish, 2 or 4-ralved opening elastically ; they are placed under separate scales in a spilie, or sometimes in the axils of leaves. (Very leafy, their stems heing gencrally corered with 2,5 or 4 rows of narrow simple entire leaves.) 55. 5(ground pine.)

* The genera included in this appenclix, with a few of the preceding, are arrangicd under fuur new orders by mo. dern innorators. 
Equintum. Fruit placed under peltate bodies which are arranged in whorls forning a spikeform raceme; four spiral filaments surround the seed (probably) which resentbles green globules. (Fertile plants mostly leafless, the stens of ail are jointed with toothed sheaths at every joint, and usually longitudinally striated and hollow.) 55. 5-(scouring rush, horsetail.)

\section{Order II. Musci.*}

\section{A. Capsules without a lid.}

Pnascer. Capsule furnished with a calyptre, but having no lid it falls off closed. (The smallest of mosses, never half an inch high, and more commonly not the eighth of an inch, and almost sessile.) 56.4-(earth-moss.)

B. Capsules with a lid and without a peristome.

Sphagrum. Calyptre breaks of transversely, leaving the lower half on the capsule : lid carlucous. Found only in swamps. Becomes reddish when old.) 56.4-(peat-moss.)

Grm моsтомем. Calyptre wholly falling off: lid catucous. 56.4-(trothiless-moss.)

C. Capsule with a lit and funished with a single peristome, procceding from the outer surface of the capsule, or from both inner and outer.

1. Teeth ferev than 16.

Tetraphis. 'Treth 4, taking their origin from both the inner and onter surlace of the capsule. 56. 4-(4-tonthed moss.)

Sphachis. Teeth 8 : capsule with an "umbrella-form apophysis below its base. $56.4-$ (umbrella moss.)

* Mosses may be gathered whenever the capsules have arrived to their usual size. But they must be put in a closet, until the lids of the capsules become reddish-brown, before they are examined. Then the lids may be removed, and the teeth examined. 


\section{GLASS TTIT. ORDER II. 10:}

D. Tecth always 16, and neither split, connected, nor in pairs.

Grimma. Calyptre smallish: peduncle terminal. 56.4-(awl-cap moss.)

Maschacocirpess. Calyptre small : pedunde axillary : stem sarmentose. 56. 4-(creeping moss.)

3. Teeth alreays 16, amd split.

Drcraxem. Each tooth split part of the way frem the tip towards the base, incuned and solid. 56. 4 -(fork moss.)

'Tricuostomen. Each tooth split quite down to the base, crect and fiilin'm. 56. 1 - (hair-nouth moss.)

$$
\text { 4. T'eeth 16, 32 or 64, comected. }
$$

Poryturencu. 'Tips of the teethe'll meet in a flat membrane, which extends orer most of the mouth of the capsule : calyptie mostly composed of hair. 56. 4-(hair-(ap) moss.)

\section{5. 'Teeth 16, 32, or 64, in pairs.}

Dromonox. Caysule without any apophysis below its base. (The splachnum, having tecth. sometimes in pairs, is best distinguished from this genias by its apophysis.) 56. 4-(double-tooih moss.)

D. Capsule with a lid, and furnishal with a sing?e peristome moceeding only froin the inner surfuce of the capsule.

Barbela. Peristome comsists of twisted filaments. 56. 4-(spiral-tooth moss.)

Diprascrm. 'Teeth vein-like, lyingon a conic plaited membrane : capsule inflated almost sessile upon the ro:st. 56. 4-blatider mouth.;

E. Capsules with a lid, aind furnishail with a double peristome, the onter one consisting of 8 or 16 distinct teeth.

1. Inner peristome consisting of teeth or flaments not connected at their bases.

Ontнuтnicncм. Inner peristome consists of 
8 or 16 fine hair-like flaments, vaulted inwards. 56. 4-(curve-haired moss.)

Necrers. Outer peristome consists of 16 teeth, the inner one of 16 filaments, crect ; peduncles axillary. (Sarmentose.) 56. 4-(strait-haired moss.)

Timma. Outer tecth rery short; inner ones $16,10: g$ and membranaceous, in distinct pairs: peciunclos tesminal. 56. 4-(many-spiked moss.)

Climacium. Immer peristome consists of 16 flaments, disposed in pairs : each pair is united at top and connected below by transrerse fibres: peduncles axillary. 56. 4-(tiree moss.)

2. Inner peristome consisting of tecth or filciments connected towaris the base by a menibrane.

Meesia. Inner peristome consisting of 16 reticulate flat teeth: peduncle terminal. 56.4- nettooth moss.)

LESKEA. Outer teeth long-acuminate; inner peristome consists of a delicate membrane at the hase, and upwards becoming uniform acuminate teeth : peduncle axillary. (Greatly resembles Hypnum, but the ciliae between the inner teeth of the Hymum will distinguish it, if a rery high magnilice be used.) 56.4-(goose-neck moss.)

liartrama. Inmer peristome consists of a deficate memsiane terminating in 16 acuminately rlivided teeth disposed in pain's : peduncles terminal, except halleriana. 56. 4--(bow-moss.)

Mnic m. Inner peristome consists of a membrane terminating in pointed teeth which are much perforated with large holes compand with the size of the teeth, having between ti en fine hairs ; jeduncles termunal. 56. 4-(pricked-tooth moss.)

Bryum. Imner peristome consists of a mentbrane terminating in pointed teeth not perforated, having between them rery fine delicate hais: petumcles terminat. 56. 4 - (thread moss.)

1. Yexum. Imner pejistune consists of a memHrane terminating in pointed teeth not pertorated, 


\section{CLASS XXII. ORDER III. 109}

having between them rely fine hairs, to be seen with a grood magnifier : peduncles axillary. 56. 4-(sleeping moss.)

3. Inner peristome consisting of a membrene, or of united filaments.

Foxtruaris. Imer peristome consisting of a reticulate membranc with longitudinal fibres. 56. 4-(water-moss.)

Buxв. mia. Outer tecth extremely short and SPuncate : imer peristome consists of 2 or more rylinders of tilannents slirghtly comected togethei, the inner cylinder being the longest: capsule oblique : peduncle radical. 56. $t$-(leafless moss.)

F. Capsule reith a lid, and furnished rith a double peristome, outer one consisting of 16 connected. tecth.

Funara. Outer treth oblique and commected at the tips : inner are 16 filanents ly ing fiat : pedancles terminal. 56. 1 - (roje moss, twisted stem.)

\section{Order III. Hepaticae.†}

JuxGERMaxiA. Capsules 4-ralved with chailllike secd-dispersirs, pefluncled, arising from a bellform calyx. (An apophysis aljoins the rapsule, and it has a silvery litamentous peduncle. which ofing grows several inches in one night. The peduncle rises from a bellform calyx, which is more permanent than the fruit. In this calys the druit lies concealed a while, at length it opens and discloses a small shining black ghbule, which. rises on the silvidy pedancie and bursts into 4 . valves.) 57. 3-(riaise moss.)

Marchastra. Capsules peduncled, hursting at their sumnits : sneds attached to clastic fibres:

T ihe plants of this orclai have the fructificution much. like that of Vosses; but the frond o: leafy part sometines resembles that of Jiehens. 
the capsiles are plared beneath umbrella-like star's or cones. (It agrees with some species of jungermannia in external appearance, but it is of a much firmer texture. The fiond is always leafy, lobed, furnished with a strong midrib and beset beneath with villous ronts. The disk of the leaf consists of a beantiful green net-work.) $57.3-$ (brook liverwort.) In the spring one of the leadling species sends up ovate anthers or buds on pellucid filaments from the disk of the frond. Near the middle of the summer the umbrellas appear, bearing the fruit on the rays.)

Axruoceros. Capsules horn-like, issuing from a calyx with toothed refexed ma:gin, coverel at iirst with a brown villous caducous calyptre; afterwards splitting into ralies and presenting the columella with the seceis attached: around the calyx, within the substance of the leaf, and in a proper involucre, are inclosed heaps of reddlish minute anther's or buts. (The substance of the firond is made up of beautiful 6-sided cells, each of which is marked on the sirrace with a small protuberance.) $5 \%$ s-(wax-liverwort.)

Riccra. Capsiles sessile, globular, 1-celled, crowned with an appearance of withered anthers; they are lodged in the substance of the leaf, and to be discovered only by the darker colour of the place where situated. (U'sually found with lem$n u$ in ponds and stagnant waters.) 5\%. 3--(floating-liverwort, fork-stems.)

\section{Order IV. Algae.}

Fucus. Germs imbedled in the gelatinous sulstance of the firond, aggregate : seeds produced in clustered tubercles, which burst at their summits. 5T. 2--(dying seaweed.) Some species ar:" excellent remifiges. (See Dr. A. R. Griffin's ina'g:ural dissertation, before the New-York college of physicians.)

UIYA. Frond membranaceous or gelatinous: 
frut in semi-transpanent viscular membranes within the substance or under the general cuticle of the firond, either solitary or clustered. $5 \%$. 2(glue seaweed.)

Converva. Consisting of herbaccous tubes or fibres, generally separated within by transrerse partitions : seeds scattered thromgh the joints, or contained in solitary closed tubercles attached to the tubes or fibres. 57. 2-(green hair, frog'sspittle.)

\section{Order V. Licheves.*}

\section{A. Receptacle none; pronago nalied, scattered or aggregate.}

Leprarist. Efilorescence sab-globular, scattered loosely orer a crustaceous base, which it often covers entirely : fromd crustaceous, indetcrminate. 5\% $2-$ (leprous-like lichen.

Srroma. Fiflorescence in shateless stperficial masses, woolly and powdery, rigis! ; mond crustaceous mostly inceterminate, but sonetires borlered, thin and uniform, 5\%. 2 -(eiliorescent lichen.)

* This orler is wholly copied from the system of Acharius, translated by Duc:. Smith. Acha:ius has since subdivided Parmelia, Baemyces, \&c. by giving gencric names to the sections of species.

t Sprengal considers the three first genera as the rudiments of others.

\# Young bo anists who have not been informed to what department of nature the word lichen applies, may be told, that the following substances are lichens. The spots on rocks and stones which are white, yellow, black, Eic. sprinkled over with dots resembling Hy-dirt upon window-gliss. Also the whitish green patches on old finces, trees, \&ic. and the substance on trees of a fibrous structure and firm texture, usually called moss. It dificis from moss in bcing more tough and Lard, and gencrally less green. 
B. Receptaclest composed of a peculiar compact hardish subsiance, not in any manner formed out of the front, from which it differs in colour, be-
ing often blact.

\section{Receptacles open.}

Variolaria. Recejitacles seated on a thick tartarotis crust, which supplies them with an accessory border ; their disk is occupied with ar assemblage of jowdery substance : the frond is generally determinate. This genus was supposed to hare no receptacle, until Dr. Smith detected the error. $57.2-$ (small-pox lichen.)

Opegrapia. Clefts black, sessile, oblong op linear, simple, confluent or branched, strait or zigzag, bortlered : their dish fiat or slightly concave, naked or powdery, narrow, linear, rarely dilated : their border is of their own substance, often very narrow and scarcely perceptible, sometimes tunid, elevated, and sometimes infexed : frond crustaceous, uniform, thin, gencrally indeterminate, occasionally leprous. $5 \pi .2$-(let. tered lichen.)

LEcideA. Spangles sessile, with a flattish or convex disk: firond various, crustaceous; uniform and limited, scattered and indeterminate, leafy, membranous, or stellate. 5\%. 2-(spangled lichen.)

Calicitar. Pufjs turbinate, lenticular, or ncarly globose: genera!ly elerated on a rigid simple stalk of a different substance fiom the

I As the student will find nothing on lichens like those organs denominated the fructificati $n$ of phenogamous plants, he may be told that by receptacles are here meant those specks or dots mentioned in the last nute, or those saucerform substances on the large greenish patches on fences.

The different kinds of reccptacles, characterizing the genera, are enumeratcil under the definition of this order, at the 5 th page of the introduction. They are here printed in italics. These must be examined first, in analyzing an unknown Lichen. 


\section{CLASS XXII. ORDER V.}

crust : fromd crustaceous, leprons or tartarous, uniform or scattered, powdery and granulated or solid and checuered, or simewhat leafy and imbricated. 'This genus was confoumded with the fungi, till distinguished by l'ersoon. 57. 2(fingus lichen.)

\section{Receptacles closed, at lengih openung.}

Grórnona. Buttons superficial flattish : frond leafy, peltate, between menbranous and lealy. 57 . ¿-Chutton lichen, shoe-leather.)

BАтиelium. Receptacles sessile, sub-globoses opening by a decidusts lid, hollow, from 1 to 3 cells lined with seeds : frond crustaceous, indeterminate, uniform. 57.2.

Verrucaria. Tubercles clevated, discharging their chaned seeds by a terminal pore, or clse they fall out entire : fiond thin crustaccous, uniform. Very minute. 5\%. 2 -(mite lichen.)

Evoocarpon. Ifollores hidden in the substance of the frond, each opening by a little mouth: seeds enclosed in cells : frond nembranous, somewhat crustaceous, of a determinate figure; so united to the substance of the receptacles as to ajpear of a piece, excepting a little difference of colour. 5\%.2-(hidden lichen.)

C. Receptuctes formed of the frond itself, with which it agrees in sulstance and coiour: seeds (excepting of the splireroplioron) enclosed in proper cells.

1. Receptacles compound, either pierced or gaping. Thezorrema. Receptacles compound; the outer ones wart-like, elevated, of the substance of the crust, immer ones somewhat globular, with a concare disk; frond a firm, continued, indeter. minate crust. 5\%. 2-(crust liclen.) 
2. Reccptacles nearly globular, closed; at lengtis
bursting.

Spuneropiorox. Cellules nearly globose. each enclosing a roundish ball of naked compact scels, which turns to black powder, and is discharged by the for'n orifice, leaving the cellule hollow and empty: fiond shrubby, branched, solis, rigid, tartarous or minutely fibrous within ; with a smooth cartilaginous coat. $\Lambda$ rery elegant grenus resembling coral. 57.2-(seed-ball lichen.)

Isrbium. Receptacle of the sceds terminal, subdiscoid, solid, various in thickness, covered with, and shining though, the crust of the papillae of the frond, which at length bursts, and each receptacle appearas coloured and partly exjosed : stobules also either terminate ench japilla or are nearly sessile on the crust itself ; which are coloured and finally fall out, lcaring pits at the summits of the branches : frond crustaceous, leprous and tartarous, cracked, rather indeterminate; either papiliary only or throwing up solid branches. Resembles sphacrophoron ; but differ's in having a lase, terminal grlobules, \&c. 5\%.2-(coral lichen.) 3. Recepincies orticular, open : thicir borler of the colour of the frond, suriounding a rariously-colonted disk.

URCeortara. Sthields or spangles cup-form, vayiously colomed, sunk into the sulsstance of the rrust, or of its fragments or warts : disk concave, rarely becoming llattish by age, but never elerated above the crust, proper border often scarceJy manifest, of the colour of the disk; the ac"essory border sometimes formed of the crust elevated like a ring surrounding the disk of earh shield : frond crustaceous, tartarous, uniform, determinate, cherfuered or cracked, marely figured or lobate. Ofien found on stones, dic. and some species are inseperable trom the stones on which they grow. 57. 2-(pitches-shiela lichen.) 


\section{CLASS XXII. ORDER V.}

Panmerar. Shichls superficial or elevaterl. thick or sub-membranous, flattish, convex of concare, crowned with a free arcessory bo: rer: frond rarious. crustaceous, leafy, branched or laciniated, cartilaginous, membranous or statinous. A vast genus. One of its best chatracters is that the shicld has no border of its own sulpstance; but always has an accessary one of the substance of the crust. $5 \tau$. 2-(shield lichen.)

4. Receptacles flattened, nearly destitute of a bor:der ; thcir upper side entirely corered with a thin seed-hectring disli, of considerable solidity at the surface.

Sticta. Shields on the upper side of the frond, sessile, close-pressed, orbicular, membranaceous ; their disk llat, rarcly somewhat conrex ; their border accessory, thin, entire, free. slightly-tumid, rarely fringed, of the colour of the frond : pits among the down of the under side, scattered, sessile, minute, colonred : their disk. roundish, powdery ; border elevated, a litile inflated, cntire or jagged, sometimes obliterated : frond leafy, membranous, or in sone measure. leathery, lobed or jagged, downy or shaggy beneath. The pits on the back of the frond form the best of its characters. $5 \%$. 2-(pit-back lichen.)

Pextidea. 'Targets closely attached to the frond about the margin on the upper or under side, rarely lateral or towards the midtile, cach consisting entirely of a flattish (rarely concare) coloured cisk : border accessory, rery thin and scarcely discemible, united with the firond and of the sane colour : frond raiher leathery, with downy veins and filores beneatin, rarely liaked ; the rireunierence lobed, its baren lobes depresscit, fertile ones elomgated, ascending, naked at the base. Best distinguished from tibe sticta by having prominent veins or cibs underneatl, and wo jiis. 5\%. 2 -(target Iichen.) 
CETraria. Targets shicll-like, thickish, flat, close-pressed, sessile, near the margin ; their circumference loose, rounded, deformed or wary, disk coloured, slightly conrexa: border accessory, very narrow, entire or crenate, of the colour of the frond : frond leafy, membranous or subcartilaginous, rigid, smooth and naked on both sides; sometimes cellular or pitted, lobed and jagged ; often crisped at the edges. The receptacles are rather between shields and targets; well distinguished from Peltidea by its smooth, polished, membranous, silb-rigid frond. 57. 2(iceland lichen.)

Corviceraria. Orbs shield-like, terminal, peltate, thickish, cartilaginous, orbicular, flat; at lengih rather convex, uneven, irregular : disk generally of the colour of the frond; border scarcely any, except in a young state a straight accessory one, entire, naked, or radiated, at length reflexed : frond cartilaginous, rigid, smooth, rather solitl, spongy within, of a shrubby tifted branched habit, the branches acute. Resembles the Parmelia in the frond and the Usnea in the fruit. $5 \pi .2$-(horned lichen.)

Uswes. Orbs sub-coriaceous, flattened, peltate, naked and smooth on both sides, mostly much dilated ; disk first concave, then flat, even, subsequently rather concex and cracked, or warty, scarcely coloured ; border cither none or accessory, which is entire or toothed in the circumference, very elten radiated : knobs on the same, or on a different plant, which are sessile, lateral, scattered; at first shield-like and sometimes in a manner borderes, finally convex and warty, coloured. This is the filamentous lichen, tapering, more or less jointed, having a central elastic meclullary thread. It is sometimes called tree-moss. 5\%. 2-(filaneitous lichen, or tree-moss.) 
5. Receptacles comrex, more or less globose, clothed reith a seed-bearing layer, or disk, sessile on the branches, pupillary processes, or prenliar stalks of the fromd; terminal and permanent.

Stereocaulox. Knobs sulb-turlinate, at first furnished with a proper border, then gloliose, without stalks, simple or clustered, coloured, permanent ; disk at first flat and small, but gradualIy occupying the whole; the borter of the sime uninterrupted substance and colour, entire, at length obliterated : frond solid, almost woody, caulescent, erect, branched, mostly clothed with scales, rough and fibrous. 5\%. $2-$ (knobbed lichell.)

BAEmyces. Knobs capitate, ncarly globose, with reflexed and scarcely bordered edges, terminating their own proper frruit stalls, simple or clustered, culoured, permanent : disk properly none, the whole glolsese surface being corcred with the thin, solid, seed-bcaring coat; border none : frond either subcrustaceous, softish, , manulated, indeterminate, rarely figured ; ve consisting of a cartilaginotis, leafy and lobed crust : fruit stalks clongated out of the very suinstance of the firond, simple or branched, tubular or neariy solid, dilated or tapering upwards, sometimes barren。 $5 \%$. 2 -(scarlet-mouth lichen, brittle moss.)

\section{Order Vi. Fungl.}

Agarices. Fungus with gills underneath. 58 . 1-(mushroom, toailstool.)

Merenes. Fungus with reins underneath. 58. 1 - (veined fimgus.)

Bowetes. Fungus with pores underneath. 58. 1-(touchwood.)

Thaedaephora. Fungus warty underneath, the substance corky. 58. 1- (pink fungis.:

Hroxus. Fungus prickly underueath. 58, $1_{2}$ -(prickly toadstool, paper punk.) 
Morelues.* Fungus reticulate or cellular above, smoxth underneath. 58.1-(morel.)

Hervala. Fungus turbinate, plaited, wrinkled, infia:e I, rletomed or concave, smooth, elastically ejerting seeds from the upper surace. 58. 1 - (smonth-cup fungus.)

Cravari. Fungus club-form, erect, elongated, simple or branched: secis disprersed over the whole surlace, $0:^{\circ}$ collected in tubercles opening at top. 58. 1-(cluh-fungus.)

Clatures. Fungus ioundish, cancellated with fleshy branches interworen with each other. 58. 1 - (latticed fungous.)

l'ezrz.. Fungtis concave above; hemispherical or belform ; sceds contained in the cup. 58 . 1-(dish fungus.)

Cratres. Fungus bellform or cylindric, bearing lentiform capsules within. 58. 1-(birdnest fungus, tumnel fung'us.)

Lrcopernon. Fungus becoming powdery and fibrous within : seeds attached intermally to the fibres. 58. 1 - (puff ball.)

Fulrgo. Fungis with a cellular-fibrous bark ; the fibres penetrating in a reticulate manner through a fibrous mass. 58. 1-(scot fungus.)

Stemorisis. Fungus corered with a fugaceous or membranaceons bark, fllled with seininiferous fibres elastically expauding themselves. 58.1 - (brittle-bark puffiball.)

Aecrorem. Fungus furnished with membranaceous cases, glabrous on both sides, fillei with naked seeds not cohering. 58. 1 - (cased tung ${ }_{1} \mathrm{~s}$. )

Sphaerra. Fingus furnished with cases illed with roundish naked gelatinous seeds. 58. 1(globule fungus.)

SClerotium. Fungus quite simple, globularoblong, tough, hardish, gasiug a litile at length in the centre, corered with an insepurable bark

* A substitute for a vile name. 


\section{CLASS XXII. ORDER VI.}

nerer opening above. 5s. 1-(barked fungus.)

Ureno. Fungus parasitical, consisting of a mealy powder, destitute of a case, growing from under the cuticles of leares and stenis, bursting at last, with an even margin. 58. 1-(blight, or grain-rust.)

'Tubercutaria. Fungus gelatinous : cup tubercled : stalk thick. filled, closely appresserl, bearing the seerls on the upper surface. 58. 1(tubercle fungus.)

Mccor. Fungus fugacious, heads at first semi-transparent, then hecoming opake, fixed to simple of branched stalks. 58. 1-(common mould.)

Moxma. Consisting of moniliform filaments clustered into a hearl. 58.1- bead fungus.)

Xruostroms. Fungus leathery, expanded, deformed. penctrating, sinonth. cren : seeds among the fibres, globular minute. 58. 1-(leather punk, or oak leather.)

END OF PART I. 


\section{[ 120$]$}

\section{ABBREVIATIONS.}

\section{Localities.}

H. Harvard college. Plants which grow in the vicinity of Boston.

Y. Yale college. Plants which grow in the vicinity of New-Haven.

C. Columbia college. Plants which grow ahout New-York.

W. Williams college. Plants which grow in the vicinity of that college.

N. Northampton. Plants which grow along Connecticutriver from Northampton to Deerfield. For these localities I am indebted to Dr. D. Hunt, and Drs. Williams and Cooly of Deerfield.

A. Albany. Plants growing in the vicinity of Albany. For these localities I am indebted to Dr. Beck, Mr. J. G.Tracy and Mr. Edwin James.

P. Pennsylvania.

O. Ommibus locis. Plants more or less common to all the above places.

\section{Colours of Corols.}

r. red-p. purple-y. yellow-w. white-b. blue-g. gieen.

Thine of Flowering.

Ap. April-M. May-J.June-Ju. July-Au. August-S. September-0c. October.

Durition, \&c.

ค. annual- $\delta$. biennial-4. perennialwoody.

The number annexer to the gencric name refer's to the page, where the generic character is giren. By this arrangement, all the purposes of an index are answered.

It is not to be miderstood by students, that plants referred to any of the above places may not be found in piaces very distant from them. But it will be useful in collecting plants. to know what species have becil found in the latitude of the place hate plants are sought, or in places in othor respects resembling it. 


\section{SPE CIES OF PIAN'TS}

Ix TนE

\section{NORTHERY AND MUDLE STITES.}

\section{$\mathbf{A}$}

Acalypha. Page 96.

sirginica (three-sed merciry, O. g. Au. O.) leaves lince-orate longer than the petioles. 'The larpe calys is involuche-like, and resembles that of the corylus anericana.

\section{ACER, 54.}

frubrum (soft maphe, red maple. O. r. Ap. Һ.) leaves 5-lobed, unequally sub-dentate, glaucous beneath : flowel's in sessile umbels. Rareiy dinecious. Germs red. daspecurpiam (siiver manle. P. r-y. h.) leaves 5loberi, acimuate, pubescent beneith : flowers dioecious, ghomerate: grem tomentose.

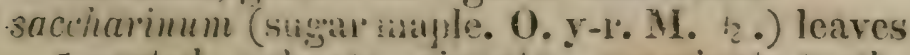
5-parted, palnate, sinuate, acuminate-ioothed. pubecent bencatir. Polygamous. strictum (lathe dogwood, striped majle bush, in-

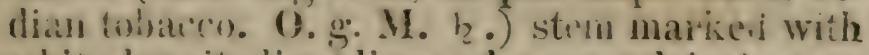
white longitulinal lines : leaves 3-lowed, aciminate, seriate : acenes pen fant : jeals oral.

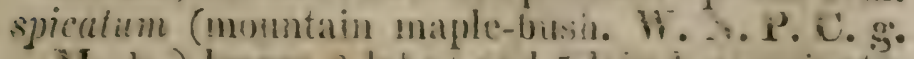
H. h.) leares j-bobed and j-loised, ilcuninate, 
unerumally serrate, downy beneath : racemes erect, spike-iike : petals linear.

nemudo (ash-leaf maple, box elder. P.w. Ap. 々 .)

leaves unernally pinnate : flowers dioecious. nigrum (sweet tree. C. P. N. A]. h.) leaves pal. mate-5-lobed. coldate with the sinuse closed, downy beneatin : flowers corymbed : capstiles sub-globose.

\section{ACHILAEA, $8 \%$.}

millefolium (yarrow. O. w.J.27.) leaves 2-pinnate, stib-glabrous, divisions of the leafets linear, toothed.

\section{- ACrin A, 99.}

cannabina (water hemp. Y. P. C. II. Ju. (.) leaves lancestate : caisules smoothish, acuteangled.

rursocarpa (P. Ju. O.) leares lance-oral : capsules olstuse-angled, rugrose.

\section{Aconitum, 65.}

rapellus (monk's hood. F. b. J. 24.) flower cowled : spur strait, obtuse; lip lanceolate, bifid: leaves 5-parted.

unimatum (woll-bane. P. b. S. భ.) stem zigzag: flowers with about 5-styles: leares many-iobed.

\section{Acores, 51.}

calcums (swect-flag. 0. y. J. 4.) spike projecting from the side of a sword-1orm leaf.

Acrostichum, 101.

aureum (fork-fern. Ju, 24.) frond pinnate with alternate lealets, fruit on the upper lealets. 


\section{ACTAEA, RGCIYNOMENE. 1\%3}

\section{ACTAEA, 64.}

rubra (bane-berry. O. W. M. 2\%.) putals acnte ; pedicels of the raceme less than the geturat jefluncle. BBig. MS. Berries red.

alba (necklace weed. (O. w. M. 24.) petals trimcate: prodicels of the paceme as large as the general peduncle. Big. ML. Barros white.

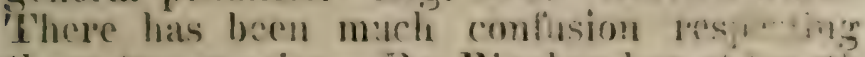
these two species. Dr. Bigelow has ai length rery satisfartorily deined thein.

\section{Adintum, 103.}

pedatum, (maidenhair. O. J. u.) frond pedate branches pinnate, leafets halved.

\section{Apovis, 6\%.}

autumnalis (pheasant's cye. E. Au. O.) flowers 5 to 8-petalled; fruit sub-sylinhic.

\section{Acinivm, 118.}

cormutum, (cased fungus) clustercel : ycllow : cases long, curved, olive-grey.

rhammi, clustered : cylindric: rosy : serts orange. cancellatum, clustered : opening laterally, cntire at top.

tussitaginis, clustered: rather prominent: yellow:

seed orange.

anemoncs, solitary : scattered : near?y słobular.

\section{Ascirmoneme, 81.}

hispida (filse sensitive plant. P. y. Au. O.) stem lerbaceous, hispid : leaves lincar obtuse : racemes simple : loments hispid. 
Esculus, 53.

hippocastanum (horse chesnut. E. J. 々.) leaves digitate, divisions about 5 : enrol 5-petalled.

\section{Agáticus, 117 .}

A. Stem with a ring, without a curtain.

mocerus, widely conic, bossed, white brown : gills white, uniform, fixed to a collar: stem scaly.

campestris (eatable mushrnom) convex, whitishbrown, spotterl : guils pink, becoming liver-colour : stem white.

D. Stem roithout ving or wrapper.

riolaceus, convex, purplish-hrown, inflected at the

eige : gills ptirple : stem purplish, bulbous. sadicatus, greenish or brownish, obtusely conical : gills white, few : stem brown, tapering upwards.

flaridus, yellow, obtusely conic: gills deep buff: stem pale yellow, brownish at the base.

fascicularis, yellow and orange : gills brown:* green : stem yelinw, long, crosked.

C. Exuding a juice whein crushed. coccineus, scarlet, conic, smail : stem long, solid, a little crooked, woolly at the hase. piperatus, dirty-yellow-white, woolly, depresser in the center: gills pale pinky-red: stem pale yellow : juice milky, jeppery.

D. Smooth, membranous or fieshy : cap and gills coriaceons.

castaneus, smooth, silky, chesnut: gills tender, red-brown: stem linear, white, hollow, clastic. relutipes, clustered, reddish-buff : gills pale yellow, 8 in a set : stem yellow and dark brown, velveíy below. 
corriaceus, depressed-convex, lle:ily-ochre : grills pale brown, thicker abore. semiglobalus, greenish-yellow, hemispherical : gills brown, mottled : stem pale buff. clicus. pale orange or scarlot. depressed-convex : gills white, in pairs : stem pale orange, sleniler, solid.

cempenella conic-conver, bossed, glabrous, striate, saffron: gills pale-sulphur colour: stem slender, saftron.

F. Smooth, temder, mosity pellucid, with the eap striate and plaited; sencrally of an uniform colour. gracilis, somewhat conic clastic, dry : gills few, trifid, red : stem very long, slender. confertus, white, acutely conic, downy : gills brownish-white, thin uniform : stem white, tapering upwards.

rotula, hemispheric, white, crenate : gills fixed

to a collar surrounding the stem: stem black at the bottom, often branched. conicus, bellform, acute, shining, livid, striate : gills white : stem hollow, grey. parpyraceus, white, hemispherical, membranous: gills 3 in a set, blackish when old: stem hollow.

narcoticus, convex with forked plaits : gills grey, in pairs: stem subulate, white.

F. Cap opalie, conic : gills sooty when old, and dissolving into a black sanies : stem hollow.

winereus, warty-grey, striate, brown in the centre: gills grey, not reaching the stem: stem white.

G. Stemless.

mollis, deformed, red buff : gills in pair's reddishyellow.

['These species were chieily taken firom Muhlenberig. 


\section{Agave, 49.}

virginica, (agave.P. y-g. S. 2:. .) stemless : leaves with cartilaginous serratures, scape very simple.

\section{Agrimonia, 61.}

enpatoria (agrimony. O. y. Au. $\boldsymbol{\psi}_{\text {. }}$ ) cauline leares interruptedly pimate, the terminal one petioled : fruit hispirl.

parviflora (dotted agrimony. P. y. Au. 24.) caulline leaves pinnate; leafets mostly lanceolate: terminal ones sessile, petals one and a half the length of the calyx.

\section{Agrostemm, 59.}

githago, (cockle. 0. 1. J. .) hirsute : calyx and. corol about equal ; petals entire. coronaria (rose campion. E. Au. 占.) tomentose : leaves lance-ovate : petals emarginate.

\section{Agrostis, 30 .}

\section{Sroned.}

spicarenti (bent-grass. P. J. O.) a very long straight stiff beard, or awn, upon the exterior petal: panicle spreading: Naturalized. tenuiflora ( $\mathrm{P} . \mathrm{Au}$. 4.) panicles very simple with appressed branches : corol awned, and the awn longer than the flower.

difiusa (P.Au. 4.) buanches diffused and erect : leaves lanceolate, sub-perforate : corol glumes sub-pubescent at the base: one valve with a short strait awi.

sericea (C. P. J. 2l.) leaves terete-filiform rery long: panicle capillary, very slender : corol small, and the calyx but one third as long: awns strait naked.

filiformis (P. S. Z..) panicle contracted, filiforus, 
becoming purple ; peduncles and pedicels scabrous : calyx 2 -valved, equal, 1 -flowered : corol equalling the calyx.

stricta (New-England. J. \%ै.) panicles clongated

stiff : corols less than the ralyx : awn from the base of the petal, longer than the twisted flower.

setosa (P. S. 4.) culm erect, sending out shoots from the base : stipules none : panicle contracted, cylindric : calyx awned : colol awnless. sobolifera (P. C. S. - . ) culm erert senting off shoots from the base: leaves 5-nerved: stipules none : sheathes gaping, glabrous : calyx valves acuminate, carinate.

juncea (C. P. Ju. 2.) panicle oblong-pyramidal : flowers awnless : the extreme valves half as large : leaves stifly erect, rigid with couvolute. bristles.

\section{Without arens.}

incoluta (P. C. Oc. 2!.) leaves long, filiform at the apex and recurved, rough, upper one strait: stipules obsolete.

rulgaris (reiltop. O. Ju. $\varkappa_{\text {.) }}$ panicle spreading": branches divergent capillary : calyx equal ; petal within, half as long, retuse. clanilestina (P. S. 4.) leaves glancous, rery long, rigid, with rough margins : stipule very small or none; mouth of the sheath hairy : panicle concealed, often sooty, and spike-for'm : corol twice as long as the calyx, spotted.

virginica (P. C.S.) culm geniculate and branching at the base : leares hairy at the base ; stipille 0 ; mouth of the sheath hairy around the culm : panicles lateral and terninal, spikeform, lower ones concealed : seed traisparent. glanca (P. New-England. J. 2\%.) leaves glancous, keel white : stipule white split: panicle terminal crouded : lower branches whorled in fires. alba (white top. 0. Ju, 2f.) panicle las: culm 
rooting at the lower joints : calyx valves equal, awnless, keels rough.

mexicana (P. J. 24.) panicle oblong heaped together : calyx and corol acuminate, subequal, awnless.

lateriflora (C. P. J. 24.) panicles lateral and terminal compact: flower's awnless, valves very acute, interior greater, bearded at the base: leaves short and flat.

pungens (C. J. 2\%.) panicle contracted, spikeform : leares inrolute rigid, pungent, upper ones obliquely opposite : culm ramose.

\section{AIri, 31.}

melicoides (hair-grrass. P. C. Ju. 24.) panicle small compact sub-racemed : glume common, the partial ones rather larger, linear-lanceolate awnless : corols villose at the base ; there is but the rudiment of a third flower : leaves flat glabrous : culm erect.

pumila (dwarf hair-grass. Y.J. น.) panicle fewflowered, level-top; pedicels short : colol awnless, olituse, twice as long as calyx : culm erect, of the length of the leares. About one inch high.

obtusata (Y.C. J.) panicle compressed into an oblong raceme of dense flowers : corol awnless compresserl at top : one valve of the glume narrow-linear acute, another broad oborate roundobtuse : leares flat : culm erect slender. cespitosa (P. New-England. J. 2\%.) panicle spreading : petals awned, villose at the base: awns strait and short. A rariety has subbristleform leaves.

flexuosa (W. P. C. J. 2'.) panicle spreading trichotomous: peduncle flexuous: awn geniculate: leaves bristle-form : culm nakedish. mollis (1. C. M. 4.) leaves with solt hairs: stipule short, retuse, many-cleft ; sheaths pubes- 
cent : panicle spreading. sub-simple : calyx witls one valve broad, s-nerved ; the other lanceolate, acute.

pallens (I. C. J. \& S. 2\%.) leaves lance-linear glabrous with glabrous joints : stipules retise ciliate : panicle contracted noriding : corol with $\approx$ punctate valves ; awn below the anex contorted.

jiecox (C. M. ().) leares bristle-form: sheath angular : flowers in panicled-spilies : florets awned at the base.

murpurea (C. Au.) panicle scattered, purple: flowcrs awned; glumes, one bifid awned at the nerve, the other entire, plumose, concave : leares subulate: culm erect. Grows on the scashore. Torrey.

\section{Aletris, 50.}

farinosa (false aloc, unicorn-ront. Y. y. 2\%.) stemless : leaves linear-lanceolate, withering" at the tips: scape with alternate flowers. 'This plant grows plentifully in Brimfield, (Mass.) Ilere the inhabitants use the root as a tonic, which at the same time serres as a moderate cathartic. The root is intensely bitter.

\section{Arisma, 5 ร.}

pilciniago (water plantain. O. w. Ju. 21.) Ieares ovate acute: fruit obtusely 3-connered. A tri$\therefore$ vialis. Pursh.

garijlora (C. P. Ju. 2r.) leares oval, subcordate,

abruptly-acuminate, 5-nerved : umbels in

whorled panicles, pedicelled, filiform.

subulcia (C. P. Au. (.).) leares linear-suisulate,

Aximus, 49.

porrum (leek. E. Ju. 21.) stem flat-leared, ums. 


\section{ALIIUM, ALNUS.}

belliferous : stamens tricuspidate : leaves sheatit. ing at the base.

sutirun (garlic. E. Ju. 4.) stem fat-leaved, bulib-baring; bulb compound : stamens tricuspidate.

vineale (fiell ganlic. C. l. p. J. 2\%) stem tereteleaved, bulb-beaning: stamens tricuspidate. oleraceum (striped onion. B. $2_{\text {. }}$ ) stem terenteleaved, bub-bearing: lcares sciniots, seniterete, silcate beneath: stamens simple. ascalonicum (shallot. E. Ju. 2.) ape naked terete : leares subulate : anbels globose: stamens tricuspirlate.

triforum (mountain leck. P. M. 21.) scrpe naked, terete, shorter than the leaves ; leaves lanceo-

late nerved: umbels few-flowered. canadense (mearlow garlic. P. Y. A. r. M. 24.) scape naked terete : leaves linear : little heads bulb-bearing.

cepa (garden onion. E. Ju. 24.) scape naked, swelling towards the base, Ionger than the terete leaves.

tricoccum (three-secd leek. P. W. Ju. 2L.) scape naked, semiterete : leares lance-oblong, flat, glabrous : umbe! globular. fistulosum (wclch oution. E. 2') scape naked, equalling the terete ventricose leaves. schoenoprasum (cires. E. Ju. 2!.) scape naked, equalling the leares which are terete-filiform.

\section{Alves, 92.}

incana ( $\Gamma$. 々.) leares ollong acute, pubescent bencath ; axils of the reins naked : stipules lanceolate. undulata (waved alder. Muh. says it grows in N. England. $h_{2}$.) leaves oblong, acute, rounded at the base : petioles and reins hairy beneath: axils of the veins naked: stipules ovate-oblong. 
scrmulata (aliler. O. racluinate; voins and thedr anils hairy : stipules oval, obtuse.

glutinosa (Canada. Ap. h. . leaves round-wedgeform, obtuse, glutinous: axils of the veins downy.

\section{Alopecures, SC.}

pratensis (meadow-grass, foxtail. P. C. J. 2!.) culm erect : ghtume vilios : celon bearlless. geniculatus (Hoating foxtail. W. II. C.Ju. I.) culm spiked and geniculate : corjl beardless.

\section{AtsIxe, 4\%.}

media (chickweed. O. w. M. 27.) stem with al. ternate lines of lairs on the sides: petals 2 parted: leaves heart-ovate.

\section{ALTiLiel, \%ั.}

nfficinalis (marsh mallows. F. 2!.) leares downy, oblons-bure : onsoletely s-lobed, toothed. rosea (hollylurk. E. $\delta$.$) stem erect : leares$ i rough, heart-form. 5 to -angled, crenate. ficifulia (ig-hollyluck. E. $\delta$.) leares F-lobed, subpalmate, ubtuse.

\section{Auxsers, 73.}

Eexatile (mar?wort, basket of golil, E. h.) stem worly. panicled: leares laicenlate, re:y soft spreailing.

hyperlioreum (Conata.) stem her'iarenus: leares hoary, toothe: : stanens 4 , 2 -inrked. sat roui (I', y. . .) stem erect: l'ares lanceolate, funthed, clasping, alternate : Howers corymbed.

incumum (E. ? . \& 3.) stem erect : leares lanceolate, chitie, hoary : fowers coryubed, petals 2-cleft. 


\section{Amaranthus, 93.}

albus (white coxcomb. P. g-w. Au. (०.) glomerules axillary triandrous: leaves obovate retuse : stem 4-comered simple. Common garden weed.

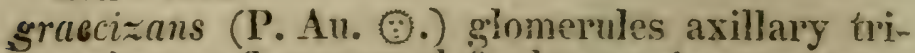
androus : flower's s-clelt: leares obovate cmarginate : stem teretish branching.

melanclidicus (love-lies-blecting. E. r. O.) glo. merules axillary peduncled joundish : leaves ovate-lanceolate coloured.

ivicolur (three-coloured coxcomb. E. Ju. O.) glomerules sessile: leaves oblong-lanceolate coloured.

livilus (learl amaranth. E. J. O.) glomerules triandrous stb-spiked roundish : leares eliptic retuse : stem erect.

olereceus (pot anaranth. Y. W. A. C.Ju. O.) glomerules axilary branching: leares winkieal, oblong, very obtuse, emarginate. Sometimes the tio wers are pentandrous.

hujuridus (P. Y.Ju. .) lacemes pentandrous aloubly-compound, herped togetlier, erect : leaves ovate-lanceolate. paniculatus (P.Ju. ) raremes pentandrous trip-

ly-compound : branches spreadirg probescent:

leares ovate-lanceolate.

setroflexus (rough amanth. P. W. H. Au. .)

racemes pentandrous, triely-compound, compact, erect: branches pubcscent: leares ovate undulate.

hypochoisiriacus (spleen amaranth. P. Au. .)

pacemes pentandrous, compound, compact, erect : leaves oblong-lanceolate, mucronate. Leaves red. (ialse prince's feather.) spinosus (1:Ai. .) ra enes pentandrous, terminal, compound : axils spinose. 


\section{Amarycues, 49.}

atamasco (atamasco lily. P. w. J. 24.) spathe 2-cleft, arute : Hower pedicelled : corol bellifor'm suberual, erect : stamens declined. formosissima (jacobea. E. 24 .; spathe 1-flowered: corol ringent-like : petals declined.

\section{Ambrosia, 93.}

irifila (P. N. C. A. S. ๑.) bristly, rough : leares 3-lobed serrate, lobes oval lanceolate acuminate : fruit 6-spined beneath the apex. From 5 to 8 leet high.

integrifolia (1:. Ju. O.) leaves ovate sessile accummate serrate, bristly on both sides, ciliate. at the base : racemes terminal, sometimes ternate. Flowers very inconspicienus.

clatior (hogwcerl. 0.S. Q.) leaves doubly-pinnatiticd smoothish: petioles long ciliated: racemes terminal, panicled: stem wand-like. arlemisifolia (P. S. @.) leaves doubly-pimnatifid, hoary beneath, at the summit pinnatific! : racenes terminal in threes : branches level-top. ped.

puniculata (P. J. ○.) leares glabrous doubly pinnatifid, at the pimmatilid summit : racemes terminal solitary : branches level topped. heterophylla (P. S. O.) cauline leaves pinnatifid sub-toothed petioled; on the npper branches lanceolate sessile: péioles long-ciliate: ra. cemes termanal solitary : stem panicled.

\section{Amannia, 55.}

humillis (tooth-cup. P. p. Au.) procumbent : deas es lan eolate, narpower downwads: llow. exs all solitary. 


\section{AMm, 45.}

capillaceim (bishop-weed. $\mathbf{Y} \neq \mathrm{w}$. Au.) leaves all capillary, many-cleft : seed glabrous.

\section{Amorpha, 78.}

fruticosa (false indigo. P. Ju. h.) calyx with 4 u teeth acute, and one accuminate.

\section{Ampelopsis, 42.}

g̃uinquefolia (false grape, $\mathbf{0}$. w. Ju. $\iota_{\text {. }}$ ) leaves in fives, toothed.

\section{Amsonia, 43.}

Iatifolia (beard throat. b. M. 2!.) stem glabrous : leaves lance-oval, upper ones acuminate.Southern states.

\section{AMYGDALUS, 62.}

mersica (peach. E. r. M. h.) scrratures of the leaves all acute, flower's sessile, solitary. niznc, (flowering almond. E. h. leaves ovate, tapering to the base, sharply serrate.

\section{AvagaxeIs, 38.}

arrensis (red chickweed, scarlet pimpernell. $\mathbf{Y}$ C. P. H. r. J. O.) stem spreading naked: petals entire llat, with hairs at the margin.

\section{Axchus $1,3 \%$.}

nfficinalis (buglos. E. y. 2!.) leaves lancenlate: spikes imbricate, one-sided : bracts ovate. 


\section{ANDROMEDA, 57 .}

hypnoides (moss bush. Whitehills. Au. h. ) leares imbricate subulate glabrous : perluncles solitary terminal 1-flowered : corol nociding globose bellorm. Small, creeping.

mariana (P. J. h.) leaves oval sub-acute at: both ends, glabrous leathery paler heneath: branches flower bearing, almost lratless: peduncles fascicl-d: corol ovate-cylindric: calyx leafy : anther's beardless: capsule ovate and resembling the form of a pine-apple. Une variety has narpow lanceolate leaves.

pulverulenta (dust-lraf. E. 々.) white dist-like substance, scattered over the lcares and stem; leaves alternate.

polifolia (1'lainfield and Goshen. Masc. P-w. M. b.) leaves linear-lanccolate convex revolute, whiteglancous beneath and hoary-glancous above : flowers aggregate terminal; corol sub-globose: anthers bearded towards the top. Une foot high.

artorea (sorrel tree. P.w. Ju. h.) branches te. rete : leaves oblong acuminate mucronate-serrate glabrous : panicles terminal many-spiked: corol ovate-cylindric pubescent: anthers linear beardless. About 40 lect high, with sour leaves.

paniculata (white bush. W. Y. A. C. H.w. J. 々.) pubescent : leaves oborate-lanceolate acute sub-entire : branches fiower-bearing terminal panicled nakedish : glomerules peduncled : corol sub-globular pubescent: anthers obtuse heardless. A shrub rumning into sereral varieties-flowers small.

racemosa (P. C. w. J. 々.) leares oval-lanceolate acute serrulate membranaceous glabrous : spikes terminal, one-way, elongated, simple or branched : bracts lincar acute: corol cylindric: 


\section{ANTROMENA, ANDROPOGON.}

calyx acute with bracts at the base: anthers donbly 4-bearded at the apex. A micidling sized shrub, odoriferous.

axillaris (E.w.J. 々.) leaves oblong-oval, base acute short acuminate, cartilaginous-serrate bright-glabrous leathery : racemes spiked axillary sessile : bracts scale-like : flowers crowdod on all sides: corol ovate-cylindric : anthers bearlless. A variety has long linear-lanceolate leaves.

acuminata (pipe-stem. Southern states. w-r. M. 々.) very glabrous : leaves ovate-lanceolate; upwards they graclually become narrow acuminate entire or unequally serrate, glabrous shining net-veined leathery : pacemes axillary rery short corymbed nakedish ; fiowers pericelled noding : corols cylindric-orate, anthers beardless, gibbous behind. Stem hollow. calyculata (leather leaf. Y. C. H. A. P. N. w. M. h.) leaves lanceolate-oblong sub-serivulate, with scaly dots, rust-coloired beneath : racemes terminal leafy flower's turned one way: calyx with 2 broad-ovate acuminate bracts: corol oblong-cylindric.

figustrina (P. w. J. h.) racemes naked : stem shruby : leaves crenulate, oblogg : racemes numerous, alternate.

\section{Andropogon, 33.}

mutans (beard grass. Y. W. P. S. 21.) panicles branching compact nodding: flowers doullebearded : calyx bristly : perfect flowers sessile, staminate pedicelled caducous.

macrourus (Indian grass. P. S. Hf.) shenths villose at the margin : panicleslateral with many fascicular spikes ; flowers monanirous, beard 4 or 5 -fold of the length of the glume; anterior valves glabrous. 
dissitiflom $($ P.S. 24.) slicaths glabrous ; culm erect : spikes lateral distant : flowers monandrous ; awns long strait ; interior valves glabrous.

3urpur(uscens (P. Au. 21.) spikes simple pedumcled, double, close-panicied ; flowers double, the perfect is sessile lanceolate bearded, the nettral is pedicelled bearded ; rachis ciliate.

furcatus (forked spike. W. P. Au. 24.) spikes digitate, partly in fours, flowers double; the perfect ones sessile awned, the staminate ones beardless pedicelled : rachis hairy.

ambiguus (C. 2\%.) leares clasping sub-cordate lanceolate: panicle with branches bristly the whole length, simple erect: glumes solitary alternate 1-flowered : corol not bristly, longawned, triandrous; florets cxtended by an awnform increase.

\section{ANEMoNe, 66.}

hortensis (garden anemone. E.) radical leaves digitate, divisions 3-cleft; cauline ones ternate, lanceolate, connate, sub-divided : seed woolly. virginiana (wind flower. P. g-w. J. 4 .) stem dichotomous : leaves thrice ternate, upper ones opposite, leafets gash-lobate and serrate acute : peduncles solitary, 1-fiowered elongated : seed oblong, headed woolly mucronate. aconitifolia ( $\mathbf{H}$. w. J. 24.) stem dichotomous : radical leares paimate ; cauline leares sessile clasping 3-cleit, the lower ones ternate, with the lobes acute-lanceolate gash-serrate : peduncles solitary 1-flowered : seed head-globose naked subulate-beaked. Flower's large.

dichotoma (Can. W-r. M. $\not \psi$.) stem dichntomous: leaves all cauline opposite clasping 3-cleft, lobes wedge-lanceolate with the upper ones gash-serrate : pedincles solitary 1 -flowered : seed with a globose head naked recurved-mucronate. 
nemorosa (low anemone. H. W. Y. P-rr. M. 24.) stem 1-flowered : cauline leaves thrice ternate, leafets wedge-form, gash-lobed, toothed acute: corol 5-6-petalled : seeds ovate with a short style hooked. A variety, quinquefolia, has lateral leares deeply 2-cleft.

lancifolia (P. w. M. 2i.) stem 1-flowered : leaves cauline thrice ternate : leafets lanceolate crenate-toothed : corol 5-petalled: seeds ovate with a short style hooked.

thalictroides (rue anemone. A. Y. H. C. P. w. 24.) umbels involucred : radical leaves twice ternate, leafets sub-cordate 3-toothed : involucre 6-leared, leafets petioled uniform : umbel few flowered : seed naked striate : root tuberous. A variety, uniflora, has a 1 -flowered involucre.

Anemone. See Hepatica.

Anethum, 46.

grareolens (dill. E.) fruit compressed : plant annual.

foeniculum (fennel. E.) fruit orate : plant perennial.

\section{AngELicA, 45.}

archangelica (archangel. E. $\delta$.) the odd terminal leafet lobed.

atropurpurea (P. Can. g.J. ४.) leaves compound, leafets oblong sublobate serrate sub-sessile, the last pair united at the base, the terminal petioled. 3 to 6 feet high, root fragrant.

triquinata (angelica. 0. w. J. 4.) petiole 3-part- ed, partitions pimate, 5-leaved ; leafets gashtoothed; the odd terminal one sessile rhombic, lateral ones decursive.

lucida (nondo. w.J. 2\%.) leafets equal ovate gash= serrate. 


\section{Annowa. 66.}

glabra (custard apple. E.) leares lance-ovate : fruit conic, glabrous.

\section{ANTHEMIS. $8 \%$.}

nobilis (chamomile, E. w. Au. 24.) leaves 2-pinnate ; leafets 3-parted linear-subulate sub-villose : stem branching at the base. Gives out a fragrant odour.

arvensis (C. w. Au. of.) receptacle conic, chaff lanceolate: seed crown-margined: leares ?pinnate subdivided lanceolate linear. cotula (mayweed. 0. w. J. (2).) receptacle conic, chaff-bristly : seed naked : leaves 2-pinnate, leafets subulate s-parted.

\section{Avthoceros, 110.}

levis (wax-liverwort) frond flat, crenate. punctatus, frond sinuate, lobed, obtuse.

\section{Anthoxanthum, 27.}

odoratum, (sweet vernal grass. O. M. 2\%.) spike oblong-ovate ; florets subpeduncled, longer than the awn. An American variety, altissimum, is larger and of a darker green. Ives.

\section{ANTIRRIINUM, 72.}

elatine (creeping snap-dragon. A. P. Y. Ju. .).) procumbent pilose : leaves alternate hastate entire : peduncles solitary very long.

triornithophorum (three-birds. E.) leaves whorled, lanceolate 3-nerved : stem decumbent : receme terminal, few flowered, flowers large, peduncled.

linaria (snap-dragon, E. y. Ju. 2\%) crect glabrous : leaves scattered linccolate-linear, crowd- 
ed together : spikes terminal dense-flowered : calyx glabrous shorter than the spur. Flowers large-(toad-flax.)

canadense (flax snap dragon. Y. P. w-b. J. 4.) rising in a curve, glabrous, very simple : leaves scattered irregularly, erect narrow linear obtuse remote : flower's racemed : scions procumbent. Flowers small.

\section{Anychia, see Queria.}

\section{Apargia, 82.}

autumnalis (false hawkweed. H. Y. J. 24.) scape branching scaly : leares lanceolate runcinatepimnatifid, smoothish.

Apios, see Glycine.

APIUN, 47.

petroselinum (parsley. E. Ju. $\delta$.) cauline leares

linear : involucels minute.

graveolens (celery. E. Ju. $\widehat{\delta}$.) stem channelled:

cauline leaves wedge-form.

\section{APOCYNUM, 43.}

androsaemifolium (dog-bane. O. r-W. J. 24.) leaves ovate, glabrous : cymes lateral and terminal : tube of the corol longer than the calyx. cannabinum (Indian hemp. 0. g-y. Ju. 4 .) leaves lanceolate, acute, glabrous : cyme panicle-like: tube of the corol and the calyx equal. hypjericifolium (john's dogbane. C. P. W. Ju. 24.) stem erectish : leaves oblong heart-form glabrous : cymes shorter than the leaves. Flowers very small; the plant low and smooth.

\section{AQUIEEGIA, 65.}

vulgaris (garden columbine. E. J. 2\%) nectaries incurved-horns: leafy stem and leaves glabrous. 
canatensis : wild columbine. O. ז. \& y. Аp. u.) horns strait: stamens exsert. Growing liequently in crevices of rocks.

\section{ARABIS, 74.}

rhomboidea (wall cress. P. A. w. M. น . ) lcaves giabrous rhomisoid, with obsolete spreal ling teeth ; lower leaves with long petioles: root tuberous. thaliana (mousear cress. W. P. C. W. Ap. ().) redical leaves oblong petioled; cauline leaves lancenlate sessile : siem erect rough-haired at the base : petals twice as long as the calyx. reptans (P. C J. 4.) leaves sub-rounded cutire rough-haired : shoots creeping.

hyrata (P. C. Can. w. Ap. \%) leares glabrous, radical ones lyrate, cauline ones linear.

hispida (P.w. NI. U.) leaves toothed obtuse hispid, radical ones sub-lyrate, cauline ones : hispid petals crect.

hastata C. w. M.) leares lanceolate, narrowed at the base, hastate, sessile, ver'y glabrous : peduncles glabrous erect; siliques pendant, falcate, very narrow. Found at $\mathbf{F}$ ishkill by Dr: John Torrey-New species.

falcata (C. Y. W. W. 2.) leaves hirsute lanceolate, narrowed at both ends, remotely toothed, sessile : silique pendant, 2-edged, falcate. $\Lambda$. canadensis. Will.

\section{Arachis, 78.}

hypoguea (false ground-nut. E. (.) stem pilose procumbent: leares pinnate abrupt: flowers axillary.

\section{Aratia, 48.}

spinosa (shot bush, angelica tree. P. $\mathrm{y}$-w. Au. h.) woody : stem and leaves thorny, leaves doubly- 
pinnate ; leafets slighitly-serrate : panicles very branching: umbels numerous.

hispida (bristly stem sarsaparilla. W. P. w. J. h .)

low: sub-shrubloy : stem and petioles rough with bristles : leaves doubly-pimnate; leafets ovate gash-seprate unarmed glabrous : umbels with long peduncles.

racemosa (spikenard. O. w. J. 2/.) spreading branches : petioles 3-parted, the partitions 35-leaved, leafots often heart-form; branchlets axillary leafy : umbels many sub-panicled, leafless above.

mulicaulis (wild sarsaparilla. 0. w. M. 2\%.) hardly a proper stalk, 1 -leafed ; the leaf thriceternate or thrice-quinate ; leafets oblong-oval : scape naked, shorter than the leaf: umbels few.

\section{Arbutus, $5 \%$.}

uva-ursi (bear berry. A. N. Y. C. P. II. W-r. J. 々.) stem procumbent : leares wedge-obovate, entire : berry 5 -seeded. alpina (Can. w. J. $7_{2}$.) leaves serrate.

\section{Arctrum, 83.}

lappa (burdock. O. r. Au. 24.) cauline leaves heart-form petioled toothed: flowers panicled globose : calyx smooth.

\section{Arenari, 58.}

\section{Leaves oblong.}

lateriflora (sandwort. P. C. W. J. 24.) stem filiform simple: leaves orate obtuse sub-triplenerved : peduncles lateral solitary elongated ¿-cleft, one pedicel mididle-bracted: corol longer than the calyx.

serpyllifolia (P. C. W. Ju. a.) stem dichotomous 
spreading : leaves ovate acute sub-riliate : calyxes acute sub-striate: petals shorter than the calyx.

\section{Leaves linear-subulate.}

slabra (C. 2f.) very glabrous sub-erect filiform many-stems : leares subulate-linear flat spreading : pedicels 1-flowered elongated divaricate: leatits of the caly $\mathrm{x}$ oval obtusish smooth, shorter than the petals.

stricta (N. Whitehills. w. M. 21.) glabrous crect many-stems : leaves subulate-linear erect: panicles few-flowered : petals much longer than the calyx, which is oval-lanceolate apparently striate.

squarrosa (C. w. Ju. 24.) turfy : lower leaves scaly-imbricate channelled glabrous: stems few very simple : flower's few terminal erect: petals much larger than the roundish calyx. melora (P. Y. C. r. J. 2.) glabrous, humifuse: leaves filiform, fleshy, much longer than the joints: stipules connate-membranaceous, sheathing: stamens 5 : capsule angular or globose. Var. canadensis, leaves linear, fleshy.

\section{Arethusa, 89.}

oplinglossoides (snakemouth. Y. C. P. A. 1. Ju. 4. root fibrous : scape with 2 distant leaves, 1 or 2 -liowered ; leaves oval-lancenlate: lip fringed. Flower's large.

oulbosa (arethusa. C. Y. P. r. J. 4.) leafless: root globose: scape sheathed 1-liowered: calyx with the superior divisions incurved: lip suib-crenulate. Flower's large sweet-scented. irianthopiloms (P. C. w-p. Au. 24.) pale : ruot tuberous : stem leafy, 3 -flowered at the summit; leaves ovate alteriate: flowers long-peduniled alternate: lin entipe. Three or four inches high, flower's small. 


\section{ARETHUSA, ARISTOLOCHIA.}

verticillata (P. y-r. J. 4.) leaves 5, in wholıs, oblong-lanceolate: stem 1-flowered: 3 outer petals very long linear, inner ones lanceolate; fip 3-lobed, the middle division wavy. Flower's of the largest and handsomest kind; sometimes there are 2 or 3 on the stem.

medeoloiles (P. y-r. Ju. 24.) leaves whorled, oblong, acuminate : flowers sub-sessile ; interior petals short, obtuse. Pursh. Probably the stellata of Muhl.

\section{Argemone, 65.}

mexicana (P. y. Ju. ㅎ․) leaves pinnatificl, gashed, spinose : flowers axillary. Var. alba, flowers white.

\section{Aristid A, 30.}

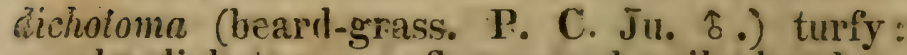
culm dichotomous : flowers sub-spiked, sub-1awned, awn twisted, shorter than the glume. sligantha (P.Ju. ४.) culm strait sub-branched: leaves convolute-iiliform : flowers distant solitary : awns long spreading.

\section{Aris'rolochia, 90.}

sipho (birthwort. dark purple.J. h.) leaves heartform acute : stem twining : peduncles 1 -flowerel furnished with an ovate biact: corol ascending, limb s-cleft equal. A rery high lumning vine, with large leaves.

serpentaria (P. C. p. J. $\boldsymbol{\psi}$.) leaves heart-form, oblong acuminate : stem zigzag ascending : peduncles radical : lips of the corol lancerlate. ('The Virginia snakeroot.) There is a variety vith very long na: wo leaves. 


\section{ARMENIAC, 61.}

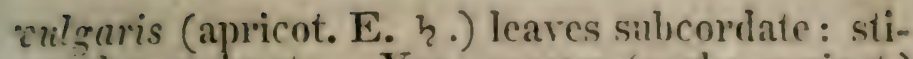
pules palmate. Var. precox (early apricut.) fruit small, yellow. Var. persicoides (peach aprirot) firuit subcompressed.

dasyearpa (black apricot. E. ?.) leares orate ar'uminate, doubly-serrate, petioles glandular : drupe globose, pubescent.

\section{Arnici, 86.}

montana (arnic. E.) leaves ovate entire; cauline ones in opposite pair's.

\section{Aroxis, 62.}

nroulifolia (red choak-berry. Y. W. P. C.W-1. M1. h.) leaves lance-obovate, crenate, downy beneath, with the midrib glandular above : Howers corymbed : calyx downy. botryapium (shad-bush. O. w. Ap. 々.) leares oblong-oval ; cuspidate, glabrous : flowers racemed ; petals linear : germs pubescent: segments of the calyx glabious. sansunea (bloody choak-berry. C. W. M. i. .)

leaves oval, obtuse at both ends, mucronate, serratures very slenier : racemes few-llowereu: caly $\mathrm{x}$ glabrous : petals linear, obtuse. meianocarpa (black choak-berry. Y. W. P. C. W. M. 2., leaves obovate-oblong, acuminate, serrate, glabrous beneath ; midrib glandular aiove : flower's corymbed : calyx glaiorous. oralis (medlar bush. Y. C. $1^{3}, \ldots$. M. h.) leaves pound-oral, acute, ghlobrous : flowers racemed: petals obovate : germ and segments of the caly $x$ puiljescent. 


\section{ARtemista, 85 :}

abroianum (southem wood, E. 24 . and $h_{2}$.) stem strait : lower leaves bipinnate, upper unes hair-form pinnate : calyx pubescent hemispheric.

canaderisis (wild wormwood. Y. w. y. Au. भ.) subdecumbent, scarcely pubescent : leaves flat linear-pinnatifid: branchlets spike-flowered : flowers sub-hemispheric : calyx scarious. Receptacle smooth.

pontica (roman artemisia. E.) leares downy beneath ; canline ones bipinnate, leafets linear: branches simple: flowers roundish peduncled nodding.

absynthium (wormwood. E. 2!.) stem branching, panicled : leaves hoary; radical ones triplypinnatifid, divisions lanceolate toothed obtuse ; cauline ones 2-pinnatifid or pinnatifid, divisions lanceolate acutish : floral ones undivided lanceolate.

vulgaris (mugwort. P. C. S. 21.) leaves downy beneath; cauline ones pinnatifid, divisions lanceolate sub-toothed acute ; floral ones undividell linear-lanceolate : flowers sub-sessile oblong erect : calyx downy.

\section{ARUM, 94.}

tracontium (green dragon. P. J. 21.) stemless : leaves pedate; leafets lanceolate oblong entire: spadix subulate longer than the oblong convolute spathe.

atrorubens (brown dragon. P. M. 21.) stemless: leaves ternate, leafets ovate, acuminate : spam dix cylindrical ; spathe sessile ovate acuminate, spreading horizontally above. Spathe dark brown, disagreeable smell. triphyllum (Indian turnip, wild turnip, false wane: 
robin. 0. p. \& g. M. ४.) sub-('aulescent: leares tejuate : leafets ovate acuminate : spadix clubfor'm: spathe orate acuminate peduncled, with the lamina as long as the sparlix. One variety, rirenes, has a green spathe ; another, atropurpirrenm, has a lark pu. ple spathe.

rirginicum (poison arum. H. Y. C.P. ३. J. ४.) stemless : leaves hastate-heart-form achie, lobes obtuse : spathe elongated incurved; green : spadix long-stamen-flowered.

\section{Ardado, 35.}

donax (reed grass. F. Nov.) calyx 5-flowered: panicle diffuse : culm somewhat woody. phragmites (marsh reed greass. Y. P. C. Ju. भ.) calyx 5-flowered : panicle lax. connides (compact reed grass. P. Au. 24.) panicle sprearling: calyx 1 -flowered acuminate equalling the corol : awn on the back geniculate.

epigejos (C. \%.) calyx 1-flowered: panicle erect: leaves glabrous beneath lanceolate. Flowers small.

canadensis (P. J. 2\%) panicle oblong : calyx 1flowered lanceolate, scabrous pubescent upon the keel : corol awned upon the back, awn of the length of the corol; pubescence equalling the corol : leaves and culm glabrous narrow. arenuria (sand reed grass. Can. C. Ju. భ.) panicle spiked: caly $\mathbf{x}$-flowered longer than the corol : flowers erect beardless : leares involute prickly.

agrostoides (P. C. Ju. 4.) panicle lax diffused : calyx 1-flowered acuminate glabrous: corol sliorter than the calyx membranaceous; outer valve gashed at the top: pubescence equalling the corol: leaves flat a little scabrous : culme sheathed and glabious. 


\section{Asarum, 60.}

canadense (white snake root, wild ginger. W. N. A. P. p. M. 4.) leaves broad-kidney-form in pairs : calyx woolly decply 3-parted, divisions sub-lanceolate refiected. Root aromatic. virginicum (P. M. 24.) leaves solitary round-heartform glabrous leathery: flower sub-sessile: - calyx glabrus above, short, bellform. Leaves speckled smooth.

\section{Asclepias, 89.}

\section{Leaves opposite.}

syriaca (common milkweed. 0. w-p. Ju. 4.) stem very simple: leaves lanceolate-obi ing gradually acute, downy beneath: umbels subnodling downy. 3 to 5 feet high ; flowers in large close cluster's sweet-scented-nectaries are fly-traps.

obtusifolia (Y. P. C. p. J. 21.) leares clasping oblong round-obtuse waving : umbel terminal long-peduncled many fiowered glabrous ; the horn of the nectary exsert. Flowers large. acuminate (C. $\mathrm{r}-\mathrm{W} . \mathrm{Ju}$. 2 2 .) stem erect glabrous simple : leaves orate sub-cordate acuminate short-petioled, upper ones sessile : umbels latcral solitary erect. About 2 feet high, roots large.

fmoena (Y. P.p. Ju. 2.) in wet places. Stem simple, stem-leaves pointing two ways, sub-pubescent ; leaves sub-sessile oblong-oval pubescent beneath : terminal umbels and nectaries erect, appendage exsert. finipurascens (C.P.p. Ju. 24.) stem simple : leaves orate villose bencath : umbels erect: nectaries resupine.

riridiflora (P. Y. g. Ju. 2\%) stem simple erect hirsute : leares lanceolate-oblong obtusish, 
suib-sessile, downy-hirsute : umbels lateral solitary sub-sessile nodding sub-globose denseflowered; no appendage. rariegata (C. P. W. Ju. ४.) stem simple erect: leaves orate petioled rugose naked : umbels sub)sessile pedicelled tomentose. 'The umbels dense. incarnata (0. 1. Ju. $\boldsymbol{\psi}_{\text {. }}$ ) grows in wet places. stem erect branching above downy : leaves lanceolate sub-downy both sides: umbels mostly double at their origin: the little hor'n of the nectary exsert. A variety, pulchra, is more hairy.

debilis (W. A. C. w. Ju. 2!.)"smoothish ; stem weak erect simple: leaves petioled oral-lanceolate, acute at both ends, membranaceous : umbels terminal lax-flowered; pedicels capillary. The bark is a substitute for flax. guadrifolia (O. w. M. 24.) stem erect simple glabrous leaves ovate acuminate petioled, those in the middle of the stem are largest and in fours : umbels two terminal lax-llowered; pedicels filiform. About 10 inches high, flower's small and sweet-scented. iaurifolia (P.p. Au.) stem erect glabrous : leaves sub-sessile oval-lanceolate gradually growing narrower, very acute glabrous with a roughish margin.

\section{Leares not opposite.}

serticillata (dwarf milkweed. Y. A. P. C. Ju. 24.) stem erect very simple marked with lines and small pubescence: leares yery narpow-linear strait glabrous, whorled generally : horn in the nectary exsert. tuberosa (N. Y. A. I. y. Ju. 2.) stem erectish, at the top spreading-branched very rough-haired : leaves oblong-lanceolate rough-liaired; umbels terminal, sub-corymbed. A rariety, the clecumbens, has a decumbent stem : leaves sublinear, hiu'sute. 


\section{ASCYRUM, 64.}

crux-andreae (peter's wort. P. C. y. Ju. 々.) many stems, diffuse : leaves sub-lanceolate-oblong obtuse : corymb terminal : flowers sub-sessile 2-styled : stem sub-terete, 2 feet high, petals narrow.

Jypericoilles (C. y. Ju. 々.) erect branching, branches 2-edged : leaves oblong with 2 glands at the base : flowers terminal solitary with short pedicels, 3-styled. From 1 to 2 feet high.

\section{Asparagus, 50.}

efficinalis (asparagus. E. Ju. 24.) stem herbaceous unarmed sub-erect terete : leaves bristle-form soft : stipules sub-solitary.

\section{Asphodenus, 51.}

Tuteus (asphodel, king's spear. E. 21.) stem leafy : leaves 3-sided, striate. ramosus (E. 4.) stem branching, naked : leaves ensiform, carinate, smooth.

\section{AspiniuM, 103.}

\section{Fronds ternate.}

cicutarium (P. 24.) leafets pinnatifid, divisions acuminate sinuate-pinnatifid entire ; the lower and outer divisions of the sides elongated : fruit-dots in rows.

2. Fronds pinnate.

acrostichoides (O. J. to Au. 4.) leafets lanceolate sabre-form acute ciliate-serrate, the upper ones eared and dagger-pointed, the lower ones wedge-form ; the upper fruit-bearing ones smaller : stipe and rachis chaffy : fruit-dots solitary but at length become confluent. 
3. Fronds sub-pinnatifid ; intolucre [indusinm] halved kidney-form.

novebaracense (N. W. C. P. Ju. 4.) frond pinnate; leafets linear-lanceolate pimatifid, divisions oblong obtusish sub-entire cilliate : liruit-dots marginal : stipe smooth.

cristatum (C. P. J. 24.) frond lanceolate-ovate glabrous pimate ; leafets sub-cordate-oblong pinnatifid, divisions oblong obtuse tooth-serrate : stipe chaffy. A variety, callipteris, largeish : leafets alternate, divisions oblong unequally appressed-serrate : frond bearing the firuit at the top. Another variety, lancastriense, leafets sub-opposite, divisions triangular orate acute serrate: stipe naked.

4. Frond doubly or triply-pinnate, involucre halved kidney-form.

obtusum (P. Ju. 24.) frond doubly-pinnate the lesser leafets oblong obtuse, the upper ones having united bases tooth crenate : rachis pubescent above. 4 or 5 inches high.

aculeatum (Vermont, Au. 24.) frond doubly-pinnate; the lesser leafets ovate sub-sabre-for'm acute dagger-serrate, the base of the upper ones truncate, of the lower ones short-wedgeform ; the upper ones bear the fruit : stipe and rachis chaffy.

margincile (WV. Y. C. P. Ju. 2\%) frond doublypinnate : lesser leafets oblong obtuse decurrent crenate, more deeply crenate at the base : fruitclots marginal: stipe chaffy. 'I'wo or three feet high.

filix-mas (W. N. C. P. Ju.) frond doubly-pinnate, lesser leafets oblong obtuse serrate, serratures beardless : fruit-dots of the middle rib approx- 
imate: stipe and rachis chaffy. 2 or 3 feet high. A variety, erosum, lesser leafets erose. serrate more remote.

intermedium (P. W. J. 4.) frond doubly-pinnate; lesser leafets linear gash-pinnatifid, divisions sub-mucronate-serrate : stipe chaffy. Resembles the next species in many respects.

spinulosum (P. Ju. 24.) frond doubly-pinnate : lesser leafets oblong decurrent running togethcr gash-toothed; divisions mucronate-serrate : spike chaffy: involucre glandular, Large. dilatatum (P, Ju, 24.) frond doubly-pinnate ; lesser leafets oblong distinct gash-pinnatifid, divisions mucronate-serrate: stipe chaffy : involucre smooth. Leaves more compound, larger and broader than the filix-femina.

Remark. This genus has been divided, and the remainder of the species are placed under the genus Athyrium. 'There is no dificulty in distinguishing that genus from the Aspidium, if care be taken to ascertain the precise origin of the involucres. In some species of the Aspidium, the involucres appear, at first view, to be attached to one side of the fruit-dots; especially those which are kidneyform. But on a minute examination, the point, by which the involucre is attached to the frond of the Aspidium, will be found to be surrounded by the capsules of the firuit-dot. Whereas the involucres of the Athyrium are attached to the frond entirely outside of the capsules of the fruit-dots.

\section{Aspleniom, 102.}

\%hizophyllum (walking leaf. O. Ju. 4.) frond lanceolate stiped sub-crenate, heart-form ear's at the base; apex very long linear-filiform rooting. 
(tngustifolium (spleenwort. W. C. P.Ju. 24.) frond pimate ; leafets alternate, upper ones sub-alternate, linear-lanceolate sub-repand, base of the upper ones truncate, of the lower ones rounded. 1 foot high.

cbenenm (W. C. P.Ju. 4.) frond pinnate : leafers sessile lanceolate sermulate, cordate at the basse, auricled above. A very small species.

melanocaulon (W. P.A. Ju. 2̌.) frond pimate; leafets roundish obtuse crenate at its latice werlge-form: stipe particoloured. Very small; stem black, polished.

thelypterioiles ( W P.. Ju, 4.) frond pinnate; leafets sessile lanceolate acuminate, rlecply innatifid, divisions oblong nbtase, obtusely-scrrate : fruit-dots parallel, at length confluent. jute-muraria (W. C. P.Ju. 4.) firond bipinuate at the base, simply pinnate at the apex; lealcets rhombic-oblong, obtuse, with the apex obtuscly denticulate.

montanum (W. Ju, 4.) frond glabrous, bipimate; leafets lanceolate, pinnatifid, divisions $2-01-3-$ toothed.

\section{Aster, 86.}

\section{Leaves cntire.}

Myssopifolines (starflower. C.w.y.p. Au. to O.) leaves linear-lanceolate 3-nerved pinctate acute margin scabrous: branchlets level-top-corymbed compact : rays sub-5-flowered ; calyx inbricate twice as short as the disk. 12 to 24 inches ligh.

soliduginoides (P. w. Au. 4.) leaves linear-lanceolate obsolete 3-nerved entire obtuse, margin scabrous : branches level-top-corymbed : llowers sessile aggregate ; rays 5-flowered, calyx shorter than the disk imbricate, scales oblong obtuse close-jressed, sub-reflexed at the apex. 
About 2 feet high: scales of the calyx white with green tips; rays long and white.

ledifolius (C. N.P. y. W. S. and Uc. 21.) leaves linear-lanceolate tapering to the base, without nelves, roughish, revolute margin: branches corymbed : branchlets filiform 1-flowered nakedish : caly $\mathrm{x}$ lax imbricate twice as short as the disk: leafets very acute : rays sub-20flowered. A variety, uniflorus, has a very simple stem bearing but one flower. About a foot high ; sometimes the leaves have a small indenture on each side.

rigidus (N. Y. C. p. y. Au. 2!.) leares linear mucronate sub-carinate rigid, margin rough-ciliate; the cauline leaves reflexci, the branch ones spreading subulate : stem erect sub-branched above, branchlets 1 -flowered corymbed: calyx imbricate twice as short as the disk : scales carinate very obtuse : rays sub-10-flowered reflexed. Hardly a foot high.

linaviifoluis (N. 1. p. y. Au. 24.) leaves thick-set linear mucronate dotted carinate rough stiff, rameous, recurred: stem sub-decumbent: branches level-topped 1 -flowered calyx imbricate of the length of the disk. A little lower than the preceding species and flowers smaller; stem rough, purplish.

linifolius (N. P. S. 4.) lcares linear without nerves dotted rough reflexed-spreading: branches level-top-corymbed leafy : calyx imbricate short : rays about equal to the disk.About 18 or 24 inches high.

subulatus (P. Au. 24.) very glabrous; small-flowered : stem panicled : branches many Howered : leaves linear-subulate : calyx cylindric; ligulate florets of the ray minute.

foliolosus (P. C. W. Au. 2\%.) leaves linear-lanceolate tapering to both ends acuminate: stem pubescent panicled erect : branches few-flowered ; calyx imbricate : scales linear acute 
close pressed. Flowers small ; hardly distinct from the next species.

tcnuifuius ( . W. Au. 4.) leaves linear-lanceolate tapering to both ends, hispid margin : stem glabrons branching erect ; branchlets 1-flowered : calyx imbricate, scales oblong arute lax. dumosus (H. C. w. y. Au. 2!.) leaves linear glabrous, those of the branchlets are the shortest: hranches panicled : calyx cylindric closely imbricate. A rariety called riolaceus, has pale violet rays and a pubescent stem. Another varicty, alhus, has white rays and a glabrous stem. Flowers small.

cricniles (1', w-y. Au, 21.) leares linear rery glabrous, those of the branchlets subulate approximate, cauline ones elongated : calyx somewhat scurfy : leaves acute : stem glabrous. Flowers small.

muit, florus (P. W. W-y. Au. to N. 24.) leares

linear smoothish : stem rery branching diffuse pubescent, branchlets one-way : calyx imbricate, scales oblong scurfy acute. Probably a varicty of the last.

sipursiflorus (?'. C. Y. W. p. S. 24.) rery glabrous: leaves subulate-linear sub-carinate sub-reflexel : stem slender rery bianching; branches and branchlets spreading bristle-form 1-flowered : scales of the preduncles divaricate subillate : calyx imbricate, scales close-pressed acute. Resembles tlie last ; flowers smaller. zoneolor (P. P-p. Au. 24.) leares oblong-lanceolate

white pubescent both sides; stem very simple erect pubescent : raceme terminal : ralyx imbricate, scales lanceolate silky close-presceil. About a foot high : ray and disk colomed alilie. cornifolins P.J. 2\% glabrous : leaves oblong-ov ie acuminate short-petioled, margin rough : pansicle lew flowered, branches 2 -Howered; caigx sub-imispicate. Flowers white. Inmiits (1.w. Au. 2.) leaves sub-rhomboid oral- 
lanceolate, acuminate at both ends, sub-petioled glabrous, mai'gin hispid : corymb divergingly dichotomous nakedish few-flowered: calyx lax imbricate : rays 8-flowered. About a foot high ; flowers large.

anygelalimus (P. w.S. 26.) leaves lanceolate tapering to the base acuninate, margin rough : stem simple, level-top-corymbed at the top: calyx lax imbricate, scales lanceolate obtuse.Rays large.

salicifolius (C. r-b. Au. భ.) leares lincar-lanceolate sub-entire glabrous : stem glabrous panicled at the top: calyx lax imbricate, scales acute spreading at their tips. From 4 to 6 feet high ; Hower middle-sizerl.

acstivus (C. P. b. Ju. to S. $\boldsymbol{\Psi}$.) leares lanceolate sub-clasping tapering to the apex, margin rough : stem branching from its base, erect hispid ; branchlets pilose : calex scaly, scales lax linear acute equal. About a feet high ; the flower's resembling the last.

no:ra-angliae (C. N. b-p. S. to Nov. u.) leaves lincar-lanceolate pilose clasping, auricled at the base : stem sub-simple pilose straight and stifi: flowers sub-sessile terminal crowded : scales of the calyx lax coloured lanceolate longer then the disk. In rich soil it grows 10 feet high : flowers large.

ryaneus (N. P. b-p. S. to Nov. 4 .) leaves linearlanceolate clasping smooth : stem wand-likepanicled rery glabrous : branches racemed: scales of the calyx lax lanceolate equalling the disk, inner ones coloured at the apex. 3 or 4 feet high ; flowers many and large. This is the handsomest of all asters.

phlogifolius (C. P. p. Au. 2.. leares lanceolate heart-form clasping pubescent beneath, rough margin : stem very simple pubescent: panicle terminal lax few-llowered: scales of the caigs 
lax imbricate lanceolate. From 18 in 24 inches hight.

gotens (P. p-y. S. to Now u.) leares ohlong-lar:ceolate ciliate, heart form claspiag rough both sides laary: stem bianching boighin with hairs; branches spreating elongates lew-flowered, small-leared: scales of the calyx imbricate lanceolate spreading. From 1 tio a fect high.

\section{Leares heart-form and ovate, serrate.}

undulatus (P. p. S. 4 .) leaves oblong heart-form clasping entire hairy sub-!mlulate; lower ones ovate heart-forin sub-serrate petioled ; petioles winged : stem panicled hispid; branchlets oneway lealy, 1-fiowered. Flowers small. puincilatus (P.b-p.Au. to Nor. 4 ) leares oratelancenlate sub-s(rerate petioled giabrous ; radical ones ovate-heartform serrate rough petislel ; petioles naked : stem very branching glabzous; branchlets pilose : calyx lax sub-ininrirate. From 2 to 4 leet high ; flowers smallish, numerous.

cordifolius (N. A. W. P. w-p. S. 4.) leaves heartform pilose beneath, sharp-serrate petioled; petioles winged : stem panicled smoothish : pa mircles divaricate: calyx lax sub-inbricate. Howers small. A. heternhyllus. Willd. rorymbosits (N. 1'. W. A 4. \%.) leaves ovate sharpserrate acuminate smuothish; lower ones herart-form petioled ; petioles naked : stem glabmois. leveliop-corymed above : branches pilose : calyx oblong imbricate, scales obtitse ve$x y$ close-pressed. 12 to 24 inches high : How. ers rather large.

macrophyllus (1'. W-b. S. to Nov. 2'.) leaves ovate petioled seriate rough ; upper ones ovate-heartform sessile; lower one's heart-form petioled; petioles sub-margined : stem branching diffused: calyx cylindic closely imbricate, scales 
oblong acute. 1 or 2 feet high ; flowers largeish.

chinensis (china aster. E. . ) leaves ovate thickly toothed petioled; cauline ones sessile at the base wedge-for'm, floral ones lanceolate entire : stem hispid; branches 1 -flowered : calyx foliaceous. A varicty has very full flower's various-coloured and very short rays.

3. Leares lanceolate and orate, lower ones serrate.

amplexicuulis (P. b. S. 24.) leaves orate-oblong acute clasping heart-lorm serrate glabrous: stem panicled glabrous; branchlets 1-2-flowered : scales of the calyx lanceolate closely imbricate. Flowers mid-sized.

prenanthoides (P. b. Z.) leaves clasping spatulatelanceolate acuminate, serrate in the middle, heart-form at the base : branchlets pilose : scales of the calyx lanceolate scurfy.

laevigatus (P.r-p. S. to Nov. $44^{\circ}$ ) leaves sub-clasping broad lanceolate sub-serrate smooth: stem rery branching glabrous, branchlets nany flowered : scales of the calyx lanceolate lax neaily equalling the disk.

versicolor (C. y-w. Au. 24.) leares sub-clasping broad-lanceolate sub-serrate glabrous: radical ones serrate in the midule : sten rery branching glabrous : scales of the calyx lanceolate lax shorter than the disk. Flowers many and large, elegant.

mutabilis (P.p-y. Au. to 0c. 2.) leaves sub-clasping: upper ones lanceolate aruminate entire ; lower ones lanceolate at the base narrow serrate : branchlets wand-like : calyx shorter hinan the disk lax: stem glabrous.

lnevis (C. b-p. S. to Nor. 2 .) leares sub-clasping remote, oblong entire sinining; radical ones sub-serrate : bianches simple $\mathrm{L}$-fowered : caly $\mathrm{x}$ 
imbricate, the leafets sub-wedgeform acuto thickened at the apex : stem glabrous angular.

roccinneus (P. C. h-p. S. to Nov. 21.) lcaves lanceolate sub-clasping: lower ones sub-serrate glabrous : stem simple panicled at the top: calyx closely imbricate.

puniceus (N.W.P. A. p. S. to Nov. 27.) Iraves claspinglanceolate scriate poughish: lranches panicled : calyx lax exceeding the disk, the leafets Jinear-lanceolate sub-equal: stem hispid. A rariety, purpureus, seven feet; stem deep purple. Another variety, mifescens, cight-fect : from green becoming reddish. From three to ten feet high ; flowers largo.

nor-i-belgii (N. P. W-p. Au. 2!.) leaves sub-clasping lanceolate glabrous, riugh at the margin; lower ones sub-serrate : bratiches stib-divided : calyx lax imbricate, the leafets linear-lanceolate: stem terete glabrous.

spectubilis (P. b. Au. 2 .) leaves lanceolate roughthish sub-clasping: lower ones serrate in the micldle : branches corymbed : leafets of the calyx foliaceous sub-wedgeform acutish scurly. Alout two fect high : flowers large.

serotinus (C. b. S. Z.) leaves oblong-lanceolate acuminate sessile glabrous; margin rough; lower ones serrate : branches corymbed giabrous ; branchlets 1 -flowered : scales of the calyx lanceolate acuminate spreading. About three feet ; flowers large. zardiflorus (C. b. Oc. 4.) leares sessile serrnte glabrous spatulate-lanceolate, tapering to the base, deffected at the margin and both sides : branches divaricate: calyx lax, the leafets lanceolate-linear sub-equal glabious. Flowers not middle size.

blandus (Can. p. Oc. 4.) leaves sub-clasping oblong-lanceolate acuminate serrate glabrous: stcm branching in a pyramid form : branches axillary liower's in racemes scarcely longer than 
the leaf; peduncles downy and nakerl : ratry lox sub-equal, shorter than the disk. Flowers largish.

recuminatus (P. W. w. Au. 4.) leares broadlanceolate, lower ones tapering entire, upper ones unequally serrate long-acuminate: stim simple zigzag angular : panicle corynilsed slivaricate-nirhotomous : leatrts of the calvx las linear shorter than the disk. A variety calleil elatior, has a taller stem; panicles manyRoweresl and leafy. Another variety, pumalus, has a lower stem; corymb few-flowercd nakeil scarcely higher than the leaves. Commonly 12 inches high and upwards ; flowers middle-size.

conyzoicies (P.w. Au. 24.) leares oblong 3-nervel, narrow aclite at the base ; "piper ones sessile sub-entire; lower ones petinled serrate: stem simple corymber at the tom : calyx cylindric scurfy : rays 5, very short. About 12 inches high ; llowers small.

vacula (P. w. S. 4.) leares lanceolate scruate acuminate rigose rery rough : stem erect angular simple : corymb terninal: calyx imbricate, leafets lanceclate obtusish sib-scurfy. Flowers mid-size.

strictus (P. Y-3. S. 4.) lcares sessile narrowlaticeolate serrate rough : stem 1 or $2-$ howered abore: scales of the calyx inbricate closemeressed oblong acute nerny equalling the disk. Four to seren inches high ; flowers nithle-sized. tratescanti (P. W-1). Au. 2\%.) leares lancedate serrate sessile glabrous : branches wand-like : calyx imbricate: stem terete glabrous. 3 to 4 feet high ; flowers small.

recurvatus (N. I'. b. S. 2t.) leaves scssile narrowlancenlate, tapering to the base : lower ones serrate in the middle : stem bianching glabrolis recurvate: scales of the calyx lax imbricate linear lancculato sub-equal. Resembles the last. 
laxus (C.w-y. S. to Nov. 21.) leaves linear-lanceolate acuminate rough margin: Lower ones subserrate: stem sub-ieflexed: branches very spreading: stem lax panicled at the apex : calyx imbricate, lcafets lanceolate acute reflexed sipex.

junceus (P. r. Au. 2'.) leaves lanceolate-linear sessile glabrous; lower ones sub-serrate; those of the branchlets lanceolate; stem panicled glabrous : branches wand-like: calyx imbricate. 4 to 6 leet light.

dracunculoides (C. W. S. 2\%.) leares linear acuminate entire; lower ones linear-lanceolate sub-serrate : branches corymbed : calyx imbricate: stem smoothish. About $500^{\circ} 4$ feet high.

miser (Can. Au. 21.) leaves sessile lanceolate serrate glabrous: calyx imbricate, leafets acute: florets of the disk and ray equal : stem sub-villose.

divergens (C. w-p. S, 2.) Ieaves elliptic-lanceolate serrate glabrous; cauline ones linear lanceolate elongated : branches spreading : calyx imbricate: stem pubescent. S to 5 feet high; flower's small.

diffiusus (P. w. S. to Nor. 4.) leaves elliptic-lanceolate serrate glabrous all proportioned: branches spreading: calyx imbricate : stem pubescent. Flower's small.

pendulus (P. w. Oc. Nov. 24.) leaves elliptic-lanceolate serrate glabrous ; those of the branchlets remotish : branches very divaricate pendulous : stem pubescent. Resembles the preceding; but the disk turns brown.

\section{Astragatus, 80 .}

glaux (milk vetch. E. (․) caulescent, diffuse : the little heads peduncled imbricate ovate: flower's erect; legume ovate callous inflated.

$\mathrm{O}_{2}$ 
depressus (trailing retch. E. 4.) sub-caulescent, procumbent: leafets obovate : raceme shorter than the petiole: legume terete lanceolate reflexed.

secuntus (Can. p. Ju. 24.) caulescent, procumbent: leafets ovate pubescent : spikes peduncled : legumes one-way strait acuminate, both ends pendulous.

canadensis (P. C. y. Ju. 2!) caulescent diffuse : leafets (21) glabrous both sides: legume subcylindric mucronate.

vorolinianis (P. y. J. 2\%) caulescent, erect : leafets (41) oblong, pubescent beneath : spikes peduncled : bracts lanceolate of the Jength of the peduncle: legumes orate tumid beaked.

\section{ATHEROPOG0N, 32.}

rpludoides (hair-beard. P. S. 21.) leaves narrow: flowers alternate on a spike About a foot high.

\section{AtTHYRIUM, 103.}

\section{Frond pinnate.}

ikelypteris (snuffbox fern. C. P. Ju. 2!.) leafets pinnatifid, lance-linear, glabrous; divisions of leafets acute, fruit-dots marginal, at length confluent.

s. Frond doubly-pinnate, leafets with toothed serratures.

filix-femina (P.Ju. 21.) fruit-dlots strait, oblong: leafets lance-oblong.

aspleniodes (1'. New-England. Ju. 2.) fruit-dots lunate.

angustum (C. P. J. น.) frond bipinnate, leafets lanceolate, gash-serrate, serritures sub-dentate, the lower one clongated abore : fruit-slots oblong sublunate. 
3. Same with leafets semate.

bulliferum (C. P. Ju. 2.) lealcts opposite: fruitdots romdish, lower leafets pinnatifid.

4. S'ame reith leafets notched, or toothed.

lenue (P. Ju. 21.) leafets decurrent, toothed: finitdots solitary, near the teeth. mufidu?um (C. P. J. 24.) leafets setose-chaffy beneath, oblong obtuse crenate, coatlunate : firuitdots at length confluent.

junctilohum (P. Ju. 21.) leafets decurent, orateoblong, pimnatifid, the divisions about 4 -toothed furnished with a solitary fruit-dot: midribs pubescent : stipes glabrous.

\section{Atragene, 6\%.}

americana (C. P. b. M. 々.) leares in fours, ternate; leatets cordate, subentire : climbing.

\section{Atriptex, 44.}

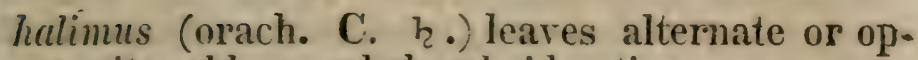
posite, oblong-subrhomboid entire.

hortensis (garden orach. Ju. .) stem erect herbaceous : leares triangular toothed of an uniform colour : calyx of the fruit orate, netted, entire.

lacinicta (C. J. (.).) stem erect herbaceous : leaves triangular deeply toothed white be. neath: calyx of the fruit rhomboid s-nerved denticulate. patula (C. Ju. (.).) procumbent; stem herbaceous spreading : leares triangular-lanceolate: calyx of the fruit triangular acute, toothed at the margin. 


\section{ATroPd, 39.}

belladonna (deadly nightshade. E. W-y. 4.) stem herbaceous, brachiate : leaves ovate entire. Berries black and poisonous.

physaloides (P. w-b. Ju. ().) stem very branching : caly $x$ membranaceous, 5-angled, netveined : belry fleshy corcred with the calyx. Nicandra physaloides of Persoon.

\section{AUCUBA, 92.}

japonica (japan shrub. E. y. J. 々.) leaves opposite, serrate, with yellowish spots.

\section{AVENA, 32.}

sativa (oats. E.J. O.) panicled : calyx 2 -seeded ; seeds smooth, one of them awned. First discovered in the island of Juan Fernandes. A variety is awnless and has black seeds. sterilis (animated oats. E. Ju. p.) panicled: calyx about 5-flowered : fiorets hairy, the middle ones awnless. When dry the heads are set in motion, if moistened, by the warmth of the hand.

fatua (P. Au. O.) panicled : calyx 3 flowered; florets spreading, all awned and the base roughhaired.

elatior (W. H. J. भ.) panicle sub-contracted nodding' : glume 2-flowered; flerets, perfect subawnless, staminate awned : culm geniculate glabrous : root creeping.

spicata (W. P.J.24.) panicle sub-spiked few-flowered : calyxes in spikelets 6-flowered longer than the spikelets : valves awned outwardly from the 2-liomed apex ; awn spiral at the base: leaves sub-bristle-form villose at the neck. sensylvanica (P. New-England. J. O.) panicle tapering : calyx 2-flowered : seed villose ; awn twice as long as the calys, 
AZALEA, 40 .

lupponica (mountain honrysurkle. Whitelilis. p. du. ?.) leaves oval, punctate, excasated, rough : corol bellform.

promombens (Whitehills. r. Ju. . .) leafy finuspert: branches diffise-procumbent: leaves oppusice ciiptic glabrous, margin pevolute: corol leflfin'm ghabrous : filaments inclosed equal. Flower's small : rescmbles Lealum buxiloliom : all the other species resemble the Rhododentron.

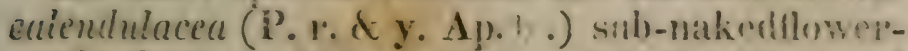
ed: leaves oblong pubescent both sides, and

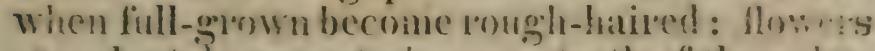
alondant large not visenes : teeth of the raily $x$ oldmg : corol with a hisute tube shorte? than its clivisions. A 1 ariety flammere has a flatesecribured flower. Another, crocea, has a saffentcoloured flower.

canescens (Catskill mountains. r. J. J. .) subnakedifowered : leaves oborate-oblong pubascent on the urrex sile and downy bencath; nerves not bristle-bearing: flowers not viscous: tube of the corol scarcely shorter than its dirisions : teeth of the calyx rery short rumedclutuse: stamens scatcely exsert. muifflor (early honeysackle. O. r. M. Һ.) sub-nakedtowered : leaves lancelate-oblong, sinothish both sides, wiform-coloured : nereses on the upporer side downy and bencath bristly ; maigin ciliate: flower's aisundant not visenus: the tuhes longer than their divisions : terth of the calyx sineri oval sub-10undcol: stamens rery nuch exsert. A variety, coccinea, has scarlet flowers and laneculate leares. Anther, mutiluns, has deep red fhweis and minute calyx. Anothre, cornece, has pale red flowers, with red bases and leafy cafyx. Another, albu, has white tioner's vith a midulling calyx. Another, pupilionucel, Las 
red flowers with the lower divisions white, calyx leafy. Another, partita, has Hesh-coloured flowers 5-parted to the base. Another, polycundria, has rose-coloured flowers with from 10 to 20 stamens.

nitida (swamp honeysuckle. Y. C. w. J. 々.) leafyflowered: branches smoothish: leaves few oblanceolate sub-mucronate leathery, giabrous both sides and the upper side shining; nerve bristle-bearing bencath, margin revolute-ciliate : flower's viscous, tube a little longer than the divisions : calyx very short ; filaments exsert. Leaves dark green, smallish.

viscosa (white honeysuckle. O. w. J. z.) leafyflowered : branches hispid: leares oblong-obovate acute, both sides glabrous and one-coloured : nerve bristle-bearing, margin ciliate : flowers viscous, tube twice as long as the diviso ions: teeth of the calyx very short rounderl: filaments scarcely longer than the corol. Flowers very sweet scented.

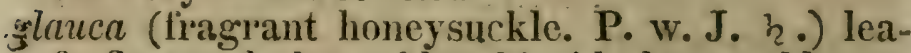
fy-flowered : branchlets hispid : leaves oblanceolate acute, both sides glabrous and glaucous beneath ; nerve bristle-bearing, margin ciliate : flowers very viscous : tube of the corol twice as long as its divisions : calyx very short; filaments about equal to the divisions of the co? rol. Rather lower than the other species : flow. ol's abundant.

B.

Baccharis, 84.

halimifolia (grounisel tree. C. W. S. 々.) leares obovate, gash-toothed above : panicle compound leaty, fascicies proluncled. The whole shrub covered with white nowder. 
anguslifolia (ploughman's spikenard. Southern states. W. Ju. h2.) rory glabrous much branched-panicled : leaves narrow-linear entire : panicle compoimd many-flowered: calyx smatl, about 20 -flowered.

\section{BaEMYCES, 117.}

1. Crustaceous, nearly nniform: knobs on short so!id cylindric simple soft stocks.

rosen, thin, leprous, a little granular, greyishwhite: stalks rery short, cylindric white : knols simple flattish, becoming tumid and lobed, flesh colour.

bygsoides (II. W.) greenish-grey, mealy: stalks white compressed, dilated upwards : knobs globular, becoming clustered brown.

3. Ifafy cartilaginous-crustaceous imbricate: knobs on long cylindric, mostly solid stalks, which are simple or divided at top.

symphycarpa, segments cut-crenate, grey-greenish brown, white beneath : stalks short, the colour of the fiond, a little pervious and slightly branched at top: knobs crowted, brown. carinsa, segments minute, cut-crenate, whitishgreen : stalks carious, cancellated, rough, whitis!-green, a little pervious and branched at top : knobs are crowded, purplish-black. delicata, segments rery minute, linear manycleft, curled, petioled, rather erect, mealy, white: stems filifirm, naked. simple and somewhat divided: Lnobs clustered, pale brown becoming black. papillaria, lobes very minute, rounded-crenate, greenish-giey : stalks listular, intlated, simple or slightly dirided, greenish-grey : knoks simple, ret-brow!! 
3. Leafy cartilaginons-crustacens, imbricate: stallis fistular, cupped at top.

bacillaris, segments in many sinnate-crenate divisions : stems filiom, greyish-white; cupss nearly cylindric, minute, entire, closeu or none: knobs scarlet.

coccifera (scarlet lichen. 0.) lobes cut-crenate: stoms short, obconir greenish-grey : rips dilatad, entire, closed : knows marginal, neatly sessile, larger, scarlet.

deformis, lobes cut-crenate : stems long, thick, a little inflated, pale yellowish-girey : cups irregula:, toothed, closed, becrming pervious : knobs marginal scarlet.

belidiiflora, lobes minute, cut-crenate : stems long, cylindric, slightly brancherl, rotigh pale-greenish : cupss terminal, clavate closed : knobs marginal, globulai, very minute, much crowded, scarlet.

pyrilata (H.) lobes cut-crenate : stems short, obconic: cups dilated, wineglass-form, closed, entive : knobs maiginal, dark-brown.

cormata (brittle lichen. H. W. Y.) lobes cut-crenate : stems long, simple, a little inflated, pointed, barren cup-bearing : cuus cylindrir, closed, nearly entire : knobs minute, marginal, sessile, brown.

gracilis. Iobes cut-crenate : stems long, filiform. pointed, bar'en cup-bearing' cups wineglassiorm, closed, subuate-toothed: knobs pedicelled, brown.

zentricosa, segments deeply cut and crenate: stems erect, rigid, inflated, grey scaly roughish : cups obsolete, pervious, radiate-branched : kubs terminal, pale brown.

silcicornis, lobes rather erect, sinuate-lober, obtuse: stems leafy all orer, short: cups minute, tublinate : innobs marginal, nearly sessile, blackish-brown. 
pareclia. lobes sub-erect. deep-manyclefi, subpinnate, narrowed: cups supra-foliaceous, turbinate, form-toothed : stems becoming branchcd, thick inflated ; branclies very short projecing, denticulate at top ; knobs clustered, bay.

4. Ienf!. cartilaginous-crustacens, eranescent: sicmi inoslly fistular, long, rigid, tapering, shrubby-brancheil.

ancialis, closely tufted, tubular, grecnish-white : branches shoit ; spread, radiate-stellate toothed and perforated at top ; knolys small, giobular, tawny.

nilunen, scattered, tubular, pale-lioary, vaguely branched. radiately hook-spinous and perforatod at the tipe and axils : knobs on the terminal spines, pale rust-colour.

sangijerur (Y. H.W.A.) cylindric tubular, crect,

match branched, greyish. pertirated at the ax-

ils: imanchlets recurved at theip tips: knobs

5 or 4 togretier, globular, red-brown.

furcala, cylimbic, tubular, crect, tapering. grey-

brown; branches ascending dichotomous and

forked: knobs dull brown.

spinuar, nearly cylindric, tubnlar. grey-brown,

ragudy branched branches effuse. curved,

fexuntis, with spines pointing backwards ; fer-

tile batnchlets sub-digitate, with brown knobs. :ermiculuris, stems tubular, sub-iliform, subulate, almost simple, prostrate, pure white.

\section{Ballota, 69.}

nigure (lalso motherwort. Y. น. naturalizerl and grows wild about Now-lfaren.) Latres hartfinsm, undivided, serrate : leafets of the calyx acuminate. Ives. 


\section{Balsamita, 84.}

sulurolens (costmary, swect tansey. E. 24.) leares toothed; upper ones with eared bases.

\section{Banetuli, $10 \%$.}

apiculata (spiral tonth-moss. W. M.) stem short, simple: leaves remotish lance-oblong, acuminate, crect, spread, capsule oblong ; lid beakedl.

acuninula (W. J.) leares linear : capsule cylindric, erect ; lid acuminate.

Znmilis, short, nearly simple : leares oblongspatulate, acuminate, keceled, crowderl, erect, spread : capsule oblong : lici acuminate.

"fallax, branched: leares lance-linear, acuminate, kecled, recuive-spreading : capsule oblong, lid oblique.

fortuos $\epsilon_{\text {, }}$ branched: leares awl-form, spread, twisted when dry : capsule orate-obiong: lid conic, erect.

\section{BARTONIA, SA.}

paniculata (screwstem. Y. N. P. C. w. Ju. ०.) stem somewhat branching, 4-sided, somen lat spirally twisted : peduncles opiosite. Stem mearly leafless, 5 or 6 inches hight.

\section{Bartramia, 108.}

1. Peduncles taller than the stem.

fontana (papcr-tooth moss) branches fascicled, nearly simple, cylindric : leaves orate, pointed, serrulate at top, close-pressed.

murchia, branches fisscicled, nearly simple and cylindric : leares lanceolate, pointed, entire, crect, spread. 
menziesir. stem long. forkerl, cylindric : leares lance-subulate, entiore. close-pressed : peduncles alsont efualling the stem.

oederiana. stem long. somewhat divided : hrancless

scattered : laves lanceolate, acute, serrulate, reflex-spread.

arispe, stem nearly simple : learcs bristle-firm, serrate. sprearl. curled when dry : capstile inclined : lid obtusely conic.

\section{Peduncles shorter than the leares.}

arcucia, branched: leaves lanceslate, scruate, striate, recurve-spread : peduncles lateral curred : capsules pendulous.

Znellerianu stem slightly divided : leares subulate, serrulate, erect-spread peduncles lateral, curred : capsule pendulous.

\section{BARTSIA, 71 .}

coceinea (painted cup. Y. P. yı\& P. J. ô.) leares, alternate linear gash pinnatifid ; divisions linear: bracts dilated gencrally 3 -cleft longer. than the flower's: treth of the calyx rombledobtuse. Flowers yellow with scarlet bracts. One variety, pa!lens, has yellow bracts.

pullida (Whitelibls; W-y. Au. Yे.) leaves alternate linear umdivided; upper ones lanceolate; floral ones sub-oval, sub-toothed at the simmit; all are 3 -nexred : teeth of the cally acute.

\section{Batueliem, 113.}

mastoideum (olive lichen.) efiuse, glabrous, somewhat cartilaginous, uneren, olive-brown: receptacles neaily globular, opening alter the lid fitls off:

\section{BATsChI, 57.}

sanescens (pucconn. false buglosis. Г. У. Tu. 2..) whitening-villose: leaves all oblong: calyx 
very short : divisirns of the corol entire. A re: isubstance corering the root is the puccoon of the Indians.

\section{Beluts, 85.}

prevenis (daisy. E. w. \& p. Ap. u.) leares obo. vate, crenate: scape naked, 1 -flowered.

\section{Berberris, 48 .}

iulgaris (barherry. H. N. Y. C. P. Y. M. 々.) branches punctate: prickles mostly in threes: leaves obovate, remotely serrate : flowers raeened.

\section{BeTA, 44.}

rulgaris (bect. E. g. Au. $\delta$.) flowers heaped together: lower leaves ovate. cicla (white beet, scarcity. E. 5.) flowers in threes : radical leaves petioled, cauline ones sessile: lateral spikes very long:

\section{Betonica, 69.}

Affcinalis (betony. E.) spike interrupted : upper lip entire, midule division of the lower lip cinarginate : calyx and bract glabrous.

\section{BETULA, 95.}

populifolia (whic birch, poj?tar birch. N. C.Ju. h.) leares deltoid long-acuminate nnequally serrate, very glabrons; scales of the strubile with rounded lateral lobes : peticles glabrous. 30 to 40 feet high. excelsa (tall birch, yellow birch. C. W. N.J. 々.) leaves ovate acute serrate : petioles pubcscent shorter than the peduncle : scales of the stro-' 
bile with romoded lateral bohes. 70 to so feet hight.

fublira (eed birch. M. h.) leares rlombic-ovate donbly-serrate acule pubescent beneaho base entire : pistillate ament ovate: sales villose ; divisions linear equal. About in feet high; excellent calsinet timber. B. nigirat.

papyracee (paper birch, canoe birch. C. W. h.) leares orate acuminate douhly-serrate ; vins hirsute beneath; petiole glabrous : pistillate ament peduncled nodding ; scales with lateral short sub orbicular lobes. Ifas a paprer-like bark, of which the Indians construct canoes. tenta (spicy birch, cherry birch. $\mathbf{0 . M .}$.. .) leares lieart-ovate sharp-serrate acuminate; nerres and petioles pilose benenth : scales of the strobile glabrous with obtuse egual lobes having elevated reins. Large tree whose wood is much. like malıgany ; rery sweet-scented. B. nigra. Wangh.

glandulosa (scrub birch. C. P. M. ho) branches glandulan-totted glabrous : leares obovate serrate at the base entire glabrous sub-sessile : pistillate ament oblong, scales hali-3-cleft : seed orbicular with a narrow margin. About 2 feet light.

pumila (dwarf birch. C. P. J. h.) branches pubescent dotted : leares or bicular-oborate peiinled, dense-pubescent beneath : pistillate ament cylindric. 2 or 3 feet high.

\section{Bidens, 84.}

cermua (water beggar-ticks $\mathbf{0}$ y. Au. O.) flowers sub-rayed drooping: outer calyx longer than the flower : leaves lanceolate sib-connate teothed. One rariety, minima, has sessile leaves and erect flower's and seeds. Another varicty, coreopsis, has serrate opposite clasping leares. 
chrysanthemoides (daisy begegar-ticks. O. y. Aw: O.) flower's rayed drooping, the ray thrice as long as the sub-equal calyx : leaves oblong, tapering to both ends, toothed, connate. Flowers large; $2,301^{\circ} 4$ awns to a seed.

fromiosi iburr-marygoll. O. y. Ju. (.) flowers discoid : outer calyx six times as long as the flower, leafets ciliate at the base : lower leaves pinnate, upper ones ternate lanceolate serrate. connata (P. y. Ju. (.) flowers discoid : outer caIyx thrice as long as the flower: cauline leaves ternate: lateral leafets comnate, floral ones ob. long-lanccolate.

pilosa ( 1 . Ju. . ) flowers discoid : outer calyx of the lengtlt of the inner: lower leaves pinnate, upper ones ternate ; leafets oblong, a terminal lanceolate one twice as long as the rest. bipinnata (hemlock beggar-ticks. P. y. Ju. (2.) flowers sub-rayed : cuter calyx of the length of the inner. Leares doubly pinnate, leafets lanceolate pinnatifid.

\section{Bignonit, \%.}

gralicans (trumpet flower. P. r. \& y.Ju. $h_{2}$.) leaves pinnate : leafets orate toothed acuminate : corymb terminal: tube of the corol thrice as long as the calys : stem rooting. Most beatltifuil climbing shrub. Une varicty, flammea, has yellow-scarlet flowers. Another variety, coccinea, has bright scarlet flowers.

\section{Bignonia, see Catalpa.}

\section{BLEChNuM, 102.}

borcalis (Roman fern. Au. 24.) barren frond pinnatifid, divisions lanceolate obtusish parallel: fertile frond pimate, lealets linear acuminate. serrulatum ( $\because$.) firond pinnate : leafets lanceolate, tapering to both ends, at the base decurrent, sharp serrate. 
BLitem, 25.

capitatum (strawberry blite, W. C. r. J. (.) hearls in a terminal spike, mot intermixed with feaves: leaves triangular toothed. rirgatum (slender blite. P. r. J. ค.) lateral heads stattered, top ones leafy : leares triangular toothed.

\section{BozmMeri, 9\%.}

cylindrica (false nettle, round head. C. P. Au. 21.) leares opposite ovate-oblong aruminate toothed glabrous : flowers sub-dioecious : staminate spikes glomerate interrupted : pistillate spikes cylindric : stem herbaceous. About of ficet high. lateriflora (P. Ju. 24.) leaves alternate ovatelancelate acuminate serrate rough: flowers glomerate lateral : stem herbaceous. Leaves 3-nerved, and on long petioles.

\section{Boletés, 117.}

\section{On a stem.}

borinus (honey-comb toadstool) tubes not touching the stem, unequal in length: pileus thincdged, brown clammy large ; flesh spongy white: stem dirty-white with reddish stains, 7 inches high, and 1 inch diameter.

edulis, tubes not fixed to the stem, readily parting from the pileus; pores circular, small : pileus brown with rust-colomed patches, nealy globular, about $\%$ or 8 inches across : flesh white, greenish when wounded: stem light brownishyellow, tapering upwards. communis, deep scarlet, convex; pores jellow stem redulish-yellow.

rubeolarins, dark-grecn, hemispherical: pores deep crimson : stem bulboas. perennis, flattish, tawny with darker zones : pores

oclue-brown: stem tawny. 
granulatus, viscid, cushion-like : pores round and?

rather angular, truncate, with the anglc granular.

luteus, viscid, cushion-like, deep buff striate : tubes round deep-yellow: stem annulate.

frondosus, greyish-brown, lobed, imbricate, tubes

whitish : stem black at the base.

betulinus, pinky-brown, incurved: tubes pure

white, short : stem short, black.

substrictus, dirty yellow, convex, thin : pores

pale yellow angular: stem dirty yellow, tough. subtomentosus, yellow, sub-downy: pores sub-angular, tawny : stem yellow.

lateralis, dead yellow, thin smooth, tubes yellow, short: stem yellow, lateral.

\section{Stemless.}

igniarius (touchwood. 0.) tubes rery slender with fine pores, yellowish changing to red-brown: pilcus in the form of a hor'se's hoof.

versicolor (0.) tubes short minute: pileus thin,

relvety, striped with various-coloned concen-

tric cir les. Smaller than igniarius.

albidus, white tender. cushion-like.

anguslatus, rich purijle, zoned, lobed, convex :

pores dull yellow.

impuler, rich tawny, convex, crenate-lobed: pores tawny-brown.

fomenturius, cuslion-like, uneren, obtuse, brown :

pores round, equal, glaucous or rusty

rehutinus, irregular, villous, grey or black : tubes

brown-rellow: pores pale brown.

labyrinthiformis, kidney-form, winkled, zoned,

brick-l'ed: tubes red-brown, long.

hepaticus, tubes distinct: thick, soft, red, lobed:

pores round, pale yellow.

pectinatis, white or buff becoming brown : tubes

oblique, cohering at the base. 


\section{BCLTONIA, BOTRYCIILY, 17\%}

\section{BotTonis, 87.}

asternides (fatse aster. P. W-T. An. 2'.) leares very entire : flowers long peduncled : seed oral glabrous sub-awnless.

glest flyit false chamomile. P. W. Ju. 24.) !omer

leaves serrate: flowers short-peduncled: sen its obrerdate apparenty winged pubescent: awns of the pappus two of equal length with themselies.

\section{Borago, 37}

officinalis (borage. E. b. Ju. O.) Ieares alternate : calyx spreading.

africana (E. O. leares opposite petiolcd orate: peduncle many-flowered.

BotrYcHuv, 105.

fumarioides (grape fern. C. P. J.) scape naked, frond glabrous, near the root 3-parted-2-pinnate : leafets limate crenate: spikes piniate. abliquaim (P. J. Ju.) scape below 1-fronded ; frond subdoubly-terinate ; leafets oblong-lancenlate scrrulate, dilated at the base unequally heartform : spikes donbly pimate. Perhaps only a varicty of the last. dissectum (P. J.) scape below 1-fronded ; frond 3paired o-pinnatific, divisions lincar: 2 -parted at the apex 2 -toothed. xirginieum (N. W. C.P. J. Ju.) hirsute: scape in the middle fironded; froml stib-ternate 3parted ¿-pimatifid ; leatets gash-pinnatifid, rlivisions obluse sub-j-tgothed, spikes apimate disaricate. Large. (ratilesnake fern.) gracile (C.Y. W.P.A.J.) glabrous : scarre in the midele fronded; frond 3-parted 2-pininatifid, divisions gash-subpinnatild acnte subiouthed: spikes slender pinaate erect. Smaller. 


\section{Brachystemum, 68.}

Gerticillatum (virginian thyme. C. P. w. J.2!.)

leaves lance-orate, entire; flowers in sessiles compact whorls : bracts acuminate.

Banceolatum (C. P w. Ju. 24.) stem stifly erect, very branching, roughish : laves lance-linear? veiny, entire : heads terminal, fiscicle-corynised.

rirginicum (0. w. Ju. 26.) stem stiffly erect, very branching, roughish : leaves linear s-nerved, entire : heats tominal, fascicle-corymued, nearly level-topped.

Brasenia, sec Hylupoltis.

Brassica, 75 .

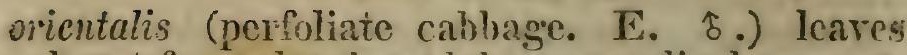
heart-form clasping glabious; radical ones entire : silique 4-sided.

napnis (kale or ccle. L. ô.) root caulescent fusìform : leaves smooth, upper ones heart-lanceolate clasping, lower ones lyrate toothed. (Rape.) rapa (tumip. E. o.) root caulescent orbicular depressed fleshy : radical leaves rough, cauline ones rer'y entire smooth.

oleracea (common cabbage, including all the varieties caused by calture. E $\hat{\delta}$.) root caulescent terete fleshy : leares smooth glaucous repand and lobate. (esculent cabbage.)

\section{BrIZA, 52.}

ranudensis (quake grass. H. C. M. 2\%) panicle lax ; spikelets erect 4 to 20 -fiowered, the common glume smallish; outer valve of the flower acute ovate : leaves long: culm erect. ercugrostis (l. Ju. 24.) spikelets oral-lanceolate 
20-flowererl. flowers sub-acute : neck of the sheathing leares pilose: culm grniculate decumbent.

media (1'. New-Fingland. M. 24.) sheath striate, gialnous : panicle erect, spreading ; with the branches in pairs ; spikelets subtriangular : corol eyualling the calyx, one ralse broad, the other compressed. maxima (rattlesnake grass. E. G.) spike cordate, about 7 -flowered. Flowers very large.

\section{Bromelia, 48.}

ananas (jine appile. E. 24 .) flowers ciliate-spinose mucronate: spikes comose.

\section{Broves, 52.}

secalinats (chess. O. J. (.) panicle notding; spikelets ovate compressed? : glumes naked distinct; awns subulate straitis!l-zigzag. Probably from Europe, common in rye and wheat-fichls. ciliatus (C. W. P.J. 24. paricle noddling : spikelets oblong compressed 6 to 8-flowered, florets awned at the margin cilliate-villose : sheadhs and beth siles of the leaves subpilose : culm bearded at the joints.

pubescens (broom grass. C. P. J. 2\%.) culm hairy below joints brown: stipules very short : pariicle at length nodding, pubescent: (alyx less thatin corol. 8 to 12-fiowered : corol pubescent, one ralre anned bencath the apex.

purgans (C. W. P. An. 4.) panide nodling spikeleis lanceolate terete : llorets awnel pilose, awns erect : leaves glabrous both sides, their sheaths pilose.

\section{Broussoneti, 98.}

bapyrifera (paper mulberry. E. M. 12 $_{2}$ ) leares sub. cordate, fu,bate and undivided. 


\section{Browatura, 71.}

elata (E, b. O.) peduncles one or many flotrered.

\section{BRYUM, 108.}

conoiderum (thread moss. W.) stem divided : leares oblong-lanceolate, entire, imbricate, spread: capsule pear-form, erect : lid subulate, curved. androgynum, nearly simple: leaves ovate-lanceolate, seriate at top, imbricate, spread : capsule oblong, erect : litl conic.

pralustre, stem forked: leares lanccolate, pointed,

entire : capsule oblong, oblique : lid conic. mutans (W.) simple : leaves linn colate, seruate at top, spread : capsule oblong, pendulons : lid convex.

arem, simpie : leares bristle-form, entire, zig-

$\mathrm{zag}$ : capsule pear-form, crintracted in the mindle, pentulous : lid conic, bossed. curneum, nearly simple : leares lancerlate, acute,

entire, rather remote: capsule pendulous : lid convex, bossed.

capillare, slightly branched : leaves olnorate, olytuse, awned, concave, involite when dry : (ap)sule clavate, pendulous.

caespititum, slightly branched ; leaves ovate-lan-

ceolate, entire, flat, awned: capsite orate-obIning, pendulous : lit llat, brssed.

ficolor, slightly brancheu, very short : leaves

orate-lancenlate, pointed, entire : capsule ovate,

pendulous : lid conver, bossed.

argenteum, slightly branched : leares orate con-

cave, awneil, imbricate, entire : capsule ob-

long, pendilous.

juluceum, slightly branched : leaves orate, concave, obtise, entire, inbricate: capsule clawate, pendulous. 


\section{BUCHNERA, CACALIA. 181}

\section{BUCINERA, 72 .}

americana (blue-hrarts. P. J. Au. ४.) leares Ian: ccolate, s-nerved, toothed.

\section{BunIAS, 73.}

'maritima (sea rocket. II. C. Ju. (:).) leares obo. rate, sinuate : silicles with two smooth, 1 -seeded, toothless joints. Big.

\section{BUPHTHATMUM, $8 \%$.}

grandifforum (ox-cye. E. น.) leares alternate,

lanceolate, sub-rlenticulate, gla.jrous.

\section{Buxbaumia, 109}

alply ylla (leafless moss) capsule peduncled : leares none.

for erect linear-subuiate, i-nerved.

\section{Buxus, 93.}

semperitens (box. E. h.) leaves ovate, petioled, stmewhat hatry at the maighn: anther's orate arrow form. Yar. ansust:juia, ieaves fanceolate. Yar. siffruticosa, Jeares obovate, stem hardly woody.

\section{C}

\section{Cacalia, 84.}

suareotens (wild caraway. P. w. An. 21.) stem herbacens : lases peioled hationt-arpowlorin serrate glabrous one-columed : flowers $\mathrm{cos}^{\circ}$ rymbed erect: calyx many-llowered. from 3 to 4 leet light. 
atriplicifolia (orach caraway. P. w. Au. 21.) stem herbareous : leares petiolerl glabrous glaucous beneath, radical ones cordate toothed, cauline ones rhombrid sub-2-tontherl both sisles: Howers corymbed erect : calyx 5-flowered. Flowers small.

reniformis (P. w. Au. భ.) stem liérbaceous : leares petioled glabrous beneath, pilose at the reins : radical ones ample heart-kidney form repandtonthed ; cauline ones tootherl, at the base wedge-form entire : corymbs level-topped : calyx many flowered. From 5 to 10 feet high.

\section{Cictes, 62.}

flamelliformis (creeping cereus. E. x. Ju. 々 .) creeping, cylindric, or 10-angled, rooting. opuntia (prickly pear. Y. P. C. Catskill. y.J. 4.) proliferous ; compressed and orate between the isthmusses : bristles fascicular. Flowers large. The plant appears like a series of thick succulent leares, one growing from the top of another.

\section{Caliile, see Bunias.}

\section{Calendula, 88.}

officinnlis (pot-marygold. E. y. .) seed liceled. muricate, incurved.

\section{Calicium, 112.}

strigonelium (fungus lichen.) crust none : puffs ses-

sile, near!y globular, minute, black, with a flat-

tish opake disk, and thin glabrous inargin. surbinatum, puffs turbinate. nearly sessile, black

rather polished, with a dot-form disk within the connivent margin. sranforme, granular leprous greyish-white : 
puffs scattered roundish, hlack, polished, wrinkled, mostly-sessile without border.

\section{Cilua, 94.}

pralustris (water arum. W. C. P. II. W. Ju. 21.) laves sub-roundish heart-form acute: spathe orate cuspidate spreading when mature. Grows in wet places.

\section{Catuchipl; 34.}

americana (bermula mulberry. E.r.J. 々.) leares oval serrate, tomentose beneath: cymes sessile. Flowers in branches, axillary ; berries sed very permanent. Southern states.

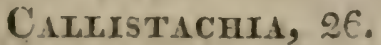

virginica (Culrer's physic. A. Y. W. C. P. w. Aw. 21.) spikes terminal : leaves in fours or tives. Five or six fect high. Very properly separated from the genus Veronica by Mr. Rainesque.

\section{Chititriche, 2E.}

verna (water chick weed or starwort. C. P. Y. W.

H. W. M. 6 .) upper leares spatulate obovate, lower ones linear obtuse and emarginate, C'. heterophylla. intermedia (1'. w.Ju. O.) upper leares oral ; cauline ones linear, ?-cleit at the apex. mutumnalis (Y. P. C. w. S. .) leaves all linear, bifid at the apex : fowers perfect. C. linearis. brevifulia (C. Au. (.).) leares all lineat truncate, sliort, approximate. Small, moss-like.

Cilthi, 66.

palustris (American cowslip. 0. y. Ap. 24.) stem erect corymbed : learce heart-hidney form, 
lobes spreading, acute-crenate all around; flo. ral leares sub-sessile : petals orate. ficurowies ( $f g$ cowslip. C. y J. 2!.) stem crect 1 flowered, 1-leafed ; radical leaves heart-ovate, rery obtuse, few toothe i, many-nerved : petals eliptic.

Alabellifolia (tooth-leaf cowslip. P. y. J. 2/.) stem procumbent: leaves spread-kidneyform; lobes very spreading, acute and sharp toothed all around: peduncles axillary solitary 1 -flowered : petals oborate : cajsule hook-beaked. Probabiy the dentata of Muhi.

integervima (New England. P. y. M. 21.) stem crect corymbed: leaves entire, with a closed sinus, orbiculate-heartiorm; floral leaves sessile kidney-form, at the base obsoletely-crenate : petals obovate.

\section{Cartcanthus, 41.}

floridus (carolina allspice. Southern states. p. M. $h_{2}$.) divisions of the calyx lancenlate : leares broad-oval acute, tomentose beneath : branches spreading.

\section{Campanura, 41.}

grandiflora (great bellfiower. E. 4.) leares ternate, oblong, serrate : stem 1-flowered; flower spreading.

rotundifolia (flax bellfower, hair-bell. 0. b. Ju. 2 \%.) glabrous : radical leaves kidney-heartform crenate ; cauline ones lineal entire : panicle lax few-flowered, flowers nodding. Without particular care the radical leares ivill be orcrlooked. americana (P. b. J. $\delta$.) glabrous : leaves heartform and lanceolate serrate ; lower prtioles ciliate : flowers axillary sessile ; corol 5-parted flat, style longer than the corol. Flower's small, 2 or $s$ in the axils of the leares; from 2 to 3 feet high. 
nilida (P. Niagana. b. Ju. z.) rery grlalurous: radical leaves spatulate-oblong leathery cartilaginous, crenate : cauline ones lanceolate-oblong sub-entire: flowers on branches ; corol bel!wheclform. About a span high.

ucuminata (P. W-b. Ju. 24.) smoothish crect: leaves ovate-lanceolate emling in a lons accominate point, subserrate : spike lascicular many-flowered : corol somewhat whecl-form. Flower's like the americana.

erinoides (prickly bellfower. O. w-b. J. O.) slender : stem simple angular: angles and the margin and nerve of the leaves with reversed prickles : leares linear-lanceolate glabrous on the upper side: peduncles few, those on the top of the stem flexuose, axillary ones 1 -flowered filiform. Flowers small.

medium (cauterbury bells. F. b. Au. ô.) capsule 5-celled, covered : stem undivided erect leafy : flower's erect.

speculum (renus' looking glass. E. b. Au. G.) stem rery branching diffuse : leaves obloug, subcrenate : flowers solitary, often destitute of the scales at the base. perfuliata (clasping bellilower. O. b. J. .) stem simple erect : leaves heart-form (renate clasping : flowers axillary sessile glomerate. Flower's small.

\section{Cannabrs, 99.}

sativa (hemp. F. g. Au. (P) stem pilose : leares digitate serrate pilose : staninate flower's solitary axillary, pistillate flowers spiked.

Cajrifolium, sce Lonicera.

Capsicum, 40.

anmun (guinea pepper, E. w. Au. O.) stem her. baccous : peduncles solitary. 


\section{Cardamine, 75 .}

imputiens (cuckow flower. E. w. O.) leaves pinhate. gashed stiputel : flower's apretalons. rotulilfolia (Whitehills. W. du. 2!.) stem proru nuent, an n what simjle: leares sub-orbiculate, nearly entire.

jensylüica (anerican watercress. 0. w. M. ४.) ghabr :s, bmanchiag: l:aras inate : leaiets Foun lish-ohlong, obtıse, tosth-anghled : silique narrow erect.

virginica (P. w. M. 24.) glabrous, crect: leaves pi:mate ; lalots lanceolate, sub-auricled : silique iong strait erect.

teres (Nev-Englanl. Pursh. w.J.24.) small crect

ramose: leaves all sublyrate-pinnatifid: silique sinort, terete acuminate.

hirsuta (P. w. M.) leaves without stipules, pinnate; leafe's romdel, repand-toothed petioled, with the terminal one oblong, gashed; flowers totrandrous.

\section{Cardiospermum, 55.}

halicacalum (heart-seed. E. Au. ().) glabrous: leafets gash-lobate, the terminal one rhomboid. A small climbing plant with small flowers.

\section{Carduus, 83.}

pectincetus (comb thistle. P. p. o .) unarmed : leaves decurrent: pedun les terminal, very long, 1-flowered, somewhat leafless ; flowers nodding after the discharge of pollen : scales of the calyx linear spieading:

\section{Carex, 91.}

1. S'tigmas truo; spilies dinecious.

seirpniten 'Can.) solitary spike in'uricats, cylindric : capsules densely-pubescent : leaves flat. 
sterilis (P. M. 2.) spikes sub-sixfold : fruit ovate compressed S-sided acuminate, at the apex recurved doubly-cuspidate, margin ciliateseriate.

2. Stigmas tro: spilies single reith staminate flowers at the apex.

eephalophora (P. J. 2\%.) spikes aggregated in an elliptical form : fruit ovate, compressed, bifid, margined, ciliate-serrate above.

3. Stigmas treo: spilies several rith staminate flowers at the top.

arenaria (P. C. J. Ju. 2 .) spikelets alternate crowded, upper ones staminate, lower ones pistillate, intermediate ones staminate at the apex : capsules orate margined bifid ciliateserrate: culm incurved. Generally grows in loose sand near the sea.

hromoiles (C. M. 2'.) spikelets oblong alternate remotish sessile : capsules oblong acuminate beaked bicuspidate: scales oblinng mucronate. On dry land.

retruflexa (P. W. 4.) spikelets somewhat in fours remotish: fruit ovate $\approx$-toothed glabrous at the margin, reflexed spreading: scales oblonglanceolate. On dry land.

stipata (W. Y. C. P.J. 2!.) spikelets somewhat in fives oblong aggregate : fruit spreading orate. acuminate bicuspidate convex-flat nerved : culm S-sided rery rough. On wet land.

muricata (C. P. Ma.J. 24.) spikelets orate approximate, fruit horizontal orate plano-consex 2-toothed, margin at the base, which is ciliateserrate. On wet land.

muhlenhergii (P. Ma. J.) spikelets somewhat in fires ovate alternate approximate : firuit roun!ish-ovate margined compressed 2-toothed ciliate-serrate: scales mucronate. On dry land, 
multifiora (P. 21.) spikes in narrow panicles oblong obtus: : fruit ovate acuminate bicuspidate: scales orate mucronate : bracts lcafy filiform. On wet land.

sparganioides (P. C. Ma,* to Ju. 24.) spikelets many-flowered, somewhat in eights, ovate, subapproximate : fruit ovate compressed margined bifid, the margin ciliate-serrate horizontal. On wet ground.

dirulsa (C. P.J. Ju. 2.) spike somewhat branched at the base ; spikelets ovate approximate, lower ones remotish : fruit erectish orate planoconvex 2-toothed margined, the margin glabrous. On wet ground.

rosea (P. 21.) spikelets somewhat in fours remote:

fruit ovate acuminate 2-toothed, at the margin ciliate-serrate horizontal: scales orate obtuse : bract leafy at the base of the lower spike. On dry land.

paniculata (P. Ju. భ.) spikes panicled ; fruit orate, margined abore, 2 -toothed, the margin ciliate-serrate : culm 3-sided. On wet land.

4. Stignas tre: spikes sereral reith pistillate flowers at the top.

leporinu (C. P. J. 24.) spikelets in threes roundish-elliptic alternate compact : fruit elliptic compressed acuminate entire at the orifice, or mouth.

scirpoides (W. P. Mía. JI. U.) spikeiets somewhat in fours approximate clliptic : fruit orate 2-toothed compressed, at the inargin ciliate-serrate, erect: scales elliptic obtuse. On wet giound.

lagopodioides (C. J. Ju. भ॰) spilielets in twelves, alternate elliptic obtuse approximate : fruit ovate-lanceolate margined bicuspidate : bract leafy rery long at the base of the last spike. On wet ground.

avalis (C. J. 24.) spiliclets somewhat in sires 
romolish-elliplic alternate sub-approximate Sinmmate beneath : liveit ovate maregined \&-

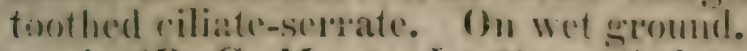
scopraria (P. C. Ma. to Ju. 4.) spibelets somewhat in fives alternate el!iptic obtuse sub-alpproximate : fruit orate-lanceolate margined bicuspiclate : bracts oblong mucrenate. Coirmon onl wet and dry latud. eurla (C.J. 4.) spikelets somewhat in sixes alternate approximate cylindric : fruit wate flano-convex acutish; at the mouth cutire, erect, longer than the scales, which are ovate acute. On wet land.

romota (1.J. H.) spikelets alternate remote: bracts leafy very long somewhat appendaged: firuit orate, acuminate bifid sub-compressed. festucreeu (W. P. Ma. J. ४.) sprikrlets sumewhat in cights sub-apuroxinate aiternate cylindric, the fruit-bearing ones club-form : fruit romdish-ovate beaked 2-toothed, at the margin ciliate serrate greater than the scales, which are lanceolate mucronate. Common on dry land.

5. Stigmas treo : staminate and pistillate florers mostly on distinct spities.

saxatilis (Vermont. J. 2.) pistillate spikes in pair's oblong, the lower one peduncied : fruit el. liptic obtuse cqualling the oblong obtuse scale : liracts oblong clasping, sub-foliaceous at the apex : culm glabrous, caespilosa (Y. IT. I. Na. T. 24.) pistillate spilies cylindric obtuse, son:ewhat in threes, disant, exsertly-pedaucled, lower one rery short, fruit orate oistuse, perforated at the mouth, larger than the oblong obtuse scale : leaves spreating. On wet land. (Staminate sjike sonctines single.)

crimita (Y. W. C. P. J.Ju. ל.) staminate spikes in 
pairs : pistillate ones in fours, distant, perluncled. pendulous, cylindric : fruit rountish-elliptic, ventricose, very short-beaked, at the orifice entire, shoriep than the ohlong awned sraje. A rariety, paleacer, has cylindric spikes, the staminate ones several peduncles long, reclined : bracts leafy, distant: scales terminatci with long scrrate sharp points : cal sules romolish emarginate at the orifice : culm lax. acutru P. C. J. Ju. 24.) staminate spikes in pairs os in threes ; pistiliate ones somewhat in lons's sil-preduncled, a little nodding, cylindric , remote : fruit oblong with a rery slint beak, at the orifice entire perforated, it nearly equais the oblong acute scale.

6. Stigmas three: spities with staminate flowers at the top.

fraseri (P. Ap.4.) spike simple orate: fruit oratesubgiobular. at tire crifice entire, Inngrex than the oblong scale : leaves lanceolate undulate crenulate: scape sheathed at the base. On dry land.

willénorii (P. Ma. J. భ.) spike simple : finit alternate oblong, terete-3-siced, rough, acuminate: scales ovate acuminate; the lowest apex leafy. On wet land.

polyirichoides (I. W.J. 24.) spike simple; fruit ghlong-lanceolate compressed-3-sided obtuse emarginate : scales oblong obtuse emarginatc.

On wet ground. C. microstachia. Michaux. pedunculata (T. P. Ma. to Ju. 4.) sprikes somewhat in fours, pedunc led, much branched : fruit whorate 3-sidcd obtuse ; scales oblong obtuse mucronate. On dry gromd.

orata ('an. 24.) spikes somewhat in fives peduncled orate pendulcus : fruit obovate, acute at both ends : scales orate acuie equalling the capsule. 
7. St:gmas thire : the terminal spilies pristiliate, the others androg!nnous.

rivescens ( $\because$. P. Ma. 27.) The androgymons spike limar-pedmoterlo staminate florets below; the pistillate ones suh-approximate, in pairs. suhpedmolerl. linear : fruit globular-3-sided, obtuse. pubescent. On dry lind.

hirsutu (1'. Ma.J. 4.) andrognous spikes ol, long obovate, stamina!e flopets bolow : the pistillate ones remutish, sub-ternate, suh-sessile, oblong: finit orate rery obtuse, obtusely s-sided : leaves and shemilis hirsute. Ondry hills.

buriremii (C. P. Ju. Au. 2̌.) androgrnous sjoikes pelumrled obovate : staminate fiorets below: pistillate ones suh-ternate, remote, subfreduncted : fruit elliptic, S-cided obtuse, absofotoly a-tootlind, neatly equalling the oblong mucionate stale. On wet grotind.

trichuearpa (Now-Engliugl. l’.J. 4.) androgronous spikes in theres p pistillate ones in prairs pes!uncled exect. rylinflyc inmote ; fruit ovate, acuminate. bionsividate. pilose, longer than the awned ovate-iancolate scale. On damp! land.,

S Stigmas three: the stamens and pistils on distinct spilies ; the staminate spilie's solitary, the pistillate ones sessile or having an inclosed peduncle.

raria (W. A. C. Ma. J. 4.) pistillate spikes somewhat in threes, sub-apneroximinate. se silce sub-ghobular : limit sub-gholular s-sided, beaked s-tonthed. puhesent. shorter than the ohlung scale: culm ereet. On diy land.

sumblelu (C. 24.) pistillate sprikes somewhat in fours, very remote, semsile ; staminat me sessile: frwit sublate, divaricate, refiexed: culm slender: leaves flat. 
marginata (P. C. Ap. Ma. 4.) pistillate spikes somewhat in pairs, approximate, sub-glohular, sub-sessile : fruit globular, tomentose, 2-toothed, larger than the oblong-ovate scale : radical leaves of one year longer than the culm. Common on dry land.

restitu (W. P. C.J. 4.) staminate spike lanceolate; pistillate ones orate, in pair's sessile approximate : fruit orate, beaked, at the orifice oblique, pubescent, nearly equalling the acute ovate scale. On wet land.

tentracelata $\mathbf{Y}$. W. C. P.J. Ju. 24.) pistillate spikes in threes with inclosed peduncles, orate subapyroximate : bracts very loug leafy : fruit orate, ventricose, nerved very long-beaked, at the orifice 2-toothed, longer than the lancenlate mucionate scale. On wet land. A variety, rostratu, has the beak very large and long: milaris (Vermont. Ju. 4.) pistillate spike generally solitary sessile, orate: bract bristle-form : firut globose glabrous. On damp land.

Pupulina (Y. W. C. P. J. to Au. Z.) pistillate spikes in threes with enclosed peduncies, olylong ajproximate : bracts very long, leafy : firut ovate ventricose nerved, with a very long cinlc brak, at the orifice bicuspidate, several times longer than the mucronate orate scale. On damp land.

flac (P. J. 4.) pistillate spikes somewhat in threes, sub-approximate, elliptic with an inclesed pe mincle : firit ovate, rellexed, beak longei than the ovate lancelate scale, the beak curre:! o-toothed. On wet land.

di gurerpa (W. C. P. Ma. Z.) pistillate spikes in paiss, somewhat 4-flowered, the lower nozets feduncled, freit roundish-s-sided, obovats, beaked, at the orifice entire, Ionger thin the mucronate oblong scale.

folliculat z (W. P. C...J.Ju.น.) pistillate spike subsolitary, sub-6-liowerei, suj-exsert-p,eduncled: 
Penit orate rentricose nerred beaked, at the coifice \&-parted, longer than the ovate scale. A rariety, major. has the fruit more swollen. mbescens (P. Mat. 2\%.) pistillate spilies in fours, sessile, the lowermost florets exseri-peduncled: firuit orate-3-sirded pubescent beraked a-toothed, lomger than the oblong mucronate scale : culm and leares pubescent. On damp land.

9. Stigmas three : the stamens and pistils on disfinct spilies : staminate spilies solitary ; pistillate anes lons-peituncled, the shecths shorter.

plantaginea (0. Ma. J. 4.) pistillate peduncled spilies in lours, distant : fruit ciliptic, S-siled, pedicelled, gyliorois. shorier than the cuspidate wral scale: biact sheathing sub-foliaceous at the apex, ratical ones lanceolate nerved. On dry ground.

arceps (C. P. J. 24.) pistillate spikes in threes remote, lower ones perlunclul : fruit urate nervel, at the orifice membranaceons, longer than the mucrontate oblong scale. On wet ground.

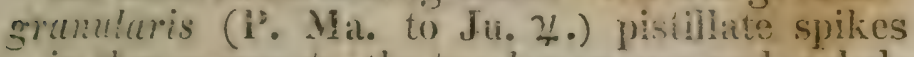
in threes remote. Uhe two bover ones pedunded: fout globular-ovate nered rentricose, rery shrirt-bcaked, at the orifice obsoletely-emarerinate. longer than the ovate-lanceolate scale. On dry lant.

concitele (1.J. Z.) pistillate spikes in pairs remote: the upiger one sub-sessile, the lower one lons-peduncled : firuit oblong-conic obtuse egltalling the awn scale. Bn dry ground. letenucil (l'. Ma.J. 24.) pistillate spities in pairs remote, the unger one sub-sessile, line lower

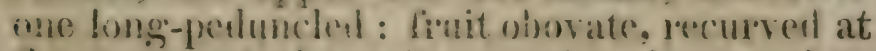
the apex, at the orifice entire, longer than the obtuse orate scale. Common in dry groumel.

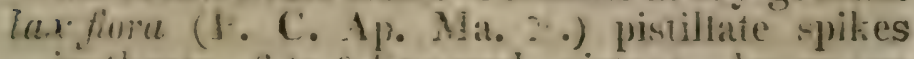
in thees, i to s-lewered, cistant ; luwce une il 
remotely peduncled, fruit obleng ventricose obtuse, larger than the mucronate ovate scale. On diry land.

Jystericina (P. J. Ju. 21.) staminate spike solitary, scales orate-oblong sub-mucronate ; pistillate spikes cylindric in pairs, the lower one pedunclerl, firuit ovate many-nerved beaker, at the orifice bifid, Ionger than the awned oblong" scale. On wet land.

diste!ls (P.J.Ju. 24.) pistillate spikes in threes oblong distant, the last one sessile, the others perluncled fruit orate acuminate bicuspicate, mearly eifualing the acuminate orate scale. On wet land.

flexusa ( $\mathrm{l}$. J. 2\%.) pistillate spikes somewhat in fours, remote, filiform, peduncled, nodding: fruit distant, alternate, oblong, beaked, bihrl, twice as long as the mucronate ovate scale. On wet land.

digitalis P. 2i.) pistillate spikes somewhat in threes remote filiform perluncled nodding : fruit ellipti: obtuse, longer than the oblong-lanceolate scale.

10. Stignas t7:ree : the stanens and pistits on cistinct spilies; stuminate spilie solitariy, pistillate ones peduncleal; slieaths scarcely any.

3̧ımbellata (C. P. Ma.4.) pistillate spikes in threes peiluncled, 8-flowered, orate, whored : fruit wate pubescent, beaked, at the orifice entire, e'pualling the ovate-lanceolate scale. On dry land.

miliacea (P. C. Ju. 24.) pistillat e spikes in threes filiorm, the highest sub-sessile, the other's jeduncled: fruit ovate 3-sided short-bealied, at the orifice entire, longer than the awned cmarginate oblong scale. On wet land.

pseuto-cyperus (P.J. Ju. L.) pistillate spikes in lours with the pechucles in jain's, pendulous 
eylindric: fruif ovate-lancenlate bicuspodate peilexed equatling the bristle-form scale. Common on wet land.

11. Stigmas three: the stamens and pistits on dislinct spilies : siaminule splilies maliy.

recura (P. J. 21.) staminate spikes in pairs; pistillate ones cylindric, somm what in threes, peduncled, pendulous : fruit elliptic, ohtuse, ortene roughish, equalling the orate cuspiciate scale. On wet giround.

pellita (P. C.J. Ju. 4.) staminate spil:es in pairs; pistillate ones in pairs cylindrir. crect, remoir. "uper one sessile : huit nvate bihid, pilase, shomfr than the awned oblongs scale. Common om wet land.

lacustris (1.. C. J. Ju. భ.) staminate silites in. fours ; pistillate ones in pairs erect cylindric peduncled : fruit oblong many-nerved beaked bifurcate, longer than the mucronate oblong scale. On wet land. A large varicty is callei gigantea.

resicaria ( $\mathbf{P}$. Ma. to Ju. 24.) staminate spikes in threes; pistillate ones somewhat in pairs, peduncled, cylindric : fruit oblong-jnflated, beaked. bicuspidate, larger than the lanceolate scale, culm acutely 3 -cornered. On wet land. bullata (P. J. 21.) staminate spikes in threes; pistillate ones in pairs, cylindric, pesluncled, erectish : fruit olovate-globular, bealced, bifurcate ; the beak hispid and longer than the lanceolate scale. Common on wet land.

\section{Carpines, 95.}

americana (hormbeam. 0.g. M. hz.) leares ollongorate, arminate. unequally scriate : scales of the strobile 3 -parted, the nidalle division with a lateral tooth. 
Carthamus, 83.

linctorius (false saffron. E. y. J. ()) leaves nvate; entire serrate-aculeate.

coerulius (blue safirom. E. T. 24.) stem about 1flowered: leares lance-orate, spine-toothed.

\section{CAREM, 47.}

carui (caraway. E.w. 今.) stem branching: leares. with rentricose sheaths : partial involucre none.

\section{Cassia, 56.}

semua (Egyptian senna. E. o.) leares in 6 pairs ; petioles glandiless : legume reniform. marilandica (senna. 0. y. Au. 24.) somewhat glabrous : leares in 8 pairs, lance-oblong, mucronate : flowers in axillary racemes and in terminal panicles: legumes linear curved. An crcellerit catharic. See Barton's Med. Bot. chamaecrista (cassia, partridge pea. M. Y. C. P. y.Au. somewhat glabrous : leares linear in many pairs, the glands or the petioles subpedicelled : petals with a spots : legumes pubescent. A most elegant plant, from 8 to 16 inches high.

fusciculata (C. P. y. Ju. O.) somewhat glabrous: leaves at the summit in 9 pairs : fascicles many-flowered, lateral : petals and stameis of the same colour : legumes glabrous, ascending arched.

mictitans (C. P. New-England. Pursh. y. Ju. g.) spreading, pulbescent : leaves in many pairs, linear ; glands of the petioles pedicelled : peduncles short, supra-axillary, 2 or 3 -fiowered ; flowers petandrous. The leaves of this species and of the chamaecrista possess a considerable degree of irritability. 


\section{CASTAYEA, CELASTRTS. IOF}

\section{Castanea, 95.}

americana (chesnut. O. g. J. Һ.) leares lance-

oblong, sinuate-serrate, with the serratures mucronate, glabrous both sides. Large trece.

pumila (chinyuapin. C.P.g.J. 々.) leaves oblong, acute, mucronate-serrate, with white dowin beneath. Small tree.

\section{Catulpa, 26.}

syringaefolia \{catalpa tree. P. w. \& p. Ju. 々.\} leaves corrlate, flat. An elegant tree.

\section{Catcatis, 45.}

mauritania (base parsley. E. 9.) general inrolucre 1-leaved, partial one s-leaved.

\section{CaUlophither, 48.}

thalictroitles (poppose root, false cohosh. 0. p-y. Ap. 24.) rery glabrous : leares more than decompound ; leafets oval, the lower ones petioled and lobed, the end ones 3-lobed.

\section{Cenatius, 41.}

americanus (New-Jersey tea. O. w. J. h.) leares orate acuminate, serrate, S-nerred, puhescent bencath : panicles axillary long-peduncled, sub-corymbed.

Celastrus, 41.

scundens (false bitterswect, staff trce. $0 . y-\pi$. J. 々.) stem twining : leares oblong, acuminate, serrate: racemes terminal. Retains its scarlet berries through the winter, though dry and senerally opening by valres. 


\section{Celosia, 42.}

cristata (cock's crest. E. Ju. \%.) leares oblongorate: pedincles terete, sub-striate : spikes oblong.

\section{Cextis, 44.}

occidentalis (nettle tree. C. P. w. M. $h_{2}$.) leares ovate, acuminate, erfually serrate except near the base; scabrous above, rough-haired beneath : fruit solitary.

crassifolia (hag-berry, hoop-ash. C. P. w. M. 々.) leaves orate, acuminate, unequally serrate, unequally cordate at the base, sub-coriaceous: peduncles about 2-flowered.

\section{Cexchrus, 29.}

cchinatus (hedgehog grass. P. Au. S.) spike ol)long, conglomerate : involucresub-globose, 10 parted.

bribuloides (C. P. Ju. (.) spike glomerate, with alternate spikelets : pistillate glumes globose, nuricate-spinose, hirsate.

\section{Centacrea, 88.}

solstitialis (New-Jersey. Pursh. y. Ju. O.) calyx palmate-spinose, solitary; spines strait : leares hoary, lance-linear, decurrent, entire ; radical ones lyrate.

cyanus (blue-bottle. Naturalized. b. Ju. O.) scales of the caly $x$ serrate leaves linear entire; lower ones toothed.

secebiosa (scabious centaury. E. 21.) leares pinnatifd, ronghish ; divisions lanceolate, spreacting, acute, and pimnatifid at the base : calyx ciliate. 
centaurium (great centanry. E. 2\%.) leares pinnate glabrous ; leafets sharply and doubly serrate, decurent : caly $\mathbf{x}$ smooth. jacer (knapweed. P. p. Ju. 4.) leares lanceolate, entire; radical ones sub-dentate: branches angular, calyx scarious.

suaveolens (yellow sultan. E. (-).) leaves lyratepimnatificl: calyx smonth.

benedicta (blessed thistle. E. .). Icares semidecurrent, tooth-spinose : calyx with branched spines.

moschata (sweet sultan. E. (-).) leaves slightly pinnatifid ; lower divisions mostly entire : calys smooth.

Ccntaurella, see Bartonia.

Cephatantius, 34.

occidentalis (button bush. 0 . g. Ju. 々.) leares opposite, and in threes. In swamps.

Cerrastium, 60.

vulgatum (mousear chickweed. O. w. Ap. ค.) hirsute, viscill, cespitose : leares orate : petals oblong, about equal to the calyx : flower's longer than the peduncle.

semidecandrum (Y.P.w. M. O.) hirsute, viscid : leares ovate-oblong, acute: petals emarginate, shorter than the calyx : peduncles longer than the calyx : flowers pentandrous.

arvense (A. I. W. J. 2\%.) pubescent, cespitose: leaves lance-linear, obtuse, ciliate at the base, shorter than the distance between the joints of the stem : petals obcrordate, twice as long as the calyx : leafets of the calyx obtuse.

dichotomum (P. w. .). leaves lanceolate: stem dichotomous : capsules erect, twice as long as the calyx. 
viscosum (P.w. M. 24.) hirsute, viscous, diffuse : leares lance-oblong, obtusish : petals obovate, scarcely longer than the calyx : flowers shorter than the pedumcle.

tenuifolium (P. W. M. 4.) very slender, pubescent, cespitose : leaves narrow-linear, longer than the distance between the joints of the stem : petals obovate, emarginate about thrice as long as the acute calyx.

\section{Ceratophyluma, 93.}

demersum (horkwort. C.P. Ju. \%.) leaves 8 in a whorl, dichotomous in pairs, tooth-spined on the back : flower's axillary : fruit 3-spined.

Cercis, 56.

canadensis (red bud, judas tree. P. Can. r. M. Һ.) leaves round-heartform, acuminate : stipules ninute : legumes short-stiped.

\section{Cerinthe, 36.}

Inajor (honey wort. E. -. ) corols obtuse, spreading: at the top rentricose, bellform : stamens shorter than the corol.

\section{Cetraria, 116.}

islandica (iceland lichen. Y.) greenish chesnut, sinuate-laciniate many-cleft ; segments ascending, channelled. ciliate : targets nearly marginal, chesnut, slightly margined.

lacunosa, (0.) expanded, rounded-lobed becoming raguely lacinate, rough-netted, callular, greenish-white : targets riised, nearly marginal, a little tumid, rust-coloured, with a thin sub-entire borter.

juniperina, membranous, pale yellow, deep yellow 
beneath : jagrget-laciniate, segments flat, asconding, complirate, crase-crenate, ruiled, naked : targets raised, nearly marginal, bay, with a thin yellow crenulate bonder.

\section{Cinerothyluen, 46.}

morumbens (chervil. P. w. M. .) seeds shining, smonth: leares decompoind : stem pocunbent : umbels few-flowered.

clastoni (poison cicily. 0. W. J. 21.) Irares oblong-oval, sub-pinnatifid-lnbed : mimbeis iewrayed, diraricate : fruit smooth. This plant can linitly be flistinguished firoth the mymhis dulris, exirent by the dasie. Doct. Bigelow sats, the latter plant loses its aromatic taste in some stiils; and he suspects they lialy be rariectes of the same species.

Chaerophyllum, see Myrrhis.

\section{Cunara, 90.}

zulgaris (feather-beds. P. Ju. s.) stem and branches naked at the base; branchlets terete; leares jointed : leafets oblong subulate : bracts shorter than the berry.

foliosa (P. Ju. (:).) stem naked, papililose above;

branchlets terete at the base and in the leafy joints : leaves linear : bracts shorter than the berry.

flexilis (P. Au. @.) stem translucent, naked: branchlets jointless, lealless, compressed : berries lateral, naked.

Chemlaxthes, 104.

resitita (lip fern. W. 21.) frond doubly pinnate, hairy both sides; lealets pimnatificl.

Cuemantines, 75 .

cheiri (wall-flower, E. J. 4.) leaves lanccolate, 


\section{CHEIRANTIUS, CHENOPODIUM.}

acute, glabrous: hranches angled: stem somewhat of a woorly texture.

fenestralis (wared wall-flower. E. 占.) leaves

crowded together in a headg recurved undulate: stem undivided.

cmmus (stock joily-flower. E. Ju. (.) leaves

lancenlate, subdentate, ohtise, hoary : sili:iue cylindric with an arute apex. incamus (brompionstork, brompton queens. E. $\hat{5}$. )

leaves lancentiate, entire, obtuse, hoary : silique truncate compressed at the apex, stem somewhat of a wooly texture.

\section{Chelidonium, 63.}

majus (celantine. O. y. MI. 24.) umbels axillary, jeduncled : leares altemate, pimnate, lobed.

\section{Chelone, 72.}

glabra (snalchearl. 0. w. \& r. Ju. 2!.) leares opposite, lance-nblong, acuminate, scirrate; spikes termina!, dense-flowered. Some authors make a species obliqua, which, they say, has all the leaves oppesite, and that the glabra has the lower leares alternate-sed quere?

\section{Cinemopontum, 44.}

Gonus-henricus (english mercury. E. §. J. 4.) leaves triangular saggitate entire, spikes compound leafless axillary.

rubrum (rusty pigweed. H. W. P-g’. Ju. f.) leares

triangular-cordate, obtusish, sinuate-toothed:

racemes crectish, compound, sub-foliaccous, shorter than the stem.

album (pigwecd. 0. g. Ju. 0.) leaves rhomboidovate, erose, entire behind, the upper ones ob-

long entire, seeds smooth. vivide (green pigrweed. P. g. S. O.) leares lance- 
CTEYOPODTCM, CIIMAPIII.A. 203

rhomboid sinuate-tonthed : racemes ramose, subfoliaceous : stem very green.

hylorilum (W. Y. C. g. J:. (8.) leaves cordate, anglef-acnminate : racemes branching, divaricnte naked.

bolrys (oak-of-jerusalem. O. g. Au. . .) leaves ol)long. sinuate : racemes naked many-clelt. Sweet scented.

annlinosicides (sweet pigwerd. C. P. ... Ju. ..) Iraves lanreolate, toothed : racemes leafy simnile. Siwcet scented.

anthelnentiam (wormsed. Y. C. P. s. A». 4.) leares ovate, oblong. rarely toothed racemes leatless : styles 3 . Udour stiong and disagreeable.

maritimum (sea pigwerl. C. P. Y. g. Aiı. '.) leaves subulute. Hlesing, semiterete: flowers glomerate, axilla!y. On the sea-rnast. glimem (C. 2\%) liaves orate-obleng. xepand, glaucous bencith ; raceness naked, simple, glomerate.

scoperium (sumber cypress. E..) leares lat, lanrelinear, margin ciliute : lowe's ghonerate, arillary.

\section{Crimapinia, 56.}

maculata (spotted winter-green. 0.7. Jn. 2:) leaves lanceolite, loninded at the base, leniriteIy serrate, market with lons spots : scale id or j-fluwered ; fifanents wolly.

zombellata (princes's pine, bitter wintergreen. 0 . r-w. Ju. 2-) leaves wedge-ianceolate, with an arute base : scape congmbed : filaments glatbrous. Pursh says the monalutu is the sipsisewa of the Indians. and is uschul in hy steric alfections. Cxencral Farnum says the umbellata is the sipsisewa or pipsisewat, and is highly effracious in the rume of cancers. Both are taken from the genus l'y rola, 
Chionanthes, 26.

virginica (fringe tree. C. P. w. M. $h_{2}$ ) panicle terminal, trifid : peduncles 3 -flowered : leares acute. Berries purplish blue.

\section{Chironia, 39.}

angularis (American century. P. p. Au. ô.) erect : lcaves ovate, clasping, flower's with long peduncles, corymbed : dirisions of the calyx lance-linear : stem with 4 margined angles. gracilis ( $\mathbb{P}$. J. Ju. ô.) slender: branches lax clongated, 1 -flowere! : leaves oval-linear : divisions of the calyx linear about equalling the conol: divisions of the corol obovate : stem angular. chloroiles (C. P. r. Au. ô.) weak : leaves lanecolate, erect: branches few, 1-flowered; flowers 7 to 13-parted : divisions of the calyx linear, shorter than the divisions of the corol.

stellaris (C. r. Au. of.) erect : branches dicliotomnus, elongated, 1-flowered: leaves lanceolate, acute : calyx subulate : divisions of the corol obovate : stem terete.

calyensa (C. l'. r. Au. o.) erect, leafy : learc; oblong-oboratish : flowers solitary, absut 7 - jarted ; calyx leaiy, exceeding the corol, divisions oblanceolate.

paniculata (C. w. Ju. Ұ.) erect: leares lance-lincai" panicle many-fowered, brachiolo, spibiastigiate : calyx subulate : stem 4 -cornered.

\section{Chryanthemum, 85.}

Ieucanthemum (0.J. 21.) leaves clasping, lancenlate serrate, cut-toothed at the base : stem circt hranching. garthenium (feverfer. E.) leaves petioled, compmint, flat ; leatets ovate, gashed : peduncles branching corynbed : stcin erect. 
coronarium (garden chrysanthemum. E. Au. B.) leaves bipimatifid, acute, broader outwards : stem branching.

\section{Cirry sospleniem, 55.}

oppositifolium (golden saxifrage, water-rarpet. A. V. I'. y-1. M. ४.) Jeaves opposite, roundish, slightly crenate, tapering for a little distance to the petiole.

\section{Cichortum, 83.}

intibus (succory oi endive. 0. b. Ju. 2!.) ffowers axillary in pairs sessile; leares runcinate. sndivia (garden cndive. E. 5 .) peduncles axillary in pairs: one long 1 -flowered, the other short about 4-flowered : leares oblong, denticulate. Var. crispum, has lringed leaves and solitary flower's.

\section{Crcuta, 46.}

-irosa (water hemlnck. E. 2l.) umbels opposite to the leaves ; petioles margined, obtuse : leafets ternate, acutely serrate. Root containing a yellow juice.

Gullifira (C. Ju. 24.) branches bearing bulbs in whorls : leaves tennel-like. maculata (U.w. Ju. 24.) serratures of the leares mucronate : jetioles membranaceous, 2-lobed at the apex.

\section{Cimicifuga, 65.}

serpentaria (bugbane, black snakeroot, cohosh. Y. A. P. W. JU. . , leates decompound; leatets orate-oblong, gash-toothed ; racemes in wandlike suikes: sumetines monogyuious. 


\section{Cineraria, 86.}

heterophylla (ashwort. P.y.M. 4 .) downy : radical leaves long-petioled, obovate-spatulate, obtusely toothed; the other leares pinnatifid: peduncles 1-flowered, long, solitary.

\section{Crina, 25.}

arundinacea (indian reed. C.) glabrous : panicle large, many-flowered, capillary : one valve somewhat awned below the apex.

\section{Circhea, 27.}

Iutetiana (enchanter's nightshade. O.r-w. Ju. Z.) stem erect: leaves ovate, denticulate, somewhat glabrous. Var. alpina, has an ascending stem, itives sub-cordate, and the calyx membranareous. This varicty is generally considered as a distinct species. But they certainly pass into each other by almost imperceptible gradations.

\section{Cistus, 64.}

canndensis 'rock-rose, frost plant. H. Y. A. C. $\mathbf{P}$ y.j. 4 .) withut stipules, erect; leares alternate erest linear-lanceolate, flat, tomentose beneath ; divisions of the calyx broad-orate actuninate : capsiles shorter than the calyx. At the foot of Pine-sock, New-Haven, the bamen plains produce great quantities of this plant. In Nov. and Dec. of 1816 , I saw hundreds of these plants sending out broad, thin, curved ire crystals about an inch in breadth from near the roots. These were melted away by day, and renewed every morning for mure than 20 days in succession. 


\section{Citros, 64.}

durantium (orange tree. E. w. h. .) leaves oval acuminate with winged petioles.

meliea (lemon tree. E. W. I. l. $_{2}$ ) Iraves orate

acuminate. with linear petioles. Var. linume (lime tree) bears smaller fruit, which is atmost round.

\section{Ceatmens, 118.}

cancellatus (latticed fumgus) pileus desembling lattice-work.

\section{Clavaria, 118:}

syrans (club fungus. W.) cylindric, white, rather taper at the ends : stem capillary, pellucid, simple.

pistillaris, nearly çllindric, mostly undivided, tubular, brittle, smooth.

repitata, heat orate, chesnut, dotted, stem simple, ycllow, round; root roirate. corneci $(\mathbf{Y}$.) simple or cloven. somewhat pointed, red orange, horny and brittle when dry. muscoides (shrubly limgus, W. y.) much branched : Inanches mustly forked, pointed unequal, yellow.

\section{Clattoni, 42.}

virginica (spring beanty. Y. C. w. \& r. Ap. ४.) leaves lance-lincar : raceme solitary : leaves of the calyx acutish : petals obovate, retuse: root tuberous.

spatulate (spring beasty. W. H. P. A. W. \& P. Ap. 4.) leaves spatulate: rareme solitary: leaves of the calyx obtuse : petals roundish, letuse : root tuberous. 


\section{Cenmatis, 66.}

viticella (pumple virgin's bower. E. p. Ju. 24.) climbing : leaves componnd and decompound; leafets oral sublobate entire : petals obovate spreading.

ciorna (leather fiower. P. b. J h.) climbing: leares compound and decompound; learets lance-oral, acute at both ends, trifid and entire: flowers solitary, belifor'm : petals thick leathery, acuminate.

virginica (virgin's bower. 0 . w. Ju. $h_{2}$.) climbing: leaves ternate; leafets ovate, subcordate, gashtoothed and lobate: corymbs dichotomous, fow flowered : petals longer than the stamens. Uften dioecious.

flaminula (sweet virgin's bower. E. b.) lower leares laciniate; upper ones simple, entire, lanceolate.

ochrolenca (P. C. w. \& y. J. 24.) erect, simple, pubescent: leaves simple entire. About one toot high.

Jiexagrona (W. p-b. M. h. ) stem climbing, 6-angled ; leaves ternate with climbing petioles; leafets glabrous, heart-ovate acuminate, subentire : seeds caudate, with hairs not plumose. A new species, which $I$ found two miles west of Williams College.

\section{Cheore, 49.}

dodecendra (false mustaid. P. C. p. Ju. O.) glabrous : fiowers axiliary, solitary : leares ovate, ternate generally lodecandrous.

pentaphylla (P.W-1.Ju. unarmed. Flowers gynandrous. The corols of this genus being cruciform, it is by some placed in the 15 th class. 


\section{Cuetrirs, 56.}

atnifolia (spiked alder, sweet pepper bush. Y. II. C. P. W. Ju. h.) leaves nedge-oborate, acute, coarse-serrate above, glabrous both sides: flowers in spike-form racemes.

\section{Cumacium, 108.}

Iendroides (tree moss) haring a projecting collar bclow the outer teeth.

\section{Crrigopontui, 70.}

vulgare (field thymc. 0. P-w. Ju. 2\%.) flowers in heal-for'm whorls: bracts setaceous, hispicl: leaves above pilose, remotely toothed: sten simple.

\section{Caricus, 83.}

lanceolatus (common thistle. O. p.J. 今.) leares decurrent, hispid, pinnatifid; divisions 2-lobed divaricate, spinose : calyx orate with spiderweb-like pubescence; scales lanceolate, spinose, spreading.

riscolor (P. W. p. Ju. §.) leares sessile, pimatifid, rough-haired, downy beneath ; divisions 2lobed, diraricate, spinose : calyx globose witls spiderweb-like pubescence; scales orate closepressed, with sureading spines at the tips.

sullissimus (tall thistle. C. P. W. W-1. Au. 24.) leares sessile, lance-oblong, scabrous, downy beneath, toothed, ciliate; radical ones pimatifid : calyx bracied, orate; scales lance ovate, spinose, close-pressed. arrensis (canadia thistle. W. H. C. A. Y. p. J. 2\%.) leares sessile pinnatifid, ciliate, spinose: stem panicled : calyx ovate, mucronate; scales broad-lanceolate, close-pressed, margin woolly. S 2 
horrilulus (C. I'. w-y. Ju. 2\%) tall : leaves sessile, pimnatifit, acutely gashed, very spinose : involucre terminal, 1-flowered, many-leaved; leafets very spinose double : calyx unarmed. muticus (C. P. p. Ju. b.) leaves all pinnatifid, woolly beneath; divisions sublanceolate, acute, a little spinose: branches at the summit many, nakedish, 1-flowered: calys globose; scales not spinose.

\section{Cochleiria，74}

officinalis (scurvy grass. E. W. J. 4.) radical leaves roundish ; cauline ones oblong, subsinuate: silicles globose.

armoracia (horse radish. E.w. J.24.) radical leares lanceolate, crenate; cauline ones gashed.

Corx, 91.

qachryma (job's tear. E. Ju. . culm semiterete above : flowers naked : fruit ovate.

\section{Colurrsorid, 27.}

canalensis (horse balm, rich-weesl. O. y. Au. 2'.) leaves heart-oral : teeth of the calyx short, subulate, about equal to the tilue.

\section{Coletea, 79.}

arborescens (bladier semma. E. y. h.) leares oval retuse, banner gibbous, abbreviated : stere woody.

\section{Comarum, 63.}

palustre (marsh fivefinger. Y. C. H. P. p. J L. भ.)

leafets in threes, fives or sevens, serrate.

\section{Commelina. 28.}

comumuis. (day-flower. Southern states. b. Jis 
21.) glabrous : leaves lance-ovate, subsessile, acute: stem creeping : involucres cordate, conduplicate.

erecta (1.. b. Ju. 4.) leaves lance-orate, scabrous : involucres cowled, turbinate : stem erect.

cirginica (long-leaved dayflower. P. b. Ju. 21.) leaves lanceolate, sub-petioled, glabrous above, sheaths sub-pubescent: stem simple, creeping.

\section{Comptonia, 92.}

asplenifolia (sweet ferm. O. g. Ap. z.) leares long-linear, alternately crenate-pimatifid. Gives a pleasant resinous odlour.

\section{Conferta, 111.}

1. Filaments simple.

fontinalis (spring greenhair, frogspittle. 0 .) filaments closely compacted, very short, equal, without visible partitions. nitida, splendidly lubricrous : joints rather long, cylindric, with double spiral lines of carpogenation. - cupilluris, round, rigid, curled, cntangled, brittle: joints cylindric, short, with pellucid partitions : tubercles sessile.

limosa, thin, short, mucous, closely compact, greenish-blue, with indistinct partitions. muralis, thin, fascicled, rather rigid, with obsg. lete partitions and very short joints.

\section{Filuments branched.}

rulbra, branchlets bristle-form, forked at inp : joints pellucid in the middle, a little contrarted at the partitions: capsules globular, laterali 
litoralis, much branched, thin, closely entangled, with pointed segments : joints cylindric, short, with dark partitions.

fluviatilis (river greenhair. 0.) divisions rather rigid, mostly alternate, tapering to both ends : joints long, dilated 2-ways, partitions warty, swelled.

amphibia, slightly jointed, entangled : branches sprearl remote : branchlets uniting into needlelike points when dry : partitions a little contracted : capsules nearly oval.

crispata, forked, capillary, closely inflected : joints oblong, with a spiral line, alternately compressed when dry : partitions very thin. fracta, much branched, entangled divaricate : older joints oblong, younger ones cylindric : capsule roundish.

glomerata, branches alternate; branchlets oneway, fascicled pencil-form : joints cylindric, rather long : partitions pellucid. gelutinosa, much branched, moniliform, slippery; branchlets thin, pencil-form, somewhat whorled : joints short: partitions obscure : capsules roundish, among the branchlets.

eliaphana, much branched, forked at the ends: joints swollen at each end, diaphanous in the middle ; partitions obsolete : capsules globular, lateral.

Conrum, 46.

maculatnm (poison hemlock. W. Y. H. C. P. w. Ju. 4.) stem very branching, spotted: leaves very compound: seeds striate.

Conostruis, 50.

americana (wced-grass. C. y. Ju. 4.) colol woolly within : scape corymb-panicled : leares grass ensiform, glaucous : filaments equal. 
Cosvaluaria, 51.

1. Corals bellform.

majalis (lily of the valley. E. W. Ju. น-) scape natked, smooth : leaves ovate.

\section{Corols funnel-form.}

angustifolia (o-flowered solomon seal. P. y-w. M. 4.) stcin tercte: leaves alternate, sessile, lanceor al, sharp, sub-trinerred, glabrous : peduncles axillary, Iong, aboit ¿-flowered.

conaliculata (clasping solomon seal. P. W. w. Ju. 24.) stem chamelled : leaves alternate, clasping, oblong, margin pubescent : peduncles axillary, about a-flowered. C. polygonatum. pubescens (C. New-England. W. M. 2.) stem teretish, decply furrowed : leaves alternate, clasping, orate, pubescent beneath : peduncles axillary about 2 -fiowered.

multiflora (giant solomon seal. O. w. Ju. ४ .) stem terete: leaves alternate, clasping oblong-oval : peduncles axillary, some of them many-ilower. ed.

umbellulata (wild lily of the valley. W. P. y-W.J. 24.) leaves radical, oblong-oval, margin and hed ciliate : scape pubescent : umbel terminal; pedicels bracted.

Iatifolia (P. J. 2\%.) stem angled: leares sessile, ovate, acuminate : pedunicles one or many-fowered. Very tall.

\section{Corols rwheel-form.}

racemosa (spiked solomon seal. (). I-w. M. 24.) stem with alternate leares: leaves sessile, oblong-oral, acuminate, nerved, pubescent : flowers in a terminal raceme-panicle. 


\section{CONVALLARIA, CONVOLVTLUS.}

stellata (W. C. P. W. M. \%. stem with alternate, clasping, lanceolatr leaves : raceme simple, terminal. 8 to 12 inches high.

giluta (Can. w. J. 4.) stem archerl : leares sessile, orate ciliat : panicle terminal, crowded. Flower's very smail.

irifolia (P.C. W. J. stem with three alternate pubescent, lance-oblong leaves : raceme terminal, lax.

Bifolia (dwarf solomon seal. O. W.Ju. 24.) stem with two heart-oblong, sub-sessile. glabrous leaves: raceme simple, terminal : flowers tetrandrons.

Remark. The above genus has been divided, and the new genera, Smilacina and Polygonatum taken from it. Vid. I'ursh, page 252 and on.It is true that artificial characters have been assumed which are constant and distinct. Any nat tural genus may be livided in the same way. But I never knew artificial characters applied in making such ummatural and unnecessary havoc in a genus containing such a natural asisemblage of plants. Some of the species most nearly related are separated, and those least related are kept together; as the umbellulata and raccmosa.

\section{Corvorrutus, 38.}

arensis (bind-weed. P. New-Engiand. w. Ju. 21.) twining glabrous : icares sagittate, both lobes and apex acute : peduncles about 1-flowered : bracts minute, remote from the flower. sepium (field bind-weet. 0. W. \& 1.J. 21.) twining: : leaves sagittate, with the apex acute and the lobes trincate entire (some obtuse) : bracts acute, longer than the calyx and shorter than the middle of the corol : peduncle exceeding the angle of the petal.

peindurutus (meclioacan. C. P. w. \& r.Ju. 2 .) twining, pubescent : leares broad-cordate, entu'c or lobed: guitar-form; peduncles long: 


\section{CONVULVUICS, CONYZA. 215}

flower's fascicled : calyx glabrous, awnless : corol subulate bellform.

batatas (sweet potatoc, carolina potatoc. Southorn states. W-r. Ju. U.) (repping, tuberous : leaves cordate, hastate, ingular-lobed, 5-nerved, smoothish : peduncles long; flowers fiscicled : corol subcanpanulate.

jalapa (jalap. Southern states. W. J.24.) pubescent:

leaves condate, cutire andi lohed. rugose-plaited, downy beneath : peduncios 1 to 3-flowered: flowers sub-campanulate : ront very thick. stuns (dwarf morning giory. C. Y. W.J. 4.) erect downy : leaves lance-oblomg, acuminate, cordate, hind-lobes obtuse : peduncle 1-flowered, long : bracts ovate, acute : stem floriferous below.

repens (C. r. \& w. 4.) leaves sagittate, obtuse behind: stem crecping geniculate : peduncle 1flowered.

sagittifo!ius (arrow bintwced. (‥ r. J. 21.) (limbing. glabrous : leaves thick, with romblishoftuse sinnate lobes; the odd one larger, emarginate : peduncles 1-flowered; corol shurt subcampanulate.

spithameus (A P. w. J. 2.) erect, pubescent; leaves heart-oral, obtuse : peduncles 1 -llowercl shorter than the leares; bracts orate, at ute stem floriferous above. Grows plentifully in Cambringe, Washington co.

hricolor (3-coloured bindweed. E. Ju. ¿. Irares lance-orate, glabrous : stem declined : llowcrs solitary.

Convolvulus, see Ipomaca.

Covyza, 85.

3ifrons (plowman's wort. P. y. Ju. 7!.) s!ıbglutinous : leaves clasping spatulate-oblong. at ate, serrate: coryubs of the paricle glonerate. 
marilandica (camphor plant. C. r. Au. . .) pubescent : leaves sessile, broad-lanceclate acute, serrate : corymbs terminal, level-topped, partly leafless: scales of the calyx subulate-mucrow nate : flowers short.

\section{Coptrs, 66}

Erifolia (gold-thread. 0. w. M. 4.) srape 1-flow. ered : leaves terinate. Helleborus trifoliatus.

\section{Cornorsis, 88.}

inipteris (tickseed sunflower. C. P. A. y. य.) glabrous : leaves opposite, petioled, lanceolate, entire ; radical ones pinnate, cauline ones ternate : rays entire : sceds obovate, naked at the apex.

trichosperma (C. Y. Au. ô.) glabrous ; dichntomous : leares opposite, quinate-pinnate, lanceolate serrate : outer leafets of the calyx (8) spatulate, ciliate serrate: rays entire : seed wedge-form, aisout 4-toother.

dichotoma (c. y. Ju. (t.) stem glabrous, nakedish and dichotomous alove : leaves mostly altermate, undivided, entire, narrowing into the petiole : sced oborate 2 -bristled, scabrous, with a tol'n margin.

alternifulia (P. y. \& w. Au. 21.) stem winged: lea: es lanceolate, acuminate, subpetioled, sierrate: flowers corymbed; ray-liorets lanceolate.

\section{Cortakntum, 45.}

satirum (coriander. E. w. J. (.).) fruit globose calyx and style permanent. 


\section{CORYICULARIA, CORNUS. 217}

\section{Cornicularia，116.}

tristis (hopmed lichen.) blackish-lnown : branches cylindric-compressed, ascending, llat-topped, dark above : orbs black-brown, becoming convex, slightly radiate. spudicea, chesnut-brown : branches plann-compressed slightly pitted, zigzag, toothletted : or'bs spinous-radiate, becoming conrex, rustbrown.

lanata, decumbent, warty, brownish-black, much branched ; branches cylindric, intricate, short, many-forked : orbs black-brown, with a granular-radiate margin.

\section{Cornus, 35.}

canculensis (dingweed. H. W. C. A. P. N. w: M. 4.) herbaceous : leares at the top, whorled, veiny : involucres ovate, acuminate : fruit globose. About 6 inches high. Berries red.

florida (false box, dogwood tree. O. W-y. M. Һ.) leaves ovate, acuminate : involucres 4 , very large, somewhat obcordate, and appear like petals : fruit ovate. Size between shrub and tree. Berries red. Inrolucres white, very showy, but the corols are obscure.

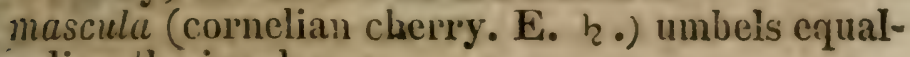
ling the involucre.

sanguinea (red osier. N. W. C. P. w. J. 々. .) branches strait : leaves ovate, both sides pubescent: and coloured alike: cymes spreading. About 10 feet hight. Berries dark-brown. Anther's yellow.

alba (white dogwood. O. J. Һ.) branches recurved; branchlets glabrous : leaves orate, acute, pubescent, hoary beneath : cymes depressed. About 10 feet high, with red branches. Berries blucish-white.

sericea (P. C. Vermont. w. J. h.) branches 
spreading; branchlets woolly : leares ovaic; acuminate, rusty-pubescent beneath : cymes depressed, woolly. About 7 feet high: Berries bright blue.

alteritifolia (C. P.w. M. h.) branches warty : leaves alternate orate, acute, hoary beneath : cymes depressed, spreading. About 18 feet high. Berries purple.

circinata (C. P. w. J. Һ.) branches warty : leaves broad-oval, acuminate, white-downy beneath : cyme much sprearl. About 8 feet high. Berries blue.

stricta (C. P. w. Ju. h.) branches strait, fastigiate:

leaves orate, acuminate, glabrous, colour near-

ly alike both sides: panicled-cyme conrex. paniculata (bush dogwood. 0 . w. J. h. .) branches erect : leaves ovate, acuminate, glabrous, hoary beneath : flowers in a thyrsed cyme. Abont 6 feet high. Berries white, globular flattened.

\section{Conydatis, 78.}

sucullaria (colic weed. O. y. \& w. M. 24.) stem. less : corol 2-spurred: scape nakerl; raceme simple, one-sided : nectaries of the length of the corol: style inclosed: root bulbous. Leaves more than decompound. All the specimens, which were found by my class at Williams College, were hexandrous. They had also a 2leaved bract so near the calyx, as to give the appearance of a 4-leaved calyx.

fingosa (climbing colic weed. P. C. Catskill. Flainfield, (Mass.) r-w.J. o . stem climbing: leaves cirrose: racemes axillary, corymbed, notling: corol monopetalous gibbous both sides of the hase. thick and fungus-like.

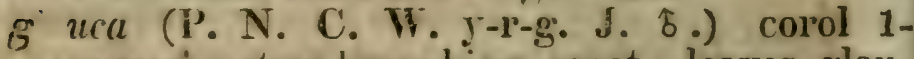
: wryed : stem brancling, elect : leaves glau-

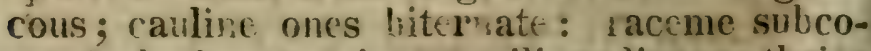
rombed : bracts minute : silicue linear, thrice 
as long as the peduncle. Grows 3 or 4 feet ligh two miles north of Williams C'ollege.

formosa (C. Can. r. M. 2 .) srape naked : rareme some what compound, nodding, many-thowered : nectaries very short, incurved: stile extended : divisions of the leaves oblong, gash-pinnatifid: prot tuberous : flowers 2-spurred. nurea (P. y. M. (.).) stem branching, diftise; leaves doubly-pinnate; leafets divided, lancelinear, acute at both ends: racemes nne way : bracts broad-lanceolate, subdenticulate : silirjuc terete, thick, twice as long as the peduncle.

\section{Corylus, 95.}

avellana (filbert. E. Ap. Һ.) stipules obłong, ob. tuse : calyx of the fruit campanulate, spreading at the apex, torn-toothed : leaves round-cordate, acuminate. Var. maximu, has a gashtoothed calyx : nut depressed-ovate.

americuna (hazel nut $0 . \mathrm{Ap}$. $\mathrm{T}_{2}$.) leares broadcordate : calyx of the fruit hispid with glandular hearls at the ends of the hairs, campanulate, longer than the roundish nut, limb spreading, tooth-serrate.

'cstruta (beaked hazel. 0.Ap. 々.) leaves oblongovate, acuminate : stipules lance-linear : caly $\mathrm{x}$ of the fruit bell-tubular, 2-parter, divisions gash-toothed; elongated beyond the nut into a beak.

\section{Crataegus, 62.}

coccinea (thorn bush. O.w. M. h.) thorny : leares heart-ovate, gash-angied, glabrous, acute-serrate : petioles and calyx pubescent, slandular: petals orbicular : styles 5. Var. riridis, has lance-ovate leaves, subtrilobate : stem unarmcd. Vil. Persoon, lart II. page 36. The berries are large red and pleasantis tasted. 


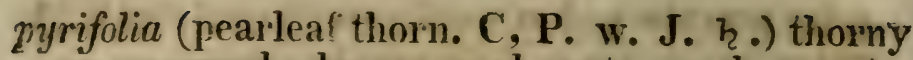
or unarmed leaves oval-ovate, gash-serrate, somewhat plaited and rather rough-haired : calyx a little villose ; leaiets lance-linear, serrate : flowers with 5 styles.

populifolia (C. P. w. J. r. .) thorny : leaves heartovate, truncate at the base, gash-angled, glabrous : petioles and calyx without glands : styles 5. Berries small, red.

elliptica (P. M. 々.) thorny : leaves oval, unequally serrate, glabrous : petioles and calyx glandular : divisions of the calyx obtuse : berry globose 5-seeded.

glandulosa (P. Can. w. M. h.) thorny : leaves wedge-obovate, angled, glabious, shining: petioles, stipules and calyx glandular : berries oval, 5-seeded.

flara (yellow-berried thorn. Vermont. M. h.) tholny ; leaves wedge-obovate, sublobate, crenate-serrate : petioles short: stipules cordate glandular : calyx glandular : fowers subsolitary : berry 4-seeded, turbinate.

munctata (P. w. M. $\xi_{2}$.) thorny or unarmed : leaves wolge-obovate, subplicate, glabrous, 3ash-serrate, decurrent into the petiole : calyx villose, clivisions subulate entire : berry subglobose, depressed.

crus-galli (thom tree. O. w. M. h.) thorny : leaves wedge-obovate, sub-sessile, shining, leathery : corymbs compound: leafets of the calyx lanceolate, subserrate : styles 2.

oxyacuntha (quickset. E. w. M. ${ }^{2}$.) leaves obtuse somewhat 3-cleft, scriate, glabrous : peduncles and calyx somewhat glabrous : segments of the calyx lanceolate, acute; styles 2 .

\section{Crocus, 27.}

afficinalis (saffron. E. y. 2\%.) leaves linear with revolute margins : stigma exsert, with long li- 


\section{CROCUS, CUCUMIS.}

near segments. Var. salixus, liaving riolet corols.

\section{Crotolaria, 78.}

sagillalis (rattle-box. Y. N. C. I. y. Ju. (.) hirsute, erect. branching : leares simple lance-ohlong: stipules lanceolate, acuminate decurent : racemes opposite to the leaves, about S-llowered : conol less than the calys. grariflora (P. C.y. J. O.) hirsute, erect, branching : leaves simple, lance-linear : stipules above decurrent with two short teeth : racemes; opposite to the leaves: colul smaller than the calyx.

\section{Cucubatus, 59.}

behen (bladder campion. C. P. II. w. Ju. 1 t. glabrous, glaucous, decum!cint : leaves oblongoval, acute, nerveless : calyx inflated-mem!ra. naceous, veiny.

stellatus (A. Y. C. P. w. Ju. 21.) pubescent, erect: leaves whorled, in fours, lance-oval, very longacuminate. About 8 or 3 f'cet high.

\section{Cucumis, 97.}

iolocynthis (bitter apple. E. O.) leaves manycleft : pomaceous berry globose, giabro!s. Fruit very bitter. anguria (prickly cucumbex. E.) leaves palmatesinuate : fruit globose, echinate. anguinis (snake rucumber. Is. 5.) leaves lobed: pomacerous berry cylindric, very long. smont?!y contorted plaited.

anelo (musk-meinn. E. y. Ju. O.) angles of the leares rounded: pome oblong, torulose. Sw at scented.

sativus (cucumber. E. y. Ju. Q.) angles of the 
leares strait: pomaceous berry oblong, scalb. rous. Brought from Asia.

africanus (wild cucumber. W. $\mathrm{y}-\mathrm{w} . \mathrm{Au}$.) fruit oval, echinate : leares palmate, sinuate: stem angled. This plant grows plentifully on the banks of the Hoosack, near Willians College. It is evidently indigenous. The stem is 5-cornered, climbing by dichotomous and trichotomous tendrils : the pistillate flowers generally solitary : the staminate in panicled racemes.

\section{Cucunbita, 97.}

orifera (ezg-squash. E. (.).) leares cordate, angled-5-lobed, denticulate, pubescent : pomaceous berry with fillet-like stripes lengthwise.

serrucosa (club squash. E. y. J. O.) leares cordate, deeply 5-lobed; middle lobe narrowed at the base, denticulate: pomaceous berry clavate, a little warty.

melopepo (fiat squash. E. .. J. (.).) leaves cordate, obtuse, sub-5-lobed, denticulate : pomaceons berry depress-based, swelled at the margin. pepo (pumpkin. E.y.Ju. s.) leaves cordate, obtuse, sub-5-lobed, denticulate : pomaceous beryy roundish or oblong, smonth. Var. poliro has the fruit more or less flattened. From Asia.

citrullus (water melon. E. y. Au. s.) leares 5lobed; the lobes sinuate-pinnatifid, obtuse : pomaceous berry oral smooth. Fruit watery, often striped. From Africa, and the south of Asia.

lagenaria (gourd, calabash. E. w. Au. (:) leares cordate, round-obtuse, pubescent, denticulate; with 2 -glands at the base on the under side : pomaceous berry clarate somewhat woody. 
Cunui, 69.

mariana (dittany.C.P. P.-b. I. Z.) leares orate, serrate, sessile : corymbs terminal, dichotomous.

\section{Cunila, sec Hedeoma.}

Cuphea, 60.

viecosissima (warweed. P. p. J. O.) viscous: leaves opposite, petiolerl, ovate-oblong : flower's with 12 stamens, lateral, solitary, peduncles very short.

\section{Cupressus, 96.}

disticha (cypress tree. C. Ap. 々.) leaves 2-ranked flat, deciduous: staminate flowers in leafless panicles: strobiles sub-globose. A large tree. thyoides (white-cedar. C. H. M. 々.) branchlets compressed : leaves imbricate four ways, ovate, tubercled at the base: strobile globular.

\section{Cuscuta, 43.}

americana (dodder. 0. w. Au. (.)) flowers peduncled, umbelled, 5-cleft. A bright yellow leafless vine, twining around other weeds in damp places. In some parts of New-Lngland it is called gold-thread vine.

\section{Cinthus, 118.}

striatus (tumnel fungus.) dark brown, villous, striate within.

crucibulum, inflated, golden, glahrous. laevis, yellow, inflated, smooth within. lentiferus, (A.) pale, roughish, mouse-colour without.

Remark. This genus is wrongly called the bridsnest under the generic name. 


\section{Crmeidrum, 89.}

pulchellum (grass pink. O. r. Ju. 2 .) leaves rad. ical, ensiform, nerved : scape few-flowered: lip erect, slender at the base ; lamina spread; disk concave bearded.

hyemule (alam an'? eve P. C. g-p. M. 4.) leaves radical, in pairs, many-nerved : scape simple, sheathed, erect : petals erect ; the 3 exterior ones lanceolate, the inner ones oblong: lip obovate, wavy-crenate at the margin. A cement may be marle of the biuised roots.

corallorhizum (coral ront. W. w-y. M. 2!.) scape sheathed, leatless : flowers pedicelled : petals lanceolate; the two lower ones lanceolate-linear, deflected : lip oblong acute. A yellowishwhite plant with a white coral-like root. aloutorhizum (toothed coral. W. C.P. p. Ju. ?) scape sheathed, leafless : flower's pedicelled; petals lanceolate, equal : lip ovate, obtuse. Resembling the last in habit. These two species are found in great plenty near Williams College. Their distinctive chararters are clear and decided; notwithstanding the random assertions of a reviewer, who scems fond of judging vithout exannination.

\section{Crantehum, 90.}

obliqunn (choak-dog. P. p. Ju. భ.) stem twining, hirsute : leaves cordate, acute, villose : flowcrs umbeller! : petals oblique, revolute. Pursh says, he doubts its being an Anerican species.

\section{Cryara, 82.}

cardunculus (cardoon. E. 2!.) leaves spinose, all pinnatilit: scales of the calyx orate. sco'ymis (garlen artichoke. E. భ.) leaves sub. spinose, pinnate : scales of the calyx ovate. 


\section{Crnoglossum, 37 .}

officinale (hound tonguc. P. W. A. H. N. C. p. J. 8.) very solt-pubescent : Icaves broad-lanceolate, sessile : paniclest-racemes. amplexicanle 'W. C. P. W. \&. b. J. 2.) rery hirsute : leaves oval-oblong; ; uper ones clasping: corymbs terminal, leafless, long-peduncled.

\section{Crperus, 29.}

\section{Spikelets aggregate.}

kyllingoeoides (C. J. 2\%.) little heads globose: spikelets oblong, convex, about 8-flowered : involucre 4-leaved : leares keeled, lax. poaeformis (C. Y. W. g-p. Au. H.) spikelets oblong, flat, fascicle-corymbed ; fascicles sessile and peduncled : involucre s-leaved, very long. uncinatus (Vermont. J. $\delta$.) little heads sub-globose, glomerate : spikelets linear, about 8-flowered; valres lanceolate, recurve-acuminate : involucre about 2-leaved, very long.

2. Umbels rvith elongated rays; spilielets terminal, umbelled.

compressus (P. Ju. 21.) spikelets digitate, ahout in fours, lance-oblong, valves mucronate, broad, membranaceous.

filiculmis (C. ४.) spikelets linear, head-globular, much spread : umbels about 1-rayed : involucres and culm setaceous, involucer's s-leaved. tenuis (C.) umbel terminal, simple : involucre 3 or 4-leaved, longer than the spikelets, rough at the apex : peduncles unequal : spikelets lanceolate, alternate, yellow, acute, 10 to 17 flowered, bracted at the base. brizeus (C.Ju. 21.) spikelets oblong-ovate, obtuse : umbels crowded, leatless : leaves narrow. inflexus (P. Ju.) umbels S-leaved, simple : spikes 
S, ovate, one sessile, the others peduncled, conglomerate ; spikelets oblong, green, compressed, 7 -flowered : plant sweet-scented.

riandrus (C. Au.) culm obtusely s-cornered; umbels sub-radiate : spikes crowded, capitate: each spike lance-oblong, many flowered ( 14 to 16) glumes acutish, carinate: stamens 2 : styles bifid : secd ovate compressed. Torrey. A now species, discovered by J. Le Conte, Esq. on the borclers of salt marshes..

3. Umbels with elongated rays; spikelets alter. nate.

faricomus (P. ร-y. Ju. 24.) spikeiets lance-linear : valves oblong obtuse ; fruit-bearing, spreading : involuc re very long.

phyymatodes (P. Au. 24.) unbels simple or decompound, rayed: involucre 3 to 9-leared, unequal ; three of the leafets very long, scabrous at the margin : peduncles compressed : spikelets 2 ranked linear; lower ones compound, upper one simple, 15-flowered : bracts linear.

crythrorhizus (P. Au. (.).) umbel decompound, 3leaved; umbellets mostly wanting : involucre 3 to 6 -leaved, rery long, scabrous : spikelets alternate, linear, approximate, long, horizontal, 12-flowered, terete-comiressed.

parviflorus (P. Au.) unbel compound : inrolucre s-leared, longer than the pecluncles: peduncles glabrous, many ( 6 to 10 ) 3 -sided : spikelets 3 , compressed, alternate, ovate, 8 . flowered.

flavescens (C. P. Au. o .) spikelets lance-linear, crowded: involucre s-leaved, longer than the 3-cleft umbel.

strigosus (C: W. Y. P. §-y. Au. 4.) spilies oblong, lax ; spikelets subulate spreading, remotish : involucres neal'y wanting: rays of the umbellets alternate, 
virens (P. Ju. 24.) spikes 'rorymbed ; spikelets oral : involucre very long.

bulferusus (nut-grass. P.Ju. Z., spikelets lanrelinear, convexish : involucre 3-leared, longer than the 5-rayed umbel.

4. Umbels reith short rays; spilics digitale.

acstuarius (C.) stem 3-rornered : umbel lax, sulradiate, rays short : spikes 3 to 5-fingered, lance-linear: 7 to 10 -flowered, compressed: glumes lance-acute: stamens $\approx$ : style bifil: seed oblong olbtus: compressed. A new sper.. cies discovered and described by $13 \%$. John Torrey. Grows in salt marshes.

\section{Cypripentum, 89.}

candicum (white ladies' slipper. P. w. M. 21.) stem leaty; Icares lance-oblong: lobe of the style lanceolate, obtusish : lip compresscd, shorter than the lanceolate petals. parviflorum (C. P. y-g. M. 2.) stem leafy : lobe of the triangular style acute; outer petals oblong-ovate, acuminate; inner ones linear, contorted: lip shorter than petals, compressed. pubescens (yellow ladies' slipper. W. P. C. y. M. 21.) stem leafy : lip of the style triangular-ollong, obtuse : outer petals oblong-ovate, acuminate ; inner ones very long, linear, contorted : lip compressed, shorter than the petals. spectabile (gay ladies slipper. W. A. C. P. w. \& p. J. 2.) stem leafy : lip of the style oval-corate, obtuse : outer petals broad-ovate obtuse :

lip longer than the petals.

humile (low ladies' slipper. O. w. \& p. M. 4.) scape leafless 1-flowered: radical leaves in pairs, oblong, obtuse : lip of the style poundrhomboid, acuminate, deslexed ; lip longer than the lanceolate petals, split ioclore. 
D.

\section{Dactruis.}

glomerata (orchard grass. 0.J. 21.) panicle onesided, glomerate.

Dalibarda, 63.

repens (New-England. P. W. J. 2\%.) villose : having creeping shoots : leaves simple, cordate, crenate : peduncles 1 -flowered.

fragarioides (dry strawberry. W. P. y. M. 4.)

leaves ternate: leafets wedge-form, gash-serrate, ciliate : peduncles many-flowered : tube of the calyx obconic.

DAPHNE, 54.

mezereum (mezereon. F. M. 々.) flowers sessile, cauline, in threes : leaves lanceolate.

odora (sweet mezereon. E. w. Ap. h.) having many flowers in little terminal heads; leaves scattered, lance-oblong, glabrous.

Datisca, 100.

hirta (false hemp. P. y. భ.) stem hirsute: leaves pinnate ; leafets rumning together at the base. Flowers small, panicled.

Datura, 38.

stramonium (thol'n apple. Y. A. H. C. P. w-b. Au. O) pericarps spinose, erect, ovate : leaves ovate, glabrous. Odour very disagreeable. tatula (C. P. w. Ju. Q.) pericarps spinose, erect, ovate : leaves cordate, glabrous, toothed.

Dacces, 45.

carota (carrot. E. w. Ju. of .) seeds hispid : petioles nerved underside : divisions of the leatets narrow-linear, acute. 


\section{Decumaria, 60.}

sarmentosa (derumary. Sunthern states. w. Ju. ${ }_{2}$.) leaves ovate, acute ; rounted ai the base, serrate at the apex. A climbing shrub, grow. ing în swamps.

\section{Detpurnidm, 65.}

consnitium (larkspur. E. b. Ju. ...) nectaries 1leaved: stem subdivided.

ajue is (rocket larkspur. E. b. Au. (.) nectary 1-leaved : stem simple.

exaltatum (l’. b. Ju. 4.) nectary ¿-leared; lip oblong S-cleft; divisions lanceolate, equal: leaves s-parted, divisions s-cleft. azureum (southern states. b. M. 21.) stcm stilliy erect : latves linear, many-cleft: Hirwers spiked : petals reny downy : spur arched. sle?plisagria (3. b. o.) nectaiy -teavel, short(ii than the petals: leaves palmate, with obtuse lobes.

\section{Dentaria, 74 .}

(iiplu?lu (tonth-root, trickle. 0. 5. \& p. M. 4.) stem with 2 leaves ma: each other' which are ternite, ovate-n!blong. unequally gash-toothed : ront tootherl. The rot is white, brittle, and has a strong taste resem ing the home-radish. laciniata (Ne:-England. C. 13. p. M. 24) leaves in threes, ternate : leafets 3-panted, linear-1)!)lung, gash-toothed : root tuberous, moniliform.

\section{Drantiues, 58.}

Garbatus (sweet william. E. r. \& w. Ju. भy.) flower's fascirled : scales of the calyx orate-sululate. equatliug the tube : leaves lancenlate. arincria (pints. Sicw-Jersey? r. 'll, g.) Howers u 
aggregate, fascicled : scales of the calyx lance. olete, villose, equalling the tube. caryophyllus (carnation. E. r. \& w. 4.) flowers solitary : scales of the calyx subrhomboid, very short : petals crenate, beardless : leaves linearsubulate, channelled. By rich culture the stamens mostly change to petals.

chinensis (china pink. E. Ju. O.) flowers solita$r y$ : scales of the calyx subulate, spreading, leafy, equalling the tube : petals crenate : leaves lanceolate.

plumnarius (single pink. E. r. \& w. 4.) flowers solitary : scales of the calyx subovate, rery short and obtuse, awnless : corol many-ileft, with the throat hairy.

Dilpensia, 39.

Iapponica (Whitehills. Big. w. Ju. 2/.) leaves spatulate, glabrous : anthers oblique, awnless. cuneifolia (Whitehills. Peck. C. W.J. 々.) leaves lance-werlgeform, pubescent below : anthers horizontal, beaked at the base.

\section{DrCksoniA, 104.}

pilosiuscula (fine-haired fern. 0.) frond doubly pinnate ; leafets lance-oblong, pimatifid; di. vision gash-toothed at the upper margin : stem subpilose.

\section{Dicrantm, 107.}

\section{A. Leaves 2-rorved, compressed.}

Eryoides (fork moss) stem simple : leaves alternate, ovate, oblong, pointed: capsule terminal, erect.

taxifolium, stem simple: leaves oblong-lanceolate, acute: capsule nearly radical, inclined: lid beaked. 
riliantoides, erect, branched : leaves ovate-lanceolate, sheathing: capsules inclining fom abont the middle : lid aw-form, erect.

\section{Leares pointing one-way, or sprealing.}

scoparium, branched, crect : leaves lance-awlform, spreasl at top) : capsule solitary, obliejuce. with an awl-form lid.

flasellare, somewhat branched, crect : leares. lance-awlform, nearly nerveless : capsule cylindric, erect, grooved : lid awl-form, incurved.

heteromallum, nearly simple : leaves cutlass-form, capillary, broarler at base : causule olyovate, gibbous, inclined : lid awl-ferm. incurred. turium, nearly simple: leaves lance-awlfurm,

1-nerved, spread, zigzag at top : capsule inclin-

ed, top-form : lid conic, slightly curved. pulvinatum, branched : leares orate-lanceolate, bearing hairs : capsule orate, immer'sed in the, leaves, inclined : lid strait-awlform.

glaucum, branched at top): leaves crowaled, crect, lanceolate, pointed nerveless : capsule orate, inclined : lid awl-form, curved.

strichum (W.) forked or branched at top : leaves lance-awlform : capsule cylindric, inclined : lid conic.

rirens, slightly branched: leaves linear-lancenlate, pointed, kecled : capsule oblong-ovate, curved, wen-like at base. polycarpon, branched : leaves linear-lanceolate, twisted when dry : capsule obovate, nearly strait, grooved,

latifolium, erect : leares oblong dilated, concare, ending in a short hair : capsule cylindric strait. ambiguum, erect, simple : leaves imbricate 4 ways, ovate-lanceolate, pointed : capsule wenlike, on a long receptacle, ovate, drooping : lid oblique. 


\section{DiDYMODON, 107.}

lineare (double-tooth moss) leaves linear.

\section{Diervilia, 41.}

Inmitis (bush honeysurkle. O. y. Ju. 々.) peditncles axillary and terminal, dichotomous, 3 1iowered: leares ovate, sestate, acuminate. 1). canadensis. Fariable in size.

\section{DrgitaIIs. 72.}

purpurea (forglove. E. p. Ju. $\delta$.) leafets of the calyx ovate, acute : colol obtuse : upper lip entire : leares lance-orate, rugose.

\section{Digitaria, 30 .}

sangainalis (finger-grass. 0. \&-p. Ju. ().) spikes many : flower's imbricate, in pairs: slicaths and leares papillose-pilose : culm creeping. paspciolcs (C. P. Au. O).) spikes in pairs, subrillose at the base : rachis broadish, glabrous : flowers solitary, imbricate two ways, glabrous: leares spreading; sheaths glabrous, villous at the neck : culn creeping.

yilosa (C. P. Au. o) spilies from 2 to 5 , erect, fliform : flowers remote, liisute, in pairs, with one of them scarcely pedicel'ed : leares short ; sheaths flilose : culm erect, glabrous, naked above.

raclylon (P. Au. 24.) spikes digitate, spreading, villose at the bases within : flowers solitary : shoots creeping. A new genus, Cynodon, is made of this species by Richard,

\section{DrLatris, 28.}

tinctoria (red-ront. C. y. Ju. \&.) petals lanceolate, downy outsile : panicle corymbed, downy: leares long, naked, linea. 


\section{\&34 DODECATHEON, DRACAENA:}

\section{Dodecatheon, 38.}

meadia (false-cowslip. P. p. M. 2\%.) leaves oh. long-oval, repand-toothed : umbels manyflowered, lax : bracts oval. integrifolium (P. b. J. 2l.) leares spatulate, entire : umbels few-flowered strait: bracts linear.

Doxichos, 79.

gurpureus (cowhage, or cowitch. E. p. ().) twining, stem glabrous : petioles pubescent: corol with spreading wings.

Doronicum, 86.

naldicaule (leopard's bane. P. y. J. 24.) stem nearly leafless : in some the peduncles are divided at top : leares decussate opposite oblong-orate.

\section{Draba, 73.}

verna (whitlow grass. C. P. w. Ap. s.) scape naked, leaves oblong acute sub-serrate, roughhaired : petals bifid : stigma sessile.

caroliniana (C. p. w. Ap. ().) scape naked : leaves oval acute, very hirsute: silicles long-linear, glabrous, approximate. arabisans (P. New-England. M. 古.) stem leafy, somewhat branched: radical leaves werlgelanceolate ; cauline ones lanceolate ; all acute, divaricate-toothed: silicles acuminate with the permanent style.

\section{Dracaena, 50.}

borealis (wild lily of the valley, or dragoness plant. I P. A. C. W. g. y. J. 24.) subcaulescent : leaves oyal-obovate, margin ciliate ; scape pubescent : 
umbel corymbed, sometimes proliferous : pedicels naked, nodding. Mr. Rafinesque says this is the same as the Convallaria umbellulata. I lave no doubt he is correct. And I now regret, that $\mathbf{I}$ admitted this genus.

\section{Dracocerhaxum, 70.}

sirginianum (dragon-heat. P. p. An. 24.) spikes clongated, with the flowers crowded : bracts subulate : teeth of the calyx nearly equal, short ; leares linear-lanceolate, serrate. canariense (balm of gilead herb. E.) flower's spiked : leaves ternate oblong. denticulatum (P. p. Ju. 2\%.) spikes elongated, with remote flowers: bracts subulate : teeth of the calyx nearly equal : leaves obovate-lance. olate, toothed above.

\section{Dracontium, see Pothos.}

\section{Drosera, 48.}

sotundifolia (sundew. O. y-w. Au. 24.) sca e simple ; leaves nearly orbicular, narrowed at the base; petioles long downy. longifolia (Y. P. C. $\mathbf{y}$-w. Ju. 24.) scape simple; leaves spatulate-obovate; petioles long, naked.

filifolia (C. p. J. 4.) scape somewhat branched; leaves filiform, very long:

\section{DuLrchios, 29.}

spathaceum (galingale. 0 . g-y. Ju. 4.) culm Scomered, leafy : spikelets sprea ding, about 6 dlowered. 


\section{E. \\ ECHINops, 88.}

sphacrocephalus (globe thistle. E.) leaves pinnati, fid: stein branching.

\section{Еснішм, 57.}

vul gare (riper"s bugloss, blue thistle. C. P. b. Ju. o.) stem tuberculate-hispid : cauline leaves lanceolate hispid ; flowers spiked, lateral.

\section{Elephantopus, 88.}

earolinianus (elephant-foot. Southern states. P. Au. 24.) leaves radical and cauline oblong, narrowed at the base, pilose on both sides: stem simple, erect, pilose.

\section{Elieusine, 31.}

budica (dog-tail grass, wire grass. C. P. Ju. ㅇ․) glabrous : sheatlis compressed, pilose at the neck: spikes digitate, long-linear strait ; spikelets about 6-flowered : fiowers lanceolate,

\section{Eurmes, 31.}

villosus (wild rye, limegrass. P. C. Ju. 24.) spikes erect; spikclets s-floweres, awned, rillose, ternate : calyx awner, exceeding the spikelets. canadensis (P. C. Ju. 2.) spike nodding, spreading; spikelets 6-flowered, awned; lower ones ternate, uprer ones binate.

reirginicus (W. P. C. J. 22.) spike crest ; spikelets 3 -flowered, awned, glalrous, in pairs : calyx lanceolate, nerved, equalling the spikelets. striatus (W.P. Ju. 2 .) spilise erect; spikelets 2- 
flowered, awned, hispid, in pairs : calyx linear, nervesl. awned, rather exceeding the spikelets : leares and sheaths glahrous.

hystrix (I'. C. Ju. 2.' spike temuinal erect; ra. chis scabrous : spikelets 6 to 9-lloweresl, diverging : involucre 1 or 2 -leared, lateral, or none.

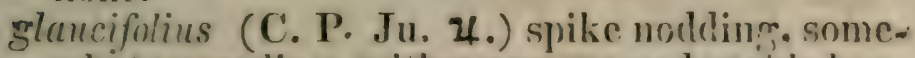
what spreading, with a compressed rachis hav. ing a pubescent margin; spikelets ternate be. low and binate above, 2 and 3 -flowered : involucre 4 or 5 -leaved. philadelphicus (P. C. Ju, 2!.) spikes nodding, spreading; spikelets 6-flowered, awned.

\section{EMretrum, 98.}

niginum (black crowberry. Whitehills. Big. Ju. 々.) procumbent : branchlets glabrous : leaves oblong, glabrous, with a revolute margin.

\section{Exdocarpor, 113.}

hedvigii, foliaceons, thickish, with distinct small rounded-angular Iobes, dull ghlancous-green, white on the margin and underneath, naked both sides.

squamulosus, foliaccous, thickish, somewhat imbricate, grey greenish-brown, beneath grey woolly : lobes clustered, roundish, deformed, repand-lobed, with the margin of the same colour.

lachenus, foliaccous, imbricate, lewwish-mrecu, beneath black spongy ; lubes small, a litule incumbent, munded, slightly crenate. flexuous. miniatus (hidden lichen.) loliaceous, peltate, pale. with minute excavations, beneath smooth ful. vous becoming wrinkled, with a spread-lobed circunference. 


\section{EPIGaEA, 57.}

repens (trailing arbutus. W. A: P. N. H. r. \& w.

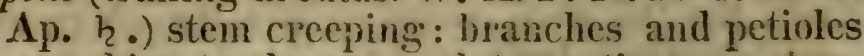
very hirsute : leaves curtate, entire: corol cylindric.

\section{Epilomium, 54.}

spicatum (willow-herb. W. A. P. N. H. C. p. Ju.

4.) leaves scattered, lance-linear, veiny, glabrous : flowers meriual : stamens declined. This species grows from 4 to 6 feet high.

lineare (Y. W. H. C. w. Ci r. Ju. U.) stem terete, pebescent, wandlike, wanched above : cauline leares opposic, branch leaves alternate, linear, very entire : fower's few, terminal, long-peduncled. Flowers small.

coloratum (P. C. Lake-George. r. Ju. 24.) stem terete, pabescent, leaves lanceolate, serrulate, petioled, opposite; upper ones alternate, glabrous, red-veined.

ietragonum (W. Y. P. r. Ju. 24.) stem with pro. minent subquadrangulate lines: leaves opposite ; upper ones alteruate, lanceolate, serrulate. Flowers small.

palustre (W.P.Ju. ४.) stem terete : leares ses. sile, lanceolate, sub-denticulate : stigma undivided.

alpinum (Whitehills. w-r. Au. 21.) stem simple, subterete, 1 or 2-flowered : leaves opposite, oval, entire : flowers sessile. Very minute.

EpIfactis, 89.

convallaroides (lily orchis. C. $\mathrm{g}-\mathrm{p}$. M. 2.) stem with 2 round-cordate, acute, opposite leaves: spike few-flowered: lip oblong, dilated at the apex, obtusely 2-lobed : germ sub-globose : root fibrous, 
Equisetrim, 106.

arrense (horsetail. O. Ap. 24.) barren stems with simple bramches; the branches scahrous, 4 -sided : frutification simple: sheaths cylindric gash-toothesl, teeth acote.

sylraticum: (O. Ap. 24.) barren and fertile stems doubly branched : branches scalirons, deflected, 4-sided ; branchlets somewhat 3-sided. alliginosum (C. P'. W. M. 24.) stem subramese: branches generally in lours, 4-sided, glabrous: spike terminal, cylindric. scirpoides (Can. Vermont. Ju. 21.) stem simple, ascending, glabrous, itliform, bearing a spike at the top: sheaths 3-toothed; teeth withering, with callucous awns at the apex. hyemale, (scoming rush. O. Ju. 21.) stems erect, very scabrous, bearing spikes at the apex : sheaths 2-coloured, withering at the base and apex: tecth with caducous awns.

EnICA, 54.

pubscens (lowny heath. E. r. M.) corol linear, pubescent, with the limb erect: capsule glab. rous : leaves fringerl. tetralix (E. 々.) anthers awned : corol ovate; style inclosed : leares in forms, ciliate : flow. ers in heads.

\section{Erigeron, 86.}

canadense (flea? ane, pride-weed. O. w. Ju. P.) stem hispid, panicled : leaves lance-linear, ciliate : calyx cylinlric : rays crowded, short. Flower's small. Plant strong-scented. Powdepe! leares useful in stopuning blood.

byssopifolium (l'. y. Ju. ô.) stem panicled with sterile branches; a few extended into maked periuncles: leaves linear, glabrous, ciliate: a'ays much longer than the cylindeic calys. 
strigosum (P. W. w. Ju. ₹.) strigose-pilnse: leaves lanceolate, tapering to both ends ; in the middle are a few croarse teeth or it is entire: flower's corymb-panicled.

heterophy"uin (P. C. w. J. ô.) radiral leares round-orste, deeply-toothed, petioled ; cauline ones lanc colate, acuite, scrrate in the mididle : corymb terminal.

philadelphicum (0. b-p. Au. 2\%) pubescent : leaves werige-oblong, rarely gash-toothed; cauline ones half-clasping: stem weak, simple, corymbed above: pethincles elongated, 1-flowered: rars capillary, twice as lung as the hemispheric calyx.

parpuireum (P. C. p. Ju. 2\%.) pubescent : lcares oulong, tonthed, clasping; upper ones entire : peduncles thickened, corymbed ; lower ones elongated : scales of the calyx hairy on the keel: 1ays twice as long as the calyx. bellidifolium O. b. \& w. M. 24.) hirsute, loary : radical leares oborate, subscreate; cauline ones

few, distant, lanceolate, entire: stem about 3 flowered : rays long.

nervosum (P. w.Ju. 24.) white pribescent: leares lance-linear, very entire, silky, nerved : flowers panicled.

\section{ERINUs, 72.}

Ifricamis (P. b. Au.) leares lanceolate, toothed: stem weak, zigzag-erect.

\section{Ertocaulon, 98.}

pellucidum (pipewort. Y. C. N. P. H. g. Au. 21.) scape very slender, about 7 -striped : leares linear-subulate, channelled, glabrous, peilucid, 5-ncived, transversely striate : heat smail globose : scaics of the involucre oral-obtuse. Grows in water from 6 to 12 inches high. 
decangulare (tall pipewort. P. C. S. Z.) scape 10)-striped : leares (msiform, grahorous: hearls large, depresseri-globrse : scales of the involucre ovate, acute: chatf of the receptacle mucronate. 'Three or four leet high.

\section{Eniophorum, 29.}

rirginicum (cotton grass. C. P. M. 4.) culm terete, leafy : leaves flat: spikes crowded, sub. sessile, shorter than the involucre. In bogmealows, as all the following species are. angustifolium (W. Y. C. M. ४ ) culm leafy, terete : leaves 3-sided, chamnelled: spikes peduncled : sceds ovate.

jolystachium (C. P. M. 24.) culm leafy, terete: leaves flat: spikes peduncled : seed orate.

\section{Enodidm, 76 .}

riconium (stork-bill geranium. E. ○.) peduncle many-flowered : leaves pinnate : leafets pinnatilid, toothed : petals oblong, obtuse : stenx ascending.

cicuturium (hemlock geranium. P.p. A. (.) peduncles many-flowered : leares pinnate; leafets sessile, pinnatilid, gashed: corol larger than the calyx: stem prostrate hirsute. moschatum (musk geranimm. E. .) peduncles many-flowered : leaves pimnate; leafets subpetioled, oblong, gash-toothed : petals efualling the calyx : stem procumbent.

\section{Eryxgiui, 44.}

oralifolium (sea-holly. P. C. b. Ju. 24.) simple: leares heart-ovate, with rery short petioles: heads all peduncled : latets of the involucre chaify and S-cloft: stem wanilike, branching above, not below. 
virginianum (P. C. g. \& b. Ju. 2 .) very tall : leares long lance-linear', serrate : branches linear, many-parted : leafets of the involucre longer than the head, chaffy, 3 to 5-cleft : heads panicled.

\section{ERYsMrum, 74.}

officinale (hedge-mustard. 0. y. J. .) siliques close-pressed to the rachis of the spike : leares runcinate.

barbarea (water radish. W. N. y. M. 4.) lower leares lyrate, with the terminal lobe roundish ; upjer leaves oborate, toothed: silique almost square.

\section{Erythrontum, 50.}

dens-canis (dog-tonth violet, adder"s tonguc. $0 . \mathrm{y}$. Ap. \& ) leaves oblong-orate, glabrous, spotted. Scape 4 to 8 inches high.

\section{Esula, 61.}

lathyrus (spurge caper. E. J. 今.) umbel 4-cleft, dichotomous: leaves opposite, cutire, lanceolate, pointing four ways.

jeplus wild caper. Ju. E.) umbel 3-cleft, dichotomous, involucels ovate: leaves entire, obovate, petioled.

mercurialina (l'. Ju. 24.) stems slender, weak, leaves opposite or in threes, subsessile, oval, entire : peduncles teminal, solitary, 1 -flowered. corollata (C. P. Jı. 4.) umbel, 5-cleft, 3-cleft, and dichotomous ; involucels and leares oblong, obtuse : appendages of the calyx oborate and resembling petals.

Remark. These species were taken from the genus Euphorbia. See Persoon. This division is very proper. Every one has obserr- 
ed the unnatural union of the spotted spurge and garden caper.

Ethulia: 84.

uniflura (floating daisy. C. p. Au. 24.) leaves setaceous-linear, whorled : stem about 1-flowered : egret 5-tooted, bellform.

\section{Euonymus, 41.}

atropurpureus 'spindle-tree. C. P.p. J. . .) lcaves petioled, lance-oblong, acuminate, scrrate : peduncles diraricate, many-flowered; flowers 4. cleft : fruit smonth. Fruit red. americanus (burning bush. P. $\mathrm{P}-\mathrm{y} . \mathrm{J} . \mathrm{h}$. ) branches 4-angled: leaves subsessile, lance-oval, acute, serrate: peduncles about S-flowered; flowers all 5-cleft: lruit warty-muricate. Fruit red. Said to grow in New-Ingland.

\section{Eupatorium, 84.}

\section{Calyxes not more than 5-flowered.}

hyssopifolium (hyssop-thoroughwort, hempweed, C. W. Au.2!.) leares opposite, somewhat whorled, linear, entire, pubescent, 3-nerved, punctate ; radical ones subdentate. About one foot high.

sessilifolium (P. C. Au. \% .) leaves sessile, clasping, distinct, lance-ovate, rounderl at the base, scrrate, very glabrous : stem somewhat glabrous. About two leet high, grows in rocky hills.

truncutum (P. Ju. Һ̨.) leaves sessile, clasping, distinct, lanceolate. truncate at the base, serrate, somewhat glabrous : siem pubescent. Resembles the last. album (1’. Au. 2r.) leares subsessile, latige-oblong, 
roughish, serrate, inner'scales of the calyx long; lanceolate, scarious, coloured. About 18 inches high.

lanceolatum (P. Aur. 2\%.) leartes sessile, distinct, lance-oblong, scabrous, deeply serrate : scales of the calyx one-coloured. Resembles the last. trifoliatum (C. P. Au. 4.) leaves petioled, in threes or fours, orate, tapering to both ends, serrate roughish. Tall, not branched.

teucrifolium (New-England. P. C. Au. 24.) leaves sessile, distinct, ovate, scabrous; upper ones with coarse teeth at the base and with the summit entire. About 2 teet high. melissoiles (P.Au. 24.) leaves petioled, ovate, obtusish, obtuscly-scriate, veiny, somewhat glabrous. Resembles the last.

sotundifolium (P.Au. Ұ.) leares sessile, distinct, round-cordate, obtusely-serrate, reiny : scales

of the calyx acuminate. About 12 to 18 inches high.

pubescens (C. P. Au. 4.) leares sessile, distinct, ovate, scabrous, veiny ; lower ones doubly-serrate, upper ones subserrate, stem panicled, pubescent; branches fastigiate. Not above two feet high.

allissimum (P. Au. 2!.) lcares snbsessile, lanceolate, 3-nerved, tapering to both ends, pubes-

cent; lower ones serrate in the middle. From 5 to 7 feet highl.

amoenum (C. 1. S. 4.) leaves with short petioles, opposite and in threes, lance-oblong, acute at both ends, serrate, sub-glabrous, sub-rugose, net-veined beneath : corymb fastigiate : scales of the calyx oblong, coloured. 2 teet high. ceanothifolium (C. P. Au. 24.) leaves petioled, ovate, acuminate, toothed, S-nerved, glabrous. Rescmbles, in general aspect, the New-Jersey tea.

stacile (slender thoroughwort. C.) stem erect, simple, glabrous below, pubescent above: leaves 


\section{EUPATORICM.}

upposite, short-petioled, lance-orate, from the middle upwards serrate, tajering to the base and entire, glabrous above, pubescent at the reins beneath (sometimes lanceolate, entire:) cyme large, peduncled, somewhat lax, pubescent : calyx 5-flowered, scales obtuse. Mbout 4 fret hight. A new species by Dr. Joln 'Torrey.

laerigatum (smooth hempweed. C.) lenves in fires, lanceolate, petioled, serrate, slender, glabrous both sides: stem hollow, terete, smooth, sub-glaurous: calyx about 5-flowered. Grows 5 or 6 feet high, stem marked with purple lines. Resembles E. purpureum. $\Lambda$ new species by Dr. John Torrey.

\section{Calyaxes more than 5-floreved.}

jurpureum (рuиple thoroughwort, or joe-pye. $\mathbf{0}$. p. Au. 2\%.) leaves in four's or fires, petioled, lance-orate, serrate, rugose-reined, roughish: stem hollow. 5 or 6 feet high. maculatum (C. P. p. Au. 2l.) leares in fours or fives, unequally serrate, pubescent beneath: stem solid, furrowed. Ifardly so tall as the last.

.punctatum (P. p. Au. 2 .) leaves in fours or fives, petioled, ovate, acuminate, serrate, scabrous both sides : stem solid, terete. Hardly so tall as the last.

rerticillatum (joe-pye's weed. 0. p. Au. 24.) leaves in threes or fours, lance-ovate, werlgeform at the base, unequally serrate, somewhat glabrous : stem solid, smooth. 4 to 6 feet high.

perfoliatum (boneset, thoroughwort. $\mathbf{0}$. w. Au. 24.) leares comnate-perfoliate, oblong, serrate, rugose, downy beneath : stem villose. About 3 feet high. Excellent in colds and some fevers. 


\section{EUPATORIUM, EUPHRASIA.}

coelestinum (P. b. Au. 4 ) leares petioled, heartovate, obtusish, 8-nerved, obtusely-serrate: flowers corymbed.

agerutoiles (0. w. Au. 24.) leaves petioled, ovate, acuminate, s-nerved, unequally and coarsely toothed, serrate, glabrous : corymb many-flowered, spreading : calyx simple. About 2 feet high.

\section{EUPHORBIA, 61.}

hypericifolia (spurge. Y. P. Ju. (.)) dichotomous, glabrous, very branching, erect, spreading: leaves opposite, serrate, oval-oblong, subfalcate : corymb terminal.

shaculata (spotted spurge. 0. w. Ju. (.).) crectspreading: leares opposite, serrate, oblong, hairy : flowers axillary, solitary : appendages to the calyx coloured. Leaves when young and in dry ground, spotted.

dentata (P. Ju. \%.) small, hirsute : leaves opposite, oval, dentate : flowel's crowded together at the summit. E pper leaves spotted. polyzonifo!ia (C. P.Ju. 2.) rery giabrous, diffused: leares opposite entire, lance-linear, obtuse: flower's solitary, axillary. ipecacuanhue (C. P. Ju. H.) procumbent, small, glabrous : leaves opposite, oboval or lanceolate; peduncles axillary, elongated, 1-fiowered. Very long ront.

portulacoiles (P. Ju. 24.) erect : leares entire: oval, retuse : peduncles axillary, 1-flowered, equalling the leaves.

Euphorlia, see Esula.

EupHasia, 71 .

officinalis (cyelright. Can. P. w. Ju. (.) leares orate, obtissely toothed : lower divisions of the Jip emarginate. 
F.

FaGUS, 95.

fervuginea (bech. O. y-w. J. h.) leares orate. oblong, acuminate, pubescent loneath, coarsely tonthed, at the base obtuse, subcordate-obliqne: nuts acutely orate, S-sided. Middling sized tree.

\section{Fedia, 2\%.}

olitoria (lamb letture. E.) stem diehotomous : leaves lance-linear. radiata wild lamb-lettnce. C. P. Ju. O.) leares spatulate-oblong, sub entire : fruit pubescent, about 4-sided, naked at the apex.

\section{Ferdela, 45.}

anadensis (giant femel. Y. P.) leares termate, more than decompound ; leafets ovate, serrate, rigid,veiny : stem, peduncles and unbels villose.

Festuca, 32.

elatior (fescuc-grass. C. H. W. P. Ju. 2\%.) panicle nodding, very branching, lax ; spilkelets lance-ovate, acute : florets at first cylindric. and closed, spreading in maturity, obsoletely nerved.

poneoides (Can. Ju. 2\%.) panicle somewhat crowded ; lower branclies simple: spikelets alternate, oblong, subsessile, awnless : leaves flat, very glabrous.

Aluitens (water-fescuc. C. P.J. 21.) panicle long, lax ; branches simple : spikelets close-pressed, linear-terete, many-flowered : lionets awnless, striate : culm decumbent : liaves very glabrous. 
nutuns (New-England. P. Ju. 2\%.) branches of the panicle one-way, nodding, scabrous : spikelets orate, compressed, about 6-flowered, acute, awned: leares lance-linear.

clanidestina (C.) panicle concealed ; branches solitary ; one spikelet sessile, another peduncled: leaves with long sheaths, linear, nerved; stipules acuminate.

tenella (C, W. P.Ju. O.) panicle rery simple, oneway : spikelets about 9-flowered, awned: leaves linear-setaceous ; stipules 2-eared : culm 4-sided above, branching at the base.

duriuscula (C. Ju. 21.) paniele one-way, diffuse : florets awned : culm terete : cauline leaves flat: root fibrous.

'rubra? (P. 21.) culm striate, red at the base, pubescent, geniculate, with dark-coloured joints : panicle contracted, erect and a little nodding; rachis 3-sided, zigzag: spikelets lanceolate, terete, pedicelled, having pedicelled florets: leaves rery long, with striate glabrous sheaths.

Ficus, 98.

carica (fig tree. E. g. Ju. 々.) leares cordate, 3 or 5-Iobed, repand-toothed ; lobes obtuse, scalrous above, pubescent beneath.

\section{FLOERKEA, 49.}

uliginosa (false merimaid. P.w-y. Ap. 24.) leaves alternate; those under water ternate, those above water quinate-pimate. Nectris pinnata. Pursh.

\section{FuUvialis, 90.}

fragilis (river-nymph. P. S. O.) leaves opposite or in threes, linear-subulate, recurved, aculeatstoothed, rigid. In water. 
flexilis (C. P. Au. (.) leaves in sixes, linear, denticulate at the apex, spreading. Flowers ver'y small.

\section{Fontinatiss, 109.}

capillacea (water moss.) leares acute, linear-awlform, spread, longer than the capsule : sheath and peduncies long, filifin'm.

antepyretica, stem branched, 3 -sided : leaves lanceolate, acute, kecl-form, nerveless, 3-rowed: sheath-leaves obtuse : lid awlform.

\section{Fothergitua, 65.}

alnifolia (fothergill's bush. Southern states. wै. Ap. 々.) leaves wedge-obovate, crenate-toothed above. Var. major, has ovate-oblong leares, subcordate. Var. acuta, has ovate acute leaves.

\section{Frigaria, 6 ร.}

vesca (cuglish strawberry. E. w. M. 21.) calyx of the fruit reflexed : hairs on the petioles spreading, on the peduncle close-pressed. elatior (hautboy-strawberry. E. w. భ.) calyx of the fruit reflexed: hairs on the peduncle and petiole spreading.

grandiflora (pineapple-strawberry. E. భ.) calyx

of the fruit erect: hail's on the peduncle and petiole erect : leares coriaceuus, somewhat glabrous above.

rirginiana (wild sirawberry. 0. w. M. य.) calys of the fruit spreading: hairs on the petioles erect, on the peduncles close-pressed: leares somewhat glabrous abore. canadensis (mountain strawberry. Can. P. w. M. 24.) large : leafets broad-oval, lateral ones manifestly petioled : pedicels long, recurve- 
pendulons : receptacle of the seeds globose, hơ ney comb-scrobiculate, villose.

\section{Frasera, 34.}

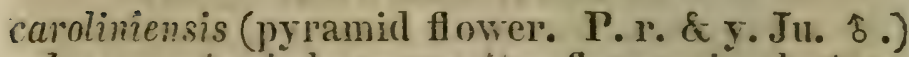
leaves whorled or opposite: flowers in cluster's, From 3 to 6 feet high.

\section{Fraxinus, 98.}

acuminata (white-ash.) 0. w-g. M. 々.) leafets petioles, oblong, shining, acuminate, very entire, glaucous bencatí : flowers calycled,

juglandifolia (walnut-leat ash, swamp) ash. P. W.

M. h.) leatets petiolci, orate, opake, serrate, glaucous beneath, axils of the reins pubescent: branchlets glabrous : fiower's calycied. mubescens (black-ash, red-ash. O.M. h. .) leafcts petioled, oval-ovate, serrate, petioles and branchlets downy beneath : flowers calycled. sambucifolia (water-ash. M. 々.) leafets sessile, lance-orate, scrrate, rugose-shining, roundoblique at the base, axils of the reins villose beneath : flowers naked, not calycled.

epiptera (I'. Can. M. Һ.) leafets lance-oral, subserrate: samaras werlgeform, obtuse emarginate at the apex, terete below.

\section{Fritmliaria, 51.}

imperialis (crown imperial. E. r. \& y. M. џ.) flowers under a leafy crown, nodding" leaves lancelinear, entire. From Persia. maleagris (fritillary, guineahen flower. E. p \& y. M. 21.) leaves alternate, linear, channelled: stem 1-flowered : nectary linear. Flower checkered.

Fucus, 110.

nntuns (floating seaweed) filiform compressed, 
pinnate: leaves oblong-lanceslatr, serrate : vesicles globular, peduncled, scittered, on flat dilated peduncles.

resiculosus (bubble-seawecl.) linear forked, enlire; with globular, innate and axillary resicles, cloven at the tips ; bas'en ones flat, fertile ones tumid.

edulis (worm seaweed.) fleshy, wedge-form, near-

ly simplr. glabrous both sides, rounded at top,

entire at the margin.

finticulosus (eather seaweed.) leathery ; round, fi-

lifoim, decomponndly branched above : branches nearly bristle-i:m, with alternate lax branchlets and small pinnate toothletted subdivisions. noilosus (notly sia-weed.) somewhat forked :

leaves a-rowed, pediuncled, roundish, entire, frrtile: resicles innate, solitary, broader than the firond.

\section{Fumena, 29.}

squamosa (umbrella grass. C. Ju. Ұ.) flowers in simple unibels ; spikelets ovate: culm glabrous: leaves ciliate, sheaths hairy.

\section{Fuligo, 118.}

septica (soot fungus.) yellow, lacinate. capitata, yellow, head-form.

\section{FUMARIA, 77.}

offinalis (fumitory, Y. C. P. r. J. O.) stem branching, spread : leaves more than decompound; lealets wedge-lanceolate, gashed.

\section{Funaria, 109.}

hygrometica (hygrometer moss.) leaves ovate, a.uti. concarie. entire, inflected: capsules swelling, drooping. 
muhlenbergii, leaves obovate, awned, concave, sclrulate, spread : capsule obovate, obliguc.

\section{G.}

\section{Gatictra, 80.}

glabella (milk-way plant. C. P. r. \& w. J. 2.) piostrate, smewhat twining and glabrous : leaves ternate, oval-oblong, ointuse, emarginate at both ends : racemes axillary, simple, abbreviated, few-flowered: legumes villose. Root long, fusiform.

mollis (C. P. r. \& w. Ju. 2.) twining, having soft whitish pubescence : leares terrate, orate-oblong, obtuse, smorthish, glaucous beneath : racemes axillary, simple, elongated, few-flowered : legumes villose.

\section{Galanthus, 49.}

nivalis (snow drop. F.w. Ap. 21.) leaves linear, keeled, acute, radical : scape 1-ilowered.

\section{Galega, 80 .}

virginiana (goat's rue. P. Y. A. r. J. ४.) erect, liaving whitish down : leafets ( 17 to 21$)$ ovaloblong, acuminate : raceme terminal, short, subsessile: legumes reversed-falcate, villose, calyx woolly. Tephrosia. Persoon.

\section{Gileopsis, 69.}

tetrahit (flowering netille. H. W. Y. P.r. \& w. Ju. Q.) the spaces between the joints of the stem thicken upwards : the ripper whorls nearer together : caly $x$ prickly, a little shorter than the corol : stem lough-hated. 


\section{Gatidu, 35.}

\section{Fruit glabrous.}

irifulum (bedstraw. W. C. P. w. Ju. 2\%) stena jrocumbent, scabrous backwards: cauline leaves in lives, branch leaves in fours, linear, obtuse, scabrous at the margin and on the nerves : fascicles terminal, few-flowered ; pedicels short: co:ols mostly 3-cleft. tinctorium (dyer"s clearer's. (). W. Ju. \% .) stem diffuse, smoothish : cauline leaves in sixes, branch leaves in fours, linear, acutish ; margins and nerves with slender prickles : peduncles terminal, clongated, mostly s-flowered. asprellum (rongh bedstraw. O. W. Ju. 24.) stem diffuse, very branching, prickly backwarls: cauline leaves in sixes; brandh leares mostIy in fours, lanceolate, acuminate, margins and nerves prickly : branchlets flower-bearing, many-1lowered: pedicels short.

\section{Fruit hirsute.}

Grachiatum (hell-straw. C. P. w. Ju. 4.) stem limber. long, brachiate-ramose, hispid ; branches short : leares in sixes, lance-oblong, acuminate, shabrous, margin and keel ciliate: branches whorled, the longest dichotomous : pedi(cis g-ilowered: fruit with hooks. Pursh. boreale (W. C. P. W.Ju. Z.) stem erect, smooth leaves in fours, linear, acute, s-nerved, glabrous: margins and nerves scabrous : panicle terminal, spread : fruit with slender bristles. bermudianum (A. P. p. Ju. 2'.) stem very branching. scarcely pubescent : leaves in fours, ovate, obtuse, glabrous, margins and nerves pubesecnt, sometimes pellacid : branchlets floriferous, elongated : fruit with hooked bristles. mieranthum (Can. I. W.Ju. 2l.) stem rery brauche 
ing, prickly backwards : leaves short, lanceolate, mucronate, glabrous, margin and keel prickly : pelicels about 2 -flowered : fruit hisjicl. Flowers small, many.

circae $\approx$ ans (wild liquorice. H.Y. C. P.w-y.J. ४.) stem erect, smooth : leaves in four's, oval, obtuse, glabrous, margins and nerves a little ciliate: perlumcles few-flowered; flowers remote, - subsessile : fruit with hooked bristles. Leaves taste much like liquorice.

iriflorum (W. C. A. P. W. Ju, 2 .) stem procumbent, smoothish : leares in fives or sixes, lancerbovate, linucronate, glabrous, scarcely ciliate at the maigin : branchlets 3 -fowered at the end ; fowers pedicelled : fruit small, hispid.

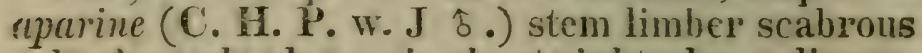
backwards : leares in about eights, lance-linear, mucionate, hispid above, margin and keel prickly : branchlets of the length of the leares, about S-flowered : firuit hook-bristled.

pilosum (C. P. p.J. Y.) stem nearly simple, long, ascending, remotely geniculate, hispid : leaves in fours, oval, short-mucronate, very hirsute both sides, nerveless : branchlets nearly simple, about 3-flowered at the end : fruit pilose. sirictum - (C. A. W. Ju. 24.) stem stiflly erect, smoothish, branching; buanches short, erect: leares in fours, linear-lanceolate, obtuse, 3nerved, with involute scabrous margins : flowers panicled crouded; peduncles short 3-flowered at the top, forked, hispid. Torrey. A new species discorered by Dr. C. W. Eddy.

\section{Gaultheria, 57 .}

procumbens (spicy wintergreen. 0. W.J. 2l.or h.) stem procumbent ; branches erect: leaves obovate, acute at the base : flowers few, nodding. Berries red, consisting in part of the permaaent calyx; a little mealy, pleasant tasted. 


\section{GALLTIIERIA. GENTIANA. ¿55}

hispidula (creeping wintergyern. W. N. P. Can. w. M. h. sten creping, hispial, leaves oval, arute : flowers solitary, axillary, subsessile, hasing but s stamens, short-beilform. Very plenty in Plainfichl, Mass. and at the margin of a jond six miles north of 17 illiams College.

\section{GaURA, 53.}

biennis (rirginian lonsestrife. A. P. r. \& y. Au. o .) leaves lanceulate, toothed : spike cruwded: fruit roundish-4-cornered, pubescent.

\section{Genista, 78 .}

tinctoria (dyer"s broom. E. y. Au. h.) leares lanceolaie, glabrous : branches terete, striate, erect : legumes glabrous.

\section{Gextrana, 43.}

lukea (yellow gentian. C. y.) leares broad-nrate, nerved : corol about 5-cleit, whecl-form, whorlcd. Muhlenberg quotes Kalm, as an authority for this being found in New-Jesey. pnemonanthe (calathian violet. 1'. Can. b. A. 24.) stem terete : leaves lance-linear, oljtusish : flowers terminal, fascicled ; lateral ones solitary, peduncled; corol 5-cleit, belliom, divisions poundish, imer folds with one acute tooth. saponaric (soap-gentian. (1.b. \& w. S. 2\%.) stem terete, glabrous : leaves lance-sblong 3-nerved; fiowers sessile, fascicled, terminal and axillary: corol 5-cleft hell-rentricose, almust clused at the top ; inner folds toothed.

ochrolenca (C. P.y. \& b. S. 21.) stem somewhat angled, roughish : leaves lance-orati, roughish : flowers sessile, fascicled, terminal ; corol 5-cleft, bell-rentricose, divisions acute, inner folds simple, acute.

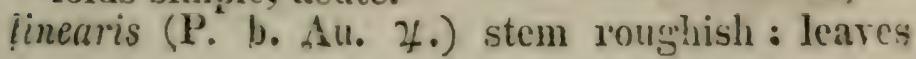


lance-linear, undulate, ciliate as the calyxes : Hower's 5-cleft, bellform, terminal, sessile, crowded ; divisions short, obtuse : interior folds denticulate.

quinqueflora (W. A. P. b. Au. ô.) stem 4-cornered, bianching : leaves half-clasping, oval, acute, S-nerved: Howers 5-clet', bell-tubular with a slabrous throat, terminal and lateral, in threes or fives, subpedicelled, cuivisions lanceolate, acuminate : calyx short, narrow.

angustifoliu (C. b. S. ४.) stem terete, simple, 1Howered: leaves narrow-linear, spreading: corol 5-cleft, divisions oval, inner folds torn. crinita (fringed gentian. O. b. S. 2.) stem terete: branches long, 1-flowered : leaves lanceolate, acute : corol 4-cleft, divisions obovate, gashciliate, interior folds simple.

\section{Geranidi, 76.}

sanguineum (bloody geranium. E. 21.) peduncle 1-flowered : leaves 5-parted, 3-cleft, orbicular : capsule bristly at the top.

maculatum (crowfoot g’eranium. 0.r.\& b. J. 24.) erect: pubescence rerersed: stem dichotomous : leaves opposite, 3 or 5 -parted, upper ones sessile: peduncles 2 -flowered : petals obovate. columbinum (P. C. b. M. 4.) peduncles 2 -flowered, longel than the leaves : leaves 5-parted ; lobes many-cleft, linear : petals emarginate, of the length of the awned caly $x$ : arils glabrous. pusillum (P. b. M. O.) peduncles 2-flowered; flowers pentundrous, petals emarginate of the length of the awnless calyx : leaves about 7 lobed, 3-cleft : arils pubescent.

robertianum (herb robert. 0 . 1.J. s. .) spread, hirsute : leaves opposite, ternate and quinate, 3cleft-pinnatifid : peduncles 2-flowered : petals entire, twice as long as the awned calyx : aril net-reined. 


\section{GERANIUM, GERARDIA. $25 \%$}

diessctum (C. r. J. 3.) spread, hairy : leaves opposite, 5-parted, lobes 3-cleft, gashed, linear : jeduncles a-flowered, long : petals cmarginate, the length of the awned calys : aril with glandular hairs.

Geranium, see Pelargonium and Erodiun,

Gerardi, $7 \%$.

Shara (false foxglove. O. y. Ju. 24.) pubescent : stem simple : leaves subsessile, lanceolate, entire or toothed; lower ones subpimatifid, gashed : flowers axillary, opposite, subsessile. 2 or 3 feet high.

glanca (oak-leaf foxglove. O.y. Ju. 4.) glabrous; stem glaucous, purple, panicle-like ; leares petioled, sinuate-pinnatilid with acute lanceolate divisions: upper leaves lanceolate entire. First discovered and named by Dr. C. W. Eddy. G. quercifolia. Pursh. S to 5 feet high. pedicularia (lousewort foxglove. N. Y. C. P. y. S. $\delta$.$) pubescent, brachiate-panicled : leaves$ oblong doubly gaslt-serrate and pimmatifid: flower's axillary, opposite, pediculled: divisions of the calyx leafy, gash-toothed.

purpurea (P. Y. C p. Au. 万. (.).) stem with opposite branches: leaves linear, slender: flowers axillary, opposite, subsessile.

crinita (W.A.C. p. Ju. ₹.) stem with opposite branches: leaves short and fleshy. Discovered by Dr. C. W. Eddy. Resembles the purpurer. Var. crassifoliu. P'ush. It is rrom 6 to 12 inches high.

ruriculata (P. p. Au. ().) nealy simple, xough: leaves lance-ovate, 2-eared at the base, entire : flower's axillary, opposite; leaves and flowers closely sessile. About 8 inches high. tenuifolia (P. p. Ju. $\delta$.) branch-panicled : leaves linear : peduncles axillary, opposite, longer than the flowers. 
setncea (P. Au. .). stcm very branching : leares setaceous: branches axillary, longer than the leaves, mostly 1-flowered.

\section{GeUM, 63.}

virginiamum (avens. 0. w. Ju. 21.) pubescent : radical and lower cauline leares ternate, upper ones lancerlate : stipules orate, subentire : flowers erect: petals shorter than the calyx : awns hooked, nalied; at the apex twisted, hairy.

strichum (upright arens. W. Can. C.y. J. 21.) hirsute : Jeaves all interruptedly pinnate, the odd one largest; leafets orate, toothed : stipules mashed: divisions of the calyx 5, alternately limear, short : flowers erect; petals roundish, longer thian the calyx, awns nakel, hooked. ngrinanoides (C. w. Ju. 2.) very hirsute: leaves all pinnate ; leafets about equal, unequally grash-toothed : stipules orate, subentire : flowols crect: divisions of the calyx about equal; petals oval, of the length of the calyx.

geniculatum (Can. 2\%.) many-fiowered, subpanicled: cauline leares stibsessile, 3-parted : stijules entire : petals werge-obcordate : awns ill orer hairy, geniculate in the midlle. virale (purple avens. O. p. M. 24.) pubescent : stem simple : radical leares interruptedly pinsate; cauline ones 3-cleit : flowers nowding; petals of the length of the calyx : awns piumose, nakedish abore, a little liooked.

aibum (P. w. Ju. 24.) pubescent: radical leares pimnate; cauline ones ternate, upper ones simjile, 3-cleft : lower stipnics gashed : flower's erect ; petals of the length of the calyx : awns hooked, naked, hairy at the end. preclii (Whitehills. Ju. 2f.) somewhat glabrous : stem 1-flowcred : ratical leares renition, romded, subtrincate at the base, gash-toothed: 
petinles very long, sometimes appendaged : pertals of the length of the calyx. Discovered by Professor Peck, of IIarrard College.

\section{Gillenia, see Spiraca.}

Guavx, 4 ,

maritima (sea milkwort. Can. r. Ju. 24.) leaves oblong, smooth : llowers axillary, sessile. In salt marshes.

\section{Grechoma, 69.}

hederacea (ground ivy, gill-nverground. 0. b. \& x. M1. 4.) leaves reniform, crenate : stem root ing. coricita ( $I^{P}$. b. 24.) leaves heart-form.

\section{GLeditschis, 100.}

triaeantha (honey-locust. P. w. J. h.) thopns strong, cross-branched : leares lincar-oblong: legumes very long, compressed. A large tree. One side of the long tlat legume contains a sweet pulp.

\section{GLYCINE, 80.}

monoica (wild bean. C. P. b. \& w. Ju. (․).) stem slender, hairy backwards : leaves ternate, ovate, glabrous, membranaceous: cauline racemes jendant, lax, mostly bearing corols and sterile: bracts orbicular, concave : radical peduncles bearing apetalous flowers, fertilc. angulosa (P. p. Au. \%.) twining, pubescent : lower leafets rhomboid-oral, upper ones 3-lobed: heads long-peduncled : legumes linear. P'haseolus trilobus. Mx.

comosa (slender bean-rine, 0. b. Ju. 2/.) stem 
twining: leaves ternate, lance-ovate, acute, hirsute : lateral racemes pendant, with flowers crowded, all fertile.

apios (ground-nut. O.b. \& p. Au. 2.) twining, glabrous : root tuberous : leaves uncqually pinnate; leafets 5 or 7 , lance-orate, upper ones narrow : spikes crowded, shorter than the leaves. Roots tuberous, fariuaccous and plea: sant tasted.

\section{Glycirrhiza, 79.}

ufficinalis (liquorice. E. \%.) leares pinnate, the terminal one petioled. Hoot tubcrous-cylindric, sweet.

\section{Graphatium, 85 .}

margaritaceum (large-flowered life-cverlasting. 0. y. \& w. Ju. 24.) leaves lanceolate, gradually narrowing, acite : stem branching above : corymb fastigiate : flowers pedicelled. About 18 inches high. Flowers with white pearly rays and yellow disks. Wrongly applied in the Boston Florula.

polycephalum (sweet-scented life-everlasting. $\mathbf{0}$. y-w. Ju. O.) leaves lance-linear, acute, glabrous above, downy beneath : stem panicled, downy; corymbs terminal. The heads of this species are more numerous than of the preceding, more close, and the flower's are smaller. Grows to about the same height.

Iuteo-album (New-England. y. (-).) leaves halfclasping, lance-linear, subundulate : stem elongated ; stem and leaves downy. Muhlenberg says, this species grows in New-England; but I never found it there.

plantagineum (carly life-everlasting. O. w. Ap. 21. shoots procumbent : stem simple: radical leaves obovate, nerved: corymb close-pressed flowers diocecious: inner scales of the calyx 
elnngated, acutish, coloured. About 6 inches high.

dioicum (mousear. W. P. w. J. 2t.) shonts procumbent: stem simple : radical leares spatulate: corymb close-pressed : flowers dioceious: inner scales of the calyx elongated, obtuse, coloured. Differ's from the last a little in the for'ms of the radical leares, the scales of the calyx and time of flowering. But perhaps it may be a variety of it.

purpurenm (C. P. p. Ju. 4.) leares linear-spatulate, downy beneath : stem erect, simple : flower's sessile, glomerate, terminal and axillary. Hardly so tall as the two last species. Calyx purple.

anericanum (P.y. Ju. @.) stem erect, bianching: leaves obovate-spatulate, pubescent bencath flowers axillary and terminal, glomerate-spiked. Abnut as tall as the last.

uliginosum (mud life-everlasting. 0. w. Ju. stem branched, spread, woolly : leares lancelinear, narrowed at both ends, downy : flowers terminal heaperl ; 4 or 5 inches long, half-prostrate, calyxes brown.

germanicum (P. w, Ju. (-).) stem erect, dichotomous : leaves lance-linear, acute, tomentose: flowers in a globular head, terminal and lateral. 5 or 6 inches high.

sylvaticum (C. y. Ju. 4.) stem very simple, erect: leaves narrow-lanceolate, slender at both ends and woolly : flowers terminal and axillary, sessile, spiked. 10 or 12 inches high.

GoMpHrena, 42.

globosa (globe amaranth, bachelor's button. E. P. Au. (.) stem erect: leaves lance-orate : heads solitary : peduncles 2-lcared. 


\section{Gordonia, 76.}

lasiantinus (lolly bay. E. S. 々.) flowers long-pedumferl: leaves coriaceous, glabrous : capsules ovate.

\section{GossyPiUM, $7 \%$.}

hemaceum (cotton. E. Au. 5.) leaves 5-lobed, mi coinate, one gland bencath : stem herbaceous, smooth.

Gratrola, 26.

ifficinalis (hedge hyssop. 0. y. Ju. ४.) leares broarl-linear, sessile, entire, S-nerved, punctate above: peduncles opposite, hardly so long as the leaves: filaments sometimes wanting and sometimes without anthers. In damp ground. G. aurea. Minhl.

airginica (creeping hedge-hyssop. Y. P. C. w-y. Ju. 4.) leaves obianceolate, lower ones slender, remotely toothed, nerved, glabrous : peduncles alternate, very short: capules acuminate, longer than the calyx. In wet ground.

acuminata (P. y.Ju. 4.) leaves lanceolate, serrate, pubescent : peduncles opposite, longer than the leaves : leafets of the calyx linear, of the length of the subglobose capsule, In wet places.

pubescens (C. Ju.) stem erect, with pubescent: branches : leaves lanceolate, narrowed, and a little connate, at the base ; remotely tooth-scrrate : leaves of calyx unequal. In wet places. A new species discovered and described by Dr. John Torrey.

Grimmin, $10 \%$.

controversa (awl-cap moss) leares linear-awlform 
serrate at top, curled when dry : capsule oval, with the awliorm (an) a little curverl.

alpico! ${ }^{\prime}$. leaves lanceolate, obtusish. awuless : capsule obconic, nearly sessile : fringe not perforated.

\section{Grmostonum, 106.}

pyriforme (tonthless moss.) leaves ovate, arute, spread : capsule pear-form : lid obtuse-pointed.

\section{Griophora, 113.}

anthracina. cartilage-membranous, rery brittle, peltate, expanded, inregularly to:m, blarkish-gecy above, sonty black and quite smooth beneath : buttons raised. rellea (moroceo leather. W. N.) membranous, peltate with a stalk, very large, with the circunference slightly spread-tuothed; glahrous above, hairy beneath with branched straitish fibres, brownish-grey both sides: buttons cilcularly plaited. papillosa (shoe-leather W. H. N.) blark both sides, papillose beneath. Very brittle when dry, and toingh when wet. Grows on rocks, from 3 to 6 inches diameter.

\section{H.}

Hamamelis, 36.

virginica (witch-hazel. O. y. Oc. h.) leaves obovate, acute, toothe:1, cordate with a small sinuse. Flowers in the fall and perfects tue fruit tho next summer.

\section{Hamtonia, 99.}

oleifera (oul-nut. P.g-y.J. $\nvdash_{2}$.) pubescent : lcaves 
oblong, entire, acuminate : flowers in terminal racemes. A shrub about 5 or 6 feet high.

\section{Heneoma, 60.}

pulegioides (penny-royal. O. b. J. (.).) pubescent: leaves oblong, serrate: peduncles axillary, whorled: lower lip of the calyx with 2 ciliate bristles. 5 or 6 inches high.

glabra (C. 4.) glabrous : lower leaves oblong, upper ones lanceolate, remotely serrate : peduncles terminal, ternate.

\section{HEDERA, 42.}

helix (english iry. E. g-w. S. h.) leares 3 or 5 lobed, iloral ones ovate: umbel erect.

\section{Hedysarum, 81.}

canadense (bush trefoil W. C. r. Ju. 24.) crect, smoothish : leares ternate, lance-oblong : stipules filiform : flowers racemed: joints of the loment obtusely-triangled, hispid.

canescens (P. r-b. Au. 21.) erect, pilose: stem angled-ciliate, hispid : leaves ternate, roundish, with close-pressed hairs bencath : stipules ovate, acuminate: racemes panicled : iracts cordate : joints of the loment triangular, hispid.

marilandicum (C. P. p. Ju. 24.) erect, branching, pilose : leaves ternate, oblong, villose beneath: stipules subulate : racemes panicled: loment 3-jointed ; the joints rhomboid, reticulate, a little hairy. Flower's large.

obtusum (C. P. p. \& g. Au. ४.) erect, pubescent: leaves ternate, ovate, obtuse, subcordate at the base : stipules lance-subulate : panicle terminal : joints of the loment suborbiculate, reticalate, hispid : loments rough, joints oval. 
viridiflnum (W. C. P. Y. g. \& p. Au. 2.) erect, branching, pubescent: leaves ternate, ovate-oblong, scalinous beneath: stipules lance-cuspidate : racemes panicled, bracted. About 3 feet high. Flowers become grieenish when old. glabellum (C. jo. Ju. 24.) enect, glatirous : leaves

telnate, ovate, obtuse, subglaurous bencath : stipules small, subulate : panirle terminal : joints of the loment rhomb-trianginlar.

ciliure (W. P. p. A11. 21.) erect, a little glabrous: leaves ternate, ovate, pubescent beneath, margin ciliate : stipules filiform : panicle terminal : joints of the loment ( 2 or 3 ) half-orbicular, hispid.

m(zniculatum (C. A. P. p. Au. 4.) erect glabrous: leares tcrnate, lance-oblong or oral, glabrous : stipules subulate: panicle terminal : joints of the loment (4) rhomboid, pubescent. rotundifolium (Y. C. P. p. Au. 2.) prostrate, hirsute : leares ternate, orbicular, pilose both sides: stipules round-cordate, reflexed : racemes axillary and in the terminal panicles few-flowered : hracts cordate : joints of the loment sub-rhombic, reticulate scalrous.

Iructeosum (P. r. Au. 4.) erect, glabrous : leaves ternate, oblong-oval, acuminate : stipules subulate : racemes terminal with scattered flowers : bracts ovate, acuminate, striate, glabrous : joints of the loment sub-oval. Flower's large.

ruspidatum (P.p.Au. 2.) erert, glabrous : leares ternate, petioled, ovate-oblong, long-acuminate, glabrous, margin scabrous : stipules lance-ovate : panicle terminal : joints of the loment triangular, reticulate, glabrous, at the margin pubescent.

glutinosum (U. 1. Ju. 2l.) erect, simple: leares long-petioled, ternate, lound-ovate, acuminate: panicle scape-like, proceeding from one side of the base of the stem : peduncles with glutinous 
hairs : joints of the loment oblong-triangular,

a little glabrous.

mudiflorum (C. p. Ju. 4.) erect, simple, glabrous :

leaves ternate, broat-oval, acuminate: scape panicled, glabrous, radical : stem bearing leaves higher : joints of the loment round-triangular, somewhat glabrous.

acuminatum (O. p. Ju. 4.) erect, simple, pubescent, leafy at the summit : leaves ternate, ovate, long-acuminate, with scattered hairs on both sides close-pressed, long-petioled; the odd leafet round-rhomboid : panicle long-peduncled, terminal.

repens (P. p. Au. 2\%.) leaves round-oval, cmarginate : racemes axillary: loments repand-toothed ; stem creeping.

prostratum (P. P. Au. 24.) prostrate : leaves petioled ; leafets oval, obtuse, thin hairs underside close-pressed : branches axillary, longer than the leaves: loments ovate pubescient. Les. pedeza prostrata. Puish.

strictum (C. p. Ju. 2\%.) stiffly erect, glabrous, simple: leaves petioled, ternate, linear-oval, glabrous net-veined, glaucous beneath : stipules subulate : panicle terminal, peduncled, lew-flowered.

Hedysarum, see Lespedeza.

HeleniUm, 87.

autumnale (false sunflower. P. y. Oc. 24.) leares lanceolate, serrate, subdecurrent: stem corymbeil above : disk florets 5 -cleft; rays flat, rellexed.

Heitanthus, 87.

1. Leaves pposite:

annus (common sunflower. South America. y. \& w. Ju. \%.) leaves all cordate, 3-nerved: pe- 
duncles thickened: flowers nodding. Flowers very large.

pubescens (1゚. y. Au. o.) white-pubescent : stem

villose : leaves sessile, heart-ovate, clatsping. 3-nerred, close-pressed subserrate : scales of the calyx lanceolate villose.

atrorubens (1'. y. \& p. Au. 24.) hispid : stem nakedish above, lax-panicled, leares spatulate, ovate, crenate, S-nerved, scabrous : scales of the calyx lance-orate, of the length of the disk. :trachelifolius (C.P. Can. y. Au. 24.) leares lanceorate, acuminate, serrate, S-scrved, very rough both sides: scales of the calyx lance-linear, ciliate, outer ones longest. About 5 feet high. - rizaricatus (C. P. Can. y. Au. 24.) stem glabrous, very branching: leaves nearly opposite, sessile, lance-ovate, s-nerved : panicle trichotomous, slender, few-flowered. 5 or 6 feet high.

frondosus (C. P. Can. y. Ju. 2.) stem glabrous below : leaves ovate, sharply-serrate : peduncles scabrous : calyx squarrose, undulate, leafy, ciliate: rays 8-flowered. 4 feet high.

\section{Upper leaves alternate.}

multiflorus (P. у. Au. భ.) leaves s-nerted, scabrous ; lower ones coldate, upper ones ovate: ray many-flowered: scales of the calyx lanceolate.

macrophyllus (P. y. Au. «.) Teaves ovate, acuminate, 3-nerved, serrate; scahrous above, whiter pribescent beneath: scales of the calyx linear, squairose.

tuberosus (jerusalem artichoke. E. y.S. 24.) leaves 3-nerved, scabrous, lower ones heart-ovate, upper ones ovate, acuminate; petioles ciliate. Root tuberous. Naturalized.

strumosus (New England. Z .) leares orate, acuminate, serrate, S-nerved, scabrous beneath: scales of the calyx lance-linear, ciliate at the base. altissimus (C. P.y.Au. \&.) leaves alternate, lance- 
ovate, serrate, scabrous, S-nerved, slender at the apex, with ciliate petioles: scales of the calyx lanceolate, ciliate. Chaff on the receptacle green, stem purple.

grigrinteus (C'an. P. y. Au. 2\%.) leaves alternate, lanceolate, serrate, scabrous, obsoletely 3-nerved, tapering to both ends, subsessile, ciliate at the base : scales of the calyx lanceolate, ciliate, Tall and rough. Chaff on the receptacle black. decapetalus (0. y. Au. 24.) leaves c,vate, acuminate, remotely serrate, S-ncreed, scabrous : scales of the calyx lanceolate, subequal, subciliate: rays ten or twelve. Three or four feet high.

mollis (P.y. Ju. 24.) leaves orate acuminate, 3nerved, with close-pressed serratures scabrous above, white-pubescent beneath very soft: scales of the calyx lanceolate, close-pressed. angustifolius (C. y. S. 2!.) stem slender, about 1Howered : leaves linear, with a revolute margin, very rough. Rays yellow, disk brown.

Heliopsis, 86 ,

laeris (ox-cye. P. Au. భ.) leaves opposite, orate, serrate, 3-nerved. 'Tall, rescmbling the sunflowers.

\section{Hextotropium, $3 \%$.}

indicum (turnsole. Southern states. b. Ju. @.) leaves heart-ovate, acute, roughish : spikes solitary : fruit bifid.

HELheBorus, 66.

foetidus (hellebore. E.) stem many-flowered, leafy : leaves pedate, remotely serrate, coriaceous : corol somewhat converging.

Helleborus, sce Coptis. 


\section{Hetoxia, 52.}

Iatifolia (helonias. C. P. p. M. 2f ) scape almost leafless : spike ovate (rowded: brart lancelinear, mucronate, nerves. Anthes's blue. cryllirosperma (P. w. \& g. J. 2.) scape leaty : ratcemes oblong: bracts short, oblong : leares glabrous, lance-linear : secd orate, reddish : pericarp legumelike, fleshy. asphorlcloides (C. W. J. 4.) scape leafy : raceme: oblong, crowded : bracts sctaccous : filamens broader at the base, equalling the corol : leares subulate-setaceous.

dioica (P.w. Ju. 2l.) scaje leafy : raceme spiked, nodding: pedicels short, sub-bracted : filaments longer than the corol : petals lincar: leaves lance-oblong.

\section{Henvelid, 118,}

fuliginosa (smoky fungus. A.) inflated, angulat, plaited, blackish or dark coloured: stem tubular, greyish, furrowed. gelatinosa, convex, brown-yellow, deflected, plaited : stem tu!bular, brownish-yellow.

fibuliformis, ochre above, Ulackish beneath : stem short dark brown.

calyciformis, ochre, glabrous, granular-surfy beneath: stem shortflesh-colour, gr'anular-scurfy.

\section{HeMerocatis, 50.}

flara (yellow day-lily. E. y. Jti. ユৈ.) leaves broadlinear, keeled : petals flat, acute; nerves of the petals undivided.

fulva (tawny day-lily. E. y. Ju. $\psi$ ) leares linearlancelate, keeled : three in.ler petals obtuse, undulate; nerves of the outer petals branching.

Hepatica, 66.

triloba (liverleaf. 0. w. \& b. Aj. 4.) leares 3 $x_{2}$ 
lobed, entire, obtuse: calyx leaves broad-ovate, obtuse. Var. acuta, leaves 3 to 5 -lobed, acute: calyx leares acute. Perhaps this variety ought to constitute a distinrt species. It has been observed by Professor Dewey, that near Williams College, all the plants of this species growing on the north sides of hills are of the variety acutu.

\section{Heracteum, 45.}

lanatum (0. w. Ji. 2\%.) petioles and nerves of the leaves very villose beneath: leafets petioled, broad, round-cordate, stibpalmate-lobed : seed orbicular. A large umbelliferous plant of a white woolly appearance. Grows plentifully in meadows cast of Williams College.

\section{HESPERIS, 74.}

Lristis (yellow rocket. E. ô.) stem hispid; branches spreading: leaves lance-ovate: silique sword-form.

unatronalis (garden rocket, dame violet. E. 21.) stem simple, erect: leaves lance-ovate, denticulate : petals emarginate, mucronate. Var. hortensis, flowers double, odoriferous, white. pinnatifula (wild rocket. P. J. $\delta$.) leaves sharply serrate ; upper ones lanceolate, lower ones pinnatifid : silique sub-peduncled, shortish.

\section{Heteraituera, 28.}

reniformis, (odd-shives. P. w. Ju. 2f.) leaves round-reniform, acute : spathe sub-3-lobed, glabrous. Leaves floating.

\section{Hevchera, 44.}

viscida (allum root. C. P. r. Ju. 2l.) viscid-pubescent: scape and leaves roughish : leaves 
moderately rount--lobed, with dilated obtuse mucronate teeth : pedincles of the panicle very dichotomous, spread : calyx short, obtuse. H. americana.

pubescens : P.r. \& y.J. Z.) dusty-pubescent : scape glabrous below: leaves sub-arute-lobed, toothed, glabrous beneath : pediuncles of the panicle slimt, with crowded flowers : calyx large, bellform : petals longer than the calyx, large.

\section{Hibiscus, $7 \%$.}

moschentus (mar'sh mallow. C. w. \& p. Au. 24.) leaves ovate, acuminate, serrate, sub-s-lobed, sub-5-nerved, white-downy beneatis : peduncles flower-bearing, calyx downy : caysules glabrous.

palustris (marsh hibiscus. C. P. p. Au. \%) leaves broad-oval, obtusely serrate, sub-s-lobed, 3-nerved, downy beneath : peduncles axilary, longer than the petiole.

viparius ( $\boldsymbol{P}^{\circ}$. p. Au. 4 ) very glabrous: leaves Slobed-hastate, acuminate, serrate : corol tubu+ lar-bellform : capsules orate, acuminate, glabrous : seeds silky.

syriacus (syrian mallow. E. w. \& p. Au. h.) leaves wedge-orate, 3-lobed, toothed : outer calyx about 8-leared, of the length of the imner : stem woody. A shrub 4 to 6 feet high.

csculentus (okra. E. . .) leaves heart-5-lobed, obtusish, toothed: petiole longer than the flower : outer calyx about 5-leaved, deciduous, bursting lengthwise.

sirginicus (sweat weed. C. P. r. Au. 24.) downy, rough : leaves acuminate, unerually toothed; lower ones cordate, undivided, upper ones cordate, undivided, upper ones cordate-oblong, 3lobed: peduncles axillary and in terminal racemes ; flowers nodding : pistils nodding. In salt marshes. 
trionum (bladder ketmia, flower of an hour. E. (-).) outer calyx many-leaved, inner one inflatod : capsule membranaceous: leaves toothed, upper ones s-parted.

\section{Hieracium, 8\%.}

iturantiacum (orange hawkweed. E. y. 4.) scape leafy, hispid : Hower's corymbed, peduncles glomerate : leaves oblong, acutish, pilose-hispid.

zecnosum (rein-leaf hawk weed. 0.y. Ju. భ.) scape naked, corymb-panicled, glabrous; pedicels filiform : leaves lance-obovate with thin hairs above and naked beneath, margin ciliate, glandular-toothed, vcins coloured: calyx glabrous. gronorii (C. P. Ju. ४.) scape somewhat leafy, oi' naked, corymb-panicled : calyx pubescent : radical leaves entile, obovate, ubtuse, ciliate.

paniculatum (0. y. Ju. ४.) very glabrous : stem erect, leafy, panicled, white-woolly beneath : pedicels capillary : leares lanceolate, naked, tonthed, membranaceous.

marianum (C. W. N. y. Ju. 2.) stem erect, villose : leaves oral-obovate, strigose, villose on the kecl, lower ones subdentate : peduncles and calyxes downy. Resembles the H. gronovii.

lialmii (P. y. Au. 2.) stem erect, many-flowered, glabrous: leaves subsessile, lanceolate, acuminate, sharply toothed outside : peduncles cauline, near the top of the stem alternate, about 1-flowered, downy.

virgatum (W. N. Ju. 4.) stem erect, simple, villose : leares sessile, lanceolate, acute, glabrous, pilose beneath, sharply repand-toothed at the margin, entire towards the apex : panicle subcorymbed : calyx and peduncle tomentose. scubrum (1'. y. Au. 4.) very hirsute : stem erect, 
leafy, hispid, scabrous with tawny dots ; leares oblong-ovate. entire, hirsute both sides : panicle sub-simple, many-flowered : calyx and panicle glandular-hispill : perlirels short, divaricate. From 3 to 5 feet high.

\section{Hippophae, 98.}

canadensis (sea buckthoru. C. M. Һ2.) leares ovate. acutish, a little glabrous above, silverhaired and brilliant beneath; scales scattered ferruginous.

\section{Hippuris, 25.}

vulgaris (mares tail. P. W. C. y-g. M. 21) leares mostly in sixes, linear. In water.

\section{Holcus, 33.}

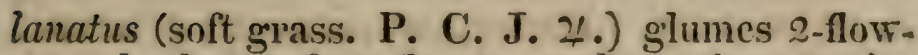
ered, the perfect flower awnless, the staminate one awned, recurved, flower much shorter. odoratus (C. P'. Ju. 4.) panicle spreading" glumes 3-flowered, awnless; florets crowded; perfect one in the middle, diandrous, glabrous ; staminate one triandrous.

monticola (Whitehills. Ju.) glumes 3-flowered, intermediate one diandrous, perfect; lateral ones staminate, triandrous : outer valve awned upon the back. A new species discorered by Dr. Bigelow,

\section{HoLOSTEUM, 33.}

succulentum (succulent chickweed. C.) leaves oral, fleshy : petals subtrifid, smaller than the calyx. Pursh doubts the existence of this plant in America. 
Hondeur, 30 .

iulgare (barłey, F. Ju. O.) florets all perfect, awned ; in tiwo erect rows.

jubatum (New-Ergland. Ju. o .) awns and involucres setaceous, very long.

Hortensia, 59.

speciosa (changeable hydrangea. r. \& w. J. h.) leaves broadly orate, serrate, acuminate : fiowcrs corymbed. From the East Indies. This is the common flower-pot shrub, usually called hyderindia.

\section{Hotтоnia, 38.}

palustris (water violet. C. Ju. 21.) flowers whorled, subsessile : stem geniculate, with inflated joints. In stagnant water's.

\section{Houstovia, 34.}

coerulea (Venus' pride. O. b. \& w. M. 2.) stem erect, setaceous, diclrotomous : radical leaves spatulate ; cauline ones oblanceolate, opposite: peduncles 1-flowered elongated.

purpurea (C. P. p. Ju. 2 \%.) stem erect, branching above, pubescent at the knee joints : leares sessile, ovate, lanceolate or lance-linear : fascicles terminal, corymber.

longifolia ( $\mathbf{P}^{3}$. p. Ju. 24.) stem erect, rery branching, glabrous : leaves lincar: flowers ter:minal, fascicled, subsessile, often ternate.

\section{Hudsoxia, 60.}

ericoides (false heath. C. y. J. h .) heaves acerosesubulate, hirsute : peduncles filiform, solitary. Alout $\mathrm{g}$ inches high., 


\section{HoMULu', 99.}

lupulus (hop. 0. g-y. Au. 2 .) stem twining with the sun: leaves lobed. This phant is ralled an exotis by sone botanists. Inthuld jurge, from the will state in which I have scen it, that if it is esotic, it was introtuced by the holians: along with the oaks, pines and maples.

\section{Hyacintues, 50.}

orientalis (garlen lyyarinth. E. P. Ap. 24.) corol funnel-form. hall-6-ileft, veniricose at the base. muscruri (musk hyacinth. E. b. Ap. 2\%.) corols ovate, all equal.

bolryoides (grape hyacintl. ... b. Ap. 2' .) corols globose, uniform : leaves cylindric, channelled, strait.

comosus (purple grape hyarinth. E. p.) corol angular-cylindric ; at the summit sterile, long-peduncled, erect.

\section{HYDNUM, 11\%. *}

imbricatum (prickly fungis) on a stem, imbricate, convex, red-brown with darkel scales : stem pale-brown or brownish-white. repandum, convex, lobed, cininamon : prickles oblique, soft, cimmamon : stem poand. corculloides, whitish, much-branched : branches compresseal, deflected at the ends : prickles incurved: on a stem.

minimum, roundish, leathery or woody, stemless: prickles solt, pale to strong golfien, becoming grey.

chrysorhizum (paper punk.) yellow, membianacenus, stemless, spread : root golcien-ycilisw, filitorm, with intersecting branches ; extending far along the grains of decaying wond. The root of this fungus has been often noticed 
several yards in length; but Dr. J. Torrey, of New-York, was the first; I believe, who traced it to the pileus, and proved it a hydmım.

\section{HYDRaNgea, 58.}

rvulgaris (hydrangea. P. w. Au. 々.) ) leares oblongovate, olituse at the base, acuminate, tonther, glabrous beneath : cymes naked. A shrub about 5 fect high.

mirea (P. w. Ju. そ.) lcaves ovate, acuminate, toothed, snow-white down beneath, scrratures mucronate : cymes radiate.

Iydrangea, see Hortentia.

Hrdrastrs, 66.

canadensis (orange root. P.w-r. Ap. 4.) stem with 2 opposite leaves above ; leaves petioled, emarginate at the base, jalmate, serrate, gashell : peduncle terminal, solitary, 1-flowered. Rnots yellow.

\section{Hy DROCOTYLE, 45.}

Iımbellata (water nave] wort. P. M. 4.) leaves peltate, crenate, at the base cmarginate : umbels peduncled, many-flowered.

americana (0. ३-W. J. 4.) glabrous, tuberous : leaves subpeltate, orbicular, doubly-crenate: subumbeller glomerules few-llowered. Flowers rery small. Plant low and subprostrate.

roulgaris (I.g-w. J. 4.) leares mbiculat', peltate, slightly crente : scape interruptedly spiked, few-liowered.

bipinnata (bulhous pennywort. P. g-w. Ap. 4.) root bulbous: stem simple, 2-leaved, lateral leaf 5 -parted; divisions subpimate, leafets divider, terminal one sub-biternate : umbels terminal, 3 to 6-1lowered. Anthers dark purjple. 


\section{Hypropextis, 66.}

purpurea (water sliclu. II. C. Chatham, (NewYork.) Plainfieh, (Mass.) P. p. Au. 2\%.) lcares peltate, oval, entire: peduncles solitary, 1-flowered. The leares float on the surface of water, haring a long tlexible petiole. P'lant mostly covered with inucilage.

\section{HYDROPIYLLUM, S7.}

appendiculatun (waterleaf. P. b. M. 24.) very hirsute: radical leares subpimatifid, cauline one lobe-angled: sinuses of the calyx appendaged: the fasicles of flowers subpanicled. Calvx very hispid.

airrinicum (bur'-1lower. W. P. b. J. 24.) glabrous: leaves pimnate and pimnatifid, divisions lanceoral, gash-sermate : fascicles of the flowers conglomerate. The flowers have the appearance of a burr sereral weeks before they expand. canadense (rough burr-flower. W. P. p. \& w. Ju.

4.) hirsute : leaves lobe-angled : fascicles of the flower's crowiled. Resembles the last in some respects ; but the leaves are much larger.

\section{Hxoscrames, 39.}

miger (henbane. E. Ju. o .) leares clasping sinua ate : flowers reiny, sessile.

HYoseris, 8..

amplexicaulis (P. C. W. y. J.) radical leaves sublyrate, cauline ones clasping, lanceolate, entire. H. prenanthoides.

\section{HYPERICUM, 65.}

1. Flowers with 5 styles?

aseyroides ('St. John's wort. A. W. P. C. y. Ju. \&.) lierbaceous, glabrous : stem simple 4-corner yX 
ed : Ieares sessile, oblong, acute, glabrous : flowers terminal; styles of the length of the stamens : leafets of the calyx lance-ovate. Flowers very large.

puramidritum (Can. Ju. 4.) herbaccous, erect : stem abont 4-angled, branching: leares sessile, oblong, acute, glabrous : flowers terminal: styles shorter than the stamens: leafets of the calyx ovate, acute.

ilatum (P. Ju, 2\%. or Һ.) branches a-edged : leaves oral-oblong, obtuse, mucronate, narrowed at the base, flower's terminal, subsolitary leafets of the calyx oblong, acute : styles coadunate, nearly equalling the calyx, corol and stamens.

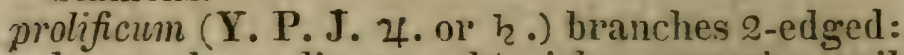
leaves lance-linear, obtusish : corymbs axillary and terminal, few-flowered : flowers at first sessile ; stamens and styles of the length of the petals : leafets of the calyx lanceolate.

2. Flowers with 3 styles,

angulosum (C. P. y-r. Ju. 24.) erect : stem 4-sided : leares oblong, acute, closely sessile : panicle terminal, dichotomous : branches divaricate, with distant, alternate flower's: calyx subcampanulate, divisions lanceolate, acute, kecled below, almost as long as the corol : pe- tals with a single lateral tooth. cunadense (N. C. W. P. Ju. s. erect, small flowered : stem 4-sided, dichotomous above : leaves sessile, linear, slender at the base : the branches of the panicle opjosite, the branchlets dichotomous: capsules long, conic, coloured. Capsules red.

sirginicum (C. N. P. Y. p. Au. భ.) flowers with 9 or 12 stamens, distinctly arranged in three parcels and separated by nectaries: leaves oval, obtuse, claspirg: stem compressed. Elodea campanulata. Pursh. 
pariflorum (0. y. Ju. ४.) erect, small glabrous; dirhotomous-1"anose, somew hat 4-sided : leaves ovate-oblong, subcoidate, obtuse, nerved, se'ssile : panicles terminal, dichotonous-corymbed: petals shorter than the lanceolate calyx. corymbosum (A. C. y. Ju. 24.) elect, glalurous, darkly-punctate: stem terete, branching: leaves clasping, oblong-oral, ohtuse : corymbs terminal brachiate, dense-fiowered : divisions of the calyx lanceolate, acute.

perforatum (0. y. J. 24.) erect, branching: stem 2-edged : leaves oblong: obtuse, transparentlypunctate : panicle terminal, brachiate, leafy : petals twice as long as the acute lancenlate callyx. This is the common St. John's wort, s!? troublesome to farmers.

\section{Hypxum, 108.}

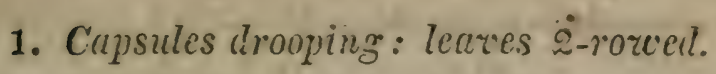

denticulatum (slecping moss.) Icares ovate, poin:ed, nervless, entire, close : capsule obloilg, lid conic.

serrulatum, creeping, much branched: leares ovate-lanceolate, pointed, scrrate, 1 -nerved at bottom, crowded, spread : lid awlform. ripurium, branched, spread : leaves orate, pointed, entire, 1-nerved, rather remote : lid conic.

$\therefore$ Capsules drooping : leares imbricate every rau.

splendens, doubly pimate: leaves lance-orate, pointed, concave, nerr! (css, cluse-pressed : capsule ovate, lid curverl.

delicatulum, procumbent, doubly-pinnate : leaves heart-lanceolate, pointed, S-nerved : lid awlform : tecth of inner fringe imperfiorate.

abietinum, pimate, compressed, villous: leares hearted, pointed, entire; 3-siriate, apyressed, lid conic. 
adnatum, creeping, with nearly simple branches : leaves oblong-lanceolate, concave, entire, nerveless, lid conic.

intricatum, creeping: leareselinear-lanceolate, pointed, serrate, 1-nerved at bottom : capsule ovate : lid conic.

serpens (IW. M.) creeping: leares lance-ovate, pointed, entire, 1-nerved at bottom : capsule cylindric : lid bossed.

filamentosum, branches numerous, interworen : leares orate, entire, 1-nervesl, appressed, capsule ovate : lid conic.

fittescens, procumbent, much branched: leares lance-pointed, S-nerved, entire : capsule cylindric: lid conic, pointed.

itlecebrum, with scattered obtuse branches : leares ovate-oral, concave, obtuse with a point, obsoletely 1-nerved.

cuspidatum, pinnate, cuspidate : leares oblongsiciti, cilspidate, entire, nerreless : lid conic, acute.

3. Capsulc drooying: leares spreading ercry ray. spiniforme (W.M.) erect, simple : leares linear awliorm, serrulate, ending in a bristle : capsule ovate: lid oblique.

- striatum, nuch branched: leares orate-deltoid, acute nearly entire, striate below: lid awlform, curved.

stellatum, erect, branched : leaves orate lanceolate, pointed, nerveless, entire : capsule cylindric : lid conic.

squarrosum, irregularly pinnate : leares heartovate, pointed, entire, nervless, incurved, keeled : lid conic.

4. Capsules drooping: leares falcate, pointing one way.

cupressiforme, prostrate, pinnate : leaves ovate. awliom, concave, nerveless, close imbricate : lid cuspiclate. 
commututum, procumbent, pimuate : leaves orateawlform, tortile, 1-nerved at bottom : capsule oblong, lid conic.

molluscum, procumbent, close pinnate : leaves ovate-awlform, close imbricate, nerveless : capo sule ovate, lid conic.

\section{Hxpoxis, 49.}

erecta (star-grass. Y. II. C. A. P. N. y. Ju. 2.)

pilose: scape $\approx$ or 3 -flowered: leares lancelinear : divisions of the corol lance-oblongs. graminea (C. Ju. 24.) pilose : scape 4-flowered: leaves long, grassy: divisions of the coro? lance-linear.

\section{Hrssopus, 68.}

afficinalis (hyssop. E. Ju. 24.) flowers whorled racemes one-way : intermediate division of the corol 2-lobed, entire : leaves lance-linear. nepretoides (giant hyssop. P. W. ; -y.Ju. 24.) spikea whorled, cylindric : styles shorter than the corol : leaves subcordate, orate, acuminate, acute. ly toothed. Near Williams College and in Pownal it grows from 4 to 7 feet high. scrophalarifolius (P.p. Ju. 21.) spikes whorled, cylindric : styles longer than the corol : leares lieart-ovate, acuminate, obtusely toothed. About; 2 teet high.

These two species seem to be the same. Tho species at Williamstown has the styles much longer than the corol; while its size, colour of the corol and the other character's, make it the nepes, toides. 


\section{I. \\ TBERIS, F to}

rimbellata (candy tuít. F. w. Ju. . .) leares lanceolate, acuminate ; lower ones serrate, upper ones entire.

\section{ILEX, 36.}

canadensis (mountain holly. W. Y. H. Catskill Mt. §̊-y. M. Һ.) leaves deciduous, orate, entire or a little serrate at the apex, glabrous: peduncles subsolitary, long, 1-flowered : fruit somewhat 4-sided. A shrub 5 to 5 feet ligh. Grows on the mountain northeast of Williams College.

Fpaca (evergreen holly. Y. C. H. P. g-W. M. 々̨.) leaves evergreen, orate, acute, spinose, glabrous, fiat : flowers scattered at the base of the shoots of the preceding year. A middle size tree.

Iaxiflnia (Connecticut? $\mathrm{g}$-w.J. h. .) leaves orate, sinuate-toothed, spinose, shining, flat : peduncles above the axils on the younger branches. An evergreen shrub. Berrjes yellowish red. I do not know that this grows in Connecticut. I saw the dried leaves only of a shrub from the southwest part of that state, which agreed with the above description.

\section{ILLECEBTRUM, 42.}

capitatum (head knotgrass. E. 4.) bracts shining, hidden under the terminal head: leaves ciliate, villose beneath.

IMPATIENS, 42.

Walsamiua (balsam weed. E. y. Au. O.) pedunclos aggregate, 1 -flowered: leares lancer. 
late, upper ones aiternate: nectary shorter than the flowers.

nolitungere (jewel-weed, touch-me-not. O. y. Ju.

๑.) peduncles many flowered, solitary : leares ovate, obtusely toothed : joints of the stem tumid.

biflora (speckled jewels. W. P. y. \& r. Ju. 6.) peduncles mostly 2-flowered, solitary : leavey ovate, sharply toothed. Is not this a variety of the last?

IMPERATORIA, 46.

ostruthium (masterwort. N. 2!, ) leaves ternates broadish, serrate. 'This plant grows wild about Northampton, and there appears no erdence of its being of exotic origin.

\section{INDIGOFERA, 79 。}

Linctoria (indigo. E. 々..) leaves pinnate, oblong"? glabrous, in four pairs : racemes shorter than the leaves : legumes terete, somewhat arched! From the East Indies.

\section{IYULA, 86 .}

Zlelenium (elecampane. O. y. Au. 24.) leaves clasping, ovate, rugose, tomentose beneati : scales of the caly $\mathbf{x}$ ovate.

falcata (C. y. S. 4.) woolly : leares sessile, linear, very acute : subfalcate, nerves hairy both sides: peduncles few, axillary, corymbed : caIy $x$ and peduncle villose, 5 or 6 inches high. mariana (C. y. Au. 2!.) villose: leaves sessile, lance-oblong, tapering to the base, obtuse, glandular-toothed, lower ones petioled, serrate: peduncles axillary, corymbed, glandular-hairy. About 12 or 14 inches high. arguntea ( $I, y, 2$. $)$ sillicy : leaves lanceolate, $S_{m}$ 
nerved, erect, zigrzag; corymb subcompound, erect: scales of the calyx flat, pubescent.

\section{IPOMAEA, 39\%}

quamoclit (jasmine bindweed. P. r.w. Au. (3.) leaves pinnatifid linear: flowers subsolitary; corol subtubular.

coccinea (Southern states. y-r. Ju. 8 .) pubescent :-

leaves cordate, acuminate, subangled : peduncles about 5-flowered : calyx awned : corol tubular : limb subentire.

tacunosa (P. w. \& p. J. \$.) glabrous: flowers cordate, acuminate, scrobiculate, angled at the base : peduncles short, about 1-flowered : calyx hairy: corol tubular, short : capsules hairy.

bona-nox (Southern states. w. Ju. (:).) very glabrous : leaves cordate, entire or angled : peduncle 1 to 3 -flowered: calyx awned : corol undivided, tube long.

nil (common morning-glory. P. b.Ju. (.).) hirsute: leaves ventricose 3 -lobed: peduncles short, 1 or 2-flowered: bracts subulate : calyx very villose, long-acuminate.

purpurea (L.J. . .) pubescent: leaves cordate, entire : peduncles 2 to 5 -flowered: pedicels nodding, thickened: dirisions of the calys lanceolate : capsules glabrous.

\section{InIs, 28.}

pumila (dwarf flower-de-luce. E. b. M. 4.) bearded : scape 1-flowered: leaves ensiform, glabrous : tube of the corol exsert : petals ob. long, obtuse.

prismatica (New-Jersey. p. Ju. 21.) beardless : stem solid, terete, equalling the leaves : leares. very narrow, long: capsules elongated, prismatic, acute at both ends. 
crisicuta (ladies" flag. Southern states. b. M. 24.) flower's with bearded crests: stem very short, compressed, about 1-flowered: leaves swordform, of the length of the flower : divisions of the corol equal.

virginica (wild flag, wild iris. 0. h. p. y.J. 21.) beardless : stem 2-crlgerl, many-flowered, tallcr than the ensiform leaves : stigmas shorter than the inncr petals : capsules oblong, with furrowed angles.

gracilis (Boston iris. Y. H. C. b. \& y. J. 4.) petals beardless, imner ones erect : leaves linear, flat : germ triangular, with 2 grooves on each side. Bigelow. I found this species in great plenty at New-Haven, in a meadow near the nortli sisle of Pine-rock, half a mile east of Mr. Lewis Bradley's. This species had been called a variety of the rirginica, until Dr. B. gave the specific distinctions.

ocholeuca (yellow iris. E. y. M.) beardless : leaves cnsiform, depressed, striate : scape subterete : germ 6-cornered. iernce (Southern states. b. \& p. M. 21.) bealdless, stemless, 1-flowered: leaves rery long, grassy, glaucous : tube long: petals sub-equal: capsules poundish, sessile at the ground. iersicolor (C. P. p. J. 4.) beardless : stem terete, zigzag, equalling the leaves : leaves ensiform: stigmas equalling the inner petals : capsules ovate, angles obtuse.

IsANTuds, 68.

cocruleus (blue gentian. C. 1'. b. Ju. (.)) viscidhairy : leaves lance-oval, acute at both ends, 3-nerved : peduncles 1 or 2 -fiowered.

\section{IsATIS, 73.}

tinctoria (woad. E. $\delta$.) radical leares crenate; cauline ones sagittate, oblong. 


\section{IsI0I0M, 114.}

daciylinus (coral lichen) effuse, rugged-warty, somewhat cracked, papillary-branched, white : warts long, cylindic, strait, clustered, solid, their tips becoming bromn and bursting in cracks : globules, when naked, a little cunvex. corcllinus, tartarous, areolate [like a garden bed] warty-branched, giey-white: globes of the branches of the same colour: globules punc. tiform, brownish.

westringii, tartarous, cracked, unequal, pale grey; in angular, naked and slightly branched patches : globules of the branches brown. L sed to form a red dye.

oculatus, leprous, papillary, white ; warts topform : globuies when naked plano-depressed, becoming conver, black.

\section{ISNARDIA, 35 .}

palustris (water purslane. 0. g. J. 24.) leaves ovate, crtire : fowers axillary, solitary, sessile. In water and wet places.

\section{ITE $1,42$.}

rirginica (itea. P. w. J. l., leares oblong, serrate. 4 to 6 leet high.

$$
\text { Iy A, S8. }
$$

frutescens (hig-water shrub. I. Y. C. P. g. Au, h.) leaves lanceolate, punctate-scabrous, deeply serrate : glomerules of florets globose, depressed. Somewhat shrubby, s or 4 feet high. Grows along the margins of salt marshes, dc. 
J.

J ASMINUM, 25.

fruticans (jasmine. E. y. $l_{2}$.) leaves alternate, ternate, simple: lcarets oborate, wedgeform, obtuse : branclies angled.

nfficinale (jasmine. E. W. h.) Icares pinnate, opposite : leafets acuminate.

\section{JEFFERSONI, 54.}

diphlylla (twin leaf. I. w. M. H. $_{\text {. }}$ stemless : pedincles naked, 1-flowered: leaves in pairs. Porlophyllum diphyllum. Lin.

\section{JegLANS, 94.}

1. Staminate ament simple, polyandrous.

regia (madieira nut. E. M. Һ.) leafets aloout 9, oval, glabrous, subserrite, subequal : firuit globose. Var. fraxinifolia, has 9 or 10 leaiets, oblong, scrate, smooth, lateral lower one adnate on the common petiole. It is said that this variety is indigenous to North America. nigra (black walnut. i’. C. M. b.) leafets numerous, lance-ovate, serrate, subcordate, narrowed above; petioles and under sides of the leaves subpubescent, fruit globose, with scabrous punctures ; nut wrinkled.

cinerea (butternut. $\mathbf{O} . \mathbf{M}$ h.) leafets numerous. lanceolate, serrate, rounded at the base, soft pubescence beneath ; petioles villose : fruit oblong-ovate, viscill. long-peduncied ; nut poughly sculptured. 'The bark is a strong cathartic.

¿. Staminate ament compressed, tetrandrous.

sulcata (P. M. 々.) leafets about 9, oblanceolate, acuminate, serrate, pubescent beneath ; the 
terminal leafet subsessile, tapering to the base : firuit roundish, 4-keeled : nut subglobose, a littie compressed, smooth, mucronate.

squarrose (shag-walnut, shag hickory. O. M. 々.) leafets about 7, long-petioled, lance-oblong; acuminate, sharply serrate, villose beneath, terminal one sessile : ament filiform, glabrous: fruit globose, drepressed ; nut compressed, oblique.

tomentosa (white-heart hickory. P. New England. M.. .) leafets about 9, lance-oblong, acuminate, slightly serrate, pubescent, scabrous beneath, terminal one subpetioled : aments filiform, very long, tomentose : fruit subglobose, smooth ; nut sub-6-angled.

amara (bitter nut. A. C. Y. P. M. 々.) leafets about 9 , ovate-oblong, acuminate, sharply serrate, glabrous both sides, the odd one shortpetioled: firuit subglobose, above the sutures are prominent; nut subglobose, mucronate, putamen brittle.

porcina (pig-nut. 0. M. 万.) leafets about 7 , lanceolate, acuminate, serrate, glabrous both sides; terminal leafet subsessile : fruit pearform, or globose; nut smonth, very hard. Var. obcoridata, has obcordite nuts. Var. ficiformis, has turbinate fruit.

\section{Junces, 51.}

\section{Culms leafless.}

effusus (rush-grass. O. J. 24.) culm strait : panicle lateral, spread, more than decompound: capsules obtuse. Resembles the Scirpus acutus in habit.

ucutus (New-Jersey. Ju. 24.) culm terete : panicle terminal : involucre 2-leaved, spinose capsules r'oundish, mucronate. Sea coast.

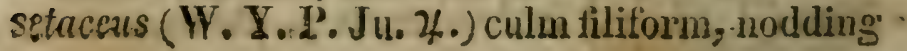


umbels lateral, compound, few-flowered : peduncles many-flowered : calys subulate. squarrosus (C. 2L.) leaves squarrose, setaceous e-panked : little heads terminal, glomerate, leafless. marginatus (C. P. J. 2!.) leares flat, glabrous: corymb terminal, simple, proliferous; little heads about 10-flowcred : callyx equalling the obtuse capsule. nudlosus (W. C.P. Ju. 2.) leares with notted joints, terete : corymb simple: little heads globose; rapsules acuminate, longer than the calyx.

\section{Culms lea y.}

jolycephalus (W. Y. P. J. 21.) stem erect, fewleared : leares with notted joints : little heads globose, many-fiowered, subpanicled : calyx linear, triandrous. Var. tennifolius has filiforme leaves.

sylraticus (P. Ju. 24.) culin erect : leaves terete, with notted joints : panicle more than decompound : leafets of the calyx awned, interior: ones longer.

fluituns (lloating recd-grass. P. Ju. 2\%) stem decumbent : leaves setaceous : flowers glomerate, whorled; glomerules leafy. ncuminatus (C. P. Jio.2.) culm leafy, erect: leares somewhat notty-jointed: panicle terminal, compound glomerules about 3 -flowered, peduncled and sessile : calyx slender, acuminate. 'Triandrous.

bulbosus (C. Ju. 4.) stem subrompressed, undivided : leaves linear channelled : cory mb terminal : calyx oftuse, shorter than the roundish obtuse capsule. On dry ground.

temuis (O. J. ४.) culm leafy, simple, teretish : leaves chamnied : corymb terminal, dichotomows, shirter than the bracts : capsule oblong, obtuse, shorter than the calyx. 
bufonius (W. Y. C. J. G.) culm leafy, dichotor mous: leaves angled, subsetaceous: flowers oblong, solitary, sessile.

spicatus (Whitehills. Au. Big*) leaves flat : spike racemed, nodding, compound at the base : capsules acute.

Remark. The three following species have been placed under genus Luzula by Willdemow, Desvoux and some other's.

pilosus (A. W. P. Ap. భ.) leares flat, hairy : co* rymb subsimple: peduncles single-flowered, nodding: petals ovate, acute, shorter than the capsule.

campestris (O. Аp. $\boldsymbol{\varkappa}$.) leares flat, with long fine hairs : spikclets peduncled, somewhat nodding, intermediate one sessile : leafets of the calys mucronate, longer than the obtuse capsule. melanocarpus (Whitehills. Ju.) culm leafy ; leaves broadish, sublanceolate, glabrous : panicle capillary, very lax : flowers distinctly pedicelled: capsules becoming black.

\section{JUNGERMANNIA, 109.}

1. Caulescent: branches compound, pinnate.

porella (false moss) branches flowering in the middle: Howers nearly sessile : sheaths inflated : leaves obovate. viticulosa, leaves tlat, naked, linear. polyanthos, leaves entire, imbricate, convex. scalaris, leares entire, orate, 2-lowed : extremity of the stem bearing the staminate flowers. lanceolata, fronds lanceolate: leaves entire : fruit terminal. bidentata, leaves ovate, 2-toothed. connivens, creeping, branched : leaves ovate, a little concave, cloven, with acute converging lobes: flowers terminal. 
bicuspidata, leares roundish, emarginate, s-rot. ed: flowers terminal.

¿. Caulescent : fronds imbricale.

complanate, creeping: leaves appendagest beneath, doubly imbricate : branches equal.

tamariscifolia, leaves doibly imbricate, roumbiahs appendamed beneath : stipules ovate, emarginate : fruit terminal.

tomentella, creeping, downy above : Icares cntire, downy.

pusilln, shonts reiy short, flowering at top: leaves imbricate, crenato on tho fore part.

\section{Stemless.}

Ppipiningui, leafet on the frond, pinguis, frond oblong, sinuate, slippers:

\section{JUNIPERUS, 101.}

sabina (savin. Can. h.) leaves opposite, obtuse, glandular in the middle, inbri ate four ways, delicate, acute, opposite. A low shrub in the; clefts of rocks. That which is cultirated is from Europe.

prostrata (american savin. 0. 々.) leaves opposite, acute, imbricate about 4 ways, smooth glaucotis: branches horizontal or prostrate. Fery plenty in Pownal, four miles north of Willians College. A shrub.

virginiana (red cedar, 0. M. $z_{2}$.) leaves in threes, adnate at their bases; in the young state they are imbricate, older they become spreading: Hardly a middle sized tree. communis (juniper. A. Y. N. Montgomery county. C. M. h.) leares in threes, spreading, mucronate, longer than the berry. On the sand plains, at the foot of Pine-rock, in New-Haven, a root of it olten sends off shoots, about 3 fẹet. 
in length, so close to each other, as to make a kind of mat 12 or 14 feet in diameter.

\section{JUsticiA, "26.}

Eulhatoda (malabar nut. E. p. 々.) leaves lanceovate : bracts ovate, nerved, permanent : helmet of the corol concave.

\section{K. \\ KATMIA, 57 。}

Zatifolia (lamrel. O. r. Ju. Һ..) lcares long-petioled, scattered and in threes, oval, smooth both sides : corymbs terminal, with riscid hairs. Generally 4 or 5 feet high. But on Catskill mountain it is found more than 20 feet high.

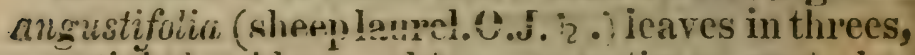
petioled, ublong, obtuse, sometimes rusty beneath : corymbs lateral : bracts linear : peduncles and calyx with glandular hairs. A shrub one or two feet high.

glunca (swamp laurel. P. N. Plainfield and Hinsdale, Mass. r. M. h.) branchlets 2-edgerl: leaves opposite, subsessile, oblong, smooth, glancous beneath, margin revolute : corymb terminal, bracted: peduncles and calyxes very glabrous.

\section{KRIGIA; 83.}

virginica (dwarf-dandelion. Y.C. P. N. y. M. ค.) smail : leaves lyrate, ylaucous, smoothish, ciliate: scape 1-flowered, twice as long as the leaves: calyx about 8-leaved.

KoHNIA, 84.

eupatorioilles (false boneset. P. ॠ. Au. 2/.) glab. 
rous : leares petioled, broad-lanceolate, serrate: corymb terminal, lew-fiowered, compart.

eritonia (P. Y. A 1. 2. ) pubescent: leaves narrowlancenlate, about 2-toothed below, petioled, punctate beneath; upper ones linear entire, sessile : panicle terminal, spreading.

\section{KyImingia, ? 8 .}

monocephala (false bog-rush. New-Jersey. 4.) culm filiform, 3-sided : hearls globose, sessile; involucres S-leaved, very long.

\section{L.}

\section{LACTUCA, 82.}

Bativa (lettuce. E. y. Ju. 9.$)$ leares loundish ; cauline ones cordate : stem corrmbed. Var. romana has oblong strait lea:cs, narrowed at the base. Var. crispa has sinuate-crenate leares, toothed, undulated, crisped ; radical ones hairy on the keel. Var. lacinata has the lower leares pimnatifid and the upper ones runcinate.

elongata (wild lettuce. 0. y. J. $\delta$.) leaves smootl beneath, lower ones runcinate, entire, clasping ; lowest ones toothed, highest ones lanceolate: flowers corymb-panicled. 3 to 6 feet high.

\section{LAMIUM, 68.}

garganicum (deavi nettle. E. 4 .) leaves cordate, concave : throat of the corol inflated, tube short.

purpureum (C. p. (-).) leares cordate, obtuse, tonthed, petioled, crowded at the top: stem nakedish downwards. amplexicaule (henbit, dead-nettle. Q. p. M. S.) L 3 
floral leaves sessile, clasping, gashed : radica! leaves lobed.

\section{LAPATHUM, 100.}

acetosellum (field sorrel. 0. g. \& p. M. 24.) leaves lance-hastate, auricled, entire. This and the next species are very properly separated in a section from the genus Rumex by Persoon. As they differ from the other species essentially in qualities and habit, as well as in being uniform$1 y$ dioecious, I have taken Persoon's section for ${ }^{2}$ a genus.

ncetosum (garden sorrel. E. భ.) stem elongated s leaves oblong, sagittate, acute, clasping.

\section{LATHYRU's, 79.}

şizapulaceus (wild ret chling. C.) stem winged, 4-cornered : stipules half-sagittate, ovate, acuminate, large : leafets in 3 pairs, oval-ovate, obtusish nucronate : peduncles 4 or 5 -flowered. 'Torrey. A new species, discovered by J. Le Conte, Esr.

palustris (C. Can. w-p. Ju. 21.) stem winged: stipules lance-semisagittate : leafets six, lancelinear, acute : peduncles about 3-flowered. myrtifolius (C. P. r. Ju. 4.) stem naked, 4-cornered : stipules semisagittate, lanceolate, acuminate : leafets 4 , lance-oblong, acute, mucronate, net-reined : peduncles longer than the leaves, about 3-flowered.

conosus (P.p. Ju. 24.) stem naked, 4-cornered: stipules semisagittate, ovate, acuminate : leafets numerous somewhat alternate, orate, obtuse, mucronate, veiny, peduncles 5, shorter than the leaves.

odoratus (sweet pea. E. J. (.).) peduncles 2 -flowered : tendril with a ovate-oblong leafets: le. gunes hirstte. 
latifolius (everlasting-peá. E. Au. 24.) peduncles many thowered : tendril with 2 lance-orato leaves ; membranaceous between joints. clymenum (various pea. E. O.) peduncles 2-flow. ered : tendril with many lanceolate leafets: stipules toothed.

articulatus (jointed pea. E. Ju. O).) pechuncles about 1 -flowered : tendril with many alternate lanceolate leafets : legume jointed. sativus (chick-retch. E. $)$ peduncles 1-flowered : tendrils with 2 and 4 leafets : legmues ovate, compressed with two narrow wings or the back.

\section{LAURUS, 55.}

camphoratus (camphor-tree. E. 々ุ.) leaves about S-nerved, lance-orate : panicle spreading. From Japan:

benzoin (spice-bush, fever-bush. O. g. y. Ap. 々.) leaves wedge-obovate : flowers in umbelled glomerules. A shrub from 4 to 8 feet high, spicy tasted.

sassafias (sassaîas tree. 0. y. M. দ..) leaves entire and lobed on the same plant. Size from a low shrub to a smallish tree. The bark of the root is very fragrant. The gum is useful for inflamed eyes. Silliman.

\section{Lavanduia, 68.}

- spica (lavender. E. Au. ४.) leares sessile, lancelinear, with revolute margins : spike interrupt= edly naked.

\section{LAVATERA, 77.}

ituringiaca (gay mallows. E. 4.) lower leares angled; upper ones 3-lobed, with the middlo one longest : peduucles solitary. 
arborea (tree inallows. E. S. $\delta$.) leaves 7 -angled? peduncles crowded.

\section{LECHEA, SS.}

major (pin-weel. 0. g-p. Ju. 4.) hirsute: leaves lance-oblong,mucronate : panicle leafy: branches bearing flowers at their tops : flowers in fascicled racemes, one way, short-pedicelled: stem erect. A dull unsighitly weed, in barren - fields, about one foot high.

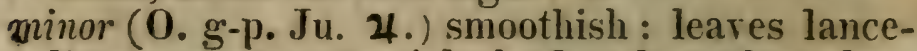
linear, acute : panicle leafy : branches elongated, bearing Howers on all parts : stem ascending.

racemulosa (C. Ju. భ.) pubescence close-pressed : leaves linear, acute, ciliate : panicle slender very branching, nakedish : flowers small, alternate, pedicelled : stem erect.

\section{LECIDEA, 112.}

\section{Frond crustaceous, uniform.}

incana, crust thin, somewhat membranous, grej glancous : spangles hoary.

lepiphaema, thin, milk-white : spangles very mi* nute, nearly palish-white.

muscorum, whitish, thin, somewhat mealy : spangles flat, margined, black, becoming hemispherir, confluent.

immersus, greyish-white, smooth : spangles im. mersed, margined, black ; becoming convex, deciduous.

parasemus, greyish, thin, uninterrupted, edged with black : sjangles black, flattish, margined, becoming convex.

lapicidus, tartarous, broad, a little rugged in the divisions, grey : spangles depressed, flattisb, 
crowded, becoming unerual angular and confluent, black.

albo-caerulescens, tartarous, equal, uninterrupted,

white: spangles raised, the disk flat, bluish-

white, frosty : margin becoming zigzag, black. corticolus, effuse, cracked, pure-white : spangles

flat, close-pressed, minute, crowded, becoming

somewhat globular, black, grey-mealy. muinosus, leprous, very thin, risty-red: spangles

plano-convex, deformed, bluish-black, mealy. icmadophilus, effuse, granular, unequal, jale, greenish-grey : spangles flat, flesh-colour, becoming dilated and a little convex, with a thin zigzag margin.

russula, rugged, garden-bed-like, white : spangles flat, deep red, becoming rusty-brown. obscurus, leprous somewhat nearly, blackishburown : spang!es margined, ditll iusty becoming blackish.

2. Frond crustaceous, imbricate or lobed.

luridus, imbricate : lobes orbicular, crenate, brownish-green, paler beneath : spangles black, becoming convex.

smithii, imbricate : lobes crenate, greenish, white beneath : spangles deformed, yellowish

3. Frond leafy, peltate.

postulatus, navelled, membranous, lobed, greenish-grey, blistered and warty abore, da!k olive and deeply pitted beneath : spangles flat, black ; margined, becoming plaited.

pensylvanicus, narelled, somewhat membranous grey-brown, wrinkled and blistered above, black-brown, pitted and gramular beneath: spangles flattish black with a margin some. what zigzag. 


\section{LEDUM, 57.}

palustre (marsh-tea. Can. w. M. 々.) leaves lî. near, margins revolute, iron-rust down beneath : stamens longer than the corol.

Latifolium (labrador-tea. I', Pittsfield, Mass. James. w. r.J. 々.) leaves linear-oblong, folded in at the margin, iron-rust down beneath : stamens mostly 5, equalling the corol. About swamps.

Ledium, see Leiophyllum.

\section{LeERST, 31.}

Ienticularis (white grass. Y. Ju: \%.) branches of the panicle sui-soirtary; spikelets imbricate : glumes orbicular, ciliate, large. Mr. Learenworth, a pupil of Prof. Ires, found this species three miles from Yale College. Heretofore it has been found only west of the Allegany mountains.

rirginica (cut grass. W. C. P. Ju. 24.) panicle scattered: spikelets spreading : glumes oblong-oval, keel ciliate. In water and wet ground. A very rough harsh grass.

LETOPHYLLCM, $5 \%$.

thymifolizm (sleek-leaf.) leaves orate, obtuse, glabrous; umbe!s terminal, head-form, sessile. From Ledum. Per.

\section{LeMra, 90.}

trisulca (duck meat. P.) leaves lanceolate, tapering into the petiole, adhering together crossform : root single.

minor (green duck meat. H. W. C. P. J. ().) leares round-oval, flat, adhering by their bases, 
a single root proceeding from the under side of each leaf.

frolyrhiza (water flaxseed. W. T. Ju. (.).) leares round oval flat, adhering by the basis : spreral roots proceed firom the under side of each leal in a fascicle. 'The leaves of this species become purplish and greatly resemble flaxseed, scattered on the surfice of the s! ut waters. 'The roots rarely reach the gre a ; but merely extend downivards a few inches into the water.The flowers proceed from fissures in the edges of the leaves.

\section{LEONTODON, 82.}

Peraacum (daudelion. 0. y. A p. 2l.) outer calyx reflexed : scape 1 -flowered: leaves runcinate, with toothed divisions.

\section{Leovurus, 69.}

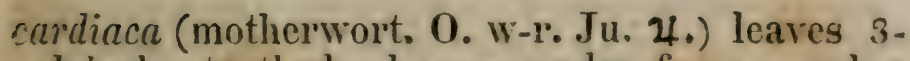
lobed, toothed, bases wedge-form : calys prickly, less than the corol.

\section{LEPIDIUM, 74.}

sativum (peppergrass, E. w. Ju. (-).) leares ob. long, many-cleft.

virginicum (wild peppergrass. Y.C.P.J. 辂) radical leares pinnatifid, cauline ones lance-linear, somewhat gash-serrate: flowers 4-petalled, mostly witl but two stamens: silicles lens-form.

\section{Jepraria, 111.}

shlorina (leprous lichen.) no visible frond; thick, deep yellow.

alba, crustaceous frond and fruit pure white. incona, crust thin, submembranous, grey-glancous : fruit hoary. 
butescens, leprous, a little cracked, rugged, yel-

lowish: fruit globular, of the colour of the frond.

fuva, thin, mealy, bright golden yellow.

\section{LePrathous, 28.}

graminea (floating $g$, ss-weed. P. y. Ju. 24.) leaves all linear. $($ ows in Fishkill and back of Newburgh. Torrey.

Leptanthus, see Heteranthera.

\section{LESKEA, 108.}

squarrosa, erect, slightly branched : leares 5rowed, reflexed : capsule oblong, inclined : lid subconic, acute.

attenuatum, simple, proliferous : leaves stellate, ovate, acute, entire, reticulate : capsule clavate, erect.

rnstrutum, simple : leaves obovate, spatulate, rery obtuse, minutely serrate: capsule orate, pendulous: lid subulate.

Lespedeza, 81.

şessiliflora, (bush clover. C. H. P. p. Ju. 2!.) erect : leaves oblong: fascicles of towers sessile, numerous : loment nearly naked, acute ; calyx minute.

violacea (C. H. Y. P. p. Ju. 4.) very branchy, spreading: leaves long-petioled : leafets oval, obtuse, with close-pressed hairs beneath : racemes short, umbelled : flower's in pairs : loment rhombic, reticulate, glabrous. procumbens (C. 1. p. y.J. ४.) procumbent, slender, hairy : leaves oval : peduncles long : legumes naked, with minute calyx. cripitata (N. C. H. I. Y. W-p. J. 4.) erect, sim- 


\section{I.ESPEDEZA, LIGUSTICUM. SOI}

ple : leares subsessile; leafets oral : spikes capitate, short-peduncled, axillary and in terminal glomerules : calys villose, of the length of the coiol: loment much smaller than the calyx. golystachia (W.N. P. Y. C. II. W-r. Ju. 24.) erect, branching, very villose : leaves subsessile ; leafets round oval : spikes axillary, long-peduncled : corol and loment about equal to the calyx.

\section{Listirs, 83.}

spicuta (gay feather. New Lebanon. P. C. r. Au. 4.) stem simple, tall : leares linear, glabrous, ciliate at the base, nerved and punctate : spike rery long: flowers sessile : scaices of the calyx linear-oblong, obtuse, close-pressed. scariosa (P. Au. น.) stem simple, subpubescent: leares lanceolate, tapering to both ends, glabrous with scabrous margins : calyxes squarose below, racemed, alternate, distant; scales spatulate, with membranous coloured margins. squarrosa (C. N. Y. P. Au. 2'.) stem simple, hairy : leares long-linear, nerved, margins a little scabrous : raceme few-flowered: scales of the calyx leafy abore, lanccolate, rigid, sprealing. zilosc (New-Jersey. p. S. นُ.) stem simple, pubescent : leaves linear, pilose, ciliate : calyxes racemed, laxish ; scales linear-oblong, obtusish : pedicels bracted.

alspera (C. p. Au. ४.) stem subramose, scabroushairy : leaves lance-linear, rough: calyxes short, spiked, distinctly alternate, solitary, sessile, scales round-obtuse, converging.

\section{Ligusticcm, 45. [Wrongly called exotic.]}

leristicum (lavage. smellage. E. w. 4.) leaves long, numerous ; leafets abore gashed. Strong scented. 
scoticum (Can. Ju. 4.) cauline leaves biternate, upper ones trifoliate; lateral leafets trapezoid, terminal one rhomboid: umbels stifly erect: involucres many-leaved.

acteaefolium (C. Ju. 24.) petiolês doubly 3-parted, secondary divisions with 2 or 3 leafets; leafets equally toothed : involucels setaceous : fruit oval, oblong-oval, subulate, 10-ribbed.

\section{LigestidM, 26.}

vulgare (prim. Y. C. P. w. J. 々.) leaves lanceolate, acutish : panicle compact. Common in the woods about New-Haven. Though it may have been introduced.

\section{Lurrum, 50.}

çandidum (white lily. E. w. J, 24.) leaves lanceolate, scattered, tapering to the base : corol bell. form, glabrous within.

,catesbaei (southern lily. P.y-r. J. 24.) leaves scattered, lance-linear: stem 1-flowered : corol erect ; petals with long claws, margin undulate, apex reflexed. About a foot high. superbum (superb lily. P. Y. A. C. Catskill. y. p. Ju. 21.) leaves lance-linear, 3-nerved, glabrous, lower ones whorled, upper ones scattered : flowers in a pyramid-raccme, reflexed; petals revolute. 3 to 6 feet high. canadense (nodding lily. 0. y. r. Ju. భ.) leaves remotely whorled, lanceolate, 3-nerved, subhirsute beneath at the nerves : peduncles terminal, longated, mostly in threes : corol nodding, raceme spreading.

philalelphicum (red lily. O. r. y. J. ४.) leaves whorled, lance-linear: stem about 2-flowered : corol erect, bellform, spreading : petals lanceolate, having claws.

„pennsylvanicu m (P. r. y. Ju. 4.) leaves scattered, 
lance-linear; the uppermost ones whorled. about equal to the flowers: stem about 1-flowered, somewhat 5 -sided : peduncles woolly : corol erect, woolly outside.

\section{Lrmnetis; 29.}

juncea (1rush salt-grass. Y. H. C. P. Ju. 2!.) leares 2-ranked, shortish, setaceous-convolute: spikes few, remote, spreading : calyx acuminate, keel rough.

polystachia (many-spiked saltgrass. Y. H. C. P. Au. 21.) spikes many (10) approximate on a scornered rachis, scabrous, short-peduncled: leaves flat, the margins scabrous ; sheath stri ate glabrous : one valve of the corol hispid on the keel.

glabra (Y. H. C.P. Ju. 24.) spikes 6 to 10, closepressed: rachis compressed and S-sided, glabrous, with sessile florets, leaves convolute, verved, pungent, glabrous : calyx and corol awnless. 'The genus Spartina. Roth.

\section{LMMODORUM, 89.}

zinifolium (limodore. New-Jersey. w.) having lut one leaf.

\section{LIMOSELLA, 71.}

subulata (mudwort. Y.) Ieares radical, cylindric, twice as long as the scape. Very minute. 'This is a new species, first discovered by professor Ives on the banks of the Housatonick, in the summer of 1816 ; and afterwards it was found by Messirs. Nuttall and Collins, on the banks of the Delaware. 


\section{LINDERTIA, 26.}

attenuata (lindern. C. P. b.Au. (-).) leaves repandtoothed : peduncles short.

dilatata (P. C. b. Au. (.).) leares oblong-ovate, obsoletely toothed, sessile : peduncles axillary, 1-flowered.

\section{LinsaeA, 54.}

borealis (twin-flower. W. P. N. Catskill. Plainfield, Mass. W-l'J. 2\%.) stem prostrate: branches erect, cach bearing 2 flowers : leaves roundish, crenate forward. Most of the Plainfield sjecimenss are didynamous.

\section{LINUM, 48.}

usitatissimum (flax. E. b. Ju. Ieafets of the calyx ovate, acute, 3-nerved: petals crenate : leaves lanceolate, alternate: stem subsolitary. wirginianum (wild flax. Y. N. C. P. W. y. Ju. ○.) leafets of the calyx acute : panicle terminal: flowers remotely alternate : leaves lance-linea!, scattered; radical ones ovate.

perenne (garden flax. E. b. Ju. 24.) calyxes and capsules obtuse: leaves alternate, lanccolate, entire : stems numerous.

\section{LIRUIDAMBAR, 95.}

slyrucifua (sweet-gum. C. P. N. Chatham, New-

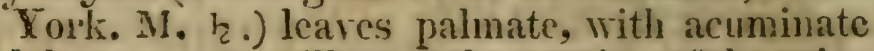
lobes, serrate, villose at the meeting of the reins beneath.

Liquiriti, see Glycyrrihiza, 


\section{LiRToDendRoN, $6 \%$.}

Eulipifer (white wood, tulip tree. A. N. Catskill. 1. y. r. J. Ł.) leaves truncate at the end, with 2 side lobes. A beautiful flowering tree. The timber is useful to cabinet makers. It is also a useful tonic. Sce Barton's Veg. Mat. Med,

\section{LTTHOSPERMUM, 36.}

officinale (stone seed, gromwell. P. y. M. 4.) seed smooth : corol scarcely. longer than the caly $\mathrm{x}$ : leaves lanceolate, veiny.

latifolium (P. $\mathbf{y}$-w. J. 21.) seed turgid ovate, shining, with hollowed punctures : calyx spreading, exceeding the corol : leares ovate-oblong, nerved.

arvense (steen-crout, wheat-thief. 0 . w. M. seed rugose : corol scarcely longer than the ca. lyx : leares obtuse, reinless.

\section{LOBEIX, 41.}

cardinalis (cardinal flower. O. r. Ju. 2\%.) erect, simple, pubescent : leaves lance-ovate, acuminate, erectly-denticulate : racemes somewhat one-sided, many flowered : stamens longer than corols.

lialmii (W. C. P. Ju. 훌.) slender, erect, subsimple: radical leaves spatulate, cauline ones linear, delicately toothed : flowers racemed, alternate, remote, pedicelled. pallida (0. b. J. 24.) somewhat hairy : stem erect, slender, simple : leares oblong-spatulate, toothed : flowers in a spike.

dortmannia (H. New-Jersey. b. Ju. 21.) radical leaves linear, recurved, fistulous, with two ca. vities, entire : scape simple, raccmose, somewhat naked ; flower's remote, peduncled. 
siphilituca (C. P. b. Ju. 4.) erect, simple, hirsufe with short hairs : leaves lance-ovate, subserrate : raceme leafy : calyx" hirsute, with reflexed sinuses. Flowers much larger than those of the pallida and inflata.

inflata (wild tobacco. 0. b. Ju. (.).) erect, branching, very hirsute : leaves ovate, serrate : racemes leafy : capsules intlated. puberula (P.b.Ju. 24.) erect, very simple, pubes. cent : leaves oblong-oval, repaud-serrulate : flowers spiked, alternate, subsessile : germs hispid : calyx ciliate.

claytoniana (C. P. b. Ju. 4.) erect, simple, subpubescent : leaves oblong, obtusish ; radical ones entire, cauline ones denticulate above : raceme wandlike : bracts subulate.

\section{LoLIUM, 32.}

perenue (damel grass. W. C. Y. P. N. H. M. ४.) spike awnless; spikelets compressed, manyflowered.

Iumulentum (P. New England. Ju. ○.) spikes awned ; spikelets compressed, about 6-flowered, equalling the calyx.

LONICERA, 40.

caprifolium (honeysuckle. E. Ł.) corols ringentlike, terminal, sessile : leaves connate-perfoliate at the top.

periclymenum (woodbine. F. J. 々.) flowers in ovate, imbricate, terminal heads : leaves all distinct. Var. quercifolia, leaves sinuate.

fraseri (Catskill MI. y.J. 々.) spikes with whorled heads : corol subringent-like with divisions oblong, obtuse : leaves ovate, glaucous beneath, with cartilagenous margin; upper ones connate-perfoliate.

srata (C, r, y.J. 々..) spike with whorls very neag 
each nther: corol ringent-like, with a long tube : leaves peremial, obovate, submucronate, net-reined and paler beneath, upper ones connate-perfoliate.

parriflora (W. Y. C. P A. N. y. J. 万.) spikes with whorled heads, subsessile : corol shortish, ringent-like, gibbous at the base : filaments bearded : leaves decideous, glauceous beneath, mostly commate, floral ones perfoliate.

semperiorens C. P.r.y. M. h.) spikes with distant, nakedish whorls : corols subequal, tube rentricose above : leares orate and obovate, glaucous beneath, upper ones comate-perfoliate.

hirsuta (rough woodbine. W. y.J. 々.) leaves hirsute. abruptly acuminate, lower ones obovate. This is a new species found by Mr.E. Washburn, a nember of the botanical class at Williams College, in the summer of 1817. It grows in great plenty on a hill two miles west of the college. It twines around trees from left to right to the height of twenty or thirty feet. I have been informed, that Mr. Le Conte had gathered the same plant in the state of New-York, before Mr. WY. found it in Williamstown.

Lonicera, see Diervilla and Xylostcum.

\section{LoDWIGIA, 35.}

alternifolia (secl-box. 0. y. Ju. (-) or 24.) erect, branching, subglabrous : leaves alternate, lanceolate, hoary beneath : peduncles axillary, 1. flowered : capsules 4 -sided: divisions of the calyx large coloured.

pilosi (New-Jersey. Ju. 2l·) erect, branchings hirsute : leaves alternate, oblong, sessile, hirsute, both sides: capsule with 2 bracts at the base. 


\section{LUNARIA, 73.}

annua (honesty. E. p. o.) leaves obtusely tooth ed : silicles oval, obtuse at both ends. rediviva (satin flower. E. b-p. 2/.) leaves with mus cronate teeth : silicles tapering to both ends. floweres odorous.

\section{LUPinUs, 78.}

gerennis (wild lupine. O.b. M. 24.) stem and leaves smoothish : leares digitate with about 8 to 10 leafets, which are oblanceolate, obtusish : calyxes alteriate, not appendaged : banner emarginate, keel entire. The keel terminates in a kind of beak when the flowers are first open. hirsutus (garden lupine. E. b. (-).) caly xes appendaged, alternate : banner 2-parted, keel 3-toothed.

pilosus (rose lupine. E. r. w. ๑.) calyxes appendaged, whorled : banner 2-parted, keel entire. butcus (yellow lupine. E. y. (.).) caly xes appendaged, whorled : banner 2-parted, keel 3-toothed. villosus (hairy lupine. Southern states. W. r.p. J.

4.) very villose : leaves simple, oblong : caJyxes not appendaged, alternate in a long spike:

banner 2-cleft, keel entire, long.

allus (white lupine. E. w. Au. (j.) calyxes not appendaged, alternate : banner entire, keel 3 a toothed.

LxCHINIS, 60 .

chalcedonica (scarlet lichnis. E.J.21.) flowers fascicled, level-top.

viscaria (clammy lichnis. E. 2 .) stem genicue late, viscous : petals entire : capsule 5-celled. glos-cuculi (ragged robin. E. 24.) petals torn : capsule 1-celled, roundish. 


\section{Lxcium, 34.}

barburum (matrimony. E. r. J.y. h.) stem angled ;

branches crect : leaves lanceolate, tapering to both ends : calyx mostly 3 -cleft. caroliniana (samphire buckthorn. Southern states.

p. J. そ.) stemless : leaves nar'ow-spatulate.

\section{LYCOPERDON, 118.}

borista (common puff-ball. 0 .) at first white, becoming black and spherical : outer coat downy, which pealing off leaves the leathery inner coat : seeds black, lighter than air, and appearing like smoke.

stellatum (starpuff-ball Y.A. N.) wrapper many. cleft, spread, stellate : head smooth with somewhat pointed mouth at the top.

pyyriforme, dirty brownish white: an inch and a half high : base tapering, top pointed.

\section{Lrcopodium, 105.}

\section{Spikes peduncled.}

clavatum (club-moss, O. g. Ja. Z.) stem crecping : branches ascending: leaves scattered, incurvebristle-bearing : spikes in pairs or single, cylindric : scales orate, acuminate, erose-dentate. complaniatum (ground pine. $0, \mathrm{~g}-\mathrm{y}$. Ju. 2'.) stem erect: branches alternate, dichotomons : leaves bifareous, connate, spreading at the tips: pen duncles 4-cleft, 4-spiked; spikes terrete.

2. Spikes sessile, leaves surrounding the stem.

dendroideum (tree-weed. O. g. Ju. 2\%.) stem erect : branches alternate, crowded, dichotomous, spreading; leares scattered, pointing 6 
ways, lance-linear, spreading: spikes solitar̂̀y terminal. L. obscurum.

annotinum (P. Can. Ju. 2/.) stem cleeping ; branches twice 2-parted, ascending: leaves pointing 5 ways, lance-lincar, mucronate, spreading and serrulate near the tips : spike solitary, terminal.

inundatum (C. J11. 24.) stem creeping, subramose ;

branches simple, solitary, erect, 1 -spiked at the top; spike leafy : leaves linear scattered, acute, entire, curved above.

alopecuroides (C. P. Ju. 2'.) stem creeping, sub. ramose ; branches simple, long, ascending, 1spiked at the top : leaves linear-subulate, ciliate-toothed at the base, spreading : spike leafy. selaginoides (C. Ju. 4) stem creeping : branches simple, ascending : leaves scattered, lanceolate, spreading, ciliate-toothed: spikes solitary terminal, leafy.

mupestre (festoon pinc. C. N. P. Ji. 24.) stem creeping, branching ; branches sub-dlivided, ascending : leaves scattered, lance-linear, ciliate with hairs at the apex : spikes solitary terminal.

\section{Spikes sessile, leares 2-ranlied.}

albidulum (P.Au. 24.) leaves ovate acute denticulate, alternate, close-pressed : spikes terminal, long, 4-sided.

apoduin (P. Ju. 2\%.) leaves round-ovate, acute, flat, denticulate; with superficial ones, alternate, acuminate : stem branching, rooting near the base : spike terminal, sub-solitary.

\section{Capsules axillary.}

lucidulum (moon-fruit pine. O. y.) leaves pointing 8 ways, lance-linear, denticulate, acute, reflexed-spreading: stem ascending bifid : fruit lunnlate. 


\section{Lrcopus, 26.}

europacus (water-horehound. C. Y. P.w. Ju. భ.) lower leaves gashed, upper ones lanceolate, serrate : calyx acuminate-spined. Flower's small, whorled.

virginicus (O. w. J. 4.) leaves broad-lanceolate, serrate, at the base narrowed and entire: calyx very short, spineless. Var. qucrcifolius, leaves sinuate-pinnatifisl.

mifiorus (W. w. J. 2\%.) leares lanceolate, subserrate, glabrous ; suckers procumbent. A low plant, with flowers mostly solitary. Mr. W. A. Hallock, found this species three miles north of Williams College. It was hitherto supposed to be confined to Canada.

\section{LxGowiuM, 105.}

palmatum (climbing fern. Granby. Miass. $\mathrm{g}^{-}-\mathrm{y}$. Au. 24.) stem climbing: leaves palmate, 5-Iobed; divisions lanceolate, obtuse; spikelets terminal, compound-panicled. This delicate fern was found in great plenty in Granby, by Mr. Eastman, a member of the botanical class of Williams College. It generally climbs to the height of about 3 or 4 feet. The hydroglosum of Willd.

\section{Lysmachia, 30.}

angustifolia (loosestrife. P. y. 21.) very glabrous, branching' : leaves opposite and whorled, linglinear, punctate : racemes terminal, short divisions of the corol oblong.

racemosa (0, y. Ju. 4.) rery glabrous, tallish: leaves lance-oval, opposite : raceme terminal, long, lax : dirisions of the corol oblong-orate. Otten bears bulbs in the axils of the leares. $L$. stricta. L. bulbilera. 
capitata (C. P. y. J. భ.) glabrous : stem very simple, punctate : leares opposite, sessile, broad-lanceolate, acute, punctate : peduncles lateral, elongated : flower's in compact heads. L. thy rsiflora.

quarlifolia (O. y. J. 24.) pubescent: leaves subsessile, oval, acuminate, punctate : whorled or in nearly opposite pairs, with axillary, 1 -flowered peduncles : divisions of the corol oval, entire. Near the outlet of the Bearer pond (New-Haren) I found this species with 2, 3, 4, 5, and 6 leaves together ; though Linneus allows but 4 .

ciliata, (0. y. J. 21.) subpubescent: leares oppo-

site, long-petioled, subcordate-oval, margin pubescent; petioles ciliate : pedicels somewhat in pairs : flowers nodding : divisions of the corol roundish, acuminate, crenate.

?hybrida (P.y. J. 2!.) glabrous : leares opposite, petioled, lanceolate, acute at both ends ; petioles ciliate: flowers nodding: corol shorter than the calyx; divisions crenulate.

\section{LYTHRUM, 60.}

salicaria (milk-willowherb. Can. New-England. p. Ju. 4.) pubescent: leares opposite and ternate, sessile, lanceolate, cordate at the base: flowers terminal, whorled-spiked : capsules oblong: stamens always 12. About two feet high.

verticillatum (swamp-willowherb. 0. p. Au. 24.) pubescent : leaves opposite, or in threes, lanceolate, petioled : flowers axillary, corymbed, aggregated somewhat in whorls: fruit globose : stamens often 10. A small island above Whitney's gun factory (New-Haven) is entirely covered with this plant, and the American dodder. 


\section{M.}

\section{Maginotia, 6\%.}

slanca (hearer tree. Cape Amm. C. P. w. J. h. lcares oval, glaucous beneath: petals obovate, tapering to the base. Var. latifolia, has obtusish leaves. Var. Ingifolia, has leaves acute at both ends. 'Tonic. See Barton's Veg. Mat. Med.

acuminata (cucumber tree. P. b-y. J. h.) leaves oval, acuminate, pubescent beneath : petals obovate, obtusish.

Iripetala (umbrella tree. P. w. J. 々 .) leaves large, oblong. wedge-oborate, acute, in the young state all over silky : petals 9, oval, acute, outer ones reflexerl.

grantliflora (big laurel, magnolia. Southern states. w. M. $h_{2}$.) leaves evergreen, oval, thick, leathery : petais broad obovate, abruptly narrowed into a claw.

\section{Mataxis, 89.}

ophioglossoides (adder mouth. P. M. 24.) Ieaves solitary, orate, clasping : scape 5-cornered : lip 2-cleit at the apex.

litiifoilia (twayblade. O.w. y.p. J. 24.) leaves 2, lance-ovate or oval; scape 3 -colnered : immer petals filifor'm, reflexed, two-coloured ; lip concave, oborate, mucronate. 'This species is often mentioned as somewhat rare. But I have seen hundreds in flower at one time along the north side of Pine-rock, New-Haven.

\section{MaxYA, 77 .}

americana (rough mallows. P. y. J. 5.) leaves I b b 
ovate, acute, toothed, scabrous : flowers axillary solitary, terminal, head-spiked.

cavaliniana (creeping mallows. Southern states.

r. Ju. ..) leaves 5-lobed or palmate, gash-tooth-

ed : peduncles longer than the petioles : petals

entire : fruit villose : stem prostrate.

rotundifolia (low mallows. 0. r.w. J. 2\%.) leaves

heart-obicular, obsoletely 5-lobed, peduncles

bearing the fruit declined : stem prostrate.

sylrestris (mallows. E. r-b. J. o. and 2\%.) stem

erect : leaves about 7 -lobed, acutish : peduncles and petioles hairy.

mispa (curled mallows. E. Au. D.) stem erect :

leaves angular, crisped : flowers axillary, glomerate.

moschata (musk mallows. E. 24.) stem erect : radical leaves reniform, gashed; cauline ones 5parted, pimate, many-cleft : leafets of the outer calys linear.

\section{Marchantia, 109.}

jolymorpha (brook-liverwort. 0. g-y. Ju. 24.) leares obtusely lobed: the calyx (or umbrella under which the flowers are placed) is about 10-cleft.

hemispherica (P.) calyx hemispheric, 5-cleft: stalk or stipe naked at the base. crucinta, calyx 4 or 5 -parted, segments tubular. 1 cornica, calyx couic, bossed: what appears to be staminate flowers are in sessile warts. tenella, calyx hemispheric, bossed: the margin has a kind of lamellar rays.

\section{Mariscus, 29.}

echinatus (hedgehog clubrush. C. Ju. 4.) culm Ssided, nearly naked, glabrous : spike ovateglobose : spikelets horizontal, 4-flowered : inrolucre 3 or 4 -leared : root globuse. 


\section{Marrubium, 69.}

vulgare (motherwort. O. w. Ju. 24.) leaves poundorate, toothed, rugose-rcined : caly $\mathrm{x}$ toothed, setaceous, uncinate.

\section{Marityia, 73.}

yroboscidea (unicorn plant. Western states. W. jo. $y$. Ju. @.) stem branching, leases altermate, cordate, entire, villose. Fruit somewhat gourdlike, with one long horn.

\section{Maschalocarpes, $10 \%$.}

julaceum (creeping moss.) ascending : leaves ovate, acute, nearly as long as the peduncle: capssule erect, ovate ; lid conic.

\section{Matricaria, 87.}

chamomilla (wild chamomile. E. W.J. O.) leaves doubly-pinnate : scales of the calyx obtusish.

\section{MEDEOTA, 52.}

virginica (indian cucumber. O. y. g. M. 24.) leaves whorled near the middle of the stem, and 3 together at the top, lance-oval : pedicels aggregate, terminal. Root white.

\section{Medrcago, 80.}

sativa (lucerne medick. E. Ju. 4.) peduncles. racemed : legume smooth, cochleate : stijules entire : leaves oblong, toothed.

lupulina (hop medick. Y. A. C. Y. J. (․) spikes oval : legumes reniform, 1-seeded : stipules entire : leaves obovate : stem procumbent. iribuloides (hedge-hog. E. ().) peduncles 2-flowered : legume cochleate, cylindric, flat both 
sides, aculeate, conic 2-ways, !eflexed : stipules toothed : leaves trothed, obovate.

scutellati (snail-shell, bec-hive, E. Ju. B.) peduncles about 2-flowered : legumes unarmed, cochleate in an orbicular form, with a convex base and flat top : stipules toothed : leaves oblong, toothed.

maculata (P. y. Ju. g.) peduncles about 2-flowered : legumes crichlcate, compressed both sides, aculeate, subulate, arched : stipules toothed leafets obcordate, toothed, spotted.

\section{Meesia, 108.}

longiseta (net-tooth moss) having a very long awi.

\section{Melampyem, 71 .}

americanum (cow-wheat. O. y. Ju. \%.) slender lower loares linear entire ; floral ones lanceolate, toothed behind : flower's axillary, distinct. latifolium (C.) leaves broad. I have no descrip. tion of this species, nor a specimen.

\section{Melintuivi, 52.}

airginieum (black flower. C. P. §-p. J. 4.) panicle pyramid-form : petals oval, subhastate, flat, with 2 spots : flower's mostly perfect. Flowers at first greenish-white, afterwards turn to dark brown.

vacemosum (bunch flower. P. W. J. 24.) panicles pacemed above, pistillate : petals roundish, having claws, undulate-plaited, hardly spotted, hirsute outside.

Melastou, 56.

masina (North America. Per.) leares 3-nerved, entire, broad-lanceolate, glabrous : panicles terminal, spreading. 


\section{Melis, 56.}

azedarcach (bead tree. E. h.) leares doubly-pinnate : leafets smooth, ovate, toothed. triflora (Whitehills. Au.) villose : panicle coarctate: glumes 3-flowered, with a small accessary appendage : florets awned. A new species discovered by $\mathrm{Dr}$. Bigelow.

\section{Melica, 31.}

speciosa (melic grass. P. J. Һ2.) panicle 1-sided : branches of the panicle solitary, 3 -flowejerl: stipules 2-cleft.

\section{Melilotus, 81.}

afficinalis (melilot. A. P. W. J. (3. or' oे.) steni erect : leares obovate, serrate : spikes axillary panicled ; legumes 2-seeded, rugose, acute? Grows wild about Albany.

\section{Metissa, 69.}

afficinalis (balm. E. w. b. Ju. u2.) flowers whorled half way around, subsessile : bracts oblong, pedicelled : leaves ovate, acute, serrate. nepeta (calamint. P. r. b. S. 24.) peduncles axillary, many-flowered, dichotomous-corymbed: leaves orate, obtuse, sub-serrate, somewhat glabrous : stem subhirsute : teeth of the calys about erual, glabrous.

MELoturia, 97.

pendula (creeping cucumber. P. y. J. ․ㅜㅇ.) leaves subreniform, lobe-angled ; terminal lobe equalling the rest: berry cylindrir, ovate. 


\section{Menispermum, 100.}

canadense (moonseed, Y. N. H. A. C. P. w-y. Ju 々.) stem climbing : leaves subcordate, roundangled, peltate with the petiole near the base. Though this plant is common in New England and New-York, it is rarely found in flower. virginicum (P. w. J. 々.) leaves lobed, cordate, pubescent beneath, subpeltate.

\section{Mentea 68.}

viridis (spear mint. O. w. J. 24.) spikes oblong, interrupted : leaves lanceolate, naked, serrate, sessile : stamens longer than the corol. piperita (peppermint. E.p. Au. 4.) spikes obtuse, interrupted below : leaves subovate, somewhat glabrous, petioled : stem glabrous at the base. grucilis (slender mint. P. w. b. Ju. 21.) flowers whorled : leaves lanceolate, subsessile : stem branching, erect : calyx at the base and pedicels, glabrous.

borealis (northern mint. O. w. Ju. 4.) ascending, pubescent, leaves petioled, lance-oval, acute at both ends : flowers whorled : stamens exsert. canadensis (Can.) flowers whorled: leaves lanceolate, serrate, petioled, pilose : stamens equalling the corol.

Menqantues, 38.

trifoliata (buck-bean. C. P. r. J. 24.) leaves texnate : corols densly bearded above. In stagnent waters.

Menyanthes, see Villarsia;

.

Menziesia, 54 ,

Ẽemilea (moụtain heath. Whitchills. r. Ju. h̨.) 
leaves scattered, crowded, linear, obtuse, cartilagenous-toothed : peduncles terminal, aggregate, 1-flowered ; flowers bellform ; calyx acute. Decandrous. Very small.

globularis (P. p-y. M. 々.) leares lanceolate, glaucous beneath, pubescent on the outer nerve: calyx 4-cleft ; flowers globose. About 4 feet high,

\section{Merulrus, 117.}

cormucopioides (veined toadstool) dull cinnamon, lobed, curled : vein running down to the root: stem grooved.

infundibiliformis, grey mouse-colour, funnel form :

veins silvery : stem compressed hollow.

cantharellus (iw.) yellow, becoming hollow, with an irregular, curled margin : veins decurrent: stem solid.

\section{MesembryanthemeM, 63,}

crystallinum (ice plant. E. w. Au. (.).) branching: leaves alternate, ovate, papillose : flowers sessile : calyx broad-ovate, acute, retuse. From Greece.

\section{Mespilus, 62,}

germanica (incllar. E. 々.) leaves lance-ovate, downy beneath : flowers sessile, solitary. pyracantha (evergreen thorn. New-Jersey.) leaves evergreen. I have no specific description of this plant.

Mikavia, 84.

scandens (climbing thoroughwort. P. Y. H. C. W Au. 24.) stem glabrous, climbing : leaves cor date, repand-toothed, acuminate, lobed, divaricate, uneriual ; flowers corymbed. 
melissaefolia (P. w. p. S. 4.) pubescent : stem erect: leaves ovate, crenate, sessile, pubescent beneath : corymbs terminal.

\section{Muidu, 30 .}

nigricans (african millet. E.) flowers panicled, crowded : valves of the calyx shining, becoming black : leaves ensiform, very long. cffusum (common millet. E.) flowers in whorled panicles, dispersed, awned.

ciliatum (millet grass. New-Jersey. C. Ju.) branches of the panicle solitary ; alternate, pubescent, erect : leaves with hairy nerves and ciliate margins: roots granular. Dr. Torrey aays this is the M. amphicarpon of Pursh.

Mrmosa, 76 .

sensitiva (sensitive plant. E.) prickly : leaves pinnate; the leafets in pairs, inmost ones minute.

\section{Mrmulus, 79.}

ringens (monkey flower. 0. b. Ju. 24.) erect, gla. brous : leaves sessile, lanceolate, acuminate, serrate : peduncles axillary, opposite, longer than the flower : teeth of the calyx acuminate.

alatus (C. P. b. Ju. 24.) erect, glabrous : leaves petioled, ovate, acuminate, serrate : peduncles axillary, oppo ite, shorter than the flower : stem winged at the 4 corners.

\section{Mirabitis, 41.}

jalapa (four o'clock. E. r. y. Ju. భ.) flower's deaped, peduncled: lcaves glabrous, 
Mitcheita, 34.

repens (partridge berry, checker berry. 0. w. J.) stem crecping : leaves roundish.

\section{Mrteixa, 58.}

diphylla' (currant-leaf. O. w. Ap. 4.) leaves coldate, sub-trilobate, dentate : scape ¿-leaved. prostrata (Can. w. M. 21.) leaves round-cordate : stem prostrate, leafy.

reniformis (Vermont. w. J. ४.) leaves reniform, repand, ciliate: scape naked.

cordifolia (P. w. 24.) leaves round-kidney-form, soinewhat doubly-crenate : scape setaccous, leafless.

\section{Maiva, 108.}

ventricosum (pricked-tooth moss) branches ascending: leaves lance-ovate, serrate at the top : capsule inflated, pendulous : lid convex, bossed.

hornium, simple : leaves lance-oblong, tooth-serrate, peduncle curved : capsule orate drooping : lid conic obtuse.

marginatum, simple : leaves lance-ovate, acute, serrate, thickened at the margin: capsules ovate, drooping: lid conic, pointed. cuspidatum, simple: leaves ovate, awned, serrate, capsule ovate drooping : lid hemispheric. punctatum, nearly simple : leaves obovate, obtuse ; entire, remote : capsule ovate, drooping: lid cuspidate. roseum, simple, proliferous : leaves orate, pointed, clustered, stellate, serrate at top : capsule oblong, drooping : lid convex. heterostichum, crect : divided leaves pointing oneway, \&-rowed, oblong obtuse, serrate at top: c apsule oblong, inclined : lid bossed, 
Remark. Muhlenberg piaces our Bryum conoideum and palustre under this genus.

\section{MoLutgo, s,s.}

rerticillatu (carpet weed. 0. w. Ju. (\%) 'stem subdivided prostrate : leaves in whorls, wedgform, acute: peduncles 1-flowered. Generally grows in gardens among purslain.

\section{MoMorpica, 97.}

balsanina (balsam apple. E. S. O.) pomaceous fruit angled, tubercled : leaves glabrous, spreading, palmate.

echinata (P. w. Au. (:).) pomaceous, fruit 4-seeded, roundish : setose-echinate : leaves cordate, 5-labe-angled, acuminate, entire.

MOXARDA, $2 \%$.

didyma (motintain mint. C. P. W ? r. J. 4.) somewhat glabrous : heads large, proliferous : outer bracts coloured, large, oblong, acuminate subentire : calyx and corol long : leaves broadovate, subcordate, acuminate, serrate, rugose; serratures mucronate: : stem glabrous.

Jialmiana (oswego tea. Oswego county. r. 2.) thinly hirsute: hoads large, simple : outer bracts coloured, lanceolate, slender : calyx and corol pubescent : corols very long : leaves oblong tapering, serrate, having thin scattered rough hairs all over : stem sharp-cornered ; stem and petioles ciliate hairy.

clinopodia (Can. P. y. p. Ju. 24.) glabrous : heads small, simple, terminal : outer bracts broadovate, acute, entire, smoothish : calyx ciliate, short : corol pubescent, slender : leaves ovateoblong acuminate, serrate, a little hairy : stem obtuse-angled, glabrous, 
cillintu (P. p. Au. 2.) hirsute: flowers small, whorled : bracts orate, glabrous, veiny, ciliate equalling the calys; leaves ovate-oblong, tapering, sub-sessile, serrate, subpilose : stem acute-angled ; hirsute.

oblongata (II ? P. W ? r. Ju. 24.) hirsute: head simple : outer bracts ovate, acute : caly $\mathrm{x}$ short, bearded in the throat, teeth spreading: stem obtuse-angled, hirsute above. M. allophylla. fishulosa (P. Can. 1). Ju. 24.) hirsute with scattered hairs : heads simple, jroliferous, leafy : outer bracts oblong, acute, glabrons : calyx long, bearded: corol hirsute, of middling length : leaves ovate, acuminate, serrate : petioles long, ciliate : stem glabrous, ohtuse-angled. migosa (Can. w. Ju. 2\%.) smoothish : heads simple, middling size : outer bracts oblong: calyx smonthish : leares orate, subcordate, acute, rugose, glabrous : nerves coloured and pilose beneath : stem acute-angled, hir'sute. menctrata (C. 1. y. J. 2f.) snoothish : flower middling size, wholdeil : bracts lanceolate, nerred, coloured, longer than the whorls : leaves iance-oblong, remotely serrate, glabrous : stem obtuse-angled, with whitish down.

pilos $u$ (C. J.) pabescent: heads lateral, slenderleaved : outer bracts linear, ciliate : corol pubescent : leaves lance-orate, obtuse, subentire. Torrey. A new species discovered by Mr. Le Conte.

\section{MoninA, 119.}

cnespitosa (bead fungus.) branched : spilses ternate.

\section{MoNoTropג, 58.}

hypopithys (yellow beech-drops. Can. P. y. J. 4.) scape spike-flowered : scales and flowers glab. rous outside ; lateral flower's octandrous. 
tanuginnsa (bird's nest. $0 . \mathrm{y}$-w. Ju. 4 .) scape spike-flowered : bracts and flowers all over woolly.

anifima (beech dropss. O. w. J. 2f.) stem 1 -flower ed ; flower nodding at first, at length erect : scales of the stem approximate. Whole plant irory white at first. Dr. Bigelow's morisoniana is undoubtedly this species. 'The diagnosis given by author's would very naturally lead lim into this crror. But the morisoniana grows only in the southern states. Torrey. irocera (A. $\mathbf{r}-\mathbf{y}$ Ju.) scape purple, very tall, manyflowered f flowers lateral and terminal, nodding; peduncles filiform longer than the flowers : lanceolate scales below, none abore. $\mathbf{A}$ hout 2 feet high, with the flowers in a terminal raceme. Found at Greenbush, by Mr. Edwin James; named and described by Dr. John 'Torrey.

\section{Morelues, 118.}

impudicus (morrel. O. y.) obtusely-conic, margin crenulate, top perforated: stem with a volva at the base.

esculentus (eatable morel. O.) ovate, cellular, margin attached to the stem : plaits undulate, growing' to each other.

\section{MoRds, 92.}

alba (white mulberry. E. M. $々_{\text {. }}$ ) leaves heartform with oblique base, ovate or lobed, unequally serrate, smoothish. From China and Persia. nigru (black mulberry. E. Ju. h.) leaves cordate, ovate, or sub-5-lobed, unequally toothed, scabrous. From Persia.

rubra (P. M. 々.) leaves cordate, orate, acuminate, or 3-lobed, equally serrate, scabrous, soft băir's beneath : pistillate spikes cylindric. 


\section{Mucor, 119.}

mucedo (common mold. O. b.) aggregated : head spherical, on a long stem ; bursting when brought from a damp place into the sun's rays.

\section{MUulenbergia, 31 .}

diffusa (dropseed-grass. Y. C. P. J. 4.) culm weak, branching ; branches and leaves glabrous : panicle compact : calyx 1-valved. crecta (woods dropseed-grass. W. C. P. Ju. 2\%.) culm strong, simple ; culm and leares pubescent : panicle lax : calyx 2-valved; awn long.

\section{MYAGRUM, 73.}

perfoliatum (gold of pleasure. E. (-).) silicle obcordate, suberose, spongy ; lower part 1-celled, fertile, upper part 2-celied, barren : leaveg clasping.

\section{Mrosotis, $5 \%$.}

scorpioides (scorpion weed. C. P. M. 2.) seeds smooth : calyx suboval, glabrous, about as long as the tube of the corol: stem subramose : lcaves lanceolate.

virginiana (W. C. P. w-b. J. (.).) pilose: seed prickly-bearded: leaves lance-ovate acuminate : racemes divaricate. Flowers small, leaves large.

arvensis (C. A. P. w-b.J.O.) seeds smooth : calyx oval, acuminate, very hirsute, fonger than the tube of the corol : stem very branching: racemes conjugate: leaves lance-ovate. Flowcr's sinall.

appula (W. C. A. Can. b. Ju. . . ) hispid : seeds prickly, bearded : leaves linear-oblong : stem stiflly branched. 
MYRICA, 98.

gale (sweet gale. P. C. Y. H. Plainfield, Mass, M. 々.) leaves wedge-lanceolate, obtuse, serrate at the apex : staminate aments imbricate; scales acuminate, ciliate: fruit in a scaly head. Very abundant at the margin of Crooked lake in Plainfield.

cerifern (bayberry. H. Y. P. g-p. M. 々.) leaves wedge-lanceolate, acute, with distant serratures at the apex : staminate aments lax, scales acute : fruit small, globose, covered with a whitish wax, in a mealy state. This is the bayberry tallow, which is obtained by melting it off in hot water.

caroliniensis (New-England. Pursh. M. h .) leares wedge-oblong, coarsely toothed: staminato aments lax; scales acute: berries globose, large. Three or four feet high. pensyicanica (C. P. M. 々.) leaves oblong acutish at both ends, entire or with a few distant serratures at the apex, margin revolute : staminate aments lax : scales acute : berry globose, large. Resembles the last.

MYRIOPHYLLEM, 94.

verticillatum (water milfoil. C. P. Can. Ju. 4.) leaves capillaceous, upper ones pectinate-pinnatifid : flowers all in axillary whorls : lower ones pistillate, upper ones staminate or perfect, octandrous. In stagnant waters.

spicatum (Can. New-Jersey. Ju. 24.) leaves all pinnate, capillacenus : spikes interruptedly naked : flowers staminate, polyandrous.

MrrRhIs, 46.

ilulcis (sweet cicily. O. w. J. 4.) leaves compound, hairy ; leafets pimatifid-lobed. There 
is still a defect in the description of this plant ; though attempts have been made to improve it. It has been removed to the genera Scandix and Chacrophyllum, without obviating the difliculty.

\section{Myrtus, 62.}

communis (myrtle. E. w. Ju. $\imath_{\text {. }}$ ) fiowers solitary : infolucre ¿-leated : leares orate.

$$
\text { N. }
$$

\section{NAJAS, 90 .}

canadensis (water-nymph. Can.) small, filiform, smooth : leares narrow-linear.

\section{NApaea, 77.}

laevis (false mallows. P. w. Ju. 4.) leaves heart5-lobed, glabrous : lobes oblong, acuminate, toothed : peduncles many-flowered : capsules awnless, acuminate. 2 to 4 feet high. scabra (P. w. Oc. 4.) leaves 7 -lobe-palmate, scabrous : lobes lanceolate, gash-toothed : corymus bracted : flowers dioecious.

\section{Narcisses, 49.}

psendo-narcissus (daffodil. E. M. 24.) spathe 1flowered : nectary bellform, erect, crisped, equalling the orate petals. tazetta (polyanthos. E. M. భ.) spathe many-flowcred : nectary bellform, plicate, truncate, thrice as short as the petals ; petals alternately broader : leaves flat. jonquilla (jonruil. E. M. \%.) spathe many flowered : nectary bellform, short : leaves subu. late. 
poeticus (poet's narcissus. E. 2'.) spathe 1-flowered : nectary wheelform, very short, scarious (red) crenulate : leaves inflexed at the margin.

\section{NARTheCIUM, 51.}

americanum (false asphodel. New Jersey. y. J. 4. racemes somctimes interpuptedly spiked, lax : one cauline bract clasping the perlicel, another chaff-bristleform below : filaments with short wool. N, ossifragum.

\section{NECKERA, 108.}

pennata, (strait-haired moss.) decumbent, branched : leaves 2-rowed, lanceolate, crowded : capsule ovate, immersed in the sheath. heteromalla, branched, diffuse : leaves ovate, pointed, -oncave, imbricate : capsules sessile, leaning one way : lid conic. macrapoda, decumbent, branched : leaves somewhat 2-rowed, lanceolate, rather concave : peduncles very long : capsules cylindric, erect : lid conic.

viticulosa, creeping: branches erect, nearly simple : leaves lance-ovate, acute : spread, a little undulate : capsule cylindric : lid pyramidal.

Nectris, see Floerkia. NELUMBIUM, 67.

Iutenm (nelumbo. P. y. Ju. 4.) leaves peltate, orbicular, entire : corol polypetalous : anthers linear above.

NeotTia, 89.

aestivalis (summer ladics' tresses. Y. P. W. C. W. J.) stem leafy : roots bulbs oblong, aggregate : leaves lance-linear : spikes spiral: flowers one. 
sided : lip crenate, crisped. N. tortilis. Ophrys aestivalis. Grows along the banks of the Hoosack, northwest from Williams College. cernua (nodding ladies' tresses. O. w. Au. 21.) leaves lanceolate, 3-nerved: stem sheathed: spike oblong, dense-flowered ; flower's recurvenodding : lip oblong, entire, acute. 'The high primitive mountains east of Pittsfield, Mass. exhibit patches, white with these tlowers, in 0 ct. and Nov.

pubescens (blood-vein ladies' tresses. O. y-w. Ju. 4.) radical leaves ovate, petioled, having coloured reticulate veins : scape sheathed ; scape and flower's pubescent : lip ovate, acuminate : petals ovate. The checkered radical leaves of this plant always attract attention early in the spring.

NEPETA, 68.

cataria (catmint, catnep. 0. b-w. Ju. 24.) flower's in whorled spikes : leares petioled, cordate, tooth-serrate.

NerIUM, 43.

oleander (rose bay, oleander. E. Au. $々$.) leaves lanceolate, narrow, ternate, ribbed beneath : divisions of the calyx squarrose : nectary flat, tricuspidate.

\section{Nicandra, see Atropa,}

\section{Nicotiana, 38.}

labacum (virginian tobacco. E. w-r. Ju. ().) leares lance-ovate, sessile, decurrent : flower's acute. rustica (common tobacco. E. Au. (:).) leaves petioled, ovate, entire : flower's obtuse. yaniculata (small-flowered tobacco. Au, (-) ) leaves C. . . 
petioled, cordate, entire : flowers panicled, olltuse, clavate.

\section{NIGELLA, 66.}

damascena (fennel-flower. E. M. 9.) flower surrounded with a leafy involucre. sativa (E.) pistils 5 : capsules muricate, rou gh lcaves subpilose.

\section{Noluxa, 38.}

jirestrata (E.) stem prostrate : divisions of calyx. triangular-saggittate.

\section{Nuphak, 65.}

lutea (water lily. C. P. y. J. 2!.) leaves cordate, entire, lobes near each other: calyx 5 -leaved : stigma repand, with 14 to 20 radiated lines, and a deep central hole.

Tialmiana (C. Can. y. Ju. 4.) leaves cordate, lobes near each other, calyx 5-leaved: stigma gashed with 8 to 12 radiated lines. Flowers small.

advena (O.y. Ju. 24.) leares erect, cordate, entire : lobes spreading asunder : calyx 6-leared : stigma with a slight central depression, and 13 radiating lines: pericarp furrowed. In stagnant waters.

\section{NxMPhaea, 64.}

ólorata (pond lily. 0. w. Ju. 4.) leaves roundcordate, entire, subemarginate, lobes spreading asuider, acuminate, obtuse : petals equalling the 4-leaved calyx : stigma with 16 to 20 radiating eretish lines. Var. rosea, has the flower purplish beneath, and the hind lobes of the leares acutish. 
Nrssa, 99.

villosa (pepperidge, tupelo. O. $\mathbf{y}$-g. M. h.) $^{\text {. }}$ leares oblong, entire, acute at both ends; the petioles, midribs and margins villose : pistillate petioles sub-3-flowered : nut short-aborate, obtuse, striate. N. multiffora.

biforr (sour-gum. C. M. Һ.) leaves ovate-oblong, entire, acute at both ends, glabrous : pistillate peduncles 2-flowered: drupe short-obovate; nut obtusely striate.

\section{0.}

\section{Obolaria, 70.}

rirginica (penny-wort. P. r. Ap. 2\%.) stem simple : leaves oblong, truncate, fleshy, purple beneath: flowers axillary, solitary, sessile.

\section{OстмUм, 70.}

basilicum (basil. E. . leares orate, glabrous: caly $x$ ciliate.

\section{Oexothera, 54.}

biennis (scabish, tree-primrose. 0. y. J. 今.) stem villose, scabrous : leaves lance-ovate, flat, toothed : flowers terminal, subspiked, sessile: stamens shorter than the corol. Phosphores- cent. Pursh.

parriftora (C. y. Ju. s. ) stem smooth subvillose: leaves lance-ovate, flat: stamens longer than the corol.

longiftora (P. y. o. or $\delta$.) leaves denticulate : stem simple, pilose : petals distant, 2-lobed: tube of the flower very long : capsule hirsute. grandiftora (P. y. Ju. s. $^{\circ}$ ) stem glabrous, branching: leares lance-orate, glabrous: stamens declined. Flowers very large. 
fruticosa (sundrops. C. Y.P.A. y. Ju. 24.) smoothish : leaves lanceolate, subdentate, acute : capsules pedicelled, oblong-clavate, angled.

muricutu (P. y. Ju. $\delta$.) stem purple, muricate : leaves lanceolate, flat : stamens of the length of the corol.

pusilla (P. Can. y. Ju. 24.) subpubescent: stem small, subsimple : leaves lance-oblong, obtusish, entire : flowers axillary at the top : capsules clavate turbinate, about equally 8-sided. chrscsantha (dwarf scabish. 0. y. J. थ.) stem slender, pubescent : leaves lanceolate, obtusish, flat, entire : tube of the calyx but half as long as the divisions : capsule clavate, acuteangled, mostly sessile. "Mr. Rafinesque has convinced me, that the plant, which Dr. Bige. low calls the 0. pumila, is this species." Torrey.

\section{Oldenlandia, 35.}

glomerata (round-head.New-Jersey. g-w. M. 3 .) procumbent: leaves lance-ovate : flowers axillary and terminal, heaped in a head, pedicel. led: germs hispid.

\section{ONOCLRA, 102.}

sensibilis (sensitive fern. W. A. C. Ju. 21.) barren frond pinnate, fertile one doubly-pinnate : stem glabrous. The leafets slowly approach each other, on squeezing the stem in the hand. struthiopteris (O. Ju. 4 .) fronds sinuate, doublypinnatifid, divisions roundish.

obtusiloba, barren frond pinnate; fertile one doubly-pinnate; stem scaly.

\section{ONoporndm, 83.}

scanthium (cotton thistle. H. p. Ju. s .) scales of the calyx spreading every way, acuminate: 


\section{ONOSMODIUM, ORCIIS.}

530

Ieares ovate-oblong, sinuate, tootherl-spinose, woolly. Dr. Bigelow says, this exotic is now vaturalized about Boston.

\section{Orosmodrus, 37.}

thispidum (false gromwell. Y. C. y-w. J. 2! .) very hispid: leaves lance-oval, acnite, papillose-punctate: divisions of the corol subulate. Very abundant on the barren plains between lolll's spring and Love's tavern, New-Haven.

\section{Opegrapha, 112.}

macularis (lettered lichen) crust almost wanting: clefts simple, roundish, convex, clustered in \& roundish black sput.

\section{Ophiogrossum, 105.}

vulgatum, (addertongue fern. C. P. M. 4.) frond orate, simple : spikes about an inch long: bulbosum (C. M. 2\%) root bulbous : frond heart. ovate, obtuse.

\section{OrChrs, 88.}

\section{Roots oval.}

ciliaris (orchis. C. Y. P. A. y. Ju. 4.) lip lanceoblong, pinnate-ciliate, twice as long as the petals : spur longer than the germ.

blephariglottis (New-Jersey. w. J. 2.) lip lanceolate, ciliate, of the length of the upper petal ; spur longer than the germ. Resembles the last.

psycodes (P. Can. y. J. 24.) lip 3-parted, divisions capillary-many-cleft : petals obtuse: spur filiform-clavate, ascending, of the length of the serm. 
eristata (C. P. y. J. भ.) lip oblong, pinnate-ciliate : petals round, 2 lateral ones toothed : spur shorter than the germ.

lacera (C. Y. H. A. g-w. Jî. 24.) lip s-parted; divisions subdigitate-filiform : spur about equalling the germ : flowers alternate. Perhaps the root is not oval.

discolor (C.Ju. 24.) lip 3-parted, longer than the petals ; lateral dirisions short acute ; middle one extended, spatulate : spur filiform, about twice as long as the germ : leaf one, radical, heart-ovate.

\section{Roots palmate.}

flara (P. J. Ju. 24.) lip 3-cleft, entire, middle dívision largor: spur filiform, of the length of the germ : spike elongated, compact : bracts longer than the flower.

fridentata (C. Y. P. w. J. 21.) lip lanceolate, 3toothed at the apex: petals obtuse : spur filiform, clavate, ascending, longer than the germ.

\section{Roots fascicled.}

fuscescens (Catskill Mt. P. p-y. Ju. 24.) lip ovate, toothed at the base : petals spreading : spur subulate, of the length of the germ : bracts longer than the flower's.

spectribilis (0. r. M. 4.) lip obovate, undivided, crenate, retuse : petals strait, lateral ones longest: spur clavate, shorter than the germ : bracts longer than the flowers : stem leafless. incisa (C. 1'. w-p. Ju. 4.) lip 3-parted, divisions wedge-form, gash-toothed, middle one emarginate : lateral petals obtuse, subdentate; spur subulate, ascending, of the length of the germ. Very tall.

rotundifolia ( $\mathbf{P}$ w.J. 24.) lip 3-cleft, intermediate divisions 2-cleft : spur shorter than the ger m, leaves round-oval. 
fimbriata (W. C. II. Y. p. Ju. 2t.) lip s-parted : divisions wedge-form, ciliate-fringed : lateral petals orate, toothed : spur filiform, clavate, longer than the germ.

orbiculata (W.C. A.P.g-w.J. 2.) lip linear, entire, obtusish : petals 3 , upper ones converging, $\approx$ lateral ones spreading, at the base oblique: spur longer than the germ : scape with \& flat, fleshy, shining, orbicular leares at the base. Very abundant near Williams College.

fissu (P. p. Ju. 4.) lip s-parted ; divisions werlgeform, toothed, intermediate one 2-lobed : spur filiform, clarate, ascending, longer than the germ. Tall.

dilatata (giant orchis. W. w. or g. J. 2/.) spur shorter than the germ : lip entire, linear, with the base clilateil, of the length of the spur: bracts of the length of the flower: stem leafy. This species grows in great abundance along the north sille of the Hoosack, near Williams College. In the mountains along Whitenak creck, the flowers are green; in the open mealows, white. It may be found in flower from 1 to 4 feet high.

\section{ORIGANEM, 70.}

vulgare (wilk marjoram. Y. A. P. r. Ju. 24.) spikes round-panicled, heaped : bracts ovate, longer than the calyx. majoranu (swcet marjoram. E. 々.) spikes roundish, ternate, compact, peiluncled : leaves petioled, oral, obtuse, smoothish. From Pales. tine.

\section{Orxithogilem, 51.}

ambellatum (star-of-bethlehem. E. M. 24.) flowers corymbed, peduncles higher : filaments dilated at the base. 


\section{Orobanche, 71:}

virginiana (false beech-drops, cancer-root. $0 . y$-p. Ju. 2.) stem very branching : flowers alternate, distant : corol 4-toothed. Flowers small. The whole plant is yellowish white, and of a naked appearance.

थniflora (squaw-root. 0 . p-w. J. 4.) scape naked 1-flowered: calyx without bracts: corol recurved. About 3 inches high, of a yellowish white colour. This plant does not agree with its generic characters. The calyx is 5-cleft, no lobed lateral leafets. The description ought to be improved.

americana (P. p-y. Ju. 2L.) stem simple, covered with imbricate lance-oval scales : spike terminal, glabrous : corol recurved : stamens exsert. About a span high : brownish yellow.

\section{Orontrum, 51.}

aquaticum (floating-arum. Y. P. C. y. M. 2.3 leares lance-ovate : spike cylindric, on a scape. Very plentiful in the west meadows, 2 miles from New-Haven.

\section{Orthotrichen, 107.}

anomalum (curve-hair moss) branched: leaves lanceolate, carinate, rather obtuse, revolute at the edges : calyptre hairy, toothed at the base. Peristome sub-simple.

striatum, branched : leares lanceolate, acute, carinate, spread: calyptre hairy. crispum, branched : leaves lance-linear, recurved and waved when dry : peduncles longer than the leaves, thickened at the top : calyptre hairy. 


\section{OlixzA, 51.}

sutiva (rice. H. ...) culm jointed : leares claspr ing : panicle terminal.

\section{Onyzopsis, so.}

asperifolin (mountain rice. X. P. N. Au. 24.) culm nakedish : leaves rough.

\section{Osmenda, 104.}

cinnamomea (fluwering fern. 0. y. J. 24.) frond donhly piomatifid; fertile ones distinct and panicle-racemed.

intermupta (0. g-y. J. 2\%.) barren leafets on the frond with the firtile ones, abore and below and someimes among them.

spectabilis ( $\mathrm{P} . \mathrm{I}-\mathrm{y} . \mathrm{J}$. 24.) firond doubly pinnate; leafets sharp serrate.

regalis (U. I-Y. J. 4.) frond bipinate, terminating in several racemes very branching and without hairs. Are these two last species the same?

\section{Ostrya, 95.}

vinginica (iron-wood, hop liombeam. O.g. M. 々.) leaves orate-ollong, subcordate, acuminate, unrqually scriate : strobiles oblong-ovate, erect: buds acutc.

\section{Oxilis, 59.}

acetosella (woodsorrel. C. W. P.W. r. M. Z.) stemless: scape 1-fiowered, longer than the leaves : leaves ternate, broad-obcordate with roumded hind lobes. riolacer (violet woodsorrel.I. A. C. p. J. भ.) stemDd 
less : scape umbelliferous ; pedicels subpubescent : flowers nodding: leaves ternate, obcordate, glabrous : divisions of the calyx callous at the apex : styles shorter than the outer stamens.

dillenii (yellow woodsorrel, 0 ?े y. J. e.) hirsute : stem leafy, erect, rongh-haired: peduncles umbelliferous, longer than the obcordate, ternate leares : petals emarginate.

stricta (yellow woodsorrel. 0 ? y. J. 0.) all over hirsute : stem erect, branching : peduncles umbelliferous, shorter than the petioles : leaves ternate, obcordate : petals oborate : styles of the length of the inner stamens. Will not the common yellow woodsorrel agree with both of these descriptions ?

corniculata (C. P. y. M. (.) all over pubescent: stem branching, diffused, or procumbent : peduncles umbellate, shorter than the petioles : leaves ternate, obcordate : petals wedge-form, erose at the apex ; styles of the length of the inner stamens.

\section{Oxycocets, 53.}

palustris (low cranberry. P. Catskill Mt. Can. x. J. h.) creeping: leaves oval, entire, margin revolute, subacute, glabrous, becoming white beneath : pedicels elongated : divisions of the corol oval.

macrocarpus (cranberry. O. r. J. 々.) creeping stem ascending; leaves oblong, entire, flattish, obtuse, glabrous, beconing white beneath: pedicels elongated : divisions of the corol lanceolate.

erythrocurpus (P. J. 々 .) erect : leaves oval, acuminate, serrulate, ciliate: pedicels axillary: corols long, at length revolute. 


\section{P. \\ Panax, 44.}

trifolia (dwarf ground-mut. W. C, P. A. w. भ.) leaves in threes, ternate or quinate ; leafets serrate, lance-oblong, subsessile ; root tuberous, roundish. Styles generally three. Root roundtuberous, and very deep in the earth in proportion to the size of the plant.

guinquefolia (ginseng. W. C. P. A. N. w. M. 24.) root fusifor'm : leaves ternate, quinate : leafets oval, acuminate, petioled, serrate. Larger than the last.

\section{Paeonia, 65.}

Efficinalis (Peony. E. r. J. 21.) leares decom. poind ; leafets lobed, lobes broad-lanceolate; capsules downy. Improperly called pina.

Panicum, 30.

crus-galli (barn grass. 0. Ju. (.) spikes alternate and in pairs, thick, sfiuarrose : glumes hispid, awned : rachis angled ; sheath glabrous.

glaucum (foxtail panic. 0. y. J. (.).) spike terete : involucels 2-flowered, fasicle-setose : seed transversely rugose. Var. laevigutum, has glabrous leaves and sheaths.

italicum (C. P.Ju. .) spike terminal, cylindric, nodding, compound, interrupted near the base ; rachis and peduncles pilose : bracts a little longer than the calyx, hispid upwards. viride (C. P. Ju. (-).) spike terete, subcompound, noddling, undivided : involucels (bracts) 10 to 15 , setose, solt : seeds nerved. The rachis is hirsute below the spise, furrowed and manycolnered. 
capillare (0. S. O.) panicle capillary, very branching, lax : flowes: minute, all pedicelled, solitary, oblong-ovate, acuminate, awnless : leaves and sheaths very hirsute. The rachis is angled. Branches of the panicle are opposite and alternate, jointed at the base ; branchlets ternate, nodding.

sirgatum (0. Ju. 4.) panicle very branching, wand-like : glumes ovate, acuminate, awnless, ?-flowered : leaves rery long, flat. The rachis, or main peduncle is coloured. Lower branches of the panicle are whorled, the others solitary.

latifolium (0.J. 2'.) panicle moderately spreading: giumes orate, acutish, subpubescent : leaves lance-ovate, clasping the stem with the base above the sheath, glabioits, broad; sheath pilose. The leares vary in brealth; but the broadest are lance-cordate. and enclose most of the few-ficwered panicle with the sheath when young. Willdenow calls this the Var. clandestimum. Muhl. makes it a new species.

nitidum (0. Ju. 4.) panicle capillaceous, branching : glumes striate, pubescent : sced shining: leares somewhat distant, lance-linear, bearcied at the neck of the sheaths : stem glabrous.

scoparian (C.P.J. 2.) panicle erect. compound, setaceous braicher; glmmes oborate, puhescent: leaves lanceolate villose. The silieatles are soft, and when young, glutinous. The lateral panicles are partly concealed.

firspidum (C.) sheath hispid, striate : spike compound, nodding; ; spikelets alternate, oblong, awned : rachis pilose, scabrous : calyx s-valved ; one very small and mucromate, the others nerved, hispid, awned.

geniculat:m (C. P. S.) culm glabrous, dichotomous, genticulate at the base; panicle diffuse, very bianching, dichotonous ; branches jointed at the base, scabrous, solitary : pedicels thickened or clavate under the calyx, scabious : 
one valve short, obtuse, sub-s-lobed ; the others acuminate, glabıous.

ramulosum (C. P. Ju. @.) panicles very small, lateral and terminal : glumes ovate, pubescent : leaves narrow, shortish, bearded at the throat. P. nodiflorum.

verrucosum (C.) culm with enlarged joints : terminal panicle spreading, lateral ones from the sheaths ; branches alteruate, solitary, divided, zigzag, glabrous : calyx 3 -valved ; one small acite, two others warty, 3-nerved. zuclteri (C. Can. Ju. O.) spikes alternate, erect, solitary, simple: glumes ovate, muricatehispid, awned; one awn rery long: rachis 3cornered : sheaths very hispid; leaves glabrous. Grows near salt-water.

agrostoides (C. P. Ju. 2!.) pauicles terminal and lateral, branching; branches distant, in threes, pair's and solitary, erect when youmg at length horizontal and reflexed, jointed at the base, scabrous ; branchlets scabrous, divided, closepressed, pedicels short: leaves keeled, glabrous.

zervosum (C.) panicle terminal ; branches numerous, spreading, glabrous somewhat zigzag: caly $x$ unequal, the small one ovate, acute, the other's acute nerved: leaves scabrous at the margins, ciliate at the base: sheaths long, striate, pubescent at the margin.

pubescens (C. P. J. 4.) erect, very branching, pubescent : panicles small, few-flowered, lax, sessile: glumes globe-orate, subpedicelled, pubescent. 'The branches of the panicle horizontal, zigzag.

macrocarpon (C.) culm erect; culm and sheaths pubescent; joints naked : leaves broad-lanceolate, nerved and glabrous both sides, ciliate: panicle subcompound, ramose, glaucous, largish, turgid, orate ; branches pubescent, striate. Le Conte. 
ambrosum (C.) slender, erect, small, glabrous : culm purple, joints naked: leaves remotish, spreading, lanceolate; sheaths ciliate : panicle smallish, simple : glumes ovate, glabrous, striate. Le Conte. A new species.

angustifolium (C.) culm glabrous, erect, joints naked : leaves glabrous, long-linear ; sheaths bearded at the neck: panicle few-flowered, long-pedicelled, largish, ovate, glabrous, striate. Le Conte. A new species.

barbatum (C. J.) erect, slender, glabrous; joints bearded : leaves lance-linear, distant, spreading, short; ; radical ones lanceolate, with ciliate sheaths : panicle sub-compound, racernose, glaucous, pubescent, striate. Le Conte. A new species.

Remark. The preceding 21 species have been collected in the vicinity of New-York, and analyzed by Dr. 'Torrey. I am indebted to him also, for the descriptions of the species of John Le Conte, Esq.

serticillatum (P. New-Jersey. Ju. (․) spikes whorled; raceines in fours : involucres 1 -ffowcred, 2-bristled; culms diffuse : leaves with scabrous margins and kecled glabrous sheaths. discolor (P. 3. 24.) panicle terminal, subsimple ; branches horizontal, in pairs and solitary, zigzag, glabrous ; florets all pedicciled : calyx 3 ralred, 1 -fiowered ; one valre minute and coloured : radical leaves abbreviated, those of the culm lanceolate, hairy at the base, margin crisped.

dichotomum (P.Ju. 21.) panicles perfectly simple, few-flowered, glumes obovate : leares lancelinear, divaricate, glabrous ; bearded at the hase and neck of the sheath : stem dichotomous. 'The lower joints are hairy, the "iper' ones glabrous. Radical leaves are lance-cordate, and abbreviated; those of the culm lancelinear, nerved, glabrous. 
elepanperutum (P. J.) panicle terminal, erect, few-flowered, (depanperate) branches in pairs ; one abbreviated 1 -flowered, the other a-flowered and twisted : Ieaves lance-linear, the lower ones abbreviated, the upper ones elongated. anceps (P.Ju. 4 .) erect : branches of the panicle simple, interruptcally racemed : sheaths twoedged, rough-hitired below: the perfect flower's have 2-valved corols, the staminate flowers have 1-valved corols.

\section{Papater, 64.}

qheas (wild poppy. Y. C. A. N. r. J. \%.) capsules glabrous, subglobose : stem many-flowered, pilose, with the hairs spreading: leares gashpinnatifid. This is usually considered as an exotic; if it was introduced it is certainly most effectually naturalized in many plares. mudicaulis (Can. $\mathbf{y} . \hat{\sigma}_{\text {.) }}$ (apsules hispid: scape 1. flowered, naked, hispid : leaves subpimate; leafets lanceolate, lower ones somewhat gashed.

somniferum (opium poppy. E.J. (.) ) calyx and capsule glabrous : leaves clasping, gashed, glaucous.

\section{Partétaria, 92.}

pensylranica (jellitory. P. J. O.) leares lanceoblong, veiny, with opake punctures : involucre s-leaved, longer than the flower.

\section{Parmelia, 115.}

1. Frond crustaceous; uniform.

atra (shield lichen) rugged-granular, unequal, whitish-grey : shields black, at length convex, with a white border becoming zigzag and crenulate. 
sophodes, nearly orbicular, granular, dull greygreen : shields crowded, flat becoming a little convex, black, with a margin somewhat tumid entire.

subfusca, very thin, contiguous, smooth, greyish white : shields sessile, scattered, rather convex, rusty-brown; margin greyish-white tumid, entire.

dispersa, scattered : unequal, lead-grey : shields scattered, minute, flattish, brown and blackish ; grey with a raised, whitish, crenulate margin.

effisa, effuse, thin, mealy, pale-brown : shields pale-brown, with a very thin greenish-yellow border, becoming convex, the margin vanishing.

caria, granular, unequal, pale greenish-yellow : shields crowded, flattich, brownish and variegated, with a slightly inflexed irregular brownish margin.

2. Frond foliaceous, somerohat membranous, dewressed, stellate, more or less imbricate, fibrous beneath.

\&quila, cartilage-membraned, somewhat stellate, tawny-brown, paler with dark fibres beneath : segments imbricate, very narrow, many-cleft, recurved elges, deffected and broader in the circumference : shields dark brown with a pa. ler crenulate margin.

saxutilis, membranous, glaucous-grey, somewhat stellate, roughish, net-pitted, black fibrous beneath : segments sinuate-lobed, imbricate, flat, somewhat truncate : shields bay, with a thin inflecteci pale crenulate margin.

conspersa (W.) membranous, stellate, glaucousgreen glabrous, dotted with black ; black-brows and fibrous beneath : segments somewhat imbyicate, lat, sinuate-lobed, cut-1'ounded-crenate: 
central shields bay, with an infiected margin nearly cutire.

stellaris, membranous, stellate, becoming plaitted-wrinkled, naked, grey, whitish with gley fibres beneath : segments somewhat linear, convex, many-cleft : shiclds flat, bluish-black, at length concave and decp black, with an inflected grey margin.

aipolia, membranous, stellate, glaurous-grey, nearly naked, black-fibrous beneath : segments flattish, wary, broader in the circumference, cut-lobed, crenate : shiclds flat, bluish, with a swelled inflected white entire margin.

anthelina, membranous, somewhat stellate, whitish, black downy beneath : segments flat, close-pressed, naked, ncarly lincar, many-cleft, obtuse, crenate : shields crowded, glaucous livid-brown becoming blackish, with a thin white entire margin.

pulverulenta, membranous, stellate, green-brown with a grey frost, black-downy beneath, segments somewhat imbricate, close-pressed, flat, many-cleft, rather linear, cut-rienate, a little retuse at top : shiclds flat, bluish, with a tumid involute entire margin.

olivacea, membranous, stellate, olive brown, shining, brownish and a little fibrous bencath : segments flat, dilated at top. rounded-lobed winkled and dotted : shields olive-brown, with an inflected crenulate margrin.

Liliacea, somewhat membranous, stellate, whitishglancous, a little frosted, blackish-brown with black fibres beneath : segments imbricate, rounded-lobed, sinuate-crenate, plaitcel, zigzag : shiclds brown, with an inflected nearly entire margin.

scortea, leather-membranous, stellate, grey-white shining, smooth, finely dotted with black, black-bristly beneath : segments somewhat imbricate, rounded-lobed, sinuate-crenate, zigzag. 
coperata, leather-membranous, stellate, ruggeaplaited, pale greenish-yellow, black-bristly beneath : srgments sinuate-lobed, rounded, slightly crenate : shields rather central, concare, chesnut, with an inflected crenulate mealy margin.

3. Frond leaf!; somerihat leathery, with rague lax expiacled lobes, rillose beneath.

perlata, somewliat leatlicry, expanded, glaucousgreen, smonth, black-biown and a little villous beneath; lowes powided, a little curled : shields cup-fom, dull red, with an entire margin. perforata, somewhat menbranous, expanded, glaucous, black-rillnse beneath, cut-lobed and fringed at the maigin : shiclds funnel-form, at length periorateí, rusi-colour, with an entire margin.

herbucer, somewhat membranous, expanded, smooth, bright-green, pale with brown down beneath ; Ioles cut crenate ; shields flattish, red-fulrous, with an inflected nearly entire margin.

4. Frond foliaceous, gela?inous, raviously formen.

pulchra, somewhat fleshy, thickish, greenish-blue, lobes s mewhat sinuate-rounded, unerual, entire, liexuous : shields scattered, pale rustcolour, with a tumid crenulate margin becoming convex and the colour of the frond. tremelloides, membranous, thin, lead-colour : lobes cut-sinuate, the segments rounded, complicate, wavy, entire : shields lateral, slightly pedicell. ed, scattered, flat, red with pale margin. lacero, some what pellucid, membranous, glaucousgreen : lobes rather erect, crowded, torn-ciliate: shiclds scattered, concave, red with an entire pale margin.

nitgrescens, membranous, of a single leaf, depress. 
ed. rugred and blistered, dark-green, with a roundrd lobed marg in : shiclds central, crowded, becoming convex, reddish-brown with an entire borreler.

furva, mrabrannus, rugged-plaited, granular both sides, gremish-black : lobes deformed, cut, rounder, wavy-curled, rather folded : shiclds scattered, flat, black-brown. tenux, imbricate, nearly orbicular, glaucus-green ; lobing flat-incumbent, roundish, unerualiy crea mate or palmate-lobed : shiclds scattred, a little imaresed, concave, with a nearly entire malyin.

fuscicuicuris, nearly nrbicular, clustered, blackgreen, with central erect anastunatising plaits ; lobes of the circumierence cut-crenate : shiclds marginal, top-pedicelled, clustered, dull rustcolour.

palmata, imbricate. pufferl, pale greenish-brown : segments somewhit membranous, linear, many cleit, somewhat palmate, zigzag, revolute and entire at the margin : shields scattered, reddish-fulvius.

submarginalis, lax, prostrate, sinuate, curled, with splicrical nearly margial dark green granulation.

5. Frond lenfy, membranous, depressed : segments linear, somerohat imbricate, vaulted, or inflected, at their tips.

physodes, glabrous, whitish, black-brown beneath, naked both sides : segments expanded, in many sinuate divisions, rather convex, a little inflated at the tip: shields red, with a thin inflected entire margin.

colpodes, pale-grey, black spongy beneath : segments divaricate, somewhat imbricate, in many sinuate defts : shiclds cup-form, dull brown, becoming dilated, with an inflected crenulate margin. 
enteromorpha, glabrous, white, black beneath; segments somewhat imbricate, lobed, obtuse, inilected : shields bay, cntire.

6. Frond leafy, mambrane-cartilaginous, tufted : segments rather erect, linear, tapering ; longitudinally channelled beneath.

ciliaris, greenish, glaucous-grey, naked and whitish beneath ; segments branched, linear, fibrillous at their tips: shields terminal, blackbrown.

leucomeli, naked, glabrous, white both sides, mealy beneath : seginents linear, branched, fringed with black on the margin: shields peflicelled, nearly terminal, flat, bluish-black with a white radiate margin.

$\therefore$ Frond spmewhat leafy, cartilaginous or leathery, segments erect or hinging, fat or cylindric-comspressed, pitted, taperings, bronched, nalied, glabrous.

fraxina. somewhat tufted, grey-white, glabrous both sides, rugged, pitted : segments flat, crect, linear-lanceolate, jagored : shields marginal and lateral, flat, pale.

fastigiata, leathery, tufted, glaucous-giey, glabrous, linear-pitted, slightly dividefi ; segments cylindric-compressed, thickened upwards, flattopped: shields nearly terminal, sessile, glatlcous-grey.

polymorpha, tufted, yellowish, glabrous, tornbranched, flat compressed or roundish ; longitudinal pits and oval warts scattered and terminal : shields flat, terminal, yellowish. chrysophthalma, tufted, orange-yellow, glabrous, jagged-divided and ciliate : segments erect, Hat, nearly lineas : shiclds terminal, orange, radiate. 
8. Frond filamentous, somerchat cartilaginous, brnached: filaments nearly cylindric, hanging or diffiuse.

usneoilies, cartilaginnus, glabrous, compressed, pale ; filaments hanging, somewhat fibrous, tapering; shiclsts marginal, slightly pedicelled, that, pale, with a thin entire margin. juluta. rartilaginnus, smonth, rather polished, cylindric, grey and black; filaments much branched, forked, filiform, the lower axils compressed : shiclds sessile, becoming convex, grey and black with an cntire margin.

Qhulybeiformis, filaments decumbent, shorter, rogucly-b:anched, rigial, ziģzag, interwoven, twisted, pitchy-black.

\section{Paxassia, 4\%.}

ilustris (false-plantain, parnassirs-grass. C. W. A. P. w-p. Ju. 21.) radical leares cerdate : nectaries many-bristled. The luristles or divisjons of the nectary are terminated by little licals, and have simewhat the appearance of stamens.

caroliniana (C. P. w-p. Ju. 4.) radical leaves suborbiculate : nectaries S-bristled.

\section{Paspalum, 30.}

seiaceum (paspalon grass. P. J. ․) spike single, slender : glumes round-obovate, glabrous : lcaves villose : culm setaceous, erect.

citiatum (P.Ju. 2l.) spikes alternate, somewhat: in pairs : glumes somewhat in three rows, paired, romil-obovate, obtuse, glabrous : leaves lance-linear, serrulate-ciliate: culm decumbent.

iaere (P.J. 4.) spikes many, alternate: glumes in two rows, roind-ovate, glabrous, smooth: Le 
Icares glabrous ; stipules ciliate; slieaths compressed : stem suberect.

stoloniferum (New-Jersey. Ju. थै.) spikelets long-

racemed somewhat whorled, spreading : glumes alternate, ovate, serrulate-ciliate, rugose transversely : leaves short, subcordate at the base: stem prostrate at its base.

\section{Passiflora, T6.}

lutea (yellow passion-flower. P.y. S. 4.) leares cordate, s-lobed, obtuse, glabrous ; petioles glandless : peduncles axillary, in pairs : petals twice as narrow as the calyx.

coerulea (blue passion-flower. E. b. Ju. h. .) leaves palmate, 5-parted, entire : petioles glandular: involucre 3-leaved, entire : threads of the crowu shorter than the corol.

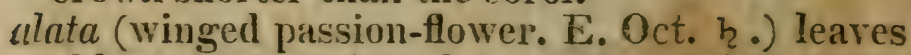
oblong-ovate, subcordate, entire, reiny ; petioles with 4-glands: stipules lance-falcate, subserrate : involucre 3-leaved : stem 4-cornered, unembranaceous.

\section{PASTINACA, 46.}

sutiva (parsnip. E. Au. $\sigma_{\text {.) }}$ leaves simply pinnate: leafets glabrous. Yar. urvensis, leafets subpubescent. This variety is often found in situations, which almost prove it to be indigenous.

\section{Pedicumaris, 72.}

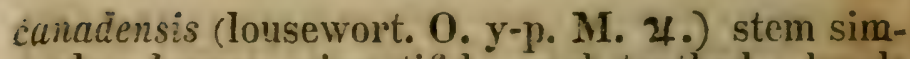
ple: leaves pinnatifid, gash-toothed : heads leafy at the base, hirsute: corol with a setaceous-2-toothed unper lip : calyx obliquely truncate. From 4 to 8 inches high ; gencrally sereral stems growing from one root. 
gladiata (hight heal-all. Y. A. C. N. Y-p. J. 24.) stem simple : Jeares laiscolate, pinnativid, toothed: sivikes leafy, with atwrinate fiorets. hirsute; caysules lengthened into an exsert, sword-mucronato form. Often 2 fict high. pallida (C. Y. y. Ju. 24.) stem ibranching, tail : leaves subepiposite, lanceolate, crenate toothed: spikes leafiess, glabrous : upper lip of the (iorol obtuse: calyx 2-clef: roumilish. From 2 to 3 foet high. If I do not misarply these characters, this snecies grows along the west sile of a mearlow, one mile northeast from love's tavern, New-Haven.

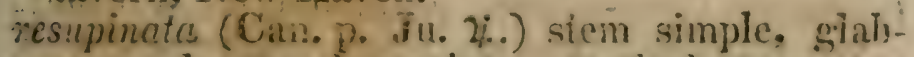
rons: leaves lanseolate, tinothes! crenate: calyx hifid truncate: uiper lip of the corol acuite.

sceptrum (P. y. S. 2.) stem simyie : leares pinnatilid ; repand-crentiate : calyx 5-cleit, crested : corol cloged.

\section{PEEATGOANIUM, T6.}

\section{Nearly stemiess; mol tuberous.}

triste (moirning geranima. F.) umisel simpin : leares rough-haired, pinnate: icafets bi-pinnatidid, dirisions oblong acute. Flowers dark green.

daucifolium (carrot geranium. E. 24.) scape very smiple: lares thrice-piniate, lursute : leaiets lance-iinear.

\section{Leaices simpie, not angied.}

aloratissimani (swect-scented geranium. $\mathbf{E} . h_{\text {. }}$ ) peduncles suib-5-llowerod: leares round cord. ăte, very solt. 


\section{Lenves simple, more or less angled or lobed.}

zonale (horse-shoe geranium. E. 々.) umbels ma-

ny-flowered : leaves heart-orbicular, obsolete-

ly lobed, toothed, with a coloured zume or band around near the margin.

inquinans (searlet geranium. E. r.) umbels ma-

ny flowered: leaves round-reniform, hardly

divided, crenate, viscid-downy. acerifolium (lemon, or maple-leaf, geranium. E.

h.) umbels about 5-flowered : leaves 5-lobepalmate, seriate; below welgefor m, undivided. capitatum (rose-scented geranium. L. h. .) flower's eapitate: leaves cordate, lobed, waved, soft : stem diffuse.

quercifolium, (oak-leaf geranium E. 々.) umbels sub-manyflowered: lcares cordate, pinnatiñd, crenate : sinuses rounded : filaments ascending at the apex.

grareolens (sweet rese-geranium. E. 々.) umbels many-flowcred, subcapitate: leares palmate-7-lobed; divisions oblong, obtuse, margins revolute.

\section{Peutidea, 115.}

rernosu, (target lichen) grey, white underneath with grey-brown downy hairs: lobes roundish divergent : targets anterior, marginal, horizontal, round, brown.

canina, expanded, greyish : whiter with brownish reins and fibres underneath: lobes oblong, large, broader outwards ; fertile ones scattered, marginal narrow : targets perpendicular, revolute, roundish, anterior, tawny-reddish.

scutata, expanded, grey, naked and veinless beneath : lobes rounded, gash-sinuate, curled at the margin ; targets marginal, orbicular, ascending, anterior, pale reddisk. 


\section{PELTIDEA, PENTSTEMON. SA}

polydactylos, expanded, glabrous, glanenus-grecr, reined with brown fibres beneatin : lohes iroundded digitate ; fertile ones marginal, long, crowleil, tapering: targets anterior, roundisin, revolute, ascending, black-brown.

aphthosa, expanded, glabrous, green with brown warts, nearly veinless, with black fibres and is bluish stripe beneath; lobes lax, rounded; fertile ones marginal, scattered narrow : targets anterior, ascending, round, red. hori $\approx$ ontalis, expanded, glabrous, glaucous-green, black-brown, reticulate with reins beneath : lobes oblong, rounded ; fertile ones marginal, short depressed : targets anterior horizontal, fransversely oblong, redulish brown.

\section{PENTHORTM, 59.}

secioides (virginian orpine. $0 . \mathrm{g}-\mathrm{y} \mathrm{Ju}, 2$.) stem hranching, angled : leares lanceolote, subsessile, uneryally and densly serrate: spikes terminal, panicled, alternate and cymed: seeds pitter.

\section{Pentstemon, 7 .}

pubescens (beard-tongue. W. A. C.P.W-p.J. 24.) stem hairy: leaves serrulate, lance-oblong, sessile : flower's panicled : the barren filament bearded from the apex to below the middle. Var. latifolia has broad smooth leaves. Var. augustifolia has narrow, hairy, obscurely denticulate leaves. From 1 to 2 feet high.

laerigata (P. A ? w-p. Ju. 21.) stem glabrous: leaves smooth, oblong-ovate, clasping at the base, slenderly toothed, lower ones entire ; flowers panicled : barren filament bearded above. Aljout o fect high.

Ee 2 


\section{Pertiploca, 43.}

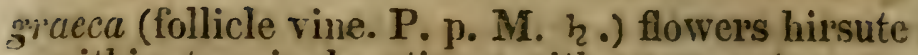
within, terminal ; stigma with 10 crenatures.

\section{Petalostemon, 77.}

Eandỉium (split flower. P. w. Ju. 4 .) spike cylindric, peduncled: bracts longer than the llower : calyx glabrous : leaves three-paired.

\section{Peziza, 118.}

scuttellata (d̊ish fungus.) sessile, fiat, orange-red, buff without ; margin convex, hairy. coccinea (scariet dish. 0 .) scarlet within and buffyellow withoit.

cinerea, sessile, grey, reflected : margin lobed, curled.

citrina, stem very short and nearly wanting: ycllow.

nurea, stem short: gold yellow, flat.

nchroleuca, stem blackish at the base: funnelform, leathery, lusky-ochre.

Phacelia, 39.

inipinnatifida (phacelia. P. b. M.) erect : leares pinnatifid, divisions gash-lobed : racemes mostly bifid, oblong, many-flowered : divisions of the corol entire.

fimbriata (P. b. M. O.) ascending, hairy : leaves sessile, pinnatifid : divisions lanceolate, acute, entire, hispid-pilose above, glabrous beneath : racemes solitary ; pedicels elongated : divisions of the corol ciliate-fringed.

sareiflora (P. b. M. O.) ditfused, pubescent: leaves subsessile, pinnatifid : divisions oblong, obtusish, entire : racemes solitary; pedicels short : divisions of the cornl round, entire. 
Pualaris, so.

arundinacea (ribbon grass, wild canary grass. W.

Y. P. Ju. భ.) panicle oblong, ventricose, coinpact: glumes acuminate, 3-nerved : leaves scabrous at the margin; sheaths striate. Var. picta, leaves variously striped-This varety is the ribbon grass of the gardens.

canariensis (canary grass. E. (-).) panicle spikeform, orate : glumes of the calyx boat-form, entire : corol 4-valved; outer ones lanceolate, glabrous, inner ones villose.

\section{Phascum, 106.}

crispuin (e arth moss.) caulescent : capsule nearly sessile : leaves lanceolate, pointed, curled when dry.

patens, caulescent : capsule about sessile : leares lance-orate, serrate at top, spreading. muticum, stemless : capsule sessile : leaves orate, without points, concave, converging.

scrvatum, stemless : shoots spreading, branched: capsule sessile : floral leares erect, lanceolate, scrrate.

\section{Phaseolus, $\% 9$.}

herennis (wild kidney-bean. C. P. p. Ju. 24.) twining, wholly pubescent: leares broad-ovate, the odd one subcordate: racemes in pairs, longer than the leaves : peduncles in pairs: bracts obsolete : legumes peduncled.

hiclrolus (C. P. P. O. Or 2 .) twining, a little rough-haired : leafets oblong-oval, subdeltoid, obtusish : heads of flowers long-pjeduncled : banner short, wings expanded, large : legumes terete-linear.

oulgaris (common pole-bean. E. p. w. Ju. O.) stem twining : racemes solitary, shorter than 
the leares : peduncles in pairs : bracts smaller than the calyx : spreading, legumes pendulous. From the East Indies.

coccincus (scarlet runner. E.) stem twining : ras cemes in pairs, longer than the leaves: peduncles in pairs : bracts obsolete : legumes pendulous.

nanus (bush-bean, six-weeks bean. E. (.).) stem erect, smooth: bracts larger than the calyx : - legumes pendulous, compressed, rugose. Seeds variously coloured.

\section{Phimadelphus, 61.}

coronarius (mock-orange, false syringa. E. w. J. 々.) styles distinct: leaves ovate, subchentate. From Asia Minor or Greece. inodorus (scentless syringa. Southern states. w.

J. 々.) leares ovate, acuminate, entire : divisions of the calyx acute: style undivided, lenger than the stamens; stigmas 4 , oblong. Flowers large.

srandiflorus (scentless syringa. Southern states. $w . J . h$.$) leaves ovate, acuminate, denticulate:$ axils of the reins with fascicles of hairs beneath: divisions of the calyz acuminate: style undirided, longer tlan the stamens: stigmas 4 , linear.

\section{Phleum, 31.}

jratense (timothy grass. O.J. \%. and t.) spike cylindric, very long, ciliate : culm erect.

\section{Prilox, 39.}

maniculata (smooth-stem lichnidia. P. r.w. Ju. \%.) glabrous, erect: leaves lanceolate, narrowing gradually, flat, margins rough : corymbs panicled: divisions of the corymb rounded: calyx awned. 
jiyramidalis (P. p. J. ४.) erect, glabrous ; stem scabrous: leares heart-ovate, acute : panicle fastigriate, pyramidal ; divisions of the corol wedge-truncate : teeth of the calyx suberect, lanceolate acute.

maculata, (spotted lichnirlia. P. r. w. Ju. $\frac{2}{\%}$ ) erect; stem spotted, scabrous : leaves lanceoblong, glabrous, margins rough : panicle oblong, flowers crowded: divisions of the corol rounded : tecth of the calyx acute, recurved. suaveolens (P. W. Ju. 4.) erect; stem very glabrous, not spotted : leaves lance-ovate, smooth : raceme panicled: divisions of the corol rounded: teeth of the calyx lanceolate, acute, erectish. Sweet-scented. aristuta (P. r. w. J. น.) weak, erect, viscid-pubescent: leaves lance-linear : panicle lax, fastigiate; pedicels somewhat in pailus: divisiuns of the corol somewhat oborate; tube curved, pubescent : teeth of the calyx long, subulate. jilosu (crecping lichnidia. Southern states. p). w.J. 21.) small decumbent, pubescent : leaves lancelinear, short, roughish : flowers subsessile and fascicled at the top: divisions of the corol round-obtuse, tube straitish, glabrous : tooth of the calyx subulate-acuminate.

diraricata (P. p-b. M. 24.) low, decumbent, pubescent : leares lance-oval, upper ones alternate : branches divaricate, lax, few-flowered: divisions of the corol subcordate : teeth of the calyx linear-subulate.

stolonifera ( P. b-b. J. 4.) stoloniferous-creeping; pubescent : radical leaves obovate-spatulate, cauline ones lance-oval : corymb spreading, few-flowered : divisions of the corol obovate: tecth of the calyx linear, reflexed. subulata (mountain pink. New Jersey. r. M. \%.) caespitose, white-pubescent : leaves linear, jungent, ciliate : corymbs fow-llowered, pe- 
licels S-cleft : dirisions of the corol, wedge iorm, emarginate: tecth of the calyx subulate, scalcely shorter than the tube of the corol.

sctacer (C. I. J. 24.) cacspitose, pubescent : leaves fascirled, subulate, pungent, ciliate : pedicels few. terminal, subumbelled ; dirisions of the corel wedge-form, cmarginate: teeth of the calyx subulate, thrico as short as the iube of the cont.

\section{PhrTMa, 70.}

Teplostachia (lopseed. 0. P. w. Ju. 2!.) Teares orate, coarscly serrate, petioled: spike terminal, slender : flowers opposite. As the fruit begins to form, it lops down against the rachis.

\section{Phimeanthes, 96.}

oborains (leaf-flower. P. J. O.) Teaves obovate, obtusish : flowers in pairs, axillary, pedicelled: stem erect, branching, terete. A span high.

Prixgatis, 40,

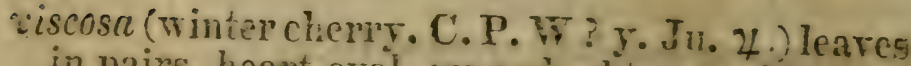
in pairs, heart-nval, "cisand, olituse, subtumentose : stem pasicled abore: linit-bearing calyx pubescent.

perisylranica (P. y. J. 24.) leares ovate, sulyepand, obtuse, nakedish : stem branching : peluncles solitary, a little longer than the per
tioles.

pililaticlphica (New England. y. p. 3u. O.) leares ovate, repand-toothed, glabrous : stem rery branching: pechucles solitary, much shorter than the petioles. lanceolata (P. .. J. 2.) Iraves in pairs, lance-oral, aubentire, gradually narrowing into the peti? 
vie, pubescent : stem dichotomous : calyx rillose.

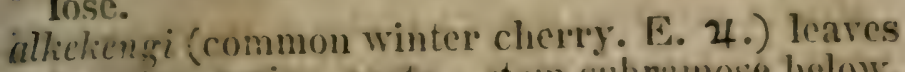
in pairs, entire, acute : stem subrumose below. Calyx of the fruit red or reddish.

\section{Phytoracca, 60 .}

deccudra (iolie weed. 0. w. Ju. น.) leares ovate, arnte at both ends : flowers retened, berries fiattened at the ends. A good substitute for tlate Iperac. Sce Bigelow's viedical Butany. T'iee young shoots, usied as a substitute for aspuraguis, are an excelient remedy in cases of habitual costiveness.

\section{Preris, S3.}

Theracioides (oxtongue. F. ž.) stem erect, scabrous : leaves clasping, lanccolate, toothed : flowers subcorymbed.

\section{Privus, 96.}

\section{Leaves solitury, with separate bases.}

balsamea (fir tree, balsam trec.0.M. . . .) leaves flat, emarginate or entire, glancous bencail?, suberect above, recurve-spreatling : cones cylinuic, erect : bracts abbreviated, jovate, long-niscronate, subserivulate.

friseri (double spruce. W. N. P.J. Ђ.) leaves solitary, flat, emarginate, glau o:is beneath, somewhat one-sided, thich above, erect : cunss orate-oblong, erect: bracts clongater, refiexed, wedge-oblong, emarginate, short mucronate, gash-trothed. Ibeiieve this species giows in all parts of the northern states. But $i$ had never observed, that this was distinct from the nigril, until last summer. 
nigra (black spruce. O. M. h.) leaves 4-sided, scattered on all sides of the branchlets, erect, strait: strobiles ovate ; scales oval, with undulate margins, erose-tonthed at the apex.

alba (white sprucc. O. M. h .) leares 4-sided, incurved: strobiles subcylindric, lax: scales obovate, entire.

canadensis (hemlock trec. O. M. 2.) leaves flat, denticulate, two-ranked : strobiles orate. terminal, scarcely longer than the leaves. 'The bark is used in tanning leather.

rubra (red spruce, spruce fir. Can. Now-England. 11. Ђ.) leaves solitary, subulate : strobiles oblong, obtuse : scales rounded, sul-2-lobed, margin entire.

:. Leares in pairs, rvith the bases bound together by sheaths.

resinosa (yellow pine, norway pine, red pine. W. Can. A. N. Catskill. M. 々.) leares and sheaths elongated; strobiles orate-conic, rounded at the base, subsolitary, about half as long as the leaves; scales dilated in the middle, unarmed. l3ark of a reddish colour and much smoother than the rigida and strubus. Often grows very tall and strait.

inops (jersey pine. C. M. h.) leares short: stro-

biles oblong-conic, recurved, of the length of the leaves: prickles of the scales subulate, strait.

banksiana (scrub pine, grey pine. District of Maine. M. h.) leaves short, rigid, divaricate. oblique, recurved, twisted: scales without prickles.

S. Leaves in threcs, with the bases bound together by sheaths.

rariabilis (threc leaved yellow pine. New-Eng- 
land? M. 1..) part of the leares in pairs, the others in threes, slender, chammelled : strobiles ovate-conic, sub-solitary; prickles of the scales incurved.

rigila (pitch pinc. O. M. 々.) leaves with ablureviated sheatlis : staminate aments crect-incumhent: stmbiles ovate, scattreel or asgregated ; spines of the scals redexed. Thinght very common, it grows the mest plentiluily on barrou sandy plains.

serutimil (pond pine. l'. Now-Jersey. M. h.) leares clongated : pitickles of the scales strait and rery sliniter. F'robably a variety of the last.

4. Leares in fires, with bases bouni together by sheaths.

shomus (whita pine. O. M. h.) leaves slender; sheaths short: strobiles pendant, cylindric, Ionger than the leares : scales somewhat lax. 'This is called Weymouth pine by the Engish. l'erlaps nine-tenths of the boardis, used in $\mathbf{N}$. Ariricica, are of this species.

\section{Leures many in a fuscic'e.}

jeiululi (black larch, tamarack, hack-matack. 0. M. 々.) leaves deciduons : strobiles obslong; margins of the scales inflexed : bracts guitarform with a slender point.

micracarpa (ied lapch. P. Can. MI. h.) leares decieluous: strobiles roundish, few-flowered ; scales reflered : bracts oval, obtuse, acuminate. These two last species were consiflered as varieties of the same ; but Mr. Lambert provred their specific difference by raising them fironit the sced.

larix (cominon larch. E. $h_{\text {. }}$ leares deciduous : strobiles ovate-ohlong; margins of the scales reflexed, torn : bracts gilitar-lorm. 


\section{Pisum, 79.}

zativum (pea. E. p-w. T. 9.) petioles terete : sti pules round and crenate at the base; perluncles many-flowered. Var. umbellatum, (bouquet pea) has the stipules 4 -cleft, acute. Var. quad"atum, (quadrate pea) fruit ash-colour, 4-sided. Var. hamile, (dwarf pea) stem erect, not climbing: leafets roundist.

maritimum (sea pea. Y. C. p-b. Ju. 4.) petioles flattish above: stem angled, decumbent: stipules saggittate : peduncles many-flowered. Ar. Rafinesque says, this may be the Vicia mitchilla. I have before me specimens of the latter, collected near New-York; and of the lormer, which I collected half a mile north-west from Whitney's gun-factory in New-Haven. They certainly appear to me to differ materialiy in some of their gencric and specific characters, particularly in the pubesence of their stigmas; though there is a very great resemblance in their habits.

\section{Pinftago, 34.}

major (plantain. 0. w. J. 24.) lcaves ovate, subdentate, subglabrous : scape tercte : spike oljlong, imbricate.

Ianceolata (ribwort. 0. J. 24.) leares lanceolate, villose : spike short, cylindric : bracts ovate, acuminate: scape angled, with close-pressed hairs.

virginica (dwarf plantain. T. C. P. r-y. J. . .) whitish pubesence on all parts : leaves lanceovate subdenticulate : flowers remotish : scape angled. The corol adheres to the germ so closely, that at first view it appears to be superior.

cordata, (P. N ? C. Can. w. J. H.) leaves hear- 


\section{PLANTAGO, POA.}

ovate, broad, subdentate, glalorous : spike very long; flowers subimbricate, lower ones scattered : brarts ovate, olstuse. panciflura (New-Englatnd. New-Jersey. Pursh. Ai. 24.) leaves lance-linear, entire, sub-glabrous: scape torete, shorter than the leaves: spike few-flowered, interrupted : bracts orate, acute, glabrous.

encullate (Bistrict of Maine. Iu. భ.) leares ovate, concave-cowled, 9-nersed, pubescent bencath : spike cylindric, imbricate : scape tall, terete.

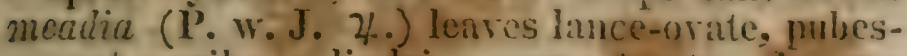
cent : spike cylindric; scape terete. In one variety the leaves are hirsute and the spikes branching.

maritima (H.Y. C. P. Au. 24.) leares fleshy subulate-linear, hairy at the base: scape terete, pubescent: spike cylindric: bracts obtuse. Near salt water.

\section{Peataxus, 95.}

occidentalis (button-wood, american planetree, false sycamore. $\mathrm{O} . \mathrm{J} . \mathrm{H}_{2}$.) leaves quinquangular, obsoletely lobed, toothed : stem and branch. es becoming white. Grows to a greater size than any other tree in America. Very frequently hollow.

\section{Poi, 32.}

protensis (common meadow grass. 0. M. 24.) paikicle spread : spikelets about 4 -flowered : ghlumes lancolate, 5-nerved, comnected by down : stipales abbreviated, outuse.

compressa (blue grass. (). J. 24.) panicle compact, sumewhat 1 -sided, glabrous : culn commessed, hardly erect : liorets angled, connectoil at the base by entangled hairs ; loranches of the panic le in pairs, abbreviated : spilielets sessile. Ront crecping. 
palustris (swamp mcadow gुrass. C W. M.91.) branches of the lanicle aggregated, five, glabrous; branrlilets scalrous with all the florets perlicelled : calyx 2 -flowered ; valves cqual, acuminate, scahmus at the keel: colol with the apex of the valres yellowish and the base pubescent: leares sonewhat clasing ; stipules orate. quinquefida (giant mearlow grass. P. C. W. J. 21.) panicle erect; lower branches naked beneath : spikelets fliong, alternate, subsessile, 6-flowered: outer raive of the florets on the back beneath, and the margin viliose, and 5 -cleft at the apex: the neck of the sheath and the axils of the panicle pilose : leares and the erect culm glabrous. It grows three or 4 feet high in wet meadows neap Williams College.

annua (C. M. M. P. panicle spreading: spilielets orate : florets remotish, 5-nerved, free (libera): culm oblique, compressed.

nervata (C. I. J. 24.) panicle equal, diffused spikelets ovate, 5 -flowered: flowers free, $\%$ nerverl, obtuse: culm sulcate, subarigled: root a little ereeping:

tenella (C. Ju. Q.) panicle capillary, somewhat whorled: peduncles zigzag : spikelets linear, abont 6-flowered, pedicelled : flowers oblong, acute, minute, gla!rous : leares short, fiat, subulate at the apex, glabrous : sheathis bearded at the neck: culm decumbent.

hirsuta (C. 1'. Ju. 2'.) panicle capillary, rery branching: spikclets scattered, long-pedicellcl, about 5-llowered: flowers cblong, acute, glabrous : leares longer than the culm, glabrous ; sheaths rery hirsute : culm thick, erect. Irerifolic (C. W ? P. M. \%.) panicle lax; branches in pairs, horizontal, zigzag at the apex, or in threes, glabrous: spikelets all pedicelled; the pedicells jointed at the base : calyx 2-ralvcd, 5 or 4 -fiowerer!, valres acute : corol with one valve keeled, 5-nerred, lubescent : culm 
subangled, erect: lower leares abbreviated, kecled.

virilis (C. I'.J. 4.) panicle spreat ; branches of the panicle aggregated, divided into 4 to 6 parts, jointed at the hase : spikelets ovate acuminate, about 4-flowered : glumes lancelate, S-nerved, scabrous on the keel ; stipule abbre. viated, retuse, crenate, truncate. capillaris (C. P. Can. J. (2).) pancile lax, capillary, very spreading: spikelets 3 to 5 -flowered: flowers ovate, acute, pubescent : leaves hairy at the nerk: calm very branching.

trivialis (W. P.J. 21.) panicle sprearling: spikelets 3-flowered : glumes lanceolate, 5-nerved, connected at the base by down : stipules elongated.

nemoralis (IF ? J. I.) panicle and leaves slender : spikelets lancenlate sub-3-flowered : glumes acute, obsoletely 5-nerved: stipules very short, crenate.

sesleroides (P. Au. ४ ) panicle erect when young": becoming lax and nodding when old ; rachis and branches zigzag: branches in pairs and alternate, jointed and hairy at the base; branchlets very short, alternate, terminated by the oblong spikelets : calyx about 5 -flowered, mucronate; one value of the corol keeled, mucronate, 3 to 5 -cleft. P. flava.

aquatica Cau. P.J. 21.? panicle erect, half-whor]ed: branchlets zigzag: spikelets orate, 5flowered, thick : fiowers obtise, glabrous, 7 nerved : culm erect, glabrous, terete.

parriflora (C. P. Ju. 2\%) panicle spread, capillary, half whorled, very branching: spikelets sinall, about 4-flowered : flowers oblong, subacute, delicately striate : leaves two ways, exceeding: the culm, glabrous: stipules Ianceolate, acuminate.

pectinacen (P. New-Jersey, Ju. ค.) panicle lax, spreading, crect : spikelets linear, 12-Hower. Ff 2 
ed: inncr ralves of the florets remain, after the remainder of the flowers are removed, and give rachis a comb-like appearance : flowers ovate, acuminate, 3-nerved : neck of the sheath and axils of the panicle pilose: leaves and erect culm glabrous.

spectulilis (C. P.Ju. (.).) panicle divaricate, very branching : spikelets pendant, linear, 10-flowered : flowers ovate, acute, margin and back scabrous : neck of the sheaths and axils of the panicle pilose : leaves and short erect culm glabrous.

reptans (P.J. O.) culm ramose, creeping : panicle fascicled: spikelets subsessile, very long, many-flowered : flowers oblong, acute, lax: leaves short, pubescent. A very delicate grass. stolonifera (P.J.) culm subscabrous, geniculate, stoloniferous at the base : panicle whorled, diffused, scabrous ; branches angled, aggregate and wlorled about in fires: calyx 2 or 3 flowered : stipules of the lower leares obtuse, of the upper ones acuminate, elongated.

pilosa (P. New-Jersey. Ju. .) panicle erect, at length diffuse ; lower branches aggregated 4 to 6 together, upper ones solitary, zigzag, branchlets scabrous : calyx 4 to 12 -flowered: leaves 5-nerved, hairy at the base, with the sheath striate, glabrous, liairy at the neck : stem oblique and procumbent, with subangled joints. abtusa (P. New-Jeısey, N̄ew-England. Au. 2/.) panicle crowder, crispid, contracted ; branches in pairs or in threes, crowded; branchlets zigzag: calyx 2 -valved, less than the corol, 5 to 7 -Howered; valves white at the apex, obtuse or acute : outer valve of the corol obtuse, 5-nerved, glabrous : culm erect, glabrous.

sinaritima? (New-England) panicle erert, with a glabrous, striate rachis; branches in threes, the middle nne shorter ; branchlets gradually thickening below the calyx : valves unequal, 
obtuse, one broader, 4-flowered : corol 2-valved, larger than the calyx : culn and leaves striate, glabrous : stipules abbreriated, torn. On the sea-shore.

aniflora (New-England and New-Jersey.) panicle very slender, stifly crect ; branches solita. ry, crect scabrous : calyx 1 -flowered, bifid at the apex : corol larger than the calyx, becoming black : leaves setaccous striate. This can hardly be called a poa, as the calyx is but 1 flowered.

festucoides (fescue mearlow grass. C. J.) panicle diffuse, nodding, subsimple ; lower branch. es very long : flowers few, at first erect: spikelets oblong, teretish, 3 to 5 -flowered, awnless, all pedicelled. Three or four feet high. 'Torrey. A new species, discovered by J. Le Conte, esq.

Podatyria, 56.

Linetoria (wild indigno. 0. y. Ju. ४.) rery glab. rous, branching : leaves ternate, sub-sessile ; leafets wed ge-form, round-obtuse : stipules obsolete, oblong, acute, many times shorter than the petioles : legumes ovate, long-stiped. coerulea (Y. b. J. 4.) glabrous: leaves ternate, very short-petioled ; leafets wedge-oblong, obtuse : stipules lanceolate, acute, twice as long as the petiole: legumes acuminate. I have never heard of this species in our distriet, excepting at the East rock in New-Haren.

\section{Podophyluda, 64.}

peltatum (wild mandrake, may-apple. O. W. M. 4.) stem terminated with 2 peltate palmate leaves; flower single, inserted in the fork, formed by the petioles of the leares. Sometimes the plant is 3-leared, and sometimes the flower is inserted on the side of one of the petioles. 


\section{Podostemum, 90 .}

ceratophyllum (thread-foot. P. Ju. 4 .) stem firiform, floating : leaves pinnate : flowers axilla ary. Attaclied to rocks and large loose stones in shallow waters.

\section{Polemoniom, 39.}

septans (greek valerian. P. b. M. 4.) leares pinnate, in serens : flowers terminal, nodding.

\section{Polyanthes, 50.}

fuberosa (tuberose. E. 4 .) flowers alternate in pair's : rootlets tuberous : scape scaly : leaves linear, long. Sweet scented.

\section{Polygara, 78.}

1. Flowers with a crest-like nectary.

incarnata (milkwort. C. r. J. ().) stem somewhat simple, erect: leaves scattered, subulate : spikes oval-oblong : corol with a slender, elongated tube.

mubella (false low-centaury, ground-flower. Y. C. P. r. J. 4.) pubescent : stem simple, erect: leaves naryow-lanceolate, acute: raceme ter-minal; bracts subulate, solitary, caducous : wings of the calyx nerre-reined,round-truncate, longer than the corol. This curious plant is very abundent on the sand plains west of Ball's spring in New Haven. In the latter part of summer it sends off flowering shoots under. ground, which produce numerous abortive capsules.

firacifolia (flowering wintergreen. H. A. N. Y.C. P. r. M. 24.) smali, large-flowered; stem simple, 
erect, nakew helow : Iraves orate, acute, giabrous, near the foip of the siem : fow ers terminal, about in threes. Tharee or four inches high; and differs much from the rest of the sjercirs-the leaves and flowers being much larger in projortion to its size.

\section{Flowers without the crest.}

uniflora (Lake Ontario. 2!.) small : stem simple, crect. nakedish below ; leaves fur, broad-ovate, narrowing into the petiole: flowers solitary, scattered, pedicelled, nodding:

senega (seneca snake-root. A. C. P. Iludson. 1. or. w. J. 4.) stem erect, simple, leafy ; leares alternate, lanceolate : spike terminal, filiform : Howers alternate.

lutea (ycllow milkwort. C. y. Ju. @. or $\hat{\delta}$.) stem simple or branching: ratical and lower canline leares spatulate, the others lanceslate: spike head-cylindric, crowded, peduncled. viridescens (P. g-w.Ju. (․).) stem erect, very simple : leaves lance-linear, obtusish : flower's in a terminal globular head.

sanguinea (O. r. Ju. (-).) stem erect, corymbbranched at the top : leares alternate, linear: flowers in a head-form spike; peduncles squarrose.

rerlicillata (dwarf snake-root. O. w. J. O.) stem erect, branching : leaves whorled and scattered: spike filiform, peduncled : flowers distinctly alternate, approximate. About 6 inches high, of a bluish appearance.

cruciata (P. N. Y. r. g. Ju. o.) stem erect, ramuse, wing-angled: leaves in fours, lance-linear: flower's in spiked sessile heads.

Po!yzonctum, see Convallaria. 
PoIXgoNum, 55.

1. Kowvers axillary.

murimun (sea knotweed, New Jelsey. 1. w. Au. $210 P^{2}$.) stamens 8 , styles 3 ; stipules (ochreis) ubtuse, torn, membranaccous : leaves lancelinear, acute, margin revolute, fleshy : stem somewhat woody. \& small, prostrate, ever. green plant.

eviculare (knot.gnass. 0. W. MI. S.) stamens 8, styles 3: leaves lanceolate, scabrous at the margin; stipules nerverl, remote: stem procumbent: fowers sessile, small. Var. latifolium, leaves broal-oval-; stem ascending;. I have gonerally found this rariety pentandrous. ramosissimum (branching knotgrass. l' s'-w. J. (9.) ) stamens $3 \mathrm{or}^{\circ}$, styles 3 : leaves lanceolate: stipules abbreviated, torn at the margins : branches interruptedly many-flowered : stem strait-branched, striate.

tenac (slender knotgrass. Y. A. N. C. w. Ju. (.).) leaves long-lincar, strait acuminate: stipules tubular, apex villose : stem slender, erect, branched, acute-angled : flowers alternate, subsolitary.

\section{Flewers in siender spikes.}

lapat7ifolium (P. $1^{2}-w$. Au. . ) stamens 6, styles $\approx$ : stipules awnless : peduncies scabrous : seeds concave on all sirles.

punctatum (water-pepper, biting knotweed. 0 . w.

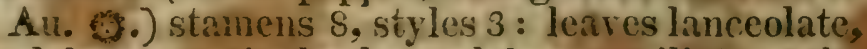
glabrous ; stipules lax, glabrous, ciliate at the apex, spotted : spike filitorm, weak, somewhat nodlings: bracts remotely alternate. We have usually called this plant the hydropper, but it difier's from the European specimens consider. 
ably. Pursh ralls it hydropiperoides, after Mich. Mr. Elliot hats removed the difficulty by giving it this name. mife (tasteless knotweed. C. P.J. . . stamens $B_{0}$ styles 3 : leaves narow lanceglate, subhirsute: stipules hirsute, long-ciliate : spikes lincar : bracts ciliate, subimbricate.

rirginiemum (C. Y. A. II. P. W. Tu. 24.) stame is

5, styles 2 unequal : leaves broad-oval: spikes wand-like : flower's remote.

\section{S. Flouer's in thick crouded spites.}

riviparmm (Whitchils. Au. 2.) stem simple : leaves lane-lincar, glabrous, margin revolute: spike single, lincar : bracts ovate, acuminate. Br. Bigclow and Mr. Buot fomand this species growing on the Whitehills in New Mampshire. Natural history in anl its departhents is greatIy incisted to the incessant excrions of these tiwo gentlemen.

coccinenm (lake knotweed. W. C. H. P. r. Au. 2..) stamens 5 , styles 2 or 1 : spities cylindric, dense : stipulics truncate, ghibrous : leares ovate.

p)ersicuria (ladies' thumb, heart-spot knotwecl. 0 . I. Ju. (2.) stamens 6 , styles 2 : spikes orateoblong, erect : peduncles smooth : leares lanceolate : stipules smoothish, ciliate.

pensylranicum. (knee knotweed. O. Ju. Q. .) stamens 8 , styles $20 \mathrm{or}^{\circ} 1$ : spikes oblong : peduncles hispid ; leaves lanceolate : stipules glabrous, not ciliate : stem with swelling kicejoints. :

orientale (prince's feather. E. r. Au. .) stamens $r$, styles $\approx$ : leaves ovate : stem erect, tall : stipules rough-haired, somewhat salverform. Griws 5 or 6 feet high. It has become naturalized in many places. 
4. Flowers in spiked, panicled racemes.

articulatum (joint-weed. A. N. Granly (Con.) 1. r.w. Ju. s.) stamens 8, styles 3 : racemed spikes in a panicle, filiform : peduncles blifom, solitary, procecting from above the imbricate muncate bracts : leaves linear: stipul's sheathing, truncate. About a fort high, teminateal by delicate raccmes; to which tise bruits gire a jointed appearance.

5. Flowers subracemed ; leares coriate, sagittate or hisistrite.

sagittalum (prickly knotired. O. w. J. (०) stameris 8 , styles 3 or 1 ; fowers in hearls: leaves sagittate : stem with pririles roversed, or curved towards its base, climbing.

arifolinm (halbert knotweed. 0. r-W. Ju. (.) stamens 6 , styles 2 or 1 ; fowers distinct: spikes few-flowered : leares hastate : stem with prickles reversed, siberect.

fagopyrum (buck-wheat. E. 1.-W.Ju. G.) stamens 8 , styles 5 : racemes panicled : leares heartsagitiate : stem erectisl:, unarmed: anghtes of the secis equal.

conroliulus (bind knotweed. 0. w. r. Ju. (.) stamens 8, styles 3 : leares oblong, heart-liastate: stem twining, angled, roughish : divisiuns of the calyx obtusely keeled.

scanders, (climbing knotweed. 0. W. r. Au. 4.) stamens 8 , styles 5 : leares broad-cordate : stipules truncate, naked : stem twining, glabrous: caly $x$ bearing the fruit 3 winged.

cilinoile (l'. Can. Ju. (.) stamens 8, styles 3 ; leaves cordate : stipules subarute, sirrounded at the base with an outer ciliate series: stem angled, prostraic or climbing, roughish : divisions of the calyx-obtusely keclet. 


\section{Potrunit, 88.}

comalensis (white leaf-rup. P. Can. w. n $n_{0} . \pi$ 2..) viscil-rillose : leares denticulate, arnminate; Inwer ones pimatificl, upper ones is-lohed or entire. Wwo of three feet high. Smell balsamic.

wedalia (cellow leaf-cup. Г. у. J1. 2\%.) Inares opposite, S-Iobed, acute, decurrent into the jetible: lobes simuate-angled: rays cimmgited. 'Taiker than the last.

\section{ToLYRUNM, 10:.}

coulgare (poilypod. O. Ju. 2.) front dcepiy pimnatitid ; divisms lance-linear, obtuse, cienulate. approximate, urper ones gradually smaller: fruit-dots solilaty : ront chanfy. Vir. virgintchum, has a naked ront.

lexagronopterum (C. P. W. Ju. 4.) fiend doubly pimatifid, sncothish ; two lower divisions deflexed; sub-divisions lanceolate, chtuse, ciliate, those of the under leafets gash-erenate and of the upper ones cntire; the lowest ones adnatedecurent : fruit-dots minute, solitary. The whole frond together presents a triangula: for'n.

conacetile (TV. Can. Ju. น.) finnd doubly pinnatifid, ciliate, divisions opposite contigunus, adnate: sub-livisins; somewhat oral: stipe chafly : fruit-dots minute.

celcareum (W. 1'. Ju. 2.) frond ternate, doubly pinnate, stiait, subrigid ; dirisins obtusish, subcntire: firut-iots marginal, confuent.

Note. A polypolium grows on the mountain near White bak Creck, 3 miles from Williams College, which agrees with nowe of the above descriptions. It is a litic more than a span high : frond pinnate, with pimatifid leafets : the divis$\mathrm{Gg}$ 
ions of the leafets sub-obovate, toothed. Wheth$\mathrm{Ox}$ it is a new species, or one already described and not credited to North America, I have not had it in my power to ascertain. It flowers in Au: gust.

\section{Polytatchum, 107.}

\section{Stem simple.}

joniperinum (hair-cap moss. O. M. 4.) leaves lance-linear, pointed, entire, inflected at the idges, rough on the keel : capsule square, on a flat receptacle.

cominune, leaves lance-linear, acute, serrulate, spread : capsule square, on a roundish receptacle.

gracile, leaves lance-linear, acute, serrate,spread ; capsule obovate, 'sub-angular, oblique, contracted at the base.

uttenuatum, leaves lance-linear, acute, serrate, spread : capsule square, drooping, contracted at the base.

\section{S'tem more or less branıshed.}

undulatum (P.) leaves lanceolate, serrate, undulate : capsule cylindric, drooping: lid subulate : calyptre naked.

hercynicum, leaves linear, incurved when dry, mostly entire : capsule ovate, cylindric, erect : calyptre single, hairy when young.

urnigerum, leaves lanceolate, serrate, spread: capsule cylindric, erect : lid pointed. ambiguum (Can.) stem almost simple : leaves long-subulate, aculeate-serrate : capsule somewhat nodding, cylindric : lid long-cuspidate, acute.

asciculatum (Can.) stem shortish, fasciclebranched above : leaves linear, acute, slightly aculeate-serrate : peduncles shortish : capsule 


\section{POLYTRICHUM, POPULUS. 375}

cylindric, strait ; lid somewhat convex, with a short mucronate beak.

\section{Stemless.}

ensylvanicum (P.) leaves resy few ; lower ones dilated and compressed into an oblong form? upper ones subulate-mucronate, obscurely toothed : capsule erect, oblong-cylindric ; lid convex, long-mucronate, inclined.

\section{Pontedenia, 49.}

ovdata (pickerel weed. A. P. H. Y. C. b. Ju. 24.) leaves heart-oblong, obtuse: spike many-flowered, compact : divisions of the corol oblong. In wet places.

\section{Populus, 100.}

remuloides (white poplar, american aspen. 0 . Ap. 々.) leaves heart-roundish, abruptly acuminate. tooth-serrulate, glabrous, a little pubescent at the margin, with 2 glands at the base on the upper side; petioles compressed, in the young state silky. The flatness of the petioles causes the leaves to take a tremulous motion, from the slighest action of the atmosphere.

randidentata (tree poplar. W.P. A. Catskill. Ap. 々.) leaves round-orate, acute, unequally and coainscly sinuate-toothed, glabrous; in the young state villose : petioles compresset.

etilifolic (birch-leaf poplar. C. Lake-1)ntario. Ap. h.) leares rhomboidal, long-acuminate, denate, gla!jrous : young branches pilose. ngulata (balm-of-gileasl, watep poplar, cotton wood. (O. Al. h.) leaves orate-deltoid, acuminate, obtusely hook-tootlsed, glahrous; younger ones broad-condate: branches wing-sungled. alsamifera (balsam joịlar. W. N. Can. Alo. h. leaves ovate, acuminate, clese-presseil serrate, rusty or mealy under side; buils zesinous. 
candicans (New England. Ap. 々 .) leaves cordate ovate, acuminate, obtusely and unequally ser zate, whitish beneath, sub-S-nerved, net-vein ed; petioles hirsute : buds resinous : branche terete.

Inevigati (cotton tree. Can. P. Ap. Ђ.) leave round-ovate, deltoid, acuminate, subcordate mequally serrate, glabrous, glandular at th base; petioles compressed : yourger branche angled.

heterophylla (various-leaved poplar. 1.M. 々.: leaves round-ovate, cordate with a small sinus sub-auricled, obtuse, hook-toothed ; younges ones downy.

milatata (lombardy poplar, italian poplar. E. Ap 21.) leaves glabrous both sides, acuminate, ser: rate, deltoid, the breadth equal to or exceeding the length : branches erect, close to the stem. It is said that no pistillate plant of this species has been brought to America. Consequently no seeds are obtained from it.

Poncelrs, 6\%.

lioiloba (cttstard apple. P. p. Ap. 12a) leaves smoothish, obiong-wedge-oborate : outer petals ordicular : fruit large, fleshy.

Pormuxacca, 60.

oleracea (purslane. 0. J. J. C.j leares nedgeform: Hower's sessile.

Potamogeton, 36.

valcus (poudweed. 0. g. J. 2..) leaves long-petioled, Hoating, lance-cial ; at first some of them ate subcordate.

Alutans (O. g. Ju. 2f.) lower leaves long, linear; upues ones lanceolate; nered, coriaccous : all petioled. 
setaceum (New Jersey. g. Ju. 2\%.) upper leares opposite, lancenlate, 5-nerved, short-petioled: lower ones alternate, filiform : spikes dense, alternate, shorter than the leaves.

perfoliatum (P. C. Can. g. Ju. 24.) leaves heartorate, clasping, all immersed : spikes terminal, above water; flower's alternate.

lucens (P. C. W ? g. Ju. 4.) leares very large, lanceolate, subsessile, middle rib thick : spikes long, cylindric. A species of this genus, which I find I have labelled P. lucens, grows in a poud 6 miles north of Williams College. But it may be a new species. The stem is branching, large, (from 1 to 2 feet long) flexouse, very leaty : leares ( 3 or 4 inches long and one wide) lauce-oblong, acute, entire, alternate, subsessile, about 9-nerved, net-reined, with the middle rib thick. The substance of the leaf is composed of translucent cellules; so that to the naked eye it appears to be a thin pallucid membrane. Spike from 1 to 2 inches long, with a peduncle thrice a: long. The stipule abore each leaf is about an inch in length; its substance resembling the leaf.

crispum (Can. P. P-g. J. 24.) leares alternate or opposite, lance-oral, undulate, scrrate : spikes few-flowereil.

pectinatum (Can. P.g.J. 4.) leaves long-bristleform, approximate, two-ranked, sheatherl at the base : spikes terminal, interrupted, whorled : fruit ovate, turgid. All immersed but the spike.

gramineum (grass pondweed. W. P. g. Ju. 4.) leaves lance-linear, alternate, sessile: stipules broad : stem terete, subdichotomous. Near Williams College this plant grows wholly immersed in staginant water. In July some of these plants begin to raise their spikes of unopened flower buds to the surface of the water. $\Lambda s$ soon as the stigmas are fertilized by the Gig 2 


\section{Sis POTAMOGETON, POTENTULLA.}

pollen, the spikes are again withdrawn to ripen the firait under water. Other individuals succeed them, and the process goes on for sereral recks. This curious operation of nature was particularly observed by the professors, sereral of the students and myself during the last season.

compressum (P. g. Ju. •. ol 24.) leaves linear, obtuse: stem compressed: spikes sliort, 4 to 6 flowered.

Potentillia, 63:

1. Leaves ternate.

norvegica (cinquefoil. 0. y. J. \%). erect, branching, hairy : stipules oval, toothed : leafets lance-rhombic, gash-tootlied : branches dichotomous : pedicels sliort, axillary, solitary : petals shorter than the calyx. Large. iridentata (mountain cinquefoil. W. C. w. Ju. 2\%.) ascending, smoothish : stipules subulate: leares wedge-oblong, s-toothed at the end, a few closepressed liairs : flowers in a terminal forked corymb : petals oblong-ovate, longer than the cal yx. Grows pientifully northeast from Williams College on the mountain.

Viirsuta (Can. Western part of New-York. w. Ju. 21.) crect, simple, very hirsute : stipules lanccolate, cntire : leaves obovate, gash-laciniate : panicle few-flowered ; pedicels short : petals smaller than the calyx.

¿. Leares digitate in fives, rarely in sevens.

canadensis (common fivefinger. O.y. M. 2٪) procumbent, subramose, whitish-silky : stipules ovate, gashed : leaves wedge-obovate, gashtoothed : stem ascending and creeping, hirsute: peduncles solitary, elongated, divisions of the calyx lance-linear : petals orbicular subentire, of the length of the calyx. This plant is solong in flower and assumes so many forms and sizes? 
What students in botany often make sererat species of it. Persoon's diagnosis of reptens can be fomnd in this plant ; but we have no such species.

mumila (dwanf firefingre. Y. C. P. Can. $\mathrm{Y}$. M. 2.) erect, almost stemless, pubescent : leares wedgeform, spread at the apex, gashed, woolly beneath : peduncles shorter than the petioles, subsimple, 1-flowered : petals round, scarcely longer than the calyx. 'The last species often flower's before the stem has attained to any considerable length; when it may be mistaken for this species. simplex (C. A. P. y. M. 2') erect, unbranched, hirsute : stipules gashed : leaves oblong-oval, coarsely toothed, upper ones sessile : peduncles axillary, solitary, elongated, 1 -flowered : divisions of the calyx lance-linear : petals roundobcordate, longer than the calyx.

argentea (silver fivefinger. O. w-y. Ju. 24.) stem prostrate and ascending, rarely sub-erect, branching, white-downy : stipules orate acute : leaves wedgeform, gasli-toothed, silvery white down beneath : petals retuse, scarcely longer than the calyx. Willdenow's description of this plant is certainly crroneous; and $\mathbf{I}$ have ventured to correct it.

recta (W ? P. y. J. 4.) stem crect: leaves in fives and sevens ; leafets lanceolate, coarsely toothed : petals obcordate, larger than the calyx. Corol large, pale.

\section{Leures more or less pinnate.}

froticosa (shrubìy cinquefoil. C.P. Can.y.J. Ђ.) crect, very branching, hirsute : stipules ovate, cntire : leaves quinate-pinnate ; leafets linear, oblong, flat; petals long: branchlets 1 or 2 flowered : fire alternate divisions of the calyx linear ; the rest broad-ovate, acute : petals ob. ovate, longer than the calyx. 5 to 5 feet lis 
floribunda (C. Can. y.Ju, 々.) erect, very branch. ing, hirsute: stipules ovate, entire : leaves quinate-pinnate ; leafets linear-oblong, margin revolute ; petioles short : corymbs terminal, dichotomous, dense-many-flowered : divisions of the calyx subequal : petals roundish, of the length of the calyx. About 18 inches high, and resembles the last.

anserina (tansy cinquefoil. P. Can. Troy. y. J. 24.) creeping : leaves interruptedly pinnate, numerous, gash-serrate, silky, white downy beneath : peduncles solitary, 1 -flowered. On the banks of the Hudson, near Troy.

pensylvanica (C. P. New-England. y. Ju. 24.) erect, down soft and whitish : leares pinnate ; leafets oblong, obtuse, subpinnatifid, tomentose : panicle strait, many-fiowered : divisions of the downy calyx semi-oval. Var. strigosa, has tooth-pectinate leares with revolute mar gins; flowers corymbed. supina (Can. P. y.J. G.) procumbent, dichotomous : leaves pinnate ; leafets oblong, deeply toothed: peduncles lateral, solitary, 1-flowered, spreading: leaves pinnate; leafets serrate: flowers in heads.

\section{Poteriedi, 94.}

sanguisorba (burnet. E. J. 2!.) stem somewhat angled, unarmed: leares pinnate; leafets serrate : flower's in heads.

Pothos, 35.

foetida (skunk-cabbage. O. p. Ap. 2\%.) stemless : leaves radical, heart ovate, very large : spadix with the flowers in a globular head. Very fetid. It is highly recommended as an expectorant and antispasmodic. See Barton's Veg. Mat. Med. unler the generic sy nonum Symplocarpus. One motiern antior has filaced this genus in the class Polyandria. I can conceive of no reason for 
this ; unless it be done by way of experiment, to ascertain what quantity of ridiculous imnovation the public will bear.

\section{Prenafines 8:.}

alla (wlite Ietuce. $0:$ w. p. $\Lambda \mathrm{n}, 2$.) ratical leares angled-hastate, toothed, somewhat lobed ; cauline ones round-ovate, toothed, petioled; up permost ones lanceolate : panicle lax, the terminal fascicle nodding : calyx S-cleft, 3 or 10flowered. About two or three feet high. altissima (0. p-y. Au. 24.) stem branching: leares petioled, 3-lobed, angled. denticulate, margin scabrous : raccmes axillary : flowers nodding: calyx about 5-flowered. Very tall. cordata (U. w-y. Au. 4 .) stem panicled sibove: leares petioled, coidate, tosthed, cilia'e; forad ones sessile, oblong, entire : panicle lax, racome-flowered ; fowers nodding : calys Gcleft, 6-flowered. 'I'all.

virgata (P. New-Jersey. W-p. Au. 24.) glabrous: stem very simple : lcares all lyrate-sinuate : branchlets somewhat one-sided : flowers pendant : calyx glabrous, 8-cleft, 10 -flowered. $\$$ to 6 feet high.

melicuida (P. b. Au. 4.) leares ciliate ; rarliral ones hastate-angled, subentire ; lower cauline ones obovate, tapering to the base, subangled ; upper ones lanceolate, entire : racene simple; flower's nodding. About 18 inches high.

\section{PRIMULA, 38 .}

acaulis (primrose. E. 2\%.) leaves rugose, toothed, hirsute beneath: scape 1-flowercul. revis (cowslip primiose. E. r-y. zy.) leaves rugose, toothed: limb of the corol concave; weck of the tube oblong, calyx inflated. clatior (oxlip prim:ose. E. W-y. 2r.) leaves rugoseg. 
toothed, hirsute: limb of the corol flat, neck of the tube hemispheric; flowers naked within. auricula (auricula tulip. E. 24.) leaves serrate, fleshy, obovate : scape many-flowered : calyx mealy.

farinosa (birds' eyo primrose, Can. r. 24.) leạves rugose, crenate, subglabrous ${ }_{2}$ mealy beneath : umbel erect.

mistasinica (Can. 2\%.) small, glabrous : leares oval-spatulate, subdentate: scaje clongated: umbel few-flowered : limb of the corol refiexed, the divisions wedge-oblong, obtusely $2-$ cleft : capsule oblong, exsert.

\section{Prinos, 49.}

cericillatus (winter berry, false alder. O.w.J. $I_{2}$.) leaves oval, serrate, acuminate, pubescent beneath : fascicles of staminate flowers axillary, umbellifernus ; the pistillate flowers are aggregated ; both 6-parted. Sometimes this shrub is monoecious and sometimes perfect-flowered. Generally in wet places. Berries red, permanent.

gluber (ink beny. C. P. Can. Ju. 2.) leaves evergreen, weige-lanceolate, coriaceous, glabrous. shining, equally subdentate above: pedicels axillary, subsolitary, mostly 3-flowered. A low shrub.

laevigatus (New-Jersey. P. Ju. 々.) leaves lanceolate, close-pressed-serrate, acuminate, glabrous both sides, shining at the upper side. hardly pubcscent at the nerves beneath : pistillate flowers axillary, solitary, subsessile : staminate flowers scattered-all 6-cleft.

ambiguus (New-Jersey. $\Lambda$. W. Ju. h.) leaves oval, acuminate at both ends, mucronate-sermulate? sub-pubescent beneatly: flowers 4 or 5 -cleft; staminate ones crowded together at the lower jranclies, pistillate ones solitary. 


\section{Proserpivica, 33.}

pulustris (mermaid weed. Y. C. P. I. g. Ju. (†.) leaves linear-lanceolate, serrate above water' pinnatifid below.

pectinata (C. P.g. Ju. ๑.) leaves all pectinatepimiatifid.

\section{Prunetici, 70.}

pensylranica (heal-all, self-heal. 0. J. భ.) Ieaves petioled, oblong-ovate, toothed at the base : lips of the calyx unequal, upper one truncate, awned : stem ascending. Willdenow calls this the oulgaris, and says the pensyluarica has the lips of the calyx erqual, and that the upper one is 3-awned. But Muhlenberg las not adopted this division of the species.

\section{Prunus, 61.}

virginiana (wild cherry, rum cherry, cabinet

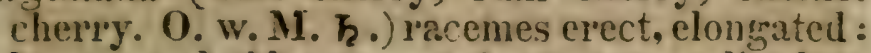
leaves oval-oblong, acuminate, unequally doubly-toothed, glabrous both sides ; petioies generally bearing 4 glands. In open fielcis the limbs of this tree spread out into an elegant oval top. But in dense forests it grows to a very great height, with a few contracted branches. The bark is an excellent tonic.

serotina (choke-berry. 0. w. J. 々.) flowers in lax racemes: leaves simply serrate; lower serratures subglandular, middle rib bearded towards the base. In MIuhlenberg's catalogue the English names of this and the preceding species are exchanged ; probably through the mistake of the printer. Pursh secms, by his popular remarks, to have totally mistaken this and several other species of the Prunus. canadensis (Can. P. w. 々.) flowers in racemes: 
leavcs glandless, broad-lanceolate, rugose, sharply serrate, pubescent both sides, tapering into the petiole.

pensylienica (C. P. New-England. w. M. 々.) umbels subsessile, aggregated, many-flowered, and at length panicle-form: leaves lance-oblong, scrrate, glabrous, 2 glands at the base: branchlets punctate. Borcalis (P. New-England. W. M. 2 .) flowers corymbed ; pedicels elongated : leaves oral-oblong; acminate, erose-denticulate, membranaccous ; glabrous : fruit subovate. Michoanx says this is a small tree, with small red, sweet fruit.

rigra (A. W. P. w. M. 々.) umbels sessile, solitary, few-flowered : leaves ovate, acuminate, unequally and sharply serrate, glabrous ljutl: sides : petioles with 2 glands. P. americana. mygmaca (american sloe. New-England. W. M. i.) umbels sessile, aggiegated, few-flowered : leaves oval-orate, acute, glabrous both sides. sharply serrate, glands at the base.

hicmalis (winter plumb. Can. P. w. M. r. .) jedicels aggregatch, glabrous : divisions of the calyx lanceolate: stipules setaceous, compound: leares obloug-oral, or oborate, abruptly longacuminate : fruit suborate.

chicasa (summer plumb, chicasaw plumb. Mr. says it was introduced. w. M. $1_{2}$.) branches rery glabrous, somewhat thorny: leaves obIon's-oral, acute or acuminate, minutely serruIate: buds aggregated, each about 2 -flowered : peciicels very short: divisions of the glabrons calyx obtuse ; fruit subglobose. 'The plumbs are small and yellow.

sphuerocarpon (along the maritime parts of NewEngland. w. M. h.? leaves short-oval, serrulate, generally 2 glands at the base: calyx with fine hairs : drupe spherical : nut roundeval. 
marilimn (C. w. M. h.) peduncles sulisolitary : leaves orate-oblong, acuminate, doubly-serrate. P'arsh has copied in the I'. acuminuta of Mx. as a symonym, which is-hranchlets glabrous: Jares oblong-oval, long acutely-acumimate : calyx glabrous : drupe long-preduncled, orate, acnminate.

qumala (P. w. M. h. .) umbels sessile, agrategate, few-lloncre l: caly $x$-acute : branches wand-terete: liaves narrow-lanceolate, scriate above, the under sides pale.

depressa ( $\mathbf{P}$. Can W. M. $h_{2}$.) umbels sessile, aggregate, few-flowered: calyxes obtuse: branclies angled, depressed-prostrate : leaves wed ge-lanreolate, remotely serrate, glabrous, glancous beneath : fruit ovate.

spinesa. (english sloe. P. W. h̨.) peduncles solitary : leaves lance-nval, pubescent beneath : fruit strait : branches thorny. Said to be introduced.

susquehanna, (P. w. M. I. .) peduncles solitary: leares obovate-oblong, glaucous beneath, serrate, entire at the base.

cerasifera (P. w. M. h.) pedundes solitary: leares oral, glabrous : fruit pendant : branches almost thornless.

Remark. Some of these species being dificult Io distinguish, more English names and popular haractirs are desirable. But I have not determined many of them, and I liave found the re marks of some modern anthors to be totally or poneons in sereral of the sprecies; therefore I resolved to give the essential characters without any reflections.

cerctsus, (garden clesiry. E. w. r. M. 々.) umbel sub-pedincleal: labes lance-vate, glabrous, conduplicate.

palus (bind cherry. F. w. M. h.) flowers racemel, lax: leaves dombiy-serrate, subrugose, petioled, with two glands. 
arium, (small bird cherry. E. w. h.) umbeis sessile : leaves lance-ovate, pubescent beneatlı, conduplicate.

domestica (plum. E. w. M. 々.) peduncles subsolitary : leaves lance-ovate, convolute : branches thornless. Var. juliana (damson plum) firuit oblong, blue. Var. claudiana (sweet plum, horse plum) fruit round, at first green, becoming yellowish. Var. enucleate (stoneless plum) the putamen obsolete.

\section{Prunus, see Armeniaca.}

Psilotum, 105.

dichotonum (naked ground pine. Southers states. J. 2 .) stem naked, dichotomous : branches 3-sided. Taken from the genus Lycopodium.

\section{PTERIS, 10\%.}

aquilina (common brake. O. Ju. 24.) frond pinnate-3-parted; barren branches doubly pinnate, with leafets lance-linear, obtuse, pinnatifid, toothed; fertile branches pinnate, with leafets pinnatifid, divisions acutish-all ciliate. atropurpurea (rock brake. C.W. P. Ju. 24.) frond pinnate ; lower leafets lanceolate, obtuse, ternate or pimate; at the base obtusely truncate or subcordate. Four miles north of Williams College, on the Pownal road, this plant grows abundantly in the clefts of the rocks. It is from three to 6 inches high, bluish green, leaves stiff. In rijening, the marginal involucre umrols, and the capsules on opposite sides meet; so that it exhiloits the generic character of the Acrostichun. Stipe dark purple. gracilis, (Can. Ju. 24.) frond pimnate ; leafets lanceolate, obtuse, alternate, sessile, lower ones pimnatifid: fertile ones entire, barren ones crenate, round-obtuse. About 4 iuches high. 
coulata (P.Au. 2\%.) (rond S-parted-pinnate : barren branches doubly-pinnate, leafets linear, rlongated, obtuse, entire, lower ones doublypinnatifid ; fertile branches pinnate, laaiats remotish below, at the base pimatifid. toothed.

\section{Pulmonaria, 56.}

afficinalis (lung-wort. E. b. M. \%.) radical leares heart-orate, hirsute : flowers raccmed. parriflora (Can. New-Fngland. b. Ju. 24.) stem. diffuse, procumbent, glahrous : Icares oralspatulate, fieshy: peduncles kateral, one-flowcred.

cirginica (P. b. M. 24.) calyx albrevinted, glalirous: leares nrate : stem crect : flower's subpanicled, terminal.

sibirica (Can. J. 24.) calyx abbreviated : ralical leaves corlate.

Punica, 62.

grronatum (pomegranite. E. Ђ.) leares lanceom late: stem woody.

Prcnanthemus, 68.

incanum (wild basil, mointain mint. 0. w. r. Ju. 21.) leares oblong-ovate, acute. suhserrate, white downy : Mower's in componad liakds. latteral ones peduncled : bracts setacoous. About 3 feet high.

aristatum (9. w. Ju. 4.) leaves lanco-nate. sub. scriate, short-petioled, whitish : healis sessile: bracts awned.

Pyreturum, 85.

serotinum (North America. W. Oc. 24.) lcaves 
lanceolate ; lower ones serrate at the apex, upper ones entire: branches corymbed.

\section{Pyroli, 56.}

rotundifolia (shin-leaf, pear-leaf wintergreen. 0 . w. J. ४.) leaves round or round-obovate, obsoletely serrulate : spike with the flowers rever'sed: pistil declined; stigma round, with 5 tubercles.

secunda (one-sided shin-leaf. O. g-w. Ji. 21.)

leaves round-ovate, acute, seriate : spike with 1-sided flowers : pistil strait: stigma peltate, gibbous.

uniflorc (A. Can. J. 24.) leaves suborbicular, serIate: scape 1-flowerel : style strait. Very abundant near 'Tracy's swamp, three miles west of Albany.

minor (W. P. Plainfield, Mass. W-r. Ju. 21.) leaves round-oval, serrulate : scape subnaked: spike with flowers reversed : pistil strait. asarifolia (P. Can. S-y. Ju. 24.) leaves reniform: scape remolely furnished with scales, sometimes convolute and sheathing : pistil declined. On mountains.

\section{Pyro!a, sec Chimaphila.}

Rcmark. Dr. Smith, President of the Linnean society at London, says; there is no diversity in the habit to justify the establishment of the genus Chimaphila. Those of us, who live among so many species of both genera, growing in their native wildness, want no arguments to convince us ; that. in this instance, the greatest botanist in the world is in an erior. We approve of his opposition to the modern rage for innovation; but in this case, no effort of the fancy can make out a fainily likeness between the stiff, strong, upright, narrow-leaved maculuta, and the broad, nabby-leaved rot:undifi!? a and its associates. 


\section{Prrưs, 62.}

communs (pear. E. w-r. M. h.) lcares ovate, serrate, (rarely entire) peduncles corymbed. Var. pyraster (dwarf) fruit very small and acid. Var. fulcrna (bergamot) fruit orbicular, appleform. Var. pompeiana (good christian.) Var. furonia (musk-pear.) Var. liqescens (butter pear.) Var. rufescens (russet pear.) Var. pyramidalis (leg pear.) These five last rarieties are distinguished more by their flaror, than by any external marks.

malus (apple. E. W-r. M. 々.) flowers in sessile umbels : leaves ovate-oblong, acuminate, serrate, glabrous : claws of the petals shorter than the calyx : styles glabrous. Var. sylvestris (wild apple) leares ovate, serrate ; fruit small, austere. Var. prasomila (pippin.) Var. castanea (chesnut apple.) Var. apiosa (ape apple) fruit small, round, red, pleasant-tasted. Var. carillea (cornered apple) leaves broad-ovate, downy beneath : fruit angled. cydonia (quin:e. E. w. J. h.) flowers solitary : fiuit tomentose : leaves ovate, entire. Var. iusitanica, leaves very broad.

Remark. The varieties into which the above species have been extended by culture, are very numerous. I have giren those only, which are set down by Persoon, as the most distinct.

coronaria (crab apple. Y. C. P.W-r. M. Ђ.) leaves

broad-oval, at the base rounded, subangled or sublobed, serrate, smooth : peduncles corymbed. Flower's sweet scented. angustifolia (P. M h.) leaves lance-oblong, at the base acute : slightly crenate-toothed shining : peduncles corymbed. Fruit very small.

Pyrus, See Aronia. 


\section{Prxmanturequ, 39.}

harbulata (box-flower. P. Ncw-Jersey. Whitehills.

W. J. T. .) leares wedge-lanceolate, acute, at the base within hairy or bearded: anthers beaked at the base.

Q.

Quercus, 94.

1. Fruit subsessile; leares mucronate with a bristle-form awn (excepting virens) entire. Fructification biennial.

phellos (willow oak. P. New-Jersey: M. 万.) leaves lance-linear, tapering to both ends, entire, glabrous, mucronate : calyx saucer-form : acorn roundish.

تirens (live oak. Southem states. M. 万.) Ieaves nerennial, coriaceous, oblong-oval, cntire, revolute at the margin, at the base robtuse, at the apex acute, awnless, stellate pubescent bcneath : fruit pedicelled: calyx turbinate, scales abbreviated ; acorn oblong. 40 or 50 feet high, very branching.

imbricaria (shingle oak, laurel oak. P. M. 々.) leaves oblong, acute at both entis, mucronate, entire, shining, pubescent lseneath : calyx sau-

- cei-form, scales broad-ovate: acorn subglobose. 40 or 50 feet high.

3. Fruit subsessile: leaves mucronate with a bristle form aron, toothed or lobed. Fructification bienuial.

7icterophylla (burrier's oak. M. 万.) leaves longpetioled lance-orate or oblong, entire or unequally coars:-toothed: calyx hemispheric : 
acoin subglobose. Pursh says, there is but one individual of this species knowa in the world, which is now growing on the Bartran plantation near Philadelphia.

Sriloba (downy black oak. I'. New-Jersey. M. Һ.) leares wedge-oblong. acute at the base, sulj-3lobed at the apex ; lobes equal in breadth, mil cronate, middle lobe longest, downy beneatir : calyx saucer-form ; acorn compressed-glubose. 20 to 40 feet high.

nigra (barren oak, black jack. P. New-Jersey. M. h.) leares coriaceous, wedge-form, subcordate at the base, spread and retuse-3-lobed at the apex, in the young state it is mueronate, glabrous above, mealy rust beneath : calyx turbinate, scales obtuse, scarious ; acorn shortovate. Sinall.

(inctoria (quercitron: oak, black oak. O.M. z $_{2}$.) leaves obovate oblong, a little sinuate, pubescent beneath ; lobes oblong, obtuse, obtusely denticulate, setaceous-micronate : calyx sailcer-form ; acorn depressed-globose.

discolor (false red oak. O. M. Ћ..) leaves oblong. sinuate-pinnatifid, pubescent beneath and on both sides when young; lobes oblong, toothed, setaceous-mucronate : calyx turbinate ; acorn ovate.

coccinea (scarlict oak. O. M. Ћ.) leares long-petioled, oblong, deeply sinuate, glabrous ; lobes diraricate, toothed, acute, setaceous-inucronate: calyx turbinate, marked with scales; acorn short-orate. 'This, the last, and the next species, are usually called red oak by farmers. And it requires some attention for the botanist to distinguish them. The leares of this species become reddish and even scarlet in autumn.

rubira (red oak. 0. M. Ћ.) lea res Inng-petioled, oblong, glabrous, obtusely sinuate ; lobes acutish, toothed, setaceous-mucronate : calyx sallscrform, smoothish : acorn subovate, turgid。 
falcata (spanish oak. P. New-Jersey. M. Ђ.) leaves long-petioled, at the base obtuse, downy beneath, 3-lobed or sinuate; lobes subfalcate, setaceous-mucronate, terminal one elongated : calyx bowl-form; acorn globose. Large tree. palustris (pin oak. Uatskill, New-England. P. C.

M. 万.) leaves long-petioled, oblong, deeply sinuate, glabrous, axils of the veins villose beneath ; lobes divaricate, toothed, acute, setaceous-mucronate : calyx saucer-form, smooth ; acorn subglobose. Generally grows in wet places. The small limbs along the body of the tree generally die as the tree advances, which gives it the appearance of having pins or trunnels driven into it.

ilicifolia (scrub oak. O. M. 万.) leaves long-petioled, wedge-obovate, 4 or 5 -lobed, margin entire, whitish downy beneath ; lobes setaceousmucronate : calyx subturbinate : acorn sub-globose. A low shrub.

3. Fruit peduncled; leaves zoithout arens, lobed.

Fructification annual.

stellata (iron oak, post oak. Y. P. Catskill. M. h.) leaves oblong, sinuate, wedge-form at the base, pubescent beneath; lobes obtuse, upper one dilated-2-lobed (often the lobes are so arranged in the young plants, as to form a crossform or stellate leaf') calyx hemispheric ; acorn oval.

macrocarpa (over-cup oak. P. M. Ђ.) leaves downy beneath, deeply lyrate-sinuate-lobed; lobes obtuse, repand, upper ones dilated : calyx bowl-form, upper scales setose ; acorn turgid, ovate, large. A large tree. oliverformis (mossy-cup oak. P. New-York. M. Һ.) leaves oblong, glabrous, glaucous beneath, deeply and unequally sinuate-pinnatifid : calys 
deeply bowl-furm with locks alove (superne crinita) acorn oval-orate. Large tree.

"lba (white oak. O. M. 々.) leaves oblong, sinuate-pinmatifid, pubescent beneath ; lobes sublincar, obtuse, entire, narrowed at their bases (particularly on full grown trees) fruit peduncled : calyx somewhat bowlform, tubercled, flattened at the base ; acom orate. 'The must useful timber tree in America.

\section{Fruit peduncled; leares without arons, toothed, not lobed.}

\section{Fructification annual.}

prinus (swamp chesnut oak. P. M. Ђ.) leares long-petioled, obovate, acute, pubescent beneath, coarsely tonthed : teeth about equal, spread, callous at the apex : calyx bowl-form, tapering at the base ; acor'n orate, large, sweet tasted. Large tree. prinoides (dwarf chesnut oak, chinquapin. P.

M. 々.) leaves short-petioled, obovate, at the base acute, coarsely toothed, giaucous benenti ; teeth nearly equal, spread, callous at the apr: calyx hemisplierical; acorn ovate. A low shinb.

montana, (rock oak, chesnut oak, inountain oak. O. A. h.) leaves moderately petioled, bioadobovate, oblong, white downy beneath, shining above ; coarsely toothed, at the base obtuse, oblique ; teeth subequal, re!'y obtuse, short: fruit in pairs, short-peduncled : caly $\mathrm{x}$ hemispheric, scales rugose tubercled : acoin ovate. castanea (yellow oak. I'. A. Catskill. New-England. Ai. 々.) leaves long-petioled, lance-oblong, obtuse at the base, acuminate, downy beneath, coarsely toothed; teath subequal, spreal, acute, callous at the apex : calyx hemispheric; acorn globular-ovate. Large trea. 'The bark is used for dying yellow. 
Bicolor (swamp white oak. P. M. h2.) leares short-netioled, oblong-obovate, white-downy beneath, coarsely twothed, cintire at the base ; teeth unequal, spircad, acutish, callons at the apex : fruit in Jairs, long-ieduncled ; the peduncle terminating in a bristle : calyx hemispheric : acom obiong-ovate. Large tree.

Remark. The localities of the oalks have not been well setlle!! to the north of l'ennsylrania. Therefore students may expect to find several of the species, credited to Pennsylsania only, in the Nortiern states. This remark will apply to ser. cral other frenern.

\section{Queria, 33.}

canadensis (fork chickweel. Y.W.M. P. A.Tu. 21.) stem dichotomous, very branching, spread? jeares lanceilate, glabroils, crect. Albout 6 or 8 inches high, very slenter and branching.slowers very small, stamens from 2 to 5 . An. ychia dichotoma. Mx.

R.

RanUifutes, $6 \%$

acris (crow-foot, butter-cup. 0. y. M. 21.) hairs close-pressed : leaves s-parted-many-cleft, upper ones linear : pedincles terete : calyx spreading.

abortivus (0.y. NT.21.) glalspous: stem striate, naked below : radical leaves heart-reniform, nbtusely crenate; cauline oncs petioled, ternate, anchled, unper ones sessile : branches sub3-1lowers. Flowers small.

- repcis (H. W. P. C. y. M. 2!.) hirrsute : leaves ternate, s-cleft, gashed : creeping shoots are sent of in the summer : perluncles sulcate: calyx spredtling.

recurvatus (A. C. $y$-w. J. 24.) pubescent; leares 
S-lohed; lobes wedgeform at the base, gashed at the apex, acute : stem many-Howered: calyx and corol recurved: petals linear. Flowcrs small.

fuscicularis (II. A. I. C. y. M. 24.) leares sulypubescent, radical ones long-pecluncled, ternate or subpinnate ; leaficts s-lobed, the terminal one deeply 3-cleft : calyx spreading, hairy underneath; petals longer than the calyx : root fascicled. See Big. Florula Bost.

fluriatilis (river crowfoot. 0. w-y. M. 2l.) stem submersed : leaves all capillary, dichotomous. The whole under water, excepting the fructification while the corol is expanded.

aquatilis (water crowfoot. I. Can. W. J. 21.) the sulbmersed leares capillary ; those alove water peltate.

delplizifolius (C, y. 24.) submersed leaves very finely divided, divisions dichotomous ; those above water cuar'ser ; calyx expauding, sinooth, concave : petals orbicular, centire, twice as long as the calyx ; nectary orbicular, bitid. A new species by Dr. Torrey ; though he sispects it may be a variety of the fluriatilis.

bulbosus (A. H. I. y. M. \&.) very hirsute : leaves ternate, S-cleft, gashed and toothed : stem crect, many-flowered: peluncles sulcate : calyx reflexed : root bulbose.

itirsutus (W. P. Vermont. y. Ju. 24.) hirsute: leares ternate, gash-lobed : stan erect, manyflowered: pedincles suleate : calyx reflexed, acuminate : seeds tubercled : root fibrous. IR. philonotis.

flammula (spearwort. A. C. P. Y. 4.) glabrous: stem declined : leaves narrow-lanceolate, acute, entire and denticulate, lower ones petioled : peduncles terminal, axillary, 1-flowered : calyx subrellexed. Flowers sinall.

scelerulus (celery crowfont. O. y. J. 2.) glabrous: lower leares palmate; upper ones sessile, digitate : fruit oblong. 
pensylvanicus (C. Y. P. y. Ju. 2’.) pilose, erect, branching : leaves ternate, 3-cleft, gashed, hairy beneath ; peduncles terete : calyx reflexcd : petals aboutefualling the calyx. Flower's large.

pusillus (C. y.Ju. 4.) glabrous : lcares petioled:

lower ones orate, toothed ; upper ones lancelincar, toothed at the apex, the very uppermost ones linear, bract-like : peduncles altemate, solitary, 1-flowered.

lingria (great spearwort. P. y.Ju. 2\%.) hairs closepressed : leaves lanceolate, subdenticulate, acuminate, sibsessile; stem erect, many-flowered. repituns (dwarf spearwort. P. y. Ju. 24.) leaves linear entire : stem creeping. Pcrhaps a rariety of the flammula.

marylandicus (1.W-y. M. 24.) pubcscent: stem cimple, rubnaked : radical leares tomate ; lesfets 5-lobed, lubes acute gashed : calyx reliexcd.

hispidus (P. w-y. J. ४.) rery hirsute, eract: leares ternaie ; leafets acutely lohed; stem naked below the first peduncle, few-fiowered: ralyx close-pressed.

cymbalciria (Ononlaga. w-y. J. 2.) g.lalur(utis, rery small, filiform, creeping, rooting at the joints: leares heart-reniform, obtusely 5-tonthed : radical peduncles solitary, mostly 2-flowered : petals linear : fruit oblong.

filiformis (P. Can. w-y. J. భ.) glabrous, small: stem filiform, creeping, geniculate, with the joints 1-flowered : leaves lincar-subulate, obtuse.

milillis (New-Jersey. P. w. Ju. 2'-) very glabrous : stem fistulous : radical leaves round-reniform, obtusely crenate, cauline ones sessile, digitate; laficts gashed, divisions obtuse: sceds subglobose, rery slabrnus. auricomus (1.. y. M. 4.) pubescent : radical leaves reniform, 3-parted, gash-c renate, can- 
line ones sessile, digitate, lincar : stem manyflowered : calyx coloured, spreading.

lanuginosus (P. y. J. భ.) lirsute : lcares S-rleft, lobed, toothed, all over silky : pedumles elongated, terete: : calyx spreading.

saniculacformis (sanicle-crowfoot. 1. (.) rery hirsute : leaves all 3-jarted; divisions gastiserrate : peluncles short, hearing 2 or 3 small flower's : calys reflexed, hirsute : leafets lanceolate, acute, Imger than the petals. Mubl. credits this plant to Delaware only. I ast summer Dr. Threry found it near New-York, and drew this description from living specimens. Dr. Leck found it also growing near Albany.

\section{Raphanes, 75.}

satirus (garden-radish. E. w. J. (-).) leares Iyrate: silique terete, torose, 2-celled. There are sereral varicties of this species-one has a fusiform, another a giobose, another a black root.

raphanistrum (wild radisl, clarlock. N. y. Au.) leares lyrate: siliruues terete, jointed, smooth, 1 -celled. Before the silirue is mature, it is generally 2-celled and not jointed. It may liare been introduced; but it is now growing wild in all the middle and southern towns of the western counties of Massaclusetts.

\section{Resedi, 61.}

inlorata (mignonctte. E. W-Y. Ju. . .) leaves entire, and 3 -lubed : calyx equalling the corol. luteola (dyer"s weed. Y. Y. Au. O) leares lanceolate, undulate, entire, a tooth on each side of the base : calyx 4-cleft : flowers spiked. Prof. Ives found this plant growing near New-Haven, in sitnations and with habits, which induced him to suspect it to be indigenous. 
Rhames, 41 .

ainifolius (dwarf alder. O. W-g. M. h. ) unarmi ed : leares oval, acuminate, serrulate, pubes. cent at the nerves beneath : peduncles aggregate, 1-flowered : calyx acute : fruit turbinate. Berries black. Pursh calls this the frangu. loides, after Mx. and gives this name to a species found up the Missouri.

catharticus (buckthorn. E. h.) thorns terminal : flowers 4-cleft,dioecious : leaves ovate, serrate.

\section{RHEUM, 55 .}

palmatum (rhubarb. E. J. భ.) leaves palmate, acuminate. From Chisa. tataricum (pie rhubarb. E. J. 4.) leaves heart. ovate, entire, flat, glabrous : petioles semiterete, angled : branches of the panicle sulcate. The radical leaves very large. From Tartary.

Rhexi, 54.

virginica (meadow beauty, deer-grrass. Y. C. $\mathbf{H}_{\text {}}$ P. p. Ju. ४.) stem wing-angled, with scatter. ed hairs : leaves sessile, lance-oval, denticulate, setaceous, ciliate-errate. About 8 inches high.

mariana (New-Jersey. w-r. Ju. 4.) stem and leaves very hirsute : leaves subpetioled, lanceoval or lance-linear: calyx smonthish, tubular; long.

\section{Rhinantries, 71 .}

crista-galli (yellow rattle. yellow coxcomb. Can. y.J. 6.) upper lip of the corol emarginate, 2. toothed, middle division of the under lip ver's short. 


\section{RHODODENDON, 57 .}

мa.ximun (wild rose-bay, H. C. r. Ju. Ћ.) leaves oblong, glabrous, paler beneath ; umbels terminal, dense : corols sub-bellform; petals rounded. A small tree.

ponticum (rose bay. E. p. Һ.) leaves oblong, glabrous, both sides coloured alike : corymis ferminal : corol bell-wheelform ; petals lanceolate.

\section{RHODORA, 56.}

canadensis (false honey-suckle, rhodora. H. Can. Granby, Mass. b. r. M. h.) leaves oval, enLirc, Flancous-pubescent bencath : flowers in terminal unabels. About o feet high.

\section{Rues, 47 .}

Iynhinum (sumach. 0. y-g. Ju. h.) branches and petioles very villose : leaves pinnate, manypaired, learets lunce-oblong, servate, somewhat downy beneath. Berries red and very sour. giabrun (slcek sumach. 0. g. P. Ju. $\gamma_{2}$.) branches, petioles and leaves glabrous: leaves pinnate, many-paired ; lealets lance-oblong, serrate, whitish beneath : fruit silky. The leares of both these species are used for tanning morecco leather. Berries red and sour. ropallinum (wing-rib sumach, mountain sunach.

O. $y$-g. J ti. $_{2}$.) brancires punclate : leares pinnate, in about 5 or 6 pair's, with the main petiole joint-winged ; leafets lance-oral entire : panicle leafy, branches sub-sessile : flower's dioecions. Berries red.

zernix (poison sumach. 0. y-g. Ju. 々.) very glabrous : leaves pinnate, many-paired ; leatets oval, abruptly acuminate, entire : paricle lax : dioccious : fruit glabrous. Berries 
green, at length whitish. Panicle few-flowered compared with the preceding species. Very poisonous. See Bigelow's Med. Bot. toxicollendron (poison vine, pöison ash. O. g.Ju. 々.) rooting: leaves ternate : leafets oval, cntire or' sinuate-crenate : racemes on the branches and axillary, sessile : dioecious. Var. radicaus (poison ivy) stem climbing and ronting; leafets broad, entire or with scattered teeth. Var. muercifolium (poison oak) erect, low: leafets variously sinuate-lohed. Var. microcarpon, leafets oblong-oval, long-acuminate, subrinombic : fruit very small. The sap of this species is an excellent marking ink for linen. aromaticum (P. y. M. 々.) a very little woody: llowers amentaceous, naked : leaves ternate : lealets rlombic-oval, toothed, pubescent beneath. Dioecious.

\section{Ruxxchospora, 29.}

sparsa (false bog-rush. P. Ju. ४.) corymbs diffuse, axillary, compound : terminal ones decompound : peduncles capillary : seeds longer than the beaks.

glomerate (P. J. 24.) spikes corymbed-fascicled, remote in yairs : culin obtuse-angled: leaves ineas.

alba (P. H. Ju. 24.) sprikes corymbed-fascicled : culm and leaves setaceous.

ciliciu (P. 24.) spikes corymbed-fascicled, terminal : bracts and leares obtusish, ciliate.

RIBEs, 42.

1. Currant-litie. Flowers racemed.

rubrum (currant. E. g. M. 々.) unarmed : 1'cemes glabrous, nodding: corol flat ; petals obcordate : leaves obtusely 5 -lobed : stem erect. Berries red. 
nigrum (black currant. F. g. M. 万.) unarmed : leares punctate beneath: racemes las: howers bellform bracts slorter than the pedicels. Berries black.

albinercium (Can. Catskill Mt. g-y. M. 々.) unarmed : leaves abbreviated, acutely lobed, smoothish, nerves white : racemes recurved ; berry glabrous. Berries red. trifilum (1'. Can, $y$-g. M. h. h) unarmed : leaves moderately lobed, glabious abore,pubescent beneath : racemes lax, pubescent : flower's flattish: divisions of the calyx about 3-cleft: pctals spatulate, obtuse : berries hirsute. Berries red. ringens (Can. P. M. h. ) unarmed : branclies strait : leaves acutely lobed and tootherl, reticulate-rugose, pubescent beneath : racemes lax, becoming stifly ereet : berry subhispid. Berries red, erect. glandulosum (O. P-y. M. h.) unarmed : branches reclined-prostrate : lcares lobed, smoothish, younger ones pubescent: racemes suberect: petals deltoid : bracts minute : berry hispid. Most of the plant, particularly the calyx, covered with glandular hairs. recurctum (1'. y. A. Б.) unarmed : branrhes recurved : leares broadish, acutely libed, pubescent, glandular-punctate : racemes reflexed : caly $\mathrm{x}$ tubular, glabrous.

floridum (wild black-currant. O. M. Ђ.) unarmed : leaves punctate both sides : ravemes pendant : caly $\mathbf{x}$ cylindric : bracts longer than the pedicels.

2. Gooseberry-like. Pedtuncles moetly fer-flow-
ered ; rarely subracemed.

grossularia (english gonseberry E. g. M. h.) branches prickly : potioles hairy : bracts 2leared : berry gialions or hirsute. ura-crispa (smooth gronseberry. E. g. M. b.)

$$
\text { Ii } 2
$$


branches prickly : berry glabrous ; pedicels with 1-leaved bracts. Perhaps a variety of grossularia.

triflorum (wild gooseberry. O. g. M. 々.) spine subaxillary: leaves glabrous, 3 to 5-lobed, gash-toothed : peduncles sub-3-flowered with the pedicels elongated: bracts very short: petals spatulate, undulate : style hirsute, half 2 or 5-cleft, exsert : berry glabrous. Berries pale red.

hivtellum (W. Troy. Can. I. g. M. . .) spines very small, subaxillary : branches subhispid : leares small, semitrifid; lobes subden. tate : peduncles 1-flowered : berry glabrous. Berries red.

oxyacanthoides (C. P. Can. M. 万.) the large and subsolitary prickles near the buds, the smaller ones scattered : leaves glabrous, with toothed lobes : peduncles short, about 2-flowered : berries glabrous.

gracile (P. W? C. M. Ћ.) little spines subaxillary : leaves petioled, slender, pubescent both sides; lobes acutely gash-toothed : peduncles capillary, about 2-flowered : calyx bell-tubular : berries glabrous. Berries bluish purple. lacustris (Can. P. g-y. M. Ђ.) spines manyfold, subaxillary : stem every where aculeate-lispid : leaves lobed beyond the middle : petioles villose : berries somewhat racemed, hispid. conobasti (Can. P. Catskill Mt. g. M. h.) prickles in pairs : leaves short-lobed, gash-toothed, with soft pubescence : racemes nodding, fewflowered : calyx erect, bellform : berry prickly, Berries dark brown.

\section{RICCIA, 110.}

natans (fioating liverwort: W. Ju.) fronds obcordate, with apexes meeting, so as to form the sectors of circles, flat: radicles beneath flat. 
Very abundant in a standing water one mile northwest of Williams College, near the north bank of the Honsack. It floats on the water, with its short flat roots extending a little distance into it. Colour sea-green. Each congeries of floating fronds hardly an inch in diameter. Channels run on their backs, like midribs in leaves.

fruitans (forkstems. W. J.) fronds repeatedly forked, linear, convex or subcylindric, smonth, reticulate, obtuse and cloven at the tips. Very plenty in stagnant water ainong the Lemna in Mr. Noble's field near Williams College. These plants appear like the branching stems of plants, without any roots. They are pellucid, very cellular, about 2 or 5 inches long. slauca, frond many parted, forked, cloven at the top, grooved, obtuse.

\section{Ricinus, 96.}

communis (caster-oil plant, palma christi. E. (․) leaves peltate, palmate ; lobes lanceolate, serrate : stem with hoary mealiness.

\section{RiviNa, 36.}

Taevis (rough-seed. P. r. S. h.) racemes simple: leaves ovate, acuminate, glabrous, flat: stem terete. Margins of the leaves often purple.

\section{Robisia, 79.}

psendo-acacia (locust tree, false acacia. Can. P. w. M. Ђ.) leaves pinnate, with a terminal lealet: stipules thorny, or a thorn : racemes pendant: teeth of the calyx aivned : legumes smooth. Cultivated every where. siscosa (clammy locust. Southern states. Ju. ..) racemes with 1-tlowered pedicels : leares 
pinnate, with a terminal leafet : branches and legumes with viscous glands: calyx acuminate. Racemes axillary, dense-flowered, erect; flowers approaching from white to red.

hispida (rose locust. Southern states. P. 々.) racemes axillary, suberect : calyx acuminate : stem mostly unarmed ; most of the plant hispid: leaves pinnate, with a terminal leafet; leafets round-oval, mucronate, sometimes alternate. An elegant shrub.

caragana (siberian locust. E.) leaves abruptly pinnate : calyx somewhat bellform : stigma glabrous, truncate : legume cylindric. There are several varieties of this plant which have been divided into species. See ad Persoon, page 312.

\section{Rosa, 63.}

corymbosa (swamp rose. O. r-w. Ju. Ћ.) germs (permanent calyxes) globose ; germs and peduncles a little hispid, or glabrous : petioles hairy and a little prickly : stem glabrous: prickles stipular, subuncinate : leafets 5 or 7 , lance-oblong, acute, sharply serrate, glaucous beneath : flowers solitary or corymbed. R, carolina. From 3 to 6 feet high. Very variable. Dr. Bigelow sent three specimens to the greatest botanist in Europe, which were all taken from different parts of the same plant. He received an answer making two of the specimens different described species, and the third one a new species.

parviflora (wild rose. 0. r. w. J. 々.) germs depressed-globuse; germs and peduncles hispid: petioles pabescent, subaculeate : stem glabrous : prickles stipular, strait : leafets lanceoval, simply serrate, glabrous : flowers somewhat in pairs. Very variable. Grows mostly on dry land. 
rubiginosa (sweet briar. C. Y. P. N. x. J. h. .) germ ovate : peduncles and petioles glandular-hispid; petioles somewhat prickly : stem glabrous ; prickles scattered, strait, slender ; leafets $(5 \mathrm{or} 7)$ orate, serrate, scarcely glandularlairy beneath : branchlets 1 -flowered : divisions of the calyx entire. R. suaveolens. The - leaves have often a rusty appearance beneath. lucila (P. r. Ju. 々.) germs depressed-globose : germs and peduncles subhispid : petioles glabrous, subaculeate : stem glabrous ; prickles stipular, strait : leafets lance-ovate, obtusish, coarsely serrate, glabrous, shining : flower's somewhat in pairs : divisions of the calyx cntire. 4 to 6 feet high.

gamella (P. New-England. r. Ju. 々 .) germs depressed-globose : germs and pedun les glab)rous : fluwers somewhat in pairs: leaves oblong;, acute, opake; petioles and reins pubescent beneath: prickles uncinate, the cauline ones in pair's below the axils.

setigerce (bristly rose. Southern states. J. দ.) germs globose: petioles and nerves prickly : bianches glabrous : prickles in pairs and scuttered : leaicts (3 or 5) acuminate, glabrous : divisions of the calyx somewhat winged-bristhe-bcaring. 5 to $s$ feet high. pendulial (thornless rose. Forth America? E? r.J. Ђ.) unarmed : germs oblong : peduncles and petioles hispid: stem and bianches glabrous : fruit pendant. nitila (I'. r. J. 々.) germs globose : the whole calyx, peduncles and branches hispid; petioles a little hairy, unarmed : lealets $(i)$ lance-oblong, very ghlabrous and shining both sides. canina (dogrose. New-Jersey, h.) germs ovate; gerus abd peduncies glabrous ; stem and petioles jrickly : leaves orate, glabrous. gallica (irench rose, common rose. E. r. J. h.) germs oraie; germs and peduncles hispid: 
st̂tem and petioles hispidi-prickly. Sometimes the colour's are rariegated.

flamascena (damask rose. E. w. r. J. 々.) calyx half-pinnate : germ ovate, turgid (thickened near its top) bristly : stem and petioles prickly ; leafets ovate, jointed, downy beneath. ${ }^{3}$

muscosa (moss rose. E. r. Au, h.) germs orate : calyx, peduncles, petioles and branches hispid, glandular-viscid (mossy-like) spines of the branches scattered, strait.

moschata (musk rose. E. h.) gurms ovate; germs and peduncles villose : stem and petioles prickly : leafets ohlong, acuminate, glabrous : panicles many-lowered.

burgundiuca (burgundy rose. E. h. .) germs subglohose; germs and peduncles hispid : leafets ovate, pubescent beneath : corol small, full, fleshy-white, disk obscure. Var. prorincialis, has scattered refiexed prickles on the branches, and glandular seiratures.

scmperforens (monthly rose. E, h.) germs oiateoblong, tapering to both ends : germs and peduncles hispid : stem prickly : flowers in prect corymbs. lusesenbles ciamascena.

filla (white rose. E. w. J. h.) germs orate, glabrous or hispid: sten and petioles prickly: leafets ovate, villose beneath.

pimpizellifolia (burnet rose. E. r. h. .) germs globose ; germs and pedincles glabrous : stem witl scattered strait prickles: leaves obtuse ; petioles scabrous. Very sinall.

centifolia (hundred leaved rose. E. 万.) gerns avate; germs and peduncles hispid: stem hispid, prickly: leaves pubescent beneath ; petioles unarmed.

cinnamomea (cinnamon roso. E. $h_{2}$ ) germs giobose; grems and peduncles glabrolis : stem with stipular prickles : petioles somewhat unarmed : leafets oblong. R. majalis. Stein brown-cinna. mon colour. 
maltiflora (japan rose. E. h .) germs orate ; germs and peduncles unarmed, villose: stem and petioles prickly." Isranclies generally purple, leafets ovate, flowers small, panicled. spinosissima (scrich rose. E. kz.) geruns globose, glabrous : peduncles hicpirl : stem and petioles rery hispiel. Far. scotice, is smaller. juarvifolia (small-leaf rose. F. h. .) smail : germs ovate, sulgglabrous : peduncles glandular : stem and petioles with slemler prickles: leafets rugose, a little villose beneath, ovate, grlandularserrate.

Remark. Thirteen exotic species of the rose may be considered disproportioned to other parts of this Manual. But as all these species are culbivated in the interior of Massachusetts, and most of them in Albany and Troy, descriptions of them may not be unacceptable. 'khese species were mostly analyzed in the living state, and obligingly fur nisher for this work by Miss Henshaw, uf Korthampton.

\section{RosManists, 27.}

officinalis (rosemary. E. h.) leaves some green. both sides, other's whitish beneath, linear, margins revolute.

\section{RUSA, S5.}

inctoria (madder. E.) leaves lancedate, about in sixes : stem prickly, climbing. Var. sylvestris, lower leaves in sixes, upper ones in fours or in pairs.

\section{RuBus, 63.}

illeus (garden raspberry. E. w. M. ら.) leaves quinate-pinnate and ternate; leafets rhombovate, acuminate, downy beneath; petioles 
channelled : stem prickly-hispid ; flowers subpanicled. A variety has a smooth stem. strigosus (red raspberry. O. w. J. $h_{2}$ ) unarmed : rigidly hispid : leafets 3 , or pinnate-quinate, oral, at the base obtuse, acuninate, marked with lines and white-downy beneath : calyx acuminate : flowers axillary, solitary at the cnds of the branches : peduncles and calyx hispid. Berries red, sweet, acines very slightly attached.

odoratus (flowering raspberry. 0. r. J. Ћ.) unarmed, erect, viscid-hispid : leaves simple, acutely 3 or 5 -lobed : corymbs terminal, spireading: calyx appendiculate; petuls suborbiculate. Flowers large, berries rather dry and thin.

occidentalis (black raspberry. O. พ.J. . .) brancl1es and petioles glaucous and prickly: leares ternate, oval, acuminate, sublobate and donbly serrate, white downy beneath ; petioles terete : prickles recurved.

villosus (high blackberry. 0. w. J. 々.) pubescent, hispid and prickly : leares digitate, in threes or fives ; leafets ovate-oblong, acuminate, serrate, hairy both sides: stem ind petioles prickly : calyx short, acuminate : racemes lax, pedicels solitary.

Irivialis (creeping blackberry, dew-berry. 0 . w.

J. 々.) sarmentose-procumbent : petioles and peduncles aculeate-hispid with the prickles recurved : stipules subulate : leaves ternate or quinate, oblong-oval, acuie, unequally serrate, subpubescent : pedicels solitary, clongated : petals obovate, thrice as long as the calyx.Var. flagellaris, has orbicular petals and small smooth leaves.

suxatilis (brier herb, rock blackberry. 0. w. J. 24.) herbaceous, pubescent : stem creeping: leares termate, rhombic, acute, gash-tootherl, naked, terminal one petioled : flowers somewhat in threes; pedicels elongated. 
obocalis (C. M. 21.) stem becoming a little woociy, hispid with stiff hair's : leaves fernate. roundobovate, serrate, naked : stipules setaccous : racemes subcorymbed, few-flowcred : bracts ovate: pedicels elongated.

cuneifulius (X. New-Jer'sey. J. 々.) branches, petioles and pedumles downy, with recurved prickles: leaves digitate, in threes or fires; leafets wedge-olovate, unequally inothed above, plaited, downy beneath, margin entire, jevelute : racemes terminal, panicled; jedi(els divaricate nakedish. hispidus ( $\boldsymbol{P}$. Can. w.J. . .) sarmentese-procumbent: stcm, petioles and peduncles very lispid with rigid bristles : leares ternate, gash-serrate, naked, midklle one perluncled. canadensis (C'an. New-England. J. 々.) a little glabious : leaves digitate in tens, fives and threes; leatets lanceolate, naked both sides, sharply serrate : stem unarmed : bracts lanceolate. Stem purple.

chamcemorus (cloud-berry. Can. New-England. w. J. 4.) herbaceous, small : stem unarmed, 1-flowered, crect : leares simple, subreniform, mumt-lobed : petals cblong.

acaulis (Can. J. \%.) herbaceous. small, nearly stemless, 1-flowered: leares almost radical, ternate : leateis sessile, lateral ones somew hat trapezoidal.

\section{RUDEICKIA, 87.}

laciniata (cone-flower, cone-disk sunfower. 0.y. Au. 24.) lower leaves pinnate, leafets S-lobed ; upper ones ovate : corret crenate: stem glabrous. From 5 to 10 feet high.

digitutr (I. y. A u. 2\%.) lower leaves pinnate, lealels pinnatifid: upper ones simply pinnate: top ones 3-cleil : egred crenate : stem smooth. pinnala (P.y.Ju, z.) leares all pimate; one n? Kh 
more of the lower leafets 2-parted, the rest undivided : egret entire ; stem furrowed, hispid. iriloba (P.y. Au. o.) pilose-hispid : stem panirled ; branches divaricate, many-flowered, leafy : leaves lanceolate, âcuminate at both endis, serrate, lower ones 3 -jobed : leafets of the cályx linear, defiexed, of the lengih of the rays. $4 \mathrm{or}^{2} 5$ fect high.

fulgide (P. Au. 2l.) stem hispid: branches wandlike; elnngated, 1-flowered: ieaves lance-oblong, denticulate, hispid, narrow at the base, subcordate: calyx leafy, about equalling the ray : disk hemispheric, with lanceolate chaff. lirta (P. y.Ju. 24.) rery hirsute: stem wandlike, sub-ramose, 1 -flowered : peluncles naked: leaves orate-spatulate, s-nerred, serrate, rough-haired : calyx leafy, nearly equalling the rays; disk conic, with lanceolate chaff. 2)urpurea (P.p. Ju. 2\%.) rough : lower leaves loroad-ovate, tapering to the base, remotely toothed: cauline leares lance-orate, acuminate at both cuds, subentire : rays long, pendant, 2-cleft.

\section{RUELIIA, \%}

strepens (ruel. P. w-b. Ju. 2\%.) erect, hirsute : leaves petioled, lance-ovate, entire : peduncles 1 to s-flowered : dirisions of the calyx lanceolate, hispid, half as long as the tube of the corol. Flowers larg'e.

\section{RUMEX, 52.}

crispus (dock. O. Ju. 24.) valves of the calys ovate, entire, all bearing grain-like appendages on their backs : leaves lanceolate, undulate, acutish.

obtusifolius (0. J. 2\%.) ralves toothed, one principally bearing a grain-like appendage : radical 
beaves heart-oblong obtace : stem a little scab. lous.

ierticillatus (Can. 'Troy. 1'.J. 24.) valves cu-

tire, a!! bearing grain liko appendiages : spikes

(a) oat 3) leadess, with th. flovers half-

whorled : leaves lanceulate : sheathing stipu.

les cylindric.

brilanicus (H. I. A.J. \% .) ralve entire, all bear-

ing grain-like appendases : spikes of the pani-

cle lealloss : sheathing stipules obsoletely torn :

leaves broad-lanceolite, flat, smowh. singuineus (bloody lock. P. J. 2.) valves entire.

oblong, one principally bearing the grain-lilic appendamo : leaves hart-lanceolate. aquaticus (water dock. P. Y. C. Ju. 21.) valves

ovate, entire, bearing ofsolete grains : louves heart-lanceolate, acute. acnitus (P. E ? Z.) valves tonthed, bearing grainlike appentatres : leares heart-oblong, acuminate.

patientia (garden dock, patience. E. 21.) valves entire, one of them bearing a grain-like appendage : leaves lance-orate.

\section{Rumex, see Lapathum.}

RUpPIA, 36.

maritima (tassel pondweed. P.J. 2\%) floating: leaves pectincte, obtiise : fowers spiked.

\section{RuTs, 56.}

grareolens (rue. E.) leaves more than decompound ; leafets oblong, terminal oucs obovate: petals entire.

$$
\text { S. }
$$




\section{SACChARUM, 31.}

nficinarum (sugar cane. E.) flowers panicled, in pairs, one sessile and one pedicelled : corol 1 ralved, awnless. From the East Indies originally.

\section{SAGINA, 36.}

procumbons (pearlwort. Y. C. W. מ.J. 24.) stem procumbent, glabrous: petals very short.Per'son and Smith say this species grows in barren fields, and Pursh repeats the remark. But at New-Haven it grows only in running water or very wet sliady places, forming a laind of water mat. I believe I was the first who found this plant in the Northern states.Prof. Ives then doubted my accuracy on acconnt of its place of growth. $\overline{\mathrm{I}}$ am row inclined to believe, that his doubts were well founded, and that this is a new species; notwithstanding it agrees with the above diagnosis.

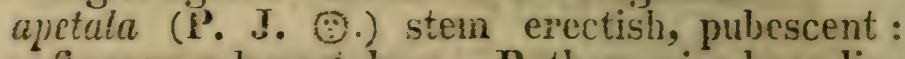
fiowers sub-apetalous. Both species lave linear, glabrous, comate leaves and axilary flowers.

\section{SAGRTARIA, 94.}

sagillifolia (arrow-head. O. w. Ju. 2'.) leares lanceoiate, acute, sagittate: Inbes lanceolate, acute, strait : scape simple : bracts and caly $x$ lanreolate, acute. In water or very wet places. latifolia (0. w. Ju. 24.) leaves ovate acutish, sagittate ; lobes ovate, slenderly acuminate, strait : scape simple: bracts roundish, obtuse. Var. major, leares largo, abruptly acute : scape subramose. Dioecions. obtusa (P. พ. J. 24.) leaves broad-ovate, round- 
ubtuse, mucroiate. sagittate; Jobes near cacis other, oblong. oblinuely acuminate, steait : scape simple : bracts ovate acute. Disecious.

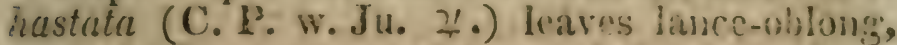
gradually acute, sagittate ; lobes sprea:ling, lanceolate, long-acuminate : scape simple: bracts and caly x roundish, olutuse. Direcinus. gracilis (P.w. Ju. 24.) leares linear, obtusish, 3.nerved. sagittate; lobes spreading, linear, elongated, gradually becoming sienderly acuminate : scape simple, few-flowered: bracts short, suborbiculate. Leaves very slender, about $s$ inches long, including the petiole. ieterophylla (P. A. New-Jersey, Plainíield, Mass. w. Au. $\frac{1}{2}$.) leaves simple, linear and lanceslate, acute at both ends; or oval, acute, at the base ob tuse, sagittate ; lobes spreading, linear : scape simple, few-flowered : pistillate llower's subsessile: bracts broad-ovate, acuminate.

Zancifolia (C. W. \&u. భ).) leaves broat-lanceolate, narrow below : scaje sub-ramose: seed's flat, sabre-form, beaked.

vigidu (Oswego. w. Ju. 4.) leares narrow-lanceolate, kecled below, rigid, very acute at botl ends : scape ramose. Grows in deep water. simp!ex (New-Jersey. W. Ju. 4.) leaves lancelinear, acute, narrow below : scape simple, many-Howered : bracts and calyx round, obtuse.

Dioecious.

graminea (Y. Can. P. w. Ju. 2.) leares linear, long, 3-nerved: scape simple, few-flowered; bracts oblong, obtuse. ncutifolia (P. w. Ju. 4.) leares subulate, sheatied at the base, convex on the back: scape simple, few-llowered : bracts dilated, acuminate.

natuns (P. w. Ju. 2l.) leares nodding, lance-oval, obtuse, 3-nerved, tapering to the base; lowel Kk 2 
ones subcordate : scape simple, few-flowered : lower peduncles elongated.

\section{SATICORNIA, 25.}

Rerbacea (samphire, glasswort. Y. H. C. Au. \$.) herbaceous, spreading: joints compressed at the apex, emarginate-bifid. Var. virginica, has the branches undivided and the jointed spikes rery long. The fructification is very obscure; but it may he knowa by its leafless nearly cyindric jointed branclies. It grows in salt marshes along the sea-board. I'ursh says, he tras seen it at the salt springs of Onondaga. It is used for pickles and lor making soda. Bigelow says, the specimens about Boston have not the eniarginate-compressed apex, as expressed above.

anhigua (C. Ju. ₹. h.) somewhat woody, ascending, very branching.

\section{SALIx, 37.}

1. Tetres cutire, or obsolcte? $y$ scrrate.

candila (white willow. P. Catskill Mt.Ap. 々.) leaves lance-linear, very long, obsoletely denticulate at the apex, pubesccint abore, whitedowny bencath, margin revolute : stipules lanceolate about equalling the petioles : aments precede the leafing, cylindric; scales lanceobovate, down very long.

mahenbergiana (speckled willow. P. Ap. 万.) leaves lanceolate, acutish, subentire, whitehairy, rugose-veiny beneath, margin revolute; stipules lanceolate, cadiacous : aments precele the leafing ; scales oblong with villose margins : germs lance-ovate, sili-villose, longpedicelled : style short, stigma 2 -cleft. Scale of the ament tipled with red. 3 to 5 feet high. 
fristis (mourling willow. Y. W. P. A. C. Ap. 々.) leaves lance-linear, acute at both ends. cutire, margin revolute, smoothish above, rugose-reined and downy beneath : stipules none : aments precede the leading, oblong.

recurzata (shrub willow. I'. New-Jersey. Ap. $\nvdash_{2}$.) leaves lance-obovate, acute, entire, margin glandular, glabrous, glaucous beneath, in the young state silky: sifpules none : aments precede leafing, recurved; scales black at the apex, hairs of the length of the germs : germs orate, short-pedicelled, silky : style short, stigma \&-cleft. Probably a variety of S. rosmarinifolia.

repens (creeping willow. Whitehills. J. . h ) creeping: leares lance-oval, entire, acute, glabrous, somewhat silky beneath: stipules none : aments precele the leafing, orate ; scales obovate, obtuse, hairy, sooty-yellow at the apex : germs ovate-oblong, pedicelled, pubescent: style short, stigma o-lobed : capsules glabrous. Ver'y small. Found on the Whitehills by Bigelow and Boot. We are indebted to these two gentlemen and Prolessor Peck, for most of the discoveries on this mountain, in every department of natural history.

pelicellaris (stem-berried willow. Catskill Mt.

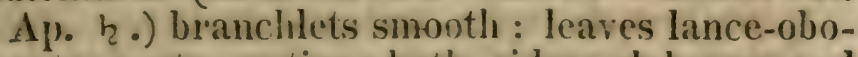
vate, acute, entire, both sides glabrous and coloured alike : stipules none : aments flower at leafing time, peduncled, eflabrous; scales oblong, scarcely pilose, but half as long as the pedicels : germs ovate-fibhong, glabrous, with very long pedicels: sủigma sessile, ¿-cleft. rosmarinifolia (rosemary willow. P. Ap. Ђ.) leaves strait, lance-linear, acute at both ends, entire, subglandular at the margin, carlucouspubescent above, silky beneath : stipules narrow-lanceolate, enect : aments precede the leafing, ovate, recurved: scales oblong, ob- 
tuse, ciliate : grerms pedicelled, lanceolate, rillose : stigma subsessile, 2-cleft. About 5 feet high.

fuscata (sooty willow. P. C. Ap. h.) leaves lance-obovate, acute, glabrois, subserrate, glaucous beneath, in the young state pubescent: stipules very narrow: aments precede the leaîng, nodding; scales obtuse, scarcely hairy within : germs short-pedicelled, ovate, silky : stigma sessile, 2-lobed.

\section{Leares remotely ond obtusely serrate.}

conifera (rofe willow, cone-gall willow. 0. . Ap. h.) leaves lance-oblong, remotely serrate, acute, glaibrous above, flat and downy beneath, the first year's growth glabrous : stipules lunulate, subdentate : aments precede the leafing: scales lanceolate, obtuse, villose : germs pelicelled, lanceolate, silky : style 2-cleft : stigma 2-lobed. The scaly cones are mere excresences or galls, cansed by the stings of insects. myricoides (grale-leaf willow. P.A. New-England. Ap. 々.) leares lance-oblong, acute, 2 glands at the base, glabrous, glaucous beneath : stipules ovate, acute, glandular-serrate : aments fiower at leafing time, villose, leafy at the base; scales lanceslate, obtuse, villose, dark-coloured : germs long-perlicelled, lanceolate, glabrous : style 2-clefi ; stigma 2-cleft. minoiles (P.Ap. Ћ.) leaves oral-oblong, acute, remotely wave-serrate, glabrous, glaucous beneath : stipules lall-cordate, gasl-toothed : aments precede the leafing, villose ; germs pedicelled, orate, acuminate, silky : style long; stigma 2-cleft.

discoior (red-root willow, basket willow, 0. Ap. ط.) leaves oblong, obtusish, glabrous, remotely serrate, entire at the apex, glaucous beneath : stipules caducous, lanceolate, scrrate: 
aments flower near leafing time, oblong, downy ; scales oblong, acute, dark-coloured, hairy : germs subsessile, lanceolate, downy : stigma 2-parted.

angustuta (C. P.Ap. 々.) leares lanceolate, acute, very long, gradually tapering to the base, serrulate, glabious, both siles coloured nearly alike : stipules half-cordate : aments precede the leafing, erect, smoothish : germs pedice!led, ovate, glabrous : style 2-cleft ; stigma :lobed.

longifolia (long-leaf willow. P. A. M. দ..) leaves linear, acuminate at both ends, elongated, rcmotely denticulate, glabrous, both sides coloured alike : stipules narrow-lanceolate, denticulate : aments flower after leafing, peduncled, downy : scales flat, retuse : filaments bearded at the base, twice as long as the scales. About 2 feet high.

\section{Leaves closely and acutely servaic.}

Renark. 'The first six of the following species have about 3 stamens to each flower. bubylonica (weeping-willow. E. M. h. , branchlets pendant : leaves lanceolate, acuminatc, serrate, gliabrous, upper and lower sides of different colours : stipules roundish, contracted : aments flower at leafing time : germs sessile, ovate, giabrous. Supposed to be the willow on which the Israelites hung their harps, when captive in Babylon. See the 13 th 1'salm.

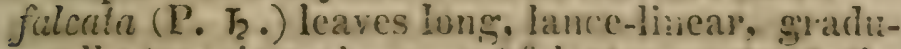
ally tapering above, subítcate. acute at the base, close-serrate, glabrous both sides, in the youig state silky : stipules lumate, toothed, deflected. Branches very slencler and brownish.

rigra (brittle-joint willow, black-willow. O. M. 々.) leaves lanceolate, acute at both cuds, serrulate, same colour both sides, g!abrous, peti- 
oles and midribs downy above : stipules contracted, toothed: aments flower at leafing time, erect, cylindric, viliose : scales oblong, very villose : filaments 5 to 6 , bearded at the base : grerns pedicelled, ovate, glabrous : style very short: sitigma 2-cleft. About 20 feet high.

lucida (shining willow. P. A. C. M. 々.) leares ovate-oblong, cuspidate-acuninate, lounded at the base, seriate, glandular, glabrous both sides, shining : stipiles oblong, glandelar-serrate : aments flower in leafing time; scales lanceolate, obtuse, hairy at the base, serrate at the apex, slablous : germs lance-subulate, glabrus ; style z-cleft; stigma obtuse. Size lietween shrub and tree.

rigida (stiff-leaf willow. P. A. New-Englant. Ap. h.) leares lance-oblong, acuminate, subcordate at the base, rigir!, glabrous, sharply gerrate ; lower sclratures clongatel : petioles villose : stipules broad, cordate, obtuse, glandular-scrrate : aments flower at leafing time : scales lanceolate, dark coloured, woolly: germs long-pedicelled, lanceolate, glabrous : style very short; stigma 2 -parted. Branches rel towaids the end, in the young state pubescent. Used also in basket-inatking.

corlata (heart-leaf willow. I'. A. A p. h.) leares lance-oblong, acuminate, corrlate at the base, sharply serrate, glabrous, paier beneath : stipules broad, round-ovate, cartilaginous-serrate: aments flower at lealing time; scales lanceolate, diark culoured, woolly : germs pedicelled, lanceolate, glabrous; style very short, stigna $\mathrm{s}$-cleft. 6 or 8 ficet high. grisea (grey-willow. P. Ap. h.) leaves lancenlate, acuminate, sorulate, glaliruis above, downy on the misrib, silky or nakc' beneath : stipules linear, defected, cadicous ; anent zreceles the leafing; scales blonng, hairy, dark colonred at the apex: germs vlilong, jedicelled, sillsy 
stigma seisile, obluse. About 8 feet highi, joints brittle at the base.

ritellina (yellow willow. (). M. h.) leaves lan-

ceolate, armminate, thickly-serrate, glabrous above, whitish-silky beneath : stipules none : aments flower in leating time, cylindleic: scales lance-orate, both sicles coloured alike, outside pubescent : germs sessile, lance-ovate, glabrous : stigma subsessile. a-lobed. Middle size trec. Pursh is certainly incorrect in saying this very common willow is introbured.Var. alba, has the leaves white-silky both sides, and very long aments. 'This rariety is usually the tallest.

ambigua (C. $\mathrm{K}^{-}$? Ap. h.) leares lanccolate. acuminate. glabrous. both sisles of the same colour. glambluar-scrate : aments fower in leafing time: the pair of nertaries larep : lobes lanceolate deformed. tonthed at the aper. stabrous: the terminal florets hare 3 stanens. Hesembles the vitellina.

russeliana (P. $\mathbf{1}_{2}$.) leares lanceolate, acuminate. serrate. glabeous : ammls llower in lnafing time ; florets generaliy with s stamens: germs perlicelled, subulate, sinootin ; styles cingated. Tall tiee.

\section{SAISOLA, 44.}

fali (saltwort. H. Y. C. I. Ju. (.) difinse : leaves 3-sided-subulate. mucronate, linear: calyx margined, axillary. Flowers rery small, seeds in a membranacens (ailyx. carolinana (H. Y. C. P.Ju. G.) decumbent, glabrous : leares spread-subulate, spinose : fowcr bearing buds very turgid: fruit-bearing calyx flat-mingerl.

traguis (New-Jersey. Ju. . .) erect : leaves subulate, spinose, smonth : calys orate. sodn (C. Q.) sprealing; liases without prickles. 
salsa (Can. (9.) erectish, very branching: leares linear, without prickles, fleshy : glomerules crowded, somewhat spiked ; fruit-bearing calyx round-depressed.

\section{SALVIA, 2\%.}

efficinalis (sage. E. b.J. 2 . or $r_{c}$ ) leares lanceovate, crenulate: whorls few-flowered : calyx inucronate.

sclara (clarry. E. $\hat{\delta}$.$) leaves rugose, cordate,$ oblong, villose, scrrate : foral bracts longer than the calyx, concave, acuminate.

lyrata (wild sage. P. Can. b. M. 4.) radical leaves lyrate, tonthed: upper lip of the coros very short: stem nearly leafless, reverse-hairy. Var. obovata, has the Ieares uborate, repand.

uerbenaca (verrain sage. P. b-1. J. 4.) leaves serrate, sinuate, smoothish : corol narrower than the calyx.

articifolic (nettle sage. New-Jersey. b. J. 24.) vilose-riscons: leares orate-ablong, torthed, decuirent along the petiole.

\section{S.MBUCEs, 47 .}

cana!lensis (black-berried elder. O. W. J. भ.) branchlets and petioles giabrous : leafets about in 4 pairs, oblong-oval, giabrous shining, acuminate, midrib subpubescent, base sometimes appendaged : cyme lax, divided into about 5 parts.

pubescens (red-herried elder. 0. w. M. h.) bark warty : leafets in 2-pairs, lunce-oral, pulescent beneath : flowers raceme-panicled or in a crowded bunch.

Stizores, 40.

ralerandi (brookweed. P. Y. N. w. Ju. 2.) Inares 


\section{SANGUINARIA, SIPONARIA, 421}

oborate : racemes elongated : pedicels bracted near the middle.

\section{Sivguiviria, 64.}

canalensis (bloodroot. 0. w. Ap. 24.) leares subreniform, sinuate-lobed : scape 1-flowered. A varicty, stenopelala, has linear petals. Rout highly efieacious in the influcnza, hoopinscough, and the late epidemic. Ires. See Bigclow's Med. Bot.

\section{Sitguisorbi, 34.}

canadensis (burnet saxifrage. N. C. P. W. Ju. 21.) flowers in a long cylindric spike : stamens sev . eral times longer than the corols. The leaves resemble the burnet. Grows plentifully in Deerfield, Mass. snclice (Can? P. P-w. Ju. 24.) spikes cylindric : stamens a little longer than the corol.

\section{Shivictla, 45 .}

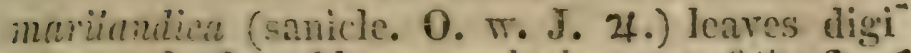
tate ; leafets oblong. gashed : part of the flow cis are fertile, sessile and sulfternate; the oth. er's are barren, pedicelled and the most nunerous. 'The stem is upright and smooth, with pretty upright branches. Whe sechs are furnished with hooked bristles. After the unopened flowers appear, they are a long time in that state before they expand. About 2 or 3 feet high.

\section{SAPONARIA, 58.}

officinalis (soapwort. Y. W. P. w. J. 21.) calyx cylindric : leaves lance-ovate. About 12 or 14 inches high. It may have been introduced from Europe. 
vaccaria (field soapwort. W. 1. Au. (-) calyx 5cornered, cone-ovate : leaves ovate, acuminate, sessile. Probably introduced; but it now grows wild along the Hoosack, near Williams College.

\section{SARothird, 47.}

gentianoides (nit-weed, false john's wort. Y. C. p. y. J. S.) small, erect, setaceous-ramose : leaves minute, close-pressed : flowers on the branchlets, alternate, solitary : stamens 5 to 10 : capsule oblong, 1-celled. On the sandy plain west of Ball's spring, New-Haven, it grows about 5 or 6 inches high, has a leafless appearance, and always 10 stamens.

\section{SARRACENIA, 64.}

purpurea (side-saddle. A. H. Y. P. N. C. p. J. 2.) leaves (which are the lateral brims of large cups) short, erectish, spreading, having reversed prickles within; petioles radical, inflated, forming large cups, a little contracted at the top, with a vertical wing along the upper side of each. The scape grows 1 to 2 feet ligh, with a single, large, nodding flower. The whole plant has a very singular appearance for this latitude, having the aspect of many tropical plants. Grows plentifully in Botany ponds, 2 miles east of Albany, and in Tracy's swamp, 3 miles west. Also in the lakes on Catskill Mt.

\section{SATÚREja, 69.}

hortensis (summer savory. E. b-w. Ju. O.) pedua cles axillary, somewhat in a cyme : leaves lanceolate, entire : stem brachiate.

montana (winter sarory. E. h.) peduncles somewhat 1-sided : segments of the calyx acuminate, mucronate : leaves mucronate. 


\section{SATYRIUM, 89.}

bracteatum (satyrion. P. W. A. g-W. M. 4.) lip linear, emarginate at the apex, obsoletely 3 toothed; coloured calyx leaves somewhat converging, lateral ones ovate, broader : hracts twice as long as the flowers, le al-like, spreading: roots palmate. About 6 to 10 inclies high. obsoletum (New-England. 1.. Ju. 24.) lip lance-nblong, undivided : coloured calyx leaves crect : germs pedicelied: scape naked : bracts short: roots palmate.

virescens (P.A ? g. Ju. 2'.) lip lanceolate, crenate: coloured calyx leaves converging: bracts longer than the flowers: poots fiascicled. 12 io 18 inches high. Pursh places all these species under the genus Orchis.

\section{SAURURES, 52.}

zernun (lizard's tail. P. (S. Can. Ju. 2.) sten leafy, many-spiked: leaves heart-sagitate. The stamens are so obscure, they can hardly be counter.

\section{SAXIfRAGA, 58.}

cirginiensis (rock saxifrage. O. w. M. 2.) minutcly pubescent : leares oral, obtuse, crenate, decurrent into the petiole : fiowers subsessile on the dichotomous branches of an almost leaf-less scape. It may be fomd in flower from 1 to 15 inches high. S. nivalis. But Push makes the nivalis a different species, growing in Labrador.

pensylvanica (water saxifrage. 0. g-w. J. 24.) pubescent : leaves lance-oblong, acute at both ends, obsoletely denticulate : scaje leafless ; panicle oblong, with fascicled branches at the top. 
Generally abont a foot high : but I have seen it three feet high along Whiteoak creek, near Williams College.

\section{SCABYOSA, 35.}

stellate (star scabious, cat's cye. E. $y-w$. 9.) co- rol 5-cleft, radiate : leaves cut and jagged: outer crown of the seeds orbicular, large, spreading, membranous, many-nerved. The heaus of seeds are very ormamental for flowerpots in the winter, on account of their permanent shining crown.

utropurpurea (sweet scabious. E. 24.) corol 5cleft, radiating : leaves pinnatifid and cut : receptacle cylindric : outel crown of the seed short, lobed and crenate.

Scandia', see Chaerophyllum and Myrrhis.

\section{SCHEVCHZERIA，5\%.}

palustris (less flowering rush. A. $\$$-y. J. 4 .) stem glabrous: leares semi-cylindric, sheathing at the base; each having a lateral pore on the inner side, immediately below the cartilaginous tip. Grows rery abundantly in Botany ponds at Grcenbush, 2 miles east from Albany,

\section{Schizata, 104.}

pusilla (one-sided fern. New-Jersey.Ju. 21.) frond simple, linear-compressed : spikes conglomerate, inflexed, one-way. $\Lambda$ party of botinists, consisting of Le Conte, Eddy, Pursh and Whitlow, found 3 specimens only of this species, in 1805, all of which have been lost.'This summer (1818) Dr. 'Torrey and Mr. 


\section{SCIIOENUS, SCIRPUS.}

Conper have found great numbers of them.The only known locality is near Guake: bridge, New-Jersey, in at swamp, 'The spncimen, which Dr. 'T. sent to me consists of 20 filamentous stems, proceeding from the saun root. Some of them have lieads not unmolled. The tallest is 4 inches high. terminated by the one-sided fan-like agerergation of spilies, which is but one-eighth of an inch.

\section{Scroenes, 28.}

setaceus (bog-1'ush. P. 21.) peduncles axillary, and terminal, abont 3-flowered : culm s-cornered ; culm and leares setaceous. Most of the species of this genus are now remored to the genus Rhynchospora.

Schoenzs, see Rhynchospora.

\section{ScHWALEEA, 71 .}

americana (chaff-sced. New.Jersey. p. J. น.) simple, pubescent : leaves lanceolate : racemes terminal ; flowers alternate.

SCrRpUs, 29.

1. Culm with one terminal spike.

iemuis (club-rush. 0. M. 2!.) spike oral, acutish at both ends; the 2 ovate, obtuse brarts are. dark-coloured with whitish margins: culiu 4sided, leatless, a span high : sheaihs truncate, submucronate : root creeping horizontally. In wet places, like most of the species of this genus. S. quallangulatus.

palustris (P. M. 24. spike oblong, erect: bracts obtuse : culin lcaliess, terete, purplish at the base, not hollow, somewhat jointed, enclosed 
at the base in a truncate sheath. About 2 feet high. Willdenow says, the sheaths and scales are lanceolate, acute. The ront creeps horizontally. Seed roundish, riggose, bristles $3 \mathbf{o r}^{\circ}$ 4 , hispid.

glancus (P. C.) spikes ovate, acute, sooty yellow; scales orate, obtuse, emarginate, menbranaceous : culm glancous, leatless, many-angled ; the sheath striate, glabrous, acute: 4 liispid bristles longer than the orbicular seeds. This is one of Muhlenberg's anonymous species. Dr. Torrey found the same near New-York, and gave it this name.

rapitutus (P. C. Au.) spike globular-orate, obtuse ; culm erect, leafless, compressed, cespitose, becoming slender under the spike ; the sheath at the base retuse-mucronate, becoming white: seed shining, oval, glabrous, with 6 bristles, longer than the seed, placed under the style. Eleocharis of Brown.

trichodes (P. C. J.) spike ovate, acute, 1,4 or 6 flowered, with a single obtuse bract: culm acicular, about an inch and an half high, cespitose, 4-sided, purplish at the base; slicath truncate, obtuse: seed 3-sided, shorter than the bristles.

intermedius (W. P.S.) spike ovate-oblong, acute, somewhat 2-cleft : culm greenish, 4 -sided, cespitose, sulcate, a hand's breath high ; sheath at the base acuminate: seed pear-form; bristles 6 , longer than the scerls.

planifolius (P. M.) spike ovate, arute, 6-flowered: bract yellowish, ovate, cuspidate, Jonger than the spike: culm S-sided, a span high, nearly leafless, cespitose: leaves subradical, alternate, linear, flat, keeled, scabrous ; lowest ones broad, abbreviated, nerves mucronate; the rest 3-nerved, equalling the culın : seed S-sides, with 3 bristles equalling the sceds. obtusus (Whitehills. Ju.) culm terete, naked: 
spike lancesiate, s ales fleshy at the apner, obtrise. A new species disconered by Bigelow and Boot.

bracteatus (Whitehills. Au.) calm terete: spike orate, acute : involucre-like bracts: flosets monandrous. A new species by Bigelow and Boot.

depilatus (C.) culm leafless, 4-sided, acicular: sjike orate, obtusish, 1 -bracted : glumes orate, obtuse, convex : pistil s-cleft, flat : seed proundish. mucronate. Borders of salt marshes.A new species discorered by J. Le Conte, Esq.

2. Culm roith sercral sprikes.

Incustris (great bull-rush. P. C. J. 24.) spikes subterminal, many, oblong-ovate, pedunrled and sessile, with sooty-yellow bracts ; peduncles flat, 2-edged and terete: scales glabrous mucronate: glumes ovate, obtuse, mucronate : pistil 2-clett : culm 4 or 5 feet high, terete, feafless, becoming slender at the tor : seeds obnrate; bristles 4 , hispid, rather longer than the seed.

scutus (common bull-rush. O. Ju. 21.) spikes with unequal compressed peduncles, oblong, sibumbelled, lateral, near the top: culm about 4-feet: high, leafless, terete, haviug oblong sooty yellow spots : glumes yellowish, keeled, uncronate, pubescent.

iriqueter (0. Ju. 4.) spikes lateral, 1 to 5 , orate, conglomerate, sessile, sooty-yellow : culm perhaps somewhat leatless, sharply 3-rorned, 3 to 5 feet high, with an erect mucronate joint, hollowed out on the sides: glumes orate, murronate, keeled: pistil 2-cleit : seed somewhat 5sided, acuminate-crowned, flat and convex, becoming black, setose at the base. Var. ? monotachizes, is about half a foot high, with a very short subradical leaf, sheath obtuse, bearing the 
leaf ; spike simple nrate, sessile ; sced oral. debilis (P. C. Au.) spikes lateral, sessile, orate, 1 , s, or 9 , bractless, many -flowered, short: glumes orate, ohtuse and acuminate, margin white, keel grreen : culm leafless, erect, channelled, about one foot high, cespitose, sheathed at the base, apex strait: seed somewhat S-sided or oborate, shining, dark-coloured, rugose or punctate, bristles 3 to 5 , hispid, a little longer: than the seed.

ferrugincus (P. C.) spikes subterminal, one in the midule sessile, the rest ( 3 or 4 ) peduncled, orate acuminate; the terminal involucre 3 leaved, unequal, pubescent, one leafet strait : glumes orate, acute, keeled, redish-brown, a iittle hairy : pistils fringed : culnis cespitose, compressed, striate, glabrous : leares radical and alternate, flat, striate, a little punctate, erualling the culm, at the base a broad sheath with a putrescent margin : seed obovate, striate, beardless. On dry land an inch or two in height, on wet land 1 or 2 feet.

spaitiens (P. C.) spikelets ovate-oblong; ; scales roundish, glabrous, chesnut-brown : spikelets in a terminal umbel ; peduncles compressed, 1 spiked and diviled into 3 or 4 spikes ; inroluires S-exie:l, unequal : style compressed, pubescent : culn compressed, about 5 feet high : radical leaves filitim, glabrous : seed compressed, striate, beardiless.

copllaris (C. P. New England. Ju.) spikes 1 to 4, lateral, ander the apex of the culm, one sessile, the rest pestuncled ; involucre 1 or 2 -leared : lower ralie subulate, ihe rest obtuse, the keel grecein or white: culn setiform, an inch or two high, j-sided, cespituse, nearly lealess : the leares are subradical and alternate, sctaceous, slicathing at the base with hains at the top of the sheath : seed smaewhat 3 sided, beardless, silhirugase, nerves transwerse. Isolepis of Brown. 
autumnulis (P. New England. Ju.) spikes terminal, panicled, subumbelled, peduncled, proliferous with a $\approx$ or s-leaved involucre, oblong, acute, sooty-ycllow, alternately sessile : glumes orafe, mucionate, kecled : culms a span high, 2-edged, cespitose, with linear, flat, norved leaves at the base : seed 3-sided, nerveless, beardless.

suỏsquarrosus (P. Ju.) spikes 1 to 3 , terminal, slomerate, ovate, sooty-yellow, sessile, manyHowered; involucre s-leared, leafets unequal, linear, broadcr at the base, striate : glumes ovate, acute, purplish under the apex, at the apex mucronate and subsyuarrose, kecl green : culm from 2 to 5 inches high, 3 -sided, almost leafless, purplish at the base, with 2 alternate, short subradical leaves ; sheaths of the leaves nerved, glabrous : seed 3-sided, beardless. retrofiactus (P. H. Ju. ४.) spikes 6 to 8, erect, ovate, peduncled, on a many-angled receptacle; involucre s-leaved, outer one very long, scabrous; peduncles 6 to 8 , unequal, compressed, glabrous, sheathed at the base ; the spikelets limear, acute, terete, imbricate, sub-pedicelled : bracts s-flowered, upper ones erect, the rest at length reflexed: lower valve ovate, middle one lanceolate, terminal one subulate: culm S-sided, 1 or $\Im$ feet high, striate, nearly leafless : the subradical leares lanceolate, striate, keeled, glaucous beneath; sheath striate : secd ssided, peduncled, beardless.

ryperiformis (New-England. Ju. 4.) spikes roundish, terminal, 3 peduncled and one sessile (sometimes but the one sessile); inrolucre loriger than the spike, 3 or 4 -leaved, channelled, inargin scabrous: spikelets 7 -flowered, linear, alternate, terete : glumes alternate, remote, ovate. obtuse, upper ones acute : culm 3-sided, almost leafless, a span high : subradical leaves linear, glabrous : seed S-sided, beardless. 
Ijunneus (P, C. S.) spikes panicled, terminal; peduncles 5 , unerual, alternately terete and flat, furnished at the base with a truncato sheath and a lanceolate leaf or inrolucre ; spikelets $3,5 \mathrm{ol}^{\circ} 16$, ovate, glomerate : glumes imbricate, orate, kceled, submucronate, brown: anthers red: culm 3-sided, striate, glabrous, leafy, about 2 feet high : leares alternate, lancelinear, nerved, margin scabrous; with a glabrous striate sheath : sced 3 -sided, with bristles longer than the seed. The general involucre is 4-leaved, erect, linger than the panicle. atrovirens (C. A. P. New.England. J. 24.) spikes in a terminal panicle, proliferous: involucre 3-leaved, with the margin and licel scabrous: branches of the panicle or peduncles unequal, - 3 to 6 , pedicels about 12 ; spikelets glomerate, about 12, ovate, acnte : glumes imbricate, ovate, acute, keel hairy : stem 3-sided, striate: glabrous, leafy, alsout 5 feet high : radical leaves lanceolate, keeled, long, those of the culm alternate, scabrous : sheathis striate, glabrous, pellucid: seed 3-sided, small, with 4 short bristles.

pendulus (P. J. 2.) spikes in terminal and lateral panicles, noddiug, all oblong-cylindric, pedicelled; involucre 1-leared : glumes imbricate, ovate, acuminate, white, with green keels: culm 3-sided, gliabrous, leafy, about 5 feet high : leaves of the culm alternate, flat, striate, margin scabrous, sheaths striate: seed S-sided, with may interwoven bristles longer than the seeds.

lineatus (New-Jersey.) spikes in a spreading terminal panicle; peduncles 10 , sheathed at the base, retuse; spikelets terminal, lanceolate, 10 -flowered, pedicels pubescent : glumes ovate, acute : involucre 1 or 2-leaved, much shorter than the panicle : culm 3 -sided, glabrous, leafy, striate : leares of the culm lanceolate, al. 


\section{SCIRPUS, SCLERIA:}

\{ernate, flat, striate, margin glabrous, with glabrous striate sheaths: seed ऊ-sided, bristly at the base.

mucrostachyos (II. W. C.) spikes sessile, peduncled, 6 or 12, ovate : involucre 3-leaved, unequal, elongated : scales of the spikes ovate, a little hairy, s-cleft, the micldle division awnform : culm exactly 3-sided, glabrous, leafy at the base, more than a foot high: leaves lancelinear, nerved, keeled, glabrous, longer than the culn, sheathing at the base : seed with bristles, hispid backwards.

gracilis (C.) spikelets oblong, a-bracted : glumes oblong, obtuse, keeled : pistils s-cleft, plimnose : culm leafless, 4-sided, with a purplish slieath at the base. On the border's of salt marshes. 'Torrey. A new species discovered by J. Le Conte, Esq.

Remark. 'The species of Scirpus are rery numerous in every part of our district ; and it is very difficult to distinguish them by their essential characters alone. Therefore to aid students in determining the species of this genus, I have here given a translation of most of Muhlenberg's enlarged descriptions.

\section{SClerantuUs, 58 .}

annu (knawel, gravel chickweed. H. Y. N. C. A. P. W-g. J O.) calyx of the fruit spreading, acute : stem spreading, subprostrate. In bunches 3 or 4 inches in extent, or more.

\section{SCleria, 91.}

J)iglomerata (whip)-grass. P. J. 4.) culm erect, simple, 3-sided, scabrous: leaves scabrous at the margin ; fiscicles few-llowered, terminal: glumes ovate, mucronate, scabrous : nuts glohose, acute, lugose. 
paucifiora (P. Au. 2!.) leaves narrow-linear, channelled, margin scalurous : fascicles very fewflowered, in pairs, terminal : nut small, white, transversely rugose. Stem erect, hardly a span high.

reticularis (New-Jersey Ju. 4.) culm and leares

glabroas : panicles terminal and lateral, few-

flowered : nut net-reined.

verticillaia (P. Au. 4.) culm simple, 3-sided:

culm and leares glabrous : spike naked, with atternate distant glomerules: nut globose, mucronate, transversely rugose-warty.

\section{SCLEROTIUM, 118.}

semen (barked puff-ball. P.) globular or pearform, blackish, scattered, becoming rugged.

\section{SCOLOPENDRIUM, 103.}

officinarum (caterpillar fern. Onondaga. Ju. 24.) irond broad-lanceolate, cordate at tho base: stipe chaffy.

\section{Scolymes, 83.}

hisponicus (golden thistle. E. 2\%) flowers aggregated : leaves scabrous, rongh-haired on the mid-rib beneath ; interruptedly decurent.

ScorpiuRes, 79.

rermiculata (caterpillars. E. J. 9.) peduncles 1 flowered : legumes covered with obtuse scales.

$\because$ Scorzonerd, S2.

hisprnica (viper"s grass. E. 1 .) stem branching, leares clasping, lanceolate, entire, subscrrulate at the base. 


\section{Scroptrutari, $r 1$.}

marilanilica (figwort. O. E-p.Ju. 24.) leaves cordate, serrate, acute, roundish at the base; petioles ciliate below : fascicles of the panicle lax, few-flowered. 3 to 7 feet hight.

lanceolata (P. g-y. Au. 2\%.) leaves lanccolate, unequally serrate, acuminate, acnte at the base ; petioles naked : faserikles of the panicie corymb: ed.

\section{Sctтmuktia, $\%$.}

gratevicuidat (sculi-cap. 0. b. J. 2\%.) somcwhat simple. gialron!s : laves sulusessile, lanceorate, sibcordite at the base, crenate : flowces usillary, solitary. Finwers large. From 10 to 18 inches high.

interifinn (mat-dog scull-cap, hrodwort. O. h. Ju. 24.) very braneing, ghabrous : leaves leng-petiole!l, ovate, tontind: (cauline ones subcondate : raremes lateral, leafy. Before the fame ef the Alisma plantago had rearibed this country, this plant was homorer with the high prerimtive of controling the monste", lifdrophothia.

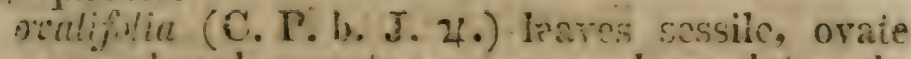
nr suboval, serwate ; upyer ones lanceolate, sub. entire.

parad ( (P. W-4, J. 24) small, simpie, densely purescent : leares sessile : ovate entire : flowems andlar, solitary. About 2 inches higho

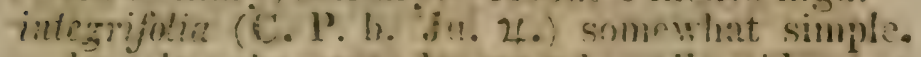
densely mikescent : leares subsessite, obling or linear, obuse, cutire, taperire, to the base : mcrmes laxist, leafy. Var, hyssenvioic, has the leaves all linear.

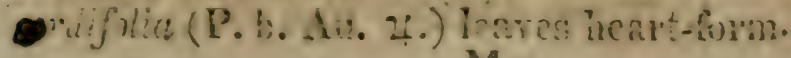




\section{Secale, 31.}

cereale (rye. E. J. o.) 'glume scabrons-ciliate: scales of the caly $x$ narrow: awns long and re. verse-prickly : leaves rough near the point.

\section{SEDUM, 59.}

telephium (orpine, live-forever. E. r. w. Ju. 4 .) leaves flattish, tooth-serrate, thickly scattered: corymb leafy : stem erect.

ternatum (false ice-plant. P. w. J. 2f.) small, creeping : leaves flat, round-spatulate, ternate : flowers somewhat 3-spiked. Varies into the eighth class.

anacampseros (stone crop. E. 4.) leaves wedgeform, entire, subsessile : stem decumbent: tlowers corymbed.

\section{SELINUM, 46.}

canadense (milk-parsley. P. Can. w. Ju. 24.) very glabrous, shining : leaves doubly pinnate; leafets many-parted, divisions lanceolate : fruit ovate.

\section{SEMPERVIYUM, 61.}

tectorum (house-leek. E. Au. 4.) leaves ciliate : bulbs spreading: nectaries wedge-form, crenulate.

arboreum (tree houseleek. E.) stem woody, smooth, branching: leaves wedge-form, glahrous, with soft spreadiug hairs.

SENECIO, 86.

1. Florets tubular; rays none.

Remark. The three first species vary from 
the character of the section, under which the genus is placed ; being destitute of rays.

vulgaris (groundsel. A. P. y. J. 27.) leares most-

ly clasping, sintate-pimnatifis, toothed : flowers panicled : stem erect, branched, angular. About Albany it grows 18 to 20 inches high, and the leaves a very little clasping.

hieracifolius (fire-weed. O. w. J. (-).) stem wandpanicled : leaves clasping, oblong, acute ; deeply, acutely and unequally toothed : ralys smooth. From 4 to 8 feet high. 'This plant springs up wherever land has been recently cleared of timber ; and more particularly if the land has been burned over. It is rery strong scented, and is said to be useful in stopping blood.

plongatus (long-stem groundsel. P. Ju. 2.) glahrous : radical leaves spatulate, serrate, taper. ing into the petiole ; cauline leaves piunatifid. toothed very remote : peduncles clongated, cory mb-umbelled.

\section{Flowers with ray florets.}

anrens (ragwort. 0.y.J. 24.) radical leaves orate, coldate, serrate, petioled ; cauline ones pinuatifid, toothed, terminal division lancenlate : peduncles subumbelled, incrassate. 18 to 24 inches high.

bulsamitue (balsam groundsel. C. P. y. J. 4.) radical leaves oblong, serrate, petioled ; lower cauline ones lyrate-pinnatilid, serrate ; ириен ones pinnatifid, toothed: flower's subumbclled: stem and peduncles villose at the base.

obovutus (C. P. Y. M. 4.) radical leaves obovate, crenate-scrrate, petioled ; cauline ones pimnatifid, toothed : flower's subumbelled, long peduncled : stem snmewhat glabrous.

gracilis ( $\mathbf{P}$. M. 4.) radical leaves rery inng-petioled, orbicular, subcordate, crenate ; cauline 
ones few, very remote, linear-obleng, dilated at the base, gash-toothed : peduncles very short, hirsute, subumbelled : calyx hairless : rays few, vexy short.

canadensis (Can.) leaves doubly joinnate, linear, glabrous ; uplermost ones simply pinnate : flowers in compound, fastigiate corymbs.

\section{SERPiocia, 93.}

occilientalis (little sirakeweed. C. P.w. Ju. ४.) flowers triandrous and perfect : stigmas straplike, reflexed, s-cleft : leaves termate, linear, acute. Flodea canadensis. Mx:

verticillatá (P. w. J.) leaves whorled, lance-linear, glatrous, denticulate : dioecious ; stamens S : calyx S-cleft. The pistillate corols are tubular. Pursh has removed this genus to the 3 d class. Though most of his changes of this kind are rejected by all our practical botanists; in this instance jerhaps we onght to have followed him.

\section{Sicyos, 9\%。}

angulata (single-seed cucumber. P. C. w. Ju. (.) leares cordate with obtuse hind inles, 5 -angleur, scalrous, denticulate : fruit capitate, hispid. Cultivated cvery where; but I nercr saw it in a situation when crinced its Loirg indigenuus.

\section{Sind, $7 \%$ :}

ubution (indian mallows. 0. y. Ju. O.) leaves round-coruate, aciminate, toothed, tomentose : peduncles solitary, shorter than the petioles: - capsules a-awned, truxcate. 4 to 6 fcet high; about gardens, roais, \&c.

spinosa (1.y. Ju. (:) stem spreading; axils subspinose : leaves long-petioled, lance-oreat, obsoletely cordate, toothed : peduncles solitary, axillary : stipules setaceous, longer than the preduncic : cajsules s.beated. 
sjispre (P. w. Ju. O.) leares oblong-contate, acuninate, crenate, top ones sessile: fedaneles s,jlitary, longer than the petioles, when they hear livit they are dellected : capsules inlated, awnless, crisp-undulate. On the sea coust.

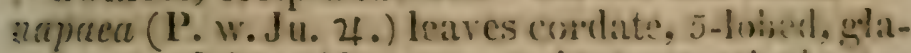
brous; lobes oblonge, acuminate, toothid : peduncles ma:ny-1lowered : caposiles awnless, acuminate. i to 4 leet high.

\section{Sinexe, 59.}

antirrlinu (slcepy catch?y. 0.w-p. J. 0.) leaves lanreolute, subulate : jeduncles s-parted : petals cmarginate : caly $\mathbf{x}$ orate. Flowes small. pensylvanica (pink catchlly. Y. II. N. C. I'. A. 1. J. 27.) viscid-pubescent : leares vitug-form; stem leares haricolase : the small stento are fe ivflowered at the sum!nit : netals ubtuse, slightly emarginate, subcienate.

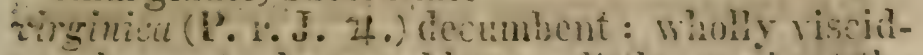
pubescent : lares oblung. a little rongh at the masym : panicle dichutomous : petais :-chen : stamens and pistils exsert. Fery landisome. ficoturna (l'. w. d. O.) Howers aitemate, sessile, on a one-sides sirite : petals $\approx$-clelt.

cutesbaci (P. i-p. J. 2i.) flowces lauge; petals tom, famished with a tooth cach side: calyx cylindric : panicle sub-trichotomotis : leares simootl, broad-lanccolate.

quinerevuluera (Southern states. E. J. O.) birattz: leares vielge-biblong, to pones linear : getals roundish, entive : caly braing the iruit creet, aldernate in a lind of pile.

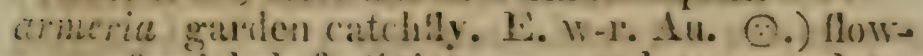

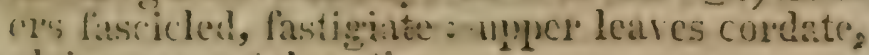
gylatrous: netals cintire.

\section{Srrirry, es.}

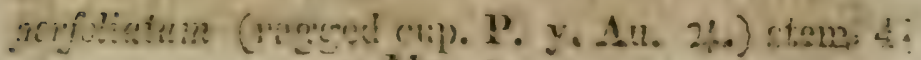
Him 2 
sided, smonth : leares opposite, triangular ; comnate, orate, serrate. 5 or 6 feet high ; very strong.

ternatum (P. y. Ju. 2\%.) stem terete, smonth: leaves whorled in threes, petioled, lanceolate, sublenticulate, a little scalirous, ciliate at the base ; the upper ones scattered, sessile : panicle dichotomous : calyx ciliate.

integrifolium (1'. y. Au. 4.) stem 4-siled, rough : leaves opposite, sessile, oblong, entire, scabrous : fiowers few, short-peduncled. About 4 feet high.

\section{Sivapis, 75.}

nitgra (common mustard. E. Y. J. glabrous, 3-sided, somewhat smooth, closepressed to the stem : leaves at the top lancelinear, citire, smooth.

alba (yellow-seerl musta rl. E. y. (.) silique bristly, rugged, shorter than the 2-edged beak : leares pimmatifid ; tipuer ones subly late, all irregularly toothed. Śeeds large, pale-yellow and sometimes become blackisl.

Sisor, 35.

cancudense (honewort, mock-sanicle. 0.w. J. 24.) leaves ternate : general involucre wanting [therefure it ought to have stood in the section next to Chaerophylium] seeds oral-oblong:Stem 1 to 2 feet high, branched, terete, smooth : leafets smooth, doubly and sharply serrate; and the lower lateral ones sometimes divided, with the middle one 2-lobed : umbels slender.

\section{SISYMBRIdM, 75.}

mphibium (water radish. W. N. A. y. J. 21.) silique (or rather silicle) oblong-orate, declined : leaves lance-oblong, pinnatificl or serrate : petals longer than the calyx. 1 to a feet high 
A student would be induced, from the shortness of the pool, to look for it in the first order. nasturtium (english watercress. H. P. w. J. \& .) silique short, declined : leaves pinnate; leafets roundish, somewhat repand-toothed.

palustre: Can. P. y. Ju. Q.) silique declined, oblong-ovate : leaves pimnatifid, serrate : petals shorter than the calyx.

\section{SistrinchidM, 75 .}

anceps (blue-cyed grass. O. b. J. 24.) scape [or culm] simple. 2-edged or 2-winged : glumelike spathe of $\approx$ unergual valres extending above the flower. Students generally puzzle themselres in examining this plant, by considering the $s$ united filaments enclosing the style, as a single filament. 10 or 12 inclie's high.

mucronutum (P. b. J. \%.) leaves and scape simple, subsetaceous : spathe coloured, with one valve terminating in a long mucronate point.

\section{SrUM, 46.}

latifolium (water-parsnep. O. w. Ju. 2?.) leares jimate : leafets oblong-lanceolate, equally serrate : stem erect, angular, hollow, smonth. The leaves are alternate, and generally consist of about 3 pair of leafets, besides the terminal one. Whenever any of the leares grow under water, they are subdivided.

lineare (W. V. C. Y. W. Ju. 24.) leaves pimate; leafets clongated, linear, or sublanccolate : serratures remotish: general involucre fewleaved; partial ones numerous, linear: umbels with short peduncles.

rigidius (P. w. Ju. ४.) leaves pinnate; leafets lanceolate, subentire, or toothed above. 'The flowers are small; leares taper at both ends: the involucres small. 


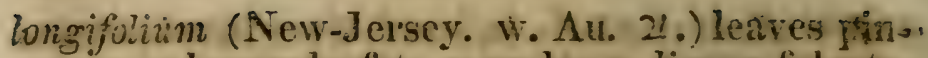
nate; lower leafets very long, linear-falcate, a few scattering tecth : stem few-leared, and - jo leaves above: umbels nakedish, somewhat in pair's.

\section{Smilacina, see Canvallaria.}

Remark. Smith says, he cannot admit thisname, notwithstanding all his respect tor its excellent author, Desiontaines. But he thinks the line of distinction should be mole arcurately drawn between the Convallaria and some of its neighbor's ; though he secms not inclined to adopt the modern divisions of this rery natural genus. Sec Rees' Cyclopocdia.

\section{Suir: 100}

1. Sicn soody ; lronches anglcd.

qualrangularis (bind-bramble. T. C. J. $r_{c}$ ) juclily : stem 4-cornered, unarmed above : leares unarmed, orate, subcordate, acute, Si nepred. Berries black.

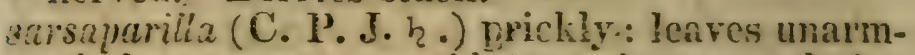
ed, lance-ovate, cuspidate, sub-5-nerved, beconing glaucons beneath : the general peduncles longer than the petioles.

\section{Stem r:ooily; lranches terete.}

rotunitfute (gareen brier. 0. w-g. J. h.) prickles scattered : leares (when in suaturity) rounduvate, acuminate, slightly cordate, 5-nerved: berry spherical. Whis singular bramble some. times climbs to the ireight of an hundied feet, while the largest part of its stem does not excecd the fourth of an inch in ciancter. 
cadrecu (P. C. Can. J. 万.) prickly : icaves ovate, mucronate, 5-nepved: general peduncles scarcely longer than the pietioles. psendo-china (New-Jersey. M. h.) unamed in

a!l parts : cauline leaves cordate, ramose ones oblong-ovate, 5-ikcreal : peduncles very long. laurifoliu (New Jersey. Ju. h.) prickly ; branch.. es unarmed : leaves oral or lance-oral, leathcry, nbtuse, recurre-prickly, 3-nerved: umbels short-peduncled.

prondurata (New Jersey. Ju. Ћ.) prickly : leaves ovate-guitarform, acuminate, S-nerved : general peduncles twice as long as the petioles.

\section{Stem Tierbaceous:}

peiluncularis (jacob's laduler. O. w-g. M. ४.) stem terete, climbing or arching vier : leaves round-ovate, cordate, acuminate, about 9-n(r. al (sometimes but 7 ) umbels long-peduncled. dierbaceu (0. g. J. 24.) stem angled, erect, simple : leaves hing-petioled, oval, about 7 -nerved: umbels with long compressed peduncles: berries depressed-globose.

\section{SMxRIIUM, 46.}

aureum (alexanders. 0. y.J. \%.) leaves biternate; leafets lance-oval, serulate : univeis with short perluncles. Some of the leases are often qui3iate. At a little distance this plant appear's like a wild parsnip ; though much smaller. cordatum (A. C. P. Y.J. 4.) radical leave's roundcordate, crenate ; cauline ones petioled, ternate; uppermost ones 3-parted : umbels with short perioles.

integerrinum (A. C. P. y. 2.) very glabrous: leares subglaucous; lower ones thrice ternate, apper ones doubly ternate; leafets oval, entire? umbels with a few setaceo!s, elongated peclue. cles. 
barbinode (P. p. y.Ju. 24.) leaves all ternate ; leafets ovate, acute, serrate. S. atropurpureum.

\section{Soranum, 40 ,}

dulcamara (bittersweet. O. b-p. Ju. . . .) siem unarmed, woorly, climbing : lower leares mostly. cordate, glabrous; upper ones mostly gruitarhastate : few-fiowered colynus epposite to leaves. This is the true bittersweet; lut the Celastrus scandeus is wrongly called so by some. Useful in astima and rheumatisın.

\section{Cutler.}

nigrum (deally nightshade. O. W. p. b.J. (.) stem unarmed, erectish or crect; branches angled, dentate : leaves ovate, repand, glabrous, racemes two-riaked, nolling:

carolinense (P. b. J. 2\%.) stem prickly : leaves angular-lastate, covered with 1 rickles both sides : racemes lax.

tuberosum (potatoe. South America. b. w. Ju. 2f.) stem wing-angled, unarmed : leares intermetfilly pinnate ; leafets entire : flowers subcorymbed : roots knobbed-tuberous.

iycopersicum (love apple, tomatoes. E. y. S. O.) stem unarmed : leaves pinnatifid, gashed : racemes 2-parted, leafless, fruit glabrous, torulose.

melongena (egg-plant. E. J. O.) stem unarmed : leaves orate, tomentose : peduncles pendant, incrassate : caly $\mathrm{x}$ unarmed. pseudo-capsicum (jerusalem cherry. E. 2.) stem woody : leayes lanceolate, repand: umbels ses. sile.

\section{Sormago, 86.}

Remark. During the last summer month and autumn, the species of this extensive genus will sccupy much of the time of the student io 
botany. Perhaps there is more dificulty in dis. tinguishing the species of this genus than of any other ; not excepting the Aster, Carex and Salix. I shall therefore give most of the extensive and accurate descriptions of President J. E. Smith [vid. Rees' Cyclopoedia.] He iook a review of Pursh and of all preceding writers, and then wrote with specimens of almost every species before him. I shall vary the expressions no more than is neressary to make ont langruage uniform.

To the essential generic characters add : calyx oblong; ; with oblonis, narrow, pointerl, strait scales: ray florets always fewer than 10 , lanceolate, ¿-toothed : filaments capillary, vely short: style thread-form, of the length of the stamens; stigma cloven, sireading : sced oblong-oborate.

1. Florvers one-sided. Lenies with three combined nerves.

canadensis (canadian golden-rod. Can. P. y. Ju. 4.) stem downy : leares lanceolate, serrate, rough ; racemes copious, panicled, recurved: rays hardly longer than the disk. 18 inches to 5 feet high. Stem angular; leares sessile, 3 inches long, sometimes nearly entire. procera (great golden-rod. P. Can. y. Ju. 4.) stem villose, erect : leaves lanceolate, serrate, rough, villose beneath : racemes spike-form, erect, drooping before flowering; rays short. 4 to 7 feet high.

serotina (smooth golden-rod. P. New-England. $y$. S. 4.) stem erect, terete, smooth : leaves lancelinear, glabrous, serrate, rough-edged : racemes panicled: peduncles downy. 'The young leaves are edged with many little white stiff hairs. gigantea (giant golúen-rod. P. New-England. y. Au. 2i.) stem erect, glabrous : leaves lanceolate, s:nooth, serrate, rough-edged, obscurely 3-nerved: racemes panicled : peduncles roughhaired : rays short. 4 to 7 feet high. 
ciliaris (fringal golden-rod. W. T.A. N. Y. y. 2.) stem erect, glabrous : leaves lanceolate, somewhat 3-nerved, glabrous, rough-edged, slightly serrate : rarcmes panicled : peduncles glabrous : bracts ciliate : rays short. The stem is angular ; radical leaves petioled, oval, pointed, veiny, serrate, rough, near a foot long: branches of the panicle spreading : bracts mimute.

ralexa (hang-leaf golicn-rnd. C. P. y. Ai. 24.) stem erect, villose : leaves lancolate, subserpate, scalsmus, relicxed : raconas panicled, very little one-sided, reflexed.

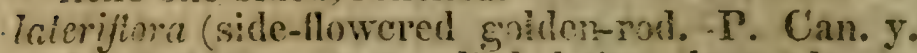
A1. 24.) stem erect, a little hairy : leares lanceolate, slightly 3-mored, glabrous, pough-nilged, lowcr ones sibserrate, racenes panicled, a litthe recurred. Flowers large, the rays being much longer than the calyx, stem 2 to 3 feet high, striated, often purphish, pimatiliel, with numerous lateral fowering brenches.

2. Iacencs, or forvers one-siled. Ieares roini.

aspera (rough golden-rou. C. P.y. Au, 4. ) stem crect, terete, hairy : leaves ornte, somewhat ovat, very jough, ruswse, selrote: macemes panicled. Abont 3 feet high ; learcs 1 to 2 inches long, acute; racemes derse, somevhat conic : ray forets twice es long as the calyx. altissima (variable golden-lonl. A. W. H. P. Y. Ail. 4.) stem erect rough-haired : leaves lanceolate, lower ones depply serrate, scabrous, r'ugose. The panicled racenes are very numerons and spread every way, so as to bring the one-sided howers uswards; rays half as long again as the calyx. Dat this species is so variable, that students generally cudearor to make sereral species of it. It is 3 to 5 feet high. The serratures of the icares are efgual snel une- 
qual ; it is hairy or villose; and sometimes the racenes direrge but little.

rugosa, (wrinkled golden-jod. P. Can. y. Au. 24) stem erect, rough-haired : leares hancelate. scahrous, rugose, lower mes with close-pressect scrmatures : Faccmes panicled, very spreading. leaves shorter and brobder than the last, and the flowers a little smaller. zillosa (solt goiden-iod. l. y. 2 .) stem mert, villuse: leaves lanceolate, softish, serrate : racomes panicled. 18 to 36 inches high.

scabru (liarsh goiden-rod. P. y. A11. 2\%.) stem erect, roligh-hairch, furrowed : leaves oblong: tapering to both encis, acuminate, glabrous alore, rugose aidd scabrous beneath, along the middle dose-pressed-serrate.

nemoralis (wobly guden-rod. A. Can. y. Au. น.) steris crect downy : cauline leares lanceolate, lispid, cutire ; radical ones somewhat wedgeform, serrate : raccmes panicled. 1 to $\approx$ fect high, of a grey asprect.

fatula (spreat golden-rod. P. C. y. S. 27.) siem erert, glabrous : leares oval, serrate, glabrous, ratical ones vblong-spatulate : racemes panicled spreabing : peduncies pubescent. Stem abritt $\approx$ feet high, wand-like, angular and striate; stem-leares scssile, about an inch long, pointed, the radical ones resemble those of the ox-cyed daisy ; racemes about an inch long, flower's rather large.

uimifolir (chm golden-roul. P. C. y. Au. 27.) stern erect, ghabrous, striate: leares oral, decply scriate, acuminate, villuse beneatî̀ ; radical ones oborate : racemes paniclod; peduncles villose : rays short. Radical leaves rescmble those of the last species and are hairy bothr sides, some of the rest are oblong-orate and only villose near the veins beneath; the petioles are bracted. nigula (uhup-notch golden-rod. A. Can. y. S. z..) $\mathrm{Nn}$ 
stent ercet, gialorous : leares ghiabrous, sharply and unequally serrate, cauline ones oval, radiral ones oblong-ovate: racemes panicled : rays clongated.

juncea (rush-stalk golden-rod. Tr ? C. P. y. Au. 21.) stem erect, glabrous : leares lanceolate, glabrous, rough-edged, lower ones serrate : iaceines panicled. Stem brownish, somewhat angular and striate, leaiy; racemes a finger's length, dense, recurred-sprearling, compound, pedicels roughish, bracted; ray twice as long as the calyx.

elliptica (oval-leaf golken-rou. P. C. Y. Au. 2l.) stem crect, glabious : leaves oval, smooth, serrate : racemes panicled : rays of middling length. asperata (file-leaf golden-rod. Can. y. 2\%.) stem panicle-corymbed : racemes suberect ; flower: ascending : leaves lanceulate, serrate, scabrous.

gecurvata (curved mollen-rod. P. y. S. 24.) stem erect. pubescent : leares lanceolate, serrate, rough-edged: racenes elongated, recurved, panicled.

sempervirens (narmw-leaf gollen-rod. C. P. Can. y. S. 2.) stem erect, glabrous : leares lanceinear, somewhat lleshy, smootis, entire, roughedged: racemes panicled ; peduncles hairy. Stem tall, puplish, a little glancous; leares many, narrow, long; ; ray florets long, narrow, rather numerous.

virgata (wand golden-iod. N. C. P. W. y. Au. 21.) stem very simple, glabrous : leaves wedgelanceolate, obtuse, entire, glabrous, close-pressed, upjer ones gradually smaller : branches of the panicle elongated, with terminal racenes ; peduncles glabrous. About 2 feet high, very smooth and slender.

pdora (sweet-scented goldien-rod. P. Can. y. Au. น.) Stem erect, pubescent : Icaves lance-linear, putire, gla!jous, pough-cdged : racemes pani- 


\section{LIDAGO.}

cled. The upper part of the stem is furrowed; a accmes 2 or 3 inches long, spreading horizonlally, each generally accompranied by a leai ; bracts oblone, sinooth; stalk angular and roigh. 'This is the true folden xod tea-plant. The flowers dried so as nit to be musty make. a pleasant tea, which is moderately astringent and promotes perspiration.

\section{Racemes erect.}

üenlor (white goluen-rod. W. A. H. Y. 1'. W. Au. 4.) stem !airy : leaves nval, hairy, lower mes serrate; those on the flower-braiches cntire. numerous. and small; scales of the calyx obtuse. Rarmes are short and compart, rays white, somowhat ntmerous and shortish; disk florets rather numcrous.

petioiaris (laie golden-rod. P. C. y. Oc. 4.) stem erect, villose: leaves oval, roughish, petioled: rays twice as long as the calyx. Stem branching, teiete, hoary ; leares hoary about the ribs, over an inch in length, those covering the flower-branches subcitire; mecmes numerons, short, with few and rather latre fivwers. stricta willow-leaf gollen-1od. P. C. Y.Au. 2.) stem erect, Glabruts : cauline leares inncoulate. chtire, giakrous, rough-edged; radical leaves scrinte : racenes panicled, crect; peduanlez glabroas. The brancles of the panicle are erect, simple, close.

lanceluta (waks-leaf gohlen-Pod. N.W.I.P.Y.Y 5. 21.) stem furrowed, smonthish (rough-haired, Wilki.) rery lomeling : leaves almost linear (lance-linear, irillu.) critire, roughish : mearly ciect, with 3 or 5 rough nerves: cory miss terminal, level-topped : flowers in lieads: rays not longer than the disk. Stem 4 or 5 feet high, leafy ; leares sessile, grass-green, about 2 inches long and a quarter of an inch wide; flow- 
ers smallish ; calyx ovate, smooth, shining, with tumid green-tipped scales.

ienuifolia (pigmy golden-rod. P. C. Y. S. 21.) stem roughi, angular, branched, corymbed: leaves spreading, linear, very narrow, slightly S-nerved, scabrous, with axillary tutts of smaller ones : corymbs terminal, level-top : flowers in heais : rays scarcely cxceeding the disk. About a foothigh ; leares very small and nawrow. :

cresicu (blue-stem golüen rou. H. y. Au. భ.) stem nearly erect, very smooth and even: leaves lanceolate, glabrous, with the margins and nerves roughish : rays rather lnnger than the risk. Sten upright, somewhat zigzag, branched, leafy ; leaves about 2 inches long, pointed, subentire, subglaucous, paler beneath : racemes nunerous, short, rough-pedicelled; bracts small, smooth, subulate.

Virida (purple-stem golden-iod. P. C. y. S. 21.) stem giabrous, paniclel : leaves lanceolate, serrate, glabrous, rough-edged : branches racemed at the extremity : rays elongated. Stcm branched, dark purpile; leaves tapering to both ends.

lispida (P. C. y. Oc. \%.) stem ercct, hispid, scabrous : leaves lanceolate, rough, entire : radical ores serwate : rays of midding length.Resembles the caesia.

livta (hairy golden-iol. North Ámerica. y. 4.) stem panicled, rougl:-haired: leaves lanceolate, scabrous both sides: cauline ones serrate, those on the branches entire : rays elongated. hithospernifolia (Gromwell gollen-rod. P. C. y. Au. 21.) stem branching, hairy : leares lanceolate, scabrous both sides, tapering, 3-nerved, entire: rays elongated. Leares bear some resemblance to those of the gromwell. Paerigala (liesh-leaf golden-1od. I. Can. P. y. S. 4) stem erect; smooth: leares lanceolate, 
Meshy, cntire, smooth in crery part : lacruess panicled : pertumclis scaly, villose: rays iwice as long as the calse. Tall, strong.Probably a variety of Maxicama. Grows in salt maishes.

mexicana (New-England. I3. y. 3u. 24) stem oblique, glabrous: leaves lancolate. some what uleshy, entire, smooth in every pare : racenes panicled : peduncles scaly, glabrous : rays elongated. Grows near salt vater. Tall, Howees large ; radical leares obovate, long-petioled : bracts numerous, lanceolate, kecled, recurved, thin, scale-like.

viminer (twig golden-1od. P. Can. y. An. u.) stem erect, subpubescent : leaves lance-lincar, nembranaccous, tajering to the base, glabrous, rough-edget, the lower ones subserrate : rays elungated. Peduncles and branches angular and very roughi ; hracts lanceolate, recur'red, smootl ; flowers numerous.

crecta (uprighti goldcn-pud. 4.) stem sub-villose : leares lanceolate, veiny, glabrous, entire, subpetioler!.

macropliylia (Can. 2).) low cip lcares ovate, acuminate, tapering, mecuntly and sharply serinte, glabrous ; cauline leaves tapering to buth ends, lanceolate, subsessile, serrate : racemes axillary, periuncled, leafy, of the length of the leaves: calyx oblon, turgit, many-flowered : rays somewhat elongated. About 3 feet high. Intermediate between this genus and the aster. fexicualis (zigzang golden-men. W. A. Y. I. y. An. 2!.) sten zigzag. glabrous, angled : leares lanceolate acuminate, seriate, glalurous : racemes axillary : rays hali as long again as the calyx. Stem slender, purplish, partly terete and partJy angular; leaves numerous on short broad petioles, harlly 2 inches long and half an inch wick, paler beneath. the wyires less sendate; $\mathrm{Nin} 2$ 
racemes much shorter than the leares, the up. per ones subcapitate.

latifolia (broad leaí golden-rod. W.A.P.y. Au. u.) stem somewhat zigzag, angular, smooth : leaves ovate, acuminate, strongly sserrate, smooth, contracted into winged petioles: racemes axillary. Leares often 2 inclies broad, and some. times hairy on the under side of the mid. rib.

virgaurea (mountain golden-rod. Saddle mountain, near Williams College. y. Ju. ..) stem erect, somewhat zigzag, angular, branching and pubescent alove : cauline leaves lanceolate, tapering to both ends, serrate or crenate ; lower leares oval, a little hairy : rays elongated: racemes lateral and terminal. Smith describes several raricties of this species. I have selectel those characters which agree with that variety which grows in great abundance on Saddle mountain. I alvays found the stem 5 or 6 angled and the ray forets 8 or 10.

rigida (hand-leaf golden-rod. P. C. y. Au. थ.) stem corymbed, hairy, scabrous : leares ovateoblong, rough, with minute rigid hairs ; lower ones serrate, upper ones entire : racemes compact : rays twire the length of the obtuse calyx. Stem 4 or 5 fret high, terete, striate, leafy ; leaves a little hodry, radical ones petioled, 12 inches long, broad, acuminate, nerved, the rest 1 to 4 inclies long; seales of the calyx roundobtuse, nerved, membranotis at the eilges. noreboracensis (star golden-rod. N. C. Y.0c. 24.) zadical leaves oval-oblong;, long-petioled, rough : stem almost leafiess, branclied, furzowed, level-top corymber : lays twice as long as the tapering calyx. Stem $\approx$ or 3 feet high, strong, rough, furrowed, liaving leares only at the origin of the flowering branches; radical leaves with shallow serratures; flowers la:ge, acsembling in form some asters; calyx scales 
narrow, purplish. Girows plentifully along the banks of Comecticut river at the Northampton meadows.

\section{SoNerros, 82.}

Zeucophacus (sow thistle. O. b-w.Ju. s.) peduncies scaly: flowers racemed: leares runcinate, actlminate : stem wand-panicled.

oleraceus (0. y. Ju. ․). peduncles sub-tomentose, umbelled : calyx glahrous : leares lance-oblong, clasping, denticulate, subsinuate. pallidus (P. New-England. y. Ju. 2'.) flowers in a compound terminal raceme or paricle: leaves lance-ensiform, clasping, toothed. Lactuca canadensis.

palustris (marsh sowthistle. 2\%.) calyx and pedun. cle hispid, subumbelled : leares runcinate, sagittate at the base.

arvensis (P.y. Au. 21.) calyx and peduncles hispid, subumbelled : leaves runcinate, denticulate, corlate at the base : root creeping.

fioridanus (P. b. Ju. $\delta$. perluncles somewhat scan ly : flowers panicled : leaves runcinate-lyrate: petioled, denticulate. Pursh says this is called the gall of the earth, and is used for curing the bite of the iattlesnake:

acuminatus (P. b. Au. 今.) perluncles somewhat scaly : flowers panicled : radical leaves subruncinate; cauline ones orate, acuminate, petioled, denticulate in the middulc.

alpinus (mountain sowthistle, Can. b-w. An. 24.) peduncles hirsute, naked: flowers racemed, bracted : leaves runcinate, sagittate at the base, glabrous, glaucous beneath:

Sorius, 62.

americana (momtain ash. W. A. C. I. P. W, M. h.) leares limate ; leafets lanceolate, serrate, 
glabrous : flowers corymber. Pursh applies. this name to a Canada species, and gives our species the name, microcarpa. This shrub on tree grows in very great plenty on Saddle mountain, near Williams College ; particularly at the height of about two thousand feet above the level of the college. It is usually from 10 to 20 feet high. The taste and smell of the bark greatly resemble that of the wild cherry tree. It is an excellent tonic.

\section{SoRGHUM, 32.}

Sacciaratum (iroom com. E. Y-g. Au. (3.) paria cle somewhat whorlcd, spreading : seeds oval, glumes corered with pernanent softish hairs. leares linear:; 6 to 8 foet high. From tho. East Indies.

sulgore (indian millet: E. 2) panicle compact, oval, nodding when mature : seed naked, sub-x compressed:

\section{SPArganium, 91.}

ramosum (bur-reed. 0 . w. Ju. Q.) the threc-sid ed bases of the leaves concave on the two ontsides : the generat fituit-stem branched: stigma linear. In water, generally. Flowers in round heads; the staminate lieads above the pistillate ones, and considerably the sriallest. simplex (lag bur-recl. A. P. W. In. 21.) threesided bases of the leaves not concave on the outsides (the concavity commences above the base) the general fiuit-stem not branched: stigma linear. This species is much taller than the preceding, and tiongh smaller peduracles are inserted uyon the main one, the latter is not itself branched. Nen the Patroon's, Aibany, it grows in moist ground about 3 feet high. ancians (C. Can. Au. \&.) leaves decumbent, flats 
general fruit-stem not hranched : stigma nvate, short : staminate head subsolitary. Var. angustifolium, has very narrow leares, greally overtopping the stem, weak, floating. Heads very small.

\section{SpargaropryoRts, 84.}

verticillatus (water crown-cup. Now Jerser. p. Au. 21.) leaves setaceous-lincar, whorled: stem generally 1 -flowered : egret companulate, ji-toothed. Floating in water.

\section{Spartina, see Limnetis.}

\section{SpartiuM, 78.}

junceum (spanish broom. E. J. h.) branches op. posite, wand-like, bearing flowers at the end:

leaves lanceolate, glabrous.

scoparium (scotch broom. E. J. 万. ) leaves ternate and solitary, oblong: flowers axillary : legumes pilose at the margin : branches angular,

\section{Spergutia, 59.}

drensis (spurry. O. w. J. @.) leaves filifarm, whorled : panicle dichotomous; perduncles be. come reffexed as the fruit advances to maturity : seed reniform. saginoides (pearl spurry. New-Jersey. w. J. 26. or (5.) leaves opposite, subulate, naked: peduncles solitary, very long, giabrous. Persoon asks, whether this is not a variety of the. Sagina procumbens.

\section{Spitaeria, 118.}

fragiformis (globule fungus. P.) aggregated like 
the acines of a raspherry, rusty-red. Having a strawberry-like ajpearance. ucuta (P.) solitary, conic, minute. bombardica (P.) lustered, globrilar, black, shin- ing. coronata (P.) imbodided, clustered, ovate-oblong;. black, ciliate. nirea (P.) white, clustered, tubercled, imbeded.

\section{SPHAEROPHORON, 114.}

Globiferus (seed-ball lichen) shrubby, branched, cylindric, brownish, smooth.

\section{SPHAgruM, 106.}

Zntifolium (peat-moss. 0.) leafets closely imbricate, concave, orate, obtuse.

cupillifolium (P.) leaves clnsely imbricate, lance. ovate, acuminate, fiattish. onspidatum (P.) leaves remotish, spreading; lane colate, cuspidate, indulate.

\section{Spigelta, $\$ 8$,}

Inarilandica (pink-root. P. p.J. 24.) stem 4-sided: leares ali opposite. The most celebrated rer. mifuge.

SpILOMs, 111.

melaleuca (efinorescent lichen) lackish, fat, sulconfluent.

Spinacta, 89.

dernoci (spinark. E. J. .) fruit sescilc, prickly or unarmed : leaves hastate-sagiliate : stema: branched. In hauit rescinbles the Chenopodi-. vim album. 


\section{SPirAEA, 62.}

\section{Stem more or less reoolly.}

Salicifolia (meadow-sweet, willow hard-liack. $\mathbf{0}$. 1. W.J. h.) leares lance-ovate, or obovate, serrate, glabrous : flower's in panicled spineading racentes. Var, albu, has whire petais, and generally the twigs are rodish. The small boanches are greiceally killet by firest in the winter, as also of the next species.

tomealosi (sterple bush, jurple harlhark. Y. N.

II. P. C. 1. ..Ju. Ћ.) leaves lancedate, unequally serrate, dosny lemath : racemes in a crowded, sub-pranicled spike. P'oot. İies considers a decoction of the leaves and branches of this plant, as one of ilie best tonics in use.

opulifilia nine-bark, snowball harhack. A. C. 1. W. J. h.) leaves subovate, lobed, doubly tontlied or crensta, glabrous : crirymbs terminal, crowhed: capstiles inflated: flowers trigynious.

Iypericifolia ijohn's wort hardhats. P. Can. w.

M. b. leaves obovate, entire, or tocthed at the apex : umbels sessile.

Erencia (C. Ђ.) leaves obovate, acute, tooth-crenate at the apex : corymbs pedincled, crowded.

\section{Stem herbaceous.}

stmaria (cucen of the mearlow. E. w. Au. 4.) leaves pinnate, downy bencets ; the terminal lealet largir, S-lubed, the lateral ones undivided ; towres in a proliferous corymb.

aruncus (steeple weedl. P. Catskil!. w. J. 4.) leaves pimnate, with 2 or 3 pair of leafets: flowers in a panicled spike : styles is to 5. Var. anericana, has very long slender spilies. 
Grows from 4 to 6 feet high, nor'th of Judge Benton's on the Catskill.

tobata (1. 1.Ju. 2\%.) leares pinnate, glabrous; the odd leafet large, 7 -lobed, lateral ones 3lobed : corymbs proliferous.

thifolicta (ipecac, indian physic, Bowman's root.

Can. 1. W. J. 1.) leaves ternate, lanceolate, serrate, subequal : stipules linear, entire, flowers terminal, lax-panicled : calyx tubular, campanulate. Gillenia trifoliata. An excellet emetic. See Barton's Veg. Mat. Med. p. 68.

slipulacea (Western states. w. J. น.) leàes ternate, lanceolate, gash-serrate, nearly equal: itipules leafy, ovate, gasli-toothed : flowers in alax paricle : calyx bell-form. Pussessing propertires similar to the last. Gillenia stipulacea. See Barton's Feg. Mat. Med. p. 75 . U1. Barton remarks, that these two last species never grow in the vicinity of each other but that one on the other can be found in most parts of North America.

\section{SPLACHNUM, 106.}

ampulaceun (umbrella moss. P.) receptacle obconic, obluse, grreenish purple : leaves swelling, lanccolate, serrate, pointed : apophysis blulw ber-like.

\section{STACHYs, 68.}

"spera (herige-nettle, clownheal. 0. w-p. Ju. น.) stem ercet, hispid backwards : leaves subpetioled, lanceolate, acutely serrate, rery glabrous: whorls about 6-flowered : calyx with sprearling: spines. Var. temifolia,leares rery thin and slender. 


\section{Staphyled, 47.}

irifolic (bladder-nut. O. y-w. M. h.) lcaves in threes : racemes pendant : petals ciliate below. A hamdsome shrub, about 10 or 12 feet high. When in flower, if the grem be cut transfersely and exammes, it will appear $200^{\circ} 3$-celled and will comiain the rudiments of 15 to 20 seeds. Bhut when the fruit is ripe, it consists of $\Omega 00^{\circ}$ : inflated, adnate, submeminimous capsules, fach containing i to 3 hard small nuts. Therefure the generic characters, giren by Limncus, Sinith, P'ersoon, Pursh, de. will mislead the student, if examined in the time of flowering only. I have rentured to omit the number of nuts, in the generic description.

\section{- Ststrice, 48.}

limonium (marsh rosemary, sea lavender. H. Y. C. b. Au. 2\%.) scape terete: pani-le much - branched: leaves lance-oborate, obtuse, mucronate, glalsin:ss. Very eficacious in dysentaries. See Muti's dissertation. A decoction of the root is an cxcellent gargle in cankers and ulcerated sore throat. See C'utler's Botanical arrangement, pagre 432. Men. Soc. Arts. cirmerir (thrift. P. P.Ju. 2\%) scape simple, pilose; Hower's capitate : Jeares linear, grass-like, flat, obtuse.

\section{STELLARI, 59.}

longifolia (long-leai starwort. H. Y. W. J.) stem decumbent, (or sub-decumbent) leaves lancelinear, opposite, entire, smooth : panicle terminal: calyx 3-nerved, about equalling the petals. Di. Bigelow informed me, that the $\mathrm{U}_{0}$ 
plant, which he called S. sraminca in the Boston Florula, is the S. longifolia.

palustris (stitchwort, meadow starwort. W. w. J.)

leaves lance-linear, entire, glaucous : flowers panicled : petals 2-parted, larger than the 3nerved calyx. This plant grows along the south margin of a meadow half a mile noith of Williams College. The stem is mostly erect, and the corol is twice as long as the calyx. I could not therefore make it agree with any species credited to this country. It ought to be compared with Smith's drawing of it, which he calls glauca ; but it is not now in my power to do it.

mubera (P. w. M. 24.) pubescent : leaves sessile, ovate, ciliate: pedicels erect: petals longer than the calys. Flowers large.

\section{STEMONITIS, 118.}

fascicularis (brittle-bark buff-ball. P.) fascicled, steel-blue : head subturbinate : stem rery short. resiculosa $(\mathbf{Y}$ ?) stemless, globular : seeds rustyochie.

\section{STEREOCAULON, 117 .}

Famulosum (knobbed lichen. P.) shrubby, rough, fibrous, pale : branches scattered, diffuse, nearly simple : knobs scattered and terminal, nearly globular, black-browr.

paschale (P.) brittle, shrubby, greenish-grey, granular-scaly : branches short, crowded : knobs flattish, turbinate, scattered, lateral and terminal, at length clustered and convex, olive. brown.

crocata (pit-back lichen. P.) subcoriaccous, sub 
depressed, round-lobed, pitted, glaucous-brown, with a citron-mealy margin and tubercles, pits beneath citron: shiclds black-brown with a glaucous-brown margin.

anthrapsis (P.) cartilage-membranous, roundlobed, pitted-reticulate, greenish-grey, nearly naked and a little ragged beneath with minute white pits : shiclds lateral, becoming convex, black. with a greenish-grey margin in the young state.

sylraticus (P.) membranous, ascending, glancousbrown, somewhat pitted, cut-lobed, ferruginous-brown and villose beneath with white pits : shields nearly marginal, ascending, brown.

\section{STIPA. 30.}

avenacen (feather grass. P. J. 2/.) leaves striate, oflabrous : panicle spreading, sub-unilateral ; branches whorled with branchlets ; calyx acute, membranaceous, eqalling the glabrous seed awn naked, twisting.

sericea (New-Jersey. J. 2\%.) leaves terete-filiform, very long: panicle effise, slenderly capiilary ; corol small, but twice as long as the calyx : awn naked strait. An elegant grass with a silky purplish panicle.

\section{STTLOSANTHUS, 81.}

Tispilla (pencil flower. C. P. y. Au. z.) stem pu. bescent on one side : leaves lanceolate, glabrous : bracts lanceolate, ciliate : heads $\approx$ or 3 flowered. Var. procumbens, stem procumbent.

\section{Swerti, 43.}

pusillu (false gentian. Whitehills. i). J. (?).) corol whechiforin, twice as long as the calyx : stem simple, 1-flowered : leaves oblong: 
corniculata (Can. Western states. g-y. Ju. of .) corol bellform, with a deflected horn : leaves ovate : branches short. In swamps.

\section{SYMPHITUM, 37.}

officinale (comfrey. E. y-w. J. 2!.) leaves ovatesublanceolate, decurrent, rugose. Naturalized. Dr. Cutler says, the leaves give a grateful Alaror to cakes.

Symplocarpus, sce Pothos.

Syrivga, 26.

vulgaris (Iilac. E. b-p. พ. M. 决) leares cordate: flowers in a styrse.

persica (persian lilac. E. b. M. 々.) leaves lanceo. late, entire and pinnatifid.

\section{T.}

Tagetes, 85 .

ereota (african marygold. E. y. Ju. (.) leaves pinnate; leafets lanceolate, ciliate-serrate : peduncles 1-flowered, incrassate, subinflated : calyx angled.

patula (french marigold. E. y. Ju. O.) leaves pinnate ; leatets lanceolate, ciliate-serrate: peduncles 1-flowered, subincrassate ; calyx smooth : stem spreading:

\section{Tatinen, 60 .}

teretifolium (taliny. P.p. Ju.น.) leaves cylindric. fleshy : corymbs terminal, peduncled. 


\section{TAMARTX, 4\%.}

germanica (tamarisk. E. Һ.) flowers decandrous : spikes terminal : leares sessile, lance-linear. gallica (french tamarisk. E. J. Һ.) spiikes lateral : leaves clasping.

\section{TANaceTUM, 85.}

vulgare (tansey. E. y. Ju. 24.) leaves doubly pis. nate, gash-serrate. Naturalized. Var. crisyum (doubly tansey) leaves crispid and dense.

\section{TAxus, 101.}

ennudensis (dwarf yew, shin-wood. P. Can. Fishkill, New-York. $\Lambda$ p. h.) leaves linear, 2-ranked, margin revolute : receptacles of the staminate flowers globose. 1 to 2 feet high, witl: creeping roots. .

\section{Tephrosia, see Galega. \\ Tetraphis, 106.}

₹ellucida (four-tooth moss. P.) capsule cylindric: leaves ovate, acute, 1 -nerved. Stem simple, 1 inch high : lid conic, reddish, thin, half as long as the capsule : teeth rigid, polished, brown.

\section{Teucriem, 67.}

canculense (wood-sage, germander. 0. r. Ju. 24.) whitish-hirsute : leaves lance-orate, serrate, all . petioled : stem erect ; spikes whorled, crowded : bracts twice as long as the calyx. virginicum (C. I. J. 2\%) pubescent ; leares ovateoblung, serrate; upper ones subsessile : stem $U_{0} 2$ 
462 THAELAEPHORA, THALTCTRUM.

erect : spikes whorled, crowded : bracts of the length of the calyx.

\section{Thaedae phora, $11 \%$.}

caryopliyllea (pink fungus. P.) head funnel-form, thin, purplish-brown, fringed, variously jagged or crisped. Substance tough and somewhat woody, chocolate brown. 1 to 3 inches in diameter.

mubiginosa (P.) ímbricated, rigid, rusty-brown, smooth both sides, with scattered, largish knobs: soft and velvety. About an inch in diameter.

hirsuta $(\mathbf{P}$.) aggregate, Pounded, coriaceous, convex, somewhat zoned, yellowish, shaggy above, smooth and tawny beneath. An inch diameter. quercina (P.) oblong, coriaceous, rugose, pale flesh coloured; margin somewhat involute, blackish-brown at the back. 'Two or three inches long, somewhat oval, light flesh coloured, with a dusty surface.

\section{Thalictrum, 66.}

Remark. Our species are mostly dioecious or polygamous.

dioicum (meadow rue. O. w-r. M. 4.) leaves thrice ternate, leafets cordate, nany-lobed, very smooth : panicles axillary, filiform : flowers dioecious : petals not longer than the filaments or germs : stigmas almost capillary.Leaves often 5 to 7 -lobed : panicles solitary or in pairs, subumbelled, often the panicle is accompanied by a long peduncled solitary flower ; seed ovate-oblong, striate. Whole plant smooth, little umbels few-flowered. cornuti (A. W. g-w. J. 24.) leafets 3-lobed, glaucous, smooth: panicles terminal : flowers dioccious : petals 5 ; roots fibrous. About 3 or 
4-feet ligh: stamens white with yellow anthers; seeds triangular.

polygamum (O.W. Ju. or $\Lambda$ u. 2\%.) pubescent witlz

slender down : leafets ovate, subcordate and wedge-form, s-lobed at the apex, subrugose above, subtomentose beneath : panicles terminal ; pedicels subumbelled, divaricate : flowers polygamous. Late in autum some individuals still remain in flower, and make a fine shew with the numerous long white stamens. C. pubescens. Pursh.

mugosum (A. C. P. w. J. 2l.) stem striate : leafets ovate and lanceolate, rugose, veiny, obtuselobed: panicle large, terminal, corymbose ; flowers erect. Tali. Panicles almost leafless. zurmurascens (P. Can. p. J. 24.) stem twice as tall as the leaves : leaves compound ; leafets roundish, 3-cleft, gashed: panicles nakedish ; flowers nodding ; stamens purple. Sinall.

\section{Thes, 64.}

bohea (bohea tea. E. M. h.) fiowers 6 petalled: leaves oblong-oval, rugose. From China and Japan.

viridis (green tea. E. 万.) flowers 9-petalled: leaves very long-oval. J. C. Lettson says, this is only a variety of the bohea.

\section{Thelotrem, 113.}

pertusus (crust lichen.) warts hemispheric, with 1 or 2 pores. Sinith has removed this species to the genus endocarpon.

\section{Thesium, 43.}

scmbellatum (false toadflax. 0 . w-g. J. \%.) crect: leaves lance-oval: fascicles of flowers corymbtorminal. Nuttall has changed this generic 
name to Comandra. With all due deference to the opinion of this learned botanist, I would ask, whether he has, in this case, sufficient reason for rejecting an established name? I know R. Brown says, that our species resembles the Santalum, an East India plant, with a single species in the genus. But why not rather improve the generic character, and retain the old name notwithstanding?

\section{ThLisPI, 74 .}

bursa-pastoris, (shepherd's purse. O. w. M. ... hirsute : silicles deltoid-obcordate : radical leaves pinnatifid.

campestris (yellow-seed, false-flax, mithridat mustard. O. J. O.) silicle obcordate, inflated, glandular-punctate : cauline leaves sagittate, toothed. Very troublesome in flax fields, and was probably introduced with flax-seed. arcense (penny-cress. C. P. Detroit. J. O.) silicles suborbicular, compressed, smooth : leaves oblong, toothed, glabrous.

\section{Thuja, 96.}

occidentalis (arbor-vitae, false white-cedar. A. Can. P. M. Ђ.) branchlets 2-edged : leaves imbricate 4 ways, rhomb-ovate, close-pressed, naked, tubercled.: strobiles obovate ; inner scales truncate, gibbous below the apex.

\section{Thymes, 70.}

serpyllum (mother of thyme. E. b-p. J. 万.) flowep* heads : stem creeping : leaves flat, obtuse, ciliate at the base.

vulgaris (thyme. E b-p. J. 4. Ћ.) erect : learas ovate, and linear, revolute : flowers in a whor!ed spike. 


\section{TIYMUS, TILLAEA.}

fanuginosus (lemon thyme. E. \%. 々.) flowers in hearls : stem.creeping, hirsute : leaves obtuse, villose.

TuREuAa, 58.

sordifolia (miter-wort, gem-fruit. W. C. P. A. w. M. 4.) leaves cordate, acute-lobed, toothed: teeth mucronate : scape racemed. Resembles the Mitella diphylla.

\section{Tiuid, 64.}

glabra, (basswood, limetree. 0. y-w. Ju. 々.) leaves round-cordate, abruptly acuminate, sharply serrate, subcoriaceous, glabrous : petals truncate at the apex, crenate: style about equalling the petals: nut orate, subcordate. Large tree; wood soft and white. 'T. americana.

nubescens (crop-ear basswond. $0 . \mathrm{y}$-w. Ju. $\mathrm{z}_{\mathrm{*}}$ ) leares truncate at the base (one lobe cropped) oblique,acuminate, fnoth-serrate, pribescent beneath : panicle dense-flowered : petals emarginate, about equal to the style : nut giobose, smooth. Resembles the last so nearly, that farmer's rarely observe, that there are tivo species.

\section{Trutadea, 36.}

ascendens (pigmy weed. Y. w.) stem ascending, routing at the lower joints: leares comnate, somewhat sheathing. Very minute. A new species. Found on the Housatunic by Prof. Ires, in the summer of 1816. It was at lirst taken for the T. connata; but on a strict examination. Dr. Ires was convinced that it was not described. I drew up this description from a spccimen, which I receired from Dr. I. last all. I would have preferred a specific des- 
cription given by himself; though I believe this to be sufficiently distinctive.

\section{TIмmа; 108}

polytrichoides (many-haired moss.) leaves lance. linear, serrate, spread : capsule drooping; on a receptacle : lid convex, depressed in the centre. Smith says, he cannot corsider Timmia an admissable genus, as it is not well distinguished from Bryum.

\section{Torrend, 25.}

pusilla (scotch asphodel. Can. s-w. J. 24.) glaibrous : leaves short : scape filiform; spike few. flowered, globular: litile calyxes adnate to the rachis: capsulo globose. Mountain sivamp.

glutinose (Can. 2 .) scape and pedicels ghtutinousscabrous : spike with a few alternate fassciclea ; capsule ega form, twice as tong as the calyx.

\section{TuLPIs, 83.}

burbrta (hawksbeard. E. S. P.) leares oblongg toothed: peduncles 1 -fiowered.

\section{'T'RuDESCANTI, 48.}

virminica (spiderwort. P. b. p. M. 2.) erect: leaves lanceolate, clongated, glabruus : flowers sessile ; umbel compact, gubescent. Gulti vated in gardens.

\section{TrAGOPOGON, 81.}

Morrifolum (vegetable oyster, goat-beard, salsify. E. p. Ju. $\delta$.) calyx longer than the rays of the corol ; the corollets very narrow, truncate: peduucles incra ssate. 


\section{Trichonuer, 31.}

Ituxiflorum (thin-grass. 0. M. 2\%.) culm erect, striate, purplish : leaves involute, subulate; upper ones llat, nerved, margin scabrous; sheaths roughish : panicie capillary, lax, spreading ; branches whorled ahout in threes : glumes lanceolate. 12 to 18 irches high ; the panicle is very thin and delicate. Csually grows in dry fields.

scabrum (C. P. Ju. 2.) culm glahrous, geniculate at the base, with erect branches : leaves lancelinear, striate. flat, margin scabrous ; stipule ?cleft, acute; sheaths striate, glabrous : panicle rery branching, spread, with whorled, zigzag. branchlets.

\section{TRICHOPHORUX, 29.}

syperinum (light-hair, clump-head grass. 0. Ju. 24.) cnlm s-sided, leafy, hollow: panicle terminal, more than decompound, proliferous, jeduncles and pedicels scabrous; spikes glomerate, 3 or 4 in a hear, or more, ovate, obtuse. 3 to 5 feet high. Very common in wet meadows and swampy ground. Eriophorum cyperinum.

\section{Trichostema, 69.}

dichotoma (blue curls. Y. N. H. P. b. Au. ().) leaves rhou-lanceolate : branches flower-bearing, 2-forked : stamens very long, blue, curved. 6 to 8 inches high. Gives out a scent, precisely resembling that of the spilienard. Far. linearis, has linear leaves.

\section{Trichostomum, $10 \%$.}

pallilum (hair-mouth moss. P.) stem simple ve- 


\section{8 TRIENTALIS, TRIFOLIUM.}

ry short : Teaves capillary, sheathing : capsule cylindric : lid conic ; calyptrê halved.

\section{Thientalis, 53.}

curopaca (chick-wintergreen. W. H. N. A. C. P. w. Ju. 24.) leares oral; stem naked below, with a tuft of oval leaves at the top. Var. america$n$ n, has lanceolate leaves, tajering to both ends. About 3 to 5 inches high. Though in the genrric description it is said the stamens vary in ntimber: in the specimens about Williams College much the largest proportion have the true number.

\section{Trifoling, 80.}

ymatense (common red dover. O. P. M. 24.) ascending, smoothish ; leafets ovate, subentire : stipules awned: spikes dense, orate: lower tooth of the calyx shorter than the tribe of the corol, and longer than the other teeth.

repens (white claver. O. w. M. ४.) creeping: leafets ovate-obleng, emarginate, serrulate : llowers in umbelled heads : teeth of the calyx subequal : legumes 4-sected. Foreign botanists often call these two species intreduced plants; but I know not on what anthority. I have never seen a place of a few miles extent where they do not grow, however wild the country.

arcense (rabbit-foot, field clover. 0. w. Ju. (-) erect, branching, villose ; leaves lance-linear, serrulate at the apex : stipules connate, subulate at the apex : spikes villose, oval-cylindric: teeth of the calyx setacenus, longer than the corrol. Grows in dry pastures or barren fields. stoloniferum (buffalo clover. Western part of the state of New-York. W. J. 2\%.) sending oif suck- ers from the base of the stem : lcares oborate, 
inequally serrate on the sides, and toothed at the end : teeth of the caly $\mathrm{x}$ narrow-lanceolate or subulate, longer than the tube : florets large, in a head-frorm spike. 'This description I drew from a dried specimen in the lierbarium of Dr. 'I. R. Beck; being unable to procure any other.

iensylranicum (P. r. J. 24.) ascending: stem rery branching, zigzag : leafets oval-ovate, obinse. entire : stipules awned: spikes ovatecylindrir, dense, solitary : lower tooth of the calyx shorter than the tube of the corol. Pursh says, this is known by the name of Buffalo clover. 'This is one of the many instances, whele $P$. makes his popular remarks at random. Want of ficlelity, as Ms. Nuttall calls it. has induced many to spreak contemptuously of Pursh's flora. 'This fault is, to be sure, a great objection to his remarks at the end of some species. But after all, take his book as it is, it affords more aid in determining North American plants, than all other works extant. "Justitia fiat," dc.

rellexum (P. 3.J. 2!.) procumbent, pubescent : leares obovale : stipales oblirue, cordate : heads many-flowered ; flowers pedicelled, at length al! reflexed : lesumes abaut 3 -seeded. procumbens (hon clover. P. y. J. (.) procumbent: strm hairy : leafets obovate, submarginate, glabrous: stipules short, lanceolate, acute : spikes oral, inbricate : banner deflexed, furrowed, permanent.

cumpestre (C.P. y. ..) spike ovate, imbricate : banner leflected, permanent : leafets lancewatr, michle one petioled: stem subdiffuse; branches decumbent.

agrarium (P. y. J. 9.) erect, subpubescent; leatets lance-wedgeform, obtuse, middle one sessile : stipules lanceolate, acute : spikes oval, imbricate : bamer deflexed, permanent : tecth of the calyx subulate, glabrous, unequal. 


\section{Trifolium, see Nlelilotus.}

\section{Triglochin, 53.}

maritimim (arrow-grass. Y. H, g. Ju. 2!.) caj) sules short, orate. furrowed. 6-celled, romderl at the base : lcares semicylindric : ront tubernus. Grows plentiful, about 12 or 14 inches highi, in the sait nieadows about New-Haven. galustre (Onondaga salt springs. g. Ju. 4.) triandrous : capsules linear, tapering to the base, 3-celled, smooth ; stigmas erect : leaves ralical, 2-ranked, sheathing, linear, channelled, smooth : routs fibrous. Albout 6 inches high. ivitmdrum (Can. P.) triandrous : fowers 3-cleft, short-pedicelled : capsules roundish-triangular : leaves subsetaceous, almost as tall as the spike $\mathrm{or}^{\circ}$ scape.

\section{TRIGONELLA, 80.}

foenum-graecum (funegreek. E. O.) legtimes sessile, solitary, strait, crectish, subfalcate, acuminate : stein erect : leaves wedge-oblong.

\section{TrILIUM, 52.}

2rectum (wake-robin. W. A. N. P. p-w. M. 4.) peduncles erect or erectish, with the fiowers a fittle nodding : petals oval, acuminate, spreading, equalling the caly $\mathrm{x}$ : leaves rhomboid, acuminate, sessile : peduncle about 5 inches long. Var. utropurpureum, petals large, dark purple. Var. album, petals smaller, white; germ red. 12 to 15 inclies high. Leaves often 3 or 4 inches broad.

cernum (nodding wake-robin. Y. H. C. P. g. \& w. M. 2.) peduncles recurved, shortish : petals lanceolate, l'eflexed, the size and form of 
the calyx-leares : leaves rhomboid, abpuptly acuminate, rery short petioled. Abont hail the size of the last species. Petalis dull brownish white, striped with green.

frictum (smiling wake-robin. W. C. P. W. d p. M. 24.) perluncles erectish: petals lance-orate, acuminate, recurved, almost twice as long as the narow-leaf ralyx : leares wate, arvininate, rounded at the base, aloruptly petiolcd.Very abundant in moderately dry womls north of Williams College. An eleganit species.

pendulum (P. W. M. 24.) pedancles erect, with the flower a little nodling: betals orafe, acuminate, sprealing, longer than the calyx : leaws shomboid, acuminate, sessile. Smaller than the erectim, germ reitish, anther's aml styles yellow, flower dull white. I took this descripinn liom Smith. He says P'ursh has given the characters of the erectum for this species. But I never sav the pentulum.

sranifionum (1'. w. M. 4.) peduncles a little curved and the flowers a little nosling : petals

lance-sipatulate, crect at the base, limis spreating, much largep than the calyx : leaves briad ilimub-orato. Berries dart parple.

sessile (P. p. M. 2.) flower's sessile, erect; petals lanceulate, eroct, twice as long as the calyx:

leaves sessile, brond-orato, acure.

pumilum (dwaif wake-1obin. P. P. M. 2'.) peduncles crect; petals scarcely longer than the falyx : leaves oral-oblong, chtuse, sessile.

\section{'Triosteum, 41.}

perfotiatum (fever-ioot, horse-ginseng. O. p.J. 24. feaves oval, acuminate, combate : fiowers sacesile, whorled. \& to 4 leet lighth berries parpile or yellow. Very valuaisle as a cathartic sul enctic. See Bigelow"s Medical Botany and Baton's Vegetable Matuia Molica. 


\section{Triticum, 31.}

hyb̄ernum (winter wheat. E. J. o .) calyx-giume 4-flowered, tumid, even, imbricate, abrupt, with a short compressed point : stipule jagged : corois of the upper florets somewhat bearded. There are several varieties of this species, which are induced by culture. aestivum (summer wheat. E. J. 8 .) calyx 4-flow. ered, tumid, smooth, imbricated, awned.Smith says this may be a variety of the last. compositum (egyptian wheat. E.) spike com pound ; spikelets crowded, awned. repens (wheat-grass, couch-grass. 0. J. 4.) calyx acuminate, many-nerved, 5 -flowered ; flowers pointed : leares flat: root creeping.

\section{Tronires, 6\%.}

7axus (globe-flower. C. P. y. M. 21.) petals 5 , oltuse, spreading : nectaries shorter than the stamens. T. americanus. Petals always, perlaps, 5 , obovate : capsules short, abrupt, crowded with the elongated style.

\section{Tropaeoutic, 55.}

majus (nasturtion, indian cress. E. y. \& r. Ju. (C). 2\%.) leaves peltate, sub-repand : petals ob. tuse, some of them fringed.

\section{Tubercularia, 119.}

valgaris (tubercle fungus. P.) aggregate or scattered, bright red, ridgy or wrinkled, with a thick pale base.

rosea (P.) scattered, loose, irregularly globose, rose-coloured. Bright pink little masses, which dissolve in rainy weather. This Smith gives as its best distinction from some lichens. 


\section{Turiss, 50.}

sulreolens (swect tulip. E. M. भ.) small : stem 1-flowered, pubescent : flower erect : petals obtuse, glabrous: leares lance-orate. gesneriana (common tulip. E. M. 4.) stem 1-flowered, glabrous ; flower various-coloured, erect : petals obtuse, glabrous : leaves lance-orate.

\section{TuRritis, 74 .}

3irsuta (tower mustard. O.w. Mr. o. or 24.) leaves all hispicl; cauline ones clasping: silique 4angled. Pursh describes a variety, probably, of this species, he calls it orata, pubescent : radical leaves petioled, ovate, toothed, obtuse ; cauline ones clasping, oblong, serrate acute.

Enerigata (P.w. M. ( $\because$ or 24 .) leares glabrous: radical ones obovate, serrate ; cauline ones lance-linear, cntire, clasping. About 12 inches high.

\section{Tussrugo, 86 .}

furfarr (rolt's foot. W. A. P. N. y. Ap. 2\%.) scape single-flowered, scaly : leares cordate, angular, toothed, downy beneath. The flower appears long: before the leaves.

frigida (mountain colt's foot. New-Hampshire, Vermont. y. M. 24.) scape many-flowered, corymbed, bracted : leaves triangular, cordate, with deep triangular teeth, downy beneath.

\section{TYPнA, 91.}

latifolia (cat-tail, reed-mace. O. Tu. 24.) leares linear, flat, slightly convex beneath : staminate and pistillate aments close together. angristifu! ia (H. Ju. 21.) leaves lincar, channelled, semicylindric below and flattish above: stac ininate and pistillate aments a little separated. Not so large as the last species.

$$
\text { Pp \% }
$$




\section{U. \\ ULEx, 78 .}

curopeus (furze. E. M. Һ.) leaves lance-linear, villose : bracts ovate lax; branchlets erect.

\section{ULMUS, 44.}

americana (elm, white elm. O. $\mathrm{s}-\mathrm{p}$. Ap. $\zeta_{\text {a) }}$ branches smooth : leares oblinue at the base, having acuminate serratures a little hooking: flowers pedicelled : fruit fringed with dense down. A rery large durable tree, with the branches gradually spreading, when it grows in open fields, so as to form a fian-form top. Var. pendula, has hanging branches and smoothish leaves. Rafinesque says this is a distinct species. See Florula Ludoviciana, page 115.

fulva (slippery elm, red elm. $0 . \Lambda$.. . .) branches scabrous, whitish : lcares ovate-oblong, acuminate, nearly equal at the base, unequally serrate, pubescent both sides, very scabrous : buds tomentose with very dense yellowish wool ; flowers sessile. May always be known by chewing the bark, which is very mucilaginous. nemoralis (river elm, grove elm. New-England.

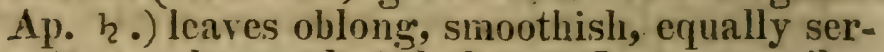
rate, nearly equal at the base: flowers sessile.

\section{ULVA, 110.}

Femark. The species examined by Muhlen berg are all membranaceous.

purpurea (glue-seaweed. P.) lance-oblong, flat, - margin entire, undulate.

lactuca (P.) several fronds from the same base, distinct, oblong, flat, somewhat undulate, tar pering below, dilated upwards, torn. 
lubrica (P.) crowded, in tufts, oblong, convolute, inflected, undulate, rugged, intersecting or anastomosing, very thin, lubricous.

intestinalis (P.) tubular, simple, green.

compressa (P.) tubular, branched, compressed,

\section{UxIOLA, 32.}

paniculata (sea rush-grass. P. Ju. 24.) panicle long; spikelets subsessile : calys many-valved: flowers glabrous on the keel : leaves conrolute : culm very tall. On the sea-shore. latifolia (P. J. 4.) panicle lax: spikelets all longpedicelled: calyx 3-ralved: flowers monandrous, subfalcate, hairy on the keel : leares broad, flat.

spicuta (C. Ju. 24.) flowers in a thyrse : spikelets approximate, close-pressed, aliout 6-flowered, awnless : leaves convolute-subulate, rigid, al. ternate, pointing 2 -ways : culm erect, glabrous. Festuca distichiphylla.

Uraspermum, see Myrrhis.

\section{URCEOLARE, 114.}

panyrga (pitcher-shield lichen. P.) effise, gramu. lar-warty, pure white : warts clustered, bearing shields which are glatcous-mealy, with convex entire margins.

bryophylla (P.) effuse, tatarous, wrinkly-plaited, granular, uneven, greyish ; with a slightly lobed leafy circumference : shields glaticousblack, with a flattish disk and nearly distiact margin.

\section{UREDO, 118.}

frumenti (blight, grain-rust. 0. J. O.) linear, oblong, black brown, growing from under the ell. 
ticle of culms through the pores. See Sir Joseph Bank's essay on blight, with a plate by $\mathbf{F}$. Bauer:

flava (yellow rust. O. J. g.) globular, yellow. growing from under the cuticle of leaves and stems which have a thickish soft cellular integ. ument. It often occurs on the stems of elder and swamp-willowherb.

segetum (smut. O.) black, powdery, in the spikelets of grasses. Is not this rather a morbid: swelling, and final disintegration of parts ?

\section{URTICA, 92:}

Gioica (common nettle. O.J. 4.) leaves opposite, cordate, lance-ovate, coarsely serrate, flower's dioecious : spikes panicled, glomerate, in pairs, longer than the petioles.

prucera (0. Ju. 2l.) leaves opposite, corlate, lance-ovate, serrate; petioles ciliate : flowers dinecious : spikes somewhat brancher, glomerate in pairs, equalling the petiole. Not so common as the last; which if examined before full maturity, may be mistaken for this. gracilis (N. Can. Au. 24.) leaves opposite, lanceovate, nakedish; leares and petioles hispid: racemes in pairss. Pursh says this and the last species al'e the same. Perhaps they are; but if so, the gracilis at Northampton, is a very. slender and delicate variety.

divaricata (O.Ju. 2\%.) leaves alternate, broadovate, acuminate, scrrate, smoothish ; petioles long, ciliate : panicles axillary, solitary, spreadsubpalmate, very branching, longer than the petiole (in maturity) stem furnished with stings. mamila (stingless nettle. O.Ju. site, ovate, acuminate, 3-nerved, serrate; lower petioles as long as the leaves : flowers monoecious, triandrous; in corymbed heads, shorter than the petioles. Stem smooth and 
shining; when in deep shatles the stem is pellucid. Adesia trinerva. Raf.

atrens (dwarf stinger. N. A. P. II. J. O.) leaves opposite, oval, about 5-nervel, sharply serrate : spikes glomerate, in pairs. capitata (C. P. Can. J. భ.) leaves alternate, heart-ovate, acuminate, serrate, S-nerved, twice as long as the petiole : glomerules spiked ; the spikes are solitary, shorter than the leaves, leafy above : stem naked. canculensis (canada nettie. 0 . Ju. $\mathcal{Z}_{\text {.) }}$ leares alternate, heart-ovate, acuminate, serrate, hispid both sides : panicles axillary, mostly in pairs, spread-branched; the lower staminate ones longer than the petioles, upper piatillate ones elongated: stem covered with stirgss. 5 to 6 feet high.

rohitlorvi (aibany hemp. A. Au. 4.) stem simple, terete, and sub-glabrous at the base ; towards the top it is 5 to 8 -grooved, and covered with reversed stings : leaves serrate, punctate (with deep green specks or spots) acuminate, longpetioled, alternate ; lower ones broad-oval, with the base wedge form; uppermost ones nearly opposite, heart-orate : "panicles peduncled; staminate ones axillary dichotomous, longer than the petioles; pistillate ones terminal : capsules orbicular-compressed, mucronate" : root tuberous-fusiform, often with tuberous branches nearly at right angles. Stem 5 or 6 feet high.

Dr. Muhlenbergexamined this plant and named it in honor of its discoverer, Mr. Charles Whitlow ; whose opinion, that it may be advantageously cultivated as a substitute for hemp, seems to be confirmed by the observations of McKinzic。 Dr. Withering also observed, long ago, that he had no doubt some species of the nettle might be used as a sulsstitute for flax. 
Serera! untanists consiler the whitowi as a variety of the canadensis. I lave therefore been particular to give a full descrition; which I took from several living spechinens on an island neai Albany, and compared it with those cultirated in Mr. G. Webster's garden. That part of the description relating to the fructification, $f$ translated fiom Br. Mullenbergos descrintion:

Whether it is a ristinct species of only a raricty, will not affect the unestion of its uschulness. And $i t$ is to be hoped, that agriculturalists wial make more extensire experinents.

\section{USNEA, 116.}

chgulutı (hat-stem trce-moss. 0.) stem anglod, flattish, naked; whole frond greenish-blue : orbs of the colour of the frond. Tery stroms and wondy. I do not knew that this is Mulilenberg"s angulata, Bit as I can find no description of this common Usnea, fund every where on trees, I have described it muler. this name. Perhaps it may be a pistillate hichon, of a describerl species.

forili (spreculing-tree moss. 0.) erect, cylindric, rough, greenish-grey, with horrontai shres : branches scattivd, sonewhat fastigiate, near-

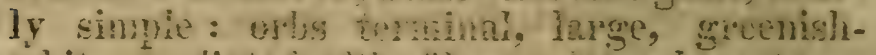
white, muliatef wh flores : Interal warts or knols, patish yeliow.

plicata (hner tre-noss. Y. Catskin Mt. P. Ware (Mass.) aud on most high mountuins, on ere?green trees.) jollsh, Mamentuis, lianging down 6 to 20 inches long. Clintric, branched, entangled : oris greenish-white, blyed with radiating fhes : latural hnobs yllowish. hirtus (P.) grensh-grey : branches tapering, crowted, fib rillous, rotigh-mealy : orls ininute, white, radiate : know pale reddish-yellow. strigowus (i).) branches scattered, short, rigid, 


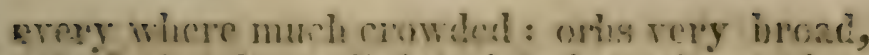

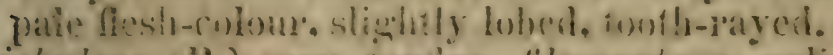
trichodens (13.) rory suder, filamentous, rylin-

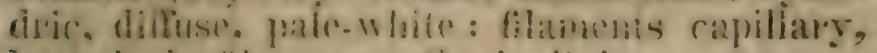
brancherl, thlores mosily inclining ome-way : orls pale-white, whth a biba inthated, naked, entire margin.

\section{UTRICUTARIA, 26.}

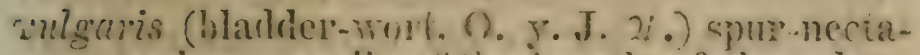
ry conic. upper lip of the lerghth of the palate, greflexed to the sides : stape strait. fow-llowered. Scape gencrally procerding from the junction of several horizontal hranches, which lie in the mud or lloat on the suriates of wates. The leaves are cajollairy, generally bearigg small bladders.

cormute (leafless bladider-wort. P. Can. Planficd, Mass. y. Ju. 24.) spun-nectary subulate, lengthencel out longer than the corol, nearly rertical, acute : fower lip of the corul broad, 3-lobed : scape with o nearly scssile flowers at the top : no leares at the base. In the marsl: on Cromed lake, Plainfield (Mass) it grows so plentifully as to give the lake the appurance of being bordered with yellow. I saw thousands there still in fower in September.

sacchaia (C. P'. p. Au. (.) scape i to s-flowered : lower lip of the corol s-lober, lateral lobes cowled on the under side; palate large and prominent : spur-nectary compressed, keeled, subacuminate, close-pressed to the corol, which is uygide down and covers the spur with its reflexed margins : upper lip almost round. This species was discovered by Mr. Le Conte. But Nutall says, it is the purpurea of Waltex. gibba (New Jersey. y. Ju.) sipur-nectary gibisous: divisions of the corol rounded : scape generally 1 -fiowered. Very small. 
subulata (Can. P. New Jersey. y. J!. \$. s.) spurnertary obtuse, shorter than the under lip: scape about 2-flowered. Flowers small.

sctacea (C. New Jersey. P. y." J.) leafless; scape minate, terete, slenderly setacenus, 2 or 3-1lowfercl, rooting; fiowers on longish peduncles: spur-nectary longish. It appears that MM: Le Conte sometimes found 6 or 7 fioweris on a scape; and Mr. Elliott says the lower lip of the calyx is sube marginate. Pursh says this is the subulata; but Nuttall says it camot possibly be that.

minor (New Jersey.y. Au. 21.) spur-nectary gilb. bous, keeled : throat of the corol oper. Flowers small.

ceratophilla (C. y. Ju.) leaves at the base of the scape cylindric, capillary, divided, branched at the extremities: scape producing 6 to 10-flowered racemes : lower lip of the corol with 3 retuse lobes : spur compressed. The largest of the species.

\section{UWCIARIA, 51 .}

1. Capsules 3-connered ; stigmas reflexed.

perfeliata (bellwort. $0 . y_{0}$ M. 4 .) lcaves perfolliate, oval, obtuse (lance linear or oval-oblong; in the young "state) corol bell-liiliaceous, scabrous or gramular within : anther's cuspidate. sessilifolic (O. Y. M. 24.) leaves sessile, lanceoval, becoming glaucous beneath : petals flat, smooth within : capsule stiped (raised above the receptacle on a little stem) : stem giabrous. lanceolata (P. Can. y. S. 24.) leaves perfoliate, oblong; acute; petals smooth within : anthers obtusish : nectaries roundish. Flowers large. U. grandiflora.

fara (New-Jersey. y. M. 4.) leaves perfoliate, oval-oblong, obtuse, undulate at the base : co- 
rol tapering to the hase, scabrous within : anthers cuspridate. Is not this description drawn from the U. perfoliata, which was gathered in the carliest state of llowering? Excepting the tapering base of the corol, I am sure we can always find all parts of this description in the U. jerfoliata, for several days after the flowcrs begin to cxpard ; and I can hardly find it excluded by basi attenuata.

\section{$\therefore$ Capsiules sulghlobose; stigmas :cry short.}

numplexifolia (Can. P. g-w. M. य.) iraves clasping : pedicels solitary, twisted-geniculate in the midale. Streptopus distortus.

rusea (W. Can. P.p. M. 24.) leaves clasping, serrulate-ciliate : anthers short, ¿-horned. Very abundant in a deep ravine west of Williams College. It is from 12 to 18 inches high, with purple flowers speckled with deeper purple. lcmuginosa (T. y-g. J. 24.) whitish-woolly: leaves scssile, subcorlate at the base, acuminate ; pedicels in pairs, necting upon a short general forlicel. Flowers large, berries red.

\section{Y.}

\section{VACCINIEM, 57.}

Remark. President Smith remarks upon the removing of this genus to the roth class in a waty, which strongly implies his disapprobation. He says Pursh removed it not recollecting at the moment that Personn removed it about ten years hedore Pursh wrote. 'There are about 25 species in North America, not one of them octandrous ; and bacly three octandrous species in Europe. Ought we therefore to make our 25 species into anomalies, on account of the European species? I presume Dr. Smith would not object to Qq 
taking off the $0 x y c o c c u s$ genus, should he become acquainted with all our species of the old genus Taccinium, growing in their native wilds. See Rees' Cyclopœedia.

stamineim (squaw whortleberry. O. w. M. 々.) leaves oval, acrite, entire, glaucous beneath : pedicels solitary, axillary, filiform : corol spreading bell-form ; divisions oblong, acute : anther's exsert, awned on the back : berry pear-form. About 2 or 3 feet high. Var. album, has the nerves and veins of the leaves hairy and the berry globose. Pursh makes this variety a distinct species; but Smith says it can hardly be called a variety. Berries of this species are large and light green, when ripe ; very soft and juicy within, with a tough skin.

dumosum (bush whortleberry. C. P. w. J. h.) toranchlets, leaves and racenes a little hispid, hedewed with resinous specks; the leaves oblong-obovate, acute at the base, mucronate, entire, both sides coloured alike : racemes bracted, pedicels short, axillary, sulsolitary, 2-bracted near the middle : corol bell-form, divisions roundish, including the anthers.

frondosum (blue whortleberry, P. A. W. w. M. h.) leaves oblong-obovate, obtusish, entire, glabrous, glancous beneath, bedewed with many resinous dots : racemes lax, bracted ; pedicels long, filiform, bracted ; the bracts linear: corol ovate-bellform, with acute divisions, and enclosing the anther's. War. Lunceolatum, having lanceolate leaves acute at both ends. About 3 feet high, berries large and blue.

resinosim (black whortheberry. O. p. M. h.) leaves slender, petioled, oblong-oval, mostly obtuse, entire, bedewed with resinous specks beneath : racemes lateral, one-sided ; pedicels short, somewhat bracted : corol ovate-conic, 5comered. 1 to 4 fect high ; berries black. Much taller in woods than in open fields. 
cosymbosum (giant whortleberry. 0. w. M. 々.) flower-bearing branchlets almost leafless : leaves oblong-oral, acute at buth ends, mucionate, subentire ; subtomentose beneath and hairy both sides when youmg. but glabrous above and a little hairy at the reins beneath when mature; racemes shrurt, sessile. with scaly bracts: corols cylindric-ovate : calyx erect : style somewhat exsert. In wet groun!, it grows very large; near Albany it grows 10 feet high and 2 or 3 inches in diancter. Bcrries black. Var, amnenum, has the style not exsert, and the racemes are crowded, corol cylindric and the calyx reflexed. The twigs are reddish, fluwer's large with a reddish tinge. Var. rirgutuit, has the leaves a little serrulate, glabrous, racemes corymber, corol cylindric with the throat closely pressed together, divisions very short, calyx reflexerl and style not, exsert. Flowers redilish. Var. fuscutum, has the leaves a little serrulate, glabrous, corymbed racemes tepminal, pedicels long and nodding, corol cylindric with short erect divisions, style hardly exsert. Flowers striped with led, calyx brown. Pursh and others inake these varieties distinct species. But I have followed Dr. Smith, who, after critically examining l'ursh, Michaux and others, and comparing the specimens, has judged them to be but varieties. ligustrinum, (prim whortleberry. P. p. M. h.) branches angled : leares subsessile, erect. lanceolate, mucronate, serulate, veiny, hairy : fascicles nearly sessile in sessile tufts : corol oblong-ovate. Veins of the leaves often purplish, berries black.

tenellum (dwarf whortleberry. P. Whitehills. $\mathrm{r}$ W. M. Ђ). branclies angled, green : leaves sessile, lance-ovate, mucronate, serrulate, shining both sides; flower's in crowded, inostly scssile fascicles : corols ovate.

gaultherioides (wintergleen whortleber'y, White. 
hills. Ju. Ђ.) prostrate : leaves obovate, entire : flowers subsolitary : berries oblong, crowned with the style. Very small. A new species discovered by Bigelow and Boot. witis-idaea (bilberry. Can. New-England. w-ro' M. 々.) low ; stem creeping, branchlets erect : leaves nbovate, emarginate, revolute, subserrulate, shining above, punctate beneath: : racemes terminal, nodding : corol bell-cylindric. Sometimes tetandrous.

Vaccinium, see Oxycoccus.

VALERIANA, 27\%.

phu (valerian. E. 4.) cauline leaves pinnate; radical ones undivided : stem smooth.

Talcriana, sce Fedia.

VATHISNERA, 9\%.

spiralis (tape grass. Y. Fishkili (New-York) $\mathbf{P}_{\alpha}$ Au. 24.) leaves floating, linear, obtuse, serrulate at the summit, tapering to the base : peduncle of the pistillate flower long and spiral.; of the staminate, short and erect. Var. americana, when in shallow water has the pistillate peduncle erect. But as this variety has a spiral peduncle in deep water, perhaps it is not. even a variety.

\section{VARIOLARIA, 112.}

faginea (bitter small-pox lichen. 0.) crust cartilaginous, rugged, polished, greyish, bordered. with brown : receptacles prominent, hemispheric, mealy, very white; with a pale flattish, and at length naked disk. Very bitter little after chewing it. 
liscoidea (flat-cup lichen. 1') crust cartilaginous, cracked, somewhat rugged, polished, greyish, hordered with brown ; at length powdery. Ireceptacles flattish, mealy, rery white, at length concave, depressel, with a dilated toru. border. Very white on old trees in wet weather. No proper receptacle has been found of a different colour from the frond. 'This is one of the genera, which Sprengel considers as only the rudiments of other genera, in an immaturo state.

\section{Finatroar, 50:}

sirile (itch-weed, indian poke, white hellebore. 0. g. J. 24.) flowers in terminal racemed-panicles; bracts of the branches lance-oblong, the bract of the flowers longer than the subpubescent peduncles: leares broad-ovate, plaited. many-nerved. Useful in theumatisms and many cutaneous eruptions. Doct. Cutler says. r'ows may be destroyed by boiling indian corn in a decoction of this plant, and strewing it in. corn fields.

inteum (blazing star. P. Connecticut. $\mathbf{y}$-w. M. $\boldsymbol{\psi}$.) flower's in a simple raceme: leaves sessile, narjow-Janceolate : root bulbous. I have seen a dried specimen of this species from some part of Connecticut; but I do not at this moment zecollect from what town.

\section{VERBASCUM, 39.}

ikapsus (mullein. 0. y. J. $\delta$.) leaves decurrent, downy both sides : stem generally simple, tho" sonetimes branched above : flowers in a cylindric spike. When botanists are so infatuated with wild theory, as to tell us the mullein was. introduced, they give our youngest pupils oca. casion to sneep at their teachers.

Qq. 2 
blattaria (sleck-mullein. A. N. C. P. w-y. J. ô.) leaves glabrous, tooth-seriate ; lower ones oblong-obovate, upper ones heart-ovate, clasping: perlicels solitary, 1 -flowered. This description differs widely from that given by Pursh. But it ag:ees with scores which I have examined about Albany and Troy.

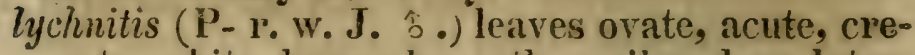
nate, white-downy beneath: spikes lax, later. al and terminal.

\section{Verbena, 68.}

hastata (vervain, simpler's joy. 0. p. w. Ju. 21.) erect, tall : leaves lanceolate, acuminate, gashserrate, lower ones sometimes gash-hastate : spikes linear, panicled, subimbricate. Var.pinratifida, has the leaves gash-pinnatifid, coarsely toothed.

urticifolia (nettle-leaf vervain. U. w. Ju. 24.) erect, subpubescent : leaves ovate, acute, serrate, petioled : spikes filiform, with flowers a little separate, axillary and terminal. Both of these species grow from 3 to 5 feet high. Generally about garden fences and old fields.

angustifolia (pigmy vervain. Y. C. P. b J. 21.) low, erert : leaves lance-linear, tapering to the base, thinly serrate, with channelled veins: spikes filiform, solitary, terminal or axillary. About a foot high, in the dry fields about New Haven.

spuria (C. Y. P. b. Ju. 2\%. 实) stem decumbent, with spreading branches: leaves in many-cleft divisions : spikes fliform : bracts exceeding the calyx. Very abindant 7 or 8 miles about New Haven.

VERBESINA, 87.

sigesbectia (crown-beard. P. y. Ju. 24.) stem 
winged : leaves opposite, lance ovate, aruminate at both ends, sharply serrate : panicle brachiate : flowers in fascicles on the ends of the branches.

virginica (P. W. Ju, $\boldsymbol{\psi}$.) stem narrow-wingrad: leaves alternate, broad-lanceolate, subserrate : corymb compound : calyx oblong, pubescent. Ray florets 3 or 4 .

\section{VERNONIA, 83.}

noreboracensis (flat-top. O. p. Au. 4.) tall : leaves thick-set, lanceolate, serrate, rough : corymb lastigiate : scales of the calyx filiform at the apex. 4 or 5 feet high.

praealta (C. New Englan!. P. r. Au. 24.) stem tall, angled, thickly pubescent : leaves thickset, lanceolate, acutely serrate, pubescent beneath : corymb fastigiate : scales of the calyx ovate, acute, awnless.

\section{VERONICA, 26.}

afficinalis (speedwell. A. Y. C. P. b. M. 21.) spikes lateral, peduncled : leares opposite, oborate, hairy : stem prorumbent, rough haired. serpyllifolia (Paul's botany, smooth speedwell. 0. b. II. 4.) racemes terminal, subspiked: leares ovate, glabrous, crenate. Stem. 4 to 6 inches long:

beccabunga (brookline. W. N. A. P. b. J. 2.) racemes lateral : leaves ovate, flat : stem creeping. Stem 8 to 15 inches long. Flowers large.

anagallis (brook pimpernel. C. A. Can. P. b. J.

24.) racemes lateral : leaves lanceolate, serrate : stem erect. scutellata (scull-cap speedwell. Y. A. W. N. b. J. 4.) racemes lateral, alternate; pedicels perr dant: leaves lance-linear. 
arvensis (wall speedwell. W. C. P. w-b. M. (?)) flowers solitary, nearly sessile : leaves ovate, serrate ; floral ones lanceolate, entire : stem. erect, seeds flat. 4 to 6 inches high. perigrina (purslane-speedwell. W. C. P. A. w. M. (.).) flowers sessile, leaves glabrous, lance-linear, toothed and entire, obtuse, lower ones opposite : stem erect.

agrestis (field speedwell. C. P. b. M. (.).) flow ers solitary : leaves ovate, . serrate, shorter than the petioles : stem procumbent : segments of the calyx ovate: 'Tlie stem is terete, hairy。 5 to 10 inches long.

hedcrifolia (iry speedwell. C. $r-b . M$. . . ) flowers solitary : leaves cordate, flat, 5-Iobed : segments of the calyx cordate, acute : seeds winkled.

Feronica, see Callistachia.

Verrucarta, 113; .

sthrnderi (mite lichen. Pe) crust tartarous, hard: whitish, smooth: receptacleg minute, crowdcd, nearly globular, navelled, sunk, semitrans. parent within. Often on limestone, or other wrought stones in burying grounds, \&c. scarcely visible.

stigmatella $(\mathbf{P}$.) rery thin, membranous, smooth, rather polished, greyish: tubercles minute, convex, warty, black.

nitida (P.) effuse, cartilaginous membrane, sinooth, pale green : tubercles crowded, hemispheric, becoming bluish-black at the top shining, warty, at length navelled.

\section{VEXILIARIA, 80 .}

irirginiana (butierfly-weed. P. b. Ju. I.) leaves ternate; ovate: calyx 5-partell, longel than 
the bracts ; its divisions subulate, incurved, diverging: legumes subensiform. mariance (P. w-b.Ju. 21.) leaves ternate : calyx much larger than the lance-linear bracts, oblong-tubular, 5-cleft: legume torulose on tho convex sides: seeds glutinous.

\section{VIBURNUM, 47.}

opulus (guelder-rose, snow-ball. E. w. J. 々.) leaves s-lobed, sharp-toothed; petioles glandular, smooth : Hower's in compact cymes, surrounded with radiating florets. Var. roseum, has the whole cyme made up of radiating florets.

tinus (laurestine. E. 1'-w. 々 .) leares ovate, entire, with tufts of hair in the axils of the reins beneath : flowers in smooth cymes.

oxycnects (high cranberry. A. W. Y. P: $\mathbf{P}-\mathbf{W} . \mathrm{J}$. h.) leaves S-lobed, acute at the base, axils of the veins hairy beneath, 3-nerved; lobes longacuminate, with a few-scattering tecth; petioles glandular, grooved above: cymes rayed. 5 to 8 feet high. Fruit resembles the low cranberry, red and very acid. Grows plentifully in various parts of Columbia county, NewYork. T. opuloides, Muhl.

lentrgo (shecp-berry. 0 . w. J. 万.) glabrous : leaves broad-orate, acuminate, hook-serrate: petioles margined, unlulate : cymes sessile.3 to 15 feethigh. 'The branches when full prown often form a fastigiate top. Berries whek, oval and sweetish, pleasant-tisted; somewhat mucilaginous.

Zantunoides (hobble-bush, tangle-legs. O. w. M. Ђ.) leaves broad, round-cordate, abruptly acuminate, unequally serrate; petioles and nerves furnished with powdery rusty down: cymes sessile : fruit ovate. Stem very flexi. 
ble and crooned, about 5 or 7 feet-long; some. times much longer.

acerifolium (maple guelder-rose, dockmackie. $\mathbf{0}$. w. J. $t_{c}$ ) leares heart-ovate, or 3-loberl, acuminate, sharp-seruate, pubescent beneath : cymes long-peduncled. Stem very flexible, lcaves broal and submembranous. 'The oldest Dutch setlicrs in Columbia county, New-York, inform us, that the Indians in that vicinity considered the external application of the leaves of the dockmackie as a sorcreign remedy in every kind of inflammatory tumour; and that they have ever since adopted this practice with success.

dentatum (armow-wood. A. N. C. w. M. h.) smoothish: lcaves roundish and ovate, acute; tooth-serrate, furrow-plaited, glabrous both sides : cyme peduncled : fruit subglobular. Berries blue. About 4 to 6 feet high.

pyrifolium (W. N. I'. w. Ju. h.) glabrous: leaves ovate, acutish, subserrate ; petioles smooth : fruit oblong-orate : cymes subpeduncled. Berries dark-coloured.

prunifolium (N. I.W. J. 万.) glabrous: branches

spreading : leaves roundish, crenate-serrate ; petioles smooth : cymes sessile : fiuit round. mudum (C. P. Can. w. M. h.) very glabrous: leaves oval, subentire, margin revolute; petioles smooth : cymes peduncled and without bracts. Benries black.

mbescens (C. W. J. 々.) pubescent: leaves roundoval, acuminate, tooth-serrate, furrow-plaited, downy-villose beneath : cymes peduncled : fruit oblong. Small bush. edule (Can. 1..w. Ju. 々.) leaves S-lobed, obtus. ish at the base, 3-nerved; lobes very short, tooth-serrate, with acuminate serratures ; petioles glandular : cymes radiate. Small and upright. 


\section{VICIA; 79.}

fiba (garden bean, windsor bean. E. w, \& black. J. (.).) stem many-flowerol, erect, strong: legumes ascending, tumid, coriareous : leafets oval, acute, entire; stipules sagittate, toothed at the base. From Persia. 'This is very different from the beans most commonly cultivated in our gardens, under the names pole-bean and bush-bean. They belong to the genus Phaseolus.

pusilla (creeping retch. Y. C. J-w. J.) peduncles solitary, 1 -flowered, capillary : stipales semisagittate (that is arrow-form on one side) entrie : leafets somewhat iil sixes, lance-linear, obtusish : legumes small, oblong, glabrous.

mitchilla (mitchill's vetch. C. b. p. Ju.) peduncles many-fiowered: leafets in about 7 pairs, retuse-mucronate : legume 2-seeded. Raf.'Sec Pisum maritimum.

americana (C. P. P. M. 2/.) peduncles somewhat many-flowered, shorter than the leaves : stipules semi-sagittate, toothed: Ieafets 8 to 12 , lance-oval, obtuse, glabrous.

sativa (tare. C. W. A. P. b-p. Jti. .). flowers in pairs, stibsessile : stipules toothed, marked with dots : leafets oblong-ovate, retuse, mucronate : legumes erect, linear-terete, glabrous. Perhaps it may have been introduced ; but it is now very common in all parts of Berkshire county, Mass.

cracca (Can. 1. b. S. 2'.) spikes many flowered, imbricate backwards, larger than the leares: stipules semi-sagittate, linear-subulate, entire : leafets numerous, lanice-oblong, pubescent. caroliniuna ( $\mathbf{H}$. w. M. 24.) peduncles many-flowered; Hower's distant : stipules lance-orate, entire : leafets 8 to 10 , lance-oval, smoothish : stem glabrous. The banner of the flower is tipped with black. 


\section{VIELARSTA; S8.}

lacunnsa (spun'-stem, floating heart. Plainfield, Mass. C. P. w. Ju. H.) leaves heart-reniform (or shortish heart-form) sub-peltate, lacunose beneath, floating : petioles bearing the fiowers : corol glabrous. Menyanthes trachysperma. Grows in great abundance in Crooked lake in Plainfield. The peduncles proceed from the side of the petioles, under water a little below the lcaf, and ascend raising the flowers through the sinns at the base of the leaf. Opposite to the origin of the petioles, proceed several spurs about an inch long. I visited the lake in September (1817) and the flowers were still in perfect bloom; as well as of the Hydrapeltis purpurea and Utricularia cornuta, all of which flower in July. This lake is about three thousand feet higher than the tide waters at Albany.

\section{Vrrct, 40.}

minor (periwinkle. P ? E ? b. Ap. iz.) stem procumbent : leaves lance-oval, smooth at the edges : flowers petioled : teeth of the calyx lanceolate.

\section{Viora, 40.}

1. Stemless; leaves all vadical and the flowers on scapes.

odorata (swreet violet. E. b. M. 24.) scyons crecping : leares cordate, crenate, smoothish: calyx obtuse : two lateral petals with a bearded or hairy line. Cultivated in gardens. pedata (birdfoot violet. Y. H. C. P. A. b. M. 24.) leaves many-parted-pellate; divisions lance- 
Iinear, subentire : divisions of the calyx linear, acute.

pulmata (hand violet. Y. C. P. A. b. M. 4.) pubescent : leaves cordate, hastate-lobed, or palmate ; divisions toothed : divisions of the calyx lanceolate, glabrous : $\Omega$ opposite petals bearded at the base. Var. asarifolia, leaves sub-reniform. Muhl. makes this a distinct species; but Nuttall calls it a varicty.

sagittata (arrow violet. H. P. C. b. Ap. 21.) pubescent : leaves oblong, acute, liear't-sagittate, subserrate, gashed at the base: scapes Ionger than the leares : divisions of the calyx linear, glabrous : three lower petals bearded at the base. Iower petal white towards the butom with purple reins; the rest longer, narzower, and whiter towards the base.

dentata (toothed violet. P. b. M. 2\%.) glabrous: leares oblong, acute, truncate at the base, serrate, coarsely toothed or hastate below: scapes shorter than the leaves : divisions of the calyx linear: three lower petals bearded at the base. lanceolata (spear violet. Y. C. P. H. w. Ap. ४.) glabrous : leayes lanceolate, subserrate : scape sicarcely longer than the leaves : petals beardless ; 2 upper ones roundish and painted with purple veins. Small. Grows in wet places, is on the margin of Beaver pond, New-Haven. blanda (smooth violet. H. W. A. C. Y. N. P. Y-w. M. 2'.) glalırous : leaves cordate, acutish, flatiish, remotely serrate : scapes of the length of the leaves : jetals beardles 3 , the 2 laterai ones shorter, the lower one lan eolate and longer than the rest. Lower petal marked with blue stripes.

obliqua (twisted-wing violet. A. W. P. W-p. M. ४.) glabrous : leaves cordate, acute, crenateserrate, flattish : flowers erect; scapes of the length of the leaves : petals twisted a little into an oblique position, lateral ones narrower $\mathrm{Ri}$ 
and longer, bearded below the middle. Flots. ers with purple and yellow vcins.

primulifolia (primrose-leaf violet. C. Y. A. P. H.

N. w-b. Ap. 2\%.) pubescent : leares orate, subcordate, crenate ; petioles margined : calyx ciliate, long: : petals all oborate, ? lateral ones bearded.

cucullata (common blue violet. O. b. M. \%.) glabrous : leares cordate, glabrous, serrate, cowled (or rolled in at the base) scapes of the length of the petioles: petals bent obliquely, lateral ones bearded. Petals all whitish at the base.

sororia (bearded violet. W. P. b. M. 4.) leares cordate, crenate-serrate, obtuse, pubescent : scapes shorter than the leares : petals oblong, the lower one bearded at the base, and reined. papilionacea (butterfiy violet. A. P. b. M. 4.) leares heart-triangular, acute, crenate, somewhat cowled, smoothish : scapes of the length of the leaves: petals obovate; 3 lower ones bearded below the middle, converging; 2 upper ones reflexed. Beard yellow. Nuttall considers this as a variety of the $\mathbf{V}$. cucullata. rotundifolia (ground violet. W. C. P. y. Ap. 4.) smoothish : leaves round-cordate (when mature) obtusisb, crenate-serrate-the sinus at the base closed and serratures glandular : [scions flower-bearing; Pursh] petals linear, scarce$1 y$ longer than the calyx. The leaves lie very close to the ground. Y. clandestina, Pursh.

2. Haring a stem; more or less of the leares cauline.

Iricolor (garden violet, heart's ease, pansy. E. p. Y. b-p. M. 2.) stem angular, diffuse, divided: leaves oblong, deeply crenate : stipules lyrate-pinnatifid.

canadensis (woods violet. 0. b. \&.W.J. 24.) smooth- 
ish : leaves subcordate, acuminate, scrrate : perluncles of the leingth of the leaves : stipules short, entirc. Sometimes 6 or 8 inches high, in damp woods.

striata (striped violet. W. P. Catskill Mt. W-p. M.

4.) glabrous : leares corlate, acuminate, serrate, flattish : peduncles very long: stipules lanceolate, serrate-ciliate.

debilis (weak-stem violet. A. P. b. M. 4.) glabrous : leaves heart-reniform, short-acuminate, crenate, cowled at the base : peduncles twice as long as the leaves : stipules serrate-ciliate. Flowers small.

rostrata (beakel violet. W. A. P. b. M. Ұ.) g.lal)rous : leaves cordate, acute, scrrate : peduncles twice as long as the leaves: stipules lanceolate, serrate-ciliate : spur longer than the corol, extending into a beak.

pubescens (yellow woods-violet. O. y. M. 21.) ril. lose-pubescent : stem erect, leafy towards and at the top: leares broad-cordate : stipules oblong, serrate at the apex. Varies much in its height. Usually 6 or 8 inches high ; but 1 have seen it 20 inches high. Dr. Solon Sinith showed me a sperimen about 4 feet high, which he found in New-Hampshire.

hastata (halbert violet. P. y. M. 24.) glabrous : stem simple, leafy abore : learcs hastate, short petioled : stipules minute, denticulate. concolor (green violet. P. W-g.J. 24.) strait, erect : leares broad-lanceolate, entire : stipules lancelinear, entire : peduncles axillary, in pairs, short. About 20 inches high, flowers small. bicolor (two coloured violet. P. C. w. p. M. Q.) stibpubescent : stem angled, simple : lower leares round spatulate; subdentate; upper ones lanceolate, entire; stipule's comb-tooth pinnatifid : calyx acute, about half as long as the corol. 
tenclla (slender violet. New-Jersey. w.) lower leaves opposite, roundish, minute; upper ones sub-alternate, oblong, obtuse ; all glabrous entire : peduncles longer than the leaves. Flowers smalI, solitary, wítí capillary peduncles.

nrvensis (field violet. P.W. Ap. (.) stem angled, grooved ; leaves lance-ovate, serrate ; stipules gashed at the base : calyx hairy a little longer than the corol. Petals white, the lower one spotted with yellow. Smith sets this down under $\mathbf{V}$. tricolor as one of its varieties.

Remark. Nuttall says, that all the North American species of violet (excepting V. concolor) after their blooming season is over, still continue to produce flower's without petals, through the rest of the summer.

\section{Viscus, 99}

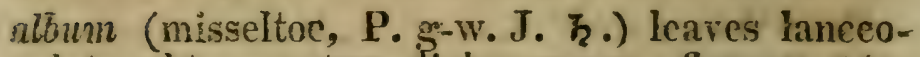
late, obtuse : stem dichotomous : flowers 5 together, in terminal sessile heads. On the branches of old trees. Leaves an inch long, thick and leathery. This, Smith says, is the golden hough of Virgil, and the sacred plant of the Druids.

\section{FiTIs, 41.}

vinifera (wiue grape. E. I. i2.) leaves sinuate-lobed, naked or downy.

Remark. All the Nortir American species of grape are polygamous or dioecious.

Labnisca (plum grape. A. Y. C.H. P.w-g.J. h.) leaves broad-cordate, lobe angled, white-downy beneath : fertile racemes small : berries (blue, Hesh-colour and green) large. Var. labruscoides (fox grape) has smaller fruit, approaching a tart taste.

ncstivalis (summer grape. C.P.w-g. J. 3..) leaves 
broad-cordate, 3 to 5 -lobed ; in the young state rust downy bencath; fertile racemes oblong: berry small.

cordifolic (frost grape. $0 . w-g . J . T_{2}$.) leaves cordate, acuminate, gasli-toothed, glablyous both sides: racemes lax, many-llowere:1 : berries small. Var. vulpinu, leaves very varialble; but the uppermost mature leaves will agree with the description.

riparia (odoriferous grape. C. P. w-g. M. 々.) - leaves unequally gash-toothed, shortly S-cleft, pubescent on the petioles, nerves and margins.

Vitis, see Ampelopsis.

VITTARI, 102.

lineata (ribbon fern. P. 4.) frond linear very long, pendant: fruit-dots solitary within the margin.

\section{YY.}

\section{WoonsIa, 104.}

hyperborea (flower-cup fern. Can. P. Ju. 24.) frond pimate; leafets 3 -parted, or gash-pinnatifid, wedgeform, obtuse, toothed, roughhaired beneath : fruit-dots solitary, at length confluent. Small, in tufts.

irensis (N ? Can. P. Ju. 24.) frond bipinnatifid; divisions oblong, obtuse, lower ones repand, upper ones entire, rough-haired beneath : fruitdots submarginal, at length confluent : stipe rillose above. Small.

\section{WoODWARDIA, 103.}

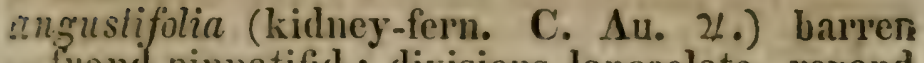
trond pinnatifid; divisions lanceolate, repand $\mathrm{Rl} 2$ 
slencerly serrulate : fruit-bearing frond pinnate; leafets entire, acute, lincar. About a foot high. $W$. onocleoides.

virginica (C. Ju. భ.) frond rery glabrous, pinnate; leafets sessile, lanceolate, pinmatifid; divisions oblong, obtuse, cranulate, fertile ones elongated : stipe glabrous, terete. About a foot high.

\section{$\mathbf{X}$}

\section{Xaxtmiun, 93.}

strumarium (clott-lurr. N. Y. C. H. Au. (;.) stem unarmed, branching : leares cordate, lobed, serrate, scabrous, 3-nerved at the base : firuit oval, pubescent, with stiff hooked bristles. Has a little the habit of a burdock. orientale (C. O). stem unarmed : leares wedgeovate : fruit in strobiles. Here Pursh is experimenting upon our patience again. He has remored this grenus to the class Syngenesia.

\section{XEROPHYLLUM, 52 .}

sctifolium. This species is describer under the Helonias asphodeloides. But Nuttall thinks it ought to be placed here.

\section{XrzostedM, 40.}

ciliatum (fiy-honeysuckle, twin-berry. 0 . W-y. M. $\left.h_{.}\right)$berries distinct: leaves ovate and subcorrate, margin ciliate, in the young state villose beneath: corol a little gibbous or calcarate at the base, tube ventricose abore, divisions short, acute : style exsert.

solonis (swamp twin-berry. W. New Hampshire. y. M. ..) berries united in one, not distinct: two flowers situated on one germ: leaves ob- 
long-orate, villose. Berries dark purple.Found first by Dr. Solon Smith (1815) at the foot of Whitehills. In 181- found by Professor. Dewey and Tutor Bascom, one mile cast of Williams College, in a swamp. It is a small shrub, not exceeding 2 feet high.

Renark. Dr. Bigelow thinks this may be the villosum of Mx. But I camnot believe that Michaux would have omitted the most important character of the species, the united berry, if this were his plant. Besides, the place of growth given by Mx. is very different from this, as well as the colour of the firuit.

\section{Xrmostioma, 119.}

giganteum (punk, oak-leather. 0.) fibres parallel, the whole fungus filling the intorstices between the cleareages of decaying wood. I have attentively compared our punk with a coloured drawing of the European species, and find it the same. 'This drawing nay be seen in a splendid anonymous work of 3 vols. 8 ro. designed as an illustration of the Linnean system, published about 5 years ago in London.

\section{Xrers, 28.}

anceps (yellow-cycd grass. Y. H. P. Y. Au. भ.) leares linear, obtuisish : scape spread and $\approx$ edged near the top : scales of the head roundish. 6 to 10 inches high. Grows on the margin of the Beaver pond, New-Haven. X. Caroliniana. Pursh.

brerifolic (C. P. y. Au. భ.) leaves sword-subulate: scape teretish : head globose.

plexuosu (C. y.) leaves grassy, long: scape and leares twisted, zigzag : head globose, scales roundish obtuse. Perhapss this description ic not accurate. 


\section{$\mathbf{z}$.}

\section{ZANTHORHIZA, 48.}

apiifolia (parsley yellowroot. P. p. Ap. h.) flowers panicled : leaves compound, subpinnate, a little sheathing at the base.

\section{ZaNThoxyLUM, 99.}

fraxineum (prickly ash, tooth-ache bush. $0, \mathrm{~g}-\mathrm{w}$. M. h.) prickly : leaves pinnate ; leafets lanceoval, subentire, sessile, equal at the base ; common petiole turarmed : umbels axillary. I have examined this plant in various parts of New-England and of New-York, without ever being able to find the staminate plant.

\section{Zapania, 71.}

nolliflora (fog-fruit. P. w. Ju. 2/.) leaves wedgeobovate, serrate above: spikes head-conic, solitary, long-peduncled : stem creeping. lanceolata (P. w. Ju. 24.) Ieaves lance-linear, sharply serrate : spikes head-conic, solitary, long-peduncled : stem creeping.

$$
\text { - Zea, } 91 .
$$

mays (indian corn. 0, y-g. Ju. linear, entire, keeled. Var. precox (dwarf corn) stem low : seeds mostly 8-rowed.

\section{Zigadenus, 52.}

slaberrimus (zigadene. P. w. J. 24.) scape leafy: bracts ovate, acuminate : petals acuminate: leaves long, recurved, channelled. 


\section{ZiNNIt, 85.}

multiflora (P. r. S. (.).) leaves npposite, lancoorate, subpetioled : flower's peduncled. I'crhaps not a native of North America. Nuttal.

\section{Zizania, 93.}

clavulosa (water-oats, wild-rice. C. P. S. 8.) panicle pyramid-form ; staminate flowers below, spreading; pistillate flowers above, spikrd: appendages to the flower's clavate, awned, long; seed long, cylindric, becoming blark. fluituns (Lake Champlain. Pursh. In. 4f. small s cuhn slonder, branching: leaves linear, flat: spikes solitary, axillary, setaceous, about 4 * flowered : glumes awnless. miliacer (P. Au. 4.) panicle effuse : glumes short-awned : staminate and pistillate flowers intermixed : seed ovate, smooth.

\section{End or Padi I IX}




\section{ADDITIONS AND CORRECTIONS.}

During the progress of this work, some new re marks have been made by my correspondents, some thoughts have occurred, and several errors have been detected, which.I shall notice here.

But this addenda is more particularly necessary on another account. After 432 pages werc struck off, I received Nuttall's genera of North American plants. * on comparing his generic character's and remarks, with those given in this Manual, I found he had greatly improved them in some of those natural assemblages, which are always the most difficult. These improvements will be found hero.

Nuttall is a strong adrocate for some of those innovations, which are not received by all botanists. But he has arranged his genera very near-

* Every leacher of botany, who adopts this Manual, is ad. vised to proctire, Nuttall's most excellent work an North American genera. It will be found very useful in all cases of doubt. His extensive notes and remarks, which are the result of long experience and the most perseverilig industry, will be found very instructive; though they are mostly confined to the southern and western stales. While I am on the subject of botanical works, I will take the liberty to recommend two more cheap and very useful bonks. I mean the Catalogiues of the New-Haven and New-York plants; both of which will appear in a few weeks. Many of the materi. als of which the original part of this Manual is composed, were derived from a manusclipt copy of the New.York cata. logue, obligingly furnished by Dr. John Torrey. It will not be a naked list of plants ; but will contain many interesting remarks, popular characters ind localities; also fulllength descriptions of the new species.

Those who wish to study the genera only of the Crypto. gamous class, or both genera and species of ferns, will find a very good system in this Manual. But those who wish to study the species of fungi, lichens, mosses, liverworts and algae, extensively, must wait for the works of Mullenberg and of Collins, which we hope will shortly appear. Sees preface, page 6. 


\section{ADDITIONS AND CORIECTYONS. 50:3}

jy upon Personn's plan, excepting that he has rejected the cless bodecandria.*

The following remarks will be male thder au alplabetical ariangenent of the genera. The

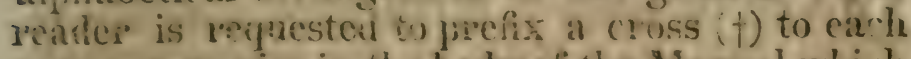
genus or species in the body of the Mannal which is noticed here. 'Bhen during the investigation of plants, it will appuar by the occurrence of the cross, that something furtier may be found, by seatiching for the same grenus, alihabetically, in this addenda.

Agrostis, stoloniferc (fiorin grass. E. Ju. 21.) panicle compact : culm creeping, isanching: Howers heaped together : glumes equal, lanceolate, pubescent. This grass was introduced from Europe by Gen. Stephen Van Rensselaer. Now it is periectly naturalized and grows in great plenty near Albany.

Air., oespitosa should be coespitosa.

Ammi. Improved from Nuttall-fruit oblong, having a kind of bark, angular, ridges 5, obtuse, with the intervals between the ridges convex : involucre pinnatifid.

AxGeurc. Improved. General involucre none, or caducous.

Arabis. Nuttall. Silique linear, mostly compressed, crowded, with a subsessile stigma : valves veined or nerved: seeds disposed in a single series : calyx erect.

Aster, linarifoluis should be linarifolius.

Atrixrom, aspleniodes should be usplenioules. Barsanita, suarolens. should be suaveolens. Bromus. Improved, Nuttall. Outer valves of

* He has distributed our genera of the 11th class, as fol. lows: Asarum to class 19, order 13 (taking our method of numbering classes and orders.) Iludsonia to 13.1. Portulacca to 13.1. Lythrum to 12.1. Decumaria to 12.1. Talinum to 13.1. Cuphea to 12.1. Agrimonia to 12.2. Euphorbia to 2016 . Esula [by the same rule would be] 20.16. and Reseda 13.2-5. 


\section{ADDITIONS AND CORRECTYONS.}

the corol often bifid at the point-interior: glume pectinately ciliate.

Bunias, maritina should be edentula.

Cilurstacuia. Improved. Nuttall. Calyx 5parted, divisions acuminate-capsule acuminate. See Nuttall's genus Leptandia, which is a synonym of this genus. M. Rafinesque had constructed this genus and published it, belore Mr. Nuttall. And though this was no known to M. N. still it is the legitimate name on account of its being first published. See the New-York monthly Magazine.

Centaurea acea should be jacer.

Cirmapima. Nuttall Calyx 5-tonthed : petals 5 : style rery short, immersed in the germ; stigma surrounded or colged around with a ring, orbicular, with a 5-lobed disk : filaments with broad ciliate bases :* capsules 5 -celled, malgins unconnected.

Crmirnuga. Nuttall. Calyx 4 or 5-leared : petals 4 to 8 , deformed, thickish, sometimes wanting: capsules 1 to 5 , many-seeded : seeds scaly.

Cinmitis, hexagona. I am now convinced, that this is a very singular variety of the Atragene americana, in which the mumerous petals, within the coloured calyx (or according to Pursh, the spatulate nectaries, alternating with the petals, and the dilated outer filaments) were nearly all cylindric and bearing perfect anthers. I have found some of this character, while other's were as described by Pursh, on the same plant, this scason. The reader will please to prefix the cross to the Atrogene americana also.

* The reader is not to make Mr. Nuttall responsible for what may be deemed unscientific, or not sufficiently technical, in the language. For I depart from his language in all cases where it is necessary, for the purpose of making the language of this Manyal uniform. 
- Crataegus, punctala, erase P. and subsitute 0.

Crmbrorus, hiemale, crase the words "in pairs" and insert" solitary." Mir. Edwin James had found this plant in abundance near Mildlebury College in Vermont, (where it is called puity root) and about Albany. But could never make it agree with any author's description ; as all give it two radical leaves. Mr. Nuttall has corrected the emror. See his Genera, vol. 2, p. 198. He has however separated from this genus, this species, together with the corellorhizum and odontorhizum, and made a new genus, which he calls Corallorhiza.

QYNoglosum. In: proved. Nutall-throat of the corol closed by 5 converging, conves, process. es : stigma emarginate.

Eriocacxur, gnaphalioides (New-J̌crsey. Ju. 2\%.) scaje subcompressed, with 10 grooves : leaves short, subulate-ensiform, glabrous : heads hemispheric-convex : the involucre consists of shining, scarious, oval, round-abtuse scales. Lately found in New.Jersey by Dr. Torrey. Heretofore found only in the Southern states.

Evoxymus. Improved. Nuttall-the base of the calyx inside corered with a flat, peltate disk : petals 5, spreading, inserted on the outside margin of the glandular disk.

Finur.1. Improved. Nuttall-petals oblong: secds marked with 3 lines on the back : inter. vals and seam (or the place where the seeds unite, commissure) striate.

Eestuca. Improved. Nuttall-spikelets compressed, two-ranked, acute at both ends : outer valve of the corol entire-seed growing on the corol.

Grandu. sirictum should be strictum. Geranium, diessctum, should be dissectum. GrycrRrhiza, afficinalis, should be officinalis. Heraclecm. Improved. Nuttall-fruit emar. ginate at the top, seed with 3 lines, intervals Ss 


\section{E६G ADDITIONS AND CORRECTIONS,}

spotted or dotted half way down; the joining of the seed (commissure) flat, 2-dotted: involu(re none. Persoon says the involucre is caducous. We rarely find the involucre; but I believe it is because it falls of, while the umbel is unfolding.

IMPERATORI. Improverl. Nuttall-fruit emarginate at the base, 3 ridges on the back of each secd, obtuse, intervals flat, convex.

Krumsara. The geuns, at page 28 , should have been placed uncier section $\mathbf{D}$. at page 29.

Latrures, stapulaceus, should be stipulaceus, Mr. E. James found this species this season (1818) on Catskill Mt.

Lrmnetrs. Improved. Nuttall-flowers in unilateral, or one-sided, spikes-seeds oblong, compressed.

Ixcrum, barbareum. This species varies into the fifth class.

LYchNis. At page 60, strike out the word "smooth," and add at the end-capsule with a 5-toothed opening.

Mataxis. Nuttali. Petals 5, narrower than the lip, spreading or deflected : lip flattencd, undivided, sessile (mostly situated behind) the column (including the style, \&r.) lengthencd ard somewhat straightened : rolls of pollen (pollinia) 4, parallel, affixed to the summit of the stigma.

Marrebiem. Motherwort should be horehoumd. Mariscus. The genus at page 29 , should have been placed under section 1 . at the bottom of the same page.

Menyantues. Improved. Nuttall-corol funnel-form : border densely villose on the upper side.

Mrcropetalum. [Make one cross and interline this word on page 59, immediately over PENTAGYNIA ; and again on page 319 , orer Mikania] caly x 5-leaved, spreading: petals 5, en- 


\section{ADDITIONS AND CORRECTIONS 50\%}

tire, minute or none : capsule orate, 4-valved. Nuttall says this is a trilling gon!s, and ought to be united to Stellaria. Panceu'utum (Catskill Mt. P. Ju. 4.) glabroas: leaves lanceolate, narrowed at both ends: flower's panicled : petals orate, very short. grainineum (C.J. 2t.) very glabrous: Ieares linear, erect: panicle terminal, lax : pedicels filiform : petals lanceolate, of the length of the calyx.

Myosotis. Inploved, Nuttall-thoat of the corol closed with. 5 small convex, converging scales.

Mrrruis, see Uraspermum further oll.

Nymphate. Imploved, Nuttall and Tracypetals about equalling the caly $x$ in length, inserted upon, or alliering to, the germ, bencath the stamens.

Nuphar. At page 65, about one third of the edition was struck off with Naphar instead of Nupha1.

Oenothera, chrsesuntha, page 332, should be chrysantha.

Orobarcue. [Nuttall lias divided this genus, so that our three species are in separate genera. I regret, that he hail nut rather left them as ihey were, and given us an improved definition of the old gemus with his usual accuracy. I will now attempt it from his remarks.] Improved. Calyx 4 or 5-cleft, or 5-tootheal: corol more or less ringent, or equally 5-cleft : capsule ovate, acute, al oblique-truncate, 1-celled, 2valved, many-seeded. Sometimes there is a gland beneath the base of the germ; when this is wanting, the capsule is truncate and opens only on one side.

Orontrum, aquaticum. Erase floating arum and insert, golden-club.

Panassia, alter to Parmassia. Page 549.

Prinus.t, auriculu, for anricula t!lip, write auricula primrose. 


\section{ADDTTIONS AND CORRECTIONS.}

Prunus serotina. Erase choke-berry and insert chole-cherry.

Pxroris. Nuttall. Calyx 5-cleft or 5-parted: petals 5, caducous : style exsert : capsule 5. celled, opening at the angles near the base ; margins of the valres connected by entangled down. The middle partitions of the capsule uniting with the coiumella : seeds very numerous, minute, and nartaking a little of the form of a.samara.

Salvis, sclara, shouid be sclara:

Scirpus. [Erroneously printed at page 29.] Improted-style caducous. This is its best chisacter by which it in distingushed from Rhynchaspora. Foo in the latter some part of the style remains permanent upon the seed. Somroago, rautu, should be arguta. This elros. extends through but part of the edition.

TRADEgCanzuA. At jage 43, for heads-read hair's.

TuRriris, Nuttall. Silique elongated, 2-edlgod : valves nerved or keeled : seeels disposed in two pows, or a double series. By this last character it is best distinguished from Arobis 2 . whose seeds are all arranged ia one serics.

URASPERMUN. [Prefix the cross, roferring to this, to Myrrhis, page 326 and 46.] Nuttall has here added another name, to the many heretofore given, intended, I presume, to include the sweet cicily. Fruit sublinear', solid, acuteangled, tailed, and not striate; angles a little furroved, hispid ; the joining sides of the seedsfurrowed; style subulate, permanent, terminating the fruit. I am still altogether at a loss respecting the two plants, which we call the sweet cicily and poison cicily.

Veroxica. Improved. Nuttall. Capsules obcordate. This is a decisire character to distinguish this genus from the Callistachia. Note, Several specific names, which should 


\section{ADDITIONS AND CORRECTIUNS. 509}

begin with $c$, begin with e ; but they may be readily corrected without being referred to. At the font of page 190 add. E. stands for exvics. 


\section{ADVERTISEMENT:}

The plants described in this Manual are as iollows. Phenogamous genera 690.-Indigenous sprecics 1950. Exotic species'342. Introduced from the Southern states 22. Cryptogamous genera 100. Species $4 \% 6$. Total species 2790 . None have been omitted (unless by mistake) which are known to inhabit any part of the United States, north and nortll-east of Virginia ; excepting rare exotics.

It is the intention of Messrs. Websters and Skinners, always to kcep on hand a supply of the Mianual, sufficient to answer all orders. The science of Botany is continually receiving important contributions from the original productions of able Naturalists. Such works are becoming very interesting and do honor to the American character. A pocket book of reference, embrac. ing the essence of these learned labors, is, perhaps, indispensible. No pains will be spared to add to the present contents of this Manual, the results of future inrestigation, as fast as they ap. pear.

Heretofore it seemed to be the opinion of most Botanists, that enlarged descriptions of the plants of such an extensive district, could not be included in a book of this portable size. Now the book is completed, it will be seen, that the descriptions are, in most cases nearly as extensive as those of Willdenow ; and far more cxtensive than those of Persoon. 


\section{INIDSS}

\section{TO THE ENGLISII NAMES.}

\begin{tabular}{|c|c|c|c|}
\hline \multicolumn{4}{|c|}{ 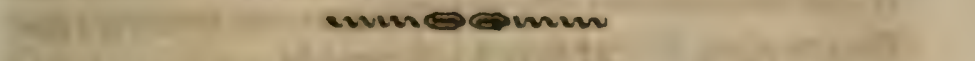 } \\
\hline A. & & Ashwort & 206 \\
\hline & $P a g c$ & Asparagus & 150 \\
\hline ACACIA & 403 & Aspen & 375 \\
\hline Adam and Eve & 204 & Asphodel 150 & $3: 8,466$ \\
\hline Addermouth & 313 & Aster & 177 \\
\hline Addertongue & 242,333 & Auricula & 382 \\
\hline Agave & 126 & Arens & 258 \\
\hline A grimony & 126 & Awl-cap moss & 262 \\
\hline Aibany hemp & 477 & $B$ & \\
\hline Alder $130,131,2$ & 209,382, & 20 & \\
\hline & 598 & Bachelor's but & ton $\approx 61$ \\
\hline Alexander's & 441 & Balm & 210,318 \\
\hline Allspice & 184 & Balm-of-gilead & 235,375 \\
\hline Almond & 134 & Balsam apple & 322 \\
\hline Allum root & 270 & Balsam poplar & 5.5 \\
\hline Aloe & 129 & Balsain tree & 359 \\
\hline Amaranth & 132,261 & Balsam weed & 282 \\
\hline Anemone & 137,138 & Bane-berry & 123 \\
\hline Angelica & 138,141 & Barberry & 172 \\
\hline Apple & , 228,389 & Barley & 274 \\
\hline Aplicot & 145 & Bar'l-grass & 339 \\
\hline Arathusa & 143 & Basil & 351,387 \\
\hline Arbor-vitac & 464 & Basket-of-gold & 131 \\
\hline Arbutus & 238 & Basswood & 465 \\
\hline Archangel & 138 & Bayberry & 526 \\
\hline Arnic & 145 & Bcad fungus & 323 \\
\hline Arrowgrass & 470 & Bead tree & 317 \\
\hline Arpow-head & 412 & Bean 259,355, & $, 356,491$ \\
\hline Arrow-wood & 490 & Bear berry & 142 \\
\hline Artemisia & 146 & Beard grass & $136,14 \frac{4}{2}$ \\
\hline Artichoke & $224,20^{-}$ & Beard throat & 154 \\
\hline Arum & 147,336 & Beard tongue & 353 \\
\hline Ash & 250,451 & Beaver tree & 313 \\
\hline
\end{tabular}


Berlstraw

$253 \mid$ Borage

177

Beech

247

Beech drops 323-24,336

Beehive

Beet

316

172

Beggarticks

Bell-flower

Bellwort

Bent grass

Betony

Bilberry

Bindweed 214,215,284

Birch

Birdsnest

Birthwort

Bishopweed

Ditter lichen

Bitternut

Bitter'sweet

Blackberry

Black-flower

172,173

173,174

184,185

480

126

172

$48 \pm$

Black-snake root

Bladder-campion

Bladder-mouth

Bladdernut

Bladder' senna

Bladilerwort

Blazing star

Blessed thistle

Blight

Blite

Bloodroot

Blue-bottle

Blue-curls

Blue-eyed-grass

Blice-grass

Blue-hearts

Blue thistle

Bog-lush $292,400,425$

Bonerent
325

144

154

484

288

197,442

408

316

205

221

233

457

210

479

485

199

475

421

198

467

439

363

181

236

815,9002
Bowman's root 456

Box

Box-flower

181,217

Brake

Bramble

390

386

Briel-herle $\quad 408$

Brittle lichen $\quad 168$

Brompton queens 202

Brompton stock 202

Brookline $\quad 487$

Brook-liverwort $\quad 514$

Brookweed

Broom 255,453

Broom corll $\quad 452$

Brooin grass $\quad 179$

Buckbean $\quad 318$

Buckthorn 275,309

Buckwheat $\quad 372$

Buffalo clover $\quad 46 s$

Bugbane 205

Bugloss $134,171,236$

Bulleush

427

Bunch flower $\quad 316$

Burdock 142

Burnet $\quad 380$

Burnet saxifrage 421

Burning bush 243

Burr-flower 277

Burr-marygold 174

Burr-reed 452

Bush clover $\quad 500$

Bush trefoil $\quad 264$

Butterfly weed 488

Button bush 199

Butternut $\quad 287$

Button wood 365

C.

Cablages?

$1 \% 8$ 


\section{NDEX.}

Calabash

Calomint

Camplor

Cimpion

Canary grass

Cancer root

Candy tuit

Cane

Canterberry bells

Caper

Caraway 181,182,106

Cardinal flover.

Eardonn

Carnation

Carolina potato

Carpet weed

Carrot

Cassel fungus

Cassia.

Caster-oil plant

Catalpa

Catchfly

Caterpillar-fern $\quad 432$

Caterpillars

Catmint

Catnep.

Cat's eyc

Cat-tail

Cedar

Celandine

Celery

Éentaury,

Chaff-seed

Chamomile $223,291,464$

202

140

198,199

204,368

425

139,177 ,

315

Charlock

Checker-berry

Cherry.

Cherville
$217,358,383$,

385,442
Chesnut:

Chess

121.107

179

Chickwerd $351,134_{2}$ 183.199.27 3,394,491

Chick-wintergeen 4 (j8

Chinat aster

1.58

Chinquapin

197

Choke-beriy:

Choke-dog

145

294

Chrysantlienum 205

Cieily

Cinguefoil. $\quad 3 \pi 8=580$

Cives

Clary.

Cỉcavers

Climbing forn

Clott-bur's

Cloud ber'y

Clover.

Clown-heal

Club fungus

Club moss

160

490

2.1.

311.

498

409

468,469

456

207

309

Club rush

314,425

Cinmp-liead grass $56 \%$

Cockle

Cock's crest

Colnosh

Colic-weed

126

198

$19 \%, 205$

218

Colt's foot

473

Columbine

Comfrey

Cone-flower

140,141

460

409

.286

224

Coral-root

Coriande:

216

170

26은

241.

332

376

$37 \approx$ 
Cowhage

Cowslip

Cow-wheat

Coxcomb

Crab apple

Cranberry

Crecping cereus

Creeping moss

Crowberry

Crowtoot

Clownbeard

Crowneup

Crown imperial

Crust lichen 394 to 397

Cuckow-flower

Cucumber, $315,317,4,36$

Cucumber-tree

Culver's physic

Currant

Currant-leaf

400,401

Curve-hair moss 336

Custard appic 139, 376

Cut-grass

Cypress

D.

Daffodil

Daisy

Dandelion

Darnel grass

Day-flower

bay-lily

Dead-nettle

Decumary

Deerginss

Dewberry

Dill

Dish-fungus

182

315

237

203,223

$172,24=$

292,299

306

210

269
234 Dittany

Dock

Dockmackie

Dodaer

Dog-bane

Dogitail grass

Dogtonth vioict

bogweed

Dogwond 121,217,218

Double-tooth moss 232

Dragon

146

Dragoness-plant 234

Dragon-head 235

Dropseed grass 325

Duckmeat 298

Dust-leaf $\quad 13,5$

Dyer's broom $\quad 255$.

Dyer's weed $\quad 397$

E.

Earth moss

35.5

Eillorescent lichen 455

Egg-plant

Elder.

Elecampane

442

Elephant foot

122,420

233

Elm

236

474

20.5

327

293

229

398

408

Endive

Eye-bright

246

\section{F.}

False flax

464

False moss

290

Featherbeds ‥ 201

Feather-grass $\quad 459$

138 Fennel-flower $\quad 330$

354 Fescue-grass … 247 
Festoon pine

Ferer-bush

Foverlew

Fevel root

vis

Figwort

Filbert:

Fine-haired fern

Finger gatass

Fil.

Fircweed

Tivefinger $210,358,379$

Flag

Flat-cup lichen

Flattop

Flax

Flaxsecd

Flcabane

Flnating daisy

Floating lieart

Flnating liverwort

Flower-cup fern

Flower-de-luce

Flowering fern

Flowering nettle

Flowering rush

Flowering wintergreen

Flower-of-an-hour

Fly homeysuckle

Fog-finit

Follicle vine

Fork chicliveed

Fork-fern

Fork-moss

Fork-spike

Forkstems

Fotleregill's bush

Four o clock

Four tooth moss
510

¿95

204

$4=1$

648

433

219

ऽ50

232

359

455

Foxelore

Foxfail

Fringe-free

Fritillary

Frog's spittle

Frost plant

Fumitory

Funegreek

Fungus-lichen

Furze

232,257

131

204

250

211

206

¿51

470

180

474
G.

Gaingale $\quad 205$

485

45:

Gall-of-the-earth 451

Garden bean 401

299 Garlic $\quad 130$

259 Gay feather 3

243 Gen-fruit 465

492 Gentian $255,250,285$.

402

$49 \%$

284

337

252

424

568

$2 \pi 0$

498

500

354

374

122

25?

137

403

$\approx 49$

52()

461
Geranium

459

241,256 ,

351,352

461

Germander

859

148

Ginger

(iinseng

Glasswort

Gilobe-flowe?

Globe-thistie

Globule-fung:!s

539,471

$4: 14$

472

236

Glue seaweed

Groat's beard

Groat's rue

Golden club

Golden rot 443 , to 450

Golden thistle 432

Guld-ol-pleasure 325

Gold thread

Grooseberry 401,402 
Gourd

Grain rust

222 Holonias

269

Grape

- 475 Hemlock

$205,212,360-$

Crape-fern

Grass-pink

Grass-weed

Greek ralerian

Green brier

Green haip

Gromwell

Ground flower

Ground iry

frround nut

$134,496,497$

177 Hempweed

224 Henbane

500 Henbit

568

440

211,212

305,333

358.

259

141,260 ,

339

Ground pine

froundse!

Guclder rose

fruinea-hen flower 250

H.

Hackmatack.

Hagberry

Hairbeard

Hair-cap moss,

Hair grass

Hair-inouth moss,

Hardhack

Hawksbearũ

Hawkweed

Hazlenut

Ifeal-all

Heart's ease

Heart seed

Heart watershield

Heath

Herlgehog 198,314,315

Hedge hyssop

Heilge nettle

Hellebore

361

198

162

4.4

128

467

455

466

140,272

819

351,383

494

186

262

456 268,485
309,386 166,435

489,490

Herb robe

Hibiscus

Hickory

Hidden lichen

, 477

High cranber'ry

245

$27 \%$

293

356

271

288

237

489

High-water shrub $\approx 86$

Hobble bush

489

Hogiweed

Holly

Hollyhock

133

Honesty

Honewort

Honeycomb toad.

$941.28 \mathrm{E}$

131

308

438 stool

Honey locust

$17 \%$

259

Honey-suckle 165,166,

Honey wort,

$232,306,399$

Hoodwort

Hoopąsh

Hop

Horehound

.200

433

198

275

311,315

Hornbeam 195,337

Horned lichen $\quad 217$

Hornwort

Horse balm

200

210

471

Horse ginseng

Horse tail

239

38 Hound tongue 295

Houseleek 434

Hyacinth 275

Hyanth

274,276

Hygrometer moss 251

862,281 


\begin{tabular}{|c|c|c|c|}
\hline \multicolumn{2}{|l|}{ I. } & \multicolumn{2}{|l|}{$\mathbf{K}$. } \\
\hline Yceland lichen & 200 & Kale & 178 \\
\hline Ice plant & $19,43:$ & Ketmia & 272 \\
\hline Indian corn & 500 & Kidney bean: & 355 \\
\hline Indian cress & 472 & Kidney forn & 497 \\
\hline Indian grass & 136 & Kingspear & 150 \\
\hline Indian hemy & 140 & Kn: & 431 \\
\hline Indian mallows & 436 & Knobbed lichen & 458 \\
\hline Indian millet & 452 & Knotgrass & 282,370 \\
\hline Indian physic & 456 & Knotweed 370 & $371, .372$ \\
\hline Indian poke & 485 & \multirow{2}{*}{\multicolumn{2}{|c|}{ F. }} \\
\hline Indian reed. & 206 & & \\
\hline Indian turnip. & 146 & \multicolumn{2}{|l|}{ Ladies' Hag } \\
\hline Indigo $\quad 134,2$ & $134,283,367$ & Ladias sippper & 227 \\
\hline erry & 382 & thumb & 371 \\
\hline Ipe & 456 & tresses & 328,329 \\
\hline 11 & 285 & Lamb lettuce & 247 \\
\hline dod & 337 & Lai & 361 \\
\hline ad & $\begin{array}{l}485 \\
986\end{array}$ & pur & 229 \\
\hline 259,26 & 259,26 & ed fungus & 207 \\
\hline 209960 & 0 & Laurel & 292,313 \\
\hline \multicolumn{2}{|l|}{ J: } & & \multirow{2}{*}{$295,+67$} \\
\hline 's ladder' & 441 & Le & \\
\hline Jal & 215 & wer: & 358 \\
\hline shruib: & 164 & moss & 181 \\
\hline Jasmine & 84,287 & Le: & 263 \\
\hline \multicolumn{2}{|c|}{ Jerusalem artichoke } & Le: & \\
\hline & $26 \%$ & & 136 \\
\hline alem cherry & 442 & ler wood & 233 \\
\hline & 28.3 & Le & 125 \\
\hline tear & 210 & Le & 207 \\
\hline & 245 & Ind's banes & $\therefore$ \\
\hline 5 srort & $77,42 ?$ & is lichen, & 299 \\
\hline weed: & 372 & lichen: & 33 \\
\hline & 327 & Let & 293,381 \\
\hline s tree & 200 & Lichnidia & 356,357 \\
\hline -Hower & 200 & Lichnis & 3.18 \\
\hline 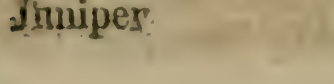 & ח & Life-everlasting & 36 \\
\hline
\end{tabular}


light hatir

467 Many-haired moss 466

Lilac

4.60

Maple

121

Iily

$153,302,330$

Lily-of-the-ralley 215 ,

Marestail

273

Marjorân

3,35

lime

Lime-grass

25.4

Marsh fivefinger 210

. $0 \%$ Marsh rosemary $45 \%$

Limodorte

Lindern

Lip-\{crin

Eiquorice

Liveforever

Liverieaf

d36

.83

Marsh tca

298

301

Mlary gold

Masterwort

182,460

201

Iatrimony

293

254,260

434

Liverwort 139,514,402

May apple

309

Lizard tail

Locust

423

Lolly bay

$259,103,1041$

262

Lombaidy poplar 376

Loosestrite

Lopseed

Jouscwort

Eoviage

Tove anple

255,311

Mayweed

367

- 139

Meadow beanty 398

Neadow grass 131,363,

364,367

Meadow rue 462

Neadow sweet $\quad 453$

Mechoacon 214

Medick

315

358 Medlar 145,319

350 Melic grritss 317

301 Meklor 317

442 Mercury 121,202

Love-líes-bleeding 132

Low centaury

Lucerne medic

Luingwort

Supine

368

515

387

308

Meruaid 248,383

Mezerecil

Miguonette

$\approx 28$

397

Milfoil $\quad 326$

Milk parsley 434

Milkway plinit 252

\section{Mr.}

Madder

Madeiri-nut

Madwort

NIagnolia

Maidenhair

Xralabar-nut

Hrallows $131,371,395$, $296,313,314,327,4.36$ Jandrike
Milkweed 148,149

Milkwoit $250, j 68,69$

ing Nillet 320,152

¿) Hillet grass $3 \div 0$

131 Mint $318,322,387$

313 Misseltoe 496

123 Mithridate nuśtard 464

292 Mite lichen 488

Mitrewort $\quad 465$.

Mock os'ange 356

ilonkey flower 320 . 


\begin{tabular}{|c|c|c|c|c|}
\hline Monk's hood & 1221 & \multicolumn{2}{|l|}{ anic mouss } & \\
\hline Hionemend & 318 & \multicolumn{3}{|l|}{ Pansey } \\
\hline Monsewool & 233 & \multicolumn{3}{|c|}{$\begin{array}{l}\text { laper-tooth moss } \\
\text { l'aper }\end{array}$} \\
\hline Morel & 324 & \multicolumn{3}{|c|}{ Pappose root } \\
\hline Anpuing glory 215, & 284 & \multicolumn{3}{|c|}{ Parmassus-grass } \\
\hline Moss bush & 135 & \multirow{2}{*}{\multicolumn{3}{|c|}{$\begin{array}{lr}\text { P'arsley } & 140,197,4,34 \\
\text { Parsnin } & 350,439\end{array}$}} \\
\hline Mother-ol-thyme & 46,1 & & & \\
\hline Mountain mint & 387 & \multicolumn{2}{|c|}{ l'artridge berry } & 321 \\
\hline Monsear & 201 & \multicolumn{2}{|l|}{ l'artridge pea } & 1015 \\
\hline Monsear chickweed & & \multirow{2}{*}{\multicolumn{3}{|c|}{$\begin{array}{l}\text { Passion-1lower } \\
\text { Pastons }\end{array}$}} \\
\hline Mullwoit & 3031 & & & \\
\hline Nugwolt & 146 & \multirow{2}{*}{\multicolumn{2}{|c|}{$394,295,36$}} & \\
\hline Mulberry 179,183, & \multirow{2}{*}{$179,183,324$} & & \\
\hline Mullcin 435 & & pear & & \\
\hline Mushrooin & 124 & \multirow{2}{*}{\multicolumn{2}{|c|}{ Pearlwert }} & \\
\hline Muskmelon & & \multirow{2}{*}{ Peat moss $\quad 14$} & & 454 \\
\hline \multicolumn{2}{|c|}{ Mustard 203,242,:38 } & & & 343 \\
\hline & & Pencil flower & & 459 \\
\hline Myrtle & 327 & Penny-cress & & $46 \%$ \\
\hline \multirow{3}{*}{\multicolumn{2}{|c|}{ N. }} & Penny-royal & \multirow{2}{*}{\multicolumn{2}{|c|}{276,331}} \\
\hline & & Pennywort & & \\
\hline & & Peony & & \\
\hline Narcissus & 523 & Pepper & & 185 \\
\hline Nasturtion & 472 & Peppergrass & & 299 \\
\hline Navelwort & 276 & Pepperidge & & 331 \\
\hline Necklace weed & 123 & Peppermint & & 318 \\
\hline Nelombo & 328 & Perivinkle & & 492 \\
\hline Nettle $175,252,476$, & & Persimon & & 233 \\
\hline Nettle tree & 197 & Peter's wort & & 150 \\
\hline Net-tooth moss & 316 & Phacclia & & 354 \\
\hline New-Jersey tea & 179 & Pheasant's eye & & 123 \\
\hline Nightshade 164,206 & & P'ickerel weed & & 375 \\
\hline Ninebark & 453 & Pigmy weed & & 465 \\
\hline Nitweed & 422 & Pignut & & 288 \\
\hline Nymph & 249 & Pigweed & 202, &, 203 \\
\hline & & & & 487 \\
\hline $\mathbf{P}$ & & Pine 309,31 & &, 361 \\
\hline & & Pine apple & & 179 \\
\hline Pastil & 171 & Pink fungus & & 462 \\
\hline & & Pink root & & 454 \\
\hline
\end{tabular}


Pinweed

Pipestem

Pipewort

Pippin

Pit-back lichen

Pitcher-shield

Tichen

Plane tree

Plantain 129,349,362

Plowman's spikenard

Plowman's wort

Plum

Poison ash

Poison ivy

Poison oak

Poison vine

Poke

Polyanthes

Polypod

Pomegranite

Pond lily

Pondweed

Poplar

Poply

Potato

Prickly ash

Prickly fungus

Prickly pear

Prick-tooth moss

Pride weed

Prim

Primrose

Prince's feather

Prince's pine

Puccoon

Puffball

Pumplin

Punk

Purslain

167

215

384,387

400

400

400

400

359,485

327

373

887

330

Pyramid flower 250

Q.

Quake grass 178

Queen-of-the-meadow

Quickset

Quince

455

220

389

$\mathbf{R}$

Rabbit foot

468

Radish 210,242,397,

438 .

Rasged cup $\quad 437$

Ragged robin $\quad 308$

Ragwolt

435

Raspberry $\quad 407,408$

Rattle

398

Rattlebox 221

Rattlesnake grass $\mathbf{1 7 . 9}$

Red bud

375

343

215,442

500

275

182

ง 21

239

302

Red root

Red top

Recd

Reed grass $\quad 147,289$

Reed mace 473

Rhodora

Rhubarb

399

398

Ribbon fern $\quad 497$

Ribbon grass $\quad 355$

Ribwort

Rice

362

371

203

171

Rich-weed

Robert

Rucket

Rockrose

337,500

2.10

256

181,270

206

Roman fern 174

Rose 206,404 to 407 
Rैosebay

Rosemary

Rought-seed

Round head

Rue

Ruel

Rush

Rush grass 288,303,475

Rust

nye

ธ.

Saffron

Sage

Saint John's wort 277

Salsify

Salt grass

Saltwort

Samphire

Sanicle

Sandwort

Sarsaparilla

Sassaliras

Satin flower

Satyrion

Savin

Savory

Saxifiage 205,421,423

Scabious

Scabisit

Scarlet lichen

Scarlet punner

Scotch broom

Screw-stem

Scull-cap

Scurvy grass

Sea burdock

Sea laventer

fearuskg?ass
196,220

475,176

236,48t

466

303

419

41 :

421,138

14.2

142

295

308

423

291

422

4อ1

331,732

168

356

4.53

170

433

210

93

467

45
Seaweed 250,251,474

Selgo

187

Seedball lichen $\quad 454$

Secthox

307

Selfhe:

383

Seneca snakeroot 369

Senna 196,210

Sensitire ferm 332

Sensitive plant 123,320

Shad-bush

Shallot

145

130

Sheep berry $\quad 489$

Shepherd's purse 464

Shieldl lichen 343

Shin leat" $\quad 388$

Shinwoort 461

Shot bush $\quad 141$

Shrubby fungus $20 \tau$

$\begin{array}{ll}\text { Sidesaldle } & 422\end{array}$

Simpler"s joy $\quad 483$

Sirrgle-seed creumber,

436

Skunk cabbage $\quad 380$

Sleek leaf $\quad$ \$98

Slecpy catchify $\quad 437$

Slecpy moss - 279

Sloe

385,384

Smallpox lichen 484

Sinellage $\quad 301$

Snoke fungis $\quad 269$

Smut

476

Sinailshell

Snakchead

306

202

Snakemouth $\quad 1 \pm 3$

Snakeweed ' 430

Snakcroot 144,148,

205,369

Snap)-rlyggon 130,140

Snuvball

suewdrop 
Snuff-box

Soapwort

Soft girass

Solomon's seal

Soot fungus

Sorrel

Sorrel tree

Sour gum

Southernwood

Sow thistle

Spanish broom

Spearwort

Speedwell

Spice bush

Spiderwort

Spikenard

Spinach

Spindle tree

Spiral-tooth moss

Spleenwort

Split-flower

Spring beauty

Spruce

Spurge

Spurry

Spur-stem

Squash

Squawroot

Staff tree

Star-flower

Stargrass

Star-of-Bethlehem

Starwort

Steen-crout

Steeple bush

Stemless moss

Stinger

Stitchwort

Stock

Stone-crop
162
421,422
273
213,214

251

294,337

135

331.

146

451

453

325,396

587,488

295

466

142,167

451

243

170

153

354

207

359,360

246

453

492

222

336

197

153

28 !

335

183,457

305

181

47

458

202

434 Thorn
305

328

$\begin{array}{lr}\text { Stra wberry } & 228,249 \\ \text { Succ ory } & 205\end{array}$

Sugar bane

412

193

399

Sumach .

Summer cypress 203

Sundew

235

Sundrops $\quad 332$

Sunflower 216,206,409

Sweatweed

271

Sweet briar

403

Sweet cicily $\quad 326$

Sweet fern

Sweet flag

Sivect gale

211

Sweet gum

122

326

Sweet pepper bush 200

Sweet tree

122

Sweet william 229

Sycamore

Syringa

356,460

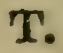

Taliny

Tamarack

460

Tamarisk

$36 i$

Tangle-legs

Tansey

Tape grass

461

489

170,461

484

$\begin{array}{ll}\text { Tal'get lichen } & 352 \\ \text { Tassel pondweed } & 411\end{array}$

$\begin{array}{ll}\text { Talget lichen } & 352 \\ \text { Tassel pondweed } & 411\end{array}$

Tea 197,298,322,463 Teasel 233

Thin grass $\quad 467$

Thistle 186,199,209,

$236,332,432$

$219,220,319$ 


\section{INDEX.}

Thornapple 228

'Thorough wort 242,319

'Tlireadloot

Thiread moss

'Threc-birds

Thyne 178,209,164,

Timnthy graiss

Toadillax 140,463

'Toadstool 124,175,319

'I'obacco 121,306,329

'Tomatoes

'Troth-ache bushi 500

'Tooth coral

'Tooth cup

'Toothless moss

'Toothwort

'Touch-me-not

'Touchwood

Tower mustard

'Tree moss

'Tree primrose

'Tree-weed

'Trefoil

'T'ickle

Trumpet flower

'Tuber'le fungus

'T'uberose

Tulip

'Tulip tree

Tumnel fungus

'T'ipelo

'Turnip

'Twin-berry

Twin-flower

'Twin-leaf

'swayblade

U.

Umbrella grass
442

224.

133

203

229

283

$1 \div 6$

4.73 209,478

$33 i$

30.)

264

229

174 Wake robin $46,170,471$

472

- 368

4.3

307

223

3.31

146,178

498

304

287

313

Walking leaf

IV all cress

IV all-fluwer

Walnat

Water arum

Watercress

$\mathrm{Vi}^{\top}$ atel-Haxsecel

Hi ate lobohound

Water leat

Water lily

Watermelon

Water milfoil

Water moss

251 Water nymph
456

313

315

129

142

368,156 466

319

233

185

274

139

486

491

ㄴ)

$212,374,4) 2$

to 96

4.2

208

$1: 2$

141

201.20ล

28\%,235

1.3

186,439

$\approx 93$

3. 1

2.7

$3 \div 0$

220

326

$2+9$

327 
Water oats.

Water pepper

Water plantain

Watershield

Was-liverwort:

Waxweed

Weedgrass:

Wheat

Wheat-thief

Whip grass

White bush

White grass

White top

White wood

Whitlow grass

Whortleberry:

Willow

Willowherb

Wind flower

Winterberry

Winter-cherry

Wintergreen 203,254, $255,368,388$
500 370

129

277

139

223

212

$47 \%$

305 .

431

135

298

127

305

234

482,48 . 414 to 419 238,312

137

382

358

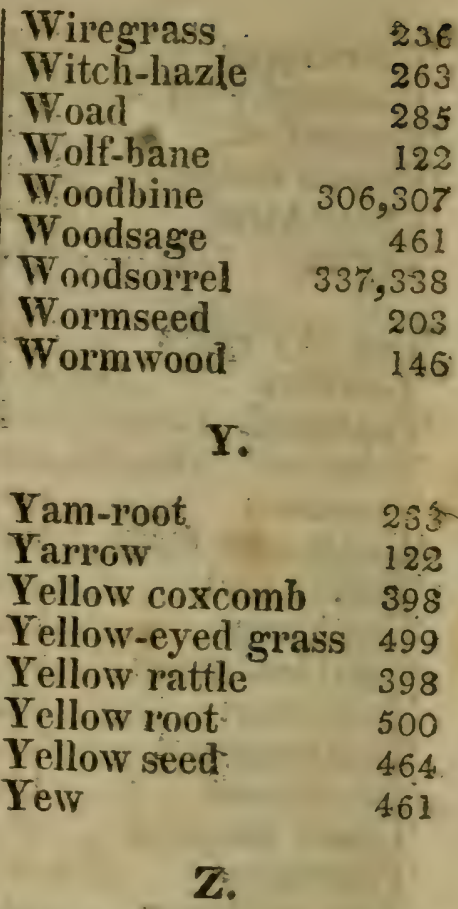

Zigadene 


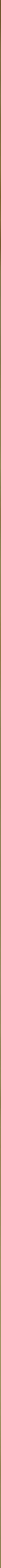






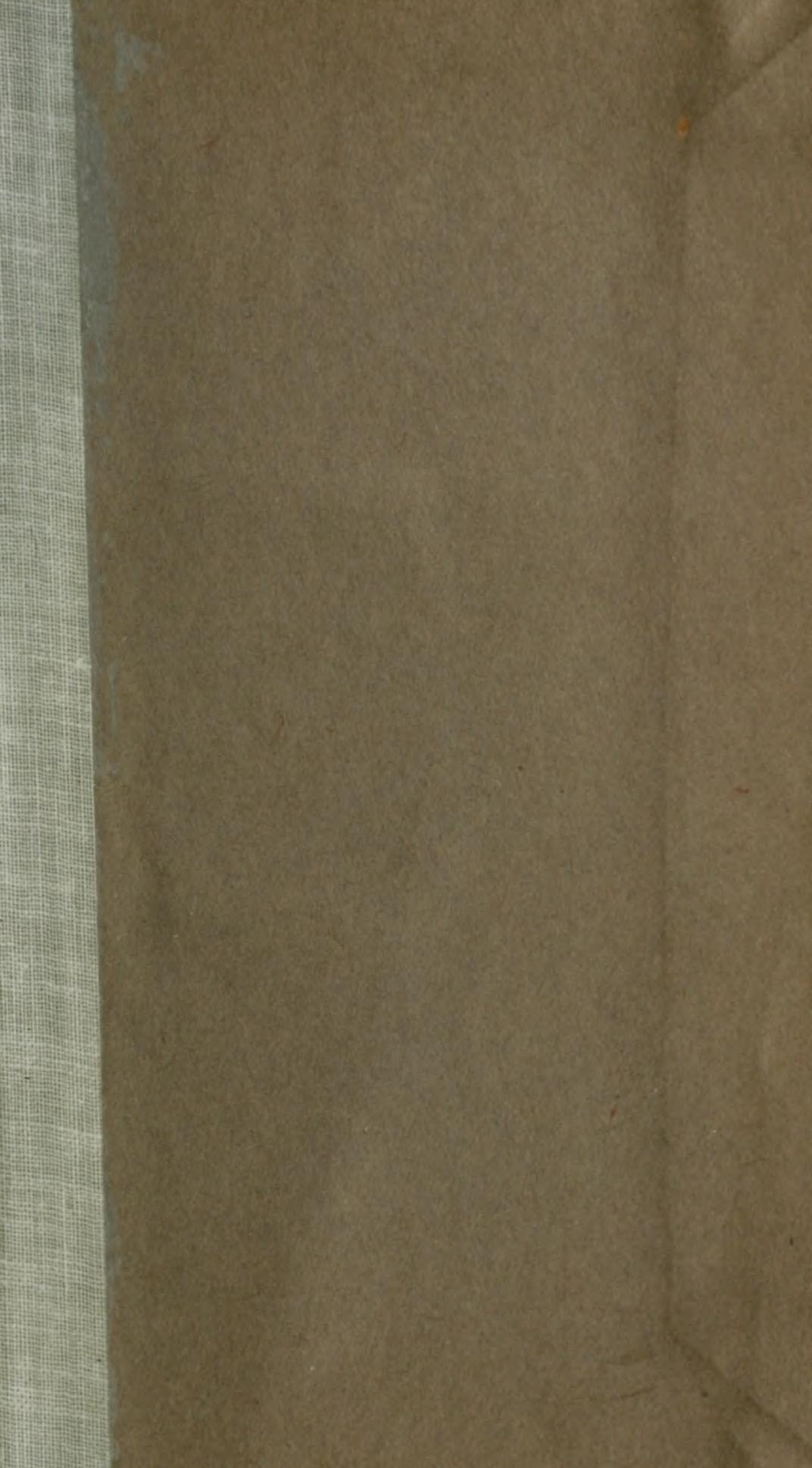




